\title{
Sociale netwerken van ambulante chronisch psychiatrische patienten : een analyse van de structuur van het sociale netwerk bij 59 ambulante chronisch psychiatrische patienten in zorg bij de Sociaal Psychiatrische Dienst van de RIAGG Maastricht
}

Citation for published version (APA):

Baars, H. M. J. (1994). Sociale netwerken van ambulante chronisch psychiatrische patienten : een analyse van de structuur van het sociale netwerk bij 59 ambulante chronisch psychiatrische patienten in zorg bij de Sociaal Psychiatrische Dienst van de RIAGG Maastricht. [Doctoral Thesis, Maastricht University]. Rijksuniversiteit Limburg. https://doi.org/10.26481/dis.19940908hb

Document status and date:

Published: 01/01/1994

DOI:

10.26481/dis.19940908hb

Document Version:

Publisher's PDF, also known as Version of record

Please check the document version of this publication:

- A submitted manuscript is the version of the article upon submission and before peer-review. There can be important differences between the submitted version and the official published version of record.

People interested in the research are advised to contact the author for the final version of the publication, or visit the DOI to the publisher's website.

- The final author version and the galley proof are versions of the publication after peer review.

- The final published version features the final layout of the paper including the volume, issue and page numbers.

Link to publication

\section{General rights}

Copyright and moral rights for the publications made accessible in the public portal are retained by the authors and/or other copyright owners and it is a condition of accessing publications that users recognise and abide by the legal requirements associated with these rights.

- Users may download and print one copy of any publication from the public portal for the purpose of private study or research. - You may not further distribute the material or use it for any profit-making activity or commercial gain

- You may freely distribute the URL identifying the publication in the public portal.

If the publication is distributed under the terms of Article $25 \mathrm{fa}$ of the Dutch Copyright Act, indicated by the "Taverne" license above please follow below link for the End User Agreement:

www.umlib.nl/taverne-license

Take down policy

If you believe that this document breaches copyright please contact us at:

repository@maastrichtuniversity.nl

providing details and we will investigate your claim. 
SOCIALE NETWERKEN VAN AMBULANTE CHRONISCH PSYCHIATRISCHE PATIENTEN

HERMAN M.J. BAARS 


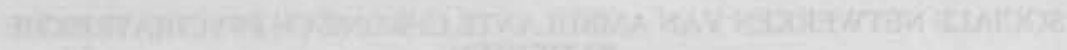

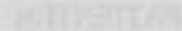




\title{
SOCIALE NETWERKEN
}

\section{VAN}

\section{AMBULANTE CHRONISCH PSYCHIATRISCHE PATIENTEN}

EEN ANALYSE VAN DE STRUCTUUR VAN HET SOCIALE NETWERK BIJ 59 AMBULANTE CHRONISCH PSYCHIATRISCHE PATIENTEN IN ZORG BIJ

DE SOCIAAL PSYCHIATRISCHE DIENST VAN DE RIAGG MAASTRICHT

\author{
PROEFSCHRIFT \\ ter verkrijging van de graad van doctor \\ aan de Rijksuniversiteit Limburg te Maastricht, \\ op gezag van de Rector Magnificus, Prof. Dr. H. Philipsen, \\ volgens het besluit van het College van Dekanen, \\ in het openbaar te verdedigen \\ op donderdag 8 september 1994 om 12.00 uur \\ door
}

HERMAN M.J. BAARS 


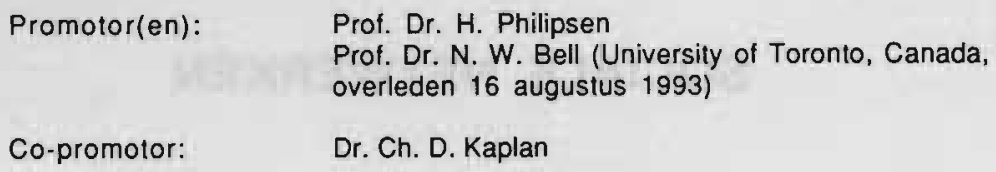

\section{CIP-GEGEVENS KONINKLIJKE BIBLIOTHEEK, DEN HAAG}

Baars, Herman M.J.

Sociale netwerken van ambulante chronisch psychiatrische patiënten : een analyse van de structuur van het sociale netwerk bij 59 ambulante chronisch psychiatrische patiënten in zorg bij de Sociaal Psychiatrische Dienst van de RIAGG Maastricht / Herman M.J. Baars. - [S.1. :

S.n.]

Proefschrift Maastricht. - Met lit. opg. ISBN 90-9007339-6

NUGI $744 / 758$

Trefw.: sociale netwerken : psychiatrische patiënten / sociale psychiatrie.

Realisatie: Universitaire drukkerij "UNIPRINT" RL Maastricht 


\section{VOORWOORD}

"Waar moest ik beginnen? Het duurde vele jaren voor ik het geheim ontdekte dat het er helemaal niet toe doet waar men begint en dat het niet nodig is dat wat men schrijft direct groot is, belangrijk is dat een mens zich neerlegt bij de waarheid dat hij slechts een mens is, en werkt...........". Met dit citaat van William Saroyan (1952) opent Gisela Konopka in 1963 haar klassieke boek 'Social Group Work'.

Ik begin dit proefschrift over de structuur van sociale netwerken bij ambulante chronisch psychiatrische patië nten, een onderzoek uitgevoerd bij de Sociaal Psychiatrische Dienst van de RIAGG Maastricht, met een verwijzing naar het volgens mij ook heden nog zeer belangwekkende werk van Konopka. Als maatschappelijk werker liggen mijn professionele wortels in het groepswerk, een methode van hulpverlening waarmee ik indertijd op voortreffelijke wijze door Mevr. M. KlijnenVeeger vertrouwd ben gemaakt. Mijn loopbaan in de psychiatrie begint in 1968 als groepswerker en wel in de Dr. Henri van der Hoevenkliniek te Utrecht. Daar leerde ik onder de bezielende leiding van de psychiater Mevr. Drs. A.M. Roosenburg de praktijk van de psychiatrische hulpverlening kennen en daar ook kwam ik voor het eerst in aanraking met de sociale netwerkbenadering van onder meer Dr. Ross V. Speck (USA) en met de toepassing ervan.

Vanuit de forensisch psychiatrische praktijk van de Dr. Henri van der Hoevenkliniek heb ik de concepten van de sociaal therapeulische gemeenschap, die van het groepswerk en van de sociale netwerkbenadering altijd als een eenheid ervaren. Globaal komt het erop neer dat in termen van zorg de psychiatrische patiënt aangewezen is op een gevarieerd aanbod van andere mensen die met elkaar hun beste persoonlijke en intermenselijke vermogens willen aanwenden ten behoeve van een bestaan waarin onder meer de opgelopen 'korsten' (Baan, 1957) kunnen wegvallen. Naar mijn ervaring is een dergelijke helende setting op zichzelf onvoldoende. De psychiatrische patiënt kan zich net als ieder ander mens eigenlijk pas veroorloven zich daadwerkelijk in te zetten wanneer hij tegenlijk kan rekenen op een vitaal persoonlijk sociaal netwerk die zijn sociale integratie wil waarborgen en kan vertrouwen op het vooruitzicht en de opbouw ervan.

Tegen vooral deze achtergrond maakte ik eind 1974 de overstap naar de vakgroep Sociale Psychiatrie van de Rijksuniversiteit Limburg le Maastricht. Ik ben Prof. Dr. M.A.J. Romme zeer erkentelijk dat hij van meet af aan mij gestimuleerd heeft en ook de ruimte gaf om het concept van een sociaal netwerk inhoudelijk en praktisch handen en voeten te geven. Voor ogen stond en staat de ontwikkeling van een werkwijze van sociaal psychiatrische hulpverlening die zich primair richt op de bevordering dan wel het herstel van de sociale inlegratie van (chronisch) psychialrische patiënten. Het is me een genoegen dat ook nadien de vakgroep Sociale Psychiatrie onder leiding van Prof. Dr. M.W. de Vries deze lijn uitdrukkelijk heeft ondersteund.

De wetenswaardigheden van de praktijk van de psychiatrische hulpverlening lopen in den regel op de wetenschappelijke analyse en beschrijving vooruit. Dat is ook bij het onderzoek in dit proefschrift het geval. Het is met name het Consultatiebureau voor Alcohol en Drugs Maastrich! / Mergelland geweest waar ik mel grote gastvrijheid de gelegenheid kreeg voorlopige nolies nader te verkennen en te toetsen. Ook de periode waarin door Prof. Dr. M.A.W. Richarlz en mij in nauwe samenwerking mel de Stichting Reclassering Zuid Limburg gewerkt is aan een forensische rapportage op geleide van 
3.4 Interventies in en met sociale netwerken 40

3.4.1 Raamwerk voor sociale netwerkinterventies 40

3.5 Sociale netwerkbenadering en psychiatrische hulpverlening 43

3.5.1 De betekenis van de werkwijze van Speck en zijn collega's 43

3.5.2 Naar een sociale netwerkbenadering

als methode van psychiatrische hulpverlening 44

$\begin{array}{lll}3.6 & \text { Afsluiting } & 47\end{array}$

4 EERDER ONDERZOEK NAAR SOCIALE NETWERKEN VAN PSYCHIATRISCHE PATIENTEN

4.1. Afbakening 49

4.1.1 Hoofdlijnen in het sociale netwerkonderzoek 49

4.1.2 Eerder onderzochte psychiatrische populaties 51

$\begin{array}{lll}4.2 & \text { De 'personal network strategy' } & 51\end{array}$

4.3 Sociale netwerken rondom een eerste opname 54

4.4 Sociale nelwerken van 'ambulante' chronisch
psychiatrische patiënten

4.4.1 Ontslagen chronisch psychiatrische patiënten 59

$\begin{array}{ll}\text { 4.4.2 Poliklinische chronisch psychiatrische patiënten } & 61\end{array}$

$\begin{array}{ll}\text { 4.4.3 Chronisch psychiatrische 'draaideur'-patiënten } & 62\end{array}$

$\begin{array}{ll}\text { 4.4.4 Typen sociale netwerken } & 63\end{array}$

4.4.5 Indrukken omtrent bevindingen 64

4.5 Onderzoek met accent op de functies van sociale netwerken 65

4.6 Onderzoek met accent op structuur én functies $\begin{array}{ll}\text { van sociale netwerken } & 67\end{array}$

4.7 Hoofdlijnen in de structuur van sociale nefwerken bij psychiatrische patiënten $\quad 71$

$\begin{array}{ll}\text { 4.7.1 Omvang van persoonlijke sociale nelwerken } & 71\end{array}$

4.7.2 Gevarieerheid van sociale netwerkleden 72

$\begin{array}{ll}\text { 4.7.3 Bereikbaarheid van sociale nelwerkleden } & 72\end{array}$

$\begin{array}{ll}\text { 4.7.4 Dichtheid van persoonlijke sociale netwerken } & 72\end{array}$

$\begin{array}{ll}4.7 .5 & \text { Structuur van de betrekkingen }\end{array}$

$\begin{array}{ll}4.8 & \text { Samenvalting }\end{array}$

5 MODEL VOOR SOCIALE NETWERK ANALYSE

5.1 Samenhang tussen praktijk en onderzoek 75

5.2 Afbakening van een persoonlijk sociaal netwerk 76

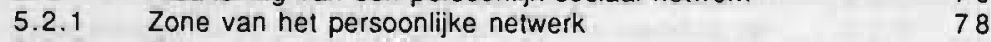

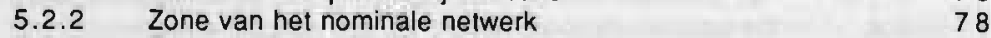

$\begin{array}{ll}\text { 5.2.3 Zone van het extensieve netwerk } & 79\end{array}$

$\begin{array}{lll}5.3 & \text { Het persoonlijke sociale netwerk: } & \\ & \text { eenheid van onderzoek en praktijk } & 79\end{array}$

5.3.1 Model van een persoonlijk sociaal netwerk 80

$\begin{array}{lll}\text { 5.3.2 De structuur van een sociaal netwerk } & \\ \text { als eenheid van analyse } & 81\end{array}$

$\begin{array}{ll}\text { 5.3.3 Selectie van de structuurkenmerken } & 82\end{array}$

$\begin{array}{lll}5.4 & \text { Afsluiting } & 87\end{array}$

6 VRAAGSTELLINGEN EN HYPOTHESEN 89

$\begin{array}{lll}6.1 & \text { Vraagstellingen } & 89\end{array}$

6.2. Hypothesen 90

6.2.1 Hypothesen bij vraagstelling I 91

6.2.2 Hypothesen bij vraagstelling II 92

6.2.3 Hypothesen bij vraagstelling III 94

6.2.4 Hypothesen bij vraagstelling IV 95 
6.2.5 Hypothesen bij vraagstelling $V \quad 96$

$\begin{array}{ll}6.3 & \text { Afsluitende opmerking } \\ & 96\end{array}$

$7.1 \quad$ Opzet onderzoekspopulatie

7.1.1 Selectie ambulante chronisch psychiatrische patiënten en hulpverleners

7.1.2 Selectie referentiepersonen 98

$\begin{array}{lll}7.2 & \text { Gegevensverzameling } & 99\end{array}$

7.2.1 Maastrichtse Sociale Netwerk Analyse (MSNA) 99

$\begin{array}{ll}7.2 .2 & \text { Semi-gestructureerd interview } \\ 7.2 .3 & 100\end{array}$

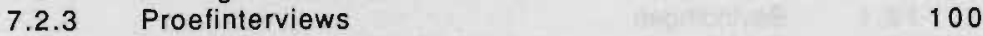

$\begin{array}{lll}7.2 .4 & \text { Betrouwbaarheid van de data } & 100\end{array}$

$\begin{array}{lll}7.3 & \text { Verwerking van de gegevens } & 102\end{array}$

8 SOCIALE NETWERKEN VAN AMBULANTE CHRONISCH PSYCHIATRISCHE PATIENTEN

8.1 Beschrijving onderzoekspopulatie 105

8.2 Beschrijving referentiepersonen 109

8.3 Resultaten vraagstelling I 111

8.3.1 Omvang en samenstelling van de omvang 112

8.3.2 Gevarieerdheid van de netwerkleden 114

$\begin{array}{ll}\text { 8.3.3 Bereikbaarheid van de netwerkleden } & 116\end{array}$

$\begin{array}{ll}\text { 8.3.4 Structuur van de betrekkingen } & 119\end{array}$

$\begin{array}{lll}8.4 & \text { Resultaten in hoofdpunten } & 128\end{array}$

9. SOCIALE NETWERKEN DOOR DE OGEN 131 VAN DE HULPVERLENING

$9.1 \quad$ Inleiding 131

9.1.1 Beschrijving hulpverleners en onderzoekspopulatie 132

9.2 Resultaten vraagstelling II 134

9.2.1 Omvang en samenstelling van de omvang 134

$\begin{array}{ll}\text { 9.2.2 Gevarieerdheid van de netwerkleden } & 137\end{array}$

9.2.3 Bereikbaarheid van de netwerkleden 139

$\begin{array}{ll}\text { 9.2.4 Structuur van de betrekkingen } & 141\end{array}$

$\begin{array}{lll}9.3 & \text { Resultaten in hoofdpunten } & 147\end{array}$

10 SOCIALE NETWERKEN VAN

JONGERE EN OUDERE PATIENTEN 151

$\begin{array}{lll}10.1 & 151\end{array}$

10.2 Resultaten Vraagstelling III 153

10.2.1 Omvang en samenstelling van de omvang 153

$\begin{array}{ll}\text { 10.2.2 Gevarieerdheid van de netwerkleden } & 156\end{array}$

10.2.3 Bereikbaarheid van de netwerkleden 156

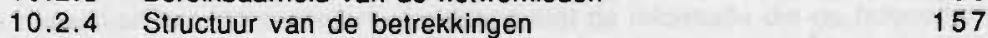

10.3 Resultaten vraagstelling IV 161

10.3.1 Omvang en samenstelling van de omvang 162

10.3.2 Gevarieerdheid van de netwerkleden 165

$\begin{array}{ll}\text { 10.3.3 Bereikbaarheid van de netwerkleden } & 166\end{array}$

$\begin{array}{ll}\text { 10.3.4 Structuur van de betrekkingen } & 168\end{array}$

$\begin{array}{lll}10.4 & \text { Hoofdpunten } & 175\end{array}$ 
11 SOCIALE NETWERKEN VAN JONGERE EN OUDERE PATIENTEN BEKEKEN DOOR DE HULPVERLENING

11.1 Resultaten vraagstelling $V$

11.1.1 Omvang en samenstelling van de omvang

11.1.2 Gevarieerdheid van de netwerkleden

11.1.3 Bereikbaarheid van de netwerkleden

11.1.4 Structuur van de betrekkingen

11.2 Resultaten in hoofdpunten

12.1 Bevindingen

12.1.1 Sociale netwerken belicht door patiënt en hulpverlening

12.1.2 Sociale netwerken van patiënten en referentiepersonen

12.1.3 Praktische consequenties

12.2 Werkwijze

12.3

Conclusies en aanbevelingen

\section{BIJLAGEN}

Maastrichtse Sociale Netwerk Analyse (MSNA);

II Interview-formulieren MSNA

III Definities sociale netwerken

IV Structuur sociale netwerk restgroep $(n=12)$

V

Samenvatting resultaten hypothesen

Tabellen omvang sociale netwerken

in clusters en sectoren

VII Tabellen gevarieerdheid netwerkleden

VIII Tabellen structuur van de betrekkingen

IX

Lijst van afkortingen

SAMENVATTING, SUMMARY

CURRICULUM VITAE 
INTRODUCTIE

Om enigszins vertrouwd te raken met de inhoud van dit proefschrift geef ik in dit inleidende hoofdstuk achtereenvolgens in het kort het onderwerp en de probleemstelling van het onderzoek dat hier gepresenteerd wordt. Tenslotte laat ik zien hoe dit proefschrift is opgebouwd.

In dit proefschrilt wordt verslag gedaan van een onderzoek naar het sociale netwerk * van ambulante chronisch psychiatrische patiënten $(N=59)$ die in behandeling zijn bij de Sociaal Psychiatrische Dienst (SPD) van de RIAGG Maastricht. Het begrip sociale netwerk staat voor het sociale milieu van mensen, het centrale thema in de sociale psychiatrie (Querido, 1946, 1980; Bell, Spiegel, 1966; Romme, Kraan, Rolteveel, 1981; Trimbos, 1985). Een sociaal netwerk kan men omschrijven als "al die mensen met wie iemand rechtstreekse, duurzame en belangrijke banden onderhoudl" (Hammer, 1981). Deze groep mensen bestaal uit familieleden, vrienden, buren, collega's, kennissen en andere mensen in de samenleving mel wie iemand een band heeft "voor de vervulling van zijn dagelijkse levensbehoeften" (Speck. Attneave, 1973).

Het onderzoek dat hier gepresenteerd wordt heeft betrekking op de structurele kenmerken van sociale netwerken van ambulante chronisch psychiatrische patiënten (Walker, MacBride, Vachon, 1977; Wellman, Berkowitz, 1988; Baars, Uffing, Dekkers, 1990). Gebruikmakend van een structureel model voor de analyse van een sociaal netwerk - dat ik samen met mijn collega Hans Uffing in de vakgroep Sociale Psychiatrie van de Rijksuniversiteit Limburg (RL) te Maastricht heb ontwikkeld (Baars, Uffing, 1987; 1991) - heb ik de omvang, de gevarieerdheid en de bereikbaarheid van het sociale netwerk en de structuur van de betrekkingen in het sociale netwerk onderzocht. Om inzicht te krijgen in wat specifiek is voor de structuur van het sociale netwerk van deze ambulante chronisch psychiatrische patiënten zijn de uitkomsten ervan vergeleken met die bij normale referentiepersonen. Vervolgens zijn de bevindingen omtrent de structuur van de sociale netwerken van de patiënten vergeleken met de informatie die de hulpverleners van de SPD aan het begin van de behandeling zelf bijeenbrengen over het sociale milieu van deze patiënten. De reden voor deze tweede vergelijking is dat ik in een eerdere

- Conform algemeen gebruik in de (sociale) psychiatric staat het begrip 'sociale netwerk' voor een persoonlijk sociaal netwerk (zie \$ 5.2.1.). Alleen waar dit uitdrukkelijk wordt verlangd wordt in dit proefschrift het begrip 'persoonlijk sociaal netwerk' gebruikt. 
verkennende studie aanwijzingen vond dat de ambulante chronisch psychiatrische patiënt over een structureel veelzijdiger sociaal netwerk beschikt dan de betreffende hulpverleners zichtbaar maken en in de zorg benutten (Baars, 1985).

\section{Sociale integratie van chronisch psychiatrische patiënten}

Waarom dit onderzoek naar de structurele kenmerken van het sociale netwerk van de ambulante chronisch psychiatrische patiënt? Het antwoord is als volgt: dit onderzoek verwijst naar het probleem van de sociale integratie van chronisch psychiatrische patiënten. In de "Tweede Nota Geestelijke Volksgezondheid" (Ministerie van WVC, 1984) wordt een hoge prioriteit gegeven aan de verbetering van de zorg voor deze "vaak meest kwetsbare categorie" patiènten. Voor een kwalitatieve en organisatorische verbetering van de zorg wordt in deze Tweede Nola uitgegaan van de optiek van de patiënt, dat wil zeggen dat de patiënt "dichtbij huis en met zo min mogelijk verbreking van sociale contacten wordt geholpen". Er is zoals Van Londen (1982) stelt "de rijksoverheid nogal veel aan gelegen - ook principieel - om te zeggen: het ordeningsprincipe gaat uit van hulp zo dicht mogelijk bij de patiënt thuis of in zijn huis".

De voorkeur voor een zorg in en met het sociale milieu vindt men ook terug in de door de SPD Maastricht in 1979 geformuleerde doelstelling van sociaal psychiatrische hulpverlening voor haar doelgroep chronisch psychiatrische patiënten. De doelstelling van de SPD luidt: de bevordering van de sociale integratie van de chronisch psychiatrische patiënt dan wel het tegengaan van maatschappelijke uitstotingsprocessen (Van Marrelo, 1979). Hoewel in het algemeen aanvaard wordt dat de chronisch psychiatrische patiènt zoveel mogelijk opgenomen wordt in het geheel van de samenleving (Van Lieshout, Van Zuthem, 1991) doen zich bij de uitvoering van dit streven een aantal niet onaanzienlijke moeilijkheden voor.

\section{2 .2}

Belemmeringen voor sociale integratie

In hoofdstuk 2 zal aan de hand van de praktijk van de SPD van de RIAGG Maastricht nader worden ingegaan op de verschillende inhoudelijke en praktische problemen. Hier beperk ik me tot enkele hoofdlijnen.

In de eerste plaats wordt de uitvoerbaarheid van een zorg gericht op de sociale integratie van de chronisch psychiatrische patiënt ernstig gehinderd door het gangbare profiel van deze categorie patiënten (Uffing e.a., 1987). Kenmerkend in het profiel van deze patiènten is juist dat zij over langere tijd - en bij sommigen is dat al van jongs af - ernstige moeilijkheden hebben in de relaties met andere mensen in bijvoorbeeld hun woon-, werk- en vrijetijdsmilieu dan wel met hun maatschappelijke omstandigheden (Test, Stein, 1978; Romme e.a., 1987). Er heerst binnen de psychiatrische hulpverlening twijfel of de chronisch psychiatrische patiênt over de capaciteiten beschikt zich in de samenleving in te passen en te handhaven (Rotteveel, Uffing, De Vries, 1987), een probleem waar Querido reeds in 1946 op wijst.

Vervolgens is er in aansluiting op de profielschets van de ambulante chronisch psychiatrische patiënt - een schets die nauwelijks lijkt af te wijken van die van de chronisch psychiatrische inrichtingspatiënt - de vraag of het eigen sociale milieu dan wel de samenleving in brede zin zelf in staat en bereid is zijn aanwezigheid en deelname meer blijvend te accepteren (Giel, 1984). Het streven naar sociale integratie veronderstelt immers de medewerking van de samenleving. Tenslotte is er de hindernis dat de gangbare referentiekaders in de sociaal psychiatrische zorg het functioneren van de chronisch psychiatrische patiënt nauwelijks of onvoldoende in beeld brengen als een modellering van de persoon vanuit de wisselwerking met zijn sociale milieu (Trimbos, 1982; Baars, 1985; Romme e.a., 1987). 
Kortom er liggen vanuit het perspectief van zowel de patiènt en dat van de samenleving in engere en in bredere zin alsook van de zijde van de psychiatrische hulpverlening zelf een aantal niet geringe praktische en inhoudelijke problemen die de uitvoering van een streven naar sociale integratie van de chronisch psychiatrische patiënt hinderen dan wel belemmeren. Het belangrijkste probleem is naar mijn mening het ontbreken van een hulpverleningsmethode waarin het sociale milieu zelf, de aangewezen plaats voor sociale integratie, het organiserend principe van (ambulante) psychiatrische hulpverlening is.

\section{2 .3}

Sociale netwerkconcept

Voor een bijdrage aan de oplossing van deze gecompliceerde problematiek is aansluiting gezocht bij een van het Noord Amerikaanse continent afkomstige nog jonge en "veelbelovende richting" (Meuller, 1980) voor sociaal psychiatrische zorg en wetenschappelijke onderzoek, waarin het begrip sociaal netwerk centraal staat (Erickson, 1984). Het gaat om:

- de zogeheten 'sociale netwerkstrategieën', ofwel vormen van zorg die primair de bevordering dan wel hel herstel van de sociale integratie van de (chronisch) psychiatrische patiënt beogen (Baars, Uffing, Dekkers, 1990). Van grole betekenis is het werk van onder anderen Speck en Attneave $(1973,1983)$ en Rueveni (1979);

de 'sociale netwerkanalyse', een sociaal wetenschappelijke systematiek en analyse waarmee de sociale integratie van mensen in termen van een sociaal netwerk bestudeerd wordt (Wellman, Berkowitz, 1988), in het bijzonder de toepassing ervan bij doelgroepen van psychiatrische zorg (Erickson, 1976. 1984; Cohen, Sokolovsky, 1978; Hammer, 1981).

De bouwstenen waarmee het model voor sociale netwerkanalyse is ontwikkeld waarvan in dit onderzoek gebruik is gemaakt zijn gevonden in zowel de vele voorbeelden van experimenten met de zogeheten sociale netwerkstrategieën en de aangevangen systematisering ervan, alsook in de weergaven van verkennende studies waarbij voorlopige en uiteenlopende constructies van sociale netwerkanalyse gebruikt zijn.

Het onderzoek dat in dit proefschrift gepresenteerd wordt sluit dus aan bij een nog jonge praktijk- en onderzoekstraditie waarin het kernbegrip 'sociale netwerk' de verhouding tussen mensen en hun sociale omgeving dan wel de samenleving concretiseert in een persoonlijk sociaal netwerk dat uit al die mensen en groepen mensen bestaat met wie iemand min of meer duurzame banden onderhoudt voor de vervulling van zijn dagelijkse levensbehoeften (Walker, MacBride, Vachon, 1977). Het komt er op neer dat "een sociaal netwerk is opgebouwd of samengesteld uit een bepaalde omvang en variatie van betrokken en bereikbare mensen en hun betrekkingen ofwel de structuur van een sociaal netwerk, waardoor iemand bevredigend aan zijn trekken kan komen op hel affectieve vlak, in de behoefte aan aansluiting, in materiële zin en wat betreft zijn sociale stabiliteit, ook wel de functies van een sociaal netwerk genoemd" (Baars, Uffing, 1991).

\subsubsection{Structuur van sociale netwerken}

In de sociale netwerkstrategieën wordt de kwaliteit van de structuur van het sociale netwerk als doorslaggevend gezien voor de mate waarin de benodigde dagelijkse bestaansmiddelen vervuld worden. De (chronisch) psychiatrische patiënt bevindt zich aldus in een situatie, door Querido (1980) "een afspiegeling van het maatschappelijk tekort" genoemd, waarin de structuur van zijn sociale netwerk, hel draagvlak voor zijn sociale integratie, ernstig aangetast is (Erickson, 1984). De opbouw dan wel de reorganisatie van de strucluur van het persoonlijke sociale netwerk is in de sociale netwerkstrategieën dan ock uitgangspunt en middel voor de bevordering dan wel hel herstel van de sociale integratie van de (chronisch) psychiatrische patient (Baars, Uffing, Dekkers, 1990).

Dit onderzoek naar de structuur van de sociale netwerken van chronisch psychiatrische patiënten heeft tot doel om zowel meer inzicht te krijgen in de 
mogelijkheden alsook in de beperkingen van de aanwezige structuur van hei persoonlijke sociale netwerk waarop de patiënt voor zijn sociale integratie aangewezen is. Vervolgens wil dit onderzoek er toe bijdragen om in de structuur van de netwerken van de cliëntèle van de SPD aangrijpingspunten te vinden die de ontwikkeling en toepassing van interventiestralegieën in de ambulante psychiatrische hulpverlening ten goede komen voor de bevordering dan wel het herstel van de sociale integratie van deze patiënten.

Samenvattend leidt bovenstaande tol de vraag of het hier ontwikkelde model, de Maastrichtse Sociale Netwerk Analyse (MSNA) geheten, en de gebruikte werkwijze van sociale netwerkanalyse een structuur en patronen in het netwerk van de ambulante chronisch psychiatrische patiënt toont die verschillen met die van normale referentiepersonen. Daaraan kan de vraag gekoppeld worden in hoeverre hulpverleners in staal zijn de structurele kenmerken van het sociale netwerk van hun cliëntèle vast te stellen als zij geen gebruik maken van sociale netwerkanalyse (Baars, 1985).

\section{3}

OPBOUW PROEFSCHRIFT

De volgende hoofdstukken 2 tot en met 6 vormen betreffen de context en de achtergronden van de hierboven in het kort weergegeven probleemstelling van dit onderzoek. In hoofdstuk 2 neem ik u mee naar de Sociaal Psychiatrische Dienst van de RIAGG Maastricht. Aan de hand van deze praktijk voor psychiatrische hulpverlening van ambulante chronisch psychiatrische patiënten zal worden ingegaan op de verschillende inhoudelijke en praktische problemen die een zorg waarin de sociale integratie van de patiënt centraal staat lijken te belemmeren.

Hooidstuk 3 gaat over de 'sociale netwerkstrategieën', een aanpak waarin het sociale milieu in termen van een sociaal netwerk benut wordt als het organiserend beginsel van een zorg ten behoeve van de bevordering van de sociale integratie en het tegengaan van uitstolingsprocessen. Ik beperk me hier tot de ontstaansgeschiedenis, de uitgangspunten en hoofdlijnen van deze strategieën, die eigenlijk vrijwel naadloos aansluiten op het sociaal psychiatrisch gedachlengoed dat in ons land in de traditie van Querido (1946, 1980) wordt aangetroffen. Hoe practisch modelmatig aangesloten is in de zin van varianten van sociale netwerkopbouw laat ik achterwege. Deze uitwerking is onder meer te vinden in het eerder verschenen boek "Sociale netwerkstrategieën in de sociale psychiatrie" (Baars, Uffing, Dekkers, 1990). Vervolgens komt in hoofdstuk 4 het eerder en elders verrichte onderzoek naar het sociale milieu van (ambulante) chronisch psychiatrische patiënten en de resultaten ervan aan de orde waarbij gebruik gemaakt is van sociale netwerkanalyse.

De hoofdstukken 3 en 4 leveren de bouwstenen voor het model van een analyse van de structuur dat ik samen met mijn collega Hans Uffing ontwikkeld heb (Baars, Uifing, 1987). In hoofdstuk 5 wordt het model voor een analyse van de structuur van sociale netwerken en de opbouw ervan gepresenteerd en belicht. Daarna komen in hoofdsluk 6 de vragen aan de orde die met betrekking tot de structuur van sociale netwerken aan de ambulante chronisch psychiatrische patiënten en hun hulpverleners van de SPD in dit onderzoek worden gesteld. Het zwaartepunt van dit hoofdstuk ligt bij de hypothesen die onder meer op basis van eerder en elders verricht sociaal netwerkonderzoek te stellen zijn. In hoofdstuk 7 wordt beschreven hoe de vraagstellingen geoperationaliseerd zijn en op welke wijze de wetenschappelijke analyse is uitgevoerd. Achtereenvolgens komen aan de orde de afbakening en de selectie van de onderzoekspopulatie, de opbouw van de referentiegroep, de constructie van het instrumentarium en de procedure die gevolgd is voor de verzameling en de verwerking van de verkregen informatie.

Heofdstuk 8 bevat de resultaten van de verschillen dan wel overeenkomsten in de structuur van sociale netwerken van ambulante chronisch psychiatrische patiënten vergeleken met die van normale referentiepersonen. Hoofdstuk 9 geeft de uitkomsten van de vraag naar de verschillen dan wel overeenkomsten die bestaan tussen de 
informatie die hulpverleners over de strucluur van de netwerken van hun cliëntèle verwerven en de gegevens die de onderzoekspopulatie met behulp van een analyse van de siructuur verstrekt.

Tenslotte de vraag naar patronen in de strucluur van sociale netwerken. In hooldsluk 10 vindt men de informatie over de patronen in de structuur van de sociale netwerken bij jongere en bij oudere patiënten in zorg bij de SPD en de resultaten van een vergelijking met de normale referentiepersonen. Hoofdsluk 11 toont de bevindingen betreffende de vraag: welke verschillen of overeenkomsten dan wel patronen bestaan er in de structuur bij jongere en bij oudere ambulante chronisch psychiatrische patiënten vergeleken met de informatie die hulpverleners over de structuur verstrekken. In hoofdstuk 12 worden in hoofdlijnen de belangrijkste resultaten besproken en zal worden ingegaan op de betekenis ervan voor de praktijk van de psychiatrische hulpverlening.

Na een overzicht van de gebruikle literatuur wordt dit proefschrift afgesloten met een aantal biilagen, waaronder de systematische beschrijving en operationalisatie van de MSNA.

Dit proefschrift beperkt zich tot de bevindingen over de structuur van het sociale netwerk bij de ambulante chronisch psychiatrische patiënt op groepsniveau. De ervaringen die lopende dit onderzoek verkregen zijn met betrekking tot de vraag of en hoe een analyse van de structuur vertaald kan worden in interventies op het niveau van de individuele patiënt zijn eveneens verwerkt en te vinden in het hierboven genoemde boek over de praktijk van sociale nelwerkopbouw (Baars, Uffing, Dekkers, 1990). Dit proefschrift kan dus tevens opgevat worden als een wetenschappelijke onderbouwing van het genoemde praktijkgerichte boek.

N.B.

Hoewel de vakgroep Sociale Psychiatrie sinds 1993 deel uitmaakt van hel Academisch Psychiatrisch Centrum en daarbinnen onderscheiden wordt met de aanduiding 'Sectie Sociale Psychiatrie en Psychiatrische Epidemiologie' hecht ik er aan in dit proefschrift de naam 'vakgroep Sociale Psychiatrie' te gebruiken. De reden is dat het betreffende onderzoek hoofdzakelijk onder deze noemer vitgevoerd is. Een zelfde reden is aanwezig bij het gebruik van de aanduiding "RIAGG Maastricht" in dit proefschrift ook al is er sinds 1992 sprake van de 'Stichting RIAGG - Vijverdal Combinatie'. 



\section{SOCIALE INTEGRATIE}

\section{EN}

\section{AMBULANTE PSYCHIATRISCHE HULPVERLENING}

In dit hoofdstuk wordt ingegaan op de Sociaal Psychiatrische Dienst van de RIAGG Maastricht en de door haar in 1979 geformuleerde doelstelling, te weten: de sociale integratie van ambulante chronisch psychiatrische patiënten. Na een korte beschrijving van het werkveld van de SPD Maastricht wordt de achtergrond van deze doelstelling en de problemen die zich voordoen bij de verwerkelijking ervan verder uitgewerkt. Tenslotte wordt aangegeven dat voor een oplossing van het centrale probleem - het ontbreken van een methode van analyse en interventie waarin het sociale milieu organiserend beginsel is - aansluiting is gezocht bij het 'sociale netwerk-concept'.

\subsection{DE SOCIAAL PSYCHIATRISCHE DIENST VAN DE RIAGG MAASTRICHT}

De Sociaal Psychiatrische Dienst (SPD) van de RIAGG Maastricht staat voor ambulante psychiatrische zorg. Ze bevindt zich in ons land binnen een traditie van sociaal psychiatrische zorg die teruggaat naar de Voor- en Nazorg Diensten waarvoor Querido in de dertiger jaren de grondslag heeft gelegd (Querido, 1980; Gersons, 1981; Heerma van Voss, 1991). De patient-gebonden ambulante psychiatrische zorg is hoewel ze het meest in het oog springt eigenlijk én deel van de taken van een afdeling sociale psychialrie van een RIAGG. In het algemeen kan overeenkomstig de beschrijving van Verhagen (1984) gezegd worden dat een afdeling sociale psychiatrie zich toelegt op:

- "de bevordering van de geestelijke volksgezondheid door voorlichting en consultatie;

- het voorkomen van psychische decompensaties en ernstige derailleringen van personen en groeperingen;

- de vitvoering van de sociaal psychiatrische zorg".

Het onderzoek in dit proefschrift staal binnen de context van 'de uitvoering van de sociaal psychiatrische zorg'. Hoewel het gangbaar is de uitvoering van de zorg door een afdeling als die van de SPD Maastricht als sociaal psychiatrische zorg te benoemen wordt hier de voorkeur gegeven om voor de directe patientgebonden zorg zelf de naam ambulante psychiatrische hulpverlening te gebruiken. Dit gebeurt in de eerste plaats ter afbakening van het zojuist vermelde totale pakkel activiteiten. Vervolgens is dat ter onderscheiding van de term sociale psychiatrie als wetenschappelijke benadering waaraan de stelling van "een fundamentele wisselwerking tussen het sociale milieu en geestelijke gezondheidsproblemen" ten grondslag ligt (Romme, Kraan, Rolteveel, 1981; Erickson, 1984). 
Een andere hierop aansluitende reden is dat het nog maar zeer de vraag is of en in welke mate een dergelijk sociaal psychiatrisch uitgangspunt karakteristiek is voor de ambulante psychiatrische hulpverlening en er niet veeleer sprake van is dat de ambulante psychiatrische hulpverlening inhoudelijk en feitelijk een spiegelbeeld is van het scala inzichten, methoden en technieken die (ook) in de intramurale psychiatrische praktijk wordt aangetroffen (Arthur, 1971; Trimbos, 1985). Bovendien sluit intramurale psychiatrische zorg op zich een sociaal psychiatrische aanpak niet uit (Bell, Spiegel, 1967; Roosenburg, 1973a; Clark, 1981; Baars, 1992). Het valt buiten het bestek van dit proefschrift nader inhoudelijk op de hier aangestipte thema's betreffende de sociale psychiatrie als vakgebied en praktijkveld in te gaan. Voor dit moment lijkt het mij voldoende om ten aanzien van de sociale psychiatrie hier Ciompi (1985) te citeren: "Ihr zentrales Anliegen ist es, psychische Störungen und Schwierigkeiten aller Art, ganz gleich ob ihre Ursachen als vorwiegend organisch, endogen oder psycho- und soziogen aufgefasst werden, in ihren Wechselwirkungen mit dem ganzen sozialen Kontekst zu verstehen und zu behandeln".

De RIAGG Maastricht - en dus ook de SPD aldaar - bestrijkt in Zuid-Limburg een verzorgingsgebied met om en nabij de 205.000 mensen. Hel strekt zich uit van Maastricht, een stad met ongeveer 115.000 inwoners, via het heuvelland van zuidelijk Zuid Limburg tot en met Vaals. Voor dit verzorgingsgebied houdt de SPD Maastricht zich specifiek bezig met de ambulante psychiatrische hulpverlening voor de categorie ambulante chronisch psychiatrische patiënten (Romme, Escher, 1988; Hamers, Romme, 1990).

Voor een eerste indruk van deze doelgroep van deze SPD volgen hier twee beschrijvingen door psychiaters die daar werkzaam zijn. Volgens Romme heeft de SPD Maastricht te maken met "mensen met ernstige handicaps in hun psycho-sociaal functioneren op wie - naast psychiatrische symptomatologie - tevens de kenmerken van het Social Breakdown Syndrome (Gruenberg, 1974) van toepassing zijn, dan wel een beperkle sociale ontplooiing hebben bereikt waarbij de deficienties in het geïntegreerd sociaal functioneren als chronisch zijn aan te merken" (Romme, Breuls, 1985). Honig (1989) noemt de criteria waaraan iemand moet voldoen om voor psychiatrische hulpverlening bij de SPD in aanmerking te kunnen komen, te weten:

- een psychiatrisch toestandsbeeld;

- stoornissen op andere probleemgebieden dan het individueel psychologisch niveau;

- meerdere behandelingspogingen vooraf aan aanmelding bij de SPD.

Deze beide omschrijvingen van ambulante chronisch psychiatrische patiënten geven reeds aan dat de SPD zich bepaald niet bezig houdt met de gemakkelijkste mensen. Calaço Belmonte (1979) spreekt zelfs van "de moeilijkste cliënten categorie" en in de Tweede Nota Geestelijke Volksgezondheid (Ministerie van WVC, 1984) worden zij aangeduid als de "vaak meest kwetsbare categorie" psychiatrische patiënten terwiji Verhagen (1984) het heeft over "gedragsmoeilijke, dikwijls maatschappelijk onaangepaste patiènten". Hel is deze calegorie ambulanle chronisch psychiatrische patienten waarbij de SPD Maastricht eind jaren zeventig de (sociale) integratie en hel tegengaan van uitstotingsprocessen als doel van ambulante psychiatrische hulpverlening stelt (Van Marrelo, 1979; Richartz, Crolla, 1980). De vraag is wat houdt sociale integratie in en hoe kan deze doelstelling in de ambulante psychiatrische hulpverlening verwezenlijkt worden.

\subsection{DE DOELSTELLING VAN SOCIALE INTEGRATIE}

Het begrip sociale integratie heeft al naar gelang het referentiekader waarbinnen het gebruikt wordt uiteenlopende betekenissen. In de door de SPD Maastricht geformuleerde doelstelling van ambulante psychiatrische hulpverlening is sociale integratie op te vatten als de tegenpool van sociale uitstoling. Deze samenhang verwijst naar een traditie van ambulante psychiatrische hulpverlening waarin sociale inlegratie vanouds een streven inhoudt dat de (ambulante) chronisch psychiatrische patiënt optimaal deel kan uilmaken van de samenleving. Aan de orde is een samenlevingsbegrip waaraan gewoonlijk een woon, werk- en vrijelijdsmilieu worden 
benoemd en onderscheiden (Esser, 1970). Afhankelijk van de mogelijkheden van de patiënt wordt getracht een $z 0$ goed mogelijke aansluiting van de patiěnt op deze en andere levensterreinen te verwerkelijken. Bijvoorbeeld met betrekking tot het eigen woonmilieu wordt met de patiènt nagegaan of dat woonmilieu kan bestaan uit een eigen zelfstandige woonsituatie of dat er meer aangepaste voorzieningen en bepaalde vormen van toezicht/begeleiding nodig zijn. Een zelfde afweging kan ook gemaakt worden bij het werkmilieu. In al die gevallen waarin een optimale aansluiting is gevonden, ook al woont de patiënt volledig onder toezicht en werkt hij in een beschutte werkplaats, spreekt men traditioneel van sociale integratie; het gaat er om dat het maximaal haalbare in de zin van sociale aanpassing bereikt wordt.

Ambulante psychiatrische hulpverlening gericht op de bevordering van de sociale aanpassing of op het herstel dan wel de versterking van het sociaal functioneren van de patient betreft in het algemeen de volgende drie onderling samenhangende domeinen.

- De beïnvloeding van de patiënt zelf met middelen als bijvoorbeeld structurende gesprekken, ondersteunende medicatie en trainingen in (sociale) vaardigheden.

- De beïnvloeding van de wisselwerking tussen de patiënt en zijn naaste omgeving. Verhagen (1984) geeft hier de volgende schets: de ambulante psychiatrische hulpverlening zal proberen "de patiënt en zijn gezin te begeleiden; de frustratie-tolerantie zal opgeheven moeten worden, er worden haalbare eisen aan de patiënt en zijn omgeving gesteld. Verbroken relaties met familieleden en vrienden worden $z 0$ mogelijk en voor zover nodig hersteld".

- De beïnvloeding van het sociale milieu, in de zin van zijn naaste omgeving alsook van de maatschappelijke context; te denken valt aan psycho-educatie, het scheppen van voorzieningen zoals werkvoorzieningen, maar ook het beînvloeden van de samenleving zelf door middel van voorlichting.

Deze en andere beïnvloedingsakties ten behoeve van de bevordering van de sociale aanpassing van de patiënt dan wel het tegengaan van uitstotingsprocessen worden voor de doelgroep "ambulante chronisch psychiatrische patiënten" ook wel samengevat onder de term "structurerende begeleiding" afgestemd op een optimale inbedding in en met een eigen persoonlijk milieu (Richartz, 1981; Romme, Breuls, 1985) te onderscheiden van programma's voor sociale integratie van groepen psychiatrische patiënten in bijvoorbeeld beschermende woonvormen (Van Lieshout, Van Zuthem, 1991).

De hierboven gegeven drieslag voor sociale integratie op te valten als sociale aanpassing impliceert achtereenvolgens een inbreng van de patiënt zelf, van zijn omgeving in engere en in bredere zin en van de wisselwerking tussen de patiënt en zijn sociale context. De eerste vraag die gesteld kan worden luidt wat brengt de ambulante chronisch psychiatrische patiënt zelf in om zich staande te houden in de wisselwerking met zijn omgeving. Een antwoord op deze vraag wordt gegeven aan de hand van het gangbare profiel van deze doelgroep in de ambulante psychiatrische hulpverlening (zie $\$ 2.2 .1$ ). Vervolgens is er de vraag naar de inbreng vanuit de omgeving van de patiënt met het oog op zijn sociale integratie. De verwachtingen die hieromtrent gewoonlijk naar de omgeving uitgaan worden weergegeven in $\S 2.2 .2$.

\subsubsection{Profiel van de ambulante chronisch psychiatrische patiēnt}

Hoe of waaraan ambulante chronisch psychiatrische patiënten herkend kunnen worden is niet zo gemakkelijk te zeggen. In de eerste plaats zijn ambulante chronisch psychiatrische patiënten niet altijd te scheiden van chronisch psychiatrische patienten aan wie intramuraal hulp geboden wordt. Een deel van de ambulante chronisch psychiatrische patiënten is éen of meerdere malen voor kortere of langere tijd intramuraal in zorg geweest. Omgekeerd gezien is dat eveneens het geval (Ten Horn, Giel, 1978). Bovendien is het niet zeker of psychiatrische patiënten die langdurig ambulant behandeld worden en nog niet eerder intramuraal opgenomen zijn geweest niet later wel in een psychiatrisch ziekenhuis in zorg zullen zijn. De inhoudelijke omschrijving van de patiënt hangt dan ook onder meer af van de plaats waar de patiënt op dat moment in zorg is. De beschrijving van de ambulante en de intramurale 
Het komt er op neer dat ambulante chronisch psychiatrische patiēnten worden gezien als "gedragsmoeilijke" mensen die persoonlijk en maatschappelijk desintegreren, dat wil zeggen "door het sleeds maken van moeilijkheden - en dat betreft vrijwel alle levensgebieden - hebben ze een steeds kleinere kring van sociale contacten gekregen, tot ze helemaal uitgestoten en eenzaam zijn. Dikwijls blijft alleen het contact met andere uitgestotenen uit de maatschappij over, wat meestal ook teleurstelt" (Verhagen, 1984). Bij deze patiënten is er een ernstige risico dat zij in een proces van toenemend marginaal maatschappelijk functioneren terecht komen.

\section{Beperkt probleemoplossend vermogen}

Naast 'gedragsmoeilijk' is kenmerkend dat bij de ambulante chronisch psychiatrische patiënt het 'probleemoplossend vermogen' beperkt is (Stein, Test, Marks, 1975), een gegeven dat volgens Rotteveel (1987) niet los gezien kan worden van "een vaak beperkte intelligentie, beperkt leervermogen en gebrek aan inzicht in het eigen aandeel in de problematiek". De beperkingen in het probleemoplossend vermogen hebben tot gevolg dat zij op moeilijke situaties reageren met 'uitzonderlijk gedrag' hetgeen weer aanleiding kan zijn voor nieuwe problemen en uitstotingsreacties in de omgeving (Richartz, 1981; Uffing e.a., 1987). Reageren op moeilijke situaties met 'uitzonderlijk gedrag' komt nagenoeg overeen met wat Verhagen (1984) noemt: "met psychiatrische symptomen uiting geven aan ernstige moeilijkheden in de levensomstandigheden". Het uitzonderlijk gedrag betreft bij chronisch psychiatrische patiënten in de ambulante psychiatrische hulpverlening een scala van ziektebeelden dat in feite de gehele psychopathologie omvat (Calaço Delmonte, 1979; Honig, 1989). De diagnosecategorieèn die er uitspringen komen overeen met de zogenaamde risicocalegorieën voor chronisch psychiatrische invaliditeit, te weten: "schizofrene en paranoide psychosen, affectieve stoornissen (manisch depressieve psychosen en depressie) en overige stoornissen zoals die als gevolg van een organisch defect, persoonlijkheidsstoornissen en fobische en dwangmatige aandoeningen" (De Jong, 1991). De bron van wat samenvattend als 'psychiatrische invaliditeit' aangeduid kan worden blijkt algemeen gelokaliseerd te worden in het 'ernstig gestoord probleem oplossend vermogen van de patiënt".

Deze eigenschap die als basaal wordt gezien voor de aanwezigheid van de eerder genoemde hoofdkenmerken en de continuering ervan heeft in de RIAGG Maastricht zeker aanvankelijk bij de opzet van een hulpverlening specifiek gericht op de ambulante chronisch psychiatrische patiënt een belangrijke rol gespeeld (Hilberink, 1978; Richartz, 1979). Het gaat om de volgende gedachtengang: in tegenstelling tot de (ambulante) chronisch psychiatrische patiënt is de 'gezonde' mens iemand die in het algemeen in een redelijk evenwicht met zijn omgeving functioneert. Dit betekent dat zo iemand zich redelijk in zijn omgeving kan handhaven en de optredende problemen op een redelijke manier weet te hanteren en op te lossen. De (ambulante) chronisch psychiatrische patiënt ontbeert dit redelijk evenwicht wat af te leiden is uit:

- $\quad$ het ontevreden zijn over eigen functioneren;

- hel niet adequaat kunnen hanteren van optredende problemen en daarvoor 'vreemde' oplossingen kiezen;

- het niet in staat zijn de 'aanvaarde' status-, positie- en situatierollen (Philipsen, 1976)) op een onderscheiden en doeltreffende manier te vervullen (Romme, e.a., 1987).

Volgens Hilberink (1978) gaat het bij ambulante chronisch psychiatrische patienten, de doelgroep van de SPD van de RIAGG Maastricht, niet om mensen met een "tijdelijk dan wel partieel verstoord probleemoplossend vermogen" maar om mensen met een "sterk en onherstelbaar beschadigd probleemoplossend vermogen" Het komt er op neer dat verondersteld wordt dat aan de eerder genoemde hoofdkenmerken in het profiel van ambulante chronisch psychiatrische patiënten een beschadiging van het 'probleemoplossend vermogen' bij de patiënt zelf ten grondslag ligt die hier vrijwel als onherstelbaar wordt beschouwd. 
Bovenstaande schets over de ambulante chronisch psychiatrische patient en zijn functioneren bouwt bepaald geen rooskleurig beeld op omtrent de inbreng van de patient zelf als het gaat om hulpverlening gericht op het herstel of de bevordering van zijn sociale integratie. Op vrijwel alle levensgebieden hapent hel of gaat het mis en lijkt de ambulante chronisch psychiatrische patiënt derhalve actief geholpen te moeten worden, terwijl de leerdoelen beperkt worden beschouwd. Alles bij elkaar verschijnt er vanuit een zekere gesystematiseerde waarneming van de hulpverlening een overwegend somber beeld omtrent de mogelijkheden van sociale integratie bij ambulante chronisch psychiatrische patienten. Van een actieve inbreng van de zijde van de patiënt lijkt weinig verwacht te worden.

\subsubsection{De soclale omgeving en het perspectlef op sociale integratie}

Een volgende vraag die aan de orde is luidt: hoe ziet in het algemeen het beeld over de inbreng van de sociale omgeving van de patiënt eruit ten behoeve van zijn sociale integratie dan wel het tegengaan van uitstotingsprocessen.

In de gegevens die in de spaarzame beschrijvingen over de ambulante chronisch psychiatrische patiènt worden aangereikt is er eigenlijk ogenblikkelijk een koppeling te vinden tussen zijn persoonlijke inbreng en zijn functioneren met andere mensen in de naaste omgeving. Echter de vermelde ernstige problemen die in de omgang met andere mensen optreden worden nagenoeg teruggevoerd op de ambulante chronisch psychiatrische patiënt zelf. De bron van het gedrag dat door de omgeving als "bedreigend wordt ervaren", "dat vaak aanleiding geeft tot uitstotings-reacties", het gedrag "dat mede veroorzaakt wordt door de gestoorde communicatie [....] en een belasting voor de omgeving kan zijn" is in wezen de patiënt zelf en is gelegen in "zijn ernstig verstoord probleemoplossend vermogen" en "zijn subjectieve ervaringswereld die moeilijk toegankelijk is" (Richartz, 1979). De patiënt zelf wordt hier voornamelijk gezien als de bron van zijn eigen sociale dysfunctioneren en van het onvermogen van andere mensen om met de patiént om te gaan.

Daarnaast komt binnen het zogeheten 'Expressed Emotion' (EE) onderzoek (Leff, Vaughn, 1981) naar voren dat het ook van het vermogen van de naasle omgeving om met de patiênt om te gaan afhangt hoe deze op zijn beurt functioneert (Asselbergs, 1986). Hoewel het EE-concept betrekking heeft op en ontstaan is aan de hand van schizofrene patiënten en dat naast het emotioneel relationele klimaat ook factoren als psychofarmacatrouw en de aanwezigheid van emotioneel belastende gebeurtenissen in de zin van 'life events' een rol spelen en tenslotte het concept zelf de nodige kritische kanttekeningen krijgt (Hulsman, 1989) kan niet bepaald verontachtzaamd worden dat een kritische, overbetrokken of vijandige omgeving ten opzichte van de patiënt in het algemeen nadeliger is voor zijn functioneren dan wanneer er sprake is van een warme en positieve omgeving.

Overigens zijn er voor zover nagegaan is kunnen worden nauwelijks studies te vinden waarin de naaste omgeving zelf aan het woord komt over haar ervaringen en opties inzake het dagelijks functioneren van en met de ambulante chronisch psychiatrische patiënt. In een onderzoek van De Weyer (1989) in het kader van het Psychose Preventie Project uitgevoerd bij de aldeling Volwassenenzorg RIAGG Centrum West te Rotterdam komen ouders van ambulant behandelde schizophrene patiënten aan het woord. Deze ouders brengen tal van moeilijkheden in de omgang thuis met hun 'schizophrene' jong volwassen zonen en dochters ter sprake. Eigenlijk worden op alle levensterreinen ernstige moeilijkheden ervaren. De Weyer geeft aan dat een probleem bij dit Project is dat de moeilijkheden die de ouders inbrengen geherformuleerd en geînterpreteerd worden als gevolgen van de ziekte van het kind, te weten: "een te snelle werking van de hersenen en een overgevoeligheid voor prikkels of indrukken en een verstoring van de informatieverwerking". In dit project treedt een discrepantie op tussen de 'leken-psychologische' inzichten van de ouders en de 'medische ziektemetaforen die in de uitgangspunten van het behandelingsprogramma figureren" van de betrokken hulpverleners, hetgeen volgens De Weyer lot de merkwaardige situatie leidt dat deze ouders "wel veel andacht krijgen maar in een aantal gevallen geen aandacht voor hun eigen problemen". 
In een onderzoek van de Stichting Pandora en de Stichting Labyrint (Horn, 1986) komen familieleden van intramurale chronisch psychiatrische patiēnten aan het woord. Dit onderzoek waarin de inbreng uit de naaste omgeving niel geherformuleerd wordt zodat er uitgepraat kan worden werpt enig licht op de problemen die in de naaste omgeving ervaren worden ten aanzien van de patiênt en de psychiatrische hulpverlening. Naar het laat aanzien staan de bevindingen niet haaks op het profiel van de ambulante chronisch psychiatrische patiënt. Een belangrijke uitkomst is de onzekerheid van de naaste omgeving hoe te handelen als er echt iets mis gaat, de problemen escaleren en schrik en angst optreedt. Mensen in de naaste omgeving blijken behoefte te hebben aan informatie over de problematiek en de rechtspositie van de patiënt enerzijds en over hun eigen positie naar de hulpverlening anderzijds. In dit onderzoek van Horn (1986) geven de familieleden aan dat ze zich buiten de ontwikkelingen voelen staan die de patiënt doormaakt en dat de patiënt los staat van de veranderingen die in de naaste omgeving optreden. Een belangrijke klacht is dat de familie vooral meetelt als onderdeel van de psychopathologie en van de problemen van de patiënt hetgeen reeds aanwezige schuldgevoelens versterkt terwij] ervaren wordt dat hulp voor hen niet echt beschikbaar is. Een studie van Methorst (1985) laat zien dat de partners van ambulant behandelde patiënten overwegend negatieve ervaringen met de hulpverlening melden.

Kenmerkend voor het profiel van de patiënt is dat tevens en over langere tijd de psychiatrische hulpverlening tot zijn omgeving behoort en ook haar omgang met de patiënt niet zelden vol angels en voetklemmen zit. De opgesomde gedragsmoeilijkheden van ambulante chronisch psychiatrische patiënten houden immers niet op bij de voordeur van de hulpverlener. De moeilijkheden blijken onvermijdelijk onderdeel van de omgang met de hulpverleners te zijn hetgeen bij herhaling interactiepatronen oplevert die gemakkelijk tot discontinuïteit leiden. Uffing e.a. (1987) merken hierbij op: "de behandeling verloopt zelden volgens van tevoren in samenspraak met de patiënt (en eventueel andere bij hem betrokken personen) uitgestippelde lijnen". Dit betekent dat de omgang tussen de hulpverlening en ambulante chronisch psychiatrische patienten algemeen als zeer gecompliceerd wordt ervaren en beschreven. Er dient zich een veelheid van ernstige problemen aan terwijl tegelijk in de loop van de tijd de mogelijkheden voor verandering beperkt blijken te zijn.

Volgens Rotteveel (1987) wordt de communicatie tussen de hulpverlener en de patiënt bemoeilijkt door verwachtingen bij de hulpverlener over de zogeheten "eigen verantwoordelijkheid" waaraan de patiënt niet kan voldoen. Giel (1984) onderkent eveneens het probleem van de "irreële verwachting dat geestelijk gestoorde mensen zelf de verantwoordelijkheid kunnen dragen voor de continuïteit van de begeleiding en behandeling"; hij verwijst naar het werk van o.a. Braff en Lefkowitz (1979) en Tessler en Mason (1979) betreffende intramurale chronisch psychiatrische patiënten. Een ander probleem is dat er tussen hulpverlener en patiënt gemakkelijk en over langere tijd geen overeenstemming bestaat of onduidelijkheden blijven bestaan over de hulpvraag. Vervolgens is er het probleem van de onzekerheid over de veranderingsmogelijkheden bij de patiënt. Er is moeilijk vooruitgang te constateren. Er wordt volgens Romme e.a. (1987) "bij de hulpverleners vaak een beroep gedaan op hun uithoudingsvermogen en creativiteit". Een niet onbelangrijk probleem zit tenslotte in het beeld dat de hulpverlener van de eigen beroepsrol heeft. Deze rol is georiënteerd op behandeling terwijl veel aktiviteiten in de omgang met de patiënt nauwelijks of in het geheel niet aan dit beeld beantwoorden.

Bovenstaande schets over het gangbare perspectief op de naaste omgeving en haar mogelijkheden voor sociale integratie van de patiënt is er een die voornamelijk samengesteld is door de hulpverlening en tekent in wezen de moeite die de hulpverlening zelf ondervindt in de omgang met de patiënt. Echter voor sociale integratie van de patiënt is de medewerking van de samenleving zowel in engere als in brede zin onvermijdelijk en noodzakelijk (Querido, 1952,1980) en wil die vereisle medewerking verkregen worden dan moeten er wat Konopka (1971) noemt "moeilijke krachten in de patiënt en in zijn menselijke omgeving - inclusief de hulpverlening - 
overwonnen worden". Hel gaat bij 'moeilijke krachten' ondermeer ook om processen van 'etikettering' (Scheff, 1969) en 'stigmatisering' (Goffman, 1973).

Voor een beter begrip in de psychiatrische hulpverlening omtrent het ontstaan, de opbouw en de continuering van dit weerbarstige krachtenveld dat resulteert in vermijding en uitstoting en een vergaande afhankelijkheid van de (ambulante) psychiatrische hulpverlening zelf enerzijds (Trimbos, 1982) en de omkering van de daaraan verbonden processen anderzijds wijzen Romme en Breuls (1985) on Rolteveel (1987) op het 'Social Breakdown Syndrome' (SBS) zoals beschreven door Gruenberg (1974). Het is echter de vraag waar ten behoeve van de omkering van de binnen het SBS beschreven processen van toenemende verwijdering van de naaste omgeving en uit de maatschappelijke context het accent van hulpverlening wordt gelegd: op het onvermogen van de patient dat in het hierboven aangegeven profiel van de ambulante chronisch psychiatrische patiënt en zijn omgang met de omgeving gemeengoed lijkt te zijn of op de wisselwerking tussen de patient en zijn omgeving. Doet men het eerste dan schept men zoals Nijhof (1978) beschrijt wellicht ongewild telkens opnieuw ruimte voor processen van individualisering en uitstoting. De verwijzing naar het SBS impliceert hier een accent van hulpverlening op de interactie van de patiënt en zijn omgeving, een oriëntatie die in eerste instantie is uitgewerkt in de zogeheten 'Probleemanalyse' (Radstake, 1985). De 'Probleemanalyse' is een in en met de SPD Maastricht ontwikkelde systematiek van probleemexploratie ten gunste van een ambulante psychiatrische hulpverlening die enerzijds aanstuurt op de bevordering van "de integratie van de patiënt met zichzelf, met zijn naaste omgeving en met de maatschappij", en die tevens tegelijk "de processen van uitstoting van de patiënt, bijvoorbeeld ten gevolge van zijn storingen, onaangepastheid en zijn dreigend gedrag die op gang gebracht zijn en in stand worden gehouden door zijn omgeving en de maatschappij tegengaat" (Romme, Breuls, 1985). In de volgende paragraaf 2.3 wordt nader op de 'Probleemanalyse' teruggekomen.

Tenslotte, de door de SPD in 1979 geformuleerde doelstelling "de bevordering van de sociaal integratie en het afremmen van uitstotingsprocessen" staat niet op zichzelf. Ze komt tot stand in een tijdsgewricht waarin een verschuiving van individu gebonden naar meer interactioneel / systeemgerichte referentiekaders plaats vindt terwijl tevens het psychiatrisch ziekenhuis heftig bediscussieerd word, er een heroriëntatie van intra- en semimurale voorzieningen in de geestelijke gezondheidszorg plaats vindt, een decentralisatie van beleid wordt gestimuleerd en waarin tenslotte de RIAGG-vorming gestalte krijgt (Trimbos, 1975; Schrameijer, 1982; Van der Poel e.a., 1985). Deze ontwikkelingen zijn op te vatten als bouwstenen voor de zogeheten "Tweede Nota Geestelijke Volksgezondheid (Ministerie van WVC, 1984), waarin de volgende optie voor geestelijke gezondheidszorg dan wel (ambulante) psychiatrische hulpverlening geformuleerd wordt: "vanuit de optiek van de (potentiële) cliënt zal de zorg kwantitatief moeten verbeteren en de organisatie zodanig zijn dat de cliënt dichtbij huis en met zo min mogelijke verbreking van de sociale contacten wordt geholpen". Een ander belangrijk element is dat de zorg voor chronisch psychiatrische patiënten een hoge prioriteit krijgt.

Kortom: de doelstelling van sociale integratie en tegengaan van uitstotingsprocessen, zoals geformuleerd door de SPD in 1979 is ingebed in een discussie en beweging in de psychiatrische hulpverlening en de samenleving over de geestelijke gezondheidszorg die resulteen in een door de Rijksoverheid uitgesproken voorkeur van zorg in en met het sociale milieu van de patięnt, met bijzondere aandacht voor de chronisch psychiatrische patiënt (Van Londen, 1982). Dit streven - zou men kunnen zeggen - herinnert aan wat Querido reeds in 1946 opmerkt over de zorg voor (chronisch) psychiatrische patienten: "de mensch heeft de gemeenschap noodig zoals deze hem noodig heeft; zonder de gemeenschap kan hij zich niet verwezenlijken, is noch zijn zelfhandhaving, noch zijn voortbestaan gewaarborgd [......] hieruit moet dan noodzakelijkerwijs volgen dat ook in zijn psychische structuur de mensch in de eerste plaats gemeenschapswezen is, en dat een beschouwingswijze, waarbij niet anders sprake is dan van het geïsoleerde individu, misschien verwrongen, maar zeker onvolledig moet zijn". 
Voor de uitvoerbaarheid van een psychiatrische hulpverlening die zich richt op de sociale integratie van de ambulante chronisch psychiatrische patiěnt waarbij comform het SBS de interactie van de patient met zijn omgeving een zwaar accent krijgt, en wel vanwege een evidentie zoals verwoord door Querido (1946) dat de patiěnt evenals ieder mens voor zijn sociale integratie aangewezen is op een naaste omgeving van andere mensen, is door de vakgroep Sociale Psychiatrie RL en de SPD van de RIAGG Maastricht rondom 1980 de zogeheten 'Probleemanalyse' ontworpen (Radstake, 1985; Honig e.a., 1987). Deze 'Probleemanalyse' is tevens gebruikt als protocol voor gegevensverzameling in het 'Evaluatieproject Team Langdurende Structurerende Begeleiding' dal tussen 1981 en 1985 door de vakgroep Sociale Psychiatrie samen met de SPD Maastricht is uitgevoerd (Romme, 1985). In de 'Probleemanalyse' is een eerste versie voor een analyse en beschrijving van een sociaal netwerk opgenomen. De bevindingen die toen zijn verkregen (Baars, 1985) hebben in hoge mate de ontwikkeling van de in dit proefschrift gepresenteerde vraagstelling en methode van sociale netwerkanalyse beïnvloed. Allereerst een beknopte beschrijving van de 'Probleemanalyse' en de betekenis die er aan gehecht wordt waarna vervolgens de indertijd gevonden voorlopige resultaten worden gegeven betreffende de informatie die door de hulpverleners in de 'Probleemanalyse' over de wisselwerking van de ambulante chronisch psychiatrische patiënt en zijn naaste omgeving zichtbaar wordt gemaakt.

\subsubsection{De 'Probleemanalyse' bij de SPD Maastricht}

De bij de SPD Maastricht gebruikte 'Probleemanalyse' behelst een analyse en beschrijving van de volgende gebieden bij de (her)aanmelding van de ambulante chronisch psychiatrische patiènt (Radstake, 1985).

a De hulpverleningsgeschiedenis ofwel de patientcarrière.

b. Hel acluele funclioneren van de patiënt waarbij vier niveaus worden onderscheiden.

1 Het orgaanniveau bestaande uit een inventarisatie van lichamelijke klachten en ziekten en de eventuele aanwijzingen dat lichamelijke klachten van functionele aard zijn (Honig, 1988, 1989).

2 Het niveau van het individu waar het gaat om een systematische beschrijving van de psychopathologie en de eventuele ontwikkelingsstoornissen. De beschrijving van de psychopathologie eindigt met een classificatie conform de DSM-III met de beperking tot As I en As II. De beschrijving van de evenluele ontwikkelingsstoornissen is conform de stadia in de psychosociale ontwikkeling zoals die door Erikson (1963) onderscheiden zijn.

3 Het niveau van de kleine groep bevattend een beschrijving van het gezin waarvan de patiënt deel uitmaakt en andere emotioneel-relationeel belangrijke naasten met wie de patiënt contact heeft. Tevens wordt een beschrijving gegeven van de belangrijke interactiepatronen binnen deze groep(en) mensen waaraan de patient deelneemt.

Tenslolte vermeldt de probleemanalyse op het niveau van de kleine groep "een beschrijving van het sociale netwerk in de kleine groep", waarmee volgens Radstake (1985) het "milieu-onderzoek, dat ten gevolge van de dominantie van een psychotherapeutische attitude binnen de AGGZ wat in de vergetelheid is geraakt, weer in ere hersteld wordt". De beschrijving van het sociale netwerk betreft hier een inventarisatie van de mensen met wie de patiënt contact heeft waarbij, conform de indeling van Erickson (1975) een onderscheid wordt gemaak in verwanten, vriendschappelijke betrekkingen en personen die maatschappelijke diensten vertegenwoordigen. Vervolgens gaat het om een beschrijving van de functies die deze mensen voor de patiënt vervullen, een 
indeling die overwegend gebaseerd is op het raamwerk van de psychosociale basisbehoeflen van Weiss (1974).

4 Het maatschappelijk niveau waar hel gaat het om maatschappelijke veranderingen en psychotraumata samengevat onder de term 'live events' en de invloed evvan op het functioneren van de ambulante chronisch psychiatrische patiënt op de vier genoemde niveaus.

c De competentie van de patiënt en zijn omgeving inhoudend de beschrijving van de draagkracht (bijvoorbeeld het intelligentieniveau, de aanwezigheid van handicaps) bij de patiënt en zijn omgeving. Radstake (1985) merkt op dat dit gebied van de Probleemanalyse' het minst ontwikkeld is en een operationalisering ervan voor de 'Probleemanalyse' eigenlijk nog ontbreekt.

Met de 'Probleemanalyse' wordt ook beoogd dat de hulpverleners binnen een periode van drie maanden tot een zo volledig mogelijke verkenning en beschrijving van de persoonlijke toestand van de ambulante chronisch psychiatrische patient en zijn levenssituatie komen. Dit wordt van iedere hulpverlener ongeacht de discipline verwacht. Bij alle te stellen vragen wordt van de hulpverleners vervolgens verwacht de consequenties van de verkregen informatie voor de behandeling dan wel begeleiding van de ambulante chronisch psychiatrische patient aan te geven. Aldus gaat het bij het gebruik van de 'Probleemanalyse' om een 'systematische wijze van informatieverzameling die recht doet aan de complexiteit van chronische patiënten en die tevens aanknopingspunten biedt voor een in te stellen behandelings- of begeleidingsplan" (Radstake, 1985). Tenslotte wordt verwacht dat het gezamelijk gebruik van de 'Probleemanalyse' op termijn de teamvorming ten goede komt ofwel in de lijn van Querido (1955) een praklische bijdrage levert aan "de integratie van de diverse disciplines en hun methoden en technieken en de weg opent voor een onderlinge samenhang tussen verschillende en uiteenlopende referentiekaders en daaraan ten grondslag liggende mensbeelden in de zorg". Al bij al herbergt de 'Probleemanalyse' het ideaal van wat Querido (1955) benoemt als 'integrale zorg' en kan ze beschouwd worden als een belangrijke opstap naar een ambulante psychiatrische hulpverlening waarin het overwegend sombere beeld van de ambulante chronisch psychiatrische patient en zijn naaste omgeving dat "aanvankelijk in fragmenten uiteenvalt weer samen gevoegd is ten einde de vraag te kunnen beantwoorden of en in hoeverre hel geïntegreerde beeld tot andere vraagstelingen en andere mogelijkheden van beantwoording kan leiden - en daarmee andere oplossingen in het vooruitzicht stelt dan de beschouwing van onderdelen zou doen verwachten". De vraag die hier nu aan de orde is luidt: welk beeld geeft de informatie van de 'Probleemanalyse' over de sociale omgeving waarop de patiënt voor zijn sociale integratie is aangewezen.

\subsection{2}

\section{Het beeld van de sociale omgeving in de 'Probleemanalyse'}

Zoals hierboven vermeld is in de 'Probleemanalyse' op het niveau van de 'kleine groep' een eerste voorlopige versie van de analyse en beschrijving van een sociaal netwerk opgenomen. Deze eerste opzet behelsde in hoofdlijnen het schema van een persoonlijk sociaal netwerk, onderverdeeld in kenmerken omtrent structuur en functies, dat binnen een samenwerkingsverband tussen het 'Clarke Institute of Psychiatry' en het 'Department of Psychiatry' van de Universiteit van Toronto door Walker, MacBridde en Vachon (1977) samengesteld is. (Vooruitlopend kan opgemerkt worden dat dit schema van de structuur en de functies in een persoonlijk sociaal netwerk als basis heeft gediend vanwaaruit, en eveneens beïnvloed door het sociale netwerkonderzoek aan de Universiteit van Toronto (Wellman, 1988), het 'model van een persoonlijk sociaal netwerk' is ontwikkeld zoals dat in hoofdstuk 5 van dit proefschrift ontvouwd wordi).

Bij 50 probleemanalyses is aldus nagegaan welke gegevens de betreffende hulpverleners van de SPD Maastricht schriftelijk vastleggen over de omvang van het sociale netwerk, over de gevarieerdheid en de bereikbaarheid van de mensen in de naaste omgeving en over het contact tussen de patiënt en de mensen die zijn nelwerk vormen (Baars, 1985). De bevindingen over de registratie van de sociale omgeving 
Een eerdere praktische kennismaking met de sociale netwerkaanpak (Baars, 1984) en een nadere bestudering van deze werkwijze in en met het sociale milieu, die in het volgende hoofdstuk 3 in hooldlijnen weergegeven wordt, leveren een volgende blauwdruk op. Een 'persoonlijk sociaal netwerk', door Speck en Attneave (1973) omschreven als "al die mensen met wie iemand - in dit geval een ambulante chronisch psychiatrische patiént - min of meer duurzame banden onderhoudt voor de vervulling van zijn dagelijkse levensbehoeften" kan benut worden als eenheid en uitgangspunt van ambulante psychiatrische hulpverlening voor het herstel dan wel de bevordering van de sociale integratie van de patiënt. Het werk van Speck en zijn collega's biedt uitzicht op een ambulante psychiatrische hulpverlening waarin de 'moeilijke krachten' (Konopka, 1963, 1971) die aanwezig zijn in het gangbare profiel van de ambulante chronisch psychiatrische patiënt $(\S 2.2 .1$ ) en van zijn naaste omgeving ( $\$ 2.2 .2$ ) enerzijds en in de gebruikelijke techniek van ambulante psychiatrische hulpverlening (§ 2.3.2) anderzijds omgebogen kunnen worden wanneer niet de patiënt alleen maar het gehele sociale netwerk inclusief de patiënt wordt aangesproken op de doelstelling van sociale integratie dan wel het tegengaan van processen van uitstoting.

Een nadere bestudering van de eerdere toepassing van 'sociale netwerkanalyse' in wetenschappelijk onderzoek naar het sociale netwerk van mensen en betrekkingen waarvan de psychiatrische patiënt deel uitmaakt (onder anderen Erickson, 1976, 1984; Cohen, Sokolovsky, 1978) - weergegeven in hoofdstuk 4 van dit proefschrift toont "een veelbelovende richting van sociaal wetenschappelijke systematiek en analyse" (Meuller, 1980) waarmee primair de sociale integratie van doelgroepen van (ambulante) psychiatrische hulpverlening bestudeerd wordt (Erickson, 1988).

\subsubsection{Sociale netwerken: een structuur van mensen en betrekkingen}

Een niet onaanzienlijke moeilijkheid is evenwel dat het belangwekkende pionierswerk van de sociale nelwerkinterventies niet in die mate gesystematiseerd is aangetroffen dat volmondig gesproken kan worden van een methode van ambulante psychiatrische hulpverlening en vervolgens dat de operationalisatie en werkwijze van sociale netwerkanalyse in wetenschappelijk onderzoek op het terrein van de psychiatrie van zeer uiteenlopende aard is. De weg die afgelegd is naar een samenhangend geheel van sociale netwerkinterventies en sociale netwerkanalyse op basis waarvan, overeenkomstig het uitgangspunt van wetenschappelijk sociaal psychiatrische onderzoek dat 'de wetenschappelijke analyse niet zozeer een doel op zichzelf is maar veeleer informatie dient op te leveren die toepasbaar is in de psychiatrische (hulpverlenings-)praktijk' (Romme, Kraan, Rotteveel, 1981; Erickson, 1984), wordt weergegeven in hoofdstuk 5. De hoeksteen in de voorgestelde samenhang is het begrip 'structuur' op geleide van de sociologisch anthropologische traditie van Barnes (1954) en Bolt (1957, 1971) en verder uitgewerkt in de lijn van Wellman (1981) in de zin van 'sociale netwerkanalyse behelst primair de analyse van de structuur van mensen en betrekkingen'.

Het is deze hoeksteen die vervolgens zowel uit de nog jonge tradilie van de sociale netwerkinterventies alsook uit die van het nog prille sociale netwerkonderzoek betrelfende doelgroepen van (ambulante) psychiatrische hulpverlening de bouwstenen aanreikt waarmee een model van een persoonlijk sociaal netwerk is uitgewerkt. Aan de hand van het voorgestelde model is de zogeheten 'Maastrichtse Sociale Netwerk Analyse' (MSNA) ontwikkeld waarvan gebruik is gemaakt in het onderzoek naar 'de structuur van sociale netwerken bij ambulante chronisch psychiatrische patiënten' dat in dit proefschrift wordt gepresenteerd. Het komt er op neer dat de sociale integratie van mensen - zowel op patiěntniveau in de praktijk van de ambulante psychiatrische hulpverlening alsook wetenschappelijk op groepsniveau - te analyseren en te beschrijven is aan de hand van de structuur van een persoonlijk sociaal netwerk van mensen en betrekkingen, te concretiseren in: 
- de omvang of het totaal aantal mensen die tot een persoonlijk sociaal netwerk gerekend worden,

- de gevarieerdheid van deze netwerkleden,

- de bereikbaarheid van de netwerkleden

- de structuur van de betrekkingen met de netwerkleden.

Toegepast op patiëntniveau vormt de MSNA onder meer de ontbrekende schakel van de fase van diagnostische aktiviteiten in de door Speck en zijn collega's gesystematiseerde werkwijze inzake de uitvoering van sociale netwerkinterventies. In de dagelijkse praktijk van de ambulante psychiatrische hulpverlening belicht de MSNA aldus in termen van een structuur van mensen en betrekkingen de mate van sociale integratie van de patiënt en de af- dan wel aanwezige hulpbronnen voor de opbouw of de reorganisatie van de structuur van het persoonlijke sociale netwerk van de patiënt (Baars, Uffing, Dekkers, 1990).

\subsubsection{Onderzoek naar de structuur van sociale netwerken}

Het onderzoek naar de structuur van persoonlijke sociale netwerken van chronisch ambulante psychiatrische patiënten in zorg bij de SPD van de RIAGG Maastricht dat in dit proefschrift centraal staat heeft ten behoeve van een verdere ontwikkeling van de werkwijze van de sociale netwerkinterventies en de implementatie ervan in de ambulante psychiatrische hulpverlening tot doel:

- meer inzicht te krijgen in de mogelijkheden alsook de beperkingen van de aanwezige structuur van mensen en betrekkingen waarop de patiënt voor zijn sociale integratie is aangewezen;

- in de aangetroffen structuur van de persoonlijke sociale netwerken van de doelgroep van de SPD aangrijpingspunten te vinden voor de ambulante psychiatrische hulpverlening die de bevordering dan wel het herstel van de sociale integratie van deze patiënten ten goede komen.

Al bij al is in dit onderzoek aan de orde of de belichting van het sociale milieu in termen van een structuur van mensen en betrekkingen aan de hand van het in de vakgroep Sociale Psychiatrie RL ontwikkelde model, geconcretiseerd in de zogeheten Maastrichtse Sociale Netwerk Analyse (MSNA), andere en nieuwe informatie geeft ten behoeve van de doelstelling van sociale integratie dan binnen de gebruikelijke hulpconstructies in de geestelijke gezondheidszorg het geval is. In concreto staan dan ook de volgende twee vragen centraal.

A Laat de hier ontwikkelde MSNA en de gebruikte werkwijze van sociale netwerkanalyse een structuur en patronen in het persoonlijke sociale netwerk van ambulante chronisch psychiatrische patiënten zien die verschillen toont met die van normale referentiepersonen?

B In hoeverre zijn de betreffende hulpverleners van de SPD in staat de kenmerken van de structuur van mensen en betrekkingen waarop de patiént voor zijn sociale integratie is aangewezen vast te stellen als door hen geen gebruik wordt gemaakt van een analyse van de structuur van een persoonlijk sociaal netwerk? 


\section{SOCIALE NETWERKSTRATEGIEEN EN PSYCHIATRISCHE HULPVERLENING}

In dit hoofdstuk wordt chronologisch een overzicht gegeven van de achtergronden en de ontwikkeling van de sociale netwerkbenadering van Speck, Attneave en Rueveni aangegeven wordt hoe in het kader van dit onderzoek bij deze werkwijze is aangesloten en ermee verder gewerkt is ten behoeve van de ontwikkeling van een hulpverleningsmethode die zich specifiek richt op de sociale integratie van ambulante chronisch psychiatrische patiènten.

\subsection{AFBAKENING}

Het begrip sociale netwerkstrategieën/-interventies verwijst in de meest brede zin naar werkwijzen in de (psychiatrische) hulpverlening waarbij in termen van een sociaal netwerk op de een of andere manier het sociale milieu van de patiènt in de zorg een centrale plaats krijgt. Het lijkt er soms veel op dat het begrip 'sociale netwerk' een modewoord is. Waar termen als sociale milieu, sociale factoren, sociale omstandigheden een rol spelen spreekt men gemakkelijk over sociale netwerkvariabelen. Deels is er ook sprake van een inruil van terminologie. Echter de loepassing van het beeld van een sociaal netwerk in de psychiatrische hulpverlening geeft wel degelijk ook een wijziging in het denken over en de aanpak van de zorg voor (chronisch) psychiatrische patienten weer. Het gebruik van het beeld sociale netwerk' geeft uitdrukking aan een streven naar zorg 'in en met het sociale milieu' van de patiënt en verwijst meer specifiek naar een aantal strategieën in de psychiatrische hulpverlening waarbij daadwerkelijk - hoewel In verschillende mate - het sociale milieu primair in de zorg benut wordt. Globaal gaat het om de volgende twee hoofdlijnen (Erickson, 1984):

1 een lijn van hulpverlening waarin in verschillende mate het eigen ofwel persoonlijke sociale netwerk, te weten "al die mensen die in het dagelijks leven met de patient min of meer duurzame banden onderhouden" het uitgangspunt van hulpverlening is: de zogeheten sociale netwerkstrategieên (Speck, Altneave, 1973; Baars, Uffing, Dekkers, 1990);

2 een lijn van hulpverlening waarin ter compensatie en/of aanvulling van een persoonlijk sociaal netwerk de professionele zorg tijdelijk dan wel meer blijvend de patiënt de ondersteuning van informele hulp aanbiedt in de zin van interventies middels "sociale support netwerken" (Gottlieb, 1985); 
Het is lang niet altijd gemakkelijk beide hoofdlijnen uit elkaar te houden. In de dagelijkse praktijk van psychiatrische hulpverlening worden elementen uit beide hoofdlijnen aangetroffen (Baars, Uffing. Dreessen, 1991).

Waar in de psychiatrische hulpverlening sprake is van sociale 'support' netwerken gaat vooral om een inhoudelijke en praktische aansluiting bij het zogeheten 'socialsupport' concept (Bruhn, Philips, 1984; Schrameijer, 1990) waarvan Caplan (1964, 1974), Cassel (1974, 1976), en Cobb (1976) de belangrijke grondleggers zijn. Binnen deze sociaal psychologisch gefundeerde lijn (Turner, 1983) neemt onder meer Gottlieb $(1978,1981,1985)$ een prominente plaats in (Van Mierlo, 1992). Ruwweg kunnen twee typen interventies onderscheiden worden. Het eerste type bestaat uit interventies met behulp van ondersteuningsgroepen, waarin mensen met vergelijkbare probleemsituaties elkaar bijstaan, bijvoorbeeld in de vorm van zelthulpgroepen (Plog, 1986). Dergelijke ondersteuningsgroepen (Polister, Pattison, 1980) helpen de (chronisch) psychiatrische patiënt om weer het gevoel te krijgen het eigen leven beter onder controle te hebben, de vervreemding van de samenleving te verminderen, het eigen probleemoplossend vermogen te vergroten en te leren vertrouwen dat de dagelijkse moeilijkheden niet onoverkomelijk zijn (Naparstek, Biegel, 1982). In de laatste jaren zijn ook ondersteuningsgroepen voor familieleden van (chronisch) psychiatrische patiënten ontwikkeld (Fiedler, 1986; Buchremer, Lewandowsky, Hornung, 1989). Het tweede type interventies heeft betrekking op het vergroten van de ondersteunende werking van de hulpbronnen in de naaste omgeving van de patiënt, zoals het mobiliseren van informele hulp op specifieke levensgebieden dan wel het opzetten van programma's (bijvoorbeeld psycho-educatie) die de inzichten en vaardigheden van mensen in de naaste omgeving van de (chronisch) psychiatrische patiënt vergroten (Anderson, 1983; Vaugh e.a., 1984; Geelen, 1992).

De hoofdlijn van de sociale netwerkstrategieën, waarop in dit onderzoek wordt aangesloten, behelst specifieke varianten van zorg in en met het persoonlijke sociale netwerk van de patiënt. Zij bieden uitzicht op een hulpverleningsmethode waarin het sociale milieu in termen van een sociaal netwerk het organiserend beginsel is voor een (ambulante) psychiatrische zorg die zich richt op de bevordering dan wel het herstel van de sociale integratie van de (chronisch) psychiatrische patiënt en het tegengaan van uitstotingsprocessen (Baars, Uffing, Dekkers, 1990). In eerste instantie is deze aanpak ontstaan tegen de achtergrond van de gezinstherapeutische methoden en technieken, in het bijzonder de 'gezinsstructuurtherapie' van Minuchin (1974). Vervolgens heeft de werkwijze van de sociale netwerkstrategieën een ontwikkeling doorgemaakt die in de richting komt van wat Trimbos (1982) een "sociodynamische benadering" in de psychiatrische hulpverlening noemt.

In dit hoofdstuk word hoofdzakelijk ingegaan op de sociale netwerkbenadering zoals die uitgewerkt is door met name Speck, Rueveni en Attneave (Thaxton, L'Abate, 1982). Het is deze prakijklijn waarop het hier gepresenteerde onderzoek in hoge mate aansluit en die tevens tijdens de uitvoering van dit onderzoek verder uitgebouwd is (Baars, Uffing. Dekkers, 1990). Dit hoofdstuk beperkt zich tot de ontwikkeling van deze praktijkbenadering waarmee zichbaar gemaakt wordt waar en hoe deze aanpak uitzicht biedt op een hulpverleningsmethode voor de chronisch psychiatrische patiënt, waarin het sociale milieu zelf als de aangewezen plaats voor sociale integratie het organiserend principe van psychiatrische hulpverlening is.

Chronologisch zijn de volgende in het oog lopende momenten aan te wijzen die de weg markeren die Speck en zijn collega's hebben afgelegd bij de toepassing van het begrip sociale netwerk in hun dagelijkse praktijk van ambulante psychiatrische hulpverlening voor met name jongere chronisch psychiatrische patiënten met een groot aandeel van patiënten met schizofrene stoornissen, te weten:

1 een verschuiving in de lokalisatie van de psychopathologie van het individu naar het gezin, en daaraan verbonden de ontwikkeling van de gezinsstructuurtherapie (Minuchin, 1974).

2 de verplaatsing van de gezinstherapeutische aanpak van de spreekkamer naar de woning van het gezin (Speck, 1964)

3 de introductie van "netwerktherapie" (Speck, Rueveni, 1969); 
4 de systematische beschrijving van sociale netwerkinterventies (Speck, Attneave, 1973) en de opzet voor een diagnostiek van een 'gezinsnetwerk' (Altneave, 1975).

Dit hoofdstuk is overeenkomstig deze chronologie opgebouwd en wordt afgesloten met de aanknopingspunten die de sociale netwerkbenadering biedt voor een oplossing van de in hoofdstuk 2 genoemde problemen die de uitvoering van een streven naar sociale integratie van de chronisch psychiatrische patiënt hinderen dan wel belemmeren.

\subsection{VERSCHUIVINGEN IN OPVATTINGEN EN WERKWIJZE}

Geen naam is zo sterk met de sociale netwerkstrategieën verbonden als die van de sociaal psychiater Ross V. Speck te Philadelphia (USA). Hij is degene die als eerste in het midden van de zestiger jaren de term sociale netwerk binnen de praktijk van de psychiatrische hulpverlening heeft gebracht (Baars. 1984). Samen met Uri Rueveni en Caroline Attneave heeft hij dit begrip uitgebouwd tot een systematische werkwijze: de sociale netwerkinterventies (Speck, Rueveni, 1969; Speck, Attneave, 1973, 1983; Attneave, 1969,1980; Rueveni, 1979a). Speck is niet alleen een belangrijke grondlegger van de sociale netwerkstrategieën, deze benadering is ook zijn leven geworden. Dat laatste maakt dat wie met het werk van Speck in contact komt het bepaald niet gemakkelijk heeft om vit elkaar te houden waar hij zakelijk en inhoudelijk de sociale netwerkstrategieën bespreekt en waar hij zijn ideeën enthousiast de vrije loop laat. Wanneer men geen rekening houdt met zijn idealisme loopt men de kans vroegtijdig af te haken, hem eigenlijk niet serieus te nemen, met het resultaat dat men tevens niet meer aan de methode zelf toekomt.

\subsubsection{Van individu naar gezin}

Vanaf het midden van de jaren vijttig treedt er een belangrijke wijziging op in opvattingen inzake de lokalisatie van de pathologie bij psychiatrische patiënten (Bell, 1962; Erickson, Rachilis, Tobin, 1974). Deze verschuiving houdt in dat de pathologie, zoals een schizofrene stoornis niet langer alleen gelocaliseerd is in het individu waarbij onderzoek en hulpverlening zich concentreren op met name de individuele psycho-dynamiek, maar dat de optredende stoornis ook kan worden gezien als een eigenschap van het hele gezin waarvan de psychiatrische patiënt deel uitmaakt (Richter, 1970). De pathologie die bij de 'identified patiënt' te benoemen is wordt tevens opgevat als een uitdrukking van stoornissen in de interacties en communicatie binnen het hele gezin (Christensen, 1964; Paolino, McCrady, 1978). Naast en met aan de persoon gebonden biologische en (psycho)therapeutische methoden en technieken ontstaan de gezinsinteractionele werkwijzen in de psychiatrische hulpverlening. De opkomst en uitbouw van het gezinsinteractieonderzoek en de gezinstherapie is onder meer nauw verbonden met namen als Bell en Vogel $(1960)$, Bowen (1961,1966) en 'scholen' zoals het 'National Instilute of Mental Health' te Bethseda (USA) en hel 'Mental Research Institute' (MRI) te Palo Alto (USA) met onder andere de namen van Jackson (1968), Watzlawick (1967) en Haley (1959, 1971). Deze en andere namen en scholen hebben een grote betekenis gehad voor de implementatie en de ontwikkeling van de gezinstherapeutische werkwijzen in Nederland (Van Veen, Van der Meulen, 1970; Van der Pas, 1973; Hendrickx, 1991).

Speck en Rueveni bevinden zich te Philadelphia (USA) in de onmiddellijke omgeving van Salvador Minuchin, die eveneens algemeen tot de "eerste generatie gezaghebbenden gezinstherapeuten" wordt gerekend (Thaxton, L'Abate, 1982). De specialiteit van Minuchin is de "gezinsstructuurtherapie". In het kort komt zijn gedachtengoed er op neer dat in de eerste plaats de sociale context, hier begrenst tot die van het gezin, invloed heeft op de intrapsychische processen van mensen. Vervolgens stelt Minuchin dat veranderingen in deze sociale context veranderingen in het individu teweegbrengen; er is sprake van een voortdurende interactie tussen het individu en de sociale context van het gezin waarvan iemand onderdeel is. Tenslotte zegt Minuchin dat een therapeut die met een gezin werkt zelf deel wordt van dit sociale systeem. Gezin en therapeut vormen dan gezamenlijk een nieuw ofwel therapeulisch systeem. Deze 
doelbewuste invoeging verandert de gezinsstructuur en dit nieuwe therapeutische systeem zal dan ook het functioneren van het gezin als geheel en van de gezinsleden ałzonderlijk beïnvloeden en veranderen (Minuchin, 1974).

Satir (1972) noemt de volgende vier gebieden waarin door een doelbewuste invoeging van de hulpverlener in een gezin veranderingen optreden:

- in de gevoelens en ideeën die men over zichzelf heeft, ofwel in het gevoel van eigenwaarde;

- in de manieren die men er op nahoudt om de bedoelingen aan elkaar over te brengen ofwel de communicatie;

- in de regels die in acht worden genomen met betrekking tot gevoelens en daden;

- in de band met de maatschappij ofwel de manier waarop het gezin en de gezinsleden zich verhouden tot andere mensen en structuren buiten het gezin.

Onder meer beïnvloed door Minuchin (1974) ontwikkelt ook Speck zich tot gezinsstructuurtherapeut. Niet alleen inhoudelijk en qua technieken wijzigt Speck zijn individu gebonden aanpak, maar hij verlegt ook de plaats van 'behandeling'. In plaats van het kantoor binnen de hulpverleningsinstelling gebruikt hij het eigen huis en de woonkamer van het gezin als locatie voor therapeutisch handelen.

Naar het gezin thuis

Speck (1964) vindt dat gezinstherapie gewoon thuis bij de patiënt dient plaats te vinden. In de eigen woning is het gezin in haar eigen natuurlijke omgeving en is het de hulpverlener die op bezoek komt in plaats van andersom. Thuis zijn de gezinsleden in staat hun gangbare dagelijks gedrag te laten zien en daar blijven alle gezinsleden ook beter beschikbaar om aan de sessies deel te nemen.

Door te werken in de thuissituatie stoot Speck op een aantal aspecten die belangrijk zijn voor de voortgang en het effect van de gezinstherapeutische aanpak. In de spreekkamer van de therapeut betekent gezinstherapie over het algemeen dat behalve de patiënt alleen de ouders aanwezig zijn. Speck ontdekt dat in de spreekkamer vooral het gezinslid ontbreekt dat thuis achter de schermen een sleutelrol heeft in de dagelijkse besluitvorming. De medewerking van deze persoon - niet zelden een broer of zus van de patiënt - is volgens Speck cruciaal. Door in de thuissituatie te werken is het vervolgens veel beter mogelijk dat ook de jongere gezinsleden - bijvoorbeeld de jonge kinderen - voor kortere of langere tijd bij de sessies aanwezig zijn. Het valt Speck op dat juist deze gezinsleden dikwijls belangrijke bijdragen leveren met hun niet zelden zijdelingse schijnbaar onbewust gegeven opmerkingen. In de thuissituatie ontdekt Speck dat wat in de spreekkamer als hoogst vertrouwelijk wordt gebracht veelal op te valten is als een 'openbaar geheim'. Bijvoorbeeld: ouders presenteren soms zaken die ze beschouwen als iets wat alleen zijzelf weten. Speck merkt dat de andere gezinsleden bepaald niet zo naief zijn of geïsoleerd van hun ouders leven dat ze niet weten of vermoeden welke 'geheimen' dan wel delicate kwesties er spelen. Hij voert voor de gezinstherapie de regel in dat er tussen gezinsleden en therapeuten geen aparte vertrouwelijkheden bestaan.

Zoals al even aangegeven, de uitvoering van gezinstherapie in de thuissituatie heeft tol gevolg dat vrijwel alle gezinsleden betrokken raken/zijn bij de sessies. Er is vergeleken met de spreekkamer de directe aanwezigheid van veel meer leden van het gezin en hun onderlinge betrekkingen; er treden processen op in de interacties en communicatie die niet meer door één therapeut te overzien zijn. Speck voert hier het gezinstherapeutisch team in waardoor het onder andere mogelijk wordt doelbewust de aandacht over de gezinsleden te verdelen. Bovendien merkt Speck dat niet zelden familieleden buiten het gezin, zoals grootouders, een zwager, een zus van bijvoorbeeld de moeder, niet alleen dagelijks over de vloer komen, maar ook als vertrouwenspersoon functioneren. Speck begint ook hen erbij te betrekken en ontdekt hoe waardevol hun raad en daad kan zijn. Het zijn niet alleen familieleden, maar ook andere mensen uit de directe omgeving zoals vrienden, buren en kennissen die nauw verbonden blijken te zijn met wat zich in een gezin voordoet en die blijken te beseffen dat de problematiek niet alieen maar toegeschreven kan worden aan degene die als de patiënt wordt gezien. 
Wanneer Speck (1964) zijn ervaringen met zijn gezinstherapeutische aanpak ordent beschrijt hij in wezen een aantal belangrijke uitgangspunten die later teruggevonden zullen worden als de aanpak in de zin van sociale netwerkinterventies in kaart gebracht wordt (Speck, Attneave, 1973) te weten:

de hulpverlening dient plaats te vinden in het eigen gezinsmilieu van de patiènt, ofwel daar waar de patiënt leeft en woont;

- de te bieden hulp is een zorg van en met alle betrokkenen in deze eigen omgeving van de patiënt;

- er zijn geen aparte vertrouwelijkheden tussen hulpverleners en de patiënt en met de andere gezinsleden;

- het gezinsmilieu van de patiënt bestaat uit meer en minder bij de pathologie betrokken personen. De inzichten in de problematiek en meningen over de aanpak van degenene die minder bij de problemen betrokken zijn blijken bijzonder waardevol te zijn voor het doorzien en zoeken van oplossingen voor de problemen;

- tenslotte: deze gezinsstructuurtherapie impliceert teamwerk.

\section{3}

INTRODUCTIE VAN 'NETWERKTHERAPIE'

Bovenstaande geeft reeds aan dat er in de praktijk van psychiatrische hulpverlening van Speck en zijn collega's een vloeiende overgang is van gezinstherapie naar een aanpak waarin hij al die mensen die een belangrijke rol spelen in het dagelijks leven van de patiënt en diens gezinsmilieu in de behandeling erbij haalt. In de gezinstherapie ervaart Speck dat de begrenzing 'gezin' arbitrair is en het gezin als sociaal systeem een levend systeem is dat niet op zichzelf staat. Speck (1967a) geeft aan te beseffen dat "de sociale omstandigheden en de samenleving zelf een grotere rol spelen in de vervreemding van iemand in de verhouding met zichzelf en andere mensen dan menig hulpverlener traditioneel gewend is in te zien". Aan de hand van praktijkvoorbeelden benadrukt hij dat het zijns inziens niet te ontkennen is dat de psychiatrische symptomatologie zoals die benoemd wordt aan de patiènt zelf en aan het gezin waarvan de patiënt deel uitmaakt, tevens nauw verbonden is met de bredere sociale omgeving (Speck, 1967a, 1967b; Speck, Olans, 1967).

Speck is naar mijn mening een schoolvoorbeeld van wal iemand doet die merkı dat zijn denken en werkwijze weglopen uit de reguliere kaders van (psychiatrische) hulpverlening. Dan zoekt men bronnen die de eigen ontwikkelde praktijk en ervaringskennis aanvoelen en handvaten geven. Het belangrijkste handvat voor zijn inzichten, aanpak en vermoedens vindt hij bij het begrip 'sociale netwerk' in het boek "Families and social networks" van de antropologe Bott $(1957,1971)$ : "all or some of the social units - individuals or groups - with whom a particular individual is in contact".

Niet zozeer deze definitie en het analytisch concept van het 'sociale netwerk' van Bott (1957), waarop nader ingegaan wordt in \$ 4.2, maar hel beeld dat hier gegeven wordt helpt Speck en zijn collega's zoals Rueveni verder om de eigen inzichten en ervaringen te doorzien en uit te werken (Speck, Rueveni, 1969). De eerste oogst van de toepassing van het beeld 'sociale netwerk' en daarmee wordt het vervolgens een begrip, vindt men in de bijdrage "Networktherapy - a developing concept" van Speck en Rueveni (1969). Het is een titel die heel wel uitdrukt dat de toepassing van de term sociale netwerk de volgende effecten heeft:

hij brengt er zijn werkwijze en inzichten in onder en gaat spreken van 'netwerktherapie', in dit stadium op te vatten als een verbreding van de gezinsstructuurtherapie van Minuchin;

- er ontstaat een begrip 'sociaal netwerk' dat tevens functioneert als eye-opener. 
Met de term sociale netwerk ontstaat er een blauwdruk voor wat Speck en Rueveni in 1969 'netwerktherapie' noemen. De volgende hier in het kort weergegeven eerste modelmatige beschrijving van inzichten en aanpak komt tot stand.

\section{Probleemafbakening}

Niet meer het gezin is de begrenzing van het aangrijpingspunt voor psychiatrische hulpverlening. Het hele gezin waarvan één van de leden beschreven wordt met bijvoorbeeld schizofrene stoornissen, tesamen met de andere belangrijke familieleden en de vrienden, bekenden, buren van dit gezin is aangrijpingspunt van therapeutisch handelen. Dit geheel wordt omschreven als een sociaal netwerk ofwel als: "that group of persons who maintain an ongoing significance in each others lives by fulfilling specific human needs" (Speck, Rueveni, 1969).

\section{Hyoothese.}

Verondersteld wordt dat psychiatrische stoornissen samenhangen met deficiënties in bredere sociale lagen dan die van het gezin alleen. Toestanden die in de psychiatrie ais 'ziekte' worden aangeduid zijn op te vatten als stoornissen in de communicatie binnen het hele sociale netwerk van bijvoorbeeld een als schizofreen gediagnostiseerde persoon en zijn gezin.

\section{Hulpverlening}

De hulp die geboden wordt heet 'netwerktherapie' met het centrale doel de communicatie in het hele sociale netwerk te verbeteren, met name de communicatie tussen de gezinsleden en die met hun familie, vrienden, buren etc. In de netwerktherapie wordt naar dit doel gestreefd door processen op gang te brengen die de banden tussen de leden van een sociaal netwerk in zijn geheel versterken en de sterke gebondenheid van enkele personen aan elkaar doen verminderen. De netwerktherapie dient thuis bij de patiënt plaats te vinden (Speck, Morong, 1967). Het gezin krijgt bovendien zelf de taak het netwerk samen te stellen en uit te nodigen. Het netwerk verplicht zich tot minimaal zes sessies. ledere sessie heeft een karakteristiek verloop.

\section{Therapeutisch leam.}

Nadrukkelijk wordt gesteld dat voor netwerktherapie een multidisciplinair samengesteld team van hulpverleners nodig is; het gaat immers om een groot aantal mensen en een veelvoud aan interacties.

\section{Proanese.}

Er heerst optimisme over de resultaten van netwerktherapie. Deze aanpak, zo wordt aangegeven, blijkt de verhoudingen in het netwerk en in het gezin ten goede te wijzigen; er ontstaat wat genoemd wordt "een levensvatbare sociale structuur" om de aanmoedigingen, de verkregen steun maar ook zaken als een werkkring vast te houden en in plaats van een beroep op professionele hulpverlening te (blijven) doen vooral op de mogelijkheden van hulp binnen het eigen sociale netwerk te vertrouwen (Speck, Rueveni, 1969).

\subsubsection{Verbreding van de 'gezinsstructuur-therapie'}

Speck en Rueveni (1969) beschouwen de netwerktherapie, zoals hierboven beschreven, als een verbreding van gezinstherapie. Rueveni blijkt hierin ook later veel stelliger te zijn dan Speck. Rueveni $(1976,1977,1979$ a) blijft in de eerste plaats gezinstherapeut en gaat dan pas tot netwerktherapie over wanneer de gezinstherapie ernstig stagneert. Bijzonder is dat Rueveni voor gezinnen die 
nauwelijks een netwerk van mensen buiten het eigen gezin kunnen bijeenbrengen door hem getrainde vrijwilligers, zogeheten "netwerkactivisten", inschakelt om tijdelijk in de omvang en de behoeften van een persoonlijk sociaal netwerk te kunnen voorzien (Rueveni, Wiener, 1976).

Ook andere in zeker opzicht vergelijkbare varianten van hulpverlening onder de noemer netwerktherapie zijn te beschouwen als werkwijzen die overwegend in het verlengde liggen van de gezinstherapeutische methoden en technieken (Driedger, 1981; Angermeyer, Klussmann, 1989). Een paar voorbeelden: in de eerste plaats de 'intersystem conference' zoals aanwezig in het werk van Erickson, Rachilis en Tobin (1974), bij Curtis (1974) en bij Trimble (1980) een aanpak waarbij het werk van Auerswald $(1968,1972)$ van grote invloed is geweest; vervolgens de werkwijze in hel 'Network Therapy Program' van Havely e.a. (1984) en Schoenfeld (1984) en het netwerktherapieprogramma van Pattison e.a. (1975); tenslotte de zogeheten 'Screening Linking Planning (SLP) Conference Methode' van Garrison $(1974,1981)$ en van Garrison en Werfel (1977).

In de $z$ in van verbreding van de gezinstherapeutische benadering hebben de netwerktherapie van Speck en Rueveni (1969) en de daaraan verwante zo juist genoemde varianten met elkaar gemeen dat in deze werkwijze(n) wat Van der Pas (1973) noemt "de leenwoorden van de systeembenadering" (Von Bertalanffy, 1966) worden aangetroffen. Een belangrijk systeemtheoretisch leenwoord dat Speck en Rueveni (1969) in navolging van de gezinsstructuurtherapie van Minuchin (1974) overbrengen naar de netwerklherapie is het begrip 'structuur' (Steinglass, 1978). Dit betekent dat het begrip "structuur" in de netwerktherapie betrekking heeft op :

a de organisalorische kenmerken van het sociale netwerksysteem;

b de patronen die zich in de transacties binnen dit systeem aftekenen;

c de reaktie(s) van het sociale netwerk op stresserende situaties.

Het komt erop neer dat bij de invoeging van een therapeutisch team in het systeem sociale netwerk er een nieuw ofwel therapeutisch sociaal nelwerksysteem ontstaat. Deze invoeging beïnvloedt en verandert de genoemde structurele dimensies in het sociale netwerk als geheel als ook van haar subsystemen, in het bijzonder dat van hel subsysteem 'gezin', de kern waarvoor de sociale netwerktherapie opgezet is. Hel is de overwegende aanwezigheid van deze inhoudelijke context dat het naar mijn mening meer voor de hand ligt hier over netwerk-structuur-therapie te spreken (Erickson, 1988). De ervaringen die in de dagelijkse praktijk met deze verbreding van de 'gezinstructuurtherapie' worden opgedaan leiden evenwel tot nieuwe gezichtspunten.

Nieuwe invalshoeken

Vanuit de praktische loepassing van de netwerktherapie vragen Speck en Rueveni (1969) zich onder meer af of hel sociale netwerk van een zogeheten 'pathologisch gezinssysteem' op te vatten is als de belangrijkste schakel tussen 'ziekte' in de cultuur en 'ziekte' binnen een gezin. Deze overweging op zich geeft aan dat in hun denken, en dat geldt in het bijzonder voor Speck, het psychologisch apriori (Paolino, McCrady, 1978; Cohen, 1984) aan gewicht verliest en meer en meer sociologische en anthropologische invalshoeken zoals van Hill en Hansen (1960), Sussman en Burchinal (1962) en Jay (1964) in hun meningsvorming over psychiatrische problemen op de voorgrond treden. Het probleem is echter dat niet alleen in dit stadium maar ook later deze optie nauwelijks uitgewerkt wordt maar slechts terloops en fragmentarisch aan de orde komt. Maar wellicht mag een inhoudelijke en wetenschappelijk gefundeerde doordenking ook niet verwacht worden. De nieuwe gezichtspunten bij Speck en zijn collega's die doorwerken zijn vooral van praktische aard. Dat geldt in het bijzonder voor de meningsvorming die optreedt inzake de positie en taken van de hulpverlening. Reeds binnen de gezinstherapie ontdekte Speck (1964) de waardevolle inbreng van gezinsleden die emotioneel-relationeel op enige afstand staan van de 'identified patient'. In de netwerktherapie gaan ze eveneens twee kringen netwerkleden onderscheiden. De zogeheten buitenkring krijgt een steeds belangrijker plaats in de hulpverlening. Deze netwerkleden krijgen een positie die onder meer inhoudt dat zij de traditionele rollen van raad en daad van de hulpverlening overnemen 
en dat zij eigenlijk met gewoon gezond verstand, mits dat door hulpverleners gemobiliseerd en gestimuleerd wordt, een doeltreffend proces van sociale integratie in werking weten te zetten en in stand te houden. Hier ligt eigenlijk reeds de kern van de regel die later geformuleerd wordt, en wel dat de hulpverlening slechts die taken en verantwoordelijkheden overneemt die niet in het sociale netwerk zelf uitgevoerd en gedragen kunnen worden (Speck, Attneave, 1973). Hier vindt men, zoals verderop aan de orde komt, tevens de aanzet tot een nieuwe rolinvulling van de hulpverlening en de opzet van een netwerkinterventieteam (Rueveni, 1979b).

\section{4}

\section{INTERVENTIES IN EN MET SOCIALE NETWERKEN}

$\mathrm{Na} 1969$ wordt de verdere ontwikkeling van de sociale netwerkbenadering voor een belangrijk deel bepaald door de inbreng van Attneave (Speck, Attneave, 1973). Haar werkwijze en gedachtengoed berust op enerzijds haar verwantschap met de Delaware Indianen en anderzijds haar werkervaringen met ethnische minderheden en randgroepen (Altneave, 1969). Voor haar cliëntèle waren de gewone voorzieningen van (psychiatrische) hulpverlening niet alleen vaak vanwege grote afstanden onbereikbaar; ze waren eigenlijk ook niet of nauwelijks afgestemd op de cultuur van deze mensen en hun problemen. Attneave werkte hoofdzakelijk in omstandigheden waarin ze in de eerste plaats was aangewezen op haar eigen levenservaringen én zodoende op de mogelijkheden en de medewerking en hulp van de sociale omgeving van de mensen die op haar een beroep deden. Zij leerde de tradities en gewoonten, de opvattingen en de technieken en procedures eigen aan die specifieke sociale milieus te gebruiken. Bijvoorbeeld bij gebrek aan professionele voorzieningen vormt zij de naaste omgeving van een meisje, dat eigenlijk opgenomen zou moeten worden in een jeugd-psychiatrische kliniek, om tot een "therapeutisch milieu". Attneave verwoordt haar aanpak als volgt: "As I worked with children, families, teachers and students, I felt a strong need to assess strengths on which to build, rather than merely ferreting out pathology - so that for me a clinical "diagnosis" became a two part affair. The first task was developing a profile of characteristics within the individual, showing both strengths as well as weakness; then I felt the necessity of matching these strengths and weakness to the resources available in the community. The goal for me was 10 build coherent relationships between persons who could stimulate each other and provide maximum reciprocal growth. This led to the development of treatment teams made up of local people significant in the lives of my so-called patients. Where needed and available other professionals were incorporated" (Speck, Attneave, 1973).

De werkwijze en werkomgeving van Attneave staan in schril contrast met die van vele collega's die strikt disciplinair en professioneel opgeleid zijn en die werken binnen een beroepsmatig goed toegeruste omgeving. Ze raakt de aansluiting met de reguliere praktijk kwijt en heeft het gevoel dat ze in de gevestigde wereld van psychiatrie en geestelijke gezondheidszorg tegen dovemansoren praat. Evenals Speck zoekt ook Attneave naar hulpbronnen die haar denken en handelen ordenen en houvast geven. Ze verdiept zich in de publicaties van het eerder genoemde "Mental Research Institute" te Palo Alto en bij een lezing van Haley ontmoet zij Speck bij wie ze gehoor vindt. Vanaf dat moment komt er lussen Attneave en Speck een nauwe samenwerking tot stand (Speck, Attneave, 1971; 1972). Ervaringen, inzichten en kennis worden uitgewisseld, gebundeld en gezamenlijk verder uitgewerkt. De oogst van deze samenwerking kan samengevat worden in een raamwerk voor 'sociale netwerkinterventies' (Speck, Attneave, 1973) en is vervolgens te vinden in een eerste verschuiving in de inhoud van het begrip 'structuur' (Attneave, 1975)

\subsubsection{Raamwerk voor sociale netwerkinterventies}

De uitkomst van de samenwerking tussen Speck en Altneave, te vinden in het boek "Family networks, a new approach to family problems" (1973), laat in de eerste plaats zien dat het begrip 'therapie' vervangen is door het begrip 'interventies'. Deze verandering in terminologie is voor Speck en Attneave wezenlijk. Ze geven hiermee aan dat ze in zekere zin breken met de gangbare individu gebonden en gezinsinteractionele 
opvattingen en werkwijzen bij psychiatrische patiënten. Het is naar hun mening het hele sociale netwerk dat de pathologie bij de individuele persoon dan wel hel gezin waarvan hij deel uitmaakt in gang zet en in stand houdt. Met de term 'interventie' en 'netwerkinterventieteam' benadrukken zij vervolgens dat de hulpverlening "in het nelwerk lussenbeide" komt en dat zij niet zelf als "genezers" of "behandelaars" optreden, maar dat met behulp van hun tussenkomst het sociale netwerk in staat wordt gesteld zijn eigen "helende vermogens en verantwoordelijkheden" te gebruiken.

In 1973 geven Speck en Attneave de volgende modelmatige beschrijving van hun inzichten en praktijkervaringen. Overigens nemen ze hierbij hun verworvenheden van de gezinsstructuurtherapie (\$3.2) en de netwerktherapie (\$ 3.3) mee.

\section{Probleemafbakening}

Het is Attneave die de uiteenzetting over een sociaal netwerk door de anthropoloog Barnes (1954) inbrengt, te weten: "Each person is, as it were, in touch with a number of other people, some of whom are directly in touch with each other and some of whom are not. Similarly each person has a number of friends and these friends have their own friends; some of anyone's friends know each other, others do not. I find it convenient to talk of a social field of this kind as a network. The image I have is of a set of points some of which are joined by lines. The points of the image are people, or sometimes groups, and the lines indicate which people interact with each other".

Deze beschrijving van sociaal netwerk levert opnieuw een bruikbaar beeld op om al die mensen met wie de patiënt en diens gezin min of meer duurzame banden hebben als één geheel te overzien. Zoals dat ook eerder bij de definitie van Bott (1957) het geval was biedt de beschrijving van Barnes een vocabularium waarin ze hun aanpak kunnen onderbrengen en waarmee ze zich kunnen onderscheiden. Hel begrip sociaal netwerk is voor hen "een onbesmet begrip" in de psychiatrische hulpverlening en het maakt bovendien duidelijk dat in tegenstelling tot kunstmatig in het leven geroepen ondersteuningsgroepen door de hulpverlening, het bij netwerkinterventies om al die mensen gaat die een persoonlijke geschiedenis met elkaar hebben en die ook voor de toekomst houden. Als geheel is het sociale netwerk bijvoorbeeld betrokken bij belangrijke gebeurtenissen in het leven van de netwerkleden, zoals geboorte, overlijden, huwelijk etc. Het persoonlijke sociale netwerk dat de eigen levensloop in samenhang met de brede sociale context vertegenwoordigt is eenheid van interventie in de psychiatrische hulpverlening.

\section{Hypothese}

Verondersteld wordt dat een sociaal nelwerk met een "vitale structuur" zelf over de middelen beschikt om de gewone onvermijdelijke moeilijkheden in het leven het hoofd te bieden. De gedragingen van mensen "die tradioneel geïnterpreteerd worden als symptomen van geestesziekte" worden hier opgevat als verschijnselen die wijzen op het ontbreken van een vitale structuur waardoor de zogeheten patiënt "vervreemd is van een sociaal nelwerk en zijn middelen". Een vitale structuur ontbreekt als bijvoorbeeld "een sociaal netwerk bij veranderende levensomstandigheden uiteenvalt en/of beladen is/raakı met schuldgevoelens, spanningen vanwege rivaliteiten, belastende geheimen en met allerlei angsten". Hel komi er op neer dat "hel hele netwerk van al die mensen die met de 'identified patiënt' een min of meer duurzame band hebben in een crisis verkeert" (Speck, Rueveni, 1977).

\section{Interventies}

De inschakeling van (psychiatrische) hulpverlening in hierboven genoemde crisissituaties die vervolgens min of meer gestabiliseerd langdurig kunnen voortduren geeft aan dat een sociale netwerk niet meer in staat is zijn vermogens te gebruiken. In de eerste plaats zal de interventie bestaan uit een herdefiniëring van het functioneren van 'de patiënt', dal wil zeggen: de gepresenteerde symptomen worden beschreven "als natuurlijke en gewone reacties op een inadequate structuur in het sociale nelwerk". Dat geldt niet alleen voor 'de patiënt' maar ook voor degenen met wie de patiënt dagelijks emotioneel-relationeel zeer nauw betrokken is, meestal de naaste verwanten. 
Deze kern van meest betrokkenen wordt verzocht en aangemoedigd hun sociale netwerk en het interventieteam samen te brengen.

Het doel van de netwerkinterventie is "de reorganisatie van de structuur van het sociale netwerk", c.q. de bestaande blokkerende en vervreemdende structuur om te buigen naar een vitale structuur zodat de "helende werking" van het sociale netwerk weer hersteld wordt. Speck en Attneave tonen aan dat dit proces van reorganisatie in fasen verloopt. De volgende fasen zijn kenmerkend voor het hele proces en komen tevens voor tijdens de afzonderlijke sessies van het netwerk: een fase van reorganisatie, een fase van polarisatie, een fase van voorlopige mobilisatie, een fase van impasse, een fase van doorbraak en tenslotte een fase van nieuw perspectief.

\section{Netwerk interventieteam}

De toepassing van sociale netwerkinterventies impliceert een team van "interventors" dat enerzijds multidisciplinair is samengesteld en anderzijds aansluit op sociaal demografische kenmerken in het netwerk, in het bijzonder de spreiding van leeftijd (Rueveni, 1979).

\section{Proanose.}

Een van de belangrijkste uitkomsten is naar hun mening dat met hun aanpak het sociale netwerk niet alleen daadwerkelijk werkt zolang de steun van een netwerkteam aanwezig is, maar ook haar vitaliserende werking continueert nadat een netwerkteam haar bijdragen heeft beëindigd (Speck, Attneave, 1973).

Overigens zijn er nauwelijks studies naar de effectiviteit van de sociale netwerktherapieenn/interventies aanwezig. Een uitzondering is de studie van Schoenfeld e.a. (1986). Zij vinden dat psychiatrische patiënten $(N=20)$ die deelnamen aan een nelwerktherapieprogramma dat verwant is met de werkwijze van Speck en Attneave (1973) aanzienlijk minder heropgenomen worden in een psychiatrisch ziekenhuis en bij heropname tevens korter zijn opgenomen dan een vergelijkbare groep psychiatrische patiönten ( $N=20$ ) die niet aan een dergelijk programma deelnamen. Twee jaar na beëindiging van het netwerktherapie-programma was het aantal heropnames bij de participanten met $74 \%$ gedaald terwijl bij niet-participanten er een daling was van $19 \%$. Het aantal dagen bij heropname in een psychiatrisch ziekenhuis nam met $76 \%$ af, terwijl dat bij niet-participanten met $112 \%$ toenam. Schoenfeld en zijn collega's (1986) concluderen dat ondanks de beperkingen van hun studie, de uitkomst van netwerktherapie in de zin van sociale integratie bijzonder gunstig en bemoedigend is, met name omdat het effect van deze aanpak over lange tijd in stand blijft.

Met het boek "Family networks" in 1973 is de conceptualisering van de sociale netwerkbenadering zoals die door Speck en zijn collega's in praktijk is gebracht in wezen als afgesloten te beschouwen. De latere bijdragen (bijvoorbeeld: Attneave, 1976, 1980; Speck, Rueveni, 1977; Rueveni, 1979, 1982; Speck, Attneave, 1983) zijn voornamelijk herhalingen en verfijningen van wat in 1973 systematisch en geïllustreerd aan tal van praktijkvoorbeelden weergegeven is. Aldus is in dit hoofdstuk tevens het punt bereikt om in het licht van de probleemstelling bij dit onderzoek een eerste balans op te maken naar de betekenis en de mogelijkheden van de sociale netwerkbenadering voor een psychiatrische hulpverlening die zich richt op de sociale integratie van ambulante chronisch psychiatrische patiënten. 

HULPVERLENING

\subsection{1}

De betekenis van de werkwijze van Speck en zijn collega's

In hoofdpunten kan ten aanzien van het werk van Speck en zijn collega's de volgende balans opgemaakt worden.

a

De sociale netwerkaanpak is ontwikkeld bij een gevarieerd aantal (chronisch) psychiatrische patiënten, die goed overeenkomt met de doelgroep ambulante (chronisch) psychiatrische patiënten bij de psychiatrische hulpverlening van de RIAGG'n in Nederland (Romme, 1985).

\section{b}

De sociale netwerkaanpak sluit aan op een beleidsvoorkeur voor psychiatrische hulpverlening "in en met het sociale milieu", (Van Londen, 1982; Tweede Nota Geestelijke Volksgezondheid, Ministerie van WVC, 1984). Het komt op het volgende neer.

De sociale netwerkaanpak huldigt het uitgangspunt dat psychiatrische hulpverlening in hel sociale milieu van de patiënt plaats vindt en ze is als zodanig op het lijf geschreven van de ambulante psychiatrische hulpverlening.

Echter in tegenstelling tot wat gebruikelijk is, wordt de zorg hier principieel in de eigen woon- en leefsituatie van de patiënt uitgevoerd en niet binnen de spreekkamer van de hulpverlening.

- De sociale netwerkaanpak gaat vervolgens uit van hulpverlening "met het sociale milieu" ofwel in termen van een sociaal netwerk met al die mensen met wie de patiënt min of meer duurzame betrekkingen heeft en ook houdt.

- Speck en zijn collega's laten zien dat de medewerking van het sociale netwerk te verkrijgen is mits hiervoor aktief gestimuleerd door de hulpverlening initiatieven worden ondernomen. (Het is opmerkelijk dat nauwelijks gesproken wordt over de motivatie van de patiënt en zijn sociale netwerk maar wel en uitvoerig over de motivatie van de hulpverlening).

\section{c}

De sociale netwerkaanpak laat zien dat het niet in de eerste plaats het gebrekkige probleemoplossend vermogen van de psychiatrische patient zelf is die de sociale integratie stagneert en vermindert, maar dat de afwezigheid van een structureel vitaal persoonlijk sociaal netwerk en haar onvermogen een gezamenlijk probleem oplossend vermogen te mobiliseren en te benutten, vooral maken dat sociale integratie achterwege kan blijven en uitstotingsmechanismen gehandhaafd worden. De (chronisch) psychiatrische patiënt in het werk van Speck en zijn collega's en ook bij andere werkwijzen onder de naam "netwerktherapie", blijkt veel minder op de verschillende levensgebieden 'gehandicapt' te zijn wanneer hij kan vertrouwen op de inzet van een persoonlijk sociaal netwerk dat deze levensgebieden vanuit het verleden en voor de toekomst vertegenwoordigt.

d

De sociale netwerkaanpak gaat uit van het beginsel dat de hulpverlening slechts die taken en verantwoordelijkheden overneemt die duidelijk niet door het sociale netwerk kunnen worden uitgevoerd en gedragen. Dit beginsel is cruciaal en heeft belangrijke consequenties zoals:

- een verandering in de rol- en taakopvatling bij de hulpverlening die kans van slagen heeft wanneer de hulpverlening deze wijziging ook daadwerkelijk kan opbrengen;

- een wijziging in de sfeer van de 'vertrouwelijkheid', en wel in die zin dat de hulpverlening niet toestaat dat er met haar 'aparte vertrouwelijkheden' ofwel e 'geheimen' ontstaan en bestaan.

De uitvoering van de interventies in en met het sociale netwerk verlopen op maat van de patiënt en zijn sociale netwerk volgens een karakteristiek proces, waarin specifieke 
fasen te onderscheiden zijn, zowel van toepassing op het hele interventieproces alsook bij de afzonderlijke sessies.

$f$

De sociale netwerkaanpak gaat uit van het beginsel van teamwerk, ofwel de toevoeging van een interventieteam aan een sociaal netwerk die niet geënt is op de traditionele disciplineverdeling, maar die voortvloeit uit andere posities en taken die vanwege een herverdeling in taken en verantwoordelijkheden tussen hulpverlening en het sociale netwerk ontstaan. Overigens blijkt de opbouw van een interventieteam overeenkomstig hetzelfde proces tot stand te komen dat kenmerkend is voor de interventies in en met het sociale netwerk gericht op de sociale integratie van de patiënt (Baars, Uffing, 1991).

Al bij al kan gesteld worden dat de aanpak van sociale netwerkopbouw in het werk van Speck, Attneave en Rueveni uiterst relevante bouwstenen levert voor een ambulante psychiatrische hulpverlening die zich de sociale integratie van chronisch psychiatrische patiënten ten doel stelt. Essentieel is dat deze aanpak een kader aanreikt waarin de verschillende problemen die een uitvoering van een streven naar sociale integratie van de chronisch psychiatrische patiënt in de weg staan (beschreven in hoofdstuk 2) omgebogen kunnen worden naar een handelen dat een meer hoopvol uitzicht biedt zonder dat de begrenzingen die inherent zijn aan deze psychiatrische patiënten genegeerd worden. De vraag is of in het werk van Speck en zijn collega's methodisch al die middelen aanwezig zijn die voor een systematische handelwijze voor het bereiken van het doel van sociale integratie noodzakelijk zijn? Ik meen dat dit niet het geval is, hetgeen hieronder in $\S 3.5 .2$ nader uiteengezet wordt. Een belangrijke overweging hierbij is dat een brede toepassing achterwege is gebleven, ook bijvoorbeeld in ons land nadat Speck hier in 1973 zijn werkwijze uitvoerig presenteerde. Voor zover mij bekend is er tot voorkort in ons land slechts beperkt binnen de forensische psychiatrie rechstreeks met en vanuit het gedachtengoed van Speck, Rueveni en Attneave gewerkt (Roosenburg, 1973b; Baars, 1984; Van den Bergh, 1991).

Het komt er op neer dat de implementatie dan wel de toepassing van de sociale netwerkaanpak pas kans van slagen heeft als deze methodisch dat wil zeggen als een systematische doelgerichte handelwijze wordt uitgebouwd vanuit een eenduidig concept voor sociale netwerkanalyse en sociale netwerkopbouw (Erickson, 1988; Baars, Uffing, Dekkers, 1990).

\subsubsection{Naar een sociale netwerkbenadering als methode van psychiatrische hulpverlening}

De hierboven beschreven aanpak van sociale netwerktherapie en sociale netwerkinterventies beperkt zich methodisch gezien in wezen tot de fase van de uitvoering van de akties ten behoeve van de reorganisatie van de structuur van het sociale netwerk en tot de middelen en technieken die hiervoor nodig zijn. In de systematisering van hun aanpak in 1973 ontbreekt in het bijzonder een diagnostiek van de structuur van het sociale netwerk ofwel een duidelijk afgebakende diagnostische fase inzake de structuur van het sociale netwerk. Bovendien valt op dat het begrip structuur weliswaar een centrale plaats inneemt maar dat dit begrip niet gepreciseerd wordt. Het ligt voor de hand te veronderstellen dat een precisering in 1973 achterwege is gelaten in de mening dat als vanzelfsprekend aangenomen wordt dat het structuurbegrip overeenkomt met het systeemtheoretische structuurbegrip zoals aanwezig in de beschrijving van de 'netwerktherapie' (zie $\$ 3.3 .2$.). Indien dit het geval is, wat niet onwaarschijnlijk is, dan moeten vooralsnog de sociale netwerkinterventies evenals de 'netwerktherapie' opgevat worden in het verlengde van en als een verbreding van de 'gezinsstructuurtherapie' van Minuchin (1974). Echter uitgaande van het structuurbegrip dat Speck en zijn collega's ontlenen aan onder meer Barnes (1954) en Bott (1957, 1971) moet de gepresenteerde werkwijze in de zin van een "systematische doelgericht handelwijze of methode van hulpverlening" (Kamphuis, 1970) nog als onvolledig beschouwd worden. 
Toch is met deze voorlopige vaststelling niet alles gezegd. De kritiek is weliswaar juist maar ook weer niet geheel terecht. Er is in de eerste plaats veel ervaringskennis in geordende samenhang bijeengebracht en er worden inzichten en technieken aangeboden die zoals hierboven in $\S 3.5 .1$ vermeld een reeel uitzicht lijken te bieden op een betere prognose bij de inspanningen van de psychiatrische hulpverlening voor de sociale integratie van de (ambulante) chronisch psychiatrische patiënt. Vervolgens moet opgemerkt worden dat volgens de criteria die Erickson (1988) aanlegt om een onderscheid te maken tussen gezintherapie en sociale netwerkbenadering Speck en zijn collega's op een paar belangrijke punten breken met de "gewoonten" en ook "beperkingen" (Erickson, 1988) van de gezinstherapeutische benaderingen. De invoering van het beeld van een sociaal netwerk heeft er toe geleid dat de begrenzing van het systeem gezin als eenheid van hulpverlening opgeheven wordt. In de plaats van het 'gesloten' therapeutische gezinssysteem komt het 'open' systeem 'sociale netwerk' dat in principe onbegrensd is (Barnes, 1954). Het belangrijkste effect is volgens Erickson (1988) de wijziging in de traditionele rolverdeling lussen hulpverlening en patiënt. Het komt er op neer dat de diagnostische, interpretatieve en interveniërende aktiviteiten, traditioneel het gebied van professioneel geschoolde hulpverleners, principieel worden toegewezen aan het sociale netwerk. Gesteld kan worden dat Speck en zijn collega's met de invoering van het beeld van een sociaal netwerk uit anthropologische en sociologische bronnen een belangrijke aanzet hebben gegeven voor de opbouw van een andere doelgerichte handelwijze of methode voor (psychiatrische) hulpverlening naast die van gezinstherapeutische benaderingen.

Een paar jaar later lijkt het erop dat het niet bij een aanzet blijt en ook de verdere uitbouw van een andere methode ter hand wordt genomen. Het is Attneave die in 1975 een handleiding ('Map') presenteert om de structuur van een gezinsnetwerk in kaart te brengen. Deze handleiding betreft een diagnostisch schema voor de structuurkenmerken 'omvang', 'dichtheid', 'multiplexiteit' en 'richting en frequentie van de betrekkingen' van een sociaal netwerk. Opmerkelijk is dat dit diagnostisch schema een context van terminologie laat zien die rechtstreeks in relatie gebracht kan worden met het analytisch concept van de structuur van een sociaal netwerk zoals ontwikkeld door de anthropologe Bott (1957, 1971). Ik beperk me hier tot een vermelding van deze terminologie in samenhang met het werk van bijvoorbeeld Bott; in de volgende hoofdstukken 4 en 5 wordt uitvoeriger op deze materie ingegaan.

De diagnostische handleiding van Attneave (1975) roept dan ook de verwachting op dat voor de analyse van de structuur van een sociaal netwerk nu wel nauw aangesloten wordt op een sociologisch / antropologische uitgangspunt en wel dat 'sociale netwerkanalyse een analyse van de structuur van mensen en betrekkingen in een sociaal netwerk inhoudt' (Mitchell, 1969; 1973; Wellman, Berkowitz, 1988; Erickson, 1988). Echter een nadere beschouwing van het diagnostisch schema van Attneave (1975) brengt een aantal inhoudelijk problemen aan het licht die opnieuw de verstrengeling met de gezinstructuurtherapie van Minuchin (1974) bevestigen. Het probleem is onder meer dat in plaats van het analytisch schema van bijvoorbeeld Bott (1957, 1971) tot uitgangspunt te nemen hier voornamelijk de terminologie wordt overgenomen. Vervolgens worden structuurkenmerken gekozen die van een verschillende orde zijn. Bijvoorbeeld een kenmerk als 'omvang' verwijst naar de analyse van de structuur van sociale netwerken, terwijl het element 'multiplexiteit' verwijst naar een patroon binnen de omvang dat een uitkomst van een analyse van de omvang is. Tenslotte vormen de door Attneave (1975) gekozen kenmerken een specifieke selectie van structuurkenmerken, een selectie die eigenlijk meer aansluit op procedures voor het verzamelen van informatie over de structuur van een sociaal netwerk conform de "whole network strategy" dan op de gebruikelijke procedures voor sociale netwerkanalyse namelijk die van de "personal network strategy" (Scoll, 1988). Bij deze kritiek moet tenslotte opgemerkt worden dat Speck en zijn collega's hun systematisering uitvoerden in een periode dat er eigenlijk nog nauwelijks sprake was van een toepassing van meer specifiek sociaal netwerkconcept in de lijn van het gedachtengoed van bijvoorbeeld Bolt $(1957,1971)$ voor de analyse van de structuur van het sociale netwerk bij (chronisch) psychiatrische patiënten. Hun praktijk moest het doen zonder wetenschappelijke informatie voortkomend uit een analytisch concept 
van de structuur van een sociaal netwerk. Vanaf ongeveer 1975 komt pas een ontwikkeling op gang van verschillende analytische schema's voor sociale netwerkanalyse op het terrein van de psychiatrie zoals bijvoorbeeld door Erickson (1976), Tolsdorf (1976), en Walker, MacBride en Vachon (1977).

In het geheel genomen komt het er op neer dat de ontwikkeling van hun praktijk die zij systematisch beschrijven hier eigenlijk op een punt is aangekomen dat de slap gezet moet worden naar een methodische benaderingswijze waarbij de sociale netwerkbenadering als werkwijze van hulpverlening wezenlijk iets anders is dan een verbreding van de gezinsstructuurtherapie/-interventies. Dit betekent dat de gegeven systematisering van hun belangwekkende praktijk van interveniërende activiteiten uitgebouwd dient te worden met een aansluitend doelgericht handelen inzake diagnostische, interpretatieve en evaluatieve activiteiten overeenkomstig een concept van sociale netwerk waarin de analyse en opbouw van een structuur van mensen en betrekkingen betrekking heeft op de sociale integratie van mensen (Erickson, 1988).

Vooruitlopend op de beschrijving van 'het model van een persoonlijk sociaal netwerk' in hoofdstuk 5 kan op basis van bovenstaande uitgangspunten voor de praktijk van de ambulante psychiatrische hulpverlening en haar doelstelling van sociale integratie het volgende stramien (zie figuur 3.1) van systematisch doelgericht handelen in en met een persoonlijk sociaal nelwerk gegeven worden (Baars, Uffing. Dekkers, 1990).

\section{FIGUUR 3.1 Stramien voor sociale netwerkinterventies}

1

een analyse van de structuur van mensen en betrekkingen in een

persoonlijk sociaal netwerk, te weten:

- de analyse van de omvang, de gevarieerdheid en de bereikbaarheid van de netwerkleden;

- de analyse van de structuur van de betrekkingen ${ }^{*}$ in het sociale netwerk;

II

de Interpretatie van de verzamelde gegevens over de structuur van een persoonlijk sociaal netwerk teneinde wat Speck en Attneave (1973) noemen

- "de inadequaatheid in de structuur van het sociale netwerk" vast te stellen;

- plannen te maken die tot een verbetering van de structuur van een persoonlijk sociaal netwerk leiden;

\section{III}

de uitvoering van de interventies ten behoeve van de reorganisatie van de structuur van een persoonlijk sociale netwerk, dat wil zeggen:

- de bevordering dan wel het herstel van de omvang, de gevarieerdheid en de bereikbaarheid van de netwerkleden;

- de bevordering dan wel het herstel van de structuur van de betrekkingen in een persoonlijk sociaal netwerk;

\section{IV}

de evaluatie van de uitvoering van de interventies en de resultaten ervan.

\footnotetext{
* In togenstelling tot eerdere publicaties wordt hier gesproken van 'structuur van de beurekkingen' in plants van 'dichtheid'. Deze wijziging wordt in $\$ 5.3 .3$. Logelicht.
} 
Lopende het in dit proefschrift te presenteren onderzoek is tevens veel aandacht besteed aan de ontwikkeling van een methodische uitbouw van de sociale netwerkbenadering en parallel daaraan is in ons land een groeiende belangstelling ontstaan voor wat nu wel 'de sociale netwerkstrategieenn' worden genoemd (Baars, Uffing, 1991; Altman, Walterbos, 1991; Uffing, Baars, Dreessen, 1992). Tevens wordt in toenemende mate de toepassing gestimuleerd (Heyendael, 1991) en ter hand genomen, zoals in het RIAGG Westelijk Utrecht (Driedonks, Geurts, Van Tellingen, 1990; Driedonks, Licher, Groen,1992; Driedonks, 1993).

\subsection{AFSLUITING}

In dit hoofdstuk is chronologisch een overzicht gegeven van de achtergronden en de ontwikkeling van de sociale netwerkbenadering zoals in praktijk gebracht door met name Speck, Rueveni en Attneave. Belicht is hoe hun manier van psychiatrische hulpverlening in en met het sociale milieu van de patiënt die zij stap voor stap systematiseren een reeel perspectief biedf voor een hulpverlening aan ambulante chronisch psychiatrische patiënten waarin het herstel dan wel de bevordering van de sociale integratie centraal staat. Tenslotte is aangegeven hoe de werkwijze die zij aanbieden lopende het onderzoek verder is uitgebouwd. Aldus kan dit hoofdstuk tevens opgevat worden als een toelichting en verantwoording van de wijze waarop in dit onderzoek op het werk van deze pioniers betreffende de sociale netwerkstrategieën is aangesloten en waar meer een eigen richting is ingeslagen (Baars, Uffing, Dekkers, 1990). De ingeslagen eigen weg is mede beïnvloed door het eerder en elders verrichte wetenschappelijk onderzoek naar sociale netwerken van (chronisch) psychiatrische patiënten hetgeen hierna in hoofdstuk 4 gepresenteerd wordt. 



\section{EERDER ONDERZOEK NAAR SOCIALE NETWERKEN VAN PSYCHIATRISCHE PATIENTEN}

Vanaf het midden van de zeventiger jaren wordt in toenemende mate in het onderzoek naar het sociale milieu en de sociale omstandigheden bij uiteenlopende doelgroepen van psychiatrische hulpverlening en geestelijke gezondheidszorg het begrip 'sociale netwerk' aangetroffen (Meuller, 1980; Gottlieb, 1981; Erickson, 1984; Angermeyer, Klussmann, 1989). Hoewel er evenals in de praktijk van de psychiatrische hulpverlening (zie $\S 3.1$.) deels sprake is van een inruil van terminologie wijst het toenemende gebruik van het begrip sociale netwerk in wetenschappelijk onderzoek op een groeiend besef dat de vraagstukken waarmee de psychiatrie dagelijks te maken heeft om mensen gaat die niet los van hun sociale context benaderd kunnen worden (Erickson, 1976; Meuller, 1980). Dit besef is op zichzelf niet nieuw (Esser, 1970; Romme, Kraan, Rotteveel, 1981). De geschiedenis van de psychiatrie laat voortdurend perioden en scholen van denken en handelen zien waarin naast de belangstelling voor het bijzondere van bijvoorbeeld de psychopathologie uitdrukkelijk aandacht wordt gevraagd voor de gewoonste zaak van de wereld en wel die van de samenleving waarvan de psychiatrische patiënt deel uitmaakt (voorbeelden zijn: Meyer, 1906; Sullivan, 1931, 1946; Querido, 1946, 1952). Nieuw is dat in de zeventiger jaren in het wetenschappelijk onderzoek op het terrein van de psychiatrie het begrip 'sociaal netwerk' haar intrede doet om de verhouding van de psychiatrische patiënt met de brede sociale context ofwel mel de samenleving te bestuderen en te beschrijven (Meuller, 1980; Baars, 1985; Hirschberg, 1988).

\subsubsection{Hoofdlijnen in het soclale netwerkonderzoek}

In het eerder verrichlte onderzoek naar het sociale netwerk van (chronisch) psychiatrische patiënten kunnen ruwweg de volgende accenten dan wel hooldlijnen onderscheiden worden (Walker, MacBride, Vachon, 1977; Hammer, 1981).

I In de eerste plaats is er een hoofdlijn waarin overwegend de structuur van sociale netwerken op de voorgrond slaat. Walker, MacBride en Vachon (1977) noemen de volgende structuur-kenmerken: de omvang ('size'), de sterkle ('strength') van de betrekkingen, de dichtheid ('density'), de gevarieerdheid ('homogeneity of membership') en de bereikbaarheid ('dispersion of membership').

Het gaat om een benadering die in verbinding staat met de anthropologisch I sociologische traditie van sociale netwerkanalyse die aanvangt bij Barnes (1954) en Bott (1957) en heden ten dage onder meer door Berkowitz (1982) en Wellman (1981, 1988) vertegenwoordigd wordl (Scolt, 1988). Uitgangspunt is dat sociale netwerkanalyse wezenlijk de analyse van de 
structuur van een sociaal netwerk van "mensen en betrekkingen" inhoudt; met andere woorden: "sociale netwerkanalyse is structuuranalyse" (Wellman, 1988).

II Vervolgens is er een hoofdilin waarbij de nadruk valt op de inhoud ofwel de functies van de betrekkingen binnen sociale netwerken. Deze lijn gaat voornamelijk uit van een sociaal psychologische orierntatie en ligt in het verlengde van het 'social support concept' zoals met name geformuleerd door Caplan (1974), Cassel (1974) en Cobb (1976). Deze onderzoekslijn richt zich in het bijzonder op de kwaliteit van de sociale ondersteuning in een sociaal netwerk ofwel op de mate waarin een sociaal netwerk voorziet in de vervulling van de psychosociale basisbehoeften (Brim, 1974; Weiss, 1974). Walker, MacBride en Vachon (1977) noemen de volgende functies: de handhaving van een sociale identiteit, het verkrijgen van emotionele ondersteuning, de beschikbaarheid van materiële middelen en het verwerven van nieuwe sociale contacten.

Het is bepaald niet eenvoudig het eerder uitgevoerde sociale netwerk onderzoek op het terrein van de psychiatrie volgens deze hoofdlijnen te ordenen. Meestal worden in onderzoek elementen uit beide hoofdlijnen aangetroffen, waarbij afwisselend de nadruk valt op ofwel de structuurkenmerken ofwel de functies van een sociaal netwerk. Daarnaast zou men een spoor van onderzoek kunnen onderscheiden waarin uitdrukkelijk geprobeerd wordt de lijnen van structuur en functies tot één geheel samen te brengen.

Het onderzoek dat in dit proefschrift gepresenteerd wordt gaat expliciet uit van de onderzoekslijn van de structuuranalyse. Een probleem is dat er eigenlijk nauwelijks onderzoek naar het sociale netwerk van psychiatrische patiënten uitgevoerd is dat zich uitsluitend concentreert op de structuurkenmerken: Dit betekent dat in dit hoofdstuk in $\$ 4.3$ en $\$ 4.4$ overwegend het eerder uitgevoerde onderzoek, zoals dat van Erickson (1976) en van Cohen en Sokolovsky (1978), toegelicht zal worden waarbij een zwaartepunt ligt op de structuur van sociale netwerken. Anderzijds dient dit hoofdstuk ook een meer algemeen beeld te geven van het sociale netwerkonderzoek binnen de psychiatrie. Vandaar dat vervolgens in $\S 4.5$ aan de hand van enkele voorbeelden, zoals het werk van Angermeyer en Lammers (1986), van Henderson e.a. (1978) en van Bolwijn (1989), het onderzoek in het kort toegelicht wordt dat primair geênt is op de functies van de onderlinge betrekkingen in een sociaal netwerk. Tenslotte zal in $\S 4.6$ beknopt worden ingegaan op het werk van de onderzoeksgroep van Pattison (1975), van Froland (1978) en van Laireiter en Baumann (1987), voorbeelden waarin gepoogd wordt structuur en functies tot één geheel samen te brengen.

Overigens valt op dat vrijwel alle onderzoekers ongeacht de accenten die ze leggen bij de achtergronden en de opzet van hun onderzoek verwijzen naar de eerste anthropologische / sociologische concepten voor sociale netwerkanalyse van Barnes (1954; 1969). Bott (1957; 1971) Mitchell (1969) en Kapferer (1969). Dit teruggrijpen op de oorspronkelijke bronnen van het sociale netwerkonderzoek geeft aan degenen die het sociale netwerkconcept toepassen in onderzoek op het terrein van de psychiatrie ondanks de viteenlopende benaderingen en werkwijzen een zekere saamhorigheid. Vooraf zal in $\S 4.2$ in het kort met name op de betekenis van Barnes (1954) en Bott (1957) inzake sociale netwerkanalyse worden ingegaan.

De te onderscheiden hoofdlijnen resulteren in verschillen in methode, onder meer ingegeven door uiteenlopende probleem- en vraagstellingen, en aldus ook in ongelijksoortige resultaten (Hammer, 1981). Daarenboven hanteert vrijwel iedere onderzoeker ongeacht de hoofdlijn dan wel de accenten naar de structuur en $/$ of de functies van een sociaal netwerk een eigen opgezelte werkwijze. Dit betekent bijvoorbeeld dat naar vorm overeenkomstige termen echter inhoudelijk qua omschrijving en vervolgens qua operationalisatie nogal kunnen verschillen (Mitchell, 1969; Tolsdorf, 1976; Mitchell, Tricket, 1980; Knipscheer, Antonucci, 1990). Dit gegeven maakt een zekere uitvoerigheid in de beschrijving van de voor dit proefschrift relevante onderzoeken en hun begrippenkaders onvermijdelijk. 


\subsubsection{Eerder onderzochte psychlatrische populaties}

Dit proefschrift gaat over de structuur van sociale netwerken bij ambulante chronisch psychiatrische patienten hetgeen betekent dat in dit hoofdstuk voornamelijk de aandacht zou dienen uit te gaan naar sociaal netwerk onderzoek bij overeenkomstige populaties in de ambulante psychiatrische hulpverlening. Opnieuw dient zich een probleem aan en wel dat er eigenlijk nauwelijks eerder onderzoek uitgevoerd is dat specifiek het sociale netwerk van ambulante chronisch psychiatrische patiënten behelst. Er zijn in het beschikbare onderzoek waarbij de nadruk ligi op de structuuranalyse slechts enkele onderzoeken te vinden die in de richting komen van de hier gekozen onderzoekspopulatie. Dit betreft bijvoorbeeld het onderzoek naar hel sociale netwerk van de zogeheten 'gedeïnstitutionaliseerde chronisch psychiatrische patient', uitgevoerd in de 'Single Room Occupancy (SRO) Hotels in New York door de onderzoeksgroep van Cohen en Sokolovsky (1978), vervolgens het onderzoek van Hamilton e.a. (1989) in Portland (USA) inzake chronisch psychiatrische patiënten die poliklinisch behandeld worden en het onderzoek naar het sociale netwerk van de zogeheten 'chronisch psychiatrische draaideur patiënten' uitgevoerd door Harris en Bergman (1985) in Washington. Om toch een toereikend beeld te geven van de aard en de betekenis van sociaal netwerkonderzoek voor de psychiatrie wordt in dit hoofdstuk ook enig onderzoek naar de structuur van het sociale netwerk bijandere (chronisch) psychiatrische populaties belicht. Hierbij zal de aandacht uitgaan naar het werk van die onderzoekers, zoals Erickson (1976, 1984). Tolsdorf (1976) en Hammer (1978, 1981) die in de meningsvorming betreffende sociaal netwerk onderzoek en psychiatrie een vooraanstaande plaats innemen.

Wanneer er over de structuur van een sociaal netwerk wordt gesproken gaat het over een 'persoonlijk sociaal netwerk', door Wellman (1981) de "personal community" genoemd. Dit betekent dat het sociale netwerk onderzocht en beschreven wordt vanuit de zogeheten 'personal network strategy' (Hirschberg, 1988; Scott, 1988). Het is in samenhang met de 'personal network strategy' dat door onderzoekers algemeen wordt gerefereerd aan de bronnen van het sociale netwerkonderzoek, in het bijzonder aan het werk yan Barnes (1954) en Bott (1957).

De 'personal network strategy' houdt in dat een sociaal netwerk wordt bestudeerd vanuit het standpunt van een individuele persoon of een sociale unit zoals een echtpaar en een gezin, door Erickson (1975) de 'focal persons' genoemd. De gegevens over een persoonlijk sociaal netwerk kunnen in principe verzameld worden via rechtstreekse observatie van de onderzoekers, via informatie van netwerkleden, via informatie van de focale persoon zelf of op basis van een combinatie van deze mogelijkheden (Brim, 1974). Hel is bij de toepassing van de 'personal network strategy' op het terrein van de psychiatrie algemeen gebruik dat de informatie over de mensen en betrekkingen in een sociale netwerk overwegend afkomstig is van of via de voor het onderzoek gekozen focale personen (Craven, Wellman, 1973; Wellman, 1981). Naast deze 'personal' - ofwel 'egocentric network strategy' bestaat er de 'whole network strategy' (Scolt, 1988; Laireiter, Baumann, 1987).

De 'whole network strategy' beschrijft de structuur van mensen en hun onderlinge betrekkingen die tesamen éen geheel vormen en vooraf als een min of meer begrensd sociaal systeem kunnen worden afgebakend; voorbeelden zijn een schoolklas, een afdeling van een psychiatrisch ziekenhuis of penitentiare inrichting (Killworth, Bernard, 1974). Ook een'social-support-network' (zie $\$ 3.1$ ) kan heel wel met behulp van de 'whole network strategy' beschreven worden. Deze laatste aanpak is sterk verwant aan de sociometrische beschrijving van groepen door Moreno (1953) en herinnert aan de sociaal psychologische bestudering van de groepsdynamiek van bijvoorbeeld Cartwright en Zander, 1954). De 'whole network strategy' wordt voor zover achterhaald is kunnen worden in het sociale netwerk onderzoek op het terrein 
van de psychiatrie nauwelijks toegepast. Overwegend wordt er uitgegaan van de 'personal network strategy' (Scott, 1988), een traditie van sociale netwerkonderzoek die teruggaat op het werk van met name de Britse sociaal antropologen John Barnes (1954) en Elisabeth Bott (1957). Zij zijn het die in de vijftiger jaren het begrip sociaal netwerk introduceren voor de systematische beschrijving van de relaties van mensen die zich uitstrekken over de grenzen van de gangbare sociale eenheden voor informatieverzameling bij sociaal wetenschappelijk onderzoek, te weten 'groepen' zoals een gezin en sociale categorieën zoals bijvoorbeeld de sociale klasse (Noble, 1973; Wellman, 1988).

Barnes (1954) wordt algemeen gezien als degene die als eerste het begrip sociale netwerk toepast en bekendheid geeft. Bij de bestudering van de sociale structuur van het vissersdorp Bremnes in Noorwegen onderscheidt hij drie velden ofwel typen van sociale betrekkingen die de interacties van de bevolking in dat dorp grotendeels bepalen. In de eerste plaats zijn dat de betrekkingen in samenhang met de dagelijkse werkzaamheden, te weten die van de visindustrie. Vervolgens zijn er de betrekkingen die samenhangen met de posities die mensen in de verschillende plaatselijke groeperingen ('social groupings') innemen. Deze beide velden van sociale betrekkingen kunnen volgens Barnes goed bestudeerd worden met de gebruikelijke sociologische werkwijzen. Bij het door hem onderscheiden derde veld van sociale betrekkingen, dat van de aan de individu gebonden persoonlijke betrekkingen, is dat volgens Barnes niet mogelijk. Het gaat om een in principe onbegrensd veld van persoonlijke betrekkingen die voortkomen uit verwantschap, vriendschap, en dergelijke. Dit derde gebied in de sociale structuur van het vissersdorp Bremnes noemt Barnes (1954) dat van de sociale netwerken: "the set of concrete interpersonal relationships linking individuals with other individuals".

Het is Bott (1957) die dit begrip sociale netwerk als eerste analytisch heeft uitgewerkt (Scott, 1988). In haar klassieke boek 'Family and social network' van haar onderzoek in Londen bij twintig echtparen en de invloed van hun sociale netwerken op hun rolverdeling, definieert zij een sociaal netwerk als "all or some of the social units - individuals or groups - with whom a particular individual or group is in contact". (Bott, 1957; 1971) Deze omschrijving van een sociaal netwerk door Bott wijkt af van die van Barnes. Bott beperkt zich niet tot individuele personen zoals verwanten, vrienden, buren en dergelijke maar zij neemt in haar definitie van een sociaal netwerk ook groeperingen ('organised groups') op zoals bijvoorbeeld een werkkring, de school, de gezondheidszorg. Het is deze (ver)brede omschrijving van een persoonlijk sociaal netwerk waarop in onderzoek naar het sociale netwerk bij psychiatrische populaties vooral teruggegrepen wordt. Deze definitie sluit zowel voor onderzoekers zoals Erickson (1976) alsook voor mensen uit de praktijk van de psychiatrische hulpverlening zoals Speck en Attneave (1973) aan bij de sociale werkelijkheid waarin de (chronisch) psychiatrische patiènt zich naar hun mening bevindt. Immers conform bijvoorbeeld het 'Social Breakdown Syndrome' (Gruenberg, 1974) lijkt de patiënt niet zozeer of veel minder verbonden te zijn met individuele personen ('kin and informal non-kin') maar veeleer en soms in hoge mate met 'organised groups' in het bijzonder met die van de (psychiatrische) hulpverlening (Romme, Breuls, 1985; Rotteveel, 1987).

Verwijzend naar de definitie van Bott $(1957,1971)$ verdeelt bijvoorbeeld Erickson (1975, 1976) een sociaal netwerk in de sectoren "kinship", "friendly relationships" en "social services". De sector "social services" sluit aan op de zogeheten "organized groups", waaronder instellingen voor (geestelijke) gezondheidszorg gerekend worden, die vervolgens geconcretiseerd kunnen worden in personen met wie de patiënt in contact is.

In het werk van Bolt (1957) neemt vervolgens het kenmerk dichtheid ('connectedness') van een sociaal netwerk een centrale plaats in. De dichtheid van een sociaal netwerk betreft de verhouding tussen het aantal potentiële betrekkingen en het aantal werkelijke betrekkingen in een sociaal netwerk (zie figuur. 4.1). 
FIGUUR 4.1 Dichtheid van een sociaal netwerk; A: voorbeeld van hoge dichtheid en $B$ : voorbeeld van lage dichtheid in de betrekkingen van een sociaal nelwerk, (ontleend aan: Walker, MacBride, Vachon, 1977).

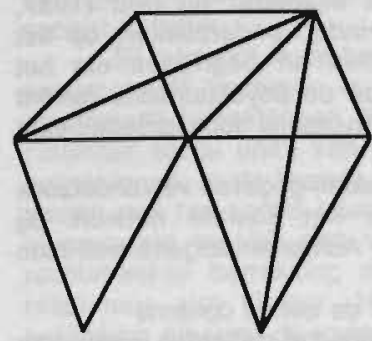

A

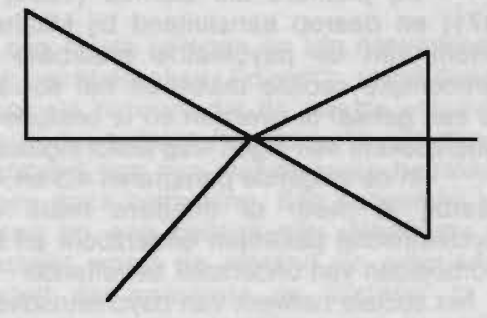

B

Bott laat zien dat de verdeling van rollen bij de door haar onderzochte echiparen samenhangt met de dichtheid van de betrekkingen in sociale netwerken, met name met de dichtheid in de sector vriendschappelijke betrekkingen. In netwerken van echtparen waar sprake is van een gemiddeld hoge dichtheid ('close-knit networks'), waarin de vrienden en bekenden elkaar over en weer kennen, is er de tendens dat beide partners meer van elkaar onderscheiden rollen vervullen. In netwerken waar vrienden en bekenden van een echtpaar elkaar niet kennen en er dus sprake is van een gemiddeld lage dichtheid in het sociale netwerk ('loose-knit networks') is er de tendens dat de verschillende rollen gemeenschappelijk worden uitgevoerd. Hoewel er aan het structuurelement 'dichtheid' nogal wat inhoudelijke en praktische problemen kleven (Kapferer, 1973; Erickson, 1976), onder anderen inzake de toepassing ervan binnen de 'personal network stralegy' zoals in het volgende hoofdstuk in $\$ 5.3 .3$. wordt uiteengezet, wordt dit begrip 'dichtheid' van Bott in veel onderzoek naar het sociale netwerk van psychiatrische patienten aangetroffen. Dat is niet vreemd, het begrip dichtheid geeft een beeld dat aansluit bij de ervaringen van de psychiatrische hulpverlening en de inzichten van een gezinsinteractionele onderzoekspraktijk dal psychiatrische patiënten en niet zelden ook hun verwanten zich in een relationeel isolement bevinden (Bell, 1962; Hirschberg, 1988).

Een korte belichting van het werk van Bolt (1957) kan niet zonder het onderscheid dat zij maakı tussen de sociaal culturele context van een 'rural society' en die van een 'industrial society'. In een niet-geïndustrialiseerde kleinschalige samenleving van het platteland zijn volgens Bott (1957) gezinnen opgenomen in een context van plaatselijke sociale systemen; kenmerkend wordt geacht dat allerlei taken, zoals de verdeling van werkzaamheden en voorkomende diensten, bijvoorbeeld kinderopvang. betrekkelijk eenvouding in en met de naaste omgeving geregeld zijn/worden. Een geïndustrialiseerde verstedelijkte samenleving zit veel ingewikkelder in elkaar bijvoorbeeld omdat veel taken overgenomen zijn door gespecialiseerde instituties. Een gezin in een kleinschalige betrekkelijk gesloten samenleving heeft te maken met een klein aantal sociale eenheden die ieder tal van functies vervullen terwijl een gezin in een grootschalige betrekkelijk open samenleving aangewezen is op een grote hoeveelheid gespecialiseerde instellingen. Deze onderscheiden typen samenlevingen en haar kenmerken werken volgens Boll (1957) door in de structuur van een persoonlijk sociaal netwerk.

Hoewel de strekking van deze typologieën van de samenleving niel onjuist is en ze herhaaldelijk in het sociale netwerkonderzoek aan de orde komt (Wellman, Leighton, 1979; Wellman, Carrington, Hall, 1988) roept het ook gemakkelijk misverstanden op. Een misverstand is bijvoorbeeld dat de toepassing van de sociale 
netwerkstrategieên meer past binnen de context van een 'rural society' dan van een 'verstedelijkte samenleving'. De casuistische beschrijvingen van de toepassing van sociale netwerkinterventies van Speck en Altneave (1973) laten zien dat de toepassing ervan in beide contexten mogelijk is en dat sociale netwerkopbouw in beide 'typen' samenlevingen even moeilijk dan wel gemakkelijk is.

Bij pioniers als Barnes $(1954,1969)$ en in het bijzonder bij Bott (1957, 1971) en daarop aansluitend bij Mitchell $(1969,1973)$ vinden onderzoekers op het terrein van de psychiatrie bruikbare concepten, beelden en begrippen om het persoonlijke sociale milieu en het sociaal functioneren van de psychiatrische patiënt als een geheel te overzien en te bestuderen en waarmee vervolgens door (groepen van) onderzoekers een eigen weg wordt ingeslagen.

In de volgende paragrafen 4.3 en 4.4 worden voorbeelden gegeven van onderzoek waarbij in meer of mindere mate de structuur van het sociale netwerk bij psychiatrische patiẻnten onderzocht en beschreven wordt. Achtereenvolgens treft men voorbeelden van onderzoek betreffende

- het sociale netwerk van psychiatrische patienten rondom de eerste opname

- het sociale netwerk van 'ambulante' chronisch psychiatrische patiënten waaronder ook die van de zogeheten 'draaideur'-patiënten in de psychiatrie.

\subsection{SOCIALE NETWERKEN RONDOM EEN EERSTE OPNAME}

Binnen het 'Social Breakdown Syndrome' (Gruenberg, 1967; 1974) vindt de eerste opname plaatst in het vierde stadium van de pathogenese. De discrepantie tussen de prestaties van een persoon en de verwachtingen van zijn omgeving hebben ondertussen vormen aangenomen dat familieleden en andere mensen in de naaste omgeving besluiten dat er iets mis met hem is. Wanneer er vervolgens een proces van etikettering in gang wordt gezet dat nog meer het zelfvertrouwen van de 'patiënt' ondermijnt, wordt tenslotte het vierde stadium bereikt waarin hij voorzien van het etiket 'ziek', 'gevaarlijk' of 'incompetent' in een (psychiatrisch) ziekenhuis wordt opgenomen (Baars, Romme, 1986). In het sociale netwerk onderzoek wordt de vraag gesteld: wat gebeurt er in het sociale netwerk ofwel in 'de structuur van mensen en betrekkingen' lijdens dit stadium van een proces waarin de gewone relaties tussen de persoon en de wereld om hem heen instorten en mislukken. Ter illustratie het onderzoek van Hammer (1961; 1964), van Tolsdorf $(1975 ; 1976)$ en van Erickson (1976, 1985).

\section{Hammer}

Het eerste voorbeeld betreft een onderzoek van Muriel Hammer $(1961 ; 1964)$. Hoewel dit onderzoek vaak aangehaald wordt als het oudste voorbeeld van de toepassing van een sociale netwerk benadering kan het eigenlijk niet gesitueerd worden binnen de twee genoemde hoofdlijnen van sociaal netwerk onderzoek (\$ 4.1.1). Hammer gebruikt hier het begrip sociale netwerk voornamelijk om aan te geven dat zij de naaste omgeving van de psychiatrische patiënt niet beperkt ziet tot die van het gezin van de patient, zoals dat hel geval is in het gezinsinteractionele onderzoek. De begrippen die Hammer gebruikt voor kenmerken van de structuur van de betrekkingen liggen evenals bij de 'nelwerktherapie' van Speck en Rueveni (1969), beschreven in $\$$ 3.3.2., in wezen in het verlengde van het systeemtheoretische structuurbegrip (Steinglass, 1978). In haar latere werk dat vooral aan de orde komt in het volgende hoofdstuk 5 bij de opbouw van een model voor sociale netwerkanalyse volgt Harnmer (onder meer 1978, 1982) overwegend hel sociologisch / anthroplogische uitgangspunt van de structuuranalyse voor de bestudering van persoonlijke sociale netwerken van psychiatrische patiënten.

Hammer $(1961 ; 1964)$ onderzocht in New York bij 55 patienten met schizofrene en manisch depressieve stoornissen de invloed van de (psychiatrische) symptomatologie van de patient op de structuur van de betrekkingen binnen het sociale netwerk, in het bijzonder binnen dat deel van het netwerk - meestal een klein aantal naaste verwanten - dat zeer nauw bij de patient betrokken is. Daarnaast bestudeerde 
zij de invloed van de structuur van deze betrekkingen op het tot stand komen van een opname van de patiënt in een psychiatrisch ziekenhuis. In dit onderzoek staan vooral de volgende kenmerken van de structuur van de betrekkingen centraal: de afstand ('distance') in de betrekking en de onderlinge verbondenheid ('degree of interconnectedness') van de netwerkleden. Deze kenmerken zijn volgens Hammer zeer belangrijk bij de vraag of afwijkend gedrag resulteert in een reorganisatie van een sociaal netwerk.

Bij 'afstand' in de betrekkingen tussen een focale persoon en zijn netwerkleden onderscheidt Hammer in de eerste plaats rechtstreekse ('direct') en indirecte ('mediated') betrekkingen. Het deel van het sociale netwerk dat de naaste omgeving ('intimate social unit') van de focale persoon vormt bestaat hoofdzakelijk uit direcle betrekkingen. In de tweede plaats hangt de 'afstand' van een rechtstreekse betrekking samen met het aantal interactiegebieden binnen deze betrekking. Een netwerklid kan bijvoorbeeld tegelijk een vriend, een buurman en een collega zijn. Naarmate de rechtstreekse betrekking meer gebieden bestrijkt wordt de afstand (in emotioneel relationele zin) kleiner. Hammer veronderstelt dat naarmate de 'afstand' in de betrekking afneemt de invloed van de (psychiatrische) symptomatologie van de patiënt op de betrekking toeneemt. Naarmate de 'afstand' groter is neemt de invloed op de betrekking af en is het betreffende netwerklid beter in staat een adequaat antwoord op het gedrag van de patiënt te geven.

De onderlinge verbondenheid ('interconnectedness') betreft bij Hammer de mate waarin de betrekkingen van netwerkleden onderling met elkaar verbonden zijn. Bijvoorbeeld $A$ woont samen met $B$ wiens vriend $C$ onbekend is bij $A$. Dit betekent dat de betrekking tussen $A$ en $B$ niet verbonden is met die van $B$ en $C$. Indien $C$ woont bij $A$ en $B$ dan zijn de betrekkingen $A$ en $B, B$ en $C$ en die van $C$ en $A$ onderling verbonden. Hammer veronderstelt dat de effecten van het gedrag van de patient op de structuur van de betrekkingen in de naaste omgeving toenemen naarmate de onderlinge verbondenheid groter is en wel in die zin dat met name het verzet tegen het gedrag van de patient toeneemt.

Samenvattend komt Hammer $(1961 ; 1964)$ tot de bevinding dat als er sprake is van ernstige, gewelddadige en bizarre gedragsmanifestaties er vrijwel steeds ongeacht de structuur van de betrekkingen tot een onmiddellijke opname in een psychiatrisch ziekenhuis, soms voorafgegaan door inhechtenisneming, wordt overgegaan. Bij gedrag van de patiënt dat gekenmerkt wordt door mildere signaalsymptomen blijkt de structuur van de betrekkingen medebepalend te zijn voor de reactie in de naaste omgeving. Naarmate de afstand in de betrekkingen kleiner word en de onderlinge verbondenheid toeneemt zijn netwerkleden minder bereid en in staat zelf adequaat te reageren. In het algemeen wordt bij mildere signaal-symptomen eerder gezocht naar ambulante psycho-medische zorg.

Het duurt enige lijd, eigenlijk tot het onderzoek van Tolsdorf $(1975 ; 1976)$ en dat van Erickson (1976), dat er onderzoek naar het sociale netwerk van psychiatrische patiënten plaats vindt waarin nadrukkellijk(er) het sociale netwerkconcept gehanteerd wordt. Ondertussen zijn er reeds wel enige sludies verschenen over de betekenis van de ondersteunende werking van een sociale netwerk zoals bij crisissituaties (Boswell, 1969), bij het zogeheten hulpzoekgedrag van mensen (McKinlay, 1973) en inzake het persoonlijk welbevinden (Brim, 1974).

\section{Iolsdorf}

Het tweede voorbeeld, tot op de dag van vandaag veelvuldig geciteerd, is het onderzoek van Tolsdorf $(1975 ; 1976)$. Zijn studie uitgevoerd in Massachussetts betreft het sociale netwerk van voor het eerst opgenomen psychiatrische patienten $(N=10)$ en hij vergelijkt deze netwerken met die van patienten $(N=10)$ die vanwege een medische indikatie, zoals een gebroken enkel, opgenomen zijn in een ziekenhuis en bij wie geen sprake is van problemen in de geestelijke gezondheid. Tolsdort gebruikt de definitie van een sociaal netwerk van Bott $(1957 ; 1971)$. Bij de opzet van zijn onderzoek loopt 
Tolsdorf reeds op tegen de grote hoeveelheid variabelen en operationalisaties ervan betreffende de analyse van sociale netwerken. Hij onderscheidt drie typen variabelen.

\section{a Structurele variabelen}

Deze variabelen, hier de omvang ('size') en de dichtheid ('adjacency density') van een sociaal netwerk beschrijven de morphologische kenmerken van een sociaal netwerk. De omvang bestaat conform de operationalisatie van Kapferer (1969) uit die personen die de focale persoon noemt als behorend tot zijn netwerk; de volgende criteria gelden: de focale persoon en het netwerklid moeten elkaar in ieder geval bij naam kennen en er moet sprake zijn van een zekere duurzaamheid in de relatie ofwel de focale persoon en het betreffende netwerklid moeten op zijn minst eenmaal per jaar met elkaar contact hebben. De 'dichtheid' van een sociaal netwerk heeft betrekking op het aantal werkelijk bestaande dyadische relaties ten opzichte van het aantal mogelijke relaties in een netwerk, een omschrijving die overeenkomt met die van Bott (1957; 1971).

\section{b 'Content'-variabelen}

Bij content-variabelen gaat het om de dagelijkse intensiteit van iedere betrekking in een netwerk. Een betrekking speelt zich af op één of meer 'interactiegebieden' variërend van het gebied van bijvoorbeeld verwant- en vriendschap, dat van de werkkring, vrijetijd en religie tot aan bijvoorbeeld het gebied van de sexuele relatie, wederzijdse hulp en dienstverlening. Een betrekking tussen de focale persoon en een netwerklid die zich beperkt tot één gebied is een 'uniplexe' betrekking terwijl een betrekking die zich over meerdere gebieden uitstrekt 'multiplex' is. Het aantal multiplexe betrekkingen in relatie tot het aantal uniplexe betrekkingen geeft de relationele dichtheid ('relationship density') van een sociaal netwerk aan.

\section{c. Functionele variabelen}

Deze variabelen beschrijven de inhoud van de betrekking fussen de focale persoon en een netwerklid. In dit onderzoek van Tolsdorf gaat het om de volgende drie functies: support, advies en feedback. Indien in de betrekking geen van deze drie functies aanwezig is is er hier sprake van een niet-functionele relatie.

Tolsdorf komt tot onder meer de volgende bevindingen. De omvang van het sociale netwerk van de voor het eerst opgenomen psychiatrische patiënt is gemiddeld 30 netwerkleden (range: 9-45) terwijl bij de referentiepersonen een gemiddelde omvang van 38 personen (range: 19-45) wordt aangetroffen. De netwerken van de referentiepersonen tonen een iets hogere structuur-dichtheid dan die van de onderzoekspopulatie. De verschillen die gevonden worden betreffen vooral de intensiteit en de inhoud van de betrekkingen. Bij de onderzoekspopulatie worden multiplexe betrekkingen in het algemeen aangetroffen bij die netwerkleden met wie functionele relaties bestaan, terwijl de referentiepersonen ook multiplexe betrekkingen hebben met niet-functionele netwerkleden. De onderzoekspopulatie heeft de neiging meer functies te ontvangen dan zelf te geven terwijl er bij de referentiepersonen over en weer functies gegeven en ontvangen worden. Bovendien hebben de psychiatrische patiënten slechts met enkele netwerkleden multiplexe betrekkingen, waarbij het accent ligt op naaste familieleden, hetgeen tevens inhoudt dat een klein aantal netwerkleden, met name naaste verwanten nagenoeg alle hier genoemde functies vervullen. Bij de referentiepersonen zijn de functies verspreid over meer mensen die zich vooral buiten de kring van de naaste verwanten bevinden. In tegenstelling tot de referentiepersonen is er bij de onderzoekspopulatie sprake van een negatieve oriëntatie op de netwerkleden. De psychiatrische patiënten vinden hun netwerkleden niet geschikt om te helpen, ze ervaren slechts medelijden. Tolsdorf verklaart deze houding uit de ervaringen die de psychiatrische patiënt in het verleden met zijn netwerkleden heeft opgedaan. De referentiepersonen gaan juist binnen het sociale netwerk op zoek naar hulp en volgen de adviezen op in plaats ze naast zich neer te leggen. De referentiepersonen kunnen tal van voorbeelden van concrete hulp noemen terwijl de psychiatrische patiënt slechts een paar voorbeelden van hulp uit het sociale netwerk weet aan te geven. 
Het derde voorbeeld is het onderzoek van Gerald Erickson (1976). Hij deed in York (Canada) onderzoek naar het sociale netwerk van psychiatrische patienten $(N=40)$ over de periode dat zich de eerste psychiatrische symptomen (opnieuw) voordoen tol aan het moment dat er (wederom) psychiatrische hulp wordt gerealiseerd. Erickson is vooral geinteresseerd in de structuur van het sociale netwerk en de wijzigingen die daarin tijdens genoemde periode optreden, alsook in de manier waarop door het sociale netwerk hulp wordt geboden en hoe in het sociale netwerk de optredende problematiek wordt benoemd. Zijn bijdrage is onder meer belangrijk vanwege de ordening die hij inzake het begrip 'omvang', het grondvlak voor de bestudering van sociale netwerken, aanbrengt. Voor wat betreft dit onderzoek van Erickson (1976) beperk ik me tot een weergave van dit grondvlak.

Erickson vertrekt vanuit de definitie van een sociaal netwerk van Bott (1957; 1971). Hij brengt in de omvang van een sociaal netwerk de volgende begrenzingen aan. In de meest uitgebreide zin bestaat de omvang van een sociaal netwerk uit het totaal aantal mensen met wie de focale persoon contact heeft. Vervolgens is er het "beschikbare persoonlijke sociale netwerk", dat deel van het uitgebreide sociale netwerk dat gevormd wordt door al die mensen met wie de focale persoon regelmatig rechtstreeks contact onderhoudt onder te verdelen in de sectoren verwanten, vriendschappelijke betrekkingen en maatschappelijke diensten (zie $\S 4.2$ ). Binnen dit beschikbare persoonlijke sociale netwerk onderscheidt Erickson een effectief en een niet-effectief deel netwerkleden. Het effectieve deel bestaat bij dit onderzoek uit die netwerkleden die daadwerkelijk bij de psychiatrische symptomatologie van de focale persoon betrokken zijn.

In het tijdsverloop tussen de eerste psychiatrische verschijnselen en het moment dat de focale persoon is opgenomen in een psychiatrisch ziekenhuis zijn er volgens Erickson in het effectieve deel van het beschikbare sociale netwerk drie opeenvolgende 'actiesets' aan te wijzen, te weten:

a de actieset ('early action set') samengesteld uit netwerkleden die direct met het ontstaan van de psychiatrische symplomatologie te maken hebben / krijgen;

b de actieset tijdens de optredende crisis ("crisis set') ofwel al die personen die betrokken zijn bij het verkrijgen van psychiatrische hulpverlening;

c de behandelingsactieset ('treatment set') bestaande uit alle personen die in de periode volgend op het verkrijgen van psychiatrische zorg bij de behandeling van de focale persoon betrokken blijven / zijn.

De omvang van het uitgebreide sociale netwerk bij de onderzoekspopulatie bestaat gemiddeld uit 19 personen (range: 7 - 44). De opbouw van deze omvang is als volgt: gemiddeld zijn er 12 verwanten (range: 3 - 37), 5 personen binnen de secior vriendschappelijke betrekkingen (range: 0 - 20) en 2 personen die hulpverienende instanties vertegenwoordigen (range: 1 - 7). De omvang van het beschikbare sociale netwerk bestaat gemiddeld uit 15 personen (range: 5 - 38). Het optredende verlies in de omvang zit vooral in de sector verwanten hetgeen te maken heeft met de onbereikbaarheid van deze netwerkleden vanwege geografische afstand $(n=8)$ of hangt samen met huidige conflicten en oud zeer waardoor er nauwelijks sprake is van contact $(n=20)$.

In het algemeen bestaat de eerste actieset uit gemiddeld $25 \%$ van de netwerkleden in het beschikbare sociale netwerk. Dit betekent dat gemiddeld 4 netwerkleden (range: 0 - 9) effectief betrokken zijn bij de eerste ofwel opnieuw ontstane psychiatrische symptomatologie. Deze eerste actieset is hoofdzakelijk samengesteld uit verwanten, waarbij het opvalt dat de eventuele partner ofwel de moeder van de focale persoon hier een centrale plaats innemen. Bovendien betrekken de partners van de focale personen veelvuldig hun eigen moeder in deze eerste actiesel. De aanwezigheid van vrienden komt voor bij gehuwde en ongehuwde vrouwen en wel in die 
zin dat het hier hoofdzakelijk buren zijn die als vrienden gelden. Zelden zijn bij mannen vrienden in deze actieset aanwezig.

De crisisactieset bestaat hoofdzakelijk uit enkele verwanten zoals de partner en/of één van de ouders en wordt vervolgens aangevuld met de huisarts. Deze laatste blijkt eigenlijk de sleutel tot het vervolg van hulpverlening in handen te hebben. Het handelen van de huisarts is grotendeels afhankelijk van zijn eigen professionele netwerk zoals de specialisten die hij gewend is om raad te vragen en van de wijze waarop hij de brugfunctie vervult tussen de patient en de specialistische zorg. In de derde actieset neemt het aandeel van de (psychiatrische) hulpverlening toe. De bevinding van Erickson (1976) dat het effectieve netwerk in de periode direct vooraf aan de eerste psychiatrische zorg overwegend uit naaste verwanten bestaat is onder anderen ook de uitkomst van een onderzoek bij schizophrene patiënten door Isele en Angst (1982).

De hierboven aangehaalde onderzoeken geven vanuit verschillende invalshoeken en uiteenlopende werkwijzen enige informatie over wat er gebeurt in de structuur van een sociaal netwerk van iemand met psychiatrische symptomatologie in een stadium dat resulteert in een opname. In het algemeen blijkt er een verschuiving in de omvang van het sociale netwerk op te treden en wel in die zin dat zo iemand tenslotte feitelijk aangewezen is op een beperkt aantal netwerkleden en wel overwegend naaste verwanten. De overige netwerkleden lijken nog wel beschikbaar maar niet meer effectief betrokken bij de focale persoon. Erickson (1976) vat deze netwerken samen als 'afgeknotte' netwerken. In het restant van de netwerkleden die nog bij de focale persoon betrokken zijn wordt de emotioneel relationele afstand kleiner en is de onderlinge verbondenheid groter aldus Hammer (1965). In dat kleine 'effectieve' netwerk concentreert zich volgens Tolsdorf (1976) de vervulling van functies die normaliter verspreid is over de omvang van het 'beschikbare persoonlijke netwerk'. Men zou kunnen zeggen dat de balans tussen de draaglast en de draagkracht bij wat Erickson (1976) de 'eerste actieset' van netwerkleden noemt ernstig verstoord wordt met als resultaat dat deze netwerkleden steeds minder in staat en bereid zijn toereikend op de focale persoon te reageren. Bovendien is er vanuit eerder opgedane ervaringen bij de focale persoon sprake van een negatieve oriěntatie naar de netwerkleden. Het uitbreken van een crisissituatie kan niet achterwege blijven en dan lijkt het aan het karakter van de begeleidende symptomatologie te liggen of accuut tot opname wordt overgegaan of dan nog een beroep wordt gedaan op ambulante psychomedische hulp. In het laatste geval lijkt bij de besluitvorming de rol van de huisarts cruciaal te zijn.

In de vermelde onderzoeken gebeurt de wetenschappelijke analyse en beschrijving van dit stadium in het sociale netwerk vooral om vroegtijdig in de patiüntcarriere aangrijpingspunten te vinden die bij de eerste opvang en zorg toepasbaar zijn on in het bijzonder om interventies te ontwikkelen die de omkeerbaarheid van dergelijke processen in een sociaal netwerk bevorderen (Lipton e.a., 1981; Erickson, 1984). Bij de sociale netwerkinterventies (zie $\S 3.4$ ) wordt de omkeerbaarheid in de eerste plaats bevorderd door actief het nog bestaande 'beschikbare' persoonlijke sociale netwerk opnieuw in te schakelen en in contact te brengen met het restant van het 'effectieve' persoonlijke sociale netwerk (Speck, Attneave, 1973; Baars, Uffing, Dekkers, 1990). 
Deze paragraaf betreft onderzoek naar het sociale netwerk van 'ambulante' chronisch psychiatrische patiënten die in de richting komen van de onderzoekspopulatie binnen dit proefschrift. Achtereenvolgens wordt onderzoek naar het sociale netwerk toegelicht dat uitgevoerd is bij:

uit het psychiatrisch ziekenhuis ontslagen chronisch psychiatrische patiënten;

- chronisch psychiatrische patiënten die poliklinisch in zorg zijn;

- chronisch psychiatrische 'draaideur'-patienten.

Vervolgens wordt ingegaan op een typologie van sociale netwerken bij 'ambulante' chronisch psychiatrische patienten die opgesteld is door Harris, Bergman en Bachrach (1987). Deze subparagraaf wordt afgesloten met een eerste blik op de strekking van de bevindingen.

\subsubsection{Ontslagen chronisch psychlatrische patiēnten}

Het onderzoek van Cohen en Sokolovsky (1978; 1979, a en b; Sokolovsky e.a., 1978) inzake het sociale netwerk bij ontslagen chronisch psychiatrische patiënten moet gezien worden tegen de achtergrond van het beleid in de USA betreffende de deïnstitutionalisatie van chronisch psychiatrische patiënten (Gersons, 1983). Alleen al in 1973 werden in New York 35.960 patienten uit psychiatrische ziekenhuizen ontslagen. Velen kwamen terecht in een van de duizend 'Single Room Occupancy (SRO) Hotels' in New York. Het onderzoek van Cohen en Sokolovsky (1978) vindt plaats in een SRO-hotel in Harlem. Het algemene beeld van deze ontslagen chronisch psychiatrische patienten is dat zij zeer op zichzelf en sociaal geïsoleerd leven en wonen; zij waren gewend aan het zeer gestructureerde leven van de patientrol in het psychiatrisch ziekenhuis en komen terecht in een weinig beschermende omgeving, waarop ze nauwelijks zouden zijn voorbereid. Cohen en Sokolovsky vragen zich af hoe juist dit beeld van hun levenssituatie is. Ze gaan na hoe het sociale netwerk van deze patiënten er uit ziet en of hierin verschillen zitten die van invloed zijn op een heropname in een psychiatrisch ziekenhuis.

De onderzoekspopulatie bestaat uit 44 chronisch psychiatrische patienten in de leeftijd van 22 tot 66 jaar, die los van hun familie in het SRO-hotel wonen. Dit SROhotel heeft een 'sociaal dienstencentrum' vanwaaruit een beroep kan worden gedaan op psychiatrische hulpverlening. Op basis van de psychiatrische voorgeschiedenis worden de volgende subgroepen onderscheiden:

1 de SR-oreep $(n=11)$ : patienten bekend met de diagnose schizofrenie bij wie ernstige restverschijnselen aanwezig zijn; de gemiddelde leeftijd is 46 jaar;

2 de S-aroep $(n=21)$ : patienten met eveneens de diagnose schizophrenie, maar bij wie niet of nauwelijks ernstige restverschijnselen optreden; gemiddelde leeftijd is 38 jaar.

3 de NP-aroep $(n=12)$ : patienten bij wie geen psychotische verschijnselen aanwezig zijn; gemiddelde leeftijd is $\mathbf{4 2}$ jaar.

De onderzoekers gebruiken de door hen ontwikkelde 'Network Analysis Profile', een instrument dat uitgaat van de definitie van een sociaal netwerk door Mitchell (1969), te weten: "a special set of linkages among a set of persons with the property that the characteristics of these linkages as a whole may be used to interpret the social behavior of the persons involved". Hoewel Cohen en Sokolovsky een sociaal netwerk uitwerken zowel naar zijn 'vorm' (structuur) alsook naar zijn 'inhoud' (functies) en spreken over een sociaal netwerk in termen van een 'social support system', bestrijkt de 'Network Analysis Profile' in hoge mate de vorm- ofwel structuurkenmerken van een sociaal netwerk. De 'Network Analysis Profile' bevat de volgende kenmerken:

a De omvana, ofwel die personen met wie de focale persoon in het laatste jaar gemiddeld éenmaal per maand contact heeft gehad. Deze netwerkleden bestrijken min of meer afgeleid van de indeling van Jay (1964) de volgende interactiegebieden: 
- andere bewoners van het SRO-hotel,

- personen buiten het SRO-hotel,

- de verwanten,

- de leiding van het SRO-hotel,

- de staf van het dienstencentrum

- sociale instituties, dat wil zeggen concreet te benoemen personen die deze instituties vertegenwoordigen.

In dit onderzoek gaat hel om de drie eerste interactiegebieden, door Mitchell (1969) het deel 'van de persoonlijke informele relaties' in een sociaal netwerk genoemd.

b de dichtheid ('density' ofwel 'interconnectivity') in het sociale netwerk, dat wil zeggen de verhouding tussen het aantal feitelijk bestaande en het aantal mogelijke betrekkingen tussen de netwerkleden onafhankelijk van de focale persoon;

c de ranoerde ('degree'), ofwel het gemiddeld aantal relaties dat een netwerklid met andere netwerkleden heeft;

d de frequentie en de duur ('frequency' / 'duration') van de betrekkingen;

e de richting ('directionality') binnen dyadische relaties, in termen van:

- instrumenteel: de relatie gaat geheel van de focale persoon uit;

- wederzijds: de relatie gaat van de focale persoon én van het netwerklid uit;

- afhankelijk: de relatie gaat uitsluitend van het netwerklid uit;

$f$ de inhoud van de betrekkingen. ('transactional content') ofwel de uitwisseling van 'support'; een betrekking is multiplex wanneer deze meer soorten 'support' bestrijkt, bijvoorbeeld zowel emotionele ondersteuning alsook geld, en advies. Wanneer er slechts een 'support'-element wordt uitgewisseld is er sprake van een uniplexe betrekking. De begrippen multiplexiteit en uniplexiteit geven hier de intensiteit van een betrekking in een sociaal netwerk aan.

In de onderstaande tabel 4.1 worden de belangrijkste uitkomsten van dit onderzoek samengebracht.

TABEL 4.1 Omvang en multiplexiteit in het sociale netwerk van chronisch psychiatrische patiënten, onderzocht door Cohen en Sokolovsky. (1978).

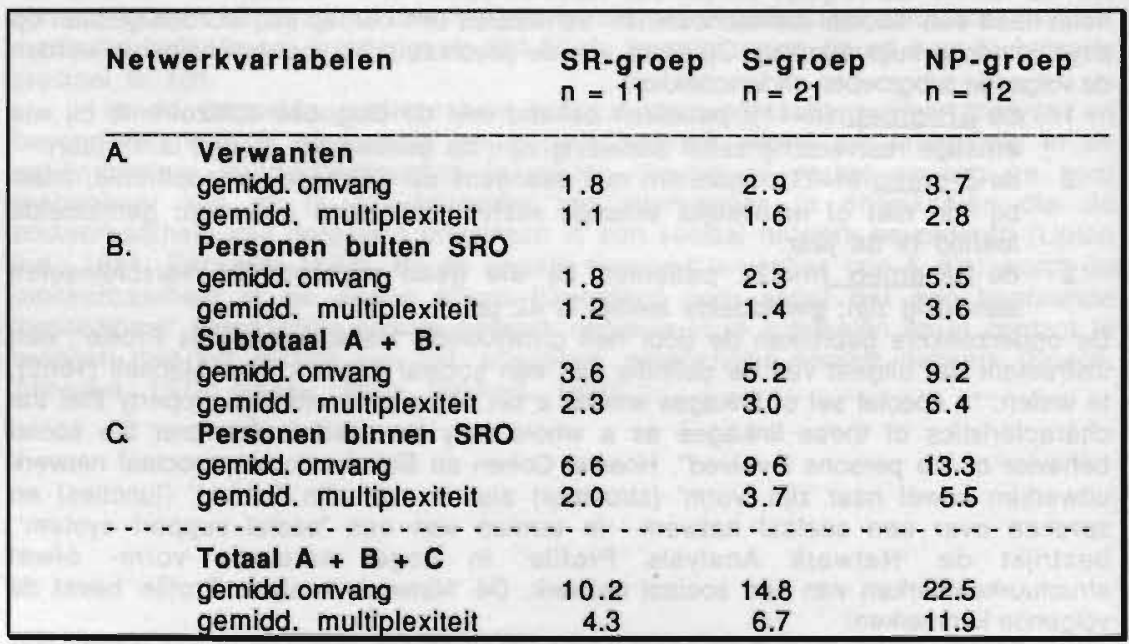


Uit dit onderzoek van Cohen en Sokolovsky (1978) komt naar voren dat de omvang van de informele persoonlijke relaties in het sociale netwerk toeneemt naarmate de ernst van de psychiatrische problematiek afneemt. De NP-groep heeft een tweemaal zo groot netwerk als de SR-groep, terwijl de totale omvang van het netwerk tussen de SR-en de S-groep niet opmerkelijk verschilt. Hoewel deze trend ook aanwezig is ten aan zien van de multiplexiteit van de betrekkingen, zijn de verschillen statistisch niet significant. De hier gevonden omvang en de verdeling ervan over de drie interactiegebieden krijgt meer reliêf wanneer het element 'richting van de betrekking' er bij wordt genomen. Zowel de patienten in de SR-groep als die in de S-groep hebben nauwelijks 'instrumentele' relaties; dat wil zeggen zij hebben in tegenstelling to de NP-groep vooral afhankelijke relaties. Met betrekking tot de kenmerken 'dichtheid' en 'rangorde' worden in dit onderzoek geen opmerkelijke verschillen gevonden bij de drie onderzochte groepen patienten.

De heropnamen zijn in de SR- en de S-groep aanwezig $(n=17)$. Deze patienten hebben gemiddeld één opname in veertien maanden tijd met een duur van gemiddeld 18 dagen. Wanneer van deze groep heropgenomen patiënten de omvang en de multiplexiteit wordt vergeleken met de overige patienten uit de SR- en S-groep dan treden er opmerkelijke verschillen op: de gemiddelde omvang en multiplexiteit is verder gedaald. Bovendien blijken de relaties van deze heropgenomen patienten nog meer afhankelijk en minder instrumenteel te zijn dan bij de overige patienten in de SR- en S-groep.

Cohen en Sokolovsky (1978) bevestigen hun vermoeden dat de onderzochte chronisch psychiatrische patiënten minder algemeen in een sociaal isolement verkeren dan aangenomen wordt. Het probleem is dat het de heropgenomen patiënten zijn die aan het beeld van een sterk sociaal isolement beantwoorden. Met andere woorden wanneer de klinische waarneming niet vergezeld gaat met adequaat sociaal wetenschappelijk onderzoek dan ontstaat er gemakkelijk het beeld dat voor langdurig opgenomen en gehospitaliseerde psychiatrische patiënten bij ontslag in het algemeen een sociaal isolement in het vooruitzicht staat. In een later vergelijkbaar opgezet onderzoek (1981) naar het sociale netwerk van thuisloze bejaarden komen Cohen en Sokolovsky eveneens tot de conclusie dat hun sociale omgeving structureel veelzijdiger en qua ondersteuning rijker is dan algemeen in onderzoek wordt aangetoond. Naar de mening van Cohen en Sokolovsky (1981) is het de techniek van sociale netwerkanalyse die een quantitatief en qualitatief gedifferentieerder beeld van de sociale werkelijkheid van mensen geeft dan met de gebruikelijke afzonderlijke technieken van de participerende observatie en de sociometrische werkwijze mogelijk is.

\subsubsection{Poliklinische chronisch psychiatrische patiënten}

Hamilton en zijn collega's (1989) verrichtten onderzoek naar het sociale netwerk van chronisch psychiatrische patiënten $(N=40)$ die poliklinisch in behandeling zijn. De onderzoekspopulatie bestaat uit mannen die meer dan twee jaar in zorg zijn vanwege schizofrene stoornissen. Hun gemiddelde leeflijd is 33 jaar (range 20-40). Hamilton e.a. gebruiken in dit onderzoek een door hen bewerkte versie van de door Pattison (1977) ontwikkelde 'Psychosocial Kinship Inventory' (PKI), (zie § 4.6.). Zij bestuderen het sociale netwerk van deze onderzoekspopulatie vooral vanwege de vraag naar een eventuele samenhang tussen netwerkkenmerken en positieve dan wel negatieve symptomen. Bij deze onderzoekspopulatie blijkt de gemiddelde omvang van het netwerk uit dertien personen te bestaan, waanan de helft wordt gevormd door verwanten. Patiěnten met meer negatieve symptomen rapporteren een geringere omvang. De daling van de omvang treedt met name op bij netwerkleden die geen verwanten van de focale persoon zijn. Ook met betrekking tot de intensiteit van de betrekkingen (de multiplexiteit) en de richting in de betrekkingen treedt bij negatieve symptomen een verarming op. Bij positieve symptomen wordt er geen correlatie met nelwerkkenmerken gevonden. 
Tot de groep ambulante chronisch psychiatrische patiënten worden ook de zogeheten 'draaideur'-patiěnten gerekend (Test, Stein, 1978; Honig, 1989). Harris en Bergman (1985) onderzochten in Washington het sociale netwerk van een dergelijke groep 'jong volwassenen' chronisch psychiatrische patienten $(N=35$, gemiddelde leeftijd 31 jaar) die frequent, gemiddeld negen maal, in een psychiatrisch ziekenhuis opgenomen zijn geweest, en tijdens het onderzoek deelnamen aan een ambulant hulpverleningprogramma. In dit onderzoek gebruiken ze de door hen voor dit ambulante programma ontwikkelde "Social Network Inventory" (SNI). Het komt er in hoofdlijnen op neer dat de patient systematisch gevraagd wordt een lijst te maken van zijn netwerkleden en bij iedere genoemde persoon de frequency van het contact en de mate van wederkerigheid in het contact aan te geven. Vervolgens wordt de patiěnt systematisch gevraagd aan te geven welke type support (zoals advies, ondersteuning, geld, huisvesting) het betreffende netwerklid vervult.

Harris en Bergman (1985) vinden dat de omvang van de sociale netwerken bij deze patiënten (gemiddeld 10 tot 15 netwerkleden) kleiner is dan bij hun leeftijdsgenoten (gemiddeld 20 tot 30 netwerkleden). Het werkelijk effectieve deel in hun sociale netwerken blijkt nog kleiner te zijn; niet zelden worden er netwerkleden genoemd die zij al jaren niet meer ontmoet hebben, maar die wel een rol in hun beleving spelen; ook worden er netwerkleden genoemd die ver weg wonen en in wezen moeilijk bereikbaar zijn. Vervolgens blijken de onderzochte patiënten vergeleken met normale referentiepersonen de mate van intimiteit en contact met hun netwerkleden anders te beoordelen. De onderzoekspopulatie lijkt dikwijls hulp te zoeken bij 'vrienden' die in feite niet in staat zijn de gevraagde hulp te bieden; ze lijken niet te weten waar de werkelijke hulpbronnen in hun netwerk liggen. Een ander probleem is dat hun sociale netwerken voor een deel ook personen bevatten die zelf weinig stabiliteit in hun bestaan bereikt hebben en die eveneens psychiatrische problemen hebben. De onderzoekspopulatie blijkt meer aansluiting te vinden bij lotgenoten dan bij gezondere, sociaal stabielere netwerkleden. Tenslotte merken Harris en Bergman (1985) op dat de dichtheid in de sociale netwerken van de onderzoekspopulatie laag is, in het bijzonder in die sociale netwerken waarin voor een belangrijk deel hulpverleners aanwezig zijn, die eveneens van elkaars bestaan niet op de hoogte blijken te zijn.

Een ander onderzoek is van Dozier, Harris en Bergman (1987) naar de samenhang tussen de 'dichtheid' van het sociale netwerk en de heropname(n) bij zogeheten 'draaideur'-patiënten $(\mathrm{N}=30)$ in de psychiatrie. Al deze psychiatrische patiënten, jonger dan 40 jaar, zijn de vier jaar voorafgaande aan het onderzoek tenminste zes maal opgenomen geweest en staan als zeer moeilijk behandelbaar bekend.

Dozier en haar collega"s zijn van mening dat de sociale netwerken van deze draaideur patienten niet echt overeenkomen met de sociale netwerken van extramuraal verblijvende chronisch psychiatrische patiënten zoals beschreven in bijvoorbeeld het onderzoek van Cohen en Sokolovsky (1978). De 'draaideur'-patiënten zijn gemiddeld jonger en ze zijn niet onderhevig geweest aan een zodanig langdurig verblijf in een psychiatrisch ziekenhuis dat op hen het "Social Breakdown Syndrome" (Gruenberg, 1982) van toepassing is. De onderzoekers veronderstellen onder meer dat er bij de 'draaideur' patient sprake is van een gemiddeld normale omvang van het sociale netwerk. Vanwege de veronderstelde grotere omvang van deze netwerken vermoeden zij dat er meer variatie in de dichtheid voorkomt en dat zowel een hoge als een lage dichtheid in hun netwerken meer kans geeft op heropname in een psychiatrisch ziekenhuis. Een sociaal netwerk met een hoge dichtheid staat immers weinig vertrouwelijke banden toe terwijl bij een sociaal netwerk met een lage dichtheid de focale persoon hoofdzakelijk op zichzelf is aangewezen.

De dichtheid van het sociale netwerk wordt door hen op de gebruikelijk manier gedefinieerd als "het totaal van de bestaande onderlinge banden ten op zichte van het totaal aantal mogelijke banden in een sociaal netwerk". Een score van 0 geeft aan dat een netwerklid geen enkel ander netwerklid kent, een score van 1 betekent dat alle 
netwerkleden elkaar kennen. De omvang van de netwerken bestaat hier uit het totaal aantal personen met wie de focale persoon gedurende de laatste twee weken contact heeft gehad. Systematisch worden de verschillende gebieden in een netwerk, zoals familie, buren, werksituatie, vrijetijdsdeelname en dergelijke nagegaan en in kaart gebracht. Hulpverleners en medepatiénten worden niet in de omvang opgenomen. In de onderstaande tabel 4.2 zijn de belangrijkste data ondergebracht.

TABEL 4.2 Gemiddeld aantal personen in een sociaal netwerk, gemiddeld aantal dagen doorgebracht in $\mathrm{PZ}$ en de diagnosen bij dertig draaideur-patiënten, vergeleken met de dichtheid in het netwerk. (overgenomen uit Dozier, Haris, Bergman, 1987).

\begin{tabular}{|c|c|c|c|c|c|}
\hline \multirow[b]{2}{*}{$\begin{array}{l}\text { dichtheid } \\
\text { score }\end{array}$} & \multirow[b]{2}{*}{$\begin{array}{l}\text { ormvang } \\
\text { netwerk }\end{array}$} & \multirow[b]{2}{*}{$\begin{array}{l}\text { dagen } \\
\text { verblijf } \\
\text { in } P Z \text {. }\end{array}$} & \multicolumn{3}{|c|}{ Diagnosen $N=30$} \\
\hline & & & $\begin{array}{l}\text { schizo- } \\
\text { phrenie } \\
n=18\end{array}$ & $\begin{array}{l}\text { Bipolaire } \\
\text { stoornis } \\
n=5\end{array}$ & $\begin{array}{l}\text { Borderline } \\
\text { stoornis } \\
n=7\end{array}$ \\
\hline $\begin{array}{l}0-.28 \\
.29-.36 \\
.37-.48 \\
.49-.72 \\
.73-1\end{array}$ & $\begin{array}{l}18.87 \\
18.87 \\
13.83 \\
14.67 \\
15.36\end{array}$ & $\begin{array}{r}103.83 \\
39.83 \\
51.50 \\
97.67 \\
186.50\end{array}$ & $\begin{array}{l}3 \\
1 \\
4 \\
5 \\
5\end{array}$ & $\begin{array}{l}1 \\
3 \\
1 \\
0 \\
0\end{array}$ & $\begin{array}{l}2 \\
2 \\
1 \\
1 \\
1\end{array}$ \\
\hline
\end{tabular}

De gemiddelde omvang van deze netwerken bestaat uit 16 personen (range $2-49$ ), exclusief hulpverleners en medepatienten. Deze gemiddeld omvang blijkt aanzienlijk hoger te liggen dan bij chronisch ofwel gehospitaliseerde psychiatrische patienten en blijkt meer in de richting te komen van de gemiddelde omvang van netwerken bij mensen bij wie geen sprake is van psychiatrische dan wel geestelijke gezondheidsproblemen. Gemiddeld hebben deze patiënten in het laatste jaar 95 dagen (range 0 - 355) doorgebracht in een psychiatrisch ziekenhuis. In dit onderzoek komt naar voren dat het vooral de dichtheid van hun netwerken is die van invloed is op het aantal dagen dat men in een psychiatrisch ziekenhuis verblijft. Een zeer lage dichtheid en een zeer hoge dichtheid vertonen een samenhang met een hoge verblijfsduur. Bovendien geeft dit onderzoek aan dat patiěnten met zowel een hoge als een lage dichtheid ook frequenter worden opgenomen.

\subsubsection{Typen sociale netwerken}

Sociale netwerkonderzoek is niet alleen gericht op de analyse en beschrijving van de structurele kenmerken van het sociale netwerk maar vooral om via deze analyse patronen in de structuur van een sociaal netwerk van mensen en betrekkingen op hel spoor te komen (Wellman, 1988). Een van de weinige studies waarin patronen in (de structuur) van sociale netwerken van psychiatrische patiënten worden beschreven is van Harris, Bergman en Bachrach (1987). Zij schetsen een drietal typen sociale netwerken bij chronisch psychiatrische patienten die in meer of mindere mate ambulant dan wel buiten het psychiatrisch ziekenhuis begeleid worden. Hun beschrijving is echter in algemene termen gesteld, hetgeen betekent dat niet systematisch wordt aangegeven hoe deze typen in termen van structuurkenmerken opgebouwd zijn.

Het eerste type sociale netwerken zijn de "institutional networks", voorkomend bij chronisch psychiatrische patiënten die bijvoorbeeld in beschermende woonvormen verblijven. Deze netwerken weerspiegelen in grote lijnen het 
samenlevingsverband van patiënten binnen een afdeling van een psychiatrisch ziekenhuis. Het sociale netwerk van de patient is overwegend opgebouwd uit medepatienten en staat in hoge mate onder leiding van personen die de psychiatrische hulpverlening vertegenwoordigen. Eigenlijk wordt niet verwacht dat de patiënt een eigen persoonlijk sociaal netwerk los van deze 'extramurale' setting zal kunnen opbouwen.

Het tweede type is dat van de "fraternal networks" die vooral aanwezig zijn bij jongere chronisch psychiatrische patiënten die geregeld wisselen van hulpverleners, veelvuldig hulp zoeken maar zich ook herhaaldelijk ontrekken aan de aangeboden programma's. Deels is dit type netwerk ook van toepassing bij de zogeheten 'draaideur'-patiënten. Hun persoonlijke sociale netwerken bestaan merendeels uit lotgenoten dan wel leeftijdsgenoten die zoeken naar een eigen autonomie, die onafhankelijk willen zijn en vooropstellen dat zij een eigen leven moeten kunnen leiden. Een probleem is dat deze sociale netwerken snel wisselen qua samenstelling.

Een derde type sociale netwerken zijn de "integrated networks", die zeer gevarieerd zijn samengesteld en aangetroffen worden bij die patiênten die in staat zijn over langere tijd de patiênt-rol los te laten. Het sociale netwerk bestaat deels uit mede -(ex-)patiënten alsook uit de eigen verwanten, vrienden, buren en bekenden met wie over langere tijd banden bestaan en worden onderhouden. Dit type sociale netwerk staat volgens de auteurs nog het dichtst bij de persoonlijke sociale netwerken van mensen zonder problemen in de geestelijke gezondheid.

Tenslotte: de gegeven indeling van globale patronen gaat in hoge mate uit van sociale omstandigheden en contexten van sociaal functioneren - in zekere zin gekoppeld aan de patiëntcarriere - waarin (chronisch) psychiatrische functioneren. Met deze benadering sluiten Harris, Bergman en Barchrach (1987) meer aan op een algemeen uitgangspunt bij de analyse en beschrijving van de structuur van persoonlijke sociale netwerken (Wellman, Berkowitz, 1988) dan bij de gebruikelijke klinische oriëntatie waarin onderzoek naar het sociaal functioneren en in het verlengde daarvan naar sociale netwerken vooral gebonden wordt geacht aan een persoonlijkheidsprofiel dan wel een diagnostische categorie.

\subsubsection{Indrukken omtrent de bevindingen}

De in deze subparagraaf vermelde onderzoeken betreffen chronisch psychiatrische patiënten die deels in de richting komen van de onderzoekspopulatie die in dit proefschrift centraal staat. Dit betekent onder meer dat er in iedere onderzochte populatie die hierboven vermeld is psychiatrische patiënten zullen voorkomen die ook te vinden zijn in de doelgroep van de Sociaal Psychiatrische Dienst (SPD) van de RIAGG Maastricht (zie $\$ 2.2 .1$ ). Echter de geselecteerde populaties als geheel zijn niet vergelijkbaar met de clièntele van de SPD. Enige vergelijking wordt bovendien bemoeilijkt door de verschillen in werkwijze en het incidentele karakter van de gegeven onderzoeken. Het komt er op neer dat de gegeven bevindingen in beperkte mate en slechts tot voorlopige indrukken aanleiding geven.

In de eerste plaats kan op basis van deze onderzoeken niet aan de indruk ontkomen worden dat het proces van de pathogenese na de eerste opname van de patiènt minder rechtlijnig verioopt en meer variaties vertoont dan in de beschrijving van het Social Breakdown Syndrome (SBS) van Gruenberg (1974) aangegeven wordi. De door Cohen en Sokolovsky (1978) onderzochte ontslagen chronische en eerder gehospitaliseerde psychiatrische patiënten sluiten in tegenstelling tot de zogeheten chronisch psychiatrische draaideur-patiënten (Dozier, Harris, Bergman, 1987) het meest nauw aan op het SBS. Het onderzoek van Cohen en Sokolovsky is interessant omdat het duidelijk maakt dat het sociale isolement van deze populatie chronisch psychiatrische patiënten in termen van een sociaal netwerk minder groot is en dat de sociale inbedding gevarieerder is dan conform het SBS verondersteld werd. Het zijn vooral de heropgenomen patiènten die qua onderzochte kenmerken van een sociaal nelwerk beantwoorden aan het beeld van de uitkomst van de SBS ofwel bij wie een structuur in hun informele netwerk ontbreekt om het builen de beschermende omgeving van de intramurale zorg te kunnen redden. 
Een tweede opmerking betreft de leeftijdsopbouw van de onderzochte populaties. De populatie in het onderzoek van Cohen en Sokolovsky (1978) is aanmerkelijk ouder (gemiddeld boven de 40 jaar) dan die van de 'draaideur'-patienten (die allen jonger zijn dan 40 jaar, waarbij de gemiddelde leeftijd om en nabij de 30 jaar ligt) in het onderzoek van Dozier, Harris en Bergman (1987). Opvallend is dat de verschillen in de gemiddelde omvang van de netwerken bij beide populaties minder opmerkelijk zijn dan het geval is ten aanzien van de dynamiek in de omvang van hun sociale netwerken (Morin, Seldman, 1986). De in deze onderzoeken aanwezige bevindingen doen vermoeden dat het verschil in de dynamiek van de omvang - te weten bij de oudere populatie van Cohen en Sokolovsky (1978) lijkı de samenstelling ervan min of meer stabiel te zijn terwijl die bij de jongere volwassen populatie aan verandering onderhevig is - zich ook uitstrekt over andere kenmerken van de structuur van het sociale netwerk.

\section{5 ONDERZOEK MET ACCENT OP DE FUNCTIES VAN SOCIALE NETWERKEN}

Onder de noemer 'sociale netwerkonderzoek' op het terrein van de psychiatrie wordt veelal ook het onderzoek in de zin van 'sociale support netwerken' vermeld. Deze lijn betreft de inhoudelijke kwaliteit van de betrekkingen in sociale netwerken. In het bijzonder richt men zich op de aan- of afwezigheid van de ondersteunende werking van sociale netwerken in relatie tot de geestelijke gezondheid van mensen (Goltlieb, 1981, 1985). De omschrijving van het sociale netwerk door bijvoorbeeld Sadoun (1989) geeft deze richling goed weer; zijn definitie luidt: "a person's social network can be defined as that group of significant others which is supposed to form a natural supportsystem". Deze definitie ligt in het verlengde van het werk van onder anderen Caplan (1964; 1974), Cassel (1976) en Brown en Harris (1978) inzake de beschermende en preventieve werking van sociale ondersteuning voor de (geestelijke) gezondheid van mensen (Gotlieb, 1985). Sociale netwerken worden in de eerste plaats opgevat als bestaande uit die mensen die in emotioneel - relationeel opzicht voor de focale persoon belangrijk zijn, in het bijzonder bij stresserende omstandigheden die een risico inhouden voor iemands (geestelijke) gezondheid (Pfingstmann, Baumann, 1987).

Onder meer de volgende terminologie word aangetroffen: "primary groups" (Henderson e.a., 1978; Brugha e.a, 1982;), "natural support systems" (Hirsch, 1980), "natural helping networks" / "social support networks" (Trimble, Kliman, 1981: Sokolove, Trimble, 1986) en "networks of informal support / helping" (Gottlieb, 1978, 1985). Ik beperk me hier zoais in $\$ 4.1 .1$. reeds aangegeven tot enkele voorbeelden waarna in het kort de belangrijkste punten in de huidige discussie inzake 'social support netwerk' -onderzoek in relatie tot sociale netwerkanalyse weergegeven worden (Hall, Wellman, 1985; House, Landis, Umberson, 1988; Laireiter, Baumann, 1991; Schrameyer, 1991).

Een goed voorbeeld waarbij de zogeheten 'primary group' centraal staat vindt men in het werk van Henderson en zijn collega's $(1978,1980)$ in Australiè. De 'primary group' betreft die mensen in een sociaal netwerk die eigenlijk min of meer tot de intimi van de focale persoon gerekend kunnen worden. Uitgangspunt is dat het benutten van deze groep bestaande uit naaste verwanten en goede vrienden, in hel bijzonder het benutten van het affectieve en emotioneel-relationele vermogen dat in de betrekkingen met hen aanwezig is, van groot belang is voor de handhaving van de geestelijke gezondheid en bij de bescherming tegen psychiatrische symptomatologie (Henderson, 1977). Voor onderzoek ontwikkelden Henderson en zijn collega's (1978. 1980) de "Interview Schedule for Social Interaction" (ISSI), een vragenlijst die nauw aansluit bij het model van de psychosociale basisbehoeften opgesteld door Weiss (1974). Weiss onderscheidi een zestal categorieën basisbehoeften, te weten: binding met andere mensen, sociale integratie, het gevoel voor anderen en zelf waardevol te zijn, hel gevoel bij anderen veilig te zijn en op anderen te kunnen vertrouwen. Als voorbeeld de categorie van de behoefte aan sociale integratie; de vervulling ervan vereist in het bijzonder andere mensen met gelijke interessen en waarden; wanneer er 
deficiênties met betrekking tot gelijkgezinden in het sociale netwerk optreden, in het bijzonder ten aanzien van vrienden, is er een verhoogd risico voor sociaal isolement.

Ter illustratie enige gegevens uit een onderzoek van Henderson e.a. (1978) naar de kwaliteit van de 'primary group' bij vijftig ambulante depressieve patiënten. Het aantal naaste verwanten $(m=1.5$ ) bij deze depressieve patienten blijkt niet te verschillen met die $(m=2.2)$ bij mensen zonder problemen in de geestelijke gezondheid. De onderzoekspopulatie blijkt echter beduidend minder 'goede vrienden' $(m=2.2)$ te hebben dan bij de referentiepersonen $(m=5.1)$ het geval is. De patienten blijken ongeveer een zelfde hoeveelheid tijd met de mensen in hun 'primary group' door te brengen als de referentiepersonen maar in tegenstelling tot de referentiepersonen envaren de patiénten de tijd die zij met hun naasie omgeving doorbrengen in hoge mate als onplezierig. De patiënten hebben minder mensen aan wie ze gehecht zijn; bijna de helft noemt slechts één persoon aan wie ze gehecht zijn. De meerderheid van de patiénten geeft aan dat zij vanuit de 'primary group' onvoldoende steun voor de vervulling van de psycho-sociale basisbehoeften krijgen.

De werkwijze van Henderson e.a. $(1978,1980)$ heeft nogal wat navolging gekregen. Zo is de ISSI onder meer door Angermeyer en Lammers (1986) in Hannover gebruikt bij hun onderzoek naar het sociale netwerk van schizophrene patiënten $(\mathbf{N}=$ 126) Ten aanzien van het aspect sociale integratie toont dit onderzoek dat een derde van de patiěnten niemand in de zin van vrienden kan noemen die zonder uitdrukkelijke uitnodiging bij hen op bezoek komt. Bij $18 \%$ van de onderzochte patiënten is de sector vriendschappelijke betrekkingen leeg.

Klassiek in de sociale netwerkliteratuur is vervolgens de Seattlestudie van Brim (1974). Hij ontwikkelde een vragenlijst bestaande uit 25 items die betrekking hebben op de volgende dimensies: daadwerkelijke hulp, gelijkgezindheid in waarden, overeenstemming, vertrouwen en contacten waarnaar wordt uitgezien. Brim onderzocht het verband tussen deze inhoudelijke dimensies in de betrekkingen bij een 'sociaal netwerk' en de mate van welbevinden van de focale persoon De aanpak van Brim brengt vooral de af- dan wel aanwezigheid en de intensiteit van de genoemde dimensies in de betrekkingen in beeld bij een omvang van het sociale netwerk die met het begrip "social intimates" kan worden aangeduid.

Deze quaestionaire van Brim (1974) is gebruikt door Bolwijn (1989) in een studie bij chronisch psychiatrische patienten $(N=23)$ die poliklinisch behandeld worden. Bolwijn stelt onder meer de vraag in welke mate de functies zoals beschreven bij Brim (1974) door deze populatie patiënten benut worden. Bolwijn vindt dat het sociale netwerk in termen van 'primary group' niet alleen kleiner is bij haar onderzoekspopulatie vergeleken met die van een controlegroep, maar ook qua samenstelling verschilt. De sector vriendschappelijke betrekkingen is bij de onderzoekspopulatie gemiddeld kleiner dan bij de controlepersonen, terwijl de patienten in tegenstelling tot de controlepersonen in de sector maatschappelijke diensten over hulpverleners beschikken. Opvallend is bij de patiënten het ontbreken van vrienden als het gaat om functionele dimensies als aansluiting, hulp (raad en daad) en vertrouwen terwijl bij de controlepersonen deze dimensies juist door vrienden worden vervuld. De controlepersonen doen vergeleken met de patiënten op alle functionele gebieden meer een beroep op hun sociale netwerk.

De ISSI van Henderson e.a. (1980) en de Quaestionaire van Brim (1974) zijn twee van de vele voorbeelden van wat men kan noemen schalen voor onderzoek betreffende 'social support networks'. Andere voorbeelden zijn het 'Classification Scheme of Informal Helping Behavior' van Gottlieb (1978), de 'Support Network Questionaire' van Trimble en Kliman (1981), de 'Inventory of Socially Supportive Behaviors' van Barrera, Sandler en Ramsay (1981).

Er is nogal wat discussie gaande betreffende onderzoek in de zin van 'social support networks' waarin zonder de waarde van dit onderzoek te ontkennen toch in toenemende mate een kritiek naar voren komt met ernstige twijfels over het theoretisch gehalte en de practische betekenis (Hall, Wellman, 1985; Jacobson, 1988). Waar waarde wordt toegekend is dat vooral omdat deze benadering uitdrukkelijk laat zien dat sociale processen van emotionele ondersteuning, advies, daadwerkelijke hulp en dergelijke 
(Weiss, 1974; Barrera, Ainlay, 1983; House, Kahn, 1985) zijn ingebed in een structureel georganiseerd sociaal milieu. (Hammer,1981)

Een van de moeilijkheden is het 'social support concept' zelf (Hammer, 1981; Broadhead e.a., 1983). Een belangrijk probleem is dat wanneer vertrokken wordt vanuit en alleen gekeken wordt naar 'ondersteunende' sociale netwerken het element steun verandert van een variabele in een constante ofwel dat zoals Hall en Wellman (1985) stellen: "a new a priory category, namely support, bounds the network". Hall en Welmann (1985) vervolgen: "This precludes the study of the circumstances under which support may be given and limits analysts to looking only at the effects of support". Daarnaast merkt Hammer (1981) op dat 'support' slechts één functie van een sociaal netwerk is. Een tweede punt van kritiek is dat het 'support'-uitgangspunt te zeer of alleen maar uitgaat van positieve ondersteunende betrekkingen. Het effect is dat de omvang van een persoonlijk sociaal netwerk ingeperkt wordt tot die mensen met wie positief ondersteunende banden bestaan en sociale netwerkananalyse zich exclusief concentreert op de bestudering en beschrijving van iemands emotioneel relationeel naaste netwerkleden. Sociale netwerken bestaan echter ook uit mensen en betrekkingen die niet positief ondersteunend zijn (Mitchell, Tricket, 1980; Hammer, 1981; Wellman, 1985). Gezien de overwegend positieve inkleuring van de betrekkingen die uitgaat van het begrip 'support' lijkt het mij gewenster inzake de inhoud van de betrekkingen tussen de focale persoon en de netwerkleden het neutrale begrip 'functie' te gebruiken (Baars, Uffing, 1991).

Een derde probleem is dat de aanpak van de 'social support' netwerken niet zelden gericht is op de analyse en beschrijving van kenmerken van persoonlijk en sociaal functioneren van de focale persoon en vandaaruit op bijvoorbeeld de individuele (psycho)pathologie van de focale persoon (Hammer, 1981). Dit betekent dat niet het sociale netwerk inclusief de focale persoon maar de focale persoon zelf en alleen primair onderwerp van sociale netwerkanalyse wordt. Kortom, het label 'social support' lijkt te gemakkelijk overgezet te worden op een sociaal netwerk. Het onderscheid tussen 'support' netwerken en sociale netwerken is meer dan een semantisch verschil; beide termen zijn niet inwisselbaar (Laireiter, Baumann, 1992).

\section{6 \\ ONDERZOEK MET ACCENT OP STRUCTUUR EN FUNCTIES VAN SOCIALE NETWERKEN}

De vasthoudendheid waarmee binnen de psychiatrie een sociaal netwerk wordt benoemd naar structuur en functies (Walker, MacBride, Vachon, 1977) en deze kenmerken als basisbestanddelen onderscheiden worden heeft ongetwijfeld te maken met het gegeven dat een ontkoppeling van beide elementen tot atzonderlijke stelsels op zijn minst als kunstmatig wordt gezien (Gottlieb, 1985; Angermeyer, Klusmann, 1989). Dit gegeven en meer in het algemeen gesteld dat er "in wezen geen structuur van mensen en betrekkingen bestaanbaar is waarin ook niet tegelijk functies worden vervuld" (Wellman, 1981) leidt er toe dat steeds opnieuw pogingen zijn/worden ondernomen een instrumentarium te ontwikkelen die beide bestanddelen van de sociale werkelijkheid van mensen in acht neemt. In deze paragraaf een drietal voorbeelden. In de eerste plaats betreft dat de "Psychosocial Kinship Inventory" (PKI) ontwikkeld door Pattison e.a. (1975). Vervolgens wordt deze invalshoek geïllustreerd aan het werk van Froland en zijn collega's (1979) en de door deze onderzoeksgroep ontwikkelde "Social Network Assessment Questionaire" (SNAQ). Tenslotte van meer recente datum de 'Interview on Social Networks and Social Support' (SONET), ontwikkeld door onder meer Baumann en Laireiter (1987) te Salzburg. 
De "Psychosocial Kinship Inventory" (PKI) ontwikkeld door Pattison en zijn collega's (1975) voor de beschrijving van functionele en structurele kenmerken van sociale netwerken, en de term 'kinship' verwijst daar al naar, moet gezien worden tegen de achtergrond van de in \$ 3.3.2. beschreven context van gezinstherapie waarin de sociale omgeving van een gezin meer en meer betekenis krijgt (Pattison, 1977). Naar de mening van Pattison is voor de (psychiatrische) hulpverlening de kennis van het gezin in samenhang met haar sociale omgeving, bijvoorbeeld met de collega's op het werk, de buren, de vrienden en andere bekenden van de gezinsleden, van vitaal belang. Met de PKI wordt beoogd wat genoemd wordt de "primary social matrix" grondig in kaart te brengen. Dit "intimate psychosocial network" van de patiënt bestaat uit al die mensen met wie de patiênt een belangrijke en waardevolle band heeft. Pattison e.a. gaan er van uit dat de relaties in dit "intimate psychosocial network" bij mensen zonder problemen in de gestelijke gezondheid gewoonlijk de volgende kenmerken vertonen:

- ze hebben een betrekkelijk hoge mate van interactie, zowel qua face to face contacten alsook per telefoon en via brieven; er wordt veel in de relatie geïnvesteerd;

- de relaties zijn emotioneel zeer intensief:

- de gevoelens zijn in het algemeen positief; negatieve relaties blijven alleen bestaan wanneer andere gegevenheden die verbreking ervan verhinderen;

- de relaties zijn gebaseerd op persoonlijk eigen initiatief, zowel met betrekking tot emotionele ondersteuning alsook voor concrele en zakelijke hulp;

- de relaties zijn bovendien wederkerig en dat geldt eveneens in emotioneel opzicht alsook voor praktische raad en daad.

Tegen deze achtergrond inventariseert de PKI wat genoemd wordt 'structurele' en 'qualitatieve' kenmerken van sociale netwerken. Structurele data betreffen onder meer de omvang van het sociale netwerk: de focale persoon wordt gevraagd een lijst te maken van die mensen die in zijn leven persoonlijk belangrijk zijn; er is een onderverdeling in de clusters bloedverwanten, aanverwanten, vrienden, collega's en mensen die sociale organisaties vertegenwoordigen. De dichtheid van het netwerk wordt in kaart gebracht door met de focale persoon een sociogram van de verbindingen tussen deze netwerkleden te maken. Bij qualitative data gaat het om de perceptie van de focale persoon over de relatie met ieder netwerklid, in het bijzonder met betrekking tot de uitwisseling van de support binnen deze relaties.

Pattison e.a. (1975) vinden bij mensen zonder problemen in de geestelijke gezondheid een omvang van het 'intime psychosociale netwerk' dat gemiddeld uit 22 a 25 personen bestaat. leder cluster blijkt uit ongeveer gemiddeld vijf à zes personen te bevatten. De relaties in deze sociale netwerken zijn conform de vijf hierboven genoemde kenmerken van interpersoonlijke relaties. De dichtheid ligt gemiddeld rondom de $60 \%$. Buiten de naaste familieleden zijn vrienden de hoogst gewaardeerde netwerkleden en worden zij het meest benut voor affectieve ondersteuning en andere typen hulp.

Bij psychiatrische patiènten met neurotische verschijnselen vinden Pattison e.a. sociale netwerken met een omvang van gemiddeld 15 personen; binnen deze omvang worden nogal eens mensen genoemd die onbereikbaar zijn. De waardering van de interpersoonlijke relaties ligt lager dan in de genoemde normale onderzoekspopulatie en er bestaan uitgesproken negatieve relaties. De dichtheid ligt op ongeveer $30 \%$. Bij psychiatrische patienten met psychotische verschijnselen bestaat de omvang van het netwerk gemiddeld uit 12 personen en wel grotendeels uit familieleden. De waardering van de interpersoonlijke relaties is ambivalent; bovendien ontbreekt er wederkerigheid in de relaties. De dichtheid is zeer hoog en wel om en nabij de $90 \%$. 
Een tweede voorbeeld is te vinden bij Froland en zijn collega's (Froland, 1978; Froland e.a., 1979) die de 'Social Network Assessment Questionaire' (SNAQ) ontwikkelden, een instrument dat zeer uitgebreide informatie oplevert over zowel de structuur als de functies van sociale netwerken. In hoofdlijnen beschrijft de SNAQ:

- structuurkenmerken, te weten:

= de omvang ofwel al die mensen met wie iemand in het dagelijks leven omgaat;

= de dichtheid, ofwel de mate waarin de netwerkleden elkaar kennen;

= de verdeling van netwerkleden die iemand vrijwillig kiest en die ongevraagd tot het sociale netwerk behoren;

- patronen in de betrekkingen in de zin van duur ofwel lengte van het contact, de frequentie van en de reden voor het contact;

- de ondersteunende functies, ofwel de mate waarin door de afzonderlijke netwerkleden voorzien wordt in sociale ondersteuning;

- de stabiliteit van het sociale netwerk, ofwel de invloed van life-events op de structuur en de functies in het sociale netwerk;

- tenslotte bevat de SNAQ een aantal vragen over de geestelijke gezondheid van de mensen die deel uitmaken van het netwerk en over de binnen het sociale netwerk verkregen zorg bij problemen in de geestelijke gezondheid.

Met behulp van de SNAQ onderzochten Froland e.a. (1979) een drietal groepen psychiatrische patiènten, te weten:

1 psychiatrische patiènten opgenomen in een psychiatrisch ziekenhuis $(n=30)$;

2 psychiatrische patienten in zorg binnen een progamma van dagbehandeling ( $\mathrm{n}=$ 20);

3 psychiatrische patiënten binnen de ambulante psychiatrische zorg ( $n=27$ ).

Deze drie groepen patienten die langdurig in zorg waren werden vergeleken met een referentiegroep ( $n=30$ ) waarbij geen problemen in de geestelijke gezondheid aanwezig waren. De gemiddelde leeftijd van de patiënten was 31 jaar (range: 18 - 55 jaar). De uitkomsten kunnen globaal als volgt samengevat worden.

In vergelijking met de referentiegroep zijn de netwerken van de drie groepen patienten kleiner in omvang, hebben de patienten minder banden met verwanten, minder langdurige vriendschappen en minder vrienden die ook door de familie van de patient gekend worden. Deze verschillen met de referentiegroep zijn het grootst bij patienten die in een psychiatrisch ziekenhuis zijn opgenomen en ze zijn het kleinst bij patienten die ambulant in zorg zijn. Froland e.a. (1979) vinden een wisselwerking tussen kenmerken van persoonlijk functioneren van de patient en de toename van structureel verval in het sociale netwerk. Een toename van gevoelens van verwarring. angst en depressie in het persoonlijk functioneren gaat gepaard met een toename in het verval van de structuur en de ondersteunende functies in het sociale netwerk. Dit is in hel bijzonder het geval wanneer er sprake is van eerdere perioden van psychiatrische hulpverlening. De toename van de behoefte aan intensieve professionele zorg loopt paralel met de toename van verval in het sociale netwerk.

\section{Interview on Social Networks and Social Support (SONET)}

De 'Interview on Social Networks and Social Support' (SONET) op naam van Baumann. Laireiter, Pfingstmann en Schwarzenbacher (1987) in Salzburg is een instrument voor de analyse en beschrijving van zowel de structuur als de functies van een persoonlijk sociaal netwerk dat bijzondere aandacht verdient. De SONET is naar mijn mening een van de weinige instrumenten op het terrein van het sociale netwerkonderzoek waarbij zowel de in $\$ 4.5$ beschreven kriliek inzake een 'socialesupport-netwerkbenadering' zeer ernstig wordi genomen (Laireiter, 1989; Laireiter, Baumann, 1992) en waarmee alsook een veelbelovende voortuitgang is/wordt geboekı ten behoeve van een theoretische en methodologische synthese van do analyse en beschrijving van de structuur en de functies in persoonlijke sociale netwerken (Feichtinger, Laireiter, Baumann, 1992). 
De SONET, waarbij de informatie via een semi-gestructureerd interview wordt verzameld, bestaat uit de volgende vier onderdelen.

1 Analyse on beschrijving van de omvang netwerkleden onderverdeeld naar hun sociale rol (zoals lid van eigen huishouden, familielid, buren, collega's, lid van een vereniging, hulpverlener) en haar hun emotioneel-relationele betekenis, zowel positief (zoals partner, kinderen, vertrouwenspersoon, goede vriend) alsook negatief gekleurd (in de zin van bijvoorbeeld ambivalentie, konflikten, en vrees).

2 Analyse en beschrijving van 'interactionele' kenmerken tussen een focale persoon en de netwerkleden te weten:

- de duur van het contact (in maanden en jaren);

- de wijze van contact (face to face, per telefoon of brief);

- de frequentie van contact ( dagelijks, wekelijks en dergelijke);

- de geografische afstand.

3 Analyse en beschrijving van de steun die van de netwerkleden uitgaat in psychologische zin (zoals geliefd-zijn, gewaardeerd te worden en erbij te horen) en in instrumentele zin (zoals advies en informatie, goederen en feitelijke hulp).

4 Analyse en beschrijving van de beoordeling die door een focale persoon gegeven wordt aan enerzijds de netwerkleden in termen van doelmatigheid en voldoening en aan anderzijds de ondersteuning in termen van doeltreffendheid en relevantie.

Het werk van Pattison en zijn collega's (Pattison e.a., 1975; Pattison, Pattison, 1981) heeft vooral toepassing gevonden op het raakvlak van onderzoek en hulpverlening bij psychiatrische patiënten waarin een voorkeur uitgaat naar een systeem-theoretisch gefundeerde gezinstherapeutische benadering. Zo gebruiken bijvoorbeeld Gottlieb en Coppard (1987) een door hen aangepaste versie van de PKI van Pattison $\boldsymbol{\theta} . \mathrm{a}$. (1975) bij een 'Social Network Therapy (SNT)' programma in de ambulante zorg voor chronisch psychiatrische patiënten $(N=35)$ te Toronto. Een bewerkte versie van de PKI is eveneens aanwezig in het onderzoek van Hamilton e.a. (1989). Een ander voorbeeld van de invloed die het werk van Pattison (gehad) heeft is te vinden bij de ontwikkeling van een 'gemeindenahe Psychiatrie' door Katschnig en zijn collega's in Wenen (Katschnig, Konieczna, 1984; Katschnig. Sint, 1984).

De SNAQ van Froland en zijn collega's $(1978,1979)$ heeft voor zover achterhaald is kunnen worden geen verdere verspreiding gekregen. Een moeilijkheid is dat de SNAQ een veelomvattend en complex instrument is en in tegenstelling tot de PKI van Pattison e.a. (1975) eigenlijk niet goed aansluit op een gebruikelijke werkwijze van psychiatrische hulpverlening. In plaats van de door Froland e.a. (1978) beoogde eenvoud en toegankelijkheid voor de hulpverlening is er in de uitwerking een verfijning opgetreden waarmee dit instrument overwegend hanteerbaar bleef voor degenen die haar ontworpen hebben.

De SONET heeft tot op heden overwegend toepassing gekregen binnen de eigen onderzoeksgroep van Laireiter en Baumann 
Aan de hand van de hierboven aangehaalde onderzoeken geordend naar hoofdlijnen dan wel accenten betreffende structuur en functies in sociale netwerken is eigeniijk ook de staalkaart van het sociale netwerkonderzoek op het terrein van de psychiatrie gegeven. In het algemeen blijkt dat het sociale netwerkonderzoek binnen de psychiatrie vooralsnog, ondanks groeiende belangstelling. incidenteel en fragmentarisch plaats vindt. De probleem- on vraagstellingen en ook de werkwijzen lopen meer uiteen dan dat er sprake is van onderlinge afstemming (Knipscheer, Antonnuci,1990). Deze vaststelling houdt in dat een vergelijking van de bevindingen een uiterst moeilijke aangelegenheid is. Toch is er bij een nadere vergelijkende bestudering van de hierboven vermelde onderzoeken aangevuld met de overzichtsartikelen van onder anderen Meuller (1980), Erickson, (1984) en Hirschberg (1988) enige lijn te vinden in de uitkomsten van de verschillende onderzoeken naar de structuur van sociale netwerken van (chronisch) psychiatrische patiënten. De hierna le geven voornaamste trekken inzake de structuur van het sociale netwerk overeenkomstig het schema van Walker, MacBride en Vachon (1977) moeten evenwel opgevat worden als voorlopig waargenomen tendenzen.

\subsubsection{Omvang van persoonlijke sociale netwerken}

Ten aanzien van de omvang van de netwerken worden er in hoofdlijnen de volgende uitkomsten in de zin van tendenzen aangetroffen.

a

Mensen zonder problemen in de geestelijke gezondheid beschikken over een sociaal netwerk dat in de regel varieert van 20 tot 50 netwerkleden (Hammer, MakieskyBarrow, Gutwirth, 1978; Pattison, Pattison, 1981), waarvan ongeveer 6 tot 11 netwerkleden met de focale persoon een meer vertrouwelijke band hebben (Meuller, 1980). Bij psychiatrische patiënten blijkt de omvang netwerkleden in het algemeen kleiner te zijn. Deze geringere omvang varieert; de variaties die in de omvang netwerkleden worden aangetroffen lijken achtereenvolgens samen te hangen met

- de afbakening en de operationalisatie van de omvang bij de opzet van het onderzoek. Het maakt verschil of uitgegaan wordt van het 'beschikbare persoonlijke netwerk' (Erickson, 1976) of van de 'primary group' (Henderson e.a., 1977);

- het moment of stadium in de patiëntcarriere dat het onderzoek plaats vindt. Het maakt verschil of op het moment van de eerste opname (Tolsdorf, 1977) of na ontslag uit een zeer langdurig verblijf in een psychiatrisch ziekenhuis (Cohen, Sokolovsky (1978).

- de diagnosecategorie (Dozier, Harris, Bergman, 1987) dan wel de begeleidende b psychiatrische symptomatologie (Hammer, 1964) bij de patiënt.

De omvang van 'beschikbare' netwerkleden van psychiatrische patiënten bij wie voor het eerst sprake is van psychiatrische symptomatologie dan wel die voor het eerst met psychiatrische hulpverlening in contact komen lijkt soms redelijk op de normaal gemiddelde omvang aan te sluiten (Tolsdorf, 1976) en dan weer lager uit te vallen zoals in het onderzoek van Erickson (1976). Het probleem is echter dat in dit stadium van de carrière van persoon naar patiënt slechts een gering aantal netwerkleden benut worden; effectief bestaat het netwerk voornamelijk uit naaste verwanten aangevuld met mensen, zoals de huisarts, die de professionele hulpverlening vertegenwoordigen. (Erickson, 1976). Al bij al lijkt er in het beschikbare sociale netwerk een verschuiving plaats te vinden qua effectieve netwerkleden en wel in die zin dat de effectiviteit van de informele netwerkleden, met name in de sector vriendschappelijke betrekkingen, afneemt en er een toename is van netwerkleden in de zin van professionele hulpverlening. Deze verschuiving is scherper bij een opname in een psychiatrisch ziekenhuis dan wanneer de patiënt ambulante zorg krijgt (Erickson, 1984). 
De omvang van de sociale netwerken van psychiatrische patiënten die langdurig in zorg zijn is aanzienlijk kleiner vergeleken met de omvang van de netwerken van psychiatrische patiënten die voor het eerst in zorg komen (Lipton, e.a, 1981). Bij chronisch psychiatrische patiënten valt op dat hun informele sociale netwerk, dat op zich zelf betrekkelijk gering in omvang is, gemiddeld groter is naarmate de patiënt meer ambulant behandeld wordt (Froland e.a., 1979). Ook hier geldt weer dat in de sector vriendschappelijke betrekkingen de daling van het aantal netwerkleden het grootst is (Bolwijn, 1989; Hamilton e.a., 1989) hetgeen resulteert in een omvang waarin (naaste) verwanten overheersend aanwezig zijn (Hirschberg, 1988).

d

In meerderheid betreft het sociale netwerkonderzoek psychiatrische patiënten met schizofrene stoornissen. De omvang van sociale netwerken bij patiënten met psychotische verschijnselen is gemiddeld kleiner dan bij patiënten met neurotische symptomatologie. In het algemeen laten de onderzoeken zien dat de omvang afneemt naarmate de last van de psychiatrische symplomatologie voor de omgeving toeneemt.

\subsubsection{Gevarieerdheid van netwerkleden}

Ten aanzien van de gevarieerdheid van de sociale netwerken worden de volgende uitkomsten aangetroffen.

a

De gevarieerdheid van de focale personen wordt algemeen beschreven aan de hand van de gebruikelijke sociaal demografische kenmerken. Daarnaast wordt de focale persoon beschreven naar kenmerken van patiëntcarriere en diagnose. Opvallend is de tendens in het sociale netwerkonderzoek dat bij de beschrijving van de onderzoekspopulatie de kenmerken van de patiëntcarriere meer op de voorgrond staan dan de psychiatrisch diagnostische categoriê die op de focale persoon betrekking heeft. Deze tendens hangt samen met de veronderstelling dat niet zozeer de diagnose maar vooral de patiëntcarriere van invloed is op het sociaal functioneren van de psychiatrische patiënt. Cohen en Sokolovsky (1978) stellen dat bijvoorbeeld de diagnostische categorie 'schizofrenie' op zichzelf geen eenduiding beeld inhoudt van de sociale capaciteiten van de psychiatrische patienten op wie deze diagnose van toepassing is. Zij wijzen er op dat er bij deze patienten een grote variatie in sociaal functioneren aangetroffen wordt samenhangend met de sociale omstandigheden waarin zij verkeren.

b

Er is geen onderzoek gevonden waarbij de gevarieerdheid van de netwerkleden in beeld wordt gebracht. Het effect is dat er geen vergelijking mogelijk is inzake de verschillen dan wel overeenkomsten in gevarieerdheid tussen de focal persons en de netwerkleden.

\subsection{3}

\section{Bereikbaarheid van netwerkleden}

De bereikbaarheid van de netwerkleden in de zin van geografische afstand wordt nauwelijks onderzocht. Alleen in het onderzoek van Froland e.a. (1979) komt naar voren dat de netwerkleden van de door hen onderzochte chronisch psychiatrische populaties vooral in de directe omgeving van de patient wonen; bij de referentiepersonen worden meer netwerkleden aangetroffen die ver(der) weg wonen.

\subsubsection{Dichtheid van persoonlijke sociale netwerken}

De dichtheid of wel de verhouding tussen het aantal daadwerkelijke betrekkingen en het aantal mogelijke betrekkingen tussen netwerkleden in sociale netwerken van psychiatrische patiënten kan als volgt samengevat worden.

a

Uitgaande van een beschikbare omvang netwerkleden lijkt de gemiddelde dichtheid van het netwerk bij mensen zonder problemen in de geestelijke gezondheid hoger te zijn 
dan bij psychiatrische patiënten. Het verschil betreft vooral de sector vriendschappelijke betrekkingen.

b

In het gemiddeld kleine zogeheten 'effectieve' sociale netwerk van bij alle te onderscheiden populaties psychiatrische patienten waarin de (naaste) verwanten in aantal overheersen (Hirschberg, 1988) komt het zowel voor dat de gemiddelde dichtheid hoog is, bijvoorbeeld rondom de eerste opname, alsook dat deze laag is, onder meer bij patiënten die langdurig in zorg zijn. Een hoge dichtheid in een klein 'effectief' sociaal netwerk impliceert een geringe emotioneel-relationele afstand tussen een klein aantal betrokken netwerkleden, een situatie waarin netwerkleden minder bereid en in staat zijn adequaat op de patiênt en zijn problemen te reageren. Bij een lage dichtheid in de betrekkingen valt op dat ook de hulpverleners die deel uitmaken van het sociale netwerk nauwelijks van elkaars bestaan weet hebben. Dozier, Harris en Bergman (1987) laten zien dat zowel een zeer hoge als een zeer lage dichtheid in het sociale netwerk een samenhang vertonen met een lange verblijfs- of zorgduur.

\section{7 .5}

Structuur van de betrekkingen

Ten aanzien van de structuur van de betrekkingen in de sociale netwerken worden de volgende uitkomsten aangetroffen.

a

Wanneer het om initiatief gaat valt op dat in het algemeen (chronisch) psychiatrische patiënten minder eigen initiatief naar hun nefwerkleden tonen dan referentiepersonen. Chronisch psychiatrische patienten in een psychiatrisch ziekenhuis tonen weer minder eigen initiatief naar hun informele netwerkleden dan degenen die ambulant in zorg zijn. De richting van de dyadische betrekkingen tussen de focale persoon en een netwerklid is overwegend afhankelijk.

b

Ten aanzien van het element frequentie zijn de bevindingen schaars en voor zover ze er zijn kunnen er eigenlijk geen tendenzen in worden waargenomen.

c

(Chronisch) psychiatrische patiënten geven minder gewicht aan (de contacten met) hun informele netwerkleden dan het geval is bij de referentiepersonen. Dit betekent onder meer dat (chronisch) psychiatrische patiënten op minder steun en hulp van hun informele netwerk rekenen dan referentiepersonen. Onderzoek van Froland $\boldsymbol{\theta}$.a. (1979) geeft aan dat chronisch psychiatrische patiënten ondervinden dat zij voor hulp in hoge mate aangewezen zijn op de (psychiatrische) hulpverlening, terwijl referentiepersonen een beroep zullen doen op hun naaste verwanten en netwerkleden in de sector vriendschappelijke betrekkingen. Een belangrijk probleem is dat chronisch psychiatrische patienten langdurig dan wel voortdurend op hulp aangewezen lijken te zijn, een investering die informele netwerkleden in tegenstelling tot hulpverleners niet (kunnen) opbrengen en volhouden (Kreissman, Joy, 1974; Walker, MacBride, Vachon, 1977).

Het gewicht ten aanzien van het contact met informele netwerkleden daalt naarmate de patiënt vervreemd raakt van zijn verwanten, meer contactbreuken en verlies van netwerkleden heeft meegemaakt en naarmate de hulp die de patiënt in het sociale netwerk zoekt meer als last wordt beleefd. Bij chronisch psychialrische patiēnten die opgenomen zijn in een psychiatrische ziekenhuis is de daling van het gewicht ten aanzien van informele netwerkleden groter dan bij diegenen die ambulant in zorg zijn (Froland e.a., 1979).

d

De lengte van de betrekkingen is nauwelijks onderzocht en beschreven. 
Met het oog op het in dit proefschrift te presenteren onderzoek naar de structuur van het sociale netwerk van ambulante chronisch psychiatrische patiënten in zorg bij de SPD van de RIAGG Maastricht kan geconstateerd worden dat er eigenlijk geen eerder onderzoek uitgevoerd is dat zich specifiek richt op de structuur van het sociale netwerk en vervolgens op deze doelgroep van ambulante psychiatrische hulpverlening.

Het profiel van de structuur van het sociale netwerk dat zich bij ambulante chronisch psychiatrische patënlen lijkt af te tekenen is zoals in $\S 4.6$. in hoofdlijnen is aangegeven ligt in het algemeen in het midden tussen het de structureel sterk afgeknotte sociale netwerken van intramuraal in zorg zijnde chronisch psychiatrische patiēnten en de structuur in de sociale netwerken die wordt aangetroffen bij normale referentiepersonen. Daarnaast mag verwacht worden dat er variaties in de structuur zullen optreden, in het bijzonder tussen de groep jongere en oudere ambulante chronisch psychiatrische patiënten (Harris, Bergman, 1985). Het komt er op neer dat met inachtneming van de hierboven vermelde algemene tendenzen in de structuur van het sociale netwerk van (ambulante) chronisch psychiatrische patiënten er vooraf slechts met de nodige reserve gerefereerd kan worden aan de uitkomsten van eerder uitgevoerd onderzoek.

Daarenboven is in de vermelde onderzoeken gebruik gemaakt van verschillende werkwijzen, een gewoonte die al het in dit hoofdstuk weergegeven sociale netwerkonderzoek betreft. Zelfs waar overeenkomstige instrumenten lijken te worden gebruikt, blijken deze voor het betreffende onderzoek bijgesteld te zijn. Een serieuze vergelijking is in wezen onmogelijk. Echter welk instrument of welke versie van een instrument onderzoekers ook gebruiken de bevindingen geven zonder uitzondering aan dat de structuur van het sociale netwerk van de onderzochte populaties psychiatrische patiënten op alle onderdelen in meer of mindere mate verlies heeft geleden vergeleken met de structuur van de sociale netwerken van de daarbij onderzochte normale referentiepersonen (Froland e.a., 1979; Meuller, 1980; Erickson, 1984, Hirschberg. 1988). 


\section{MODEL VOOR SOCIALE NETWERK ANALYSE}

\subsection{SAMENHANG VAN PRAKTIJK EN ONDERZOEK}

Vanuit een sociaal psychiatrische optiek, zoals bijvoorbeeld verwoord door Romme, Kraan en Rotteveel (1981) en door Erickson (1984), wordt een doeltreffende en doelmatige samenhang voorgestaan tussen de praktijk van de psychiatrische hulpverlening en die van het wetenschappelijk onderzoek inzake haar kernthema: het sociale milieu van de psychiatrische patiënt. Het komt erop neer dat de wetenschappelijke analyse van het sociale milieu - hier in termen van een sociaal netwerk - niet zozeer een doel op zichzelf is maar gegevens en inzichten oplevert die adequaat toepasbaar zijn in de zorg en die de doelmaligheid van de zorg gericht op de sociale integratie van de psychiatrische patiënt verbeteren. Bij vrijwel al het beschreven sociale netwerkonderzoek in het vorige hoofdstuk 4 wordt deze intentie met nadruk uitgesproken.

Zo op het eerste gezicht lijkt het mogelijk tussen de sociale netwerkstrategieen (zie hoofdstuk 3) en het sociale netwerkonderzoek (zie hoofdstuk 4) een dergelijke samenhang te vinden. De sociale netwerkstrategieën zijn immers vormen van psychiatrische hulpverlening die primair de bevordering dan wel het herstel van de sociale integratie van (chronisch) psychiatrische patiënten beogen door in termen van een sociaal netwerk een vitaal sociaal milieu met de patiënt en zijn netwerkleden op te bouwen waardoor tegemoed gekomen kan worden aan een gewenste vervulling van de dagelijkse bestaansbehoeften (Speck, Attneave, 1973; Baars, Uffing, Dekkers, 1990; Baars, Uffing, 1991). Het vermelde netwerkonderzoek betreft een sociaal wetenschappelijke systematiek waarmee in termen van een sociaal netwerk de sociale integratie ofwel de verhouding tussen de (chronisch) psychiatrische patiènt en zijn sociale omgeving geconcretiseerd, geanalyseerd en beschreven wordt (Erickson, 1984; 1988).

Gemeenschappelijk is dat uitgegaan wordt van 'persoonlijke sociale netwerken' en dat voor de grondslag ervan verwezen wordt naar een sociologisch/anthropologische sociaal netwerkconcept. Vervolgens blijken de in praktijk opgedane en systematisch uitgewerkte ervaringen met de sociale netwerken van (chronisch) psychiatrische patiënten redelijk overeen te stemmen met de in onderzoek systematisch verworven bevindingen over het sociale netwerk van mensen en betrekkingen bij doelgroepen van psychiatrische hulpverlening. De aansluiting lijkt over en weer vooral toe te nemen wanneer de inzichten vanuit praktijkervaringen en de bevindingen uit wetenschappelijk onderzoek betrekking hebben op de 'structuur' ofwel op de wijze waarop persoonlijke sociale netwerken van (chronisch) psychiatrische patie̋ten zijn opgebouwd. 
Het beschikbare sociale netwerkonderzoek en de voornamelijk experimentele praktijk van sociale netwerkinterventies blijken te bevestigen dat de bevordering dan wel het herstel van de sociale integratie van de (chronisch) psychiatrische patiënt primair afhangt van het herstel dan wel de opbouw van een structureel vitaal sociaal netwerk.

Een nadere beschouwing, eveneens weergegeven in de hoofdstukken 3 en 4, leert dat er weliswaar overeenkomstige termen en beelden gebruikt worden en dat er qua gedachtengoed verbindingen zijn, maar dat er van een samenhang in de zin van een nauwkeurige inhoudelijke afstemming en een daarop aansluitende methodische uitwerking niet echt sprake is. De belangrijkste problemen zijn:

- het ontbreken van een diagnostiek op patiëntniveau die zich expliciet richt op de structuur van een persoonlijk sociaal netwerk (zie $\$ 3.5 .2$ );

- het ontbreken van een eenduidig analystisch schema voor wetenschappelijk onderzoek naar de structuur van sociale netwerken (zie § 4.6);

- het ontbreken van een voorstelling of model van een persoonlijk sociaal netwerk dat als uitgangspunt en organiserend beginsel functioneert voor zowel de diagnostiek op patientniveau alsook voor de wetenschappelijke analyse op groepsniveau

Voor een oplossing van deze problematiek staat men echter niet geheel met lege handen.

Zowel de experimentele praktijk van sociale netwerkinterventies alsook het beschreven sociale netwerkonderzoek bevatten tal van bouwstenen voor de opbouw van een model van een persoonlijk sociaal netwerk ofwel voor de opbouw van een "hulpconstructie" (Querido, 1955) waarmee een samenhangend geheel van diagnostiek en wetenschappelijke analyse van de sociale integratie bij doelgroepen in de psychiatrische hulpverlening mogelijk wordt. De opzet van een dergelijke hulpconstructie vangt aan met de afbakening van een persoonlijk sociaal netwerk (Froland e.a., 1979).

\section{AFBAKENING VAN EEN PERSOONLIJK SOCIAAL NETWERK}

Zodra een sociaal netwerk als eenheid van onderzoek en/of hulpverlening wordt genomen is er in de eerste plaats het probleem van de uitgebreidheid van een sociaal netwerk. Er zijn omschrijvingen van een sociaal netwerk (zie Bijlage III) die zo ruim gesteld zijn dat het aantal mensen die vanuit de 'personal network strategy' binnen een sociaal netwerk vallen vrijwel onbegrensd is. Voorbeelden zijn de omschrijving van een sociaal netwerk door Bott $(1957,1971)$ en Adams (1969). De omschrijving van Adams (1969) luidt: "al die mensen met wie iemand contact heeft en op enigerlei wijze een sociale band heeft". In principe kunnen hier tot de omvang van een sociaal netwerk zowel mensen gerekend worden die een focale persoon regelmatig incidenteel tegenkomt alsook mensen met wie dagelijks intensief en langdurig contact bestaat.

Er zijn eerder stappen gezet om het ingewikkelde geheel van mensen en betrekkingen in een sociaal netwerk voor onderzoek hanteerbaar te maken. Ter illustratie een aantal varianten. Zo komt het voor dat de in principe onbegrensde omvang gebonden wordt aan een van te voren bepaald maximum aantal netwerkleden. Janssen (1993) bijvoorbeeld hanteert een bovengrens van twintig netwerkleden. In de eerste 'East York study' $(N=845)$ in 1968 was ook door Wellman e.a. (1973) een dergelijke beperking ingebouwd: maximaal zes emotioneel-relationeel belangrijke netwerkleden buiten het eigen huishouden van de focale persoon. Het probleem is dat een sociaal netwerk zowel in termen van persoonlijk welbevinden als van sociale integratie wezenlijk omvangrijker en ingewikkelder is, hetgeen aanleiding was deze benadering te verlaten. In de tweede 'East York study' $(\mathrm{N}=33)$ in 1978 gaat het om "all persons with whom East Yorkers were significantly in touch" (Wellman, Carrington, Hall, 1988).

Een andere veel gebruikte mogelijkheid tot begrenzing is om op grond van emotioneel-relationele afstand tussen een focale persoon en zijn netwerkleden grenzen in de omvang vast te stellen. Aldus onderscheidt Kapferer (1973) een 'intieme', een 'effectieve' en een 'extensieve' zone in een sociaal netwerk. De intieme zone wordt gevormd door personen met wie een focale persoon directe betrekkingen heeft die overwegend instrumenteel ofwel wederkerig en 'multiplex' zijn. 'Multiplex' betekent 
hier dat een betrekking meerdere functies vervult. De effectieve zone bestaat uit die personen met wie iemand graag en regelmatig omgaat. De extensieve zone omvat volgens Kapferer die mensen die persoonlijk gekend worden maar met wie het contact onregelmatig of incidenteel is.

Een ander indeling is die van Boissevain (1974). Hij gaat er van uit dat in het centrum van een netwerk wat hij noemt een "personal cell" aanwezig is die bestaat uit de nabije verwanten en de meest intieme vrienden. Hieromheen bevindt zich een 'eerste intieme zone', waartoe vrienden behoren met wie een focale persoon actief vertrouwelijke relaties onderhoudt, en vervolgens een 'tweede intieme zone' van vrienden en bekenden met wie een passieve relatie bestaat maar die niettemin emotioneel-relationeel belangrijk zijn. Vervolgens is er een 'effectieve zone', een kring van mensen die om praktische redenen van belang zijn, gevolgd door een 'nominale zone' bstaande uit mensen die een focale persoon wel kent maar die emotioneel en praktisch nauwelijks van betekenis zijn. De laatste cirkel van een sociaal netwerk bestaat bij Boissevain (1974) uit de 'extensieve zone' ofwel mensen die iemand wel eens gezien heeft en die hij als zodanig herkent of die hem herkennen.

Ook in onderzoek naar sociale netwerken bij psychiatrische populaties treft men zoals reeds aangegeven in het vorige hoofdstuk verschillende en uiteenlopende begrenzingen in een sociaal netwerk aan. Erickson $(1976,1984)$ onderscheidt een uitgebreid, een beschikbaar en een effectief persoonlijk netwerk. Hammer (1978) maakt onderscheid tussen een drietal zones: de zone van het persoonlijke netwerk, de zone van het nominale netwerk en de zone van het extensieve netwerk.

In dit proefschrift wordt de voorkeur gegeven aan de indeling in zones in de lijn van Hammer (zie fig. 5.1). De zone van het persoonlijke sociale netwerk sluit aan op het gebied van mensen en betrekkingen in de werkwijze van Speck en zijn collega's (1973) dat als uitgangspunt voor een diagnostiek van de structuur van een sociaal netwerk opgevat kan worden. Daarnaast is deze keuze ingegeven vanwege de praktische betekenis van de drie genoemde zones voor het opzetten van varianten van sociale netwerkstrategieern in de psychiatrische hulpverlening (Baars, Uffing, Dekkers, 1990).

FIGUUR 5.1 Zones in en sociaal netwerk

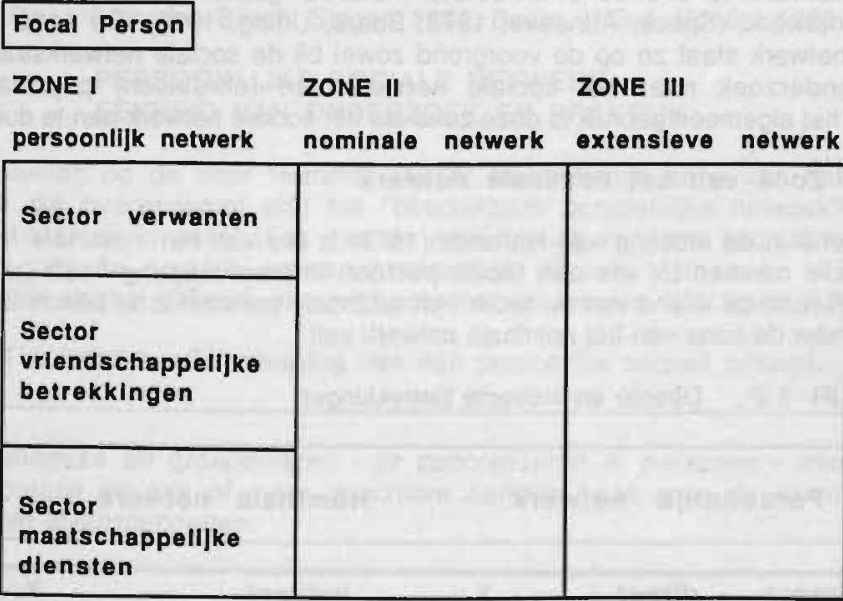


Hammer (1978) omschrijft de zone van het persoonlijke netwerk als bestaande uit "al die mensen met wie iemand in het dagelijks leven directe, duurzame en betekenisvolle banden heeft". Bij 'directe' banden gaat het om die mensen die voor iemand rechtstreeks, zonder tussenkomst van een derde persoon, toegankelijk zijn (zie figuur 5.2). 'Duurzame' banden houden in dat de contacten met de mensen in deze zone van het sociale netwerk over langere tijd in de levensloop van de focale persoon aanwezig zijn. Bij 'betekenisvolle' banden gaat het om die mensen die voorzien in wat Hammer (1978) noemt "de dagelijkse menselijke behoeften" van de focale persoon. De door Hammer (1978) gehanteerde begrenzing van de zone van een persoonlijk netwerk sluit aan bij de definitie van een sociaal netwerk zoals die door Speck en Attneave (1973) gegeven is, namelijk "al die mensen met wie iemand min of meer duurzame banden onderhoudt voor de vervulling van zijn dagelijkse levensbehoeften". De zone van het persoonlijke netwerk bij Hammer (1978) komt overigens ook nagenoeg overeen met het 'beschikbare persoonlijke netwerk' in de indeling van Erickson (1976, 1984).

Vrijwel al het in hoofdstuk 4 vermelde onderzoek bestrijkt of bevindt zich binnen de zone van het persoonlijke netwerk. Globaal genomen is er een tendens dat het onderzoek waarbij de nadruk valt op de structuur van het sociale netwerk meer de mogelijk beschikbare omvang van het persoonlijke netwerk bestrijkt. Het onderzoek dat in eerste instantie uitgaat van een 'support-netwerkconcept' behelst in meer of mindere mate de 'intimi', in zekere zin overeenkomend met wat Erickson (1976, 1984) het 'effectieve' deel van een 'beschikbaar' persoonlijk netwerk noemt en bijvoorbeeld door Henderson e.a. (1978) als de 'primary group' aangeduid wordt. Het komt er op neer dat wanneer de nadruk wordt gelegd op de structuur van de zone van een persoonlijk sociaal netwerk de omvang primair bepaald wordt door de aanwezige 'directe' banden van een focale persoon met andere mensen ongeacht de betekenis die aan deze banden wordt gehecht. Wanneer een support-concept uitgangspunt is zal vooral door de 'betekenisvolle' en 'duurzame' banden de omvang van de zone van het persoonlijke sociale netwerk bepaald worden (Meuller,1980). Tenslotte, de centrale doelstelling van de sociale netwerkstrategieěn te weten de opbouw van een vitaal persoonlijk netwerk is eveneens in eerste instantie geënt op de zone van het persoonlijke netwerk, (Speck, Attneave, 1973; Baars, Uffing, 1991). De zone van het persoonlijke netwerk staat zo op de voorgrond zowel bij de sociale netwerkstrategieěn alsook bij onderzoek naar het sociale netwerk van (chronisch) psychiatrische patiënten dat het algemeen gebruik is deze zone als het sociale netwerk aan te duiden.

\section{2 .2}

\section{Zone van het nominale netwerk}

De Iweede zone in de indeling van Hammer (1978) is die van het 'nominale netwerk'. Deze omvat die mensen tot wie een focale persoon indirect toegang heeft (zie figuur 5.2). Als voorbeeld: de vriend van de broer van de focale persoon is te beschouwen als iemand die onder de zone van het nominale netwerk valt.

FIGUUR 5.2 Directe en indirecte betrekkingen

\begin{tabular}{|c|c|c|}
\hline Persoonli]k & netwerk Nominale & netwerk. \\
\hline Focale persoon ___dire & $\frac{x_{-}}{\text {broer }}-{ }_{-}$indirect_. & $----\frac{X}{\text { vriend }}$ \\
\hline
\end{tabular}


Het nominale netwerk bestaat in principe uit al die mensen die behoren tot de persoonlijke sociale netwerken van de eigen netwerkleden van een focale persoon. Naarmate het eigen sociale netwerk van een focale persoon in omvang toeneemt neemt ook de omvang van zijn nominale netwerk toe.

Voor zover nagegaan is kunnen worden is er geen onderzoek verricht naar nominale netwerken van (chronisch) psychiatrische patiënten. In de indeling van Erickson (1976) ontbreekt een dergelijke zone. Echter in de praktijk van de sociale netwerkstrategieën speelt het nominale netwerk regelmatig een zeer belangrijke rol. Het betreft varianten van sociale netwerkopbouw waarbij het nominale netwerk als reservoir van mensen en betrekkingen wordt benut voor de versterking van het eigen persoonlijke sociale netwerk (Speck, Attneave, 1973; Baars, Uffing, Dekkers, 1990).

\section{2 .3}

\section{Zone van het extensieve netwerk}

De zone van het extensieve netwerk bestaat volgens Hammer (1978) uit al die mensen en groeperingen, te concretiseren aan personen, met wie een focale persoon incidenteel of toevallig in aanraking komt. Het extensieve netwerk heeft aldus betrekking op mensen met wie iemand in dezelfde straat of buurt woont, mensen die men eigenlijk toevallig kent omdat ze bijvoorbeeld in hetzelfde bedrijf werken, op dezelfde school zitten of die tot een zelfde (kerk)genootschap behoren.

Het extensieve netwerk bij Hammer (1978) is niet hetzelfde als het 'uitgebreide persoonlijke netwerk' in de indeling van Erickson (1976, 1984). Bij Erickson bestrijkt het 'uitgebreide persoonlijke netwerk' de totale omvang van alle mogelijke mensen met wie een focale persoon contact heeft. Bij Hammer (1978) is de zone van het extensieve netwerk voorbehouden tot die mensen met wie incidentele en toevallige contacten bestaan. Hoewel de zone van het extensieve netwerk niet als eenheid van analyse wordt aangetroffen in het sociale netwerkonderzoek bij psychiatrische patienten heeft deze zone wel degelijk een praktische betekenis voor de sociale netwerkstrategieěn. De extensieve zone is in het bijzonder van belang bij varianten van sociale netwerkopbouw die gebruikt kunnen worden in geval er niet of nauwelijks sprake is van een persoonlijk netwerk (Baars, Uffing, Dekkers, 1990). Deze zone kan dan onder meer benut worden voor bijvoorbeeld het inschakelen van zogeheten 'netwerkactivisten' (Rueveni, 1979 a) en het werven van contact- en van gastgezinnen (Van den Bergh, Slager, 1984; Baars, Uffing, Honée, 1988).

\section{3}

\section{PERSOONLIJKE SOCIALE NETWERK: EENHEID VAN ONDERZOEK EN PRAKTIJK}

In aansluiting op de door Hammer (1978) afgebakende zone van het persoonlijke netwerk die overeenkomt met het "beschikbare persoonlijke netwerk" bij Erickson (1976, 1984) en in aansluiting met de omschrijving van een sociaal netwerk uit de praktijk van de sociale netwerkinterventies (Speck. Attneave, 1973) kan een persoonlijk sociaal netwerk als volgt omschreven worden (zie figuur 5.3).

FIGUUR 5.3 Omschrijving van een persoonlijk sociaal netwerk

Al die mensen en groeperingen - te concretiseren in personen - met wie iemand rechtstreekse en min of meer duurame banden heeft voor de vervulling van zijn dagelijkse levensbehoeften.

Dit persoonlijk beschikbaar sociaal netwerk is eenheid van onderzoek en psychiatrische hulpverlening inzake de sociale integratie van de (chronisch) psychiatrische patiënt. 
De volgende opmerking dient hierbij gemaakt te worden. Hoewel er met behulp van deze afbakening een begrenzing is aangebracht kan een persoonlijk sociaal netwerk niet beschouwd worden als een duidelijk afgegrensde gesloten sociale werkelijkheid. Een persoonlijk sociaal netwerk heeft evenals de twee andere zones die Hammer (1978) onderscheidt als regel open grenzen (Barnes, 1954, 1969) hetgeen bijvoorbeeld inhoudt dat de omvang en de samenstelling van de omvang van deze zone(s) vooraf niet vastligt en zich in de loop der tijd onder meer vanwege veranderende levensomstandigheden wijzigt. Voor zover nagegaan is kunnen worden zijn er geen onderzoeken verricht waarin bijvoorbeeld door longitudinaal onderzoek de dynamiek van veranderingen en verschuivingen van mensen en betrekkingen onderwerp van analyse en beschrijving is. Ook in het onderzoek dat in dit proefschrift gepresenteerd wordt wordt deze dynamiek buiten beschouwing gelaten.

\subsubsection{Model van een persoonlijk sociaal netwerk}

De zojuist gegeven omschrijving van een persoonlijk sociaal netwerk impliceert dat 'structuur' en 'functies' de basisbestanddelen zijn die aan een sociaal netwerk te onderscheiden zijn (Walker, MacBride, Vachon, 1977; Wellman, 1988) en het grondpatroon vormen voor een modelmatige beschrijving van een persoonlijk sociaal netwerk die als uitgangspunt dient voor diagnostiek en wetenschappelijke analyse.

In hoofdlijnen bestaat het model van een persoonlijk sociaal netwerk, zoals weergegeven in onderstaande figuur 5.4 uit de volgende elementen:

FIGUUR 5.4 Model van een persoonlijk sociaal netwerk

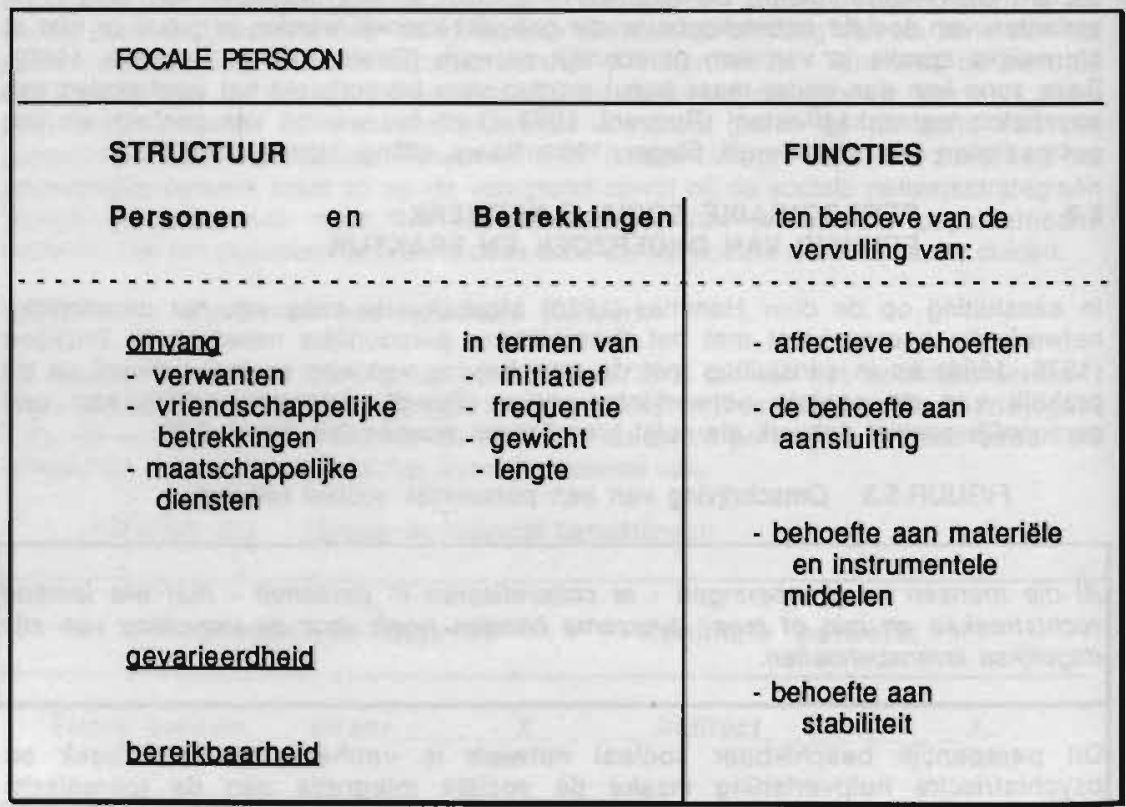


De structuur van een persoonlijk sociaal netwerk wordt opgebouwd door

a de focale persoon,

b de mensen die gerekend kunnen worden tot het persoonlijke sociale netwerk van de focale persoon ofwel de netwerkleden,

c de betrekkingen tussen de focale persoon en de netwerkleden.

Voor de analyse en beschrijving van deze structuur van mensen en betrekkingen in een sociaal netwerk zijn de volgende structuurkenmerken geselecteerd:

de omvang en de compositie van de omvang netwerkleden;

de gevarieerdheid van de focale persoon en de netwerkleden;

de bereikbaarheid van de netwerkleden voor de focale persoon;

de structuur van de betrekkingen tussen de focale persoon en de netwerkleden te analyseren en te beschrijven in termen van

$=$ het initiatief in het contact,

= de frequentie van het contact,

$=$ het gewicht van het contact en

$=$ de lengte van het contact.

Deze structuur van mensen en betrekkingen geeft vorm en inhoud aan de functies van een sociaal netwerk voor een focale persoon. Globaal kunnen de volgende vier compartimenten van functies, c.q. psycho-sociale basisbehoeften onderscheiden worden (Adams, 1969; Weiss, 1974; Angermeyer, Lammers, 1986):

- de affectieve behoeften, bijvoorbeeld de behoefte om geliefd gevonden te zijn, als persoon gewaardeerd en vertrouwd te worden, de behoefte aan emotionele ondersteuning;

de behoefte aan aansluiting zoals de behoefte erbij te horen en veilig te zijn, aansluiting en steun te vinden op basis van interessen, waarden en achtergronden;

de behoefte aan materiële en instrumentele middelen variërend van huisvesting en voeding tot informatie en daadwerkelijke hulp en bijstand;

de behoefte aan stabiliteit, hetgeen inhoudt dat de banden met andere mensen geregeld zijn, al dan niet op basis van vrijwilligheid zoals in afspraken, arbeidsovereenkomsten, lidmaatschappen en verzekeringen.

\subsection{2}

\section{Structuur van een sociaal netwerk als eenheid van analyse}

De nadruk die bij onderzoek wordt gelegd op de structuur en/of de functies van een sociaal netwerk hangt volgens Hammer (1981) af van de wijze waarop de onderlinge samenhang tussen structuur en functies wordt gezien, een samenhang die mede beïnvloed wordt door de specifieke vragen die aan een sociaal netwerk vanuit onderzoek in wisselwerking met de praktijk worden gesteld.

In dit onderzoek gaat het om de sociale integratie van ambulante chronisch psychiatrische patiënten ofwel om de verhouding van de patiënt met de brede sociale context te concretiseren en te onderzoeken in termen van een persoonlijk sociaal netwerk. Bestudering van de ontwikkeling van de sociale netwerkaanpak en van de systematiek en techniek van de interventies in en met het sociale netwerk, maakt duidelijk dat het probleem van de sociale integratie van de psychiatrische patiënt bij deze aanpak primair aangepakt wordt via de reorganisatie en de opbouw van de structuur van het sociale netwerk. De opbouw van een structureel vilaal persoonlijk sociaal netwerk is op zichzelf een in fasen verlopend doelbewust te hanteren proces van hulpverlening dat vervolgens resulteent in verbeteringen van de vervulling van de functies in het sociale netwerk. Met andere woorden, de sociale netwerkstrategieën zijn gebaseerd op een samenhang tussen structuur en functies waarbij het de structuur van mensen en betrekkingen in een persoonlijk sociaal netwerk is die als doorslaggevend wordt opgevat voor de mate waarin de benodigde dagelijkse bestaansmiddelen ofwel de functies vervuld worden (Baars, Uffing, 1991). 
De structuur van het persoonlijke sociale netwerk dient derhalve beschouwd te worden als het aangrijpingspunt en als het organiserend beginsel van hulpverlening voor de bevordering dan wel het herstel van de sociale integratie van de psychiatrische patient. Een reorganisatie van de structuur van het sociale netwerk houdt op maat van de patiënt een versterking van de omvang, de gevarieerdheid en de bereikbaarheid van netwerkleden alsook een herstel van de structuur van de betrekkingen met de netwerkleden in.

Het komt er al bij al op neer dat de wetenschappelijke vraagstelling betreffende de sociale integratie van de patiënt in verbinding met deze hulpverleningsdoelstelling van de sociale netwerkstrategieën een samenhang tussen strucluur en funclies oplevert die resulteert in een schema van diagnostiek en wetenschappelijke analyse dat aansluit bij de opstelling van bijvoorbeeld Hammer (1981) en van Wellman en Berkowitz (1988) dat sociale netwerkanalyse primair een analyse en beschrijving van de structuur van een persoonlijk sociaal netwerk inhoudt.

\section{3 .3}

\section{Selectie van de structuurkenmerken}

Hierboven is bij de beschrijving van het model van een persoonlijk sociaal netwerk reeds een overzicht gegeven van de geselecteerde kenmerken voor de analyse en beschrijving van de structuur van mensen en van de betrekkingen in een sociaal netwerk. De geselecteerde structuur kenmerken zijn omvang, gevarieerdheid en bereikbaarheid; de structuur van de betrekkingen betreft de elementen initiatief, frequentie, gewicht en lengte. Een belangrijke overweging bij deze selectie is, zoals ook bijvoorbeeld Froland e.a. (1977) aangeven, dat een analytisch schema voor wetenschappelijk onderzoek in verbinding met de praktijk van psychiatrische hulpverlening loegankelijk en hanteerbaar dient te zijn voor en binnen een hulpverleningspraktijk en niet alleen voor de medewerkers maar evenzeer voor de betreffende patiënten / cliënten.

Op basis van literatuurstudie, overleg en consultatie en mel behulp van diverse proefopstellingen, zoals bijvoorbeeld bij de dossierstudie betreffende de registratie van sociale netwerkkenmerken door hulpverleners van de SPD van de RIAGG Maastricht (Baars, 1985) zijn de genoemde structuurkenmerken geselecteerd. Globaal kan gezegd worden dat de selectie van deze structuurkenmerken met uitzondering van het kenmerk 'dichtheid' aansluit bij de inventarisatie door Walker, MacBride en Vachon (1977). De operationalisatie van de geselecteerde structuurkenmerken, tesamen de Maastrichtse Sociale Netwerk Analyse (MSNA), vormend is in Bijlage i weergegeven.

\section{OMVANG}

Het totaal aantal netwerkleden inclusief de focale persoon vormt de omvang ofwel hel grondvlak van de structuur van een persoonlijk sociaal netwerk. De analyse van de omvang is er op gericht al die mensen en groeperingen (geconcretiseerd aan personen) in beeld te brengen met wie een focale persoon rechtstreekse min of meer duurzame betrekkingen heeft. Aldus heeft de omvang hier betrekking op wat Erickson (1976, 1984) noemt het 'beschikbare' persoonlijke netwerk. Wellman, Carrington en Hall (1988) stellen dat hoe strak het lidmaatschap van een persoonlijk sociaal netwerk ook wordt gedefinieerd er eigenlijk geen sprake is van een scherp te trekken begrenzing: binnen de ruimte van de omschrijving van een netwerklid bepaalt de tocale persoon wie wel en niet tot zijn sociale nefwerk gerekend moeten worden en de genoemde auteurs voegen er aan toe: "Such fuzziness is a fact of life and not a methodological distortion".

Op zichzelf zegt een bepaalde absolute of gemiddelde getalsmalige uitkomst inzake de beschikbare omvang netwerkleden weinig. Het is een misverstand dat een groot persoonlijk sociaal netwerk 'beter' is dan een klein persooniijk sociaal netwerk. 
De som van het aantal beschikbare netwerkleden is op zichzelf geen maatstaf. De omvang van een sociaal netwerk krijgt pas betekenis op grond van haar compositie, te weten:

de verdeling van netwerkleden over sectoren en clusters;

- de verdeling van netwerkleden in informele en formele netwerkleden;

- de verdeling van netwerkleden in effectieve en ineffectieve netwerkleden.

Onderzoek van Laireiter, Ganitzer en Baumann (1993) toont dat van de sociaal demografische kenmerken van een volwassen focale persoon de leeftijd het meest bepalend blijkt te zijn voor de grootte van de omvang van een sociaal netwerk. De leeftijd bepaalt doorslaggevend het aantal kinderen, vrienden en bijvoorbeeld collega's. Uit hun onderzoek komt naar voren dat de omvang van het sociale netwerk bij jongere ( 20 tot 40 jaar) volwassen focale personen beduidend groter is dan bij oudere (vanaf 40 tot en met 65 jaar) volwassen personen.

\section{Sectoren en clusters netwerkleden}

De eerste stap om de compositie van de omvang beschikbare netwerkleden in kaart te brengen is, zoals Erickson $(1976,1984)$ voorstelt, door sectoren in een persoonlijk sociaal netwerk te onderscheiden, te weten:

a een sector verwanten, bestaande uit bloed- en aanverwanten, waaronder de partner van de focale persoon;

b een sector vriendschappelijke betrekkingen bestaande uit vrienden, buren en bekenden;

c een sector maatschappelijke diensten, die door de focale persoon aan personen geconcretiseerd kunnen worden; een voorbeeld is: de gezondheidszorg die voor de focale persoon concreet gestalte krijgt in de persoon van de huisarts.

De verdeling van de beschikbare netwerkleden over deze sectoren geeft een eerste overzicht betreffende het evenwicht in de samenstelling van de omvang en het maakt dat de door de focale persoon genoemde netwerkleden niet als los van elkaar staande individuen beschouwd worden (Hall, Weliman, 1985).

Een meer genuanceerd overzicht inzake het evenwicht in de samenstelling van de omvang van de netwerkleden wordt verkregen door in de genoemde sectoren bepaalde 'clusters' netwerkleden te onderscheiden. Een dergelijk nadere afbakening vindt men in het sociale netwerkonderzoek ook onder de noemer 'interactiegebieden'. Voorbeelden van interactiegebieden in de omvang vindt men zoals beschreven is hoofdstuk 4 onder meer bij Jay (1964) en daarop aansluitend bij Tolsdorf (1976) en bij Cohen en Sokolovsky (1978). Een probleem van de bij deze en andere auteurs aangetroffen indelingen in interactiegebieden is dat ze wisselend samengesteld zijn zowel op basis van de structuur alsook op basis van de functies van sociale netwerken. In het hier gepresenteerde model van een persoonlijk sociaal netwerk zijn de geselecteerde clusters gebaseerd op een structuurbenadering en ze sluiten aan bij de genoemde sectoren, (zie Bijlage I). De indeling in clusters maakt het bijvoorbeeld niet alleen mogelijk na te gaan hoe en over welke clusters de beschikbare netwerkleden binnen een seclor verdeeld zijn, maar laat ook zien welke clusters in de omvang wel en niet voorzien zijn van netwerkleden. Deze systematiek is vooral van belang als hel gaal om de vraag waar versterking in de omvang van het sociale netwerk geboden is. 
Naast een verdeling van de beschikbare netwerkleden over sectoren en clusters kan men in de omvang een onderscheid aanbrengen tussen informele en formele netwerkleden.

Informele netwerkleden zijn de netwerkleden die behoren tot de sectoren

- verwanten;

- vriendschappelijke belrekkingen.

Formele netwerkleden zijn de netwerkleden die behoren tot de sector - maatschappelijke diensten.

Ten aanzien van de informele netwerkleden wordt over alle structuurkenmerken informatie verzameld. Bij de formele netwerkleden is de gegevensverzameling beperkt tol de structuur van de betrekkingen.

\section{Effectieve en ineffectieve netwerkleden}

Het aspect 'rechtstreekse min of meer duurzame betrekkingen hebben' in de omschrijving van een persoonlijk sociaal netwerk is niet hetzelfde als 'contact hebben', een gegeven waarover duideljkheid ontstaat via de analyse en beschrijving van de structuur van de betrekkingen. Dit betekent dat de omschrijving van een sociaal netwerk zowel mensen in de betekenis van netwerkleden impliceert met wie effectief (daadwerkelijk) rechtstreeks en min of meer duurzaam contact bestaal alsook mensen met wie weliswaar een min of meer duurzame betrekking bestaat en die rechtstreeks toegankelijk zijn maar bij wie niet gesproken kan worden van effectief contact. Bij ineffectieve netwerkleden moel gedacht worden aan mensen die in de beleving van een focale persoon min of meer duurzaam een plaats innemen terwijl er van werkelijk contact al lange tijd (minimaal langer dan eén jaar) gewenst of ongewenst geen sprake is. Deze zogeheten ineffectieve netwerkleden dienen wel in principe 'beschikbaar' ofwel feitelijk te achterhalen te zijn. Netwerkleden die overleden zijn worden aldus niet meegeteld in het ineffectieve deel van de omvang van het sociale netwerk.

\section{GEVARIEERDHEID}

De gevarieerdheid van de netwerkleden betreft de vraag in welke mate een persoonlijk sociaal netwerk naar sociaal demografische kenmerken ten opzichte van de focale persoon homogeen dan wel heterogeen is samengesteld (Walker, MacBride, Vachon, 1977). De sociaal demografische kenmerken betreffen op groepsniveau geslacht, leeflijd, burgerlijke staat, opleiding, arbeid- en woonsituatie. Voor de analyse en beschrijving van de gevarieerdheid van het sociale netwerk op individueel niveau - de diagnostische fase van de sociale netwerkinterventies (zie $\S 3.5 .2$ ) - is het kenmerk 'laatst uitgeoefend beroep' toegevoegd.

Het komt er op neer dat een analyse en beschrijving van de gevarieerdheid van de netwerkleden ten opzichle van de focale persoon antwoord geeft op de vraag in welke mate status- en positierollen in het sociale netwerk aansluiten op die van de focale persoon ofwel in welke mate inpassing voor de locale persoon in het sociale netwerk mogelijk is en waar het sociale netwerk qua gevarieerdheid versterking behoeft. De analyse en beschrijving van de gevarieerdheid betreft hier zoals reeds opgemerkt is de focale persoon en zijn informele neiwerkleden. Het zal duidelijk zijn dat wanneer ook informatie over de gevarieerdheid van de formele netwerkleden, bijvoorbeeld van vertegenwoordigers van de (geestelijke) gezondheidszorg, in de analyse en beschrijving van de aansluiting tussen het sociaal demografisch profiel van de focale persoon en zijn netwerkleden wordt opgenomen de kans op vertekening aanmerkelijk kan zijn. 
Het is opvallend, zoals vermeld in $\S 4.7 .2$, dat het structuurkenmerk gevarieerdheid niet gebruikt is in het eerder uitgevoerde sociale netwerkonderzoek bij psychiatrische patiênten. Casuistische studies bij psychiatrische patiënten (Speck, Attneave, 1973; Baars, Uffing, 1987) maken echter duidelijk dat er in de 'gevarieerdheid' van de netwerkleden ten opzichte van de focale persoon niet zelden grote discrepanties tussen de focale persoon en zijn netwerkleden optreden. De patiënt blijkt bijvoorbeeld niet zelden met betrekking tot opleiding of arbeidssituatie een uitzonderingspositie in zijn sociale netwerk in te nemen en mist aldus de aansluiting met zijn netwerkleden. Anderzijds tonen de casuistische beschrijvingen ook veelvuldig dat de aanwezige netwerkleden in gevarieerdheid nauwelijks verschillen met de focale persoon. Tegen de achtergrond van deze laatste waarneming wordt wel verondersteld dat een dergelijk sterk homogeen sociaal netwerk minder gedragsalternatieven te bieden heeft en aldus ook minder uitzicht geeft op verandering dan een meer heterogeen samengesteld persoonlijk sociaal netwerk. Overigens zijn beide waarnemingen in overeenstemming met het door Gruenberg (1974) beschreven 'Social Breakdown Syndrome'

\section{BEREIKBAARHEID}

Een volgende in het model van een persoonlijk sociaal netwerk opgenomen structuurkenmerk is de bereikbaarheid van de netwerkleden voor de focale persoon. Dit structuurkenmerk betreft de geografische afstand tussen de focale persoon en ieder informeel netwerklid. Ook dit structuurelement is nauwelijks bij eerder onderzoek gebruikt terwijl casuistische studies dan wel mededelingen vanuit het werkveld van de psychiatrie nogal eens een sociaal isolement van de focale persoon tonen die deels samenhangt met een grote geografische afstand tussen de focale persoon en zijn informele netwerkleden bijvoorbeeld ten gevolge van verhuizing in verband met een nieuwe werkkring.

\section{STRUCTUUR VAN DE BETREKKINGEN}

Bij eerdere beschrijvingen van de structuur van de betrekkingen is door mij het begrip 'dichtheid' gehanteerd zie bijvoorbeeld het boek 'Sociale netwerkstrategieen in de sociale psychiatrie', (Baars, Uffing, Dekkers, 1990). Hoewel het begrip 'dichtheid' soms ook gebruikt wordt voor meerdere elementen in de structuur van de betrekkingen is dit begrip in het algemeen zodanig verbonden met de verhouding fussen het totaal aantal mogelijke en het aantal feitelijke betrekkingen in een persoonlijk sociaal netwerk onafhankelijk van de focale persoon (zie Bott, 1971) dat het begrip 'dichtheid' hier achterwege wordt gelaten en voortaan gesproken wordt van de 'structuur van de betrekkingen'.

Een analyse van de structuur van de betrekkingen tussen de focale persoon en de beschikbare netwerkleden laat zien in welke staat de rechtstreekse betrekkingen in de zin van potentiële communicatiekanalen tussen de focale persoon en de netwerkleden verkeren. De toestand van de betrekkingen tussen de focale persoon en de netwerkleden wordt geanalyseerd en beschreven in termen van initiatief in het contact en van frequentie, gewicht en lengte van het contact.

\section{Initiatief}

Bij initiatief gaat hel om de richting van de betrekking. Een veel gebruikt schema is dat van Cohen en Sokolovsky (1978). Dit schema (zie $\S 4.4 .1$ ) betreft betrekkingen waarin op de een of andere manier actief initiatief tot contact wordt genomen. Zo is het mogelijk dat alle initiatief ofwel uitgaat van de focale persoon - Cohen en Sokolovsky (1978) spreken dan van een "instrumentele" relatie - ofwel dat hel initiatief vrijwel uitsluitend uitgaat van het betreffende netwerklid, een situatie die Cohen en Sokolovsky benoemen als een "afhankelijke relatie". Een derde mogelijkheid in dit schema is dat het contact via wederzijds initiatief tot stand komt. DIt schema is hier overgenomen terwijl de terminologie die door Cohen en Sokolovsky (1978) wordt gebruikt 
achterwege wordt gelaten vanwege de toekenning van een waarde die reeds in termen als 'afhankelijk' ligt opgesloten.

Anderzijds is dit schema aangevuld. Immers de bij dit onderzoek gebruikte omschrijving van een sociaal netwerk veronderstelt dat er ook betrekkingen zijn waarin niet uitdrukkelijk initiatief wordt genomen, zoals contacten die gewoontegetrouw bestaan. Het kan ook voorkomen dat er betrekkingen bestaan waarbij het contact verbroken is.

\section{Frequentle}

De frequentie betreft in het algemeen de hoeveelheid contacten tussen de focale persoon en een netwerklid gedurende bepaalde tijdseenheden.

\section{Gewicht}

Vervolgens is er het element gewicht van het contact. In tegenstelling tot alle tot nu genoemde structuurkenmerken waar het gaat om objectiveerbare gegevens is de vaststelling van het gewicht van de betrekking gebaseerd op een persoonlijk oordeel van de focale persoon en aldus een subjectief gegeven. Het element gewicht is vooralsnog op te vatten als een voorlopige en mogelijke scharnier naar een meer systematische analyse van de mate waarin de verschillende functies door netwerkleden al of niet vervuld worden. De uitkomsten van de analyse van het element gewicht geven hier echter vooral een indicatie voor de mate waarin - naar de mening van de focale persoon - een bepaald netwerklid belangrijk dan wel persounlijk van betekenis is (Wellman,1981).

\section{Lenate}

De lengte van de betrekking heeft betrekking op de vraag hoelang of sinds wanneer er sprake is van een betrekking tussen de focale persoon en een netwerklid. De analyse en beschrijving van dit structuurkenmerk maakt duidelijk in welke mate een sociaal netwerk opgebouwd is uit reeds lang dan wel uit recent bestaande betrekkingen. Als zodanig geven de uitkomsten van de lengte van de betrekkingen een aanwijzing voor de dynamiek van een sociaal netwerk.

Ienslolle de volgende opmerking. De analyse van de structuur van de betrekkingen betreft een rechtstreekse betrekking tussen de focale persoon en een netwerklid behorend tot de omvang van het persoonlijke sociale netwerk. De analyse betreft dus niet de betrekkingen tussen de netwerkleden die onafhankelijk van de focale persoon bestaan, een element waarop het begrip 'dichtheid' van Bott (1971) betrekking heeft (Cohen, Sokolovsky, 1978). In het model van een sociaal netwerk dat hier gepresenteerd is wordt zoals reeds aangegeven in $\$ 4.2$ dit begrip 'dichtheid' om zowel inhoudelijke als praktische redenen niet meegenomen. Een analyse van de structuur van de betrekkingen in de zin van 'dichtheid' veronderstelt in principe een werkwijze conform de 'whole network strategy' terwijl in het hier gepresenteerde model wordt uitgegaan van de 'personal network strategy'. Bij de 'personal network strategy' brengt de focale persoon de netwerkleden in beeld tot wie hij rechtstreeks toegang heeft en vervolgens brengt de focale persoon de structuur van de betrekkingen met deze netwerkleden in kaart waaraan hij rechtsreeks deelneemt. Op het moment dat de focale persoon gevraagd wordt de zogeheten 'dichtheid' te beschrijven begeeft hij zich buiten de rechtstreekse betrekkingen en wel op het terrein van die betrekkingen waarmee hij indirect in verbinding staat, nog los van de vraag of de focale persoon tot een betrekking tussen twee netwerkleden al of niet toegang heeft dan wel krijgt.

Wanneer men dit begrip 'dichtheid' toepast in de 'personal network strategy' vraagt men de focale persoon om informatie waarbij hij zelf niet rechtstreeks betrokken is. Dit betekent, zoals ook Tolsdorf (1976) reeds opmerkt, dat de focale persoon zoals dat wel het geval is bij rechtstreekse betrekkingen niet in staat is accurate informatie te geven over de 'dichtheid' van het persoonlijke sociale netwerk. 
Dit laatste geldt niet vanwege het feit dat de focale persoon bijvoorbeeld een psychiatrische patiënt is maar het gaat ook op bij een focale persoon bij wie geen sprake is van psychiatrische symptomatologie of problemen in de geestelijke gezondheid (Tolsdorf, 1976; Bernard, Killworth, Sailer, 1981). Een mogelijke oplossing zou zijn op dit punt de aanpak van de 'whole network strategy' te gebruiken en alle netwerkleden als focale personen ofwel als bron van informatie op te vatten. De beschrijving van de 'dichtheid' van het persoonlijke sociale netwerk komt dan voort uit de informatie die ieder netwerklid over de eigen rechtstreekse betrekkingen met de andere netwerkleden heeft en kan geven. Immers ook hier geldt dat een netwerklid geen informatie geeft over betrekkingen waar hij zelf buiten staat. Het is op z'n minst opmerkelijk dat deze regel in het algemeen bij de analyse van de dichtheid in persoonlijke sociale netwerken losgelaten is. Toepassing van de 'whole network strategy' voor de beschrijving van de 'dichtheid' levert echter zo veel praktische problemen op (Erickson, 1978; Hall, Wellman, 1985) dat het structuurelement 'dichtheid' zoals gedefinieerd door Bott (1971) niet in de modelmatige beschrijving van de structuur van een persoonlijk sociaal netwerk is opgenomen.

\section{4}

\section{AFSLUITING}

In dit hoofdstuk is voortbouwend op zowel de experimentele praktijk van de sociale netwerkinterventies van Speck en zijn collega's (zie hoofdstuk 3) alsook het eerder uitgevoerde sociale nelwerkonderzoek (zie hoofdstuk 4) een model voor de analyse en beschrijving van een sociaal netwerk gepresenteerd. Primair wordt in het voorgestelde analytisch schema voor onderzoek van sociale netwerken uitgegaan van de structuur van mensen en betrekkingen (Wellman, Berkowitz, 1988) zowel in de diagnostiek op patiëntniveau als onderdeel van de sociale netwerkinterventies alsook bij wetenschappelijk onderzoek op groepsniveau naar generale informatie over de structuur van sociale netwerken. Aldus is in dit hoofdstuk een hulpconstructie van sociale netwerkanalyse gegeven dat een samenhangend geheel van diagnostiek en wetenschappelijke analyse betreffende de sociale integratie van doelgroepen van (ambulante) psychiatrische hulpverlening vormt. Met behulp van de beschreven hulpconstructie voor sociale netwerkanalyse, waarvan de operationalisatie in Bijlage I wordt gegeven, worden in het volgende hoofdstuk 6 de eerder vermelde centrale vraagstellingen (zie \$2.4.2) nader uitgewerkt en van hypothesen voorzien voor zover dat mogelijk is op grond van informatie uit eerder verricht onderzoek dan wel vanuit de gesystematiseerde waarnemingen uit de prille praktijk van de sociale netwerkinterventies. 


\section{VRAAGSTELLINGEN EN HYPOTHESEN}

In dit hoofdstuk worden de vijf centrale vraagstellingen van het onderzoek gegeven en vervolgens wordt een gedetailleerd overzicht van de veronderstellingen bij deze vraagstellingen gepresenteerd. Vooraf treft men in hoofdlijnen de structurele kenmerken van sociale netwerken aan die onderzocht worden om de gestelde vragen te beantwoorden dan wel de gegeven hypothesen te toetsen.

\section{VRAAGSTELLINGEN}

Dit onderzoek gaat over de structurele kenmerken van sociale netwerken van de doelgroep van de Sociaal Psychiatrische Dienst van de RIAGG te Maastricht. Deze doelgroep - hier de onderzoekspopulatie - bestaat uit ambulante chronisch psychiatrische patiènten.

De volgende structurele kenmerken zijn onderzocht.

- De omvang van de sociale netwerken, ofwel het totaal aantal mensen, c.q. netwerkleden, met wie de patient een min of meer duurzame band heeft, en de verdeling van de omvang over de sectoren verwanten, vriendschappelijke betrekkingen en maatschappelijke diensten en over de daarbinnen onderscheiden clusters.

- De gevarieerdheid van de netwerkleden in termen van sociaal demografische kenmerken ten opzichte van de gevarieerdheid van de patiënt.

- De bereikbaarheid van de netwerkleden in de zin van geografische afstand.

- De structuur van de betrekkingen lussen de patiënt en de netwerkleden, te weten:

- het initiatief in hel contact

- de frequentie van het contact

- het gewicht van het contact

- de lengte van het contact.

De gegevens over de structuur van de sociale netwerken bij ambulante chronisch psychiatrische patienten worden vergeleken mel die van een normale relerentiegroep. van wie de netwerken eveneens aan de hand van bovenstaande kenmerken zijn onderzocht. Op die manier kan de eerste vraagstelling van dit onderzoek beantwoord worden, te weten: 
WELKE OVEREENKOMSTEN DAN WEL VERSCHILLEN IN DE OMVANG, DE GEVARIEERDHEID, DE BEREIKBAARHEID EN DE STRUCTUUR VAN DE BETREKKINGEN BESTAAN ER TUSSEN SOCIALE NETWERKEN VAN AMBULANTE CHRONISCH PSYCHIATRISCHE PATIENTEN EN DE SOCIALE NETWERKEN VAN NORMALE REFERENTIEPERSONEN?

De gegevens over de structuur van de sociale netwerken van de doelgroep van de SPD van de RIAGG Maastricht worden tevens vergeleken met de informatie die de hulpverleners van de SPD na drie maanden zorg zelf over het sociale netwerk van de patient ter beschikking hebben. Aldus kan de tweede vraagstelling van dit onderzoek beantwoord worden, namelijk:

II WELKE VERSCHILLEN DAN WEL OVEREENKOMSTEN BESTAAN ER TUSSEN DE INFORMATIE DIE HULPVERLENERS OVER DE OMVANG, GEVARIEERDHEID, BEREIKBAARHEID EN DE STRUCTUUR VAN DE BETREKKINGEN VAN HET SOCIALE NETWERK VERWERVEN EN DE GEGEVENS DIE MET BEHULP VAN EEN ANALYSE VAN DE STRUCTUUR OVER HET SOCIALE NETWERK (MSNA) VAN DE ONDERZOEKSPOPULATIE WORDEN VERKREGEN?

Tenslotte is er de vraag naar mogelijke patronen in de structuur van sociale netwerken (Wellman, Berkowitz, 1988) bij de onderzoekspopulatie. In dit onderzoek gaat het om de volgende vraagstellingen:

III WELKE VERSCHILLEN DAN WEL OVEREENKOMSTEN, C.Q. PATRONEN BESTAAN ER IN DE STRUCTUUR VAN DE SOCIALE NETWERKEN TUSSEN DE GROEP JONGERE EN DE GROEP OUDERE AMBULANTE CHRONISCH PSYCHIATRISCHE PATIENTEN?

IV WELKE VERSCHILEN DAN WEL OVEREENKOMSTEN, C.Q PATRONEN BESTAANER IN DE STRUCTUUR VAN SOCIALE NETWERKEN BIJ DE GROEP JONGERE EN DE GROEP OUDERE AMBULANTE CHRONISCH PSYCHIATRISCHE PATIENTEN VERGELEKEN MET DE JONGERE EN OUDERE REFERENTIEPERSONEN ?

V WELKE VERSCHILLEN DAN WEL OVEREENKOMSTEN, C.Q. PATRONEN BESTAAN ER IN DE STRUCTUUR VAN SOCIALE NETWERKEN BIJ BEIDE GROEPEN AMBULANTE CHRONISCH PSYCHIATRISCHE PATIENTEN VERGELEKEN MET DE INFORMATIE DIE DE HULPVERLENENERS OVER DE STRUCTUUR VERSTREKKEN? HYPOTHESEN

Zoals in hoofdstuk 2 bij de probleemstelling is aangegeven, komen de hierboven gegeven vraagstellingen in de eerste plaats voort uit een aantal voorlopige bevindingen in een eigen verkennende studie naar de wijze waarop hulpverleners van de SPD van de RIAGG Maastricht het sociale milieu van de patiënten in de dossiers vastleggen (zie $\S$ 2.3.2); het komt er op neer dat deze verkennende studie het vermoeden oproept dat de ambulante chronisch psychiatrische patiënt een structureel rijker en veelzijdiger sociaal netwerk beschikbaar heeft dan in de hulpverlening - die gericht is op de sociale integratie van de patient - zichtbaar gemaakt en benut wordt, (Baars, 1985; Baars, Uffing, 1988). Bevindingen van elders, voornamelijk in Noord Amerika verricht onderzoek - beschreven in hoofdstuk 4 - ondersteunen dit vermoeden en laten tevens 
verschillen zien in de structuur van netwerken bij (chronisch) psychiatrische patienten en normale referentiepersonen. Erickson $(1976,1984)$ vat zoals vermeld in $\$ 4.3$ de gevonden kenmerken in de structuur van sociale netwerken bij psychiatrische patiènten samen met het beeld van "afgeknotle" sociale netwerken.

Tenslolte moet opgemerkt worden dat bij de omschrijving chronisch psychiatrische patient het concept van het Social Breakdown Syndrome (SBS) (Gruenberg, 1974) een belangrijke rol speelt (Romme, Breuls, 1985), hetgeen onder meer inhoudt dat verondersteld wordt dat tijdens het proces van persoon tot patiënt en de daarop aansluitende patiëntcarrière de beschikbaarheid van mensen in het eigen leefmilieu van de patient afbrokkelt en die van de hulpverlening toeneemt. Dit algemeen in de sociaal psychiatrische praktijk aanvaarde en gehanteerde concept van het SBS (Uffing, e.a., 1987) is mede van invloed op de hypothesen die ten aanzien van de gegeven vraagstellingen geformuleerd zijn.

\section{2 .1}

\section{Hypothesen bij vraagstelling I}

Voor de vergelijking van de kenmerken van de structuur in de sociale netwerken van de groep ambulante chronisch psychiatrische patiënten met die van een normale referentiepersonen kunnen de volgende meer specifieke hypothesen geformuleerd en getoetst worden.

Ten aanzien van de omvang en de samenstelling van de omvang van de sociale netwerken.

1 De omvang van de sector verwanten is gemiddeld bij de onderzoekspopulatie en de referentiepersonen gelijk.

2 De omvang van de sector vriendschappelijke betrekkingen is gemiddeld bij de onderzoekspopulatie kleiner dan bij de referentiepersonen.

3 De omvang van de sector maatschappelijke diensten is wat betreft het aandeel hulpverlening gemiddeld groter bij de onderzoekspopulatie dan bij de referentiepersonen.

4 Het totaal effect is dat de omvang van de sociale netwerken van de onderzoekspopulatie gemiddeld kleiner is dan bij de referentiepersonen.

Ten aanzien van de gevarieerdheid van de sociale netwerken.

In hoofdstuk 4 is vermeld dat er geen onderzoek naar de gevarieerdheid van sociale netwerken bekend is. Dit houdt in dat de bevindingen inzake de gevarieerdheid van de onderzochte sociale netwerken eigenlijk niet te voorspellen zijn. Echter op basis van het SBS-concept (Gruenberg, 1974), aangevuld met eigen ervaringen in de sociaal psychiatrische praktijk kunnen evenwel de volgende hypothesen geformuleerd en geloetst worden.

5 De sociale netwerken van de onderzoekspopulatie zijn overwegend homogeen samengesteld terwijl de sociale netwerken van de referentiepersonen vooral heterogeen zijn samengesteld.

Meer in het bijzonder wordt vermoed:

5.1 De onderzoekspopulatie heeft qua statusrollen een overeenkomstig homogeen samengesteld sociaal netwerk terwijl de referentiepersonen een meer heterogeen samengesteld sociaal netwerk hebben.

5.2 De onderzoekspopulatie neemt echter met betrekking tot de positierollen gemiddeld een geïsoleerde plaats in het sociale netwerk in terwijl de referentiepersonen qua positierollen gemiddeld aansluiting hebben met de sociale netwerkleden. 
Ten aanzien van de berelkbaarheid van de netwerkleden.

6 Er zijn geen verschillen tussen de onderzoekspopulatie en de referentiepersonen inzake de bereikbaarheid van de netwerkleden.

Ten aanzien van de structuur van de betrekkingen in de sociale netwerken.

\section{Initiatief}

7 Bij de onderzoekspopulatie komen de contacten met netwerkleden in de sector verwanten overwegend tot stand via initiatief in de zin van vanzelfsprekendheid ofwel gewoonte terwijl er bij de referentiepersonen sprake is van wederzijds initiatief.

8 De onderzoekspopulatie toont in de contacten met netwerkleden in de sector vriendschappelijke betrekkingen nauwelijks eigen initiatief, dit in tegenstelling tot de referentiepersonen bij wie er bovendien sprake is van wederzijds initiatief.

9 Het contact met netwerkleden in de sector maatschappelijke diensten komt bij de onderzoekspopulatie overwegend tot stand via initiatief van derden, terwijl bij de referentiepersonen hier het eigen initiatief overheerst.

10 Het totaal effect is dat bij de onderzoekspopulatie het tot stand komen van het contact met de netwerkleden minder gebaseerd is op eigen en wederzijds initiatief dan bij de referentiepersonen het geval is.

\section{Frequentie}

11 Tussen de onderzoekspopulatie en de referentiepersonen is er gemiddeld geen verschil in de frequentie van de contacten met verwanten.

12 De onderzoekspopulatie onderhoudt gemiddeld aanzienlijk minder frequent contact met mensen in de sector vriendschappelijke betrekkingen dan de referentiepersonen.

13 De onderzoekspopulatie onderhoudt gemiddeld frequent contact met personen in het deel hulpverlening in de sector maatschappelijk diensten; dit is in tegenstelling met de referentiepersonen.

\section{Gewicht}

14 Er treden verschillen op in het toekennen van het gewicht aan de netwerkleden tussen de onderzoekspopulatie en de referentiepersonen. De richting van deze verschillen valt niet te voorspellen.

\section{Lengte}

15 De meerderheid van de onderzoekspopulatie beschikt gemiddeld in tegenstelling tot de referentiepersonen over netwerkleden met wie al lange tijd contact bestaat.

\subsubsection{Hypothesen bij vraagstelling II}

Voor de vergelijking van de informatie over de structuur van sociale netwerken van de onderzoekspopulatie die bij hulpverleners aanwezig is met de informatie die verkregen wordt via een analyse van de structuur van sociale netwerken (MSNA) kunnen de volgende meer specifieke hypothesen geformuleerd en getoetst worden.

Ten aanzien van de omvang en de samenstelling van de omvang van de sociale netwerken.

16 De hulpverleners inventariseren gemiddeld een geringere omvang van de sector verwanten dan door de MSNA zichtbaar wordt gemaakt.

Meer in het bijzonder: 
16.1 De hulpverleners inventariseren overwegend de naaste bloedverwanten zoals de ouders en broers en zusters en aanverwanten, met name de partner, terwijl de MSNA daarnaast ook andere bloed- dan wel aanverwanten zichtbaar maakt met wie de onderzoekspopulatie contact heeft.

17 De hulpverleners inventariseren gemiddeld minder netwerkleden in de sector vriendschappelijke betrekkingen dan door de MSNA zichtbaar wordt gemaakt.

18 De inventarisatie door de hulpverleners van de omvang van de sector maatschappelijke diensten verschilt niet van die met behulp van de MSNA.

19 Het totaal effect is dat de MSNA een gemiddeld omvangrijker netwerk in beeld brengt dan door de hulpverleners zichtbaar wordt gemaakt; het verschil treedt op in de sector verwanten en in de sector vriendschappelijke betrekkingen.

Ten aanzien van de gevarieerdheid van de sociale netwerken.

20 De hulpverleners inventariseren gemiddeld minder de status- en positierollen van de netwerkleden bij de onderzoekspopulatie, dan dat dit door de MSNA gebeur.

Ten aanzien van de bereikbaarheid van de sociale netwerkleden.

21 Het valt niet te voorspellen welke overeenkomsten dan wel verschillen ten aanzien van de bereikbaarheid van de netwerkleden worden aangetrotfen tussen de informatie van de hulpverleners en de informalie die door de MSNA hierover wordt gegeven.

Ten aanzien van de structuur van de betrekkingen in sociale netwerken.

Initiatief

22 De hulpverleners laten zien dat de contacten tussen de onderzoeks-populatie en hun netwerkleden overwegend 101 stand komen via initiatief in de zin van 'vanzelfsprekendheid' en via initiatief van de netwerkleden, terwijl de M.S.N.A. een meer gedifferentieerd beeld geeft en met name ook het eigen initiatief van de onderzoekspopulatie toont.

\section{Frequentie}

23 Er treden verschillen op in de informatie die de hulpverleners geven en die door de MSNA over de frequentie van de contacten tussen de onderzoekspopulatie en hun netwerkleden verschaft.

De richting van deze verschillen valt niet te voorspellen.

\section{Gewicht}

24 De hulpverleners geven gemiddeld een lager gewicht aan de betrekkingen tussen de onderzoekspopulatie en hun netwerkleden dan door de MSNA zichtbaar wordt gemaakt. Dit geldt in het bijzonder voor de onderdelen affectieve behoeften en de behoeften aan aansluiting.

25

De hulpverleners inventariseren in meerderheid de langdurig bestaande contacten van de onderzoekspopulatie terwijl de MSNA tevens de kortere contacten toont en aldus differentiatie aanbrengt. 
Voor de vergelijking van de kenmerken van, c.q. de patronen in de structuur van de sociale netwerken van de groep jongere $(<35$ jaar) - met die van de groep oudere $(z$ 35 jaar) ambulante chronisch psychiatrische patienten kunnen de volgende hypothesen geformuleerd en getoetst worden.

Ten aanzien van de omvang en de samenstelling van de omvang van de sociale netwerken.

26 De omvang van de sector verwanten is gemiddeld voor beide groepen van de onderzoekspopulatie gelijk.

27 De groep jongere ambulante chronisch psychiatrische patiënten heeft gemiddeld meer netwerkleden in de sector vriendschappelijke betrekkingen dan de de groep ouderen.

28 Met betrekking tot de omvang van de sector maatschappelijke diensten, in het bijzonder het deel hulpverlening, zullen tussen beide groepen van de onderzoekspopulatie verschillen worden aangetroffen. De richting van de verschillen valt niet te voorspellen.

Ten aanzien van de gevarieerdheid van de sociale netwerken. Voor de formulering van hypothesen kan hier niet geput worden uit eerder en elders verricht onderzoek. Slechts op basis van het SBS.-concept (Gruenberg, 1974) kan de volgende hypothese geformuleerd en getoetst worden.

29 De sociale netwerken van de jongere groep van de onderzoekspopulatie zijn gemiddeld qua status- en positierollen homogener samengesteid dan de sociale netwerken van de groep ouderen.

Ten aanzien van de bereikbaarheid van de sociale netwerkleden.

30 Er zijn geen verschillen tussen de jongere en de oudere groep ambulante chronisch psychiatrische patienten inzake de bereikbaarheid van de sociale netwerkleden.

Ten aanzien van de structuur van de betrekkingen in sociale netwerken.

\section{Initiatief}

31 Bij de jongere groep van de onderzoekspopulatie komen de contacten met de netwerkleden overwegend tot stand via initiatief in de zin van vanzelfsprekendheid, terwijl bij de oudere groep van de onderzoeks-populalie de contacten met de netwerkleden overwegend tot stand komen door initiatief via derden.

\section{Frequentle}

32 De jongere groep van de onderzoekspopulatie ouderhoudt gemiddeld frequenter contact met de netwerkleden dan de oudere groep van de onderzoekspopulatie.

\section{Gewicht}

33 Er zullen verschillen optreden in het toekennen van het gewicht aan de nelwerkleden tussen de jongere en de oudere groep van de onderzoeks-populatie. De richting van deze verschillen is niet te voorspellen. 


\section{Lengte}

34 De jongere groep van de onderzoekspopulatie beschikt gemiddeld over meer netwerkleden met wie het contact sinds korte tijd beslaat dan de oudere groep van de onderzoekspopulatie.

\subsubsection{Hypothesen bij vraagsteliing IV}

Voor de vergelijking van de structuur, c.q. patronen in de structuur van de sociale netwerken van enerzijds de groep jongere en de groep oudere ambulante chronisch psychiatrische patiënten en anderzijds de referentiepersonen kunnen de volgende hypothesen geformuleerd en getoetst worden:

Ten aanzien van de omvang en de samenstelling van de omvang van de sociale netwerken.

35 De omvang van de seclor verwanten is gemiddeld voor beide groepen van de onderzoekspopulatie gelijk aan die van de referentiepersonen.

36 De omvang van de sector vriendschappelijke betrekkingen is gemiddeld bij de jongere groep van de onderzoekspopulatie kleiner dan bij de referentiepersonen, terwijl bij de oudere groep de omvang van deze sector vergeleken met de referentiepersonen gemiddeld nog kleiner is dan bij de jongere groep.

37 Bij beide groepen van de onderzoekspopulatie treden in de omvang van de sector maatschappelijk diensten zowel wat betreft het aandeel werkkring als het aandeel hulpverlening verschillen op vergeleken met de referentiepersonen.

De richting van de verschillen valt niet te voorspellen.

38 Het totaal effect is dat de omvang van de sociale netwerken bij de oudere groep vergeleken met de referentiepersonen gemiddeld kleiner is dan bij de jongere groep van de onderzoekspopulatie vergeleken met de referentiepersonen Hel verschil treedt vooral op in de omvang van de sector vriendschappelijke betrekkingen.

Ten aanzien van de gevarieerdheid van de sociale netwerken.

39 In aansluiting op de hypothesen 5 en 29 mag verwacht worden dat vergeleken met de referentiepersonen de sociale netwerken van de jongere groep qua status- en positierollen gemiddeld heterogener zijn samengsteld dan die van de oudere groep van de onderzoeks-populatie.

Ten aanzien van de bereikbaarheid van de sociale nelwerkleden.

40 In aansluiting op de hypothesen 6 en 30 mag verwacht worden dat vergeleken met de referentiepersonen er geen verschillen optreden in de bereikbaarheid van de netwerkleden voor beide groepen van de onderzoekspopulatie.

Ten aanzien van de structuur van de betrekkingen in de sociale netwerken.

41 Gezien eerdere hypothesen inzake de structuur van de betrekkingen mag verwacht worden dat vergeleken met de referentiepersonen er in de structuur van de betrekkingen met de netwerkleden gemiddeld meer verschillen optreden bij de oudere groep dan bij de jongere groep van de onderzoekspopulatie. Hoe de verschillen zich over de elementen initiatief, frequentie, gewicht en lengte zich uitstrekken valt niet te voorspellen. 
Voor de vergelijking van de patronen in de structuur van sociale netwerken bij beide groepen in de onderzoekspopulatie met de patronen in de structuur van de sociale netwerken die uit de informatie van de hulpverleners naar voren komen kan slechts de volgende algemene hypothese geformuleerd en getoetst worden.

42 De hierboven genoemde vergelijkingen zullen verschillen in de structuur van de sociale netwerken ofwel verschillende patronen laten zien.

De richting van de optredende verschillen is niet te voorspellen.

\section{3}

\section{AFSLUITENDE OPMERKING}

Naast de vraagstellingen geeft dit hoofostuk een overzicht van de hypothesen die bij de vraagstellingen geformuleerd zijn en getoetst worden. Het gegeven overzicht van de hypothesen toont dat niet bij iedere vraagstelling een min of meer overeenkomstig aantal hypothesen verbonden met de hoofdbestanddelen van de structuur van sociale netwerken geformuleerd zijn. Er is bijvoorbeeld een aanzienlijk verschil in de mate waarin hypothesen geformuleerd zijn tussen vraagstelling $I$ en vraagstelling $V$. Vervolgens toont het overzicht ook dat niet ten aanzien van ieder hoofdbestanddeel van de structuur van sociale netwerken in min of meer gelijke mate hypothesen geformuleerd zijn. Er treedt bijvoorbeeld een aanzienlijk verschil op in de mate waarin hypothesen geformuleerd zijn tussen het hoofdbestanddeel omvang en dat van de gevarieerdheid van sociale netwerken. Deze en andere optredende verschillen in de mate waarin hypothesen geformuleerd zijn komen deels voort uit de huidige stand van onderzoek naar de structuur van sociale netwerken van (chronisch) psychiatrische patiěnten. Het komt er op neer dat onderzoek dat specifiek de structuurkenmerken en de patronen in de strucluur van sociale netwerken bij (chronisch) psychiatrische patiènten behelst, betrekkelijk nieuw is en er ten aanzien van hypothesen nog niet echt gebruik gemaakt kan worden van een onderzoekstraditie (Angermeyer, Klusmann, 1989).

Bij de formulering van hypothesen doel zich nog een ander probleem voor. Zo er al een zekere traditie is in onderzoek naar de structuur van sociale netwerken bij psychiatrische patiënten, dan is dat hoofdzakelijk een nog jonge traditie die binnen de sociaal culturele context van het Noord Amerikaanse continent staat. Dit betekent dat voor zover er ten aanzien van de hypothesen aangesloten kan worden bij bevindingen uit eerder onderzoek aldaar verricht, deze bevindingen zelf niet los gezien kunnen worden van de context van opvattingen, normen, gebruiken en dergelijk binnen de Noord Amerikaanse samenleving. Enige terughoudendheid in het gebruik van de Noord Amerikaanse onderzoeksbevindingen bij de formulering van hypothesen over de structuur van sociale netwerken die ingebed zijn in de Nederlandse sociaal culturele context is dan ook op haar plaats. Deze reserve in combinatie met het gegeven dat in de Nederlandse context zelf nauwelijks onderzoek verricht is naar specifiek de structuur van sociale netwerken bij (chronisch) psychiatrische patiënten hebben mede bepaald de mate waarin bij de vraagstellingen hypothesen geformuleerd zijn. Aldus liggen de uitkomsten bij de verschillende vraagstellingen naar de structuur van de sociale netwerken van de onderzoekspopulatie in hoge mate open. 


\section{WERKWIJZE ONDERZOEK}

\section{$7.1 \quad$ OPZET ONDERZOEKSPOPULATIE}

Om de in het vorige hoofdstuk gegeven hypothesen te kunnen toetsen en de vraagstellingen over de structuur van het sociale netwerk van ambulante chronisch psychiatrische patienten te kunnen beantwoorden is, zoals weergegeven in figuur 7.1, een onderzoekspopulatie vereist die bestaat uit:

a ambulante chronisch psychiatrische patiënten,

b referentiepersonen,

c hulpverleners werkzaam in de ambulante psychiatrische zorg.

FIGUUR 7.1 Vraagstellingen en vereiste onderzoekspopulatie.

\begin{tabular}{|c|c|c|c|}
\hline \multicolumn{4}{|c|}{ ONDERZOEKSPOPULATIE } \\
\hline \multirow[b]{2}{*}{ Vragen } & patiënten & $\begin{array}{l}\text { referentie- } \\
\text { personen }\end{array}$ & hulpverleners \\
\hline & & & 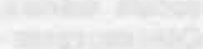 \\
\hline I & 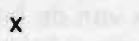 & $x$ & $\sqrt{4}+x^{2}$ \\
\hline II & $x$ & - & $x$ \\
\hline III & $x$ & thatate & - \\
\hline IV & $x$ & $x$ & - \\
\hline . & $x$ & $=$ & $x$ \\
\hline
\end{tabular}

Zoals eerder uiteengezet is het onderzoek uitgevoerd bij de Sociaal Psychiatrische Dienst van de RIAGG Maastricht. De onderzoekspopulatie - in termen van sociale netwerkanalyse 'focale personen' genoemd (Erickson, 1976) - betreft aldus ambulante chronisch psychiatrische patiënten die in zorg zijn bij de SPD Maastricht en de hulpverleners die aldaar de ambulante psychiatrische zorg beoefenen. Deze SPD is een geacademiseerde afdeling hetgeen betekent dat in beginsel iedere patiént en hulpverlener bij onderzoek betrokken kan worden (Pomerantz, 1988). De referentiepersonen zijn via het case-register 'Registratienet Huisartspraktijken' (RNH) te Maastricht verkregen (De Geus, 1985; Memic, 1989). 
De doelgroep van de SPD van de RIAGG Maastricht betreft ambulante chronisch psychiatrische patiënten (Van Marrelo, 1979; Romme, 1985). Zij voldoen aan de volgende criteria (Honig, 1989):

- er is sprake van psychiatrische symplomatologie;

- er zijn behalve stoornissen op het individueel psychologisch niveau ernstige problemen in het emotioneel-relationeel en maatschappelijk functioneren; er zijn meerdere behandelingspogingen vooraf aan de aanmelding bij de SPD. Uit deze doelgroep van de SPD is voor het onderzoek een selecte steekproef genomen.

De ambulante chronisch psychiatrische patiënten die bij het onderzoek zijn betrokken zijn patiënten die lopende het onderzoek (op)nieuw bij de SPD zijn aangemeld. Wanneer deze patiënten drie maanden bij de SPD in zorg waren werd er een verzoek tot deelname aan het onderzoek gedaan. Dit verzoek werd gericht aan de hulpverlener van de betreffende patiënt. Deze termijn van minimaal drie maanden zorg betekent onder meer dat indien er eventueel niet-chronisch psychiatrische patiënten in de zorg van de SPD binnenkomen, deze niet-chronisch psychiatrische patiënten binnen drie maanden weer uit het zorgbestand van de SPD verdwenen zijn. Zodoende mag aangenomen worden dat de patiënten die voor het onderzoek zijn gekozen chronisch psychiatrische patiënten binnen de ambulante psychiatrische hulpverlening zijn. Een tweede reden om een termijn van drie maanden in acht te nemen is dat de hulpverlener na deze periode bekend is met de patiënt en zijn problematiek. Daardoor wordt de hulpverlener in staat gesteld af te wegen of de patiënt in aanmerking kan komen aan het onderzoek deel te nemen. Het komt er op neer dat de volgende procedure is gevolgd.

- Bij iedere (op)nieuw aangemelde patiënt kreeg de betreffende-hulpverlener van de onderzoekers een verzoek tot deelname van de patiënt aan het onderzoek.

- De betreffende. hulpverlener ging naar zijn oordeel na of de patiënt in principe in staat was aan het onderzoek deel te nemen.

-. Wanneer de patiënt tot deelname in staat werd geacht ging de hulpverlener bij de patiënt na of deze zelf bereid was aan het onderzoek mee te doen.

... Bij toestemming van de patiënt namen de onderzoekers met deze contact op om een afspraak te maken voor een interview over de structuur van diens sociale netwerk.

Ook de vaste SPD-hulpverlener van de patiënt die aan het onderzoek deelname werd met medeweten van de patiënt vervolgens geinterviewd over de structuur van het sociale netwerk van de betrokken patiënt.

\subsubsection{Selectie referentiepersonen}

Voor het verkrijgen van adequaat gematchte referentiepersonen is gebruik gemaakt van het case-register 'Registratienet Huisartspraktijken' (RNH) RL te Maastricht waaraan geacademiseerde huisartspraktijken in Limburg gegevens leveren (De Geus, 1985). Het RNH wordt geleid door een registerteam van de vakgroep Huisartsgeneeskunde RL waarbij de infrastructuur wordt geleverd door het 'Medisch en Maatschappelijk Informatiecentrum' (MEMIC) van de RL. Dit register heeft tot doel het registreren van een geautomatiseerd en geanonimiseerd steekproefkader met een beperkte set patiënt achtergrond variabelen en relevante gezondheidsproblemen ten behoeve van wetenschappelijk onderzoek en onderwijs en doeleinden met betrekking tot gezondheidszorg (Knottnerus, Höppener, Metsemakers, 1992).

$\mathrm{Na}$ de procedure voor toestemming tot toegang tot het RNH doorlopen te hebben en de goedkeuring tot gebruik van het RNH verkregen te hebben werd een procedure gevolgd om de medewerking van de voor dit onderzoek in aanmerking komende huisartspraktijken in de regio Zuid Limburg te verkrijgen. In samenwerking met het Memic zijn de huisartspraktijken en de referentiepersonen uit het RNH getrokken. De referentiepersonen zijn op een aantal sociaal demografische kenmerken gematched 
conform de bij het onderzoek betrokken patiëntenpopulatie. Deze kenmerken zijn geslacht, leeftijd, burgerlijke staat, opleidingsniveau en samenlevingsverband. Voor de leeftijd is een marge van vijf jaar aangehouden. Uitgesloten werden referentiepersonen bij wie volgens de registergegevens sprake was van 'psychische problematiek. Voor iedere bij het onderzoek betrokken ambulante chronisch psychiatrische patiënt werden vanwege te verwachten uitval in principe vijf referentiepersonen uit het RNH getrokken. Na de trekking van referentiepersonen en de betreffende huisartspraktijken is op de volgende wijze toegang verkregen tot de referentiepersonen.

- De huisarts beoordeelde of betreffende referentiepersoon benaderd kon worden. Het kan bijvoorbeeld zijn dat de beoogde referentiepersoon op dat moment juist ernstig ziek is of om een andere reden naar het oordeel van de huisarts word belemmerd aan het onderzoek deel te nemen. Daarbij checkte de huisarts opnieuw of er sprake was van psychische problematiek. Wanneer de huisants oordeelde dat de betreffende persoon niet aan het onderzoek kon deelnemen werd een reservereferentiepersoon gekozen, al dan niet in dezelfde huisartspraktijk, bij wie eveneens om het oordeel van de betrokken huisarts werd gevraagd.

- Bij toestemming van de zijde van de huisarts verzond de huisarts aan de referentiepersoon een brief met het verzoek tot deelname aan het onderzoek. De referentiepersoon antwoordde de huisarts. Bij afwijzing van de zijde van de referentiepersoon werd opnieuw een reserve referentiepersoon genomen en de $z 0$ juist beschreven procedure met/door de betreffende huisarts gevolgd. Bij geen antwoord van de zijde van referentiepersoon werd deze nogmaals door de huisarts benaderd.

- * Bij toestemming tot medewerking van de zijde van de referentiepersoon werden door de huisarts naam en adres van de referentiepersoon aan de onderzoekers verstrekt, die op hun beurt met deze persoon contact opnamen om een afspraak te maken voor het interview inzake de structuur van diens sociale netwerk.

\subsection{GEGEVENSVERZAMELING}

\subsection{1}

\section{Maastrichtse Sociale Netwerk Analyse}

Voor de verzameling van de gegevens is gebruik gemaakt van het in de vakgroep Sociale Psychiatrie RL ontwikkelde instrument 'Maastrichtse Sociale Netwerk Analyse' (MSNA) (Baars, Uffing, Dekkers, 1990) en van de registratiegegevens van de SPD betreffende sociaal demografische kenmerken, de psychiatrische diagnostiek (DSM IIIR) en de patiëntcarriere.

De MSNA die gebaseerd is op het in hooldstuk 5 beschreven model brengt kort samengevat de volgende structuurkenmerken van persoonlijke sociale netwerken in kaart.

A De omvang van een sociaal netwerk, ofwel het totaal aantal netwerkleden, en de verdeling van de netwerkleden over de sectoren verwanten, vriendschappelijke betrekkingen en maatschappelijke diensten en over de clusters waaruit deze sectoren zijn samengesteld.

B De gevarleerdheid ofwel het sociaal demografisch profiel van de focale persoon en de netwerkleden.

C De bereikbaarheid van de netwerkleden voor de focale persoon in termen van geografische alstand.

D De structuur van de betrekkingen tussen de focale persoon en de netwerkleden, te weten:

$=$ het initiatief in het contact;

= de frequentie van het contact;

= het gewicht van hel contact;

= de lengte van de betrekking. 
In bijlage I vindt men de beschrijving en operationalisatie van de onderscheiden structuurkenmerken. Figuur $\mathbf{7 . 2}$ geeft de handleiding voor het verzamelen van informatie over de structuur van sociale netwerken.

\subsubsection{Seml-gestructureerd Interview}

De gegevens over de structuur van het sociaal netwerk zijn via een 'semigestructureerd interview' verzameld, de gangbare aanpak voor informatieverzameling door middel van sociale netwerk analyse bij doelgroepen van psychiatrische zorg (Erickson, 1976, Scott, 1988). Als handleiding bij de interviews dient de zogeheten 'Topografie van een sociaal netwerk' (zie figuur 7.2). Aan de hand van deze 'Topografie' worden met de focale personen (hier zowel de ambulante chronisch psychiatrische patienten in de onderzoekspopulatie alsook de referentiepersonen) voor iedere sector en elk daarbinnen genoemd cluster systematisch de 'beschikbare' netwerkleden geïnventariseerd. Over ieder door de focale persoon genoemd netwerklid wordt hem informatie gevraagd met betrekking tot de gevarieerdheid en de bereikbaarheid van het betreffende netwerklid en over de structuur van de betrekkingen tussen hem en ieder netwerklid. Bij de betreffende hulpverlener is dezelfde werkwijze gevolgd maar dan met de vraag wat deze hulpverlener na drie maanden zorg weet over de structuur van het sociale netwerk van de patiënt.

Met deze systematiek wordt zo goed als mogelijk is voorkomen dat 'effectieve' en 'niet-effectieve' netwerkleden (zie § 5.3) over het hoofd worden gezien. De interviews zijn afgenomen door in de MSNA getrainde onderzoeksmedewerk(st)ers, die tevens ervaring hadden met de praktijk van de ambulante psychiatrische hulpverlening.

\subsubsection{Proefinterviews}

Voorafgaande aan de dataverzameling is een periode voor proefinterviews uitgetrokken. De belangrijkste overweging voor een fase van proefinterviews was na te gaan of en waar een eventuele bijstelling van het instrument voor 'Sociale netwerkanalyse (MSNA) alsnog geboden was. Het instrument bleek bij de beoogde patiëntpopulatie hanteerbaar te zijn on kon gehandhaafd blijven. 'Hanteerbaar' wil zeggen dat de patienten het in het algemeen als een verademing beschouwden dat zij nu eens niet gevraagd werden naar belevingen en gevoelens maar dat zij in staat werden gesteld de actuele levensomstandigheden waarin ze dagelijks verkeren feitelijk in beeld te brengen. 'Hanteerbaar' hield vervolgens in dat de systematiek in de werkwijze de patienten hielp de te volgen procedure te overzien en een (op)nieuw geordend overzicht over hun levenssituatie te verkrijgen. Duidelijk werd dat de patienten een terugkoppeling van de door hen verstrekte informatie bijzonder op prijs stelden. Tenslotte bleek de gemiddelde duur van anderhalf uur voor het interview geen problemen op te leveren. Een dergelijke tijdsinvestering is geen uitzondering en bijvoorbeeld ook aanwezig bij de 'SONET' (Laireiter, Baumann, 1989); de 'Network Analysis Profile' (Cohen, Sokolovsky, 1978, 1981), beschreven in \$ 4.4.1, vergt een tijdsinvestering van gemiddeld vier uren te verdelen over twee interviews.

Een tweede reden voor deze fase van proefinterviews was de training in het afnemen van de MSNA van de bij dit onderzoek betrokken onderzoeksmedewerkers.

\subsection{4}

Betrouwbaarheid van de data

Een eerste opmerking betreft de betrouwbaarheid van de informatie van de zijde van de patiëntpopulatie. De MSNA is ontwikkeld in de lijn van de zogeheten 'structuurbenadering' (Hammer, 1981; Wellman, Berkowitz, 1988) hetgeen impliceert dat de betrouwbaarheid in de zin van stabiliteit, volledigheid en nauwkeurigheid van de informatie wordt gedragen door de volgende uitgangspunten:

- zoveel mogelijk objectiveerbare en zo min mogelijk subjectieve informatie in de zin van meningen, oordelen, gevoelens en dergelijke wordt verzameld; 
de focale persoon wordt naar feitelijke informatie gevraagd die hij wel of niet heeft; gevraagd wordt datgene te vertellen wat hij weet en achterwege te laten wat hij niet zeker weet dan wel vermoedt;

de focale persoon geeft informatie over zijn sociale netwerk vanuit betrekkingen waaraan hijzelf rechtstreeks min of meer duurzaam deelneemt.

Deze uitgangspunten zijn voor wat betreft de structuurkenmerken van een sociaal netwerk ook terug te vinden bij de door Pattison (1977) ontwikkelde "Psychosocial Kinship Inventory" (PKI). Onderzoek van Hamilton e.a. (1989), waarbij gebruik gemaakt wordt van de PKI, toont aan dat wat de focale persoon (hier chronisch psychiatrische patiënten met schizofrene stoornissen) rapporteert over de structuurkenmerken van zijn netwerk vrijwel overeenkom t met wat een netwerklid die de betreffende focale persoon zeer goed kent over de structuur van zijn netwerk rapporteert. De informatie van dit netwerklid kom minder met die van de focale persoon overeen waar het gaat om meer incidentele contacten of zeer recente ontwikkelingen in het netwerk waar dit netwerklid dan nog buiten staat (Hamilton e.a., 1989).

Het element 'gewicht' in de structuur van de betrekkingen neemt een aparte plaats in. Hoewel ook dit element te quantificeren is, zoals in figuur 7.2 is aangegeven en in Bijlage I wordt verduidelijkt kan de rapportage van een focale persoon als zodanig niel anders dan een subjectieve inschatting inhouden (Brim, 1974).

Een tweede opmerking betreft de betrouwbaarheid van de informatie van de zijde van de hulpverleners in relatie tot vraagstelling II van het onderzoek. De SPDhulpverleners waren overeenkomstig het onderzoeksprotocol op de hoogte van de achtergronden, inhoud en doelstelling van het onderzoek. Ze waren immers noodzakelijk betrokken in de besluitvorming om dit onderzoek in de SPD van de RIAGG Maastricht te kunnen realiseren. Dat zou kunnen betekenen dat hun kennis inzake het onderzoek van invloed is op de te verkrijgen gegevens. Tijdens de fase van proefinterviews, een fase waarvoor juist met het oog op mogelijk te verwachten effecten betrekkelijk veel tijd is uitgetrokken, bleek dat de omgang van de hulpverleners met het onderzoek overwegend neutraal was, in de trant van: "het is een interessant onderwerp, als onderzoekers daarover iets meer willen weten zullen we de medewerking niet onthouden, en misschien hebben we er zelt ook iels aan'.

Ook de terugkoppeling van de informatie naar patiënt en hulpverlener bracht tijdens de fase van proefinterviews geen verandering in deze opstelling van de betrokken hulpverleners. Wel werd duidelijk dat verwacht kon worden dat lopende het onderzoek er een moment zou komen dat deze neutrale houding zich zou wijzigen in een opstelling naar de onderzoekers om de praktische consequenties te verkennen en nader uit te werken. Dit te verwachten effect van de deelname van de hulpverleners aan het onderzoek is echter niet problematisch voor hel onderzoek. Immers, zoals in $\S 1.2 .4$. vermeld is, dit onderzoek heeft niet alleen tot doel om meer inzicht te krijgen in de mogelijkheden en de beperkingen van de persoonlijke sociale netwerken waarop de patient voor zijn sociale integratie is aangewezen.

Daarnaast wil dit onderzoek er ook toe bijdragen om in de structuur van het sociale netwerk van de doelgroep van de SPD aangrijpingspunten le vinden voor interventies in de ambulante psychiatrische hulpverlening die de sociale integratie van de patiënt bevorderen dan wel herstellen. Dit betekende dat lopende het onderzoek gewacht werd op enig moment dat de SPD-hulpverleners zelf de onderzoekers op deze practische doelstelling zouden gaan aanspreken. Voorgenomen werd dat wanneer dat moment zou optreden de interviews met de hulpverleners in relatie tot vraagstelling II van dit onderzoek beëindigd zouden worden. 
Na de afgenomen interviews betreffende de structuur van het sociale netwerk van:

A de ambulante chronisch psychiatrische patiënt;

B de kennis van de hulpverlener omtrent het sociale netwerk van dezelfde patiënt;

C de gematchte referentiepersoon.

zijn de verkregen gegevens geanonimiseerd en gecodeerd en is het databestand opgebouwd. Dit databestand bestaat uit de volgende elementen:

1 gegevens van de focale persoon;

2 sociale netwerkgegevens van de focale persoon zoals door hemzelf verschaft;

3 sociale netwerkgegevens van de focale persoon zoals door de de hulpveriener verschaft;

4 sociale netwerkgegevens van de gematchte referentiepersoon.

Dit databestand is dermate gecompliceerd dat van meet af aan de verwachting bestond dat de analyse van de gegevens c.q. de toesing van de hypothesen (speciaal waar het de koppeling van de gegevens betreffende de gevarieerdheid van de focale persoon aan die van zijn netwerkleden betrof) een moeilijke aangelegenheid zou worden. Het was zeer de vraag of volstaan zou kunnen worden met bestaande computerprogrammatuur. Daarenboven ontbraken er in de literatuur vergelijkbare onderzoeksvragen met caaraan gekoppelde analysemethoden.

Het komt er op neer dat de analyse en beschrijving van de kenmerken omvang en bereikbaarheid en van de structuur van de betrekkingen gebeurd is aan de hand van ieder persoonlijk sociaal netwerk afzonderlijk, heigeen inhoudt dat de resultaten bij deze structuurkenmerken berekend zijn in een gemiddeld aantal netwerkleden. Bij het structuurkenmerk gevarieerdheid is van deze werkwijze geen gebruik gemaakt waar de vraagstelling een koppeling tussen de focale personen en de netwerkleden vereist. Dit is het geval bij Vraagstelling I conform hypothese 5, 5.1 en 5.2, bij Vraagstelling III conform hypothese 29 en bij Vraagstelling IV conform hypothese 39 . De kenmerken van gevarieerdheid worden hier over het totaal aantal netwerkleden berekend. Tenslotte kan opgemerkt worden dat voor de analyse en beschrijving van de gevarieerdheid van de netwerkleden de antwoordcategorieën gedichotomiseerd zijn met uitzondering van het kenmerk woonsituatie die tot drie antwoordcategorieen is teruggebracht. 
FIGUUR 7.2 Topografie van de structuur van een sociaal nelwerk ofwelhandleiding voor het afnemen van de Maastrichtse Sociale Netwerk Analyse (MSNA).

A. OMVANG
1.1 Focale persoon
1.2 Volgnummer
1.3 Datum interview
1.4 Woonplaats
1.5 Gevarieerdheid

2. Netwerklid

2.1 Sector verwanten

2.2 Sector vriendschappelijke betrekkingen

2.3 Sector maatschappelijke diensten

B. GEVARIEERDHEID
3.1 Geslacht
3.2 Leeftijd
3.3 Burgerlijke staat
3.4 Voltooid opleidingsniveau
3.5 Laatst uitgeoefend beroep
3.6 Werksituatie
3.7 Woonsituatie

C. BEREIKBAARHEID
4.1 Wijk
4.2 Woonplaats
4.3 Regio
4.4 Buiten de regio

D. STRUCTUUR VAN DE BETREKKINGEN
5.1 Initiatief
5.2 Frequentie
5.3 Regelmaat
5.4 Soort contact

6. Gewicht 12345

6.1

6.2

6.3

6.4

- Geslach

- Burgerlijke staat

- Voltooid opleidingsniveau

- Laalst uitgeoefend beroep

- Werksituatie

- Woonsituatie

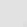





\section{AMBULANTE CHRONISCH PSYCHIATRISCHE PATIENTEN}

Dit hoofdstuk behandelt vraagstelling I van het onderzoek naar de structuur van het persoonlijke sociaal netwerk van ambulante chronisch psychiatrische patiënten. Vraagstelling I luidt:

WELKE OVEREENKOMSTEN DAN WEL VERSCHILLEN IN DE OMVANG, DE GEVARIEERDHEID, DE BEREIKBAARHEID EN DE STRUCTUUR VAN DE BETREKKINGEN BESTAAN ER TUSSEN SOCIALE NETWERKEN VAN AMBULANTE CHRONISCH PSYCHIATRISCHE PATIENTEN EN DE SOCIALE NETWERKEN VAN NORMALE REFERENTIEPERSONEN?

De beantwoording van deze vraag gebeurt aan de hand van de in $\$ 6.2 .1$ geformuleerde hypothesen 1 tot en mel 15. Voorafgaande aan de toetsing van de gegeven hypothesen wordt eerst een beschrijving van de onderzoekspopulatie en van de referentiepersonen gegeven.

\section{1}

\section{BESCHRIJVING ONDERZOEKSPOPULATIE}

Via de procedure voor de opbouw van een onderzoekscohort (zie $\S 7.1 .1$ ) zijn 59 (Op)nieuw bij de SPD van de RIAGG Maastricht aangemelde chronisch psychiatrische patiënten in het onderzoek betrokken kunnen worden. Met behulp van de procedure voor het verwerven van referentiepersonen (zie \$ 7.1.2) was het mogelijk om voor 47 ambulante chronisch psychiatrische patiënten de gevraagde adequaat gematchto referentiepersonen te verkrijgen. Voor twaalf patiexnten van de onderzoekspopulatie bleek het ondanks herhaalde pogingen niet mogelijk de vereiste referentiepersonen te vinden. In Bijlage IV zal een korte beschrijving gegeven worden van de structuur van de sociale netwerken bij deze twaalf patie̊nten.

In deze paragraaf worden respectievelijk de sociaal demografische kenmerken en de kenmerken betreffende psychiatrische symptomatologie en patientcarrière van de onderzoekspopulatie weergegeven. Vervolgens wordt nagegaan in welke mate de hier geselecteerde onderzoekspopulatie $(N=59$ ) een afspiegeling is van de doelgroep ambulante chronisch psychiatrische patienten in zorg bij de SPD Maastricht. 
TABEL 8.1 Sociaal demografische kenmerken van de onderzoekspopulatie ambulante chronisch psychiatrische patiënten $(N=59)$ en de daarbinnen te onderscheiden populaties $n=47$ en $n=12$.

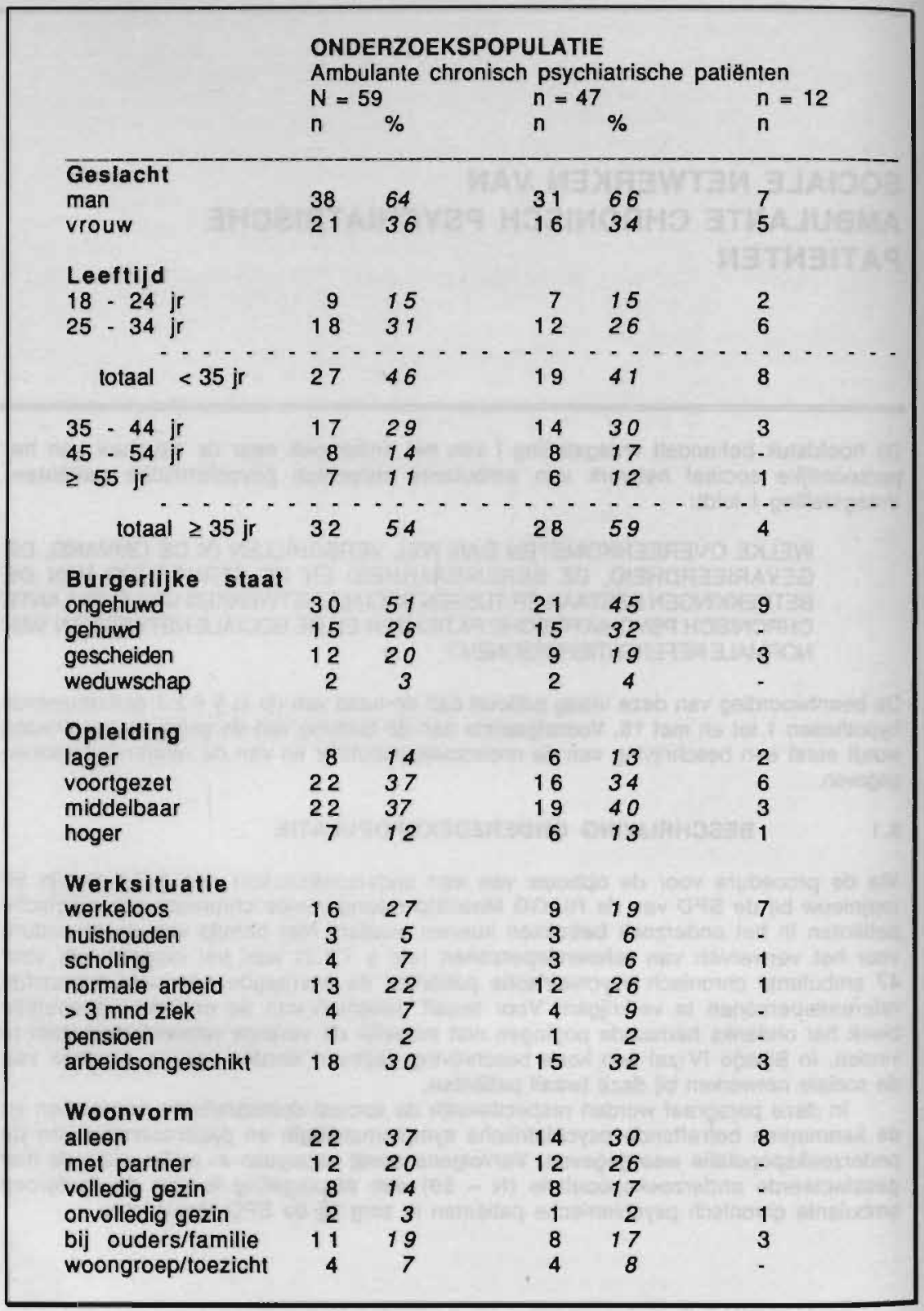


Tabel 8.1 toont de sociaal demografische kenmerken ofwel in termen van sociale netwerkanalyse de kenmerken van de gevarieerdheid bij

de totale onderzoekspopulatie $(\mathrm{N}=59)$;

het deel van de onderzoekspopulatie $(n=47)$ waarvan de netwerken vergeleken konden worden met die van normale referentiepersonen;

- hel deel van de onderzoekspopulatie $(n=12)$ waarvoor geen referentiepersonen konden worden gevonden.

Bij de weergave van de leeftijdsopbouw in tabel 8.1 is een onderscheid gemaakt tussen jongere en oudere patiénten. Dit onderscheid is aangebracht om de vraagstellingen III, iV en $V$ van het onderzoek te kunnen beantwoorden. De groep jongeren betreft de patiěnten in de leeftijd vanaf 18 tot en met 34 jaar; de groep ouderen betreft de patienten in de leeftijd vanaf 35 jaar. De keuze voor deze leeftijdsgrens komt voort uit aanwijzingen in de literatuur waarbij de grens tussen jongere en oudere volwassen psychiatrische patiënten varieert tussen de 30 en 40 jaar (Harris, Bergman, 1985; Laireiter, Baumann, 1989). Bovendien bleek het met deze leeftijdsgrens mogelijk om binnen de totale onderzoekspopulatie van 59 patiënten twee groepen van ongeveer gelijke grootte te kunnen afbakenen en te vergelijken.

Allereerst een beschrijving van de sociaal demografische kenmerken van de onderzoekspopulatie bestaande uit 59 ambulante chronisch psychiatrische patiënten. Voor bijna tweederde deel bestaat de onderzoekspopulatie uit mannen $(n=38$ ). lets meer dan de helft ofwel $54 \%$ is ouder dan 34 jaar. Ongeveer de helft ( $n=30$ ) is ongehuwd. Verreweg de meeste patiënten ( $n=51$ of $83 \%$ ) hebben na het basisonderwijs aan een vervolgopleiding deelgenomen. Hiervan hebben er 22 een opleiding voltooid op het niveau van MAVO of van het lager beroepsonderwijs (LBO) en voor nog eens 22 patiënten geldt dat voor het niveau van middelbaar-(beroeps)onderwijs. Patiënten die werkeloos, arbeidsongeschikt en ziek zijn vormen gezamelijk $79 \%$ van de onderzoekspopulatie. Een meerderheid (56\%) van de patiënten woont samen met ofwel een partner $(n=12)$ ofwel in een gezins- of familieverband $(n=$ 21 ). Het deel van de onderzoekspopulatie ( $n=47$ ) waarvoor referentiepersonen gevonden konden worden wijkt qua procentuele verdeling van de sociaal demografische kenmerken in het algemeen niet af van de verdeling ervan over de totale onderzoekspopulatie $(N=59)$. Het deel van de twaalf ambulante chronisch psychiatrisch patiënten voor wie geen referentiepersonen gevonden zijn bestaat uit zeven mannen en vijf vrouwen; zij zijn merendeels in de leeftijd van 25 tot 44 jaar, ongehuwd (allen zonder partner), alleenwonend $(n=8)$ en werkeloos dan wel arbeidsongeschikt $(n=10)$.

Voor de beschrijving van de psychiatrische diagnose en patiëntcarrière is gebruik gemaakt van de registratiegegevens van de hulpverleners van de SPD van de RIAGG Maastricht (zie $\$ 7.2 .1$ ). Vooreerst dient opgemerkt te worden dat de gegevens betreffende de psychiatrische diagnose in de registratie van de hulpverleners lacunes vertoonden. Bij 15 patiënten $(22 \%)$ van de onderzoekspopulatie $(\mathrm{N}=59)$ ontbraken in de registratie gegevens met betrekking tot een diagnose en was hel niet mogelijk op basis van de dossiers en/of bij de betreffende hulpverlener die informatie te verkrijgen die zou leiden tot een betrouwbare diagnose conform de psychiatrische classificatie DSM-IIIR. Weliswaar kon bij vier van deze patiënten gesproken worden van problemen op het affectieve vlak en bij drie patiënten van psychotische problematiek. Een andere lacune betrof het verschil in volledigheid van de gegevens in de registratie van de hulpverleners.

In zeven gevallen kon er op basis van de DSM-IIIR criteria geen diagnose worden gesteld. Bij 28 patienten $(42 \%)$ is er in de registratie van de hulpverleners van de SPD sprake van een persoonlijkheidsstoornis (As II). Bij eenderde van hen gaat het om een affectieve stoornis en terwijl er vervolgens bij negentien patiënten actueel - in gelijke mate verdeeld - neurotische, psychotische, psychosomatische problemen en/of verslavingsproblemen vermeld worden. 
In het geheel genomen leiden de gegevens omtrent de psychiatrische diagnostiek die door de hulpverleners geregisteerd zijn met betrekking tot de onderzoekspopulatie ( $\mathrm{n}=$ 59 ) tot het volgende beeld. Bij ruim eenderde van de onderzoekspopulatie is er sprake van een affectieve stoornis en wel voornamelijk unipolair depressief. Vervolgens wordt in min of meer gelijke mate (telkens $\pm 15 \%$ ) gewezen op de aanwzigheid van neurotische, psychotische en psychosomatische problematiek. Bij ongeveer $10 \%$ van de onderzoekspopulatie blijkt er (tevens) sprake te zijn van verslavingsproblematiek. Het deel van de onderzoekspopulatio bestaande uit 47 ambulante chronisch psychiatrische patiënten bij wie referentiepersonen gevonden konden worden wijkt inzake deze beschrijving naaar psychiatrische diagnose nagenoeg niet af van de totale onderzoekspopulatie $(\mathrm{N}=59)$.

Dit globale beeld - met inachtneming van de beperkingen aangetroffen in de geregistreerde gegevens door de hulpverleners van de SPD Maastricht - verwijst naar een meer algemene waarneming dat de ambulante psychiatrische hulpverlening een scale van zietebeelden bevat die in feite de gehele psychopathologie omvat (Test, Stein, 1978; Calaço Belmonte, 1979; Rotteveel, Uffing, De Vries, 1987). Overigens ligt in dit onderzoek, zoals ook elders in sociale netwerkonderzoek bij psychiatrische populaties wordt aangetroffen (zie Hoofdstuk 4), niet het accent op psychiatrische diagnosen bij de vergelijking van de structuur van sociale netwerken. Vergelijkingen vinden vooral plaats vanuit de zogeheten patiëntcarrière en vanuit het structuurkenmerk gevarieerdheid zoals het element leeftijd.

Betreffende de patientcarrière van de onderzoekspopulatie $(N=59)$ is in de registratiegegevens van de SPD nagegaan op welke leeftijd deze patiènten voor het eerst met een instelling voor geestelijke gezondheidszorg (GGZ) in contact zijn gekomen en hoelang er met de GGZ op enigerlei wijze contact is geweest vooraf aan de (her)aanmelding bij de SPD Bij drie patiënten, één vrouw en twee mannen, kon hierover geen adequate informatie verkregen worden. Bij $39 \%$ (twaalf vrouwen en tien mannen) van de overige 56 ambulante chronisch psychiatrische patiënten vond het eerste contact met een GGZ-instelling plaats op een leeftijd jonger dan 25 jaar. Een meerderheid van deze 56 patienten $(68 \%$, bestaande uit 15 vrouwen en 23 mannen) was jonger dan 35 jaar bij het eerste contact met een GGZ-instelling. Vervolgens blijkt dat $23 \%$ van de bij het onderzoek betrokken patiënten, bestaande uit vier vrouwen en negen mannen, voor het eerst in de leeftijd van 35 tot en met 44 jaar contact met een GGZ-instelling hadden. De overige vijf patiënten bestaande uit én vrouw en vier mannen waren $\mathbf{4 5}$ jaar of ouder toen zij voor het eerst met een GGZinstelling in contact kwamen. De drie patiënten bij wie geen adequate informatie verkregen kon worden omtrent hun leeftijd bij het eerste contact met een GGZinstelling blijken in elk geval al meer dan 10 jaar op enigerlei wijze met de GGZ contact te hebben.

Al bij al komt het er op neer dat $47 \%$ van de bij het onderzoek betrokken ambulante chronisch psychiatrische patiënten $(N=59)$, bestaande uit 16 vrouwen en 12 mannen, reeds 10 jaar of langer eerder contact met de GGZ hadden. Bij $31 \%$ van de onderzoekspopulatie, 2 vrouwen en 16 mannen, waren op het moment van de (her)aanmedling bij de SPD Maastricht vijf tot tien jaar met een GGZ-instelling in contact geweest. De overige $22 \%$, drie vrouwen en tien mannen bleken minmaal twee dan wel maximaal vier jaar contact te hebben gehad met de GGZ.

Om de representativiteit van de onderzoekspopulatie $(N=59)$ te bepalen is een vergelijking gemaakt met de demografische gegevens van het totaal aantal nieuwe aanmeldingen tijdens de onderzoeksperiode $(\mathrm{N}=436)$. De onderzoekspopulatie bestaat uit meer vrouwen $(64 \%)$ dan mannen $(36 \%)$. Bij het totaal aantal nieuwe aanmeldingen ziet men helzelfde patroon maar minder sterk; mannen (45\%) en vrouwen $(55 \%)$. De helft van de onderzoekspopulatie is ongehuwd en een kwart gehuwd. Bij de nieuwe aanmeldingen ziet men het omgekeerde; bijna de helft is gehuwd en $30 \%$ is ongehuwd. De groepen komen overeen wat betreft aantal gescheiden personen en aantal weduwen/naars. 
Wat betreft de werksituatie is de onderzoekspopulatie een goede afspiegeling van het aantal nieuwe aanmeldingen; tweederde van de aangemelde patiënten heeft geen werk of scholing.

Het opleidingsniveau van de onderzoekspopulatie is hoger dan bij het totaal aantal nieuwe aanmeldingen; in de onderzoekspopulatie heeft slechts $14 \%$ alleen lager onderwijs gevolgd, terwijl dit bij de totale aanmeldingen $30 \%$ betrof. Daartegenover hebben de onderzoekspersonen vaker middelbaar onderwijs gevolgd (resp. $37 \%$ en 28 $\%)$. In het hoger onderwijs komen beide groepen overeen.

De onderzoekspopulatie komt in leeftijd overeen met die van de nieuwe aanmeldingen, waarbij $\mathbf{4 2} \%$ tot de jongere groep en $58 \%$ tot de oudere groep behoort. De leeftijdsgroep van 18 tot 24 jarigen is bij de onderzoekspopulatie relatief groot (15\%) vergeleken met gegevens van het aantal nieuwe aanmeldingen ( $8 \%$ ).

Het komt erop neer dat de onderzoekspopulatie een goede afspiegeling vormt van het totaal aantal nieuwe aanmeldingen voor wat betreft geslacht en leeftijd. Daarentegen is het opleidingsniveau van de onderzoekspopulatie hoger en zijn meer mensen ongehuwd.

\section{2}

\section{BESCHRIJVING REFERENTIEPERSONEN}

Voor de samenstelling van een referentiegroep stonden aanvankelijk twee opties open, te weten:

a hel zoeken van referentiepersonen binnen de sociale netwerken van de

onderzoekspopulatie;

b het zoeken van referentiepersonen binnen de 'normale' populatie.

De eerste optie die te verkiezen zou zijn en die in de periode januari 1990 tot medio 1990 geexploreerd is bleek praktisch gezien niet haalbaar. In de omvang van de sociale netwerken van de ambulante chronisch psychiatrische patiênten konden binnen het deel informele netwerkleden (de sectoren verwanten en vriendschappelijke betrekkingen) onvoldoende adequaat gematchte referentiepersonen gevonden worden die zich in een min of meer overeenkomstige positie (bijvoorbeeld binnen een zelfde cluster) ten opzichte van de onderzoekspopulatie bevinden. Bijvoorbeeld: $30 \%(n=18)$ van de bij het onderzoek betrokken patiënten $(N=59$ ) is niet in staat netwerkleden te noemen behorend tot het cluster 'vrienden'. Een andere moeilijkheid was dat de betrokken hulpverleners huiverig waren deze optie te volgen.

Medio 1990 werd besloten de tweede optie te volgen en voor het verwerven van adequaat gematchte referentiepersonen toestemming te vragen om gebruik te maken van het case-register 'Registratienet Huisartspractijken' (RNH) van de RL te Maastricht (De Geus, 1985). In $\S 7.1 .2$ is de afgesproken procedure voor het verkrijgen van de benodigde referentiepersonen beschreven die gevolgd is nadat in september 1991 door het RNH het groene licht werd gegeven daadwerkelijk van het register gebruik te kunnen maken. De moeilijkheden die zich voordeden om toestemming tot toegang en gebruik van het RNH te krijgen en vervolgens de medewerking te verkrijgen van de voor dit onderzoek in aanmerking komende huisartspraktijken in de regio Zuid Limburg aangesloten bij het RNH zijn uiteengezel in de Jaarverslagen 1990, 1991 en 1992 van het Sociale Netwerk Project. Al bij al komt het er op neer dat er over en weer langdurig inspanningen geleverd zijn om te komen tot een optimale samenwerking waaronder de realisering van een weliswaar omslachtige maar vooral zorgvuldige procedure ( $\$ 7.1 .2$ ), ten behoeve van onder meer de bescherming van de privacy van de beoogde referentiepersonen. Deze wellicht onvermijdelijke investering leidde viteindelijk tot het resultaat dat adequaat gematchte referentiepersonen verkregen konden worden.

Vanuit het RNH is tenslotte door vier huisartspraktijken aan het onderzoek deelgenomen. Conform de aangegeven procedure is een steekproef uit het RNH getrokken. Echter de feitelijke sociaal demografische werkelijkheid van de beoogde referentiepersonen zag er niet zelden wat anders uit dan in het RNH was aangegeven hetgeen belekende dat de betrokken huisarts de gegevens corrigeerde. Als deze correcties ingrijpend waren verdween de beoogde referentiepersoon uit de steekproef. Als de correcties van dien aard waren dat de beoogde referentiepersoon bij benadering 
binnen de procedure paste (bijvoorbeeld de referentiepersoon stond op papier op het niveau van middelbaar onderwijs maar bleek - ondertussen - onder hoger onderwijs te vallen) dan werd deze als beoogde referentiepersoon geaccepteerd. Wanneer de onderzoekers vervolgens bij de referentiepersonen zelf kwamen dan kon de actuele situatie er opnieuw anders uitzien dan bij de huisarts bekend was, laat staan dat deze feitelijke sociaal demografische toestand bij het RNH bekend was. Zo kon bijvoorbeeld de beoogde en als ongehuwd bekend staande referentiepersoon een partner hebben. Hel kwam er op neer dat er pas na het interview zekerheid was of de geïnterviewde ook als referentiepersoon geaccepteerd zou kunnen worden.

Het lukte niet om via het RNH en de daarbij geldende procedures optimaal aan de benodigde referentiepersonen te komen. Vanwege dit gegeven werd vroegtijdig een niet aan het RNH deelnemende huisartspraktijk in de regio Zuid Limburg benaderd en bereid gevonden om als reservepraktijk te functioneren.

In deze reservepraktijk werd dezelfde procedure als eerder beschreven in $\S 7.1 .2$ gevolgd. In juni 1992 werd de gegevensverzameling met betrekking tot de referentiepersonen afgesloten. Onderstaande tabel 8.2 brengt de gevolgde procedure met de vijf betrokken huisartspraktijken en de uitkomsten ervan cijfermatig in beeld.

TABEL 8.2 Cijfermatige weergave van de procedure bij de betrokken vijf huisartspraktijken en van de uitkomsten van de werving van referentiepersonen.

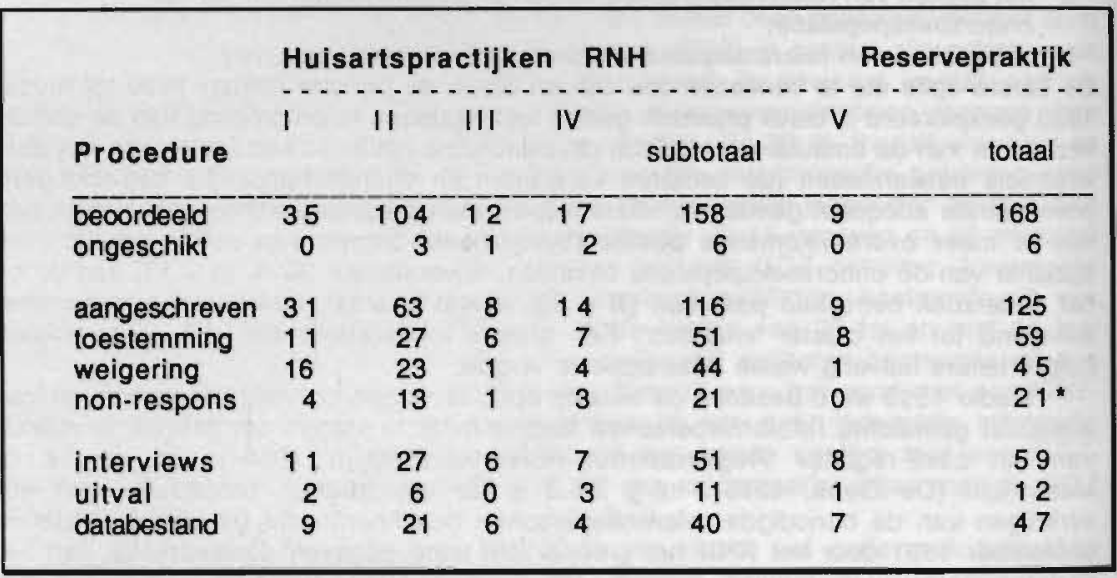

- merendeels niet te bereiken (bijvoorbeeld herhaaldelijk niet thuis, verhuisd).

Ook met behulp van de reservepraktijk bleven er tenslotte twaalf patienten uit de onderzoekspopulatie over voor wie geen referentiepersonen beschikbaar waren. Zoals eerder in \$ 8.1 vermeld gaat het voornamelijk over alleenwonende / alleenstaande. merendeels lager opgeleide en werkeloze / arbeidsongeschikte mannen $(n=7)$ en vrouwen $(n=5)$, hoofdzakelijk in de leeftijd van 25 tot 44 jaar. Referentiepersonen met de vereiste sociaal demografische kenmerken konden weliswaar (bij benadering) voor deze twaalf patiènten geselecteerd worden, maar bleken vervolgens ofwel te weigeren aan het onderzoek deel te nemen, ofwel niet opspoorbaar te zijn, ofwel elders in een GGZ.-instelling in zorg te zijn zonder dat dit laatste gegeven bij de betreffende huisarts bekend was.

Zoals tabel 8.2 laat zien konden er al bij al voor 47 ambulante chronisch psychiatrische patiënten in de onderzoekspopulatie $(N=59$ ) adequaat gematchte referentiepersonen gevonden worden. In de volgende tabel 8.3 wordt het sociaal demografisch profiel van de onderzoekspopulatie $(n=47)$ en van de daarbij gevonden referentiepersonen uit de vijf huisartspraktijken gegeven en vergeleken. Met het oog 
op de analyse en beschrijving van de gevarieerdheid van de netwerkleden ten opzichte van de onderzoekspopulatie zijn een aantal items onder de sociaal demografische kenmerken zoals die te vinden zijn in tabel 8.1 samengetrokken en wordt hier in tabel 8.3 gesproken van een sociaal demografisch profiel.

TABEL 8.3 Sociaal demografisch profiel van de onderzoekspopulatie $(n=$ 47) vergeleken met die van de referentiepersonen.

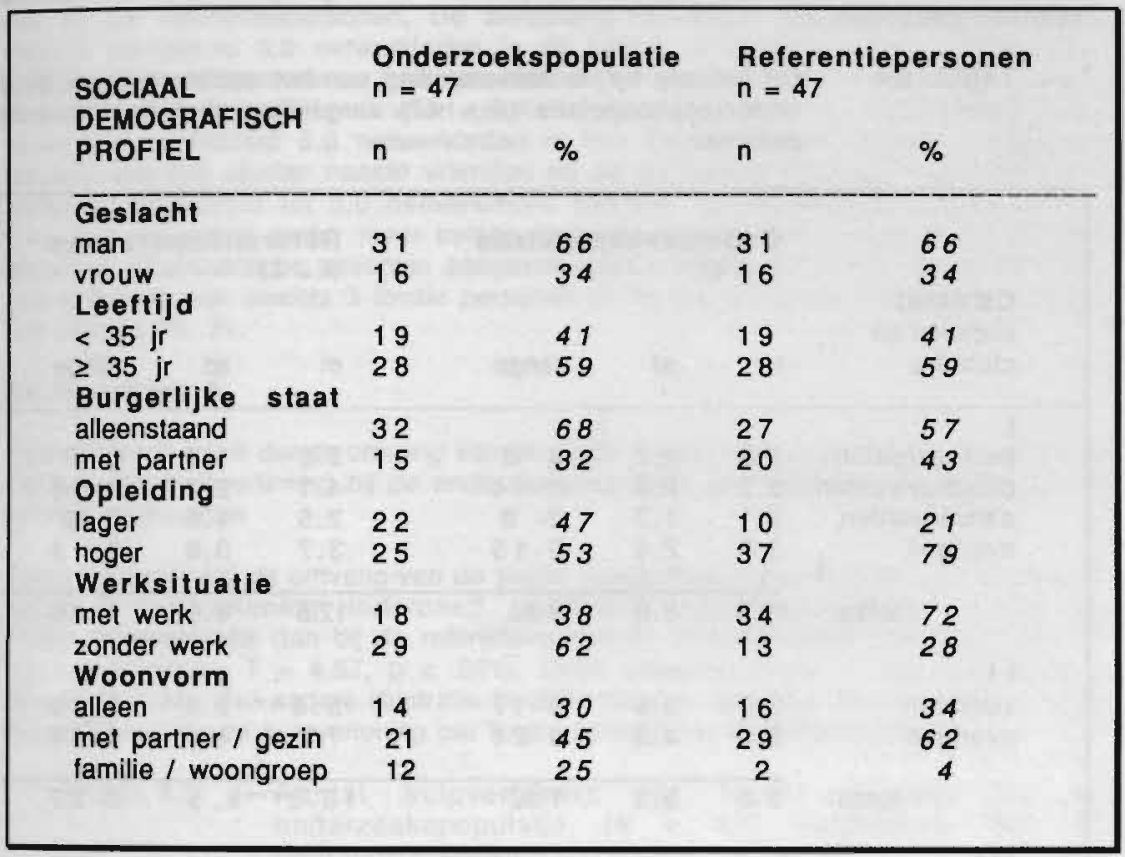

Bovenstaande tabel 8.3 toont dat het via de in $\$ 7.1 .2$ gevolgde procedure gelukt is om ten aanzien van de kenmerken geslacht en leeftijd (verdeeld in jongeren en ouderen) een op de onderzoekspopulatie adequaat gematchte groep referentiepersonen te vinden. De optredende verschillen bij de overige kenmerken hangen samen met de eerder in $\S$ 8.2 vermelde discrepanties tussen enerzijds de aangegeven toestand van de referentiepersoon in het RNH en de gegevens in de betreffende huisartspraktijk en anderzijds met de werkelijkheid die vervolgens door de onderzoekers ter plekke werd aangetroffen.

In deze paragraaf worden aan de hand van de hypothesen 1 tot en met $15(\S 6.2 .1)$ de resultaten van vraagstelling I van het onderzoek gegeven. Achtereenvolgens worden de volgende bevindingen aangaande de structuur van de sociale netwerken van de onderzoekspopulatie ( $n=47$ ) vergeleken met die van de referentiepersonen gepresenteerd.

- De omvang van de sociale netwerken en de verdeling van de netwerkleden over sectoren en clusters, cq. de samenstelling van de omvang, weergegeven in $\S 8.3 .1$.

- De gevarieerdheid van de netwerkleden, weergegeven in $\$ 8.3 .2$.

- De bereikbaarheid van de netwerkleden, weergegeven in $\S 8.3 .3$.

- De structuur van de betrekkingen, weergegeven in $\$$ 8.3.4. 
Tenslotle, en daarmee wordt dit hoofdstuk betreffende vraagstelling I afgesloten, worden de gevonden resultaten in $\$ 8.4$ in hoofdlijnen samengevat.

\section{3:1 Omvang on samensteiling van de omvang}

Onderstaande tabel 8.4 geeft de resultaten van de omvang en de samenstelling van hel sociale netwerk, c.q. de verdeling van de beschikbare netwerkleden over sectoren en clusters van de onderzoekspopulatie $(n=47)$ vergeleken met die van de referentiepersonen.

TABEL 8.4 De omvang en de samenstelling van het sociale netwerk bij de onderzoekspopulatie $(n=47)$ vergeleken met de referentiepersonen.

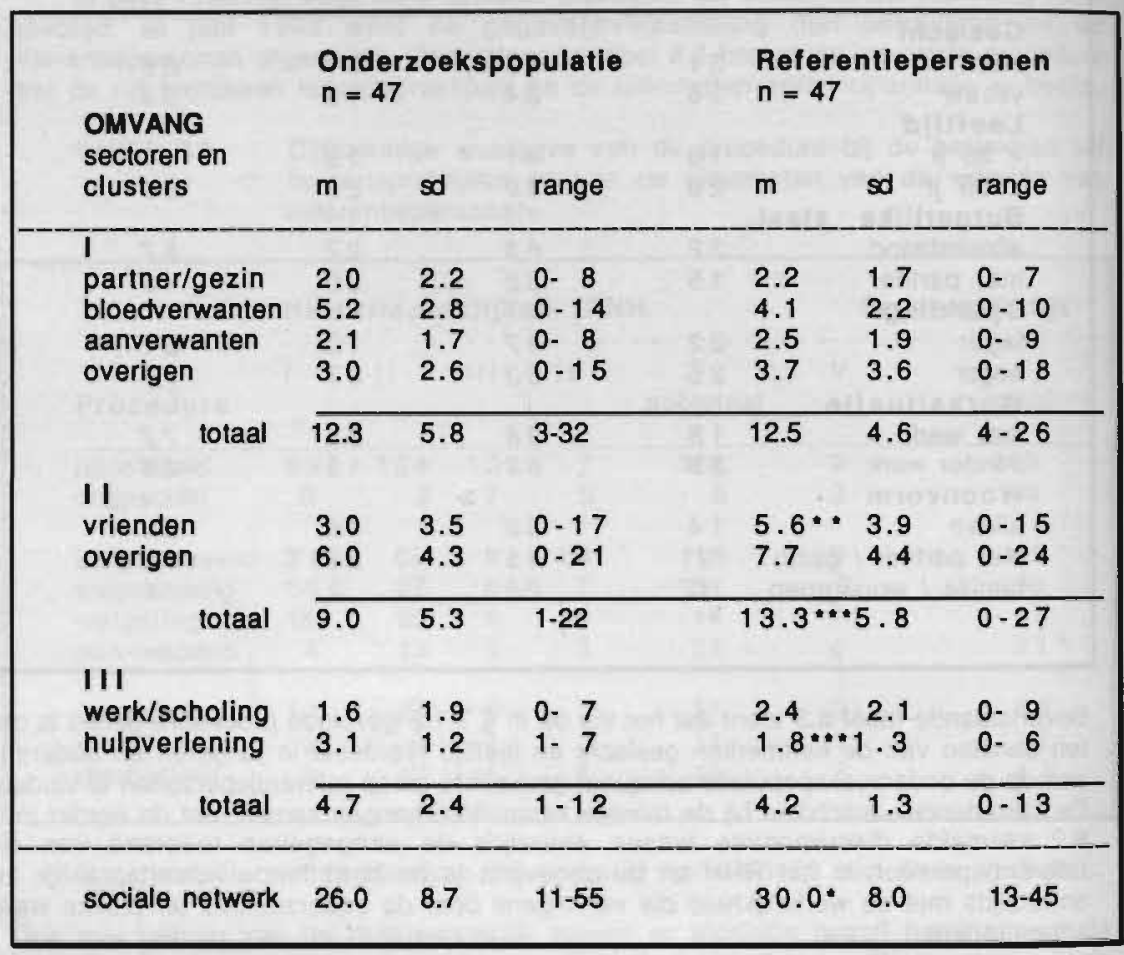

$\# p<.001 ; * p<.01 ; * p<.05$

\section{Ad hypothese 1}

Verondersteld wordt dat de gemiddelde omvang van de sector verwanten bij de ambulante chronisch psychiatrische patiênten en de referentiepersonen gelijk is.

De resultaten gegeven in tabel 8.4 bevestigen deze hypothese. De onderzoekspopulatie heeft gemiddeld 12.3 netwerkleden die tot de sector verwanten gerekend worden. Bij de referentiepersonen is er een gemiddelde omvang van 12.5 verwanten. Er treden vervolgens ook geen significante verschillen op lussen de onderzoekspopulatie en de referenliepersonen wat belrefl de gemiddelde omvang netwerkleden in de onderscheiden clusters binnen de sector verwanten. 


\section{Ad hypothese 2}

Verondersteld wordt dat de omvang van de sector vriendschappelijke betrekkingen bij de onderzoekspopulatie gemiddeld kleiner is dan bij de referentiepersonen

Ook hypothese 2 wordt bevestigd. De omvang van de sector vriendschappelijke betrekkingen blijkt bij de onderzoekspopulatie gemiddeld significant kleiner te zljn dan bij de referentiepersonen. De ambulante chronisch psychiatrische patienten hebben gemiddeld 9.0 netwerkleden in de sector vriendschappelijke betrekkingen tenwijl de referentiepersonen hier gemiddeld 13.3 netwerkleden hebben ( $T=-3.67$, $p<.001)$. Dit verschil komt voort uit het cluster vrienden. De referentiepersonen vermelden gemiddeld 5.6 nelwerkleden in het cluster naaste vrienden terwijl de omvang van het cluster naaste vrienden bij de ambulante chronisch psychiatrische patiënten gemiddeld uit 3.0 netwerkleden bestaat. Dit significante verschil $(T=-$ $3.42, p<.01)$ hangt onder meer samen met hel gegeven dat $15(32 \%)$ ambulante chronisch psychiatrische patiënten aangeven geen vrienden te hebben terwijl er bij de referentiepersonen slechts 3 focale personen (6\%) zijn die geen vrienden vermelden (zie Bijlage VI, 2).

\section{Ad hypothese 3}

Verondersteld wordt dat de omvang van de sector maatschappelijke diensten wat betreft het aandeel hulpverlening bij de onderzoekspopulatie gemiddeld groter is dan bij de referentiepersonen

Tabel 8.4 toont dat de omvang van de sector maatschappelijke diensten wat betreft het aandeel hulpverlening inderdaad gemiddeld significant groter is bij de onderzoekspopulatie dan bij de referentiepersonen (respectievelijk gemiddeld 3.1 en 1.8 netwerkleden; $T=4.57, p<.001$ ). Deze uitkomst houdt in dat hypothese 3 bevestigd wordt. Ter nadere illustratie in onderstaande tabel 8.5 een overzicht van de netwerkleden die de hulpverlening per focale persoon vertegenwoordigen.

TABEL 8.5 Aantal hulpverleners per focale persoon bij de onderzoekspopulatie ( $n=47)$ vergeleken mel de referentiepersonen.

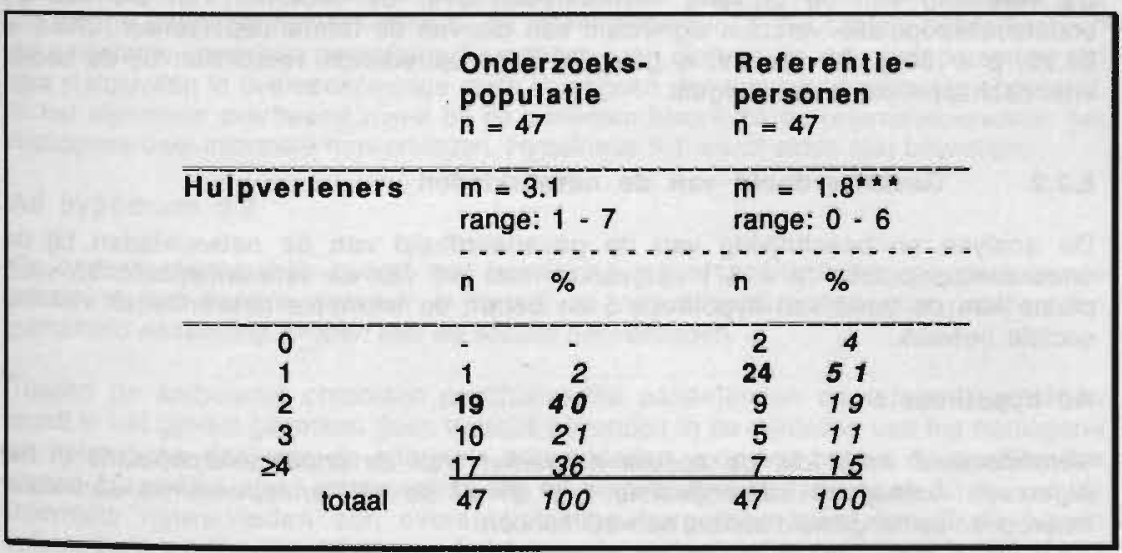


De zojuist gegeven tabel 8.5 laat onder meer zien dat de helft van de referentiepersonen zich beperkt lot éen netwerklid in het cluster hulpverlening. te weten de huisarts. Bij $40 \%$ van de ambulante chronisch psychiatrische patiènten zijn. er twee netwerkleden (de huisarts en een vertegenwoordiger van de SPD van de RIAGG Maastricht) in het cluster hulpverlening. Bij $\mathbf{4 5} \%$ van de referentiepersonen bestaat de omvang van het cluster hulpverlening uit twee of meer netwerkleden, een spreiding die bij de onderzoekspopulatie in $98 \%$ van de gevallen wordt aangetroffen.

\section{Ad hypothese 4}

Conform de hypothese 1 tot en met 3 wordt verondersteld dat de omvang van de sociale netwerken bij de onderzoekspopulatie gemiddeld kleiner is dan bij de referentiepersonen.

Ook hypothese 4 wordt bevestigd. De totale omvang netwerkleden is bij de 47 ambulante chronisch psychiatrische patiěnten gemiddeld significant kleiner dan bij de referentiepersonen. De referentiepersonen geven aan dat de gemiddelde omvang van hun persoonlijke sociale netwerken bestaat uit 30 netwerkleden terwijl die van de patiënten uit gemiddeld 26 netwerkleden bestaat $(T=-2.29, p<.05)$. Het verschil in de totale omvang hangt samen met de optredende verschillen in de sector vriendschappelijke betrekkingen, met name in het cluster naaste vrienden, en vervolgens in het cluster hulpverlening van de sector maatschappelijke diensten.

\section{Tenslotte}

Een tweetal opmerkingen. De eerste betreft de omvang van het informele deel van het sociale netwerk, de sectoren verwanten en vriendschappelijke betrekkingen tesamen. Het informele deel van het sociale netwerk bestaat bij de onderzoekspopulatie gemiddeld uit 21.3 netwerkleden terwijl deze bij de referentiepersonen gemiddeld uit 25.8 netwerkleden bestaat (zie tabel 8.6). Er is sprake van een significant verschil, $(T=-2.75, p<.05)$, dat overwegend samenhangt met het significante verschil dat in de omvang van de sector vriendschappelijke betrekkingen optreedt, (respectievelijk gemiddeld 9.0 en 13.3 netwerkleden; $T=-3.67, p<.001$ ). Aan de hand van het informele deel van het sociale netwerk zijn de resultaten betreffende de gevarieerdheid (zie § 8.3.2.) en de bereikbaarheid (zie \$ 8.3.3.) van de netwerkleden weergegeven.

Een tweede opmerking betreft de verdeling van de omvang over de drie sectoren. De verdeling van de omvang netwerkleden over de sectoren van die van de onderzoekspopulatie verschilt significant van die van de referentiepersonen (Chisq. = 26.22, $p<.001$ ). Dit verschil is gelegen in de optredende verschillen bij de sector vriendschappelijke betrekkingen.

\subsubsection{Gevarieerdheid van de netwerkleden}

De analyse en beschrijving van de gevarieerdheid van de netwerkleden bij de onderzoekspopulatie $(n=47)$ vergeleken met die van de referentiepersonen vindt plaats aan de hand van hypothese 5 en betreft de informele netwerkleden van het sociale netwerk.

\section{Ad hypothese 5}

Verondersteld word dat de sociale netwerken van de onderzoekspopulatie in het algemeen homogeen samengesteld zijn terwijl de referentiepersonen een meer heterogeen samengesteld sociaal nelwerk hebben.

Allereerst ter informatie vooraf een verduidelijking van de begrippen 'homogeen' en 'heterogeen'. Er is sprake van een homogeniteit in een sociaal netwerk wanneer informele netwerkleden qua kenmerken van gevarieerdheid zoals beschreven in het 
sociaal demografisch profiel aansluiten op die van de onderzoekspopulatie. Er is sprake van heterogeniteil wanneer de informele netwerken qua kenmerken van gevarieerdheid verschillen van de kenmerken van de onderzoekspopulatie zoals beschreven in het sociaal demografisch profiel. Ter illustratie het kenmerk 'burgerlijke staat'. Het homogene deel in de sociale netwerken van de onderzoekspopulatie bestaat uit die informele netwerkleden die met de onderzoekspopulatie overeenkomen inzake de aanwezigheid of de afwezigheid van een partner. Het heterogene deel bestaat uit die informele netwerkleden die qua aanwezigheid of afwezigheid van een partner verschillen mel de onderzoekspopulatie.

Bij hypothese 5 worden twee deelhypothesen onderscheiden: hypothese 5.1 betreft de slatusrollen inzake geslacht en leeftijd terwijl hypothese 5.2 betrekking heeft op de positierollen inzake burgerlijke staat, opleiding, werk- en woonsituatie. In deze paragraaf wordt een beschrijving gegeven van de uitkomsten. In Bijlage VII,1 vindt men de gegevens meer gedelailleerd weergegeven.

\section{Ad hypothese 5.1}

De onderzoekspopulatie heeft qua statusrollen een overeenkomstig samengesteld sociaal netwerk terwijl de referentiepersonen op dit punt een meer heterogeen samengesteld sociaal netwerk hebben.

Wat betreft het geslacht van de informele netwerkleden is er bij de ambulante chronisch psychiatrische patienten vergeleken met de referentiepersonen geen significant verschil in de verdeling van het homogene en heterogene deel informele netwerkleden. Het homogene deel omvat bij de onderzoekspopulatie $54 \%$ en bij de referentiepersonen $57 \%$ van de informele netwerkleden; het heterogene deel omvat respectievelijk $46 \%$ en $43 \%$ van de informele netwerkleden. Ook op het niveau van de sector verwanten en de sector vriendschappelijke betrekkingen Ireden hieromtrent geen significante verschillen op.

Eveneens is er qua leeftijd van de informele nelwerkleden bij de onderzoekspopulatie vergeleken met de referentiepersonen geen significant verschil in de verdeling van het homogene (respectievelijk $66 \%$ on $67 \%$ ) en het heterogene (respectievelijk $34 \%$ en $33 \%$ ) deel van de informele netwerkleden. In de sector verwanten en de sector vriendschappelijke betrekkingen treden hieromtrent wederom geen significante verschillen op.

Dit betekent dat de gevarieerdheid van de informele netwerkleden voor wat betreft de statusrollen bij de ambulante chronisch psychiatrische patienten overeenkomt met die van de informele netwerkleden bij de referentiepersonen. De sociale netwerken van de ambulante chronisch psychiatrische patiënten en die van de referentiepersonen zijn qua statusrollen in overeenkomstige mate homogeen dan wel heterogeen samengesteld. In het algemeen overheerst zowel bij de patiënten alsook bij de referentiepersonen het homogene deel informele netwerkleden. Hypothese 5.1 wordt aldus niet bevestigd.

\section{Ad hypothese $\mathbf{5 . 2}$}

De onderzoekspopulatie neemt met betrekking tot de positierollen een geisoleerde plaats in het sociale netwerk in terwijl de referentiepersonen qua positierollen gemiddeld aansluiting hebben met de sociale netwerkleden.

Tussen de ambulante chronisch psychiatrische patienten en de referentiepersonen wordt in het geheel genomen geen verschil gevonden in de verdeling van het homogene en heterogene deel van de informele netwerkleden voor wat betreft de positierollen inzake burgerlijke staat en opleiding. Bij de onderzoekspopulatie heeft $53 \%$ van de informele netwerkleden een overeenkomstige burgerlijke staat terwijl dit bij de referentiepersonen voor $57 \%$ van het informele nefwerkleden het geval is. Bij zowel de onderzoekspopulatie als bij de referentiepersonen sluit $73 \%$ van de informele netwerkleden aan bij hun opleiding. Op het niveau van de sectoren wordt alleen in de sector verwanten een significant verschil gevonden in de verdeling van het homogene 
en helerogene deel voor wat betreft de positierollen inzake burgerlijke staat. Bij de patienten bestaat het homogene en helerogene deel respectievelijk uit $49 \%$ en $51 \%$ van de verwanten terwijl dat bij de referentiepersonen respectievelijk uit $56 \%$ en $44 \%$ van de verwanten bestaat (Chisq. $3.85, p<.05$ ).

Significante verschillen treden echter in het geheel genomen op als het gaat om posilierollen inzake werk- en woonsituatie. Tussen de ambulante chronisch psychiatrische patiënten en de referentiepersonen treedt er in het geheel genomen een significant verschil op in de verdeling van het homogene (respectievelijk $53 \%$ en 66 $\%$ ) en helerogene (respectievelijk $47 \%$ en $34 \%$ ) deel informele netwerkleden inzake de werksituatie (Chisq. 27.68, $p<.001$ ). Een dergelijk significant verschil wordt hieromtrent ook aangetroffen op het niveau van de sector verwanten en de sector vriendschappelijke betrekkingen. In het geheel genomen is er tussen de patiēnten en de referentiepersonen een significant verschil in de verdeling van het homogene en heterogene deel informele netwerkleden voor wat betreft de woonsituatie (het homogene deel is respectievelijk $49 \%$ en $58 \%$; het helerogene deel bestaat respectievelijk uit $51 \%$ en $42 \%$ van de informele netwerkleden; Chisq. $11.97, p<$ $.001)$. Op het nievau van de sectoren is een dergelijk significant verschil alleen te vinden in de sector verwanten.

Hypothese $\mathbf{5 . 2}$ wordi voor wat betreft hel geheel van de informele netwerkleden alleen bevestigd inzake werk- en woonsituatie. Het komt er op neer dat vergeleken met de referentiepersonen een significant kleiner deel van de informele netwerkleden bij de onderzoekspopulatie aansluit op de werk- en woonsituatie. Vergeleken met de referentiepersonen nemen de ambulante chronisch psychiatrische patiènten voor wat betreft hun werk- en woonsituatie een meer geïsoleerde plaats in ten opzichte van hun informele netwerkleden.

Samenvattend kan gesteld worden dat bovenstaande resultaten niel aantonen dat de sociale netwerken van de onderzoekspopulatie in tegenstelling tot ${ }^{\prime}$ die van de referentiepersonen overwegend homogeen zijn samengesteld. Dit betekent dat hypothese 5 niet bevestigd wordt. Met betrekking tol hel geslacht, de leeftijd, de burgerlijke staat en het opleidingsniveau van de informele netwerkleden zijn de sociale netwerken van de ambulante chronisch psychiatrische patiënten in het geheel genomen in dezelide mate homogeen dan wel heterogeen samengesteld als die van de referentiepersonen. Het homogene deel bestaat bovendien in het algemeen uit meer dan $51 \%$ van de informele netwerkleden. Met betrekking tot de werk- en woonsituatie komt naar voren dat in het geheel genomen de sociale netwerken van de ambulante chronisch psychiatrische patiënten significant minder homogeen zijn samengesteld dan het geval is bij de referentiepersonen.

\subsubsection{Bereikbaarheid van de netwerkleden}

De analyse en beschrijving van de bereikbaarheid van de netwerkleden aan de hand van hypothese 6 betreft eveneens de informele netwerkleden. De bereikbaarheid wordt onderzocht in termen van geografische afstand, waarbij de focale persoon (patiënt dan wel referentiepersoon) gevraagd wordt naar de huidige woon- of verblijisplaats van zijn informele netwerkleden. Indien de focale persoon deze informatie weet te geven worden de betrelfende netwerkleden als bereikbaar beschouwd. Het komt voor dat een focale persoon niet weet waar een bepaald netwerklid woont (bijvoorbeeld: 'ik ben m'n vader al een paar jaar uit het oog verloren, ik weet niet waar hij tegenwoordig is') of niet voldoende nauwkeurig van diens actuele woon- of verblijfsplaats op de hoogte is (bijvoorbeeld: 'voor zover ik weet, woont mijn zus ergens in Brabant'). In deze en dergelijke gevallen ontbreekt adequate informatie over de bereikbaarheid.

In de volgende tabel 8.6 zijn de gegevens over de bereikbaarheid van de informele netwerkleden van de onderzoekspopulatie $(n=47)$ vergeleken met die van de referentiepersonen. 
TABEL 8.6 De bereikbaarheid van de informele netwerkleden van de onderzoekspopulatie $(n=47)$ vergeleken met die van de referentiepersonen.

\begin{tabular}{|c|c|c|c|c|}
\hline \multirow{2}{*}{ AFSTAND } & \multicolumn{2}{|c|}{$\begin{array}{l}\text { Onderzoekspopulatie } \\
n=47\end{array}$} & \multicolumn{2}{|c|}{$\begin{array}{l}\text { Referentlepersonen } \\
n=47\end{array}$} \\
\hline & $\mathrm{m}$ & sd & $\mathrm{m}$ & $s d$ \\
\hline $\begin{array}{l}\text { eigen woonplaats } \\
\text { zelfde regio } \\
\text { buiten regio } \\
\text { buitenland }\end{array}$ & $\begin{array}{l}8.2 \\
2.6 \\
3.6 \\
0.9\end{array}$ & $\begin{array}{l}4.3 \\
5.3 \\
4.4 \\
1.6\end{array}$ & $\begin{array}{l}13.1 \cdots \\
4.5 \\
5.6 \\
1.4\end{array}$ & $\begin{array}{l}6.7 \\
4.0 \\
5.7 \\
2.3\end{array}$ \\
\hline $\begin{array}{l}\text { bekend } \\
\text { geen informatie }\end{array}$ & $\begin{array}{r}15.3 \\
6.0\end{array}$ & $\begin{array}{l}7.1 \\
5.5\end{array}$ & $\begin{array}{r}24.6 \cdots \cdots \\
1.2 * \cdots\end{array}$ & $\begin{array}{l}7.5 \\
2.9\end{array}$ \\
\hline $\begin{array}{l}\text { Informele } \\
\text { netwerkleden }\end{array}$ & 21.3 & 8.1 & $25.8^{*}$ & 7.8 \\
\hline
\end{tabular}

$* p<.001 ; * p<.05$

\section{Ad hypothese 6}

Verondersteld is dat er geen verschillen optreden in de bereikbaarheid van de informele netwerkleden tussen de onderzoekspopulatie en de referentiepersonen.

Tabel 8.6 laat met betrekking tot deze hypothese de volgende uitkomsten zien.

- De onderzoekspopulatie is in staat over gemiddeld 15.3 informele netwerkleden inzake de woon- of verblijfsplaats adequate informatie te verstrekken die aldus als rechtstreeks bereikbaar beschouwd kunnen worden.

Bij de referentiepersonen zijn dit gemiddeld 24.6 informele netwerkleden. Het verschil dat optreedt is significant: $T=-6.15, p<.001$.

- Van de gemiddelde 15.3 bereikbare informele netwerkleden bij de onderzoekspopulatie wonen gemiddeld 8.2 netwerkleden in de eigen woonplaats van de focale persoon terwijl dit er bij de referentiepersonen gemiddeld 13.1 informele netwerkleden zijn. Hier treedt eveneens een significant verschil op: $T=$ $-4.18, p<.001$.

- Bij de overige variabelen betreffende afstand treden geen significante verschillen op in het gemiddeld aantal bereikbare informele netwerkleden van de onderzoekspopulatie vergeleken mel die van de referentiepersonen.

- Bij de onderzoekspopulatie kan gemiddeld over 6.0 informele netwerkleden geen adequate informatie verstrekt worden over de vaste woon- dan wel verblijfsplaats terwijl dit bij de referentiepersonen gemiddeld bij 1.2 informele netwerkleden het geval is; het verschil is significant: $T=5.23, p<.001$.

Al met al kan gesteld worden dat er een aantal significante verschillen optreden in de bereikbaarheid van de informele netwerkleden van de ambulante chronisch psychiatrische patiënten vergeleken met die van de referentiepersonen. Hypothese 6 kan derhalve niet als bevestigd worden beschouwd. 
Ten aanzien van de informele netwerkleden bij wie over de bereikbaarheid geen. adequate informatie gegeven wordt kan de volgende vraag gesteld worden: tot welke clusters in de sectoren verwanten en vriendschappelijke betrekkingen behoren deze informele netwerkleden van de patiënten in vergelijking met de referentiepersonen? De uitkomsten van een nadere analyse zijn gegeven in de onderstaande tabel 8.7

TABEL 8.7 De informele netwerkleden verdeeld over clusters bij wie over de bereikbaarheid adequate informatie ontbreekt.

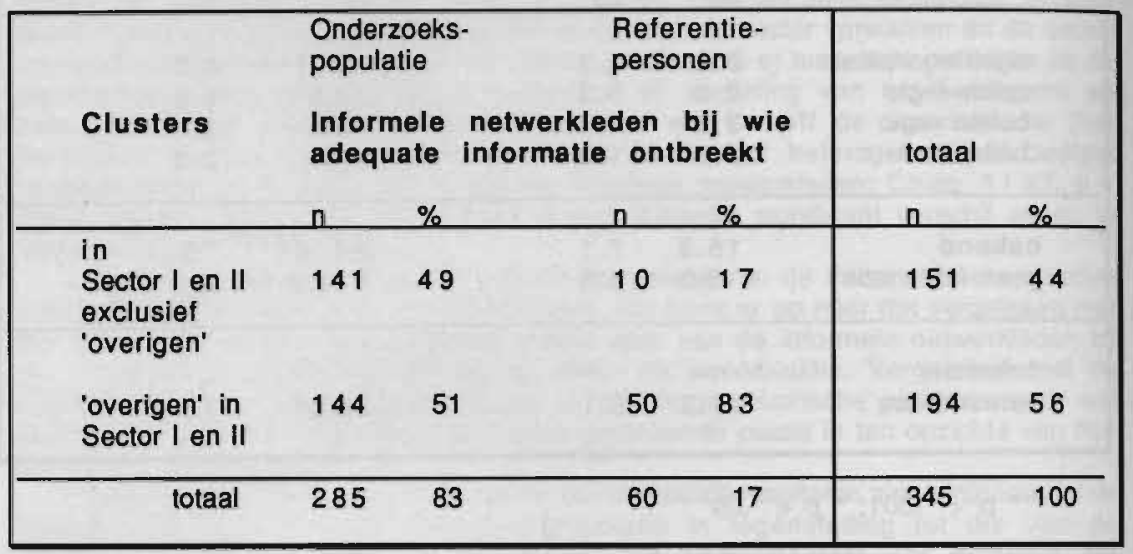

Chisq. $=21.6 ; \mathrm{p}<.001$.

Tabel 8.7 laat omtrent de informele netwerkleden bij wie adequate informatie over de bereikbaarheid ontbreekt de volgende uitkomsten zien.

- Van het totaal aantal informele netwerkleden over wie geen adequate informatie gegeven kan worden is $83 \%$ ( $n=285$ ) afkomstig van de patiënten en $17 \%$ ( $n=$ 60) afkomstig van de referentiepersonen.

- Bij de patiènten zijn de betreffende informele netwerkleden in ongeveer gelijke mate verdeeld over enerzijds de clusters overige (verre) verwanten en overige vriendschappelijke betrekkingen $(n=144,51 \%)$ en anderzijds over de resterende clusters verwanten en het cluster naaste vrienden ( $n=141,49 \%$ ).

- Bij de referentiepersonen daarentegen valt $83 \%$ van deze informele netwerkleden onder de clusters 'overigen' in de sectoren verwanten en vriendschappelijke betrekkingen.

- Met andere woorden:

er is een significant verschil tussen de onderzoekspopulatie en de referentiepersonen omtrent de verdeling van de betreffende informele netwerkleden over de in tabel 8.7 onderscheiden clusters netwerkleden.

\section{Tenslotte}

Een opmerking nog inzake de verdeling van de bereikbaarheid van de informele netwerkleden. Er blijkt een significant verschil op te treden tussen de onderzoekspopulatie en de referentiepersonen in de verdeling van de bereikbaarheid van de informele netwerkleden (Chisq. 230.92, p $<.001$ ). Dit verschil is met name toe te schrijven aan de verschillen die optreden ten aanzien van de informele netwerkleden over wie geen adequate informatie inzake de bereikbaarheid wordt gegeven. 
Met de weergave van de resultaten inzake de gevarieerdheid en de bereikbaarheid van de netwerkleden is wat betreft vraagstelling I de analyse en beschrijving van de structuur die door personen ten opzichte van de focale persoon in sociale netwerken wordt ingebracht afgerond. In de volgende $\$$ 8.3.4 wordt overgegaan tot de weergave van de resultaten omtrent de structuur van de betrekkingen tussen de focale personen en hun netwerkleden (Wellman, Berkowitz, 1988). De analyse en beschrijving van de gevarieerdheid en de bereikbaarheid betrof het deel van de informele netwerkleden in de omvang van een sociaal netwerk.

In de volgende $\S 8.3 .4$ worden de resultaten betreffende de structuur van de betrekkingen tussen de netwerkleden en de focale personen weergegeven. De analyse en beschrijving van de strucuur van de betrekkingen betreft de informele en formele netwerkleden tesamen. Ter herinnering: de onderzoekspopulatie $(n=47)$ heeft gemiddeld 26 netwerkleden helgeen significant verschilt met de referentiepersonen die gemiddeld 30 netwerkleden hebben $(T=-2.29, p<.05)$.

\subsubsection{Structuur van de betrekkingen}

De structuur van de betrekkingen tussen de focale personen (te weten de ambulante chronisch psychiatrische patiěnten en de referentiepersonen) en hun netwerkleden wordt geanalyseerd en beschreven aan de hand van de hypothesen 7 tot en met 15 (zie $\$$ 6.2.1). Achtereenvolgens worden de resultaten betreffende de volgende elementen van de structuur van de betrekkingen gepresenteerd.

- Het initiatief in het contact tussen de focale personen en de netwerkleden.

- De frequentie van het contact tussen de focale personen en de netwerkleden.

- Het gewicht dat door de focale personen aan het contact met de netwerkleden wordt gegeven betreffende de compartimenten

= affectieve behoeften,

= behoefte aan aansluiting.

= behoefte aan materièle en instrumentele middelen,

= behoefte aan stabiliteit.

- De lengte van het contact tussen de focale personen en de netwerkleden.

\section{INITIATIEF}

De weergave van de bevindingen inzake de structuur van de betrekkingen vangt aan met de resultaten betreffende het initiatief in het contact en betreft de toetsing van de hypothesen 7 tot en met $10(\$ 6.2 .1)$. De volgende tabel 8.8 toont op welke wijze bij de onderzoekspopulatie vergeleken met de referentiepersonen het initiatief in het contact met de netwerkleden gemiddeld tot stand komt.

\section{Ad hypothese 7}

Verondersteld wordt dat bij de onderzoekspopulatie de contacten met de netwerkleden in de sector verwanten overwegend tot stand komen via initiatief in de zin van vanzelfsprekend tenwijl er bij de referentiepersonen sprake is van wederzijds initiatief.

De resultaten in tabel 8.8 tonen dat bij de ambulante chronisch psychiatrische patiënten de contacten met hun verwanten niet overwegend tot stand komen via initiatief in de zin van gewoonte of als vanzelisprekend. Het gemiddeld aantal verwanten mel wie de patienten contact hebben op basis van initiatief in de zin van gewoonte verschilt niel wezenlijk van bijvoorbeeld het gemiddeld aantal verwanten bij wie het initiatief in het contact uilgaat van de patiënt zelf of hel gemiddeld aanlal verwanten bij wie het initialief in hel contact uitgaal van één van deze verwanten. Hel eerste deel van hypothese 7 wordt niet bevestigd.

Vervolgens laat tabel $\mathbf{8 . 8}$ wel zien dat er bij de patienten vergeleken met de referentiepersonen bij gemiddeld significant minder verwanten het contact tot stand 
komt via wederzijds initiatief $(T=-3.04, p<.01)$. Echter de strekking van het tweede deel van hypothese wordt hiermee niet bevestigd.

Overigens toont tabel $\mathbf{8 . 8}$ dat de patiënten naar gemiddeld significant minder verwanten zelf het initiatief in het contact met hun verwanten nemen dan de referentiepersonen ( $T=-2.47, p<.05$ ). Tenslotte laat tabel 8.8 zien dat de onderzoekspopulatie vergeleken mel de referentiepersonen gemiddeld significant meer verwanten heoft met wie uitdrukkelijk geen initiatief tot contact bestaat (respectievelijk gemiddeld 2.2 en 0.5 verwanten, $T=3.05, p<.01$ ).

TABEL 8.8 Het initiatief in het contact met de netwerkleden bij de onderzoekspoplatie vergeleken mel de referentiepersonen.

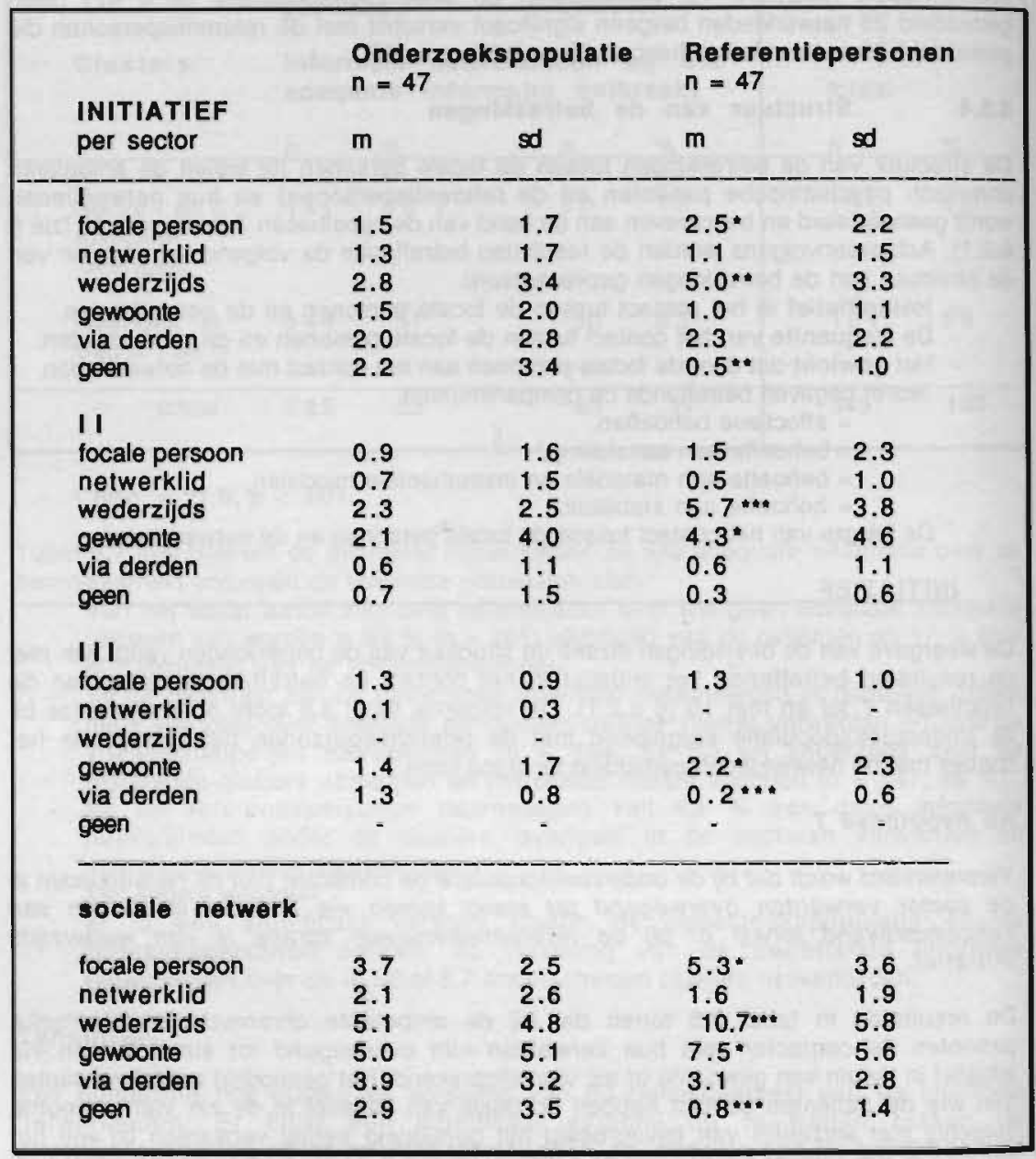

** $p<.001 ; * *<.01 ; * p<.05$ 


\section{Ad hypothese 8}

Verondersteld wordt dat de onderzoekspopulatie in de contacten met netwerkleden in de sector vriendschappelijke betrekkingen nauwelijks eigen initiatief toont, dit in legenstelling tot de referentiepersonen bij wie er bovendien sprake is van wederijds initiatiof.

Het deel van de netwerkleden in de sector vriendschappelijke betrekkingen bij wie de onderzoekspopulatie zelf initiatief tot contact neemt komt gemiddeld overeen met de referentiepersonen. Het komt er op neer dat de onderzochte ambulante chronisch psychiatrische patiönten en de referentiepersonen met gemiddeld evenveel netwerkleden in deze sector zelf het initiatief tot contact nemen. Het eerste deel van hypohese 8 wordt aldus niet bevestigd.

Echter de onderzoekspopulatie heeft vergeleken met de referentiepersonen gemiddeld significant minder netwerkleden in deze sector bij wie sprake is van wederzijds initiatief tot contact (respectievelijk gemiddeld 2.3. en 5.7 netwerkleden, $T=-4.97, p<.001$ ). Het tweede deel van hypothese 8 wordt aldus wel bevestigd.

Een ander optredend significant verschil inzake het inititatief tot contact met de netwerkleden in de sector vriendschappelijke betrekkingen is dat de onderzoekspopulatie vergeleken met de referentiepersonen gemiddeld significant minder netwerkleden in de sector vriendschappelijke betrekkingen heeft met wie contact bestaat op basis van gewoonte (respectievelijk gemiddeld 2.1 en 4.3 netwerkleden, $\mathrm{T}=-2.47 . \mathrm{p}<.05$ ).

\section{Ad hypothese 9}

Verondersteld wordt dat het contact met de netwerkleden in de sector maatschappelijke diensten bij de onderzoekspopulatie ovenwegend tot stand komt via initiatief van derden terwijl bij de referentiepersonen hier het eigen initiatief overheerst.

Tabel 8.8 toont dat de strekking van hypothese 9 niet bevestigd wordt ondanks het gegeven dat de onderzoeksopulatie vergeleken met de referentiepersonen gemiddeld significant meer netwerkleden in de sector maatschappelijke diensten hebben met wie het contact tot stand komt via het initiatief van derden. (respectievelijk gemiddeld 1.3 en 0.2 netwerkleden, $T=6.72, p<.001$ ). Daarnaast is or qua eigen initiatief tot contact geen verschil tussen de onderzoekspopulatie en de referentiepersonen.

Overigens toont tabel 8.9 met betrekking tot het initiatief in het contact met netwerkleden in de sector maatschappelijke diensten nog de volgende opmerkelijke uitkomsten.

- De onderzoekspopulatie heeft in deze sector nauwelijks netwerkleden bij wie het contact hooldzakelijk gebaseerd is op het initiatief van netwerkleden zelf. Bij de referentiepersonen zijn er in het geheel geen netwerkleden in deze sector die zelf het initiatief in het contact met de focale persoon nemen.

- Zowel de patiënten alsook de referentiepersonen hebben geen netwerkleden in deze sector mel wie het contact uitgaal van wederzijds initiatief.

\section{Ad hypothese 10}

Verondersteld word dat in het geheel genomen bij de onderzoekspopulatie hel lot stand komen van het contact met de netwerkleden minder gebaseerd is op eigen en wederijds initiatief dan bij de referentiepersonen het geval is.

Tabel 8.8 toont dat hypothese 10 bevestigd wordt. In het geheel genomen heeft de onderzoekspopulatie gemiddeld significant minder netwerkleden bij wie de contacten tol stand komen op basis van eigen intiatief dan bij de referentiepersonen het geval is (respectievelijk gemiddeld 3.7 en 5.3 netwerkleden, $T=-2.49, p<.05$ ). 
Eveneens heeft de onderzoekspopulatie vergeleken met de referentiepersonen gemiddeld significant minder netwerkleden met wie de contacten op basis van wederzijds initiatief tot stand komen (respectievelijk gemiddeld 5.1 en 10.7 netwerkleden, $T=$ $4.93, p<.001$ ).

Vervolgens toont tabel 8.8 dat in het geheel genomen de onderzoekspopulatio gemiddeld significant minder netwerkleden heeft met wie het contact via initiatief in de zin van gewoonte contact ontstaat dan het geval is bij de referentiepersonen (respectievelijk gemiddeld 5.0 en 7.5 netwerkleden, $T=-2.31, p<.05$ ). Bovenstaande tabel laat tevens zien dat in hel geheel genomen de onderzoekspopulatie vergeleken met de referentiepersonen gemiddeld significant meer netwerkleden hebben met wie enig initiatief in het contact ontbreekt (respectievelijk gemiddeld 2.9 en 0.8 netwerkleden, $T=3.66, \mathrm{p}<.001$

Tenslotte zijn er nog een aantal netwerkleden bij wie de focale personen niet in staat waren adequate informatie te geven over het initiatief. Het komt er op neer dat de ambulante chronisch psychiatrische patiënten vergeleken met de referentiepersonen in het geheel genomen gemiddeld significant meer netwerkleden hebben bij wie geen adequate informatie over het initiatief gegeven wordt (respectievelijk gemiddeld 3.3 en 1.0 netwerkleden, $T=, p<.001$ ). Deze netwerkleden bevinden zich in de sectoren verwanten en vriendschappelijke betrekkingen.

\section{Tenslotte}

Ten aanzien van de verdeling van het initiatief van de netwerkleden over het gehele sociale netwerk blijtk dat er een significant verschil optreedt tussen de onderzoekspopulatie en de referentiepersonen (Chisq. 150.35, $p<.001$ ).

\section{EREQUENTIE}

Het tweede kenmerk van de structuur van de betrekkingen betreft de frequentie in het contact tussen de focale personen (de onderzoekspopulatie en de referentiepersonen) en hun netwerkleden. Bij de weergave van de resultaten aan de hand van de hypothesen 11 tot en met $13(\$ 6.2 .1)$ is de volgende indeling aangehouden.

- Minimaal $1 x$ per twee weken; hieronder valt een frequentie in het contact die varieert van nagenoeg dagelijks tot minimaal eenmaal per twee weken.

- Minimaal $1 \times$ per kwartaal; hieronder valt een frquentie in het contact die varieert van eenmaal per twee weken tot minimaal eenmaal per drie maanden.

- Minimaal $1 x$ per jaar; hieronder valt een frequentie in het contact die varieert van minimaal eenmaal per vier maanden tot minmaal eenmaal per jaar.

Tenslotte vindt men in de tabellen betreffende de frequentie van het contact de categorie 'geen informatie'. Dit wil zeggen dat adequate informatie ontbreekt.

\section{Ad hypothese 11}

Verondersteld wordt dat er tussen de onderzoekspopulatie en de referentiepersonen gemiddeld geen verschil in de frequentie van de contacten met venwanten bestaat.

In onderstaande tabel 8.9.a worden de resultaten gegeven van de frequentie in de contacten die de ambulante chronisch psychiatrische patienten vergeleken met de referentiepersonen gemiddeld met de verwanten hebben. 
TABEL 8.9.a Frequentie van de contacten mel de netwerkleden in de sector verwanten.

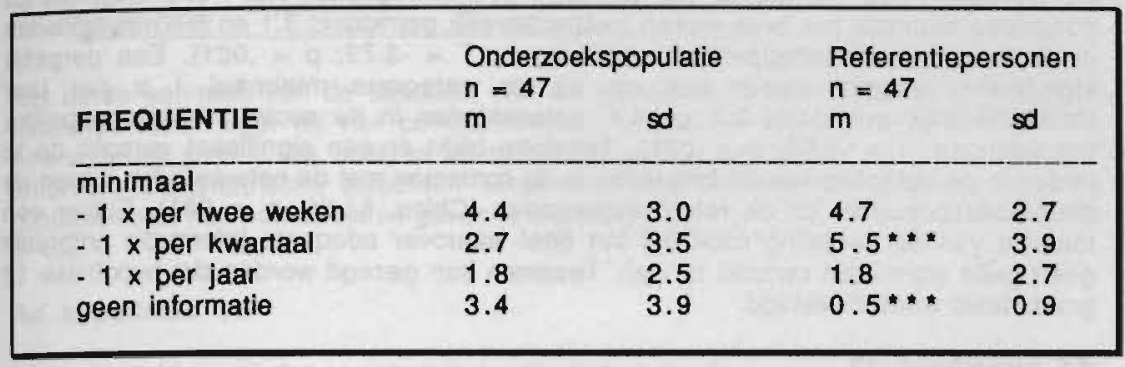

$* * p<.001$

Tabel 8.9.a toont dat er tussen de onderzoekspopulatie en de referentiepersonen gemiddeld geen verschil bestaat ten aanzien van het deel van de verwanten met wie contact wordt onderhouden met een frequentie van vrijwel dagelijks tot hoogstens eenmaal per week. Hetzelfde geldt voor het deel verwanten met wie hoogstens eenmaal per vier maanden tot minimaal eenmaal per jaar contact bestaat. Tot zover kan hypothese 11 als bevestigd worden beschouwd.

Echter tussen de onderzoekspopulatie en de referentiepersonen blijkt er gemiddeld een significant verschil te bestaan ten aanzien van het deel verwanten met wie minimaal eenmaal per twee weken tot hoogstens eenmaal per drie maanden contact is (respectievelijk gemiddeld 2.7 en 5.5 verwanten $(T=-3.64, p<.001$ ). Vervolgens blijkt de onderzoekspopulatie bij gemiddeld 3.4 verwanten niet in staat te zijn adequate informatie te geven over de frequentie van het contact terwijl dat bij de referentiepersonen voor gemiddeld 0.5 verwanten geldt; dit verschil is significant: $T=$ $4.81, p<.001)$. Tenslotte, er treedt een significant verschil op tussen de onderzoekspopulatie en de referentiepersonen in de verdeling van de frequentie van het contact met de verwanten (Chisq. 143.94, $p<.001$ ). Al bij al komt het er op neer dat hypothese 11 gedeeltelijk wordt bevestigd.

\section{Ad hypothese 12}

Verondersteld wordt dat de onderzoekspopulatie aanzienlijk minder frequent contact heeft met netwerkleden in de sector vriendschappelijke betrekkingen dan de referentiepersonen.

TABEL 8.9.b Frequentie van de contacten met netwerkleden in de sector vriendschappelijke betrekkingen.

\begin{tabular}{|c|c|c|c|c|}
\hline FREQUENTIE & \multicolumn{2}{|c|}{$\begin{array}{l}\text { Onderzoekspopulatie } \\
n=47\end{array}$} & \multicolumn{2}{|c|}{$\begin{array}{l}\text { Referentiepersonen } \\
n=47\end{array}$} \\
\hline \multicolumn{5}{|l|}{ minimaal } \\
\hline - $1 x$ per twee weken & 3.1 & 2.7 & $6.0 * *$ & 4.4 \\
\hline - 1x per kwartaal & 2.1 & 2.5 & $4.4^{* * *}$ & 3.6 \\
\hline - 1x per jaar & 0.5 & 1.1 & 0.8 & 1.4 \\
\hline geen informatie & 3.3 & 4.1 & 2.1 & 2.9 \\
\hline
\end{tabular}

*t $p<.001$ 
Tabel 8.9.b toont dat de onderzoekspopulatio vergeleken met de referentiepersonen gemiddeld significant minder netwerkleden in de sector vriendschappelijke betrekkingen heeft met wie contact bestaat met een frequentie van vrijwel dagelijks tot hoogstens eenmaal per twee weken (respectievelijk gemiddeld 3.1 en 6.0 netwerkleden in de sector vriendschappelijke betrekkingen, $T=-3.72, p<.001$ ). Een dergelijk significant verschil treedt ook op bij de categorie minimaal $1 \times$ per jaar (respectievelijk gemiddeld 2.1 en 4.4. netwerkleden in de sector vriendschappelijke betrekkingen, $T=-3.65, p<.001$ ). Tenslotte blijkt er een significant verschil op te treden in de verdeling van de frequentie in de contacten met de netwerkleden tussen de onderzoekspopulatie en de referentiepersonen (Chisq. 61.36, $\mathrm{p}<.001$ ). Echter een toetsing van de verdeling exclusief het deel waarover adequate informatie ontbreekt geeft geen significant verschil te zien. Tesamen kan gezegd worden dat hypothese 12 grotendeels wordt bevestigd.

\section{Ad hypothese 13}

Verondersteld wordt dat in tegenstelling met de referentiepersonen de onderzoekspopulatie een frequent contact onderhoudt met netwerkleden in het cluster hulpverlening.

De onderzoekspopulatie heeft gemiddeld 3.1 netwerkleden in het cluster hulpverlening terwijl de referentiepersonen hier gemiddeld 1.8 netwerkleden hebben. Dit verschil is significant: $T=4.57, \mathrm{p}<.001$ (zie tabel 8.4 ).

TABEL 8.9.c Aantal hulpverleners met wie de onderzoekspopulatie vergeleken met de referentiepersonen minimaal eenmaal per week contact heeft.

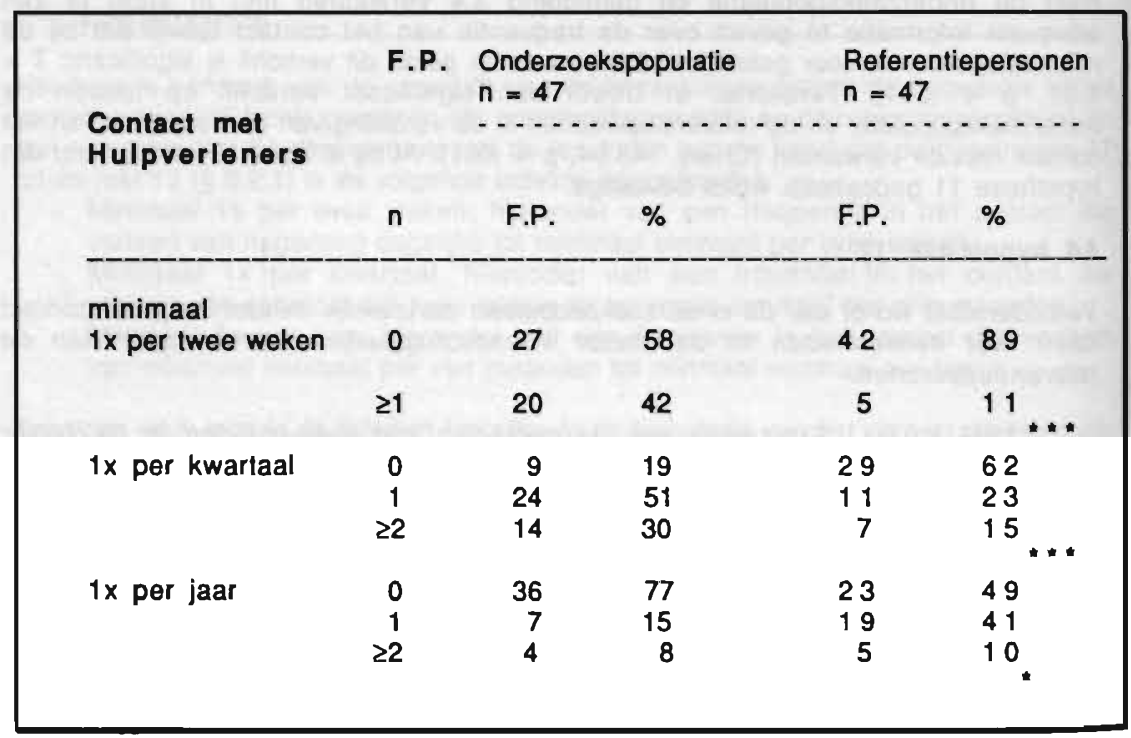

$$
\# p<.001, p<.05
$$

Tabel $8.9 \mathrm{c}$ toont dat hypothese 13 bevestigd wordt. Zo blijkt er tussen de patiënten en de referentiepersonen een significant verschil op te treden in de verdeling van hel aantal hulpverleners waarmee minimaal eenmaal per twee weken contact is (Chisq. 12.26, $p<.001$ ). Een dergelijk significant verschil (Chisq. 17.68, $p<.001$ ) treedt 
ook op bij de contacten met hulpverleners die minimaal eenmaal per kwartaal plaatsvinden.

\section{GEWICHT}

Het derde kenmerk van de structuur van de betrekkingen betreft hel gewicht dat de focale personen voor de vier compartimenten behoeften aan de contacten mel hun netwerkleden geven. De analyse en beschrijving van het gewicht dat de ambulante chronisch psychiatrische patiënten vergeleken met de referentiepersonen aan de contacten met hun netwerkleden geven is uitgevoerd aan de hand van hypothese 14 (zie $\S 6.2 .1)$

\section{Ad hypothese 14}

Verondersteld wordi dat er verschillen optreden in het toekennen van het gewicht aan de netwerkleden tussen de onderzoekspopulatie en de referentiepersonen. De richting van de verschillen valt niet te voorspellen.

De volgende tabel 8.10 betreft het gewicht dat de onderzoekspopulatie vergeleken met de referentiepersonen per compartiment behoeften gemiddeld aan de contacten met hun netwerkleden geeft.

TABEL 8.10 Het gewicht van de contacten met de netwerkleden bij de onderzoekspopulatie vergeleken met de referentiepersonen.

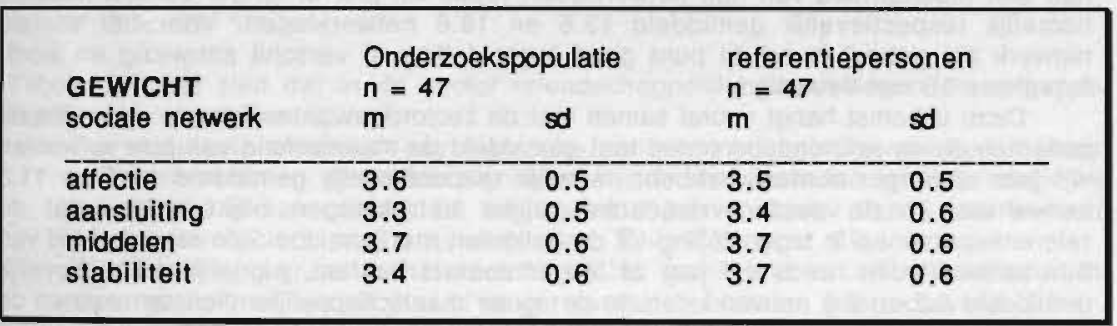

Tabel 8.10 toont dat er in het geheel van het sociale netwerk genomen tussen de onderzoekspopulatie en de referentiepersonen gemiddeld geen verschillen optreden in het toekennen van het gewicht aan hel contact met hun netwerkleden. De patiënten en de referentiepersonen geven aan dat zij voor ieder compartiment te vervullen behoeften gemiddeld een vrijwel gelijk gewicht aan hel contacl met hun netwerkleden toekennen. Deze uitkomsten worden nagenoeg ook per sector netwerkleden aangetroffen. Een vitzondering vormt het gewicht dat betreffende de behoeften aan stabiliteit aan het contact mel de netwerkleden in de sector verwanten wordt toegekend. De onderzoekspopulatie geeft voor dit compartiment behoeften aan het contact mel de verwanten gemiddeld een significant lager gewicht dan de referentiepersonen (het gemiddelde gewicht is respectievelijk 3.2 en 3.6 per netwerklid in de sector verwanten, $\mathrm{T}=-2.34, \mathrm{p}<.05)$. Al bij al houden de uitkomsten in dat hypothese 14 niet bevestigd wordt.

\section{LENGTE}

Tenslotte de resultaten van de lengte van het contact tussen de focale personen en hun netwerkleden geanalyseerd en beschreven aan de hand van hypothese 15 (zie $\S 6.2 .1$ ) en weergegeven in de volgende tabel 8.11. 


\section{Ad hypothese 15}

Verondersteld wordt dat de meerderheid van de onderzoekspopulatie in tegenstelling tot de referentiepersonen beschikt over netwerkleden met wie al lange tijd contact bestaat.

TABEL 8.11 De lengte van het contact met netwerkleden bij de onderzoekspopulatie vergeleken met referentiepersonen.

$\begin{array}{lll} & \text { Onderzoekspopulatie } & \text { Referentiepersonen } \\ & n=47 & n=47\end{array}$

m sd $\quad$ m sd

$\begin{array}{lrrrr}<\quad 1 \text { jaar } & 3.0 & 2.8 & 1.5^{\star} & 2.3 \\ 1-5 \text { jaar } & 2.5 & 2.7 & 5.7^{\star \star \star} & 6.0 \\ \geq \quad 5 \text { jaar } & 13.6 & 6.9 & 18.6^{\text {***}} & 7.4\end{array}$

$* * * p<.001, * p<.05$

Tabel 8.11 laat zien dat voor wat betreft het sociale netwerk als geheel zowel de ambulante chronisch psychiatrische patiënten alsook de referentiepersonen gemiddeld met een meerderheid van hun netwerkleden reeds vijf jaar of langer contact hebben, namelijk respectievelijk gemiddeld 13.6 en 18.6 netwerkleden. Voor het sociale netwerk als geheel is op dit punt geen tegenstelling of verschil aanwezig en wordt hypothese 15 niet bevestigd.

Deze uitkomst hangt vooral samen met de sector verwanten, waarin eveneens de patiënten en de referentiepersonen met gemiddeld de meerderheid van hun verwanten vijf jaar of langer contact hebben, namelijk respectievelijk gemiddeld 10.7 en 11.3 verwanten. In de sector vriendschappelijke betrekkingen blijkt echter dat de referentiepersonen in tegenstelling tot de patiënten met gemiddeld de meerderheid van hun netwerkleden reeds vijf jaar of langer contact bestaat, namelijk respectievelijk gemiddeld 6.2 en 2.3 netwerkleden. In de sector maatschappelijke diensten vormen de netwerkleden met wie de patiënten en de referentiepersonen al lange tijd contact hebben gemiddeld een minderheid. Tesamen komt het ef op neer dat hypothese 15 zowel voor het sociale netwerk als geheel alsook per sector netwerkleden geen bevestiging krijgt.

Overigens blijken er, zoals tabel 8.11 aangeeft, nog een aantal opmerkelijke verschillen lussen de onderzoekspopulatie en de referentiepersonen op te treden inzake de lengte van het contact met hun netwerkleden in het sociale netwerk als geheel op te treden. Het gaat om de volgende significante verschillen.

- De onderzoekspopulatie heeft vergeleken met de referentiepersonen gemiddeld significant meer netwerkleden met wie het contact in het laatste jaar ontstaan is (respecievelijk gemiddeld 3.0 en 1.5 netwerkleden, $T=2.34, p<.05$ ).

- De onderzoekspopulatie heeft vergeleken met de referentiepersonen gemiddeld significant minder netwerkleden met wie het contact minimaal een jaar of hoogstens vier jaar bestaat (respectievelijk gemiddeld 2.5 en 5.7 netwerkleden, $T=-3.34, p<.001$ ).

- De onderzoekspopulatie heeft vergeleken met de referentiepersonen gemiddeld significant minder netwerkleden in het gehele sociale netwerk met wie reeds viji jaar of langer contacl bestaat (respectieveljk gemiddeld 13.6 en 18.6 nelwerkleden, $T=-3.39, p<.001$ ).

In de verdeling van de lengte van de contacten met de netwerkleden bij de onderzoekspopulatie vergeleken met die van de referentiepersonen treedt een significant verschil op (Chisq. 72.57, $\mathrm{p}<.001$ ). 
Ook binnen de sectoren vriendschappelijke betrekkingen en maatschappelijke diensten blijken zoals de volgende tabel 8.12 toont een aantal significante verschillen op te treden tussen de onderzoekspopulatie en de referentiepersonen wat betreft de lengte van het contact met hun netwerkleden.

TABEL 8.12 De lengte van het contact met de netwerkleden in de sectoren vriendschappelijke betrekkingen en maatschappelijke diensten bij de onderzoekspopulatie vergeleken met de referentiepersonen.

\begin{tabular}{|c|c|c|c|c|}
\hline \multirow[b]{2}{*}{$\begin{array}{l}\text { LENGTE } \\
\text { sector II en III }\end{array}$} & \multicolumn{2}{|c|}{$\begin{array}{l}\text { Onderzoekspopulatie } \\
n=47\end{array}$} & \multicolumn{2}{|c|}{$\begin{array}{l}\text { Referentiepersonen } \\
n=47\end{array}$} \\
\hline & $m$ & sd & $\mathrm{m}$ & sd \\
\hline $\begin{array}{l}11 \\
1-5 \text { jaar } \\
1-5 \text { jaar } \\
\geq \quad 5 \text { jar } \\
<\quad 1 \text { jaar } \\
1-5 \text { jaar } \\
2 \quad 5 \text { jaar }\end{array}$ & $\begin{array}{l}1.4 \\
1.3 \\
2.3\end{array}$ & $\begin{array}{l}2.4 \\
2.0 \\
2.7\end{array}$ & $\begin{array}{l}0.9 \\
3.9^{*} \\
6.2^{*} \\
0.4^{\star *} \\
1.0 \\
1.2^{*}\end{array}$ & $\begin{array}{l}2.7 \\
5.0 \\
4.7\end{array}$ \\
\hline
\end{tabular}

$* * P<.01, * * p<.001$

Tabel 8.12 laat zien dat in de sector vriendschappelijke betrekkingen de volgende significante verschillen optreden.

- De ambulante chronisch psychiatrische patiënten hehhebn vergeleken met de referentiepersonen gemiddeld significant minder netwerkleden in deze sector bij wie sprake is van contact dat langer dan 1 jaar en korter dan 5 jaar bestaat (respectievelijk 1.3 en 3.9 netwerkleden, $T=-3.31, p<.01$ ).

- Significant nog groter is het verschil bij het gemiddeld aantal netwerkleden in deze sector met wie vijf jaar of langer contacten bestaan, (respectievelijk 2.3 en 6.2. netwerkleden, $\mathrm{T}=-4.85, \mathrm{P}<.001$ ).

De sector maatschappelijke diensten bevat de volgende significante verschillen.

- De patiënten hebben vergeleken met de referentiepersonen gemiddeld significant meer netwerkleden met wie in het laatste jaar contact is ontstaan, (respectievelijk gemiddeld 1.4 en 0.4 netwerkleden $T=3.87, \mathrm{p}<.001$ ).

- De patiënten hebben vergeleken met de referentiepersonen gemiddeld significant minder netwerkleden met wie langer 5 jaar of langer contact bestaat, (respectievelijk gemiddeld 0.6 en 1.2 netwerkleden, $T=-2.79, p<.01$ ).

Zowel voor de sector vriendschappelijke betrekkingen alsook voor de sector maatschappelijke diensten geldt dat er sprake is van een significant verschil in de verdeling van de lengte van de contacten met de netwerkleden van de onderzoekspopulatie vergeleken met de referentiepersonen (respectievelijk Chisq. 56.95, $p<.001$ en Chisq. 37.03, $p<.001$ ).

\section{Tenslotte}

Met de weergave van de resultaten inzake het element lengte in de structuur van de betrekkingen is de beantwoording van vraagstelling I inzake de structuur van het sociale netwerk van de onderzoekspopulatie $(n=47)$ vergeleken met die van de referentiepersonen afgerond. De resulaten die hierboven uitvoerig toegelicht zijn zullen in de volgende paragraaf 8.4 in hoofdpunten samengevat worden. 
De bevindingen omtrent de structuur van de persoonlijke sociale netwerken van de ambulante chronisch psychiatrische patiěnten $(n=47)$ vergeleken met die van normale referentiepersonen zijn in hoofdpunten als volgt samen te vatten.

\section{A Omvang en samenstelling van de omvang}

\section{a.1}

De onderzochte doelgroep ambulante chronisch psychiatrische patiënten van de SPD van de RIAGG Maastricht heeft een beschikbaar sociaal netwerk dat gemiddeld uit 26 netwerkleden bestaat terwijl de referentiepersonen gemiddeld 30 netwerkleden hebben. Dit verschil in de gemiddelde omvang is significant.

\section{a.2}

De patiënten hebben gemiddeld significant minder informele netwerkleden (de sectoren verwanten en vriendschappelijke betrekkingen tesamen) dan de referentiepersonen (respectievelijk gemiddeld 21 en 26 netwerkleden).

\section{a.3}

Dit verschil in de omvang van het totale sociale netwerk en in de omvang van het informele deel ervan is voornamelijk terug te voeren naar de sector vriendschappelijke betrekkingen waar de ambulante chronisch psychiatrische patiënten vergeleken met de referentiepersonen gemiddeld significant minder netwerkleden hebben (respectievelijk gemiddeld 9 en 13 netwerkleden). Het verschil is in het bijzonder in het cluster naaste vrienden significant groot (respectievelijk gerniddeld 3 en 6 naaste vrienden).

\section{a. 4}

Vervolgens blijken de patiënten zoals verwacht gemiddeld significant meer hulpverleners te hebben dan de referentiepersonen. Zo heeft $87 \%$ van de patienten 2 tot 4 netwerkleden in het cluster hulpverlening, een spreiding die bij de referentiepersonen in $41 \%$ van de gevallen wordt aangetroffen.

\section{B Gevarieerdheld van de netwerkleden}

\section{b. 1}

De sociale netwerken van de patiënten zijn voor wat betreft de verdeling van de statusrollen inzake geslacht en leeftijd over de informele netwerkleden op dezelide wijze samengesteld als het geval is bij de referentiepersonen.

\section{b. 2}

Voor wat betreft de verdeling van de positierollen inzake burgerlijke staat en opleiding over de informele netwerkleden wijkt in het geheel genomen de samenstelling van de sociale netwerken van de patienten niet af van die van de referentiepersonen. Alleen in de sector verwanten sluiten de patiënten vergeleken met de referentiepersonen significant minder aan op de burgelijke staat van hun netwerkleden.

\section{b. 3}

De patiénten hebben in het geheel genomen en in de sector verwanten vergeleken met de referentiepersonen significant minder aansluiting met hun informele netwerkleden waar hel gaat om positierollen inzake werk- en woonsituatie. In de sector vriendschappelijke betrekkingen hebben de patiënten vergeleken met de referentiepersonen significant minder aansluiting met hun netwerkleden inzake de werksituatie.

b. 4

In het geheel genomen blijkt zowel bij de patienten alsook bij de referentiepersonen het homogene deel in het algemeen het grootst te zijn in de verdeling van het homogene en hel hetereogene deel informele nelwerkleden. Deze uitkomst is eveneens vrijwel steeds aanwezig waar lussen de onderzoekspopulatie en de referentiepersonen in de verdeling van het homogene en heterogene deel significante verschillen optreden. 
c.1

Zowel bij de patiënten alsook bij de referentiepersonen blijkt gemiddeld een meerderheid van de informele netwerkleden in de eigen woonplaats te wonen. Echter de patiênten hebben vergeleken met de referentiepersonen gemiddeld significant minder informele netwerkleden die in hun eigen woonplaats wonen en op korte afstand te bereiken zijn.

c.2

De patienten blijken bij gemiddeld zes informele netwerkleden geen adequate informatio over hun woon- of verblijfsplaats te kunnen geven terwijl dit bij de refeentiepersonen gemiddeld bij éen netwerklid het geval is. Dit verschil is significant. Bij de referentiepersonen behoren deze netwerkleden nagenoeg tot de clusters overige (verre) verwanten en overige vriendschappelijke betrekkingen, in het bijzondere de kennissen. Bij de ambulante chronisch psychiatrische patiënten zijn deze netwerkleden meer over alle clusters in de sectoren verwanten en vriendschappelijke betrekkingen verspreid.

\section{Structuur van de betrekkingen}

\section{Initlatief}

d.1

In het geheel genomen nemen de patiënten vergeleken met de referentiepersonen bij gemiddeld significant minder netwerkleden zelf het initiatief tot contact. Een dergelijk significant verschil wordt ook aangetroffen in de sector verwanten. In de sectoren vriendschappelijke betrekkingen en maatschappelijke diensten is er tussen de patienten en de referentiepersonen geen verschil in het gemiddeld aantal netwerkleden bij wie zij zelf het initiatief tot contact nemen.

d. 2

In het geheel genomen hebben de ambulante chronisch psychiatrische patienten vergeleken met de referentiepersonen gemiddeld significant minder netwerkleden met wie het contact gebaseerd op wederzijds initiatief. Dit verschil wordt ook aangetroffen in de sector verwanten en in de sector vriendschappelijke betrekkingen. In de sector maatschappelijke diensten blijken zowel de patiënten alsook de referentiepersonen nagenoeg geen netwerkleden te hebben met wie het contact gebaseerd is op wederzijds initiatief.

d. 3

Zowel in het geheel genomen alsook in de sectoren vriendschapelijke betrekkingen en maatschappelijke diensten hebben de patiënten gemiddeld significant minder netwerkleden met wie contact vanuit gewoonte tot stand komt.

d. 4

In de sector maatschappelijke diensten hebben de patienten vergeleken met de referentiepersonen gemiddeld significant meer netwerkleden met wie het contact via derden tot stand komt. In het sociale netwerk in haar geheel en in de sectoren verwanten en vriendschappelijke betrekkingen treden hier geen significante verschillen op.

d.5

De patiènten hebben vergeleken met de referentiepersonen in het geheel genomen gemiddeld significant meer netwerkleden met wie geen initiatief tol contact wordt genomen. Dit verschil heeft nagenoeg alles te maken met de sector verwanten waar de patiénten vergeleken met de referentiepersonen gemiddeld significant meer verwanten hebben bij wie geen initiatief tot contact bestaat. 


\section{Frequentle}

d. 6

De ambulante chronisch psychiatrische pationten hebben vergeleken met de referentiepersonen gemiddeld evenveel verwanten met wie ze zeer frequent (dagelijks tot wekelijks) en met wie ze weinig (eenmaal per vier maanden of eenmaal per jaar) contact hebben. Echter de patienten hebben vergeleken met de referentiepersonen gemiddeld significant minder verwanten met wie ze minstens Iweewekelijks dan wel elke drie maanden contact hebben.

d. 7

De patienten hebben vergeleken met de referentiepersonen in de sector vriendschappelijke betrekkingen gemiddeld significant minder netwerkleden met wie zij zeer frequent contact hebben. Dat geldt ook voor het gemiddeld aantal netwerkleden net wie ze minstens tweewekelijks dan wel eenmaal per drie maande contact hebben. Er is echter tussen de ambulante chronisch psychiatrische patienten en de referentiepersonen geen verschil in het gemiddeld aantal netwerkleden met wie weinig contact bestaat.

\section{d. 8}

De patiënten hebben vergeleken met de referentiepersonen significant frequenter en met meer hulpverleners contact.

\section{Gewicht}

\section{d. 9}

In het geheel genomen blijken de ambulante chronisch psychiatrische patienten gemiddeld nagenoeg een gelijk gewicht aan het contact met hun netwerkleden toe te kennen als de referentiepersonen. Een uitzondering is dat de patiënten vergeleken met de referentiepersonen gemiddeld een lager gewicht geven aan het coniact met hun verwanten voor wat betreft de stabiliteit ervan.

\section{Lenote}

\section{d. 10}

De ambulante chronisch psychiatrisch patiënten blijken in vergelijking met de referentiepersonen in het geheel genomen gemiddeld significant meer netwerkleden te hebben met wie sinds korte tijd of minder dan één jaar contact bestaat. Een dergelijk significant verschil wordt eveneens aangetroffen in de sector maatschappelijke diensten.

\section{d. 11}

Vervolgens blijken de patiënten vergeleken met de referentiepersonen in het geheel genomen gemiddeld significant minder netwerkleden te hebben met wie het contact minimaal één jaar of hooguit vier jaar bestaat. Dit verschil wordt tevens aangetroffen binnen de sector vriendschappelijke betrekkingen.

\section{d. 12}

In het geheel genomen bestaat zowel bij de patienten als bij de referentiepersonen met de meerderheid ( $\pm 72 \%$ ) van de netwerkleden het contact al vijf jaar of langer. Deze uitkomst hangt nauw samen met het gegeven dat er zowel bij de patienten als bij de referentiepersonen met ongeveer $92 \%$ van hun verwanten reeds vijf jaar of langer contact bestaat. Echter vergeleken met de referentiepersonen hebben de ambulante chronisch psychiatrische patiënten in het geheel genomen gemiddeld significant minder netwerkleden met wie vijf jaar of langer contact bestaat. Dit verschil wordt zowel aangetroffen in de sector vriendschappelijke betrekkingen alsook in de secor maatschappelijke diensten. 


\section{SOCIALE NETWERKEN \\ DOOR DE OGEN VAN DE HULPVERLENING}

Vraagstelling II van het onderzoek naar de structuur van het sociale netwerk van ambulante chronisch psychiatrische patiënten die in dit hoofdstuk beantwoord zal worden luidt:

WELKE VERSCHILLEN DAN WEL OVEREENKOMSTEN BESTAAN ER TUSSEN DE INFORMATIE DIE HULPVERLENERS OVER DE OMVANG, GEVARIEERDHEID, BEREIKBAARHEID EN DE STRUCTUUR VAN DE BETREKKINGEN VAN HET SOCIALE NETWERK VERWERVEN EN DE GEGEVENS DIE MET BEHULP VAN DE ANALYSE VAN DE STRUCTUUR OVER HET SOCIALE NETWERK (MSNA) VAN DE ONDERZOEKSPOPULATIE WORDEN VERKREGEN?

\subsection{INLEIDING}

Dit hoofdstuk bevat de resultaten van de vraagstelling die eigenlijk de kern van dit onderzoek raakt. De zojuist vermelde vraagstelling II sluit immers rechtstreeks aan op de voorlopige bevindingen van een eerder verkennend onderzoek naar de aanwezigheid van het sociale netwerk in de informatie die door de hulpverleners over het sociale milieu van de ambulante chronisch psychiatrische patiënt in de dossiers wordt weergegeven (Baars, 1985). In $\S 2.3$ en $\$ 2.4$ is hierop uitgebreid ingegaan. In het kort samengevat komt het op het volgende neer. De gegevens die de hulpverleners van de SPD van de RIAGG Maastricht over het sociale milieu verzamelden impliceren dat de patiënt een deficient sociaal netwerk heeft. De informatie is van dien aard dat gemakkelijk de opvatting ontstaat dat deze patiënten weinig te verwachten hebben van hun persoonlijke sociale netwerk behalve dan van de hulpverlening. Zoals beschreven zijn er redenen om te veronderstellen dat allerminst op voorhand aangenomen kan worden dat de door de hulpverleners beschreven sociale situatie overeenkomt met de werkelijke sociale omstandigheden waarin de patiënt zich bevindt. De resultaten van het verkennende onderzoek in 1985 gaven aanleiding te vermoeden dat:

- de ambulante chronisch psychiatrische patiènt over een structureel omvangrijker en veelzijdiger sociaal netwerk van personen en betrekkingen beschikt dan bij de hulpverlening bekend is.

In relatie tot de praktijk van ambulante psychiatrische hulpverlening is er vervolgens aanleiding te veronderstellen dat:

- de ambulante chronisch psychiatrische patiënt over meer mogelijkheden in zijn sociale omgeving beschikt ten gunste van zijn sociale integratie dan door 
de ambulante psychiatrische hulpverlening zichtbaar worden gemaakt en eventueel benut worden.

Met andere woorden: verondersteld wordt dat een analyse van de structuur van het persoonlijke sociale netwerk waarbij gebruik gemaakt wordt van de MSNA meer en andere informatie geeft ten behoeve van een psychiatrische hulpverlening dan via de gebruikelijke werkwijze van de hulpverleners wordt verkregen. De in hoofdstuk 6 bij vraagsteling II geformuleerde hypothesen 16 tot en met 25 (zie $\$$ 6.2.1) die hier getoetst worden kunnen opgevat worden als een nadere toetsing van het hierboven globaal beschreven vermoeden.

Alvorens tot de weergave van de resultaten over te gaan volgt in $\$ 9.1 .1$ een korte beschrijving van de hulpverleners van de SPD en van het deel van de onderzoekspopulatie ( $n=44$ ) over wiens sociale netwerken de betreffende hulpverleners geïnterviewd zijn.

\subsubsection{Beschrijving hulpverleners en onderzoekspopulatie}

De Sociaal Psychiatrische Dienst van de RIAGG Maastricht bestaat zoals vermeld in hoofdstuk 2 uit twee multi-disciplinair samengestelde sub-teams. Aan het hoofd van ieder sub-team staat een psychiater. In deze sub-teams vindt men de volgende disciplines: psychiaters, arts-assistent in opleiding tot psychiater, sociaal psychiatrisch verpleegkundigen en medewerkers geschoold in een psychologische dan wel pedagogische discipline. Sociaal psychiatrisch verpleegkundigen zijn in aantal het sterkst vertegenwoordigd. Al bij al komt het er op neer dat de subteams opgebouwd zijn overeenkomstig de beschrijving die Verhagen (1984) van de personele samenstelling van een SPD geeft; echter in Maastricht ontbreekt nagenoeg het maatschappelijk werk.

Vrijwel alle medewerkers van de beide sub-teams hebben in min of meer gelijke mate aan het onderzoek hun medewerking verleend. De term 'vrijwel' houdt in dat een enkele medewerker vanaf het begin buiten het onderzoek is gebleven, hetgeen echter niet van invloed is geweest op de vertegenwoordiging van de disciplines bij het onderzoek. Het komt er op neer dat van de totale onderzoekspopulaie $(N=59)$ door de psychiaters en arts-assistenten in opleiding tot psychiater $40 \%$, door de sociaal psychlatrisch verpleegkundigen $50 \%$ en door de overige disciplines $10 \%$ van de focale personen is ingebracht.

In $\S 7.2 .5$ is nader ingegaan op de voor dit onderzoek vereiste betrokkenheid van de hulpverleners van de SPD. Aangegeven is dat verwacht werd dat de hulpverleners lopende het onderzoek op enig moment de onderzoekers zouden gaan aanspreken op de practische implicaties van het onderzoek. Dat is ook gebeurd. Het moet gezegd worden dat het niet alleen de hulpverleners waren die de onderzoekers nadrukkelijker begonnen aan te spreken op de mogelijke toepassing van de verkregen informatie in de psychiatrische hulpverlening op patiëntniveau. Het kwam ook voor dat de bij het onderzoek betrokken patient zelf er bij de hulpverlener op aandrong de verkregen informatie in de vitvoering van de hulpverlening te betrekken. Immers in het algemeen waardeerden de bij het onderzoek betrokken patiënten het bijzonder dat via de analyse van de strucluur van het sociale netwerk uitvoerig naar de feiten van hun sociale omstandigheden werd gevraagd en nauwelijks - een uitzondering is het structuurelement gewicht inzake de betrekkingen met netwerkleden - gevraagd is naar belevingen. Al bij al kwam tijdens het onderzoek een wisselwerking in zicht tussen enerzijds de patiënt en de hulpverlener en anderzijds de onderzoekers en de hulpverleners waarin op gegeven moment besloten is de interviews met de hulpverleners ten behoeve van het onderzoek te beëindigen. Het resultaat is dat voor de beantwoording van vraagstelling II een cohort van 44 ambulante chronisch psychiatrische patiēnten opgebouwd kon worden waarbij ook de hulpverleners geïnterviewd zijn.

De weergave van de resultaten bij vraagstelling II aan de hand van de hypothesen 16 tot en met 25 (zie $\S 6.2 .1$ ) is overeenkomsig de opzet van de beschrijving van de resultaten bij vraagstelling I in het vorige hoofdstuk. Dit betekent onder meer dat de gevarieerdheid en de bereikbaarheid van de netwerkleden geanalyseerd en beschreven 
is aan de hand van het deel informele netwerkleden. Evenzo is voor de analyse en beschrijving van de structuur van de betrekkingen uitgegaan van de informele en formele netwerkleden tesamen.

Onderstaande tabel 9.1 geeft een overzicht van het sociaal demografisch profiel van de ambulante chronisch psychiatrische patiënten $(n=44)$ over wiens sociale netwerken de hulpverleners geïnterviewd zijn vergeleken met de onderzoekspopulatie $(n=47)$ bij wie referentiepersonen gevonden konden worden.

TABEL 9.1 Sociaal demografisch profiel van 44 patiënten bij wie de betreffende hulpverlener van de SPD geinterviewd is vergeleken mel de onderzoekspopulatie $(n=47$ ) bij wie referentiepersonen beschikbaar zijn.

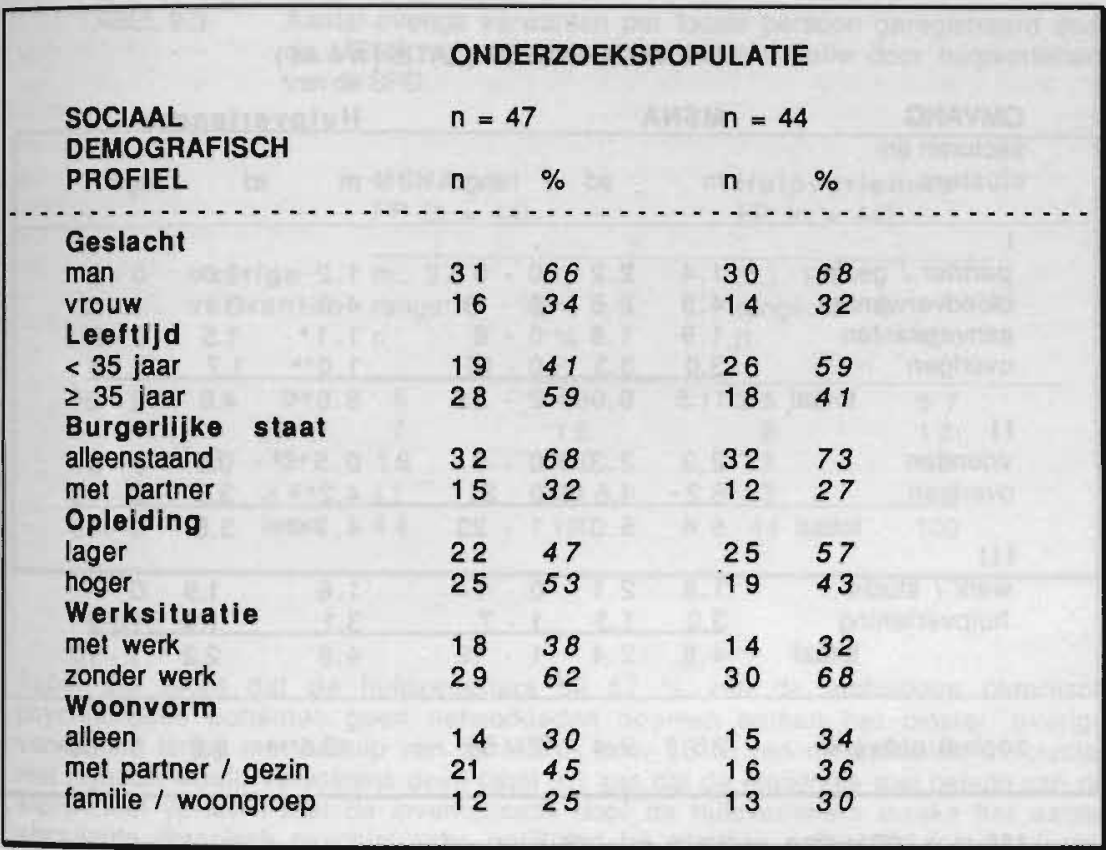

Bovenstaande tabel 9.1. toont dat de opbouw van de onderzoekspopulatie bij wie de betreffende hulpverleners geinterviewd zijn $(n=44)$ qua geslacht, burgelijke staat, werksituatie en woonvorm vrijwel overeenkomt met de opbouw van de onderzoekspopulatie ( $n=47$ ) bij wie referentiepersonen aanwezig zijn. De verschillen die optreden betreffen leeftijd en opleiding. De onderzoekspopulatie waarbij hulpverleners geïnterviewd zijn bestaat uit meer patiënten jonger dan 35 jaar dan het geval is in de onderzoekpopulatie bij wie referentiepersonen aanwezig zijn. Dit optredende verschil in leeftijd wordt ook bij opleiding leruggevonden. 


\subsubsection{Omvang en samenstelling van de omvang}

De informatie die via de MSNA bij de betreffende patiěnten verkregen is over de omvang netwerkleden en de verdeling ervan over sectoren en clusters is vergeleken met de informatie waarover de hulpverleners van de SPD Maastricht beschikten. In onderstaande tabel 9.2. zijn de resultaten van deze vergelijking weergegeven.

TABEL 9.2 De omvang en de samenstelling van het sociale netwerk bij de onderzoekspopulatie $(n=44)$ verkregen via de MSNA vergeleken met de informatie bij hulpverleners van de SPD.

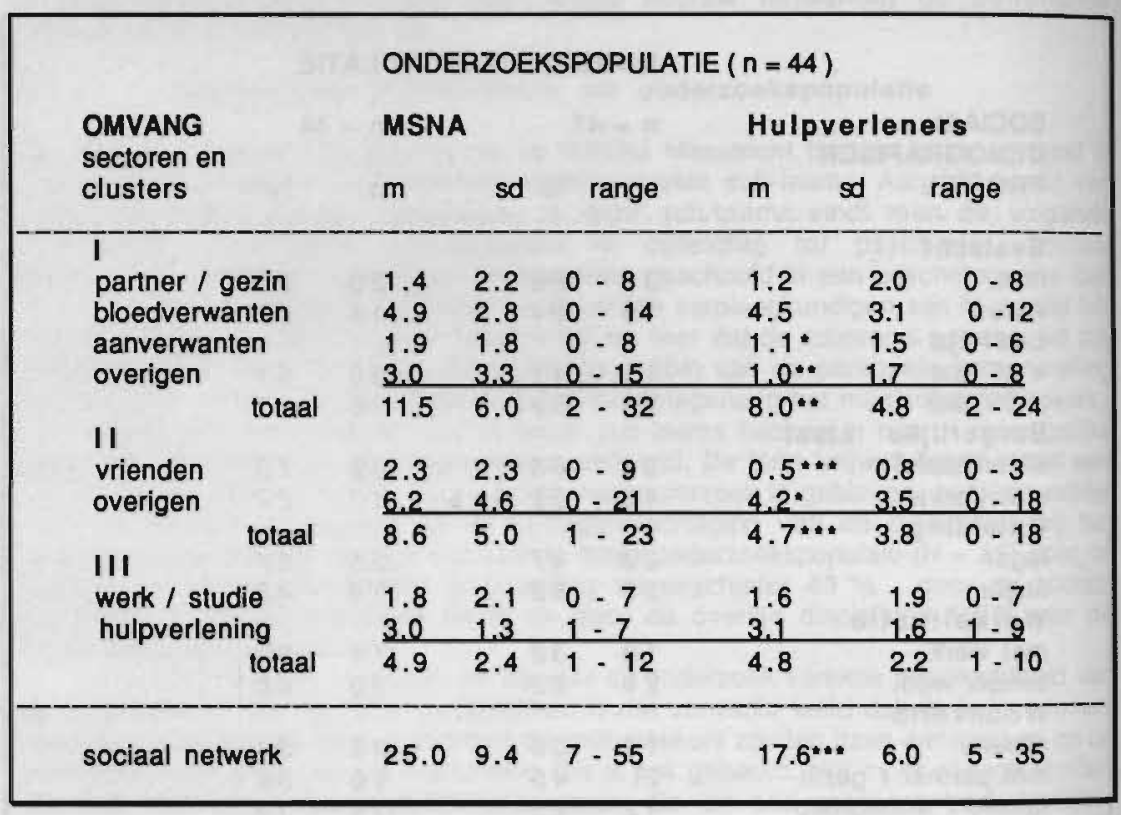

** $p<.001 ; * p<.01 ; * p<.05$

\section{Ad hypothese 16}

Verondersteld wordt dat de hulpverleners gemiddeld een geringere omvang van de sector verwanten inventariseren dan door de MSNA zichtbaar wordt gemaakt.

Deze hypothese wordt bevestigd, dat wil zeggen de gegevens over de omvang van de sector verwanten, weergegeven in tabel 9.2, tonen dat de hulpverleners van de SPD gemiddeld een significant geringere omvang netwerkleden in de sector verwanten in beeld brengen dan door de MSNA zichtbaar wordi gemaakt. De hulpverleners inventariseren gemiddeld 8.0 verwanten terwijl de MSNA gemiddeld 11.5 verwanten in beeld brengt $(T=2.94, P<.01)$. 


\section{Ad hypothese 16.1}

In hypothese 16.1 wordt gesteld dat de hulpverleners ovenwegend de naaste (bloed)verwanten inventariseren terwijl de MSNA daarnaast ook andere bloed- dan wel aanverwanten zichtbaar maakt die door de onderzoekspopulatie tot het sociale netwerk gerekend worden.

Hypothese 16.1 wordt eveneens bevestigd, dat wil zeggen het aangetroffen significante verschil in de gemiddelde omvang van de sector verwanten hangt in de eerste plaats samen met het gegeven dat hulpverleners het cluster 'overigen' minder zichtbaar maken dan met de MSNA het geval is $(T=3.56, p<.01)$. Onderstaande tabel 9.3 geeft een meer gedetailleerd overzicht van het optredende verschil.

TABEL 9.3 Aantal overige verwanten per focale persoon geregistreerd door de MSNA vergeleken met de inventarisatie door hulpverleners van de SPD.

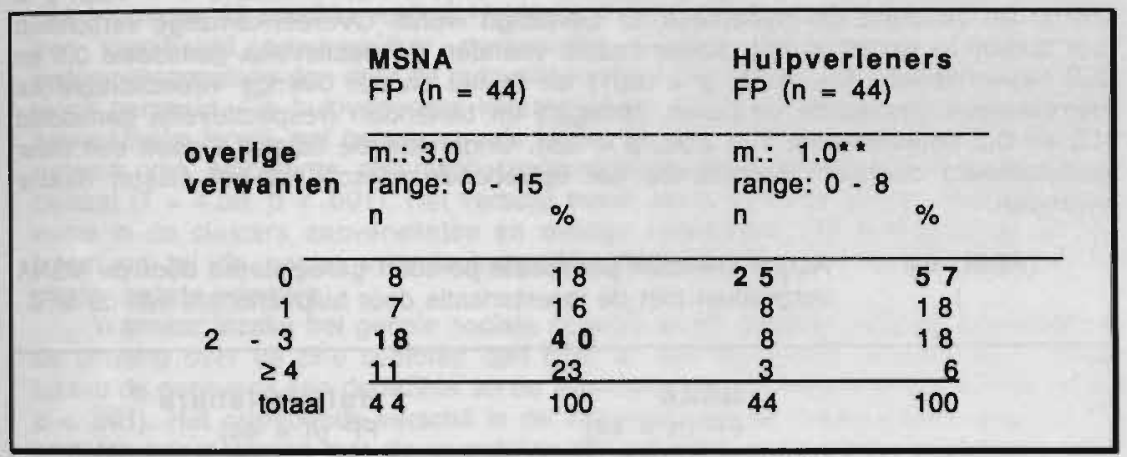

$* p<.01$

Tabel 9.3 toont dat de hulpverleners bij $57 \%$ van de ambulante chronisch psychiatrische patiënten geen netwerkleden noemen binnen het cluster 'overige verwanten' terwijl met behulp van de MSNA door $18 \%$ van de patiënten dit cluster niet ingevuld wordt. Vervolgens geeft tabel 9.3 aan dat de registratie met behulp van de MSNA niet verschilt met de inventarisatie door de hulpverleners inzake het aantal ambulante chronisch psychiatrische patiënten bij wie éen netwerklid tot dit cluster gerekend wordt. Daarna treden er weer opmerkelijke verschillen op tussen het aantal overige verwanten die de MSNA en die de hulpverleners bij de patiënten zichtbaar maken.

Het verschil in de gemiddelde omvang netwerkleden in de sector verwanten wordt mede beïnvloed door het gegeven dat de hulpverleners een significant geringere omvang netwerkleden binnen hel cluster aanverwanten in kaart brengen dan de MSNA zichtbaar maakı ( $T=2.30, p<.05$ ). Zo blijken de hulpverleners bijvoorbeeld bij de helft van deze 44 patiënten geen aanverwanten te noemen terwijl er met behulp van de MSNA iwaalf patiënten $(27 \%$ ) zijn die geen aanverwanten noemen (zie bijlage VI, tabel 1 ).

Al bij al komt het er op neer dat de inventarisatie van de omvang van de sector verwanten door de hulpverleners in de eerste plaats betrekking heeft op de clusters partner / eigen gezin en bloedverwanten. De hulpverleners brengen bij deze clusters een gemiddelde omvang (respectievelijk gemiddeld 1.2 en 4.5. netwerkleden) in beeld welke niet verschilt met die via de MSNA (respectievelijk gemiddeld 1.4 en 4.9 netwerkleden) verkregen wordt. 
Ook de variaties in de opbouw van het aantal netwerkleden per patient in de clusters partner / eigen gezin en bloedverwanten die door de hulpverleners met hun inventarisatie te voorschijn komen blijken niet te verschillen met die met behulp van de MSNA binnen deze clusters worden aangetroffen (zie Bijlage VI, 1). De verschillen tussen de inventarisatie van de hulpverleners en de registratie van de MSNA treden in de sector verwanten op bij de clusters aanverwanten en overige verwanten. In het cluster overige verwanten zijn de verschillen het grootst.

\section{Ad hypothese 17}

Verondersteld wordt dat de hulpverleners gemiddeld minder netwerkleden in de sector vriendschappelijke betrekkingen inventariseren dan door de MSNA zichtbaar wordit gemaakt.

Tabel 9.2 laat zien dat de hulpverleners gemiddeld significant minder netwerkleden in de sector vriendschappelijke betrekkingen inventariseren dan door de MSNA zichtbaar wordt gemaakt (respectievelijk gemiddeld 4.7 en 8.6 netwerkleden, $T=4.05, P<$ .001 ). Dit betekent dat hypothese 17 bevestigd wordt. Overeenkomstige verschillen zijn tevens te vinden in het cluster naaste vrienden (respectievelijk gemiddeld 0.5 en 2.3 netwerkleden, $T=4.71, p<.001$ ) en in het cluster overige vriendschapelijke betrekkingen bestaande uit buren, collega's en bekenden (respectievelijk gemiddeld 4.2 en 6.2 netwerkleden, $T=2.36, p<.05$ ). Onderstaande tabel 9.4 geeft een meer gedetailleerd overzicht betreffende het optredende verschil in het cluster naaste vrienden.

TABEL 9.4 Aantal vrienden per focale persoon geregisteerd door de MSNA vergeleken met de inventarisatie door hulpverleners van de SPD

\begin{tabular}{|c|c|c|c|}
\hline 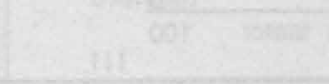 & $\begin{array}{l}\text { MSNA } \\
\text { FP }(n=44)\end{array}$ & & $\begin{array}{l}\text { Hulpverleners } \\
\text { FP }(n=44)\end{array}$ \\
\hline vrienden & $\begin{array}{l}\mathrm{m}: 2.3 \\
\text { range: } 0-9 \\
n\end{array}$ & $\%$ & $\begin{array}{l}\mathrm{m}: 0.5 \\
\mathrm{range}: 0-3\end{array}$ \\
\hline $\begin{array}{r}0 \\
1 \\
2 \\
23 \\
\text { totaal }\end{array}$ & $\begin{array}{r}13 \\
7 \\
6 \\
18 \\
44\end{array}$ & $\begin{array}{l}29 \\
16 \\
14 \\
41 \\
100\end{array}$ & $\begin{array}{rr}28 & 64 \\
10 & 23 \\
4 & 9 \\
2 & 4 \\
44 & 100\end{array}$ \\
\hline
\end{tabular}

$* p<.001$

Bovenstaande tabel 9.4 laat zien dat de hulpverleners bij 28 (ofwel bij $64 \%$ van de) ambulante chronisch psychiatrische patiënten geen vrienden noemen terwijl de MSNA aangeeft dat slechis 13 patiënten (ofwel $29 \%$ ) geen vrienden noemen. Dit betekent dat de hulpverleners twee maal zoveel ambulante chronisch psychiatrische patienten zonder vrienden zien dan met behulp van de MSNA het geval is. Tabel 9.4 toont vervolgens dat de hulpverleners van de SPD bij slechts twee patiěnten drie of meer vrienden noemen terwijl de MSNA duidelijk maakt dat 18 patiénten ofwel $41 \%$ van de onderzoekspopulatie het drie of meer vrienden noemen (zie tevens Bijlage VI, 2). 
Verondersteld wordt dat de inventarisatie van de omvang van de sector maatschappelijke diensten door de hulpverleners niet verschilt van die met de MSNA zichtbaar wordt gemaakt.

Tabel 9.2 loont vervolgens dat hypothese 18 als bevestigd kan worden beschouwd. De hulpverleners invantariseren hier in het geheel genomen gemiddeld 4.8 netwerkleden en de MSNA maakt gemiddeld 4.9 netwerkleden zichtbaar. Ook in de gemiddelde omvang van de clusters werk/scholing en hulpverlening treden geen significante verschillen op.

\section{Ad hypothese 19}

Verondersteld wordt dat de MSNA een gemiddeld omvanrijker sociaal netwerk in beeld brengt dan door de hulpverleners zichtbaar wordt gemaakt.

Cok hypothese 19 wordt bevestigd. Het komt er al bij al op neer dat de MSNA gemiddeld een significant omvangrijker persoonlijk sociaal netwerk laat zien bij de onderzoekspopulatie dan door de hulpverleners van de SPD bij deze patiënten zichtbaar wordt gemaakt. De hulpverleners inventariseren een gemiddelde omvang van 17.6 netwerkleden terwijl met behulp van de MSNA de gemiddelde omvang van het sociale netwerk van ambulante chronisch psychiatrische patiënten uit 25.0 netwerkleden bestaat $(T=4.36, p<.001)$. Het verschil treedt deels op in de sector verwanten, met name in de clusters aanverwanten en overige verwanten. Het belangrijkste verschil treedt op bij de sector vriendschappelijke betrekkingen, in het bijzonder in het cluster naaste vrienden.

Wanneer inzake het gehele sociale netwerk wordt gekeken naar de verdeling van de omvang over de drie sectoren dan blijkt er een significant verschil op te treden tussen de gegevens van de MSNA en de informatie van de hulpverleners (Chisq. 20.63, $p<.001)$. Het optredende verschil in de verdeling van de netwerkleden over de drie sectoren hangt samen met de verschillen die optreden in de sector verwanten en de sector vriendschappelijke betrekkingen

\subsubsection{Gevarieerdheid van de netwerkleden}

De analyse en beschrijving van de gevarieerdheid van de netwerkleden betreft de informele netwerkleden. De omvang informele netwerkleden bestaat volgens de MSNA bij de onderzoekspopulatie $(n=44)$ gemiddeld uit 20.1 netwerkleden terwijl de hulpverleners aangeven dat deze gemiddeld uit 12.7 netwerkleden bestaat. Er is sprake van een significant verschil: $T=4.61, p<.001$. De beantwoording van vraagstelling II omtrent de gevarieerdheid van de informele netwerkleden gebeun aan de hand van hypothese 20.

Voor de analyse en beschrijving van het gevarieerdheid van de informele netwerkleden wordt aangesloten op een hergroepering van de aanvankelijk (in de verzameling van de data) onderscheiden categorieën bij de verschillende sociaal demografische kenmerken. Deze hergroepering is overeenkomstig de beschrijving van het sociaal demografisch profiel van de onderzoekspopulatie (zie tabel 9.1).

\section{Ad hypothese 20}

Verondersteld wordt dat de hulpverleners gemiddeld minder de status- en positierollen van de netwerkleden bij de onderzoekspopulatie inventariseren dan dat dit door de MSNA gebeurt.

De resultaten van de analyse van de gevarieerdheid van de informele netwerkleden van de ambulante chronisch psychiatrische patiënten $(n=44)$ die in Bijlage VII,2 weergegeven zijn, tonen dat de de hulpverleners van de SPD gemiddeld significant 
minder de status- (geslacht en leeftijd) en positierollen (burgerlijke staat, opleidingsniveau, werk- en woonsituatie) bij de informele netwerkleden inventariseren dan het geval is met behulp van de MSNA. Hypothese $20 \mathrm{kan}$ als bevestigd beschouwd worden.

Ter illustratie geeft onderstaande tabel 9.5 eerst de resultaten van de analyse van de gegevens betreffende de statusrol 'leeftijd' en de positierol 'werksituatie' van de informele netwerkleden bij de onderzoekspopulatie $(n=44)$ die via de MSNA verkregen zijn in vergelijking met de informatie erover die door de hulpverleners van de SPD verstrekt is.

TABEL 9.5 De leeftijd en werksituatie van de informele netwerkleden geïnventariseerd door de MSNA vergeleken met de informatie die bij hulpverleners van de SPD aanwezig is.

\begin{tabular}{|c|c|c|c|c|}
\hline \multirow{3}{*}{ GEVARIEERDHEID } & \multicolumn{4}{|c|}{ ONDERZOEKSPOPULATIE $(n=44)$} \\
\hline & \multicolumn{2}{|c|}{ MSNA } & \multicolumn{2}{|c|}{ Hulpverleners } \\
\hline & m & sd & m & sd \\
\hline $\begin{array}{l}\text { Leeftljd } \\
-<35 \text { jaar } \\
-\geq 35 \text { jaar } \\
\text { geen informatie }\end{array}$ & $\begin{array}{l}5.5 \\
7.0 \\
7.6\end{array}$ & $\begin{array}{l}4.4 \\
4.5 \\
6.5\end{array}$ & $\begin{array}{l}1.7 * * \\
2.1 * * \\
8.9\end{array}$ & $\begin{array}{l}1.9 \\
1.6 \\
5.9\end{array}$ \\
\hline $\begin{array}{l}\text { Werksltuatle } \\
\text { - met werk } \\
\text { - zonder werk } \\
\text { geen informatie }\end{array}$ & $\begin{array}{l}9.0 \\
2.7 \\
8.4\end{array}$ & $\begin{array}{l}5.5 \\
1.9 \\
6.5\end{array}$ & $\begin{array}{l}2.1 \cdots * \\
0.8 \cdots \cdots \\
9.8\end{array}$ & $\begin{array}{l}1.4 \\
0.8 \\
5.8\end{array}$ \\
\hline
\end{tabular}

$\cdots p<.001$

Bovenstaande tabel 9.5 toont dat met behulp van de MSNA bij gemiddeld significant meer informele netwerkleden informatie wordt verkregen over de leeftijd en de werksituatie van de informele netwerkleden dan in de inventarisatie van de hulpverleners het geval is. Zo laat tabel 9.5 zien dat met behulp van de MSNA bij gemiddeld significant meer informele netwerkleden de leeftijd bekend is dan in de inventarisatie van de hulpverleners het geval is (voor de leeftijdscategorie $<35$ jaar respectievelijk gemiddeld 5.5 en 1.7 informele netwerkleden, $T=5.19, p<.001$; voor de leeftijdscategorie $\geq 35$ jaar respectievelijk gemiddeld 7.0 en 2.1 informele netwerkleden, $T=6.68, p<.001$ ).

Een dergelijk significant verschil treedt zoals tabel 9.5 toont eveneens op omtrent de werksituatie van de informele netwerkleden van de ambulante chronisch psychiatrische patiënten $(n=44)$. Bijlage VII, 2 toont dat dergelijke significante verschillen ook optreden inzake geslacht, burgerlijke staat, opleiding en woonsituatie. 
Een tweede gegeven in tabel 9.5 is dat met behulp van de MSNA bij gemiddeld evenveel informele netwerkleden geen adequate informatie over de leeftijd en werksituatie gegeven wordt als in de inventarisatie van de hulpverleners het geval is. Ook deze uitkomst is te vinden bij de overige kenmerken van de gevarieerdheid van de informele netwerkleden (zie Bijlage VII,2). In genoemde bijlage valt onder meer te zien dat de onderzoekspopulatie via de MSNA over gemiddeld 4.7 informele netwerkleden geen adequate informatie geeft over hun geslacht hetgeen niet significant verschilt met de informatie van de hulpverleners waar het om gemiddeld 5.1 informele netwerkleden gaat. Een nadere analyse geeft aan dat deze informele netwerkleden in de informatie van de MSNA overwegend teruggevnden worden in het cluster 'overigen' binnen de sector vriendschappelijke betrekkingen. Deze uitkomst hangt onder meer samen met het feit dat zoals vermeld in Bijlage I "onder het cluster 'overigen' in de sector vriendschappelijke betrekkingen waar sprake is van deelname aan verenigingen, clubs en dergelijke in principe drie personen geregistreerd worden". In de gegevens van de hulpverleners zijn de informele netwerkleden waarover geen adequate informatie verstrekt wordt tevens deels te vinden in de sector verwanten.

De zojuist weergegeven uitkomsten tesamen genomen wijzen op een bepaald patroon van informatieverzameling en uitkomsten inzake de gevarieerdheid van de netwerkleden via de MSNA in vergelijking met die van de hulpverleners. Dit patroon impliceert dat waar sprake is van adequate informatie de hulpverleners gemiddeld significant minder de status- en positierollen bij de onderzoekspoplatie inventariseren dan dat dit door de MSNA gebeurt. Waar sprake is van inadequate informatie blijkt er gemiddeld geen verschil te zijn tussen de inventarisatie via de MSNA en die van de hulpverleners. Het komt er op neer dat de MSNA verhoudingsgewijs bij significant meer informele netwerkleden informatie geeft over hun gevarierdheid dan het geval is in de inventarisatie van de hulpverleners. Zo geeft de MSNA bij $62 \%$ van de informele netwerkleden adequate informatie over de leeftijd terwijl de hulpverleners dit bij $30 \%$ van de informele netwerkleden doen. Een dergelijk significant verschil treedt ook op inzake de werksituatie van de informele netwerkleden; de MSNA geeft hierover bij $58 \%$ van de informele netwerkleden adequate informatie terwijl dit bij de hulpverleners bij $23 \%$ van deze netwerkleden het geval is. Verhoudingsgewijs treedt tussen de MSNA en de inventarisatie van de hulpverleners een dergelijk significant verschil ook op omtrent de informatie over de burgelijke staat, de opleiding en de woonsituatie van de informele netwerkleden. Omtrent de informatie over het geslacht van de informele netwerkleden is er verhoudingsgewijs geen verschil tussen de MSNA en de inventarisatie van de hulpverleners.

Zowel gemiddeld als verhoudingsgewijs brengt de MSNA bij significant meer informele netwerkleden hun kenmerken van gevarieerdheid in kaart dan het geval is in de inventarisatie die de hulpverleners maken.

\subsubsection{Berelkbaarheid van de netwerkleden}

De analyse en bechrijving van de bereikbaarheid van de netwerkleden aan de hand van hypothese 21 betreft evenals bij de gevarieerdheid de informele netwerkleden van de onderzoekspopulatie.

\section{Ad hypothese 21}

Ten aanzien van de bereikbaarheid van de netwerkleden wordt gesteld dat het niet te voorspellen is welke verschillen dan wel overeenkomsten er worden aangetroffen tussen de informatie van de hulpverleners en de informatie die door de MSNA hierover wordt gegeven.

De volgende tabel 9.6 toont de resultaten omtrent de bereikbaarheid van de informele netwerkleden van de onderzoekspopulatie $(n=44)$ volgens de MSNA vergeleken met de informatie die de betreffende hulpverleners hierover hebben. 

onderzoekspopulatie $(n=44)$ volgens de MSNA vergeleken met de informatie van hulpverleners van de SPD.

\begin{tabular}{|c|c|c|c|c|}
\hline \multirow{2}{*}{ AFSTAND } & \multicolumn{4}{|c|}{ ONDERZOEKSPOPULATIE $(n=44)$} \\
\hline & $\mathrm{m}$ & sd & m & sd \\
\hline $\begin{array}{l}\text { eigen woonplaats } \\
\text { zelfde regio } \\
\text { buiten regio } \\
\text { buitenland }\end{array}$ & $\begin{array}{l}8.4 \\
2.0 \\
3.5 \\
0.8\end{array}$ & $\begin{array}{l}4.5 \\
4.9 \\
4.9 \\
1.2\end{array}$ & $\begin{array}{l}3.7^{\cdots} \\
0.9^{\circ} \\
0.9^{\star} \\
0.3^{*}\end{array}$ & $\begin{array}{l}2.7 \\
1.7 \\
1.1 \\
0.7\end{array}$ \\
\hline $\begin{array}{l}\text { bekend } \\
\text { geen informatie }\end{array}$ & $\begin{array}{l}14.7 \\
5.4\end{array}$ & $\begin{array}{l}7.1 \\
5.1\end{array}$ & $\begin{array}{l}5.8^{* \ldots *} \\
6.9\end{array}$ & $\begin{array}{r}3.5 \\
4.9\end{array}$ \\
\hline
\end{tabular}

$\ldots p<.001 ; * p<.05$

Tabel 9.6 geeft de volgende bevindingen.

- Via de MSNA zijn vergeleken met de informatie van de hulpverleners bij de ambulante chronisch psychiatrische patiënten in het geheel genomen gemiddeld significant meer informele netwerkleden bereikbaar (respectievelijk gemiddeld 14.7 en 5.8 infarmele netwerkleden, $T=7.38, p<.001$ ).

- De hulpverleners inventariseren gemiddeld 3.7 informele netwerkleden die in de woonplaats van de ambulante chronisch psychiatrische patient wonen terwijl de MSNA aangeeft dat de patiernten in de eigen woonplaats gemiddeld 8.4 informele netwerkleden hebben. Het verschil is significant: $T=5.82, p<.001$.

- Opmerkelijk is vervolgens dat bij de hulpverleners gemiddeld 0.9 informele netwerkleden bekend zijn die buiten de regio van de patiënt wonen terwijl de MSNA toont dat buiten de eigen regio gemiddeld 3.5 informele netwerkleden wonen. Dit verschil is eveneens significant: $T=3.39, p<.01$.

- Ook bij de informele netwerkleden in het bultenland geeft de MSNA een significant grotere bereikbaarheid aan dan de betreffende hulpverleners $(T=$ 2.20, $p<.05$ ).

De ambulante chronisch psychiatrische patiënten blijken met behulp van de MSNA zowel in de eigen woonplaats alsook buiten de eigen regio en in het buitenland gemiddeld significant meer informele netwerkleden te hebben dan in de informatie van de betreffende hulpverleners het geval is. Hoewel er een significant verschil optreedt in het gemiddeld aantal bereikbare informele netwerkleden tussen de informatie die de MSNA en die de hulpverleners erover geven, is het deel informele netwerkleden waarbij de hulpverleners geen adequate informatie geven gemiddeld nagenoeg gelijk aan het deel dat in de via de MSNA zichtbaar wordt (respectievelijk gemiddeld 6.9 en 5.4 informele netwerkleden).

\section{Tenslotte}

Omtrent de verdeling van de bereikbaarheid van de informele netwerkleden blijkt er een significant verschil op te treden tussen de informatie van de MSNA en de gegevens van de hulpverleners (Chisq. 114.79, $p<.001$ ). Dit verschil is met name toe te schrijven aan het deel netwerkleden over wie geen adequate informatie verstrekt wordt. Wanneer de informele netwerkleden over wie adequate informatie ontbreekt buiten beschouwing worden gelaten treedt er geen signicant verschil op in de verdeling. 
De analyse en beschrijving van de structuur van de betrekkingen betreft de contacten van de onderzoekspopulatie bestaande uit 44 ambulante chronische psychiatrische patiénten met alle (zowel de informele alsook de formele) netwerkleden. Achtereenvolgens worden de resultaten inzake de kenmerken initiatief, frequentie, gewicht enlengte gegeven.

Ter herinnering: de MSNA maakt zoals eerder weergegeven in tabel 9.2 maakt gemiddeld significant meer netwerkleden in het sociale netwerk van de patient zichtbaar dan de betreffende hulpverleners inventariseren (respectievelijk gemiddeld 25.0 en 17.6 netwerkleden; $T=4.36, p<.001$ ).

\section{INITIATIEF}

\section{Ad hypothese 22}

Verondersteld wordt dat de hulpverleners laten zien dat de contacten tussen de onderzoekspopulatie en hun netwerkleden overwegend tot stand komen via initiatief in de zin van vanzelfsprekendheid terwijl de MSNA een meer gedifferentieerd beeld geeft en met name ook het eigen initiatief van de ondezoekspopulatie toont.

In de volgende tabel 9.7 zijn de resultaten van de vergelijking conform hypothese 22 weergegeven.

TABEL 9.7 Het initiatief in de contacten mel de netwerkleden volgens de MSNA vergeleken met de informatie van hulpverleners van de SPD.

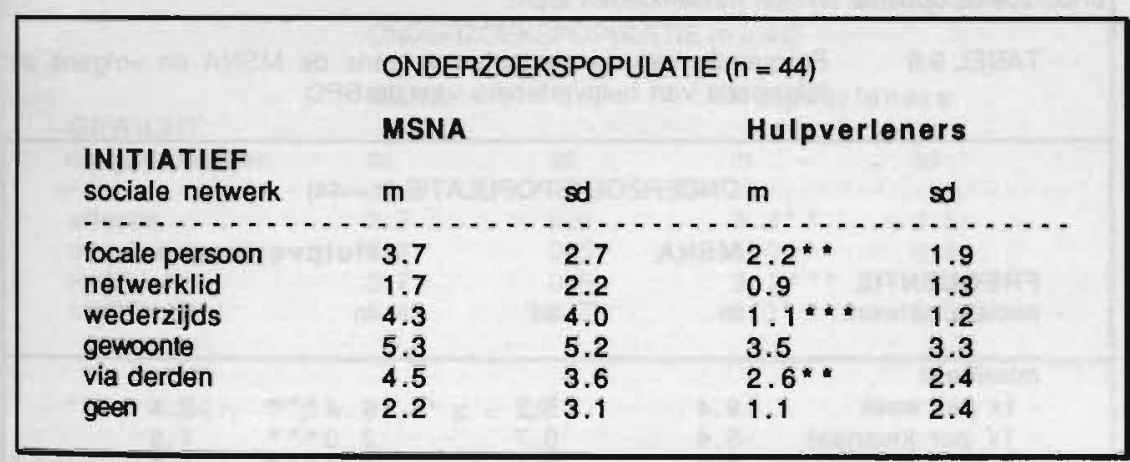

$\cdots p<.001, * p<.01$

Tabel 9.7 toont dat er in het geheel genomen geen verschil is tussen de informatie van de hulpverleners en die van de MSNA betreffende het deel van de contacten dat vanuit gewoonte ofwel als vanzelisprekend tot stand komt.

Opvallend is dat de MSNA gemiddeld significant meer contacten met netwerkleden zichtbaar maakt die overwegend uitgaan van het eigen initiatief van de patiènt dan de hulpverleners aangeven (respectievelijk gemiddeld 3.7 en 2.2 netwerkleden; $T=$ $2.97, p<.01)$. Het significante verschil dat hier optreedt hangt samen met de verschillen die optreden in de sectoren verwanten en vriendschappelijke betrekkingen. 
De MSNA toont in de sector verwanten gemiddeld meer netwerkleden bij wie het contact uitgaat van het eigen initiatief van de patienten dan de hulpverleners vermelden (respectievelijk gemiddeld 1.6 en 0.8 verwanten, $T=2.18, p<.05$ ). Hetzelfde geldt voor de sector vriendschappelijke betrekkingen (respectievelijk gemiddeld 1.0 en 0.3 netwerkleden, $T=2.69, p<.01$ ), (zie Bijlage VIII,1).

Tabel 9.7 laat vervolgens zien dat er in het geheel genomen tussen de MSNA en de hulpverleners significante verschillen optreden in het gemiddeld aantal netwerkleden met wie via wederzijds initiatief contact tot stand komt ( $T=5.07, p<.001)$ en met wie via het initiatief van derden het contact ontstaat $(T=2.76, p<.01)$. Overeenkomstige significante verschillen treden ook op in de sectoren verwanten en vriendschappelijke betrekkingen (zie Bijlage Vill,1).

Al bij al komt het er op neer dat de MSNA zowel een meer gedifferentieerd beeld geeft omtrent het initiatief in de contacten van de onderzoekspopulatie met de netwerkleden alsook aangeeft dat de onderzoekspopulatie in het algemeen gemiddeld meer initiatief toont - ook wederzijds initiatief impliceert eigen initiatief van de focale persoon - dan in de informatie van de hulpverleners zichtbaar wordt. Met andere woorden: het eerste deel van hypothese 22 wordt niet bevestigd terwijl het tweede deel van deze hypothese onderschreven wordt.

Tenslotte blijkt er tussen de informatie van de MSNA en die van de hulpverleners een significant verschil op te treden (Chisq. 28.69, $\mathrm{P}<.001$ ) in de verdeling van het initiatief over de netwerkleden.

\section{FREQUENTIE}

\section{Ad hypothese 23}

Verondersteld wordt dat er verschillen optreden in de informatie die de hulpverleners geven en die door de MSNA over de frequentie van de contacten tussen de onderzoekspopulatie en hun netwerkleden toont.

TABEL 9.8 Frequentie van de contacten volgens de MSNA en volgens de informatie van hulpverleners van de SPD.

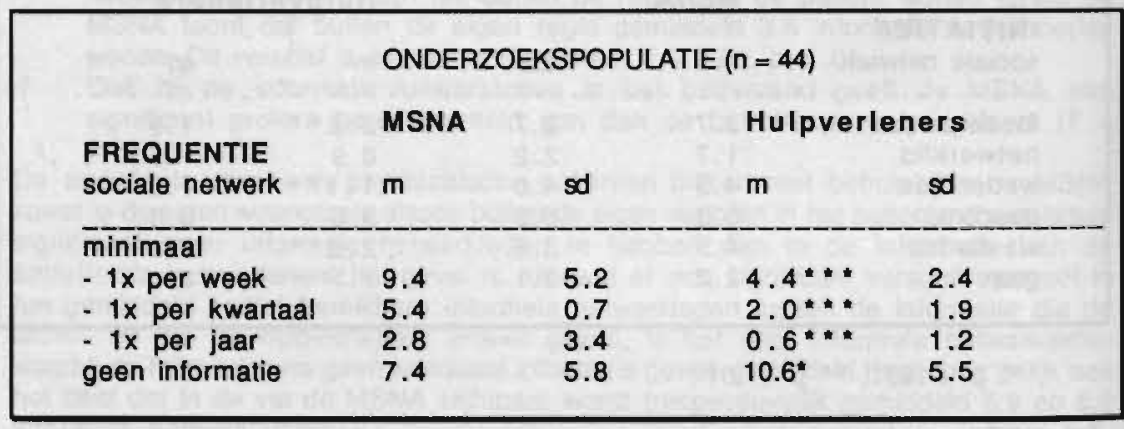

$* * p<.001, * * p<.01, * p<.05$

Er treden zoals bovenstaande tabel 9.8 toont inderdaad significante verschillen op tussen de informatie van de hulpverleners en die van de MSNA over de frequentie van de contacten met de netwerkleden. Betreffende het totale sociale netwerk toont de MSNA dat de ambulante chronisch psychiatrische patiènten met gemiddeld 9.4 netwerkleden zeer frequent (variërend van vrijwel dagelijks tot hooguit eenmaal per week) contact hebben. Bij de hulpverleners is dat voor gemiddeld 4.4 netwerkleden het geval. Dit optredende verschil is significant, te weten: $\mathrm{T}=5.83, \mathrm{p}<.001$. 
Vervolgens is er tussen de MSNA en de informatie van de hulpverleners een significant verschil in het gemiddeld aantal netwerkleden met wie minimaal eenmaal per kwartaal contact bestaat, (respectievelijk gemiddeld 5.4 en 2.0 netwerkleden, $T=$ $3.99, p<.001)$. Een dergelijk significant verschil treedt ook op ten aanzien van de nelwerkleden met wie minimaal eenmaal per jaar contact is (repectievelijk gemiddeld 2.8 en 0.6 netwerkleden, $T=3.91, p<.001$ ).

Tenslotte kan opgemerkt worden dat de MSNA vergeleken met de informatie van de hulpverleners gemiddeld significant minder netwerkleden geeft bij wie geen adequate informatie over de contactfrequentie beschikbaar is (respectievelijk gemiddeld 7.4 en 10.6 netwerkleden, $T=-2.57, p<.05$ ). Overigens blijkt er tussen de informatie van de MSNA en die van de hulpverleners een significant verschil op te treden in de verdeling van de frequentie van de contacten (Chisq. 181.17, $p<.001$ ). Ook wanneer het deel netwerkleden waarover geen adequate informatie wordt verstrekt buiten beschouwing wordt gelaten, treedt er een significant verschil in de verdeling op (Chisq. 11.49, $p<.01$ ).

\section{GEWICHT}

\section{Ad hypothese 24}

Verondersteld wordt dat de hulpverleners gemiddeld een lager gewicht geven aan het contact tussen de onderzoekspopulatie en hun netwerkleden dan door de MSNA zichtbaar wordt gemaakt. Het verschil betreft in het bijzonder de onderdelen affectieve behoeften en de behoeften aan aansluiting.

TABEL 9.9 Het gewicht in de contacten volgens de MSNA vergeleken met de informatie van hulpverleners van de SPD.

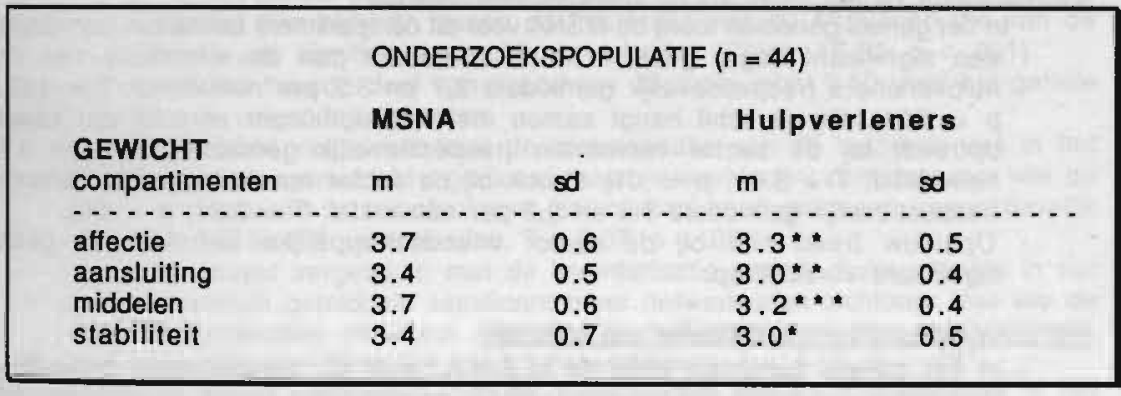

$\# * p<.001, * * p<.01, * p<.05$

Tabel 9.9 toont dat de hulpverleners in het geheel genomen gemiddeld een significan! lager gewicht geven aan de contacten tussen de ambulante chronisch psychiatrische patiënten en hun netwerkleden dan door de MSNA zichtbaar wordt gemaakt. Het verschil betreft niet alleen de compartimenten affectieve behoeften en de behoeften aan aansluiting maar ook het compartiment behoeften aan materiële en instrumentele middelen en hel compartiment behoeften aan stabiliteit. Alles tezamen wordt hypothese 24 bevestigd.

Tabel 9.9, aangevuld met de resultaten betreffende hel gewicht van de contacten met de netwerkleden per sector, weergegeven in Bijlage VIII,3 levert voor de verschillende compartimenten behoeften de volgende uitkomsten op. 
- In het geheel genomen toont de MSNA vergeleken met de informatie van de hulpverleners hier gemiddeld een significant hoger gewicht in de contacten fussen de patiënten en hun netwerkleden (respectievelijk gemiddeld 3.7 en 3.3 per netwerklid; $T=2.74, p<.01$ ).

Dit verschil hangt samen met het gegeven dat de MSNA vergeleken met de informatie van de hulpverleners gemiddeld een significant hoger gewicht zichtbaar maakt bij de contacten met de netwerkleden in de sector maatschappelijke diensten, (respectievelijk gemiddeld 3.8 en 3.4 per neiwerklid; $T=2.76, p<.01$ ).

- in de sector verwanten en de sector vriendschappelijke betrekkingen treden tussen de gegevens van de MSNA en die voortkomen uit de informatie van de befireffende hulpverleners geen significante verschillen op inzake het gewicht van de contacten voor het compartiment van de affectieve behoeften.

\section{Compartiment van de behoefte aan aansluiting}

- In het geheel genomen blijkt de MSNA voor het compartiment van de behoefte aan aansluiting gemiddeld een significant hoger gewicht in de contacten met de netwerkleden zichtbaar te maken dan in de informatie van de hulpverleners het geval is (respectievelijk gemiddeld 3.4 en 3.0 per netwerklid; $T=3.39, p<$ $.01)$.

- Een vergelijkbaar verschil wordt zowel teruggevonden bij de sector verwanten (respectievelijk gemiddeld 3.3 en 2.9 per netwerklid; $T=2.39, p<.05$ ) alsook bij de sector maatschappelijke diensten (respectievelijk gemiddeld 3.9 en 3.3 per netwerklid; $T=3.22, p<.01$ ).

- In de sector vriendschappelijke betrekkingen treden voor dit compartiment geen significante verschillen op.

\section{Compartiment van de materiele en instrumente behoeften}

- In het geheel genomen toont de MSNA voor dit compartiment behoeften gemiddeld een significant hoger gewicht in de contacten dan de informatie van de hulpverleners (respectievelijk gemiddeld 3.7 en 3.2 per netwerklid; $T=4.18$, $p<.001)$. Dit verschil hangt samen met het significant verschil dat zowel opireedt bij de sector verwanten (respectievelijk gemiddeld 3.6 en 3.1 netwerklid; $T=3.01, p<.01$ ) alsook bij de sector maatschappelijk diensten (respectievelijk gemiddeld 3.6 en 3.2 per netwerklid; $T=2.34, p<.05$ ).

- Opnieuw treed hier bij de sector vriendschappelijke betrekkingen geen significant verschil op.

\section{Het compartiment van de behoefte aan stabiliteit}

- In het geheel genomen blijkt de M.S.N.A. voor dit compartiment behoeften gemiddeld een significant hoger gewicht in de contacten tussen de patiënten en hun netwerkleden zichtbaar te maken dan het geval is in de informatie van de hulpverleners erover (respectievelijk gemiddeld 3.4 en 3.0 per netwerklid; $T$ $=2.64, p<.05)$. Dit verschil treedt echter niet in vergelijkbare mate op bij de afzonderlijke sectoren .

\section{LENGTE}

\section{Ad hypothese 25}

Verondersteld wordt dat de hulpverleners in meerderheid de langdurig bestaande contacten inventariseren terwijl de MSNA tevens de kortere contacten toont en aldus differentiatie aanbrengt. 
Hypothese 25 bevat twee onderdelen. In de eerste plaats is er de veronderstelling dat er tussen de informatie van de MSNA en de inventarisatie van de betreffende hulpverleners een verschil in de spreiding van de lengte van de contacten met de netwerkleden optreedt. In de tweede plaats wordt in samenhang met het zojuist genoemde eerste deel van deze hypothese tevens verondersteld dat de informatie van de MSNA in vergelijking met de inventarisatie van de hulpverleners een meer gedifferentieerd beeld geeft van de lengte van de contacten tussen de onderzoekspopulatie en de netwerkleden.

TABEL 9.10 De lengte van de contacten met de netwerkleden volgens de MSNA vergeleken met de informatie van hulpverleners van de SPD.

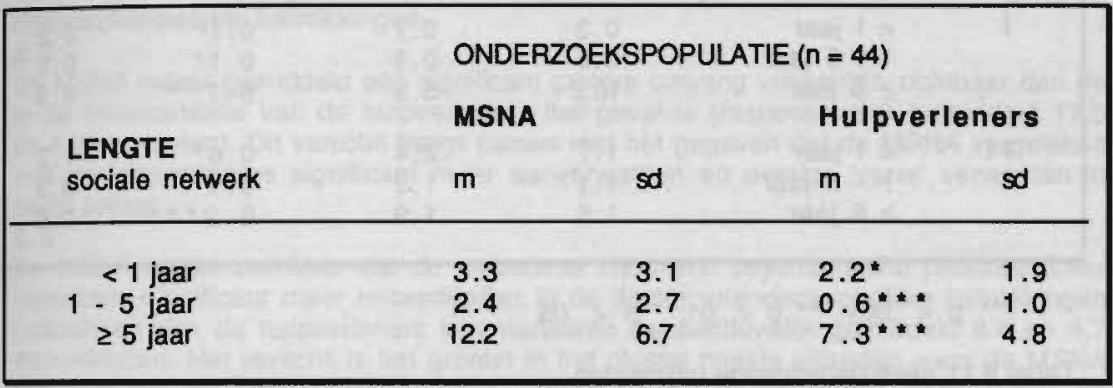

*** $p<.001, * p<.05$

Voor wat betreft het eerste deel van hypothese 25 is er de volgende uitkomst.

- Wanneer in het geheel genomen naar de verdeling van de lengte van de contacten wordt gekeken dan blijkt er tussen de informatie van de MSNA en die van de hulpverleners een significant verschil op te treden (Chisq. 16.22, $p<.001$ ).

Voor wat betreft het tweede deel van hypothese 25 toont tabel 9.10 voor het gehele sociale netwerk de volgende uitkomsten.

- De MSNA maakt vergeleken met de inventarisatie van de hulpverleners in hel geheel genomen gemiddeld significant meer netwerkleden zichtbaar met wie de onderzoekspopulatie in het afgelopen jaar contact heeft gekregen (respectievelijk gemiddeld 3.3 en 2.2 netwerkleden, $T=2.07, p<.05$ ).

- De MSNA maakt vergeleken met de inventarisatie van de hulpverleners in het geheel genomen gemiddeld significant meer netwerkleden zichtbaar met wie de onderzoekspopulatie minimaal eén jaar of maximaal vier jaar contact heeft, (respectievelijk gemiddeld 2.4 en 0.6 nelwerkleden, $T=4.13, p<.001$ ).

- De MSNA maakt vergeleken met de inventarisatie van de hulpverleners in het geheel genomen gemiddeld significant meer netwerkleden zichtbaar met wie de onderzoekspopulatie reeds vijf jaar of langer contact heeft, (respectievelijk gemiddeld 12.2 en 7.3 netwerkleden, $T=3.91, p<.001$ ).

De significante verschillen die in het geheel van het sociale netwerk tussen de MSNA en de informatie van de hulpverleners optreden betreffende de lengte van het contaci met de netwerkleden zijn ook te vinden in de sectoren verwanten vriendschappelijk betrekkingen (zie de volgende tabel 9.11). In de sector maatschappelijke diensten komen de gegevens van de MSNA nagenoeg met die van hulpverleners overeen. 

verwanten en vriendschappelijke betrekkingen volgens de MSNA vergeleken mel de informatie van hulpverleners van de SPD.

\begin{tabular}{|c|c|c|c|c|c|}
\hline \multirow{3}{*}{\multicolumn{2}{|c|}{$\begin{array}{l}\text { LENGTE } \\
\text { sectoren I en II }\end{array}$}} & \multicolumn{4}{|c|}{ ONDERZOEKSPOPULATIE $(n=44)$} \\
\hline & & \multicolumn{2}{|c|}{ MSNA } & \multicolumn{2}{|c|}{ Hulpverleners } \\
\hline & & m & sd & m & sd \\
\hline 1 & $\begin{array}{l}<1 \text { jaar } \\
1-5 \text { jaar } \\
\geq 5 \text { jaar }\end{array}$ & $\begin{array}{l}0.3 \\
0.5 \\
10.2\end{array}$ & $\begin{array}{l}0.7 \\
0.8 \\
5.9\end{array}$ & $\begin{array}{l}0.1^{\star} \\
0.1^{\star} \\
6.7^{\star}\end{array}$ & $\begin{array}{l}0.2 \\
0.5 \\
4.5\end{array}$ \\
\hline I I & $\begin{array}{l}<1 \text { jaar } \\
1-5 \text { jaar } \\
\geq 5 \text { jaar }\end{array}$ & $\begin{array}{l}1.7 \\
1.1 \\
1.5\end{array}$ & $\begin{array}{l}2.4 \\
1.9 \\
1.9\end{array}$ & $\begin{array}{l}0.6^{*} \\
0.1 \ldots \\
0.2^{*} \ldots\end{array}$ & $\begin{array}{l}1.2 \\
0.3 \\
0.6\end{array}$ \\
\hline
\end{tabular}

*** $p<.001, * p<.01, * p<.05$

Tabel 9.11 geeft de volgende uitkomsten.

- De MSNA toont vergeleken met de informatie van de hulpverleners dat de ambulante chronisch psychiatrische patiënten gemiddeld significant meer verwanten hebben

$=\quad$ met wie in het afgelopen jaar contact is ontstaan $(T=2.17, p<.05)$;

$=\quad$ met wie minimaal één jaar of maximaal vier jaar contact is $(T=2.61, p$ $<.01)$;

= met wie vijf jaar of langer contact bestaat $(T=3.03, p<.001)$.

- De MSNA toont vergeleken met de informatie van de hulpverleners van de SPD dat de patienten gemiddeld significant meer netwerkleden in de sector vriendschappelijke betrekkingen hebben

$=\quad$ met wie in het afgelopen jaar contact is ontstaan ( $T=2.62, p<.05$ );

= met wie minimaal éen jaar of maximaal vier jaar contact bestaat ( $T$ = $3.51, p<.01)$;

- met wie vijf jaar of langer contact bestaat ( $T=4.16, p<.001$ ).

Al bij al geven de in tabel 9.10 en in tabel 9.11 gepresenteerde uitkomsten van de analyse van de lengte van het contact aan dat de MSNA een gedifferentieerder en ook vollediger beeld geeft dan het geval is in de informatie van de hulpverleners. Dit betekent dat het tweede deel van hypothese 25 ais bevestigd kan worden beschouwd.

\section{TENSLOTTE}

Met de toelsing van hypothese 25 en de weergave van de resultaten ervan is de beantwoording van vraagstelling II betreffende de verschillen tussen dan wel de overeenkomsten in de informatie van de MSNA en de inventarisatie van de hulpverleners inzake de structuur van het sociale netwerk van de ambulante chronisch psychiatrische patiënten $(n=44)$ afgerond. In de volgende paragraaf 9.3 worden de resultaten in hoofdpunten samengevat. 


\section{3}

RESULTATEN IN HOOFDPUNTEN

In hoofdpunten kunnen bij vraagstelling II de volgende resultaten gegeven worden.

\section{A Omvang en samenstelling van de omvang}

\section{a.1}

Hulpverleners inventariseren gemiddeld een significant geringere omvang netwerkleden bij ambulante chronisch psychlatrische patienten dan met behulp van de MSNA het geval is (respectievelijk gemiddeld 17.6 en 25.0 netwerkleden). Dit verschil hangt samen met de significante verschillen die optreden tussen de inventarisatie van hulpverleners en die van de MSNA in de sector verwanten en vriendschappelijke betrekkingen.

a. 2

De MSNA maakt gemiddeld een significant grotere omvang verwanten zichtbaar dan de in de inventarisatie van de hulpverleners het geval is (respectievelijk gemiddeld $\mathbf{1 1 . 5}$ en 8.0 verwanten). Dit verschil hangt samen met het gegeven dat de MSNA vergeleken met de hulpverleners significant meer aanverwanten en overige 'verre' verwanten in beeld brengt.

a. 3

De MSNA maakt zichtbaar dat de ambulante chronisch psychiatrische patienten over gemiddeld significant meer netwerkleden in de sector vriendschappelijke betrekkingen beschikken dan de hulpverleners inventariseren (respectievelijk gemiddeld 8.6 en 4.7 netwerkleden. Het verschil is het grootst in het cluster naaste vrienden waar de MSNA aantoont dat de onderzoekspopulatie gemiddeld 2.3 netwerkleden heeft terwijl de hulpverleners hier gemiddeld 0.5 netwerkleden inventariseren. De hulpverleners kunnen bijvoorbeeld bij $64 \%$ van de patiënten geen naaste vrienden noemen, terwijl bij de MSNA in $29 \%$ van de gevallen geen naaste vrienden worden vermeld.

a.4

De gemiddelde omvang netwerkleden die door de hulpverleners bij de clusters partner/eigen gezin en bloedverwanten en bij de clusters werk/scholing en hulpverlening in beeld gebracht wordt komt nagenoeg overeen met de inventarisatie die met behulp van de MSNA bij deze clusters wordt gemaakt. Bij deze clusters netwerkleden hebben de hulpverleners vrijwel dezelfde informatie als die door de MSNA wordt gegeven.

a.5

De MSNA toont in vergelijking met de informatie van de hulpverleners dat de patiènten gemiddeld significant meer informele netwerkleden hebben (respectievelijk gemiddeld 20 en 13 netwerkleden).

\section{B Gevarieerdheid van de netwerkleden}

\section{b. 1}

Vergeleken met de inventarisatie van de hulpverleners geeft de MSNA over gemiddeld significant meer informele netwerkleden informatie over hun status- en positierollen. Het komt er op neer dat met uitzondering van het kenmerk 'geslacht' de MSNA vergeleken met de inventarisatie van de hulpverleners ook zowel gemiddeld als verhoudingsgewijs significant meer informatie geeft over de status- en positierollen van de informele netwerkleden van de ambulante chronisch psychiatrische patiënten. 


\section{Bereikbaarheid van de netwerkleden}

C. 1

De MSNA geeft over gemiddeld significant meer informele netwerkleden adequate informatie over de woon- dan wel verblijfsplaats van de netwerkleden dan in de inventarisatie van de hulpverleners het geval is.

\section{c. 2}

De MSNA en de inventarisatie van de hulpverleners tonen dat gemiddeld de meerderheid van de informele netwerkleden in de eigen woonplaats van de ambulante chronisch psychiatriche patiēnt woont. Echter de MSNA laat zien dat de patiënt gemiddeld significant meer informele netwerkleden in de eigen woonplaats heeft dan uit de inventarisatie van de hulpverleners blijkt.

\section{c. 3}

Ook buiten de eigen regio blijkt de onderzoekspopulatie volgens de MSNA gemiddeld significant meer informele netwerkleden te hebben dan in de inventarisatie van de hulpverleners het geval is.

\section{Structuur van de betrekkingen}

\section{Inltiatief}

d.1

De ambulante chronisch psychiatrische patiënten blijken in het sociale netwerk in haar geheel en in het informele deel ervan volgens de MSNA naar gemiddeld significant meer netwerkleden zelf het initiatief tot contact te nemen dan in de inventarisatie van de hulpverleners aangegeven wordt.

d. 2

De MSNA toont dat in het sociale netwerk van de patiënten gemiddeld met significant meer netwerkleden het contact tot stand komt op basis van wederzijds initiatief dan de inventarisatie van de hulpverleners aangeeft. Deze uitkomst wordt ook in de sectoren verwanten en vriendschappelijke betrekkingen aangetroffen.

d. 3

Er zijn in het geheel genomen tussen de informatie van de MSNA en de inventarisatie van de hulpverleners geen significante verschillen in het gemiddeld aantal netwerkleden die overwegend zelf het initiatief tot contact met de patiënt nemen en met wie het contact op basis van gewoonte ofwel als vanzelfsprekend ontstaat. Eveneens zijn er in het geheel genomen geen significante verschillen in het gemiddeld aantal netwerkleden met wie uitdrukkelijk geen contact wordt opgenomen.

\section{Erequentle}

\section{d. 4}

In de informatie die door de MSNA en die door de hulpverleners over de frequentie van de contacten tussen de ambulante chronisch psychiatrische patiënten en hun nelwerkleden wordt gegeven treden significante verschillen op. Het komt er op neer dat bij alle categorieern omtrent de frequentie van het contact de hulpverleners over gemiddeld significant minder netwerkleden informatie geven dan bij de MSNA het geval is.

d. 5

Deze significante verschillen tussen de informatie van de MSNA en die van de hulpverleners zijn het grootst $(p<.001)$ voor wat betreft het deel netwerkleden over wie adequate informatie over de frequentie van het contact wordt verstrekt. Inzake het deel netwerkleden waarbij adequate informatie ontbreekt is, hoewel er eveneens sprake is van een significant verschil $(p<.05)$, dit verschil aanzienlijk kleiner. 


\section{Gewlcht}

d. 6

In de informatie van de MSNA blijkt dat de ambulante chronisch psychiatrische palienten voor alle compartimenten behoeften aan de contacten met hun netwerkleden gemiddeld een significant hoger gewicht geven dan in de informatie van de hulpverleners het geval is. In het geheel genomen is hel verschil significant het grootst betreffende het compartiment van de behoefte aan materiele en instrumentele middelen.

\section{d. 7}

De M.S.N.A. toont dat de patienten voor wat betreft het compartiment van de affectieve behoeften aan het contact met hun netwerkleden in de sector maatschappelijke diensten een gemiddeld een significant hoger gewicht geven dan in de informatie van de hulpverleners wordt aangetroffen. In de sectoren verwanten en vriendschappelijke betrekkingen treden hier geen significante verschillen op.

d. 8

Omtrent het compartiment van de behoefte aan aansluiting geven de patiënten via de MSNA aan het contact met hun verwanten en aan het contact met hun netwerkleden in de sector maatschappelijke diensten een significant hoger gewicht dan in de informatie van de hulpverleners wordt aangetroffen.

d.9

Omirent hel compartiment van de behoefte aan stabiliteit in het contact is er gemiddeld nagenoeg geen verschil tussen de MSNA en de informalie van de hulpverleners in het gewicht dat aan het contact met de netwerkleden in de afzonderlijke sectoren wordt gegeven.

\section{d. 10}

\section{Lenate}

Zowel de MSNA als de inventarisatie van de hulpverleners toont dat in het geheel genomen de ambulante chronisch psychiatriche patiënten gemiddeld met de meerderheid van hun netwerkleden reeds vijf jaar of langer contact hebben. Echter de MSNA toont in vergelijking met de inventarisatie van de hulpverleners dat de patiènten gemiddeld significant meer netwerkleden hebben met wie reeds vijf jaar of langer contact bestaat.

d.11

Het overgrote deel van de reeds lang bestaande contacten van de patiènten betreft nelwerkleden in de sector verwanten. Daarnaast maakt de MSNA vergeleken met de informatie van de hulpverleners bij de patiënten gemiddeld signilicant meer verwanten zichtbaar met wie de patiènten reeds lang tijd contact hebben.

\section{d.12}

In de informatie van de hulpverleners komt naar voren dat in het geheel genomen de patiënten met de meerderheid van hun netwerkleden in de sector vriendschappelijke betrekking pas in het afgelopen jaar in contact zijn gekomen, terwijt de MSNA aangeeft dat dit bij ruim éénderde van hun netwerkleden in deze sector het geval is.

d.13

De informatie van de MSNA laat vergeleken met inventarisatie van de hulpverleners bovendien zien dat de patiënten in de sector vriendschappelijke belrekkingen gemiddeld significant meer netwerkleden heben met wie sinds kort en met wie al lange(re) tijd contact bestaat.

d.14.

De significante verschillen die in het geheel genomen optreden tussen de informatie van de MSNA en die van de hulpverleners omtrent de lengte van de contacten van de ambulante psychiatrische patiënten met netwerkleden worden niet aangetroffen in de sector maalschappelijke diensten. Hier komt de informatie van de MSNA nagenoeg overeen mel die van de hulpverleners. 


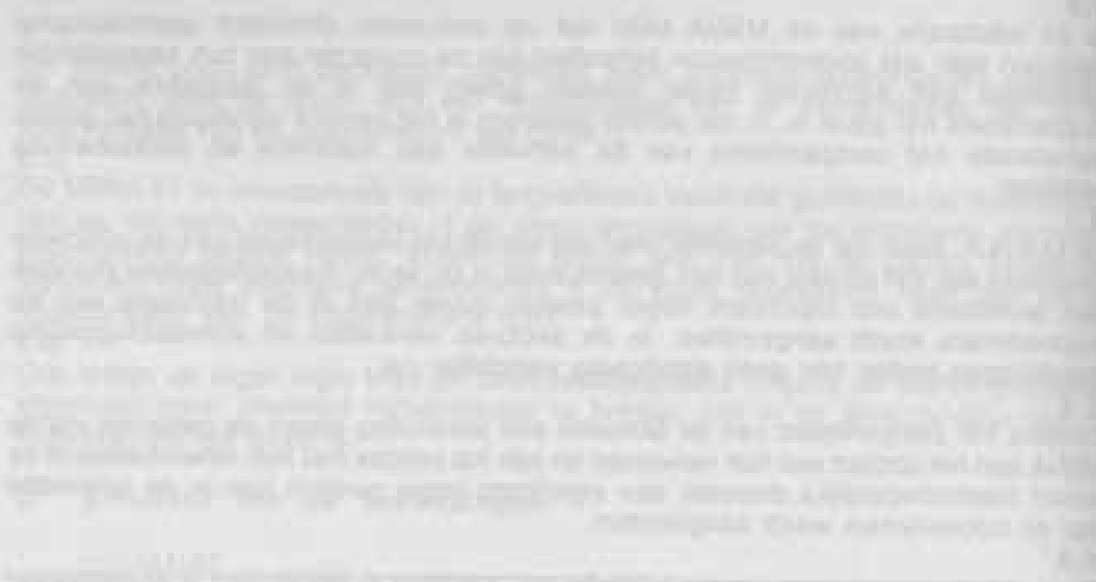




\section{SOCIALE NETWERKEN VAN JONGERE EN OUDERE PATIENTEN}

In dit hoofdstuk komen achtereenvolgens vraagstelling III en IV van het onderzoek aan de orde, te weten:

III WELKE VERSCHILLEN DAN WEL OVEREENKOMSTEN, C.Q. PATRONEN BESTAAN ER IN DE STRUCTUUR VAN DE SOCIALE NETWERKEN BIJ DE GROEP JONGERE EN BIJ DE GROEP OUDERE AMBULANTE CHRONISCH PSYCHIATRISCHE PATIENTEN?

IV WELKE VERSCHILLEN DAN WEL OVEREENKOMSTEN, C.Q PATRONEN BESTAAN ER IN DE STRUCTUUR VAN SOCIALE NETWERKEN BIJ DE GROEP JONGERE EN DE GROEP OUDERE AMBULANTE CHRONISCH PSYCHIATRISCHE PATIENTEN VERGELEKEN MET DE JONGERE EN OUDERE REFERENTIEPERSONEN?

10.1

\section{INLEIDING}

Voor de vergelijking van de structuur van de sociale netwerken tussen de groep jongere en de groep oudere ambulante chronisch psychiatrische patiënten, vraagstelling III van het onderzoek, is de gehele onderzoekspopulatie $(N=59)$ genomen. De reden is dat de resultaten betreffende de omvang van het gehele sociale netwerk en die van de omvang van de sectoren en clusters bij de totale onderzoekspopulatie van 59 patiënten nagenoeg overeen blijken te komen met de resultaten omtrent de omvang bij de 47 patiënten voor wie referentiepersonen gevonden konden worden en mel die bij de 44 paliënten over wie de hulpverleners geïnterviewd zijn (zie Bijlage VI, 1 tot en met 4).

Voor de vergelijking van de structuur van de sociale netwerken bij de groepen jongere en oudere patiënten met die van de groepen jongere en oudere referentiepersonen, vraagstelling IV van dit onderzoek, is gebruik gemaakt van de onderzoekspopulatie $(n=47)$ waarvoor referentiepersonen $(n=47)$ beschikbaar zijn. De groepen jongeren zijn focale personen uit de onderzoekspopulatie(s) en referentiepersonen in de leeftijd vanaf 18 tot en met 34 jaar; de groepen ouderen betreffen focale personen vanaf 35 jaar.

In de volgende tabel 10.1 wordt vooraf aan de resultaten het sociaal demografisch profiel van de groepen jongere en oudere focale personen bij vraagstelling III on IV gegeven en vergeleken. 
TABEL 10.1 Sociaal demografisch profiel van de groepen jongere en oudere focale personen bij vraagstelling III en IV.

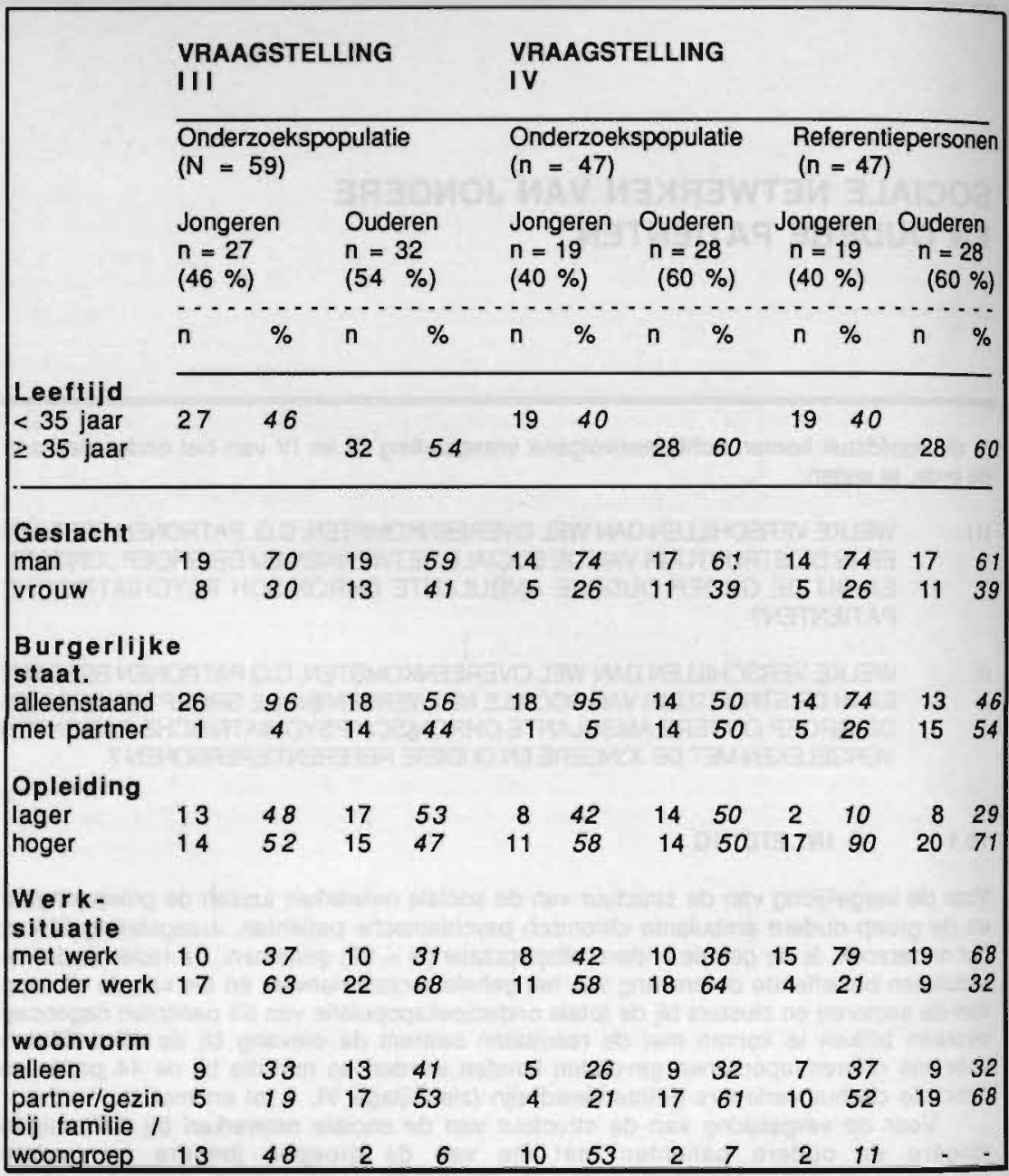

Bovenstaande tabel 10.1 toont dat de verhouding jongere - oudere ambulante chronisch psychiatrische patiënten in de totale onderzoekspopulatie van 59 patiënten bij vraagstelling III nagenoeg overeenkomt met die bij de onderzoekspopulatie van 47 patiênten bij vraagstelling IV aangetroffen wordt. De jongere patiēnten bij vraagstelling III sluiten qua sociaal demografisch profiel (in termen van sociale netwerkanalyse de kenmerken van gevarieerdheid) vrijwel aan op de jongere patiēnten bij vraagstelling IV. Datzelfde geldi ook voor de beide groepen oudere patiënten. Achtereenvolgens zullen in $\S 10.2$ de resultaten ad vraagstelling III en in $\S 10.3$ de resultaten ad vraagstelling IV weergegeven worden. Dit hooldstuk wordt atgesloten met een weergave van de hootdlijnen in de resultaten bij beide vraagstellingen. 
Allereerst een korte schets van het sociaal demografisch profiel van de focale personen bij vraagstelling III. Tabel 10.1 toont dat de 27 jongere ambulante chronisch psychiatrische patiënten van de totale onderzoekspopulatie $(N=59)$ merendeels ofwel voor $70 \%$ ) uit mannen bestaat. Bij de oudere patiënten $(n=32)$ is een meer evenwichtige verdeling tussen mannen en vrouwen aanzwezig. De jongere patiěnten zijn hoofdzakelijk ( $96 \%$ ) alleenstaand, terwijl dit bij de oudere patienten voor een meerderheid (56\%) geldt. Qua opleiding lopen de verschillen tussen beide groepen nauwelijks uiteen. Ongeveer tweederde van de jongere en van de oudere patiënten is zonder werk of dagvullende activiteiten zoals scholing. In de woonsituatie treden opmerkelijke verschillen op, dat wil zeggen een klein aantal (19\%) van de jongere patiènten woont samen met een partner dan wel in een eigen gezinssituatie terwijl dit bij de helft van de oudere patienten het geval is. Een ander verschil is dat $48 \%$ van de jongere patiënten in het ouderlijk huis (in)woont terwijl dit bij $6 \%$ van de oudere patiënten het geval is.

\subsubsection{Omvang en samenstelling van de omvang}

De analyse en beschrijving van de omvang on samenstelling van de omvang ad vraagstelling III is conform de hypothesen 26 tot en met 29 (zie $\$ 6.2 .3$ ) gebeurd.

De resultaten inzake de omvang van het sociale netwerk en de verdeling van de netwerkleden over sectoren en clusters bij de groep jongeren vergeleken met die bij de groep ouderen van de onderzoekspopulatie $(N=59)$ worden gegeven in onderstaande tabel 10.2.

TABEL 10.2 De omvang en samenstelling van het sociale netwerk bij de jongere en bij de oudere ambulante chronisch psychiatrische patiënten

\begin{tabular}{|c|c|c|c|c|c|c|}
\hline \multirow{3}{*}{$\begin{array}{l}\text { OMVANG } \\
\text { sectoren en } \\
\text { clusters }\end{array}$} & \multicolumn{5}{|c|}{ ONDERZOEKSPOPULATIE } & 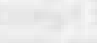 \\
\hline & \multicolumn{2}{|c|}{ JONGEREN } & \multirow{2}{*}{$\begin{array}{l}\text { (n }=27) \\
\text { range }\end{array}$} & \multicolumn{3}{|c|}{ OUDEREN $(n=32)$} \\
\hline & $\mathrm{m}$ & sd & & $\mathrm{m}$ & $\Sigma d$ & range \\
\hline \multicolumn{7}{|c|}{ 年 } \\
\hline -parnner / gezin & 0.4 & 0.6 & $0-2$ & $2.9 * *$ & 2.4 & $0-8$ \\
\hline -bloedverwanten & 4.7 & 2.4 & $2-14$ & 5.0 & 3.4 & 0.14 \\
\hline -aanverwanten & 1.7 & 1.4 & $0-4$ & 2.1 & 1.9 & $0-8$ \\
\hline -overigen & 2.8 & 3.1 & $0-14$ & 3.0 & 3.0 & e. 15 \\
\hline tolaal & 9.6 & 4.1 & $3-18$ & $13.0^{*}$ & 6.9 & $2-32$ \\
\hline \multicolumn{7}{|l|}{ II } \\
\hline -vrienden & 3.0 & 2.4 & $0-9$ & 2.4 & 3.8 & $0-17$ \\
\hline -overigen & 6.3 & 5.4 & $0-21$ & 5.8 & 3.9 & 0.15 \\
\hline tolaal & 9.3 & 5.5 & $3-23$ & 8.2 & 5.3 & $1 \cdot 22$ \\
\hline \multicolumn{7}{|l|}{111} \\
\hline -werk / scholing & 2.5 & 2.2 & 0.7 & $0.9 *$ & 1.4 & $0-4$ \\
\hline -hulpverlening & 3.1 & $\ldots$ & $2-6$ & 3.3 & $\ldots$ & $1-7$ \\
\hline tolaal & 5.6 & 2.7 & $2-12$ & $4.2^{\star}$ & 1.8 & $1-8$ \\
\hline Sociale netwerk & 24.5 & 8.5 & $12-51$ & 25.4 & 10.3 & $7-55$ \\
\hline
\end{tabular}

$* * p<.001 ; * * p<.01 ; * p<.05$. 


\section{Ad hypothese 26}

Verondersteld wordt dat de omvang van de sector verwanten voor beide groepen van de onderzoekspopulatie gelijk is.

Hypothese 26 wordt niet bevestigd. Bij de jongere patiënten is de gemiddelde omvang verwanten significant kleiner dan bij de groep oudere ambulante chronisch psychiatrische patiënten. De jongere patiënten hebben gemiddeld 9.6 netwerkleden in de sector verwanten terwill de oudere patiënten hier gemiddeld 13.0 netwerkleden hebben $(T=-2.33, p<.05)$. Dit significante verschil komt vrijwel uitsluitend voon uit het cluster partner / eigen gezin $(T=-5.55, p<.001)$. Dit significante verschil in het cluster partner / eigen gezin hangt samen met hel gegeven dat $96 \%$ van de jongere patiënten alleenstaand is. Bij de jongeren kunnen 19 patiënten (70\%) geen netwerkleden noemen die tot het cluster partner / eigen gezin behoren terwijl bij de ouderen slechts vijf patiënten (16\%) zeggen geen netwerkleden in dit cluster te kunnen noemen.

Lel wel, de term alleenstaand kan inhouden dat er eerder lemand als netwerklid in de zin van partner is geweest. Dit betekent bijvoorbeeld dat patiènten die alleenstaand zijn ofwel tijdens de fase van informatieverzameling zonder partner zijn in principe een netwerklid kunnen noemen die gerekend moet worden tot het cluster partner 1 gezin. Immers tot de omvang van een sociaal netwerk worden ook die personen gerekend 'met wie een focale persoon geen contact meer heeft (maar wel eerder gehad heeft) en die duurzaam in de beleving, positief of negatief gekleurd, aanwezig zijn' (Bijlage I). Het laatste is het geval bij vijf jongere alleenstaande patiënten die een vroegere parıner als netwerklid noemen.

\section{Ad hypothese 27}

Verondersteld wordt dat de jongere patiënten gemiddeld meer netwerkleden in de sector vriendschappelijke betrekkingen hebben dan de oudere patiënten

Deze hypothese wordt eveneens niet bevestigd. Tabel 10.2 toont dal er geen verschil is tussen beide groepen in zowel de gemiddelde totale omvang van de sector vriendschappelijke betrekkingen alsook in de gemiddelde omvang van de clusters binnen deze sector. Echter, zoals de volgende tabel 10.3 toont, achter het gemiddeld overeenkomstige aantal netwerkleden in het cluster vrienden gaan belangrijke verschillen in de opbouw van het aantal beschikbare vrienden schuil tussen de jongere en oudere ambulante chronisch psychiatrische patiënten.

TABEL 10.3 Aantal vrienden bij de jongere en oudere ambulante chronisch psychiatrische patiënten.

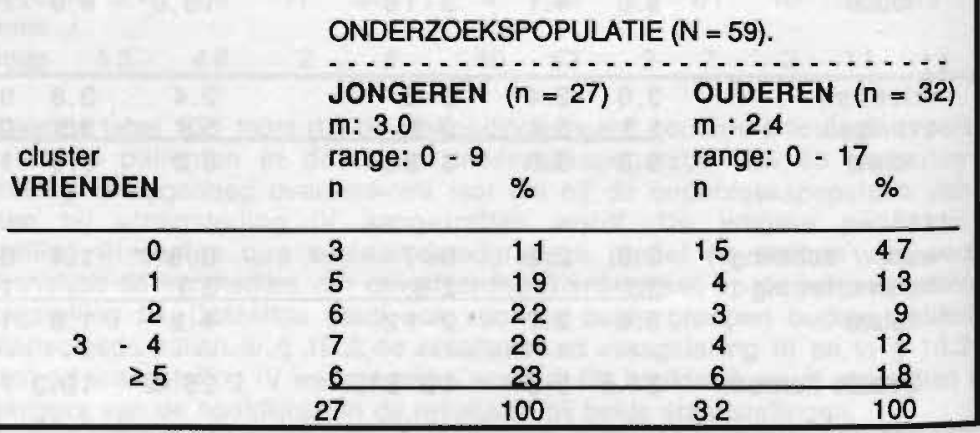


Een opmerkelijk gegeven in tabel 10.3 is dat $47 \%$ van de oudere patiènten geen netwerkleden kunnen noemen die tot het cluster vrienden behoren terwijl dit bij de jongere patiênten slechts voor $11 \%$ het geval is. Vervolgens blijkt dat ongeveer evenveel jongere als oudere patiënten één netwerklid binnen dit cluster kunnen noemen. Daarna treedt er opnieuw een verschil op, te weten: $48 \%$ van de jongere patiënten rekent twee tot vier netwerkleden tot het cluster vrienden, terwijl hiervan slechts bij $21 \%$ van de oudere ambulante chronisch psychiatrische patiënten sprake is.

\section{Ad hypothese 28}

Verondersteld wordt dat er in de omvang van de sector maatschappelijke diensten, in het bijzonder bij het deel hulpverlening, verschillen tussen de jongere en de oudere patiënten zullen worden aangetroffen.

De resultaten zoals getoond in tabel 10.2 zijn voor wat betreft de totaal gemiddelde omvang van deze sector in overeenstemming met hypothese 28 . De gemiddelde omvang van deze sector is bij de oudere patiënten significant kleiner dan bij de jongere patiënten (respectievelijk gemiddeld 4.2 en 5.6 netwerkleden, $T=2.30, p<.05$ ). Dit verschil komt voort uit het significante verschil dat tussen de jongere en oudere patiënten optreedt in de gemiddelde omvang netwerkleden bij het cluster werk I scholing (respectievelijk gemiddeld 0.9 en 2.5 netwerkleden, $T=3.21, p<.01$ ). Het significante verschil in de gemiddelde omvang van de sector maatschappelijke diensten hangt niet zoals verondersteld werd samen met het cluster hulpverlening. De jongere en de oudere ambulante chronisch psychiatrische patiënten hebben een gemiddeld gelijke omvang netwerkleden die de hulpverlening vertegenwoordigen (respectievelijk gemiddeld 3.1 en 3.3 netwerkleden). Ter illustratie in tabel 10.4 een overzicht van de opbouw van de netwerkleden in het cluster werk / scholing bij de jongere en de oudere ambulanie chronisch psychiatrische patiënten.

TABEL 10.4 Aantal netwerkleden in het cluster werk /scholing bij de jongere en de oudere patiënten

\begin{tabular}{|c|c|c|c|c|}
\hline \multirow{2}{*}{$\begin{array}{l}\text { cluster } \\
\text { WERK/SCHOLING }\end{array}$} & \multicolumn{4}{|c|}{ 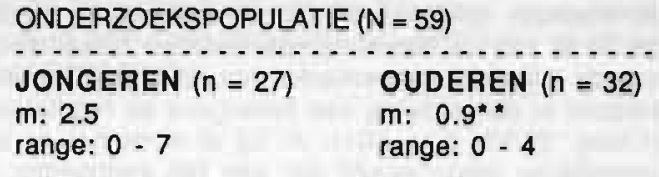 } \\
\hline & $\mathrm{n}$ & $\%$ & n & $\%$ \\
\hline 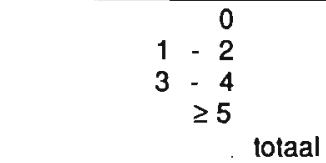 & $\begin{array}{r}8 \\
3 \\
11 \\
5 \\
27\end{array}$ & $\begin{array}{l}30 \\
11 \\
41 \\
18 \\
100\end{array}$ & $\begin{array}{r}21 \\
3 \\
8 \\
- \\
32\end{array}$ & $\begin{array}{r}66 \\
9 \\
25 \\
- \\
100\end{array}$ \\
\hline
\end{tabular}

$* P<.01$

Bovenstaande tabel 10.4 toont dat tweederde van de oudere patiënten geen nelwerkleden kan noemen binnen het cluster werk / scholing terwijl dit bij de jongeren voor $30 \%$ geldt. Vervolgens blijkt dat een vrijwel gelijk klein aantal jongere en oudere ambulante chronisch psychiatrische patiënten één tol twee nelwerkleden in dit cluster te kunnen noemen. Daarna treedt er opnieuw een belangrijk verschil op; namelijk: 41 $\%$ van de jongeren noemt drie tot vier netwerkleden terwijl de ouderen dit slechts in $25 \%$ van de gevallen doen. 
De gevarieerdheid van de sociale netwerken van de jongere $(n=27)$ en oudere $(n=$ 32) ambulante chronisch psychiatrische patiënten betreft de informele netwerkleden ofwel de netwerkleden in de sector verwanten en de sector vriendschappelijke betrekkingen tesamen (respectievelijk 18.9 en 21.2 informele netwerkleden). De analyse vindt plaats aan de hand van hypothese 29 (zie $\$ 6.2 .3$ ).

\section{Ad hypothese 29}

Verondersteld wordt dat de sociale netwerken van de jongere patiënten gemiddeld qua status- en positierollen homogener samengesteld zijn dan die van de oudere ambulante chronisch psychiatrische patiënten.

Een gedetailleerd overzicht van de resultaten ad hypothese 29 is aanwezig in Bijlage VII, 3. De resultaten komen er in het algemeen op neer dat waar er tussen de jongere en oudere patiënten in de samenstelling inzake status- en positierollen van de informele netwerkleden in hun sociale netwerken verschillen optreden, de sociale netwerken van de oudere patiënten significant homogener zijn samengesteld dan die van de jongere patiënten. Anders gezegd: waar significante verschillen optreden zijn de sociale netwerken van de jongere patiënten minder homogeen samengesteld dan die van de oudere patiënten. Ter illustratie worden hier de volgende uitkomsten gegeven.

Het deel van de informele netwerkleden dat qua leeftijd overeenkomt met de jongere patiënten bestaat uit $55 \%$ van de netwerkleden terwijl dat bij de oudere patienten uit $73 \%$ van de informele netwerkleden bestaat. Er is sprake van een significant verschil in de verdeling van het homogene en het heterogene deel: Chisq. 24.86, $p<.001$ ). Ook het homogene deel informele netwerkleden met betrekking 101 burgerlijke staat is vergeleken met de jongere patiënten significant groter bij de oudere patiënten (respectievelijk $44 \%$ en $56 \%$; Chisq. 10.32, p < .05). Anders gezegd: in tegenstelling tot de oudere patiěnten overheerst in de sociale netwerken van de jongere patiënten qua burgelijke staat het heterogene deel informele netwerkleden.

Een significant verschil treedt vervolgens op inzake het opleidingsniveau van de informele netwerkleden (het homogene deel bestaat respectievelijk uit $68 \%$ en $78 \%$ van de informele netwerkleden; Chisq. 5.75. $p<.05$ ). Tenslotte blijkt dat het deel van de informele netwerkleden dat qua woonsituatie aansluit op de jongere patiënten bestaat uit $34 \%$ van de informele netwerkleden terwijl dit bij de oudere patiënten voor $54 \%$ van de informele netwerkleden het geval is. Er is eveneens sprake van een significant verschil in de verdeling van homogene en het heterogene deel informele netwerkleden (Chisq. 30.98, $p<.001$ ). Al bij al komt het er op neer dat de resultaten van de vergelijking tegengesteld zijn aan het vermoeden dat in hypothese 29 uitgesproken wordt.

\subsubsection{Bereikbaarheid van de netwerkleden}

De analyse en bechrijving van de bereikbaarheid van de netwerkleden die plaats vindi aan de hand van hypothese 30 (zie $\$ 6.2 .3$ ) betreft de informele nelwerkleden. Ter herinnering: tussen de jongere en de oudere ambulante chronisch psychiatrische patiënten is er geen significant verschil in de gemiddelde omvang informele netwerkleden (respectievelijk gemiddeld 18.9 en 21.2 netwerkleden). 


\section{Ad hypothese 30}

Verondersteld wordt dat er geen verschillen tussen de jongere en de oudere ambulante chronisch psychiatrische patiënten inzake de bereikbaarheid van de netwerkleden optreden.

In de volgende tabel 10.5 worden de resultaten betreffende de bereikbaarheid van de informele netwerkleden van groep jongere en oudere ambulante chronisch psychiatrische patiënten gegeven.

TABEL 10.5 Bereikbaarheid van de informele netwerkleden van de jongere en de oudere ambulante chronisch psychiatrische patiënten.

\begin{tabular}{|c|c|c|c|c|}
\hline \multicolumn{5}{|c|}{ ONDERZOEKSPOPULATIE(N = 59) } \\
\hline 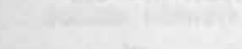 & \multicolumn{2}{|c|}{ JONGEREN $(n=27)$} & \multicolumn{2}{|c|}{ OUDEREN ( $n=32)$} \\
\hline AFSTAND & $\mathrm{m}$ & sd & $\mathrm{m}$ & sd \\
\hline & & & & \\
\hline eigen woonplaats & 8.0 & 3.6 & 8.1 & 5.0 \\
\hline zelfde regio & 1.2 & 2.2 & 3.2 & 6.1 \\
\hline buiten regio & 4.6 & 5.7 & 2.7 & 4.2 \\
\hline buitenland & 0.7 & 1.5 & 0.9 & 1.8 \\
\hline $\begin{array}{l}\text { Bekend } \\
\text { geen informatie }\end{array}$ & $\begin{array}{r}14.5 \\
4.4\end{array}$ & $\begin{array}{l}6.9 \\
4.5\end{array}$ & $\begin{array}{r}14.9 \\
6.3\end{array}$ & $\begin{array}{l}8.2 \\
5.8\end{array}$ \\
\hline
\end{tabular}

Bovenstaande tabel 10.5 geeft aan dat er in het geheel genomen gemiddeld geen significante verschillen bestaan in de bereikbaarheid van de informele netwerkleden tussen de jongere en de oudere groep ambulante chronisch psychiatrische patiënten. Hypothese 30 kan als bevestigd beschouwd worden.

\subsubsection{Structuur van de betrekkingen}

De analyse en bechrijving van de structuur van de betrekkingen betreft achtereenvolgens de elementen initiatief tot contact en frequentie, gewicht en lengte van het contact bij de beide groepen ambulante chronisch psychiatrische patiënten en al hun informele en formele netwerkleden tesamen. De jongere en oudere patiénten hebben respectievelijk gemiddeld 24.5 en 25.4 netwerkleden (zie tabel 10.2). De analyse van de structuur van de betrekkingen is conform de hypothesen 31 tot en met 34 (zie $\$$ 6.2.3).

\section{INITIATIEF}

Allereerst aan de hand van hypothese 31 de analyse en beschrijving van het element initiatief in de structuur van de betrekkingen bij de jongere en oudere ambulante chronisch psychiatrische patiënten. 


\section{Ad hypothese 31}

Verondersteld wordt dat bij de jongere patiënten in de onderzoekspopulatie de contacten met. de netwerkleden ovewegend tot stand komen via initiatief in de zin van gewoonte ofwel als vanzelfsprekend terwijl bij de oudere patiënten de contacten overwegend tot stand komen door initiatief via derden.

In de volgende tabel 10.6 zijn de resultaten van deze vergelijking weergegeven.

TABEL 10.6 Het initiatief tot contact bij de jongere en de oudere ambulante chronisch psychiatrische patiënten.

\begin{tabular}{|lllll|}
\hline \multicolumn{4}{l}{ ONDERZOEKSPOPULATIE $(\mathrm{N}=59)$} \\
$\begin{array}{l}\text { INITIATIEF } \\
\text { sociale netwerk }\end{array}$ & JONGEREN $(\mathrm{n}=27)$ & OUDEREN $(\mathrm{n}=32)$ \\
& $\mathrm{m}$ & $\mathrm{sd}$ & $\mathrm{m}$ & sd \\
\hline focale persoon & 3.9 & 2.5 & 3.6 & 2.8 \\
netwerklid & 1.6 & 2.0 & 2.3 & 2.7 \\
wederzijds & 4.2 & 3.4 & 4.9 & 5.3 \\
gewoonte & 5.1 & 5.3 & 4.9 & 4.6 \\
via derden & 4.6 & 3.5 & 3.5 & 3.1 \\
geen initiatief & 2.1 & 3.3 & 3.3 & 3.9 \\
\hline
\end{tabular}

Bovenstaande tabel 10.6 toont dat er ten aanzien van de spreiding van het initiatief tot contact over het sociale netwerk en ten aanzien van de gemiddelde omvang netwerkleden per kenmerk van initiatief tol contact in het geheel genomen geen verschillen zijn tussen de jongere en de oudere ambulante chronisch psychiatrische patiënten. Hypothese 32 kan aldus voor wat betreft het gehele sociale netwerk niet als bevestigd beschouwd worden.

Op het niveau van de sectoren netwerkleden wordt op een enkele uitzondering na eveneens deze uitkomst gevonden. Er zijn de volgende twee uitzonderingen.

- In de sector verwanten blijken de jongere patiënten gemiddeld significant minder netwerkleden te hebben met wie uitdrukkelijk geen initiatief tot contact wordt ondernomen dan bij de oudere patiënten het geval is (respectievelijk gemiddeld 1.0 en 2.9 verwanten, $T=-2.13, p<.05$ )

- In de sector maatschappelijke diensten blijken de jongere patiënten vergeleken mel de oudere patiēnten gemiddeld significant meer netwerkleden te hebben met wie het contacl op basis van gewoonte dan wel als vanzelfsprekend tot stand komt (respectieveljk gemiddeld 2.1 en 2.2 nelwerkleden, $T=2.64, p<.05$ ).

\section{FREQUENTIE}

Het tweede element van de structuur van de betrekkingen betreft de frequentie van hel contact tussen de focale personen en hun netwerkleden; de analyse en beschrijving hiervan vindt plaats aan de hand van hypothese 32 . 


\section{Ad hypothese 32}

Verondersteld wordt dat de jongere groep vergeleken met de oudere groep van de onderzoekspopulatie gemiddeld frequenter contact met de netwerkleden onderhoudt.

In de volgende tabel 10.7 worden de uitkomsten van de vergelijking conform hypothese 32 gegeven. Let wel: 'geen informatie' in tabel 10.7 wil zeggen dat er geen adequate informatie gegeven werd.

TABEL 10.7 De frequentie van het contact bij de jongere en oudere ambulante chronisch psychiatrische patiënten

\begin{tabular}{|lllll|}
\hline $\begin{array}{l}\text { FREQUENTIE } \\
\text { sociale netwerk }\end{array}$ & JONGEREN $(n=27)$ & OUDEREN $(n=32)$ \\
& $m$ & sd & $m$ & sd \\
\hline minimaal & & & & \\
- Ix per twee weken & 9.7 & 5.6 & 8.0 & 4.5 \\
- 1x per kwartaal & 5.2 & 4.1 & 6.3 & 5.6 \\
- 1x per jaar & 2.2 & 3.3 & 3.0 & 2.8 \\
geen informatie & 7.4 & 6.2 & 8.1 & 5.2 \\
\hline
\end{tabular}

Tabel 10.7 toont dat er in hel geheel genomen ten aanzien de frequentie van het contact geen verschillen optreden tussen de jongere en de oudere patiënten. Ook voor wat betreft de sectoren verwanten en vriendschappelijke betrekkingen worden geen significante verschillen aangetroffen. Alleen binnen de sector maatschappelijke diensten treedt er een enkel verschil op. De jongere patiënten blijken vergeleken met de oudere patiënten met gemiddeld significant meer netwerkleden in de sector maatschappelijke diensten minstens eenmaal per twee weken contact te hebben (respectievelijk gemiddeld 2.4 en 1.2 netwerkleden, $T=2.64, p<.05$ ). Al bij al krijgt hypothese 32 nagenoeg geen bevestiging.

\section{GEWICHT}

Vervolgens het derde element van de structuur van de betrekkingen: het gewicht van het contact tussen de focale personen en hun netwerkleden, geanalyseerd en beschreven aan de hand van hypothese 33 .

\section{Ad hypothese 33}

Verondersteld wordt dat er verschillen optreden in hel toekennen van het gewicht aan de netwerkleden tussen de jongere en de oudere groep van de onderzoekspopulatie. De richting van deze verschillen is niet te voorspellen.

In volgende tabel 10.8 zijn de resultaten van de vergelijking conform hypothese 33 weergegeven. 
TABEL 10.8 Het gewicht van het contact bij de jongere en de oudere groep van de onderzoekspopulatie $(\mathrm{N}=59$ ).

\begin{tabular}{|lllll|}
\hline \multicolumn{4}{l}{ ONDERZOEKSPOPULATIE $(\mathrm{N}=59)$} \\
$\begin{array}{l}\text { GEWICHT } \\
\text { compartimenten } \\
\text { sociale netwerk }\end{array}$ & JONGEREN $(n=27)$ & OUDEREN $(n=32)$ \\
& $\mathrm{m}$ & $\mathrm{sd}$ & $\mathrm{m}$ & $\mathrm{sd}$ \\
\hline affectie & 3.5 & 0.4 & 3.8 & 0.6 \\
aansluiting & 3.3 & 0.5 & 3.4 & 0.6 \\
middelen & 3.7 & 0.6 & 3.8 & 0.6 \\
stabiliteit & 3.3 & 0.8 & 3.5 & 0.6 \\
\hline
\end{tabular}

Tabel 10.8 geeft aan dat hypothese 33 niet bevestigd wordt. Wat betreft het gehele sociale netwerk treden er tussen de jongere en de oudere patiënten gemiddeld geen verschillen op in het toekennen van het gewicht aan het contact met de netwerkleden. Ook op het niveau van de sectoren netwerkleden worden geen significante verschillen aangetroffen.

\section{LENGTE}

Het laatste element van de structuur van de betrekkingen betreft de lengte van het contact tussen de focale personen en hun netwerkleden, geanalyseerd en beschreven aan de hand van hypothese 34 .

\section{Ad hypothese 34}

Verondersteld wordt dat de jongere groep vergeleken met de oudere groep van de onderzoekspopulatie gemiddeld over meer netwerkleden beschikt met wie sinds korte tijd contact bestaat

In onderstaande tabel 10.9 zijn de resultaten van de vergelijking conform hypothese 34 weergegeven.

TABEL 10.9 De lengte van het contact bij de jongere en de oudere ambulante chronisch psychiatrische paliënten.

\begin{tabular}{|c|c|c|c|c|}
\hline \multirow{3}{*}{$\begin{array}{l}\text { LENGTE } \\
\text { sociale netwerk }\end{array}$} & \multicolumn{4}{|c|}{ ONDERZOEKSPOPULATIE ( $N=59$ ) } \\
\hline & \multicolumn{2}{|c|}{ JONGEREN $(n=27)$} & \multicolumn{2}{|c|}{ OUDEREN $(\mathrm{N}=32)$} \\
\hline & m & sd & m & $s d$ \\
\hline $\begin{array}{lr}< & 1 \text { jaar } \\
1 & -5 \text { jaar } \\
\geq & 5 \text { jaar }\end{array}$ & $\begin{array}{r}4.3 \\
3.0 \\
10.0\end{array}$ & $\begin{array}{l}3.3 \\
2.9 \\
4.1\end{array}$ & $\begin{array}{l}2.2^{\star} \\
2.2 \\
14.7^{*}\end{array}$ & $\begin{array}{l}2.2 \\
2.6 \\
8.1\end{array}$ \\
\hline
\end{tabular}

$*$ * $p<.01$ 
Hypothese 34 wordt zoals tabel 10.9 toont bevestigd. De jongere patiënten beschikken vergeleken met de oudere patiënten in het geheel genomen gemiddeld over significant meer netwerkleden met wie het contact in het afgelopen jaar tot stand is gekomen (respectievelijk gemiddeld 4.3 en 2.2 netwerkleden, $T=2.84, p<2.84, p<.01$ ). Deze uitkomst hangt samen met het gegeven dat de jongere patiënten in vergelijking met de oudere patiënten in de sector vriendschappelijke betrekkingen gemiddeld significant meer netwerkleden hebben met wie in het laatste jaar contact tot stand is gekomen (respectievelijk gemiddeld 2.0 en 0.9 netwerkleden, $T=2.29, p<.05$ ).

Overigens toont tabel 10.14 dat de jongere patiënten vergeleken met de oudere patiënten in het geheel genomen gemiddeld significant minder netwerkleden hebben met wie vijf jaar of langer contact bestaat (respectievelijk gemiddeld 10.0 en 14.7 netwerkleden, $T=-2.83, p<.01$ ).

Een nadere analyse van de gegevens over de lengte van het contact binnen de sectoren toont dat deze uitkomst betreffende de reeds lang bestaande contacten verwijst naar een soortgelijk verschil in de sector verwanten en in de sector maatschappelijke diensten. De jongere patiënten hebben in vergelijking met de oudere patiënten in de sector verwanten gemiddeld significant minder netwerkleden met wie vijf jaar of langer contact bestaat (respectievelijk gemiddeld 8.2 en 11.5 verwanten, $T=-2.36$, $p<.05)$. In de sector maatschappelijke diensten is op dit punt een vergelijkbaar significant verschil aanwezig (respectievelijk gemiddeld 0.3 en 0.8 netwerkleden, $T=$ $-2.50, p<.05)$.

Met de weergave van de resultaten betreffende het element lengte van het contact in de structuur van de betrekkingen bij de jongere en oudere ambulante chronisch psychiatrische patiënten is de analyse en beschrijving van de structuur van de sociale netwerken conform vraagstelling III voltooid. De samenvatting van de resultaten in hoofdlijnen is weergegeven aan het eind van dit hoofdstuk in $\S 10.4$. tesamen met de resultaten in hoofdlijnen bij vraagstelling IV die nu eerst in de volgende $\S 10.3$ uitvoerig worden gegeven.

\section{RESULTATEN VRAAGSTELLING IV}

Vraagstelling IV betreft een vergelijking van de structuur van de sociale netwerken bij de jongere en oudere patiënten en de daarbij geselecteerde jongere en oudere referentiepersonen. In concreto gaat het om de volgende vraagstelling.

WELKE VERSCHILEN DAN WEL OVEREENKOMSTEN, C.Q PATRONEN BESTAAN ER IN DE STRUCTUUR VAN SOCIALE NETWERKEN BIJ DE GROEP JONGERE EN DE GROEP OUDERE AMBULANTE CHRONISCH PSYCHIATRISCHE PATIENTEN VERGELEKEN MET DE REFERENTIEPERSONEN?

Zoals aan het begin van dit hoofdstuk in tabel 10.1 aangegeven bestaat de onderzoekspopulatie bij vraagstelling IV uit 47 ambulante chronisch psychiatrische patiënten ( 19 jongere en 28 oudere patiënten) bij wie referentiepersonen gevonden konden worden. Tabel 10.1 toont tevens dat het sociaal demografisch profiel van deze jongere en oudere patiënten in de onderzoekspopulatie $n=47$ nagenoeg overeenkomt met die van de jongere en oudere patiēnten in de onderzoekspopulatie $\mathrm{N}=59$.

Vraagstelling IV zal aan de hand van de hypothesen 35 tot en met 41 (zie $§ 6.2 .4$ ) beantwoord worden. Voor de weergave van de resultaten wordt hetzelfde stramien aangehouden als bij de beantwoording van de voorafgaande vraagstellingen. 
Dat betekent dat achtereenvolgens de resultaten worden gegeven over:

\author{
de omvang en samenstelling van de omvang \\ de gevarieerdheid van de netwerkleden \\ de bereikbaarheid van de netwerkleden \\ de strucluur van de betrekkingen
}

(in $\S 10.3 .1$ );

(in $\S 10.3 .2$; ;

(in $\$ 10.3 .3$ );

(in $\S 10.3 .4$ ).

\subsection{1}

\section{Omvang en samenstelling van de omvang}

De analyse en beschrijving van de omvang en de samenstelling ervan wordt beantwoord aan de hand van de hypothesen 35 tot en mel 38 (zie $§ 6.2 .4$ ).

In Tabel 10.10 worden de resultaten van de omvang en de verdeling ervan over de sectoren en clusters bij de groepen jongere focale personen (ad A.: de jongere ambulante chronisch psychiatrische patiënten, vergeleken met de jongere referentiepersonen) en de groepen oudere focale personen (ad B.: de oudere ambulante chronisch psychiatrische patiënten, vergeleken met de oudere referentiepersonen) gegeven en onderling vergeleken.

\section{Ad hypothese 35}

Verondersteld wordt dat de omvang van de sector verwanten voor beide groepen van de onderzoekspopulatie gemiddeld gelijk is aan die van de referentiepersonen.

Deze hypothese wordt zoals tabel 10.10 toont zowel wat betreft de gemiddelde omvang netwerkleden van de gehele sector verwanten alsook wat betreft de gemiddelde omvang netwerkleden in de onderscheiden clusters verwanten bevestigd. Toch dienen hierbij een tweetal kanttekeningen gemaakt te worden.

De eerste kanttekening verwijst naar het significante verschil tussen de jongere en de oudere patiënten van de onderzoekspopulatie $(N=59)$ in de gemiddelde omvang van het cluster partner / eigen gezin en in de gemiddelde omvang van de totale sector verwanten zoals aangetroffen bij hypothese 26 ad vraagstelling III (zie $\$ 10.2 .1$, tabel 10.2). Hier bij hypothese 35 ad vraagstelling IV worden tussen de jongere en oudere patiënten van de onderzoekspopulatie ( $n=47$ ) eenzelfde significant verschil inzake het cluster partner / eigen gezin aangetroffen. Tabel 10.10 toont immers ook dat de oudere groep patiënten significant meer netwerkleden in he cluster partner / eigen gezin hebben dan de jongere patiënten (respectievelijk gemiddeld 3.0 en 0.5 netwerkleden, $T=-5.20, p<.001$ ); tussen de jongere en oudere patiënten van deze onderzoekspopulatie ( $n=47$ ) wordt eveneens een significant verschil gevonden in de gemidelde omvang van de totale sector verwanten $(T=-3.38, p<.01)$.

Echter dit patroon is deels ook aanwezig is bij de referentiepersonen; de oudere referentiepersonen hebben zoals tabel 10.10 laat zien gemiddeld significant meer netwerkleden in het cluster partner / eigen gezin dan de jongere referentiepersonen (respectievelijk gemiddeld 3.1 en 0.9 netwerkleden, $T=-6.37, p<.001$ ). Met andere woorden: de verschillen die tussen de jongere en oudere patiënten optreden in de gemiddelde omvang bij de sector verwanten zijn weliswaar significant maar niet in alle opzichten ałwijkend van die bij de jongere en oudere referentiepersonen.

De tweede kanttekening heeft betrekking op de opbouw van het cluster partner I gezin bij de jongere patiënten vergeleken met de jongere referentiepersonen. $\mathrm{Bij}$ de 19 jongere referentiepersonen kunnen slechts drie focale personen $(16 \%)$ geen netwerklid en kunnen 15 focale personen (79\%) éen netwerklid noemen binnen het cluster partner / eigen gezin, terwijl elf $(58 \%)$ jongere patiënten geen netwerklid en zes (32\%) patiënten één netwerklid binnen dit cluster kunnen noemen. Met andere woorden: achter het overeenkomstig gemiddeld aantal netwerkleden in het cluster partner / gezin gaan tussen de jongere patiënten en de jongere referentiepersonen aanzienlijke verschillen schuil in de opbouw van dit cluster netwerkleden.

Het komt er op neer dat de bevestiging van hypothese 35 binnen de context van de zojuist gegeven kanttekeningen gezien dient te worden. 
TABEL 10.10 De omvang en samenstelling van het sociale netwerk van jongere en oudere ambulante chronisch psychiatrische patiēnten ( $N=$ 47) vergeleken mel die van jongere en oudere referentiepersonen.

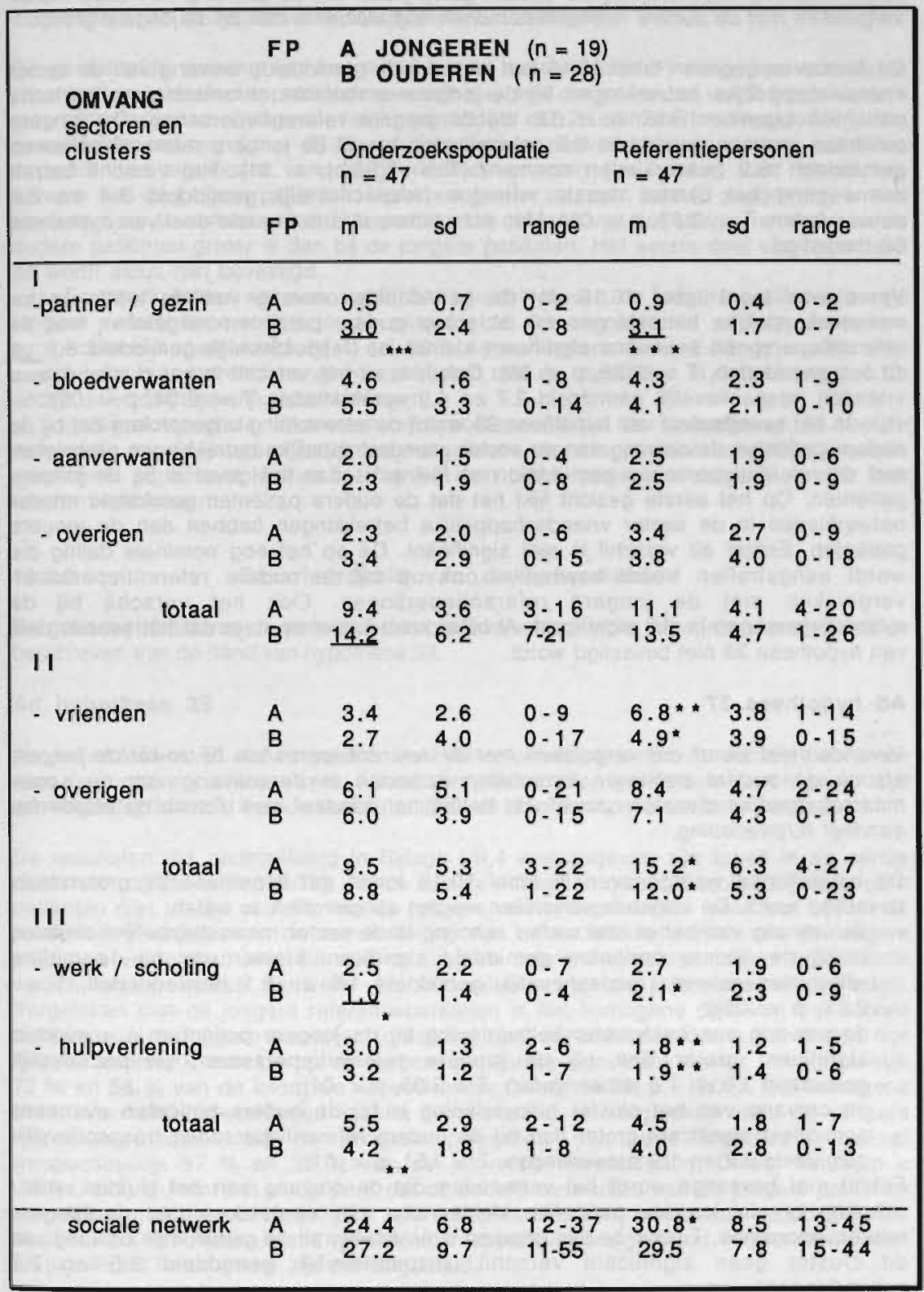

$\star \star * p<.001 ; * * p<.01 ; * p<.05$ 
Verondersteld wordt dat de omvang van de sector vriendschappelijke betrekkingen bij de jongere groep van de onderzoekspopulatie kleiner is dan bij de jongere referentiepersonen, terwijl bij de oudere groep patiënten de omvang van deze sector vergeleken met de oudere relerentiepersonen nog kleiner is dan bij de jongere groep.

De hierboven gegeven tabel 10.10 laat zien dat de gemiddelde omvang van de sector vriendschappelijke betrekkingen bij de jongere ambulante chronisch psychiatrische patiënten significant kleiner is dan bij de jongere referentiepersonen. De jongere patiënten noemen gemiddeld 9.5 netwerkleden terwijl de jongere referentiepersonen gemiddeld 15.2 netwerkleden noemen, $(T=-2.98, p<.01)$. Het verschil betreft overwegend het cluster naaste vrienden (respectievelijk gemiddeld 3.4 en 6.8 netwerkleden, $T=-3.09, p<.01$ ). Met deze uitkomst is het eerste deel van hypothese 36 bevestigd.

Vervolgens toont tabel 10.10 dat de gemiddelde omvang van de totale sector vriendschappelijke betrekkingen bij de groep oudere patiënten vergeleken met de referentiepersonen eveneens significant kleiner is, (respectievelijk gemiddeld 8.8 en 12.0 netwerkleden, $T=-2.28, p<.05$ ). Ook hier zit het verschil in het cluster naaste vrienden (respectievelijk gemiddeld 2.7 en 4.9 netwerkleden, $\mathrm{T}=-2.04, \mathrm{p}<.05$ ) .

In het tweede deel van hypothese 36 wordt de verwachting uitgesproken dat bij de oudere patiënten de omvang van de sector vriendschappelijke betrekkingen vergeleken met de referentiepersonen gemiddeld nog kleiner is dan hel geval is bij de jongere patiënten. Op het eerste gezicht lijkt het dat de oudere patiënten gemiddeld minder netwerkleden in de sector vriendschappelijke betrekkingen hebben dan de jongere patiënten. Echter dit verschil is niet significant. De op het oog nominale daling die wordt aangetroffen treedt bovendien ook op bij de oudere referentiepersonen vergeleken met de jongere referentiepersonen. Ook het verschil bij de referentiepersonen is niet significant. Al bij al komt het er op neer dat het tweede deel van hypothese 36 niet bevestigd wordt.

\section{Ad hypothese 37}

Verondersteld wordt dat vergeleken met de referentiepersonen bij zowel de jongere alsook de oudere patiënten verschillen optreden in de omvang van de sector maatschappelijke diensten zowel wat betreft het aandeel werk / scholing alsook het aandeel hulpverlening.

De bevindingen weergegeven in tabel 10.10 tonen dat hypothese 37 grotendeels bevestigd wordt. De volgende verschillen worden aangetroffen, te weten:

- de omvang van het cluster werk / scholing in de sector maatschappelijke diensten is bij de oudere patiënten gemiddeld significant kleiner dan bij de oudere referentiepersonen (respectievelijk gemiddeld 1.0 en 2.1 netwerkleden, $T=$ 2.21, $p<.05)$;

- de omvang van het cluster hulpverlening bij de jongere patiënten is gemiddeld significant groter dan bij de jongere referentiepersonen, (respectievelijk gemiddeld 3.0 en 1.8 netwerkleden, $T=3.06, p<.01$ );

- de omvang van het cluster hulpverlening is bij de oudere patiënten eveneens gemiddeld significant groter dan bij de oudere referentiepersonen (respectievelijk gemiddeld 3.2 en 1.9 netwerkleden, $T=3.51, p<.01$ ).

Echter niet bevestigd wordt het vermoeden dat de omvang van het cluster werk I scholing bij de jongere patiënten kleiner zou zijn vergeleken met de jongere referentiepersonen. Tussen beiden groepen is er wat betreft de gemiddelde omvang van dit cluster geen significant verschil (respectievelijk gemiddeld 2.5 en 2.7 netwerkleden). 
Verondersteld wordt dat de omvang van de sociale netwerken bij de oudere patiènten vergeleken met de referentiepersonen gemiddeld kleiner is dan bij de jongere patiënten vergeleken met de referentiepersonen. Het verschil treedt vermoedelijk vooral op in de omvang van de sector vriendschappelijke betrekkingen.

De gemiddelde omvang van het totaal aantal netwerkleden bij de oudere ambulante chronisch psychiatrische patiënten verschilt niet met die gevonden wordt bij de oudere referentiepersonen (respectievelijk gemiddeld 27.2 en 29.5 netwerkleden). De gemiddelde omvang $(m=27.2)$ van het sociale netwerk van de oudere patiënten verschilt niet significant van de gemiddelde omvang $(m=24.4)$ van het sociale netwerk van de jongere patiënten. Nominaal gezien zou men kunnen zeggen dat er een tendens waar te nemen valt dat de gemiddelde omvang van het sociale netwerk van de oudere patiënten groter is dan bij de jongere patiěnten. Het eerste deel van hypothese 38 wordt aldus niet bevestigd.

Er treedt echter wel een significant verschil tussen de jongere patiënten en de jongere referentiepersonen in de gemiddelde omvang van de sociale netwerken (respectievelijk gemiddeld 24.4 en 30.8 netwerkleden, $T=-2.53, p<.05$ ). Het verschil dat hier optreedt hangt vooral samen met de verschillen in de omvang van de sector vriendschappelijke betrekkingen.

Al bij al tonen de uitkomsten bij hypothese 38 dat de omvang van de sociale netwerken bij de jongere patiënten vergeleken met de jongere referentiepersonen gemiddeld significant kleiner is dan bij de oudere patiënten vergeleken met hun referentiepersonen.

\section{3 .2}

\section{Gevarieerdheid van de netwerkleden}

De gevarieerdheid van de netwerkleden conform vraagstelling IV wordt geanalyseerd en beschreven aan de hand van hypothese 39 .

\section{Ad hypothese 39}

Verondersteld wordt dat vergeleken met de referentiepersonen de sociale netwerken van de jongere patiënten qua status- en positierollen gemiddeld heterogener zijn samengesteld dan die van de oudere ambulante chronisch psychiatrische patiënten.

De resultaten die gedetailleerd in Bijlage VII,4 weergegeven zijn tonen in de eerste plaats aan dat de samenstelling van de sociale netwerken qua statusrollen bij de jongere patiënten niet afwijkt van die van de jongere referentiepersonen. Voor wat betreft de positierollen treden er in de samenstelling van de sociale netwerken van de jongere patiënten vergeleken met die van de jongere referentiepersonen alleen significante verschillen op inzake de werk- en woonsituatie van de informele netwerkleden. Vergeleken met de jongere referentiepersonen is het homogene deel van het sociale netwerk van de jongere patiënten (ofwel het deel netwerkleden dat in het al dan niet hebben van werk aansluit op de jongere patiënten) significant kleiner (respectievelijk $72 \%$ en $58 \%$ van de informele netwerkleden; Chisq. 14.23, $p<.001$ ). Het homogene deel informele netwerkleden inzake woonsituatie is vergeleken met de jongere referentiepersonen bij de jongere patiěnten eveneens significant kleiner (respectievelijk $57 \%$ en $39 \%$ van de informele netwerkleden, Chisq. 18.93; p < .001). Al bij al komt het er op neer dat de sociale netwerken van de jongere patiènten vergeleken met die van de jongere referentiepersonen voor wat betreft de positierollen inzake werk- en woonsituatie gemiddeld respectievelijk significant minder homogeen en significant heterogener zijn samengesteld. 
In de tweede plaats tonen de resultaten van de analyse van de gevarieerdheid van de informele sociale netwerkleden ten opzichte van de focale personen aan de hand van hypothese 39 dat er in de samenstelling van de sociale netwerken van de oudere patienten vergeleken met die van de oudere referentiepersonen qua statusrollen een significant verschil optreedt inzake de leeftijd van de informele netwerkleden. Het sociale netwerk van de oudere patiënten is vergeleken mel die van de oudere referentiepersonen inzake de leeftijd van de informele netwerkleden significant minder homogeen samengesteld (het homogene deel bestaat respectievelijk uit $73 \%$ en uit $81 \%$ van de informele netwerkleden; Chisq, 8.57, $p<.01$ ). Qua positierollen treedt er alleen een significant verschil op inzake de werksituatie: het homogene deel bestaat bij de oudere patiënten uit $49 \%$ en bij de oudere referentiepersonen uit $62 \%$ van de informele netwerkleden; Chisq. 13.29, $p<.001$ ).

De hierboven gegeven resultaten tonen dat in de sociale netwerken merendeels geen verschillen optreden in de verhouding tussen het homogene en het heterogene deel van de informele netwerkleden voor wat betreft de status- en positierollen. Dat is zowel het geval bij de sociale netwerken van de jongere patiënten vergeleken met die van de jongere referentiepersonen alsook bij de sociale netwerken van de oudere patiënten vergeleken met die van de oudere referentiepersonen.

Waar aldus geen significante verschillen optreden in de verhouding tussen het homogene en heterogene deel in de sociale netwerken is er zowel bij de jongere patienten alsook bij de jongere referentiepersonen een tendens waar te nemen dat het homogene deel informele netwerkleden de overhand heeft. Waar geen significante verschillen optreden bestaat zowel bij de oudere patiënten alsook bij de oudere referentiepersonen het homogene deel van de sociale netwerken uit meer dan $50 \%$ van de informele netwerkleden: bij de oudere patiënten varieert het homogene deel hier van $54 \%$ (geslacht) tot $77 \%$ (opleiding) van de informele netwerkleden terwijl bij de oudere referentiepersonen het homogene deel varieert van $57 \%$ (geslacht) tot $74 \%$ (eveneens opleiding) van de informele netwerkleden.

De significante verschillen die in de verhouding tussen het homogene en het heterogene deel in de samenstelling van de sociale netwerken bij de jongere patiënten vergeleken met de jongere referentiepersonen optreden hebben betrekking op de werk- en woonsituatie en wel in die zin dat ten aanzien van deze kenmerken de sociale netwerken van de jongere patiënten significant heterogener zijn samengesteld dan die van de jongere referentiepersonen. De significante verschillen die optreden in de samenstelling van de sociale netwerken bij de oudere patiënten vergeleken met de oudere referentiepersonen hebben betrekking op leeftijd en werksituatie en wel in die zin dat ten aanzien van deze kenmerken de oudere patiënten een significant minder homogeen samengesteld sociaal netwerk hebben dan de oudere referentiepersonen.

Al bij al komt het erop neer dat de de sociale netwerken van de jongere en oudere referentiepersonen overwegend homogeen samengesteld zijn en dat bij de oudere referentiepersonen het homogene deel informele netwerkenleden in het algemeen groter is dan bij de jongere referentiepersonen. De samenstelling van de sociale netwerken qua status- en positierollen bij de jongere en de oudere ambulante chronisch psychiatrische patiënten blijkt merendeels met die van de jongere en oudere referentiepersonen overeen te komen. Waar verschillen optreden blijkt bij de jongere patiënten het sociale netwerk meer heterogeen samengesteld te zijn en bij de oudere patiēnten het sociale netwerk significant minder homogeen samengesteld te zijn. Hypothese 69 kan aldus niet als bevestigd beschouwd worden.

\section{Bereikbaarheid van de netwerkleden}

De analyse en beschrijving van de bereikbaarheid van de netwerkleden heeft evenals dat het geval was bij de gevarieerdheid van de nelwerkleden betrekking op de informele netwerkleden. 
Verondersteld wordt dat vergeleken met de referentiepersonen er geen verschillen optreden in de bereikbaarheid voor beide groepen van de onderzoekspopulatie.

Onderstaande tabel 10.11 geeft de resultaten van de bereikbaarheid van de informele netwerkleden bij de jongere en oudere groep patiënten van de onderzoekspopulatie $(\mathbf{n}=$ 47) vergeleken met die bij de jongere en oudere groep referentiepersonen.

TABEL 10.11 De bereikbaarheid van de informele netwerkleden van de jongere en oudere ambulante chronisch psychiatrische patienten vergeleken met die van de jongere en oudere referentiepersonen.

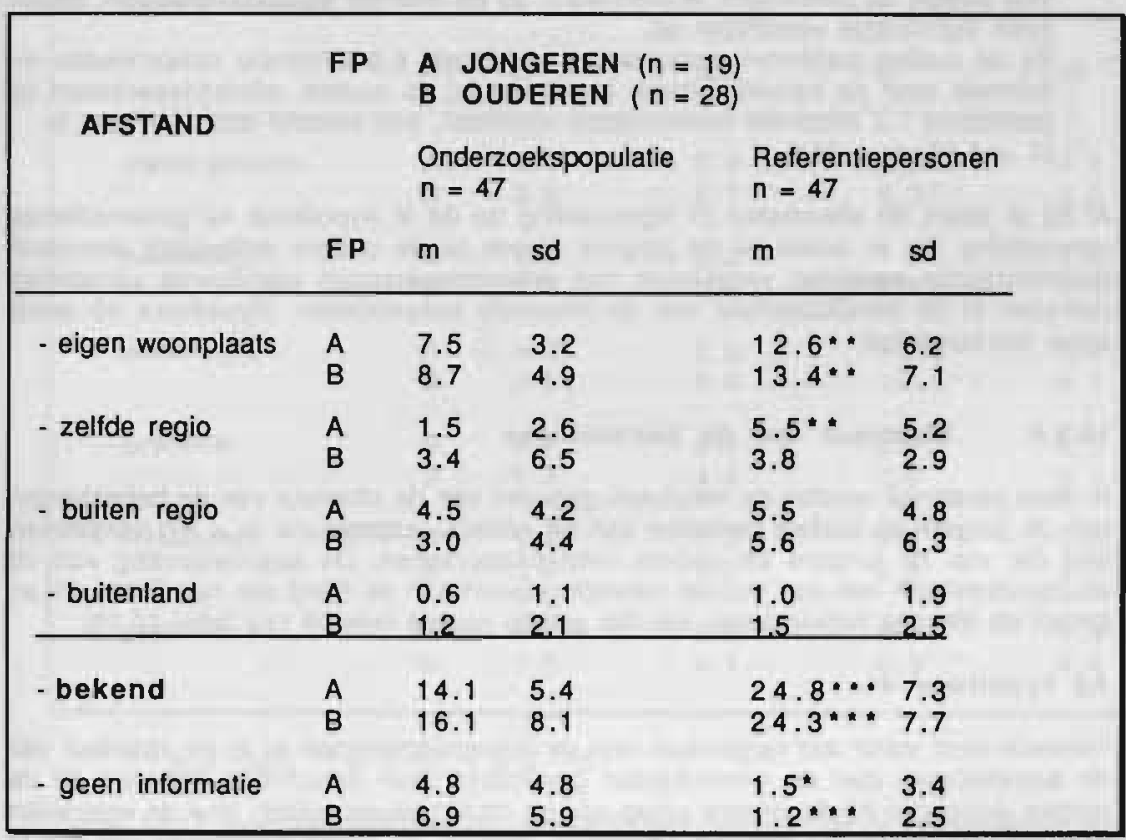

*** $p<.001 ; * * p<.01 ; * p<.05$

Wat betreft de bereikbaarheid van de informele nelwerkleden vann jongere ambulante chronisch psychiatrische patiënten vergeleken met die van jongere referentiepersonen zijn er de volgende resultaten.

Gemiddeld 14.1 informele netwerkleden zijn voor de jongere patiënt bereikbaar; bij de jongere referentiepersonen zijn gemiddeld 24.8 informele netwerkleden bereikbaar; er is sprake van een significant verschil $(T=-5.10, p<.001)$.

In de eigen woonplaats hebben de jongere patiënten gemiddeld significant minder netwerkleden dan het geval is bij de jongere referentiepersonen (respectievelijk gemiddeld 7.5 en 12.6 informele netwerkleden; $T=-3.12, p<.01$ ).

Een dergelijk significant verschil treedt ook op betreffende de informele netwerkleden in de eigen regio, (respectievelijk gemiddeld 1.5 en 5.5 netwerkleden die bereikbaar zijn; $T=-3.01, p<.01$ ).

$\mathrm{Bij}$ de jongere patiènten is over gemiddeld 4.8 informele netwerkleden geen informatie over de bereikbaarheid voorhanden, terwijl dat bij de jongere 
referentiepersonen voor gemiddeld 1.5 netwerkleden het geval is. Dit verschil is opmerkelijk ( $T=2.43, \mathrm{p}<.05)$.

Inzake de bereikbaarheid van de informele netwerkleden van de oudere ambulante chronisch psychiatrische patiënten vergeleken met die van de oudere referentiepersonen toont tabel 10.11 de volgende uitkomsten.

- Bij de oudere patiënten zijn gemiddeld significant minder netwerkleden bereikbaardan bij de oudere referentiepersonen (respectievelijk gemiddeld 16.1 en 24.3 netwerkleden, $\mathrm{T}=-3.94, \mathrm{p}<.001$ ).

- De oudere patiënten hebben gemiddeld significant minder netwerkleden in de eigen woonplaats dan de oudere referentiepersonen (respectievelijk gemiddeld 8.7 en 13.4 informele netwerkleden, $T=-2,91, p<.01$ ).

- Wat betreft de bereikbare netwerkleden bij de overige afstandsvariabelen treden geen significante verschillen op.

- $\quad$ Bij de oudere patiënten ontbreekt bij gemiddeld 6.9 informele netwerkleden informatie over de bereikbaarheid, terwijl dat bij de oudere referentiepersonen bij gemiddeld 1.2 informele netwerkleden voorkomt, een verschil dat significant is $(T=4.75, p<.001)$.

Al bij al tonen de uitkomsten in tegenstelling tot de in hypothese $\mathbf{4 0}$ geformuleerde verwachting dat er zowel bij de jongere alsook bij de oudere ambulante chronisch psychiatrysche patiënten vergeleken met referentiepersonen significante verschillen optreden in de bereikbaarheid van de informele netwerkleden. Hypothese 40 wordt aldus niet bevestigd.

\subsubsection{Structuur van de betrekkingen}

In deze paragraaf worden de resultaten gegeven van de structuur van de betrekkingen van de jongere en oudere patiënten van de onderzoekspopulatie ( $n=47$ ) vergeleken mel die van de jongere en oudere referentiepersonen. De beantwoording van dit structuurkenmerk van een sociaal netwerk gebeurt aan de hand van hypothese 41 en betreft de omvang netwerkleden van het gehele sociale netwerk (zie tabel 10.10).

\section{Ad hypothese 41}

Verondersteld wordt dat vergeleken met de referentiepersonen er in de structuur van de betrekkingen met de netwerkleden gemiddeld meer verschillen optreden bij de oudere groep dan bij de jongere groep van de onderzoekspopulatie. Hoe de verschillen zich over de elementen initiatief, frequentie, gewicht en lengte uitstrekken valt niet te voorspellen.

Achtereenvolgens zullen aan de hand van de vermelde hypothese 41 de afzonderlijke elementen van de structuur van de betrekkingen aan de orde komen. Allereerst het element 'initiatief' in de structuur van de betrekkingen. 


\section{INITIATIEF}

TABEL 10.12 Het initiatief in het contact met de netwerkleden bij de jongere en oudere ambulante chronisch psychiatrische patiënten vergeleken met de jongere en oudere referentiepersonen.

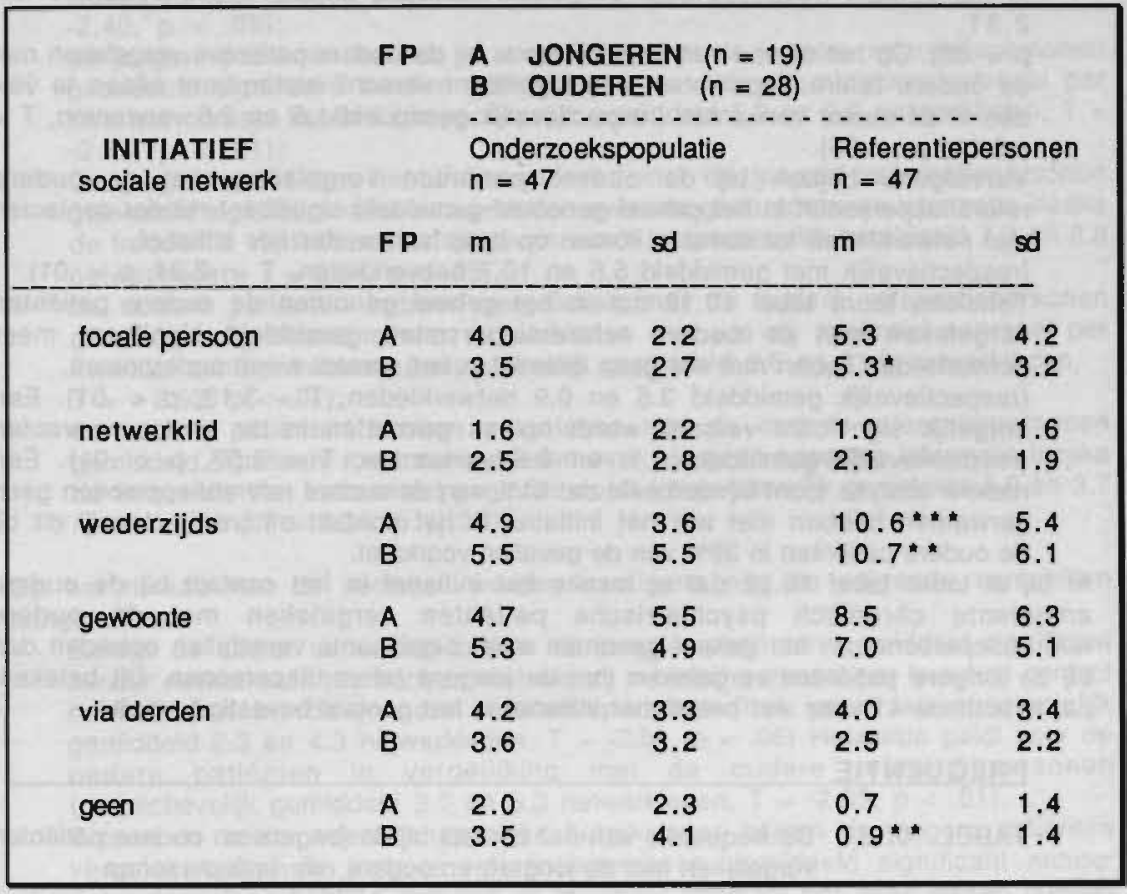

*** $p<.001, * * p<.01, * p<.05$

Tabel 10.12 toont betreffende het initiatief in het contact met de netwerkleden bij de jongere ambulante chronisch psychiatrische patiënten vergeleken met de jongere referentiepersonen in het geheel genomen de volgende resultaten.

- Er treden met uitzondering van het wederzijds initiatief in het contact tussen de jongere ambulante chronisch psychiatrische patiënten en de jongere referentiepersonen in het geheel genomen gemiddeld geen significante verschillen op in het initiatief in het contact met de netwerkleden. Bijvoorbeeld de jongere patiënten nemen vergeleken met de jongere referentiepersonen gemiddeld naar nagenoeg evenveel nelwerkleden zelf hel initiatief in het contact. De uitzondering is dat er bij de jongere patiënten vergeleken met de jongere referentiepersonen in het geheel genomen gemiddeld significant minder contacten met netwerkleden tot stand komen op basis van wederzijds initiatief (respectievelijk gemiddeld met 4.9 en 10.6 netwerkleden, $T=-3.81, p<.001$ ). Een dergelijk significant verschil wordt ook aangetroffen in de sector verwanten (respectievelijk gemiddeld 2.5 en 4.4 verwanten, $T=-2.39, P<.05$ ) en in de sector vriendschappelijke betrekkingen (respectievelijk gemiddeld 2.4 en 6.2 netwerkleen, $T=-3.65, p<$ .01). Overigens treden er op het niveau van de sectoren inzaken het initiatief in het contact met de netwerkleden nagenoeg geen verschillen op tussen de jongere patiënten en jongere referentiepersonen. 
Tussen de oudere patiënten en de oudere referentiepersonen treden in het geheel genomen de volgende significante verschillen betreffende het initiatief in het contact met hun netwerkleden op.

- De oudere patiënten nemen vergeleken met de oudere referentiepersonen in het geheel genomen naar gemiddeld significant minder nelwerkleden zelf het initiatief in het contact (respectievelijk gemiddeld naar 3.5 en 5.3 netwerkleden, $T=-$ 2.31,

$p<.05)$. Op het niveau van de sectoren is bij de oudere patiënten vergeleken met de oudere referentiepersonen een significant verschil hieromtrent alleen te vinden in de sector verwanten (respectievelijk gemiddeld 1.5 en 2.6 verwanten, $\mathrm{T}=$ - 2.11, $\mathrm{p}<.05$ ).

- Vervolgens blijken bij de oudere patiênten vergeleken met de oudere referentiepersonen in het geheel genomen gemiddeld significant minder contacten met nelwerkleden tot stand te komen op basis van wederzijds initiatief, (respectievelijk met gemiddeld 5.5 en 10.7 netwerkleden, $T=-2.34, p<.01$ ).

- Tenslotte toont tabel 10.12 dat in het geheel genomen de oudere patiënten vergeleken met de oudere referentiepersonen gemiddeld signifcant meer netwerkleden heben met wie geen initiatief in het contact wordt ondernomen, (respectievelijk gemiddeld 3.5 en 0.9 netwerkleden, $T=3.13, p<.01$ ). Een dergelijk significant verschil wordt tevens gevonden in de sector verwanten (respectievelijk gemiddeld 3.1. en 0.6 verwanten, $T=3.07, p<.01$ ). Een nadere analyse toont bijvoorbeeld dat $61 \%$ van de oudere referentiepersonen geen verwanten hebben met wie het initiatief in het contact ontbreekt, terwijl dit bij de oudere patiënten in $39 \%$ van de gevallen voorkomt.

Al bij al toont tabel 10.12 dat er inzake het initiatief in het contact bij de oudere ambulante chronisch psychiatrische patiënten vergeleken met de oudere referentiepersonen in het geheel genomen meer significante verschillen optreden dan bij de jongere patiënten vergeleken met de jongere referentiepersonen. Dit betekent dat hypothese 41 voor wat betreft het initiatief in het contact bevestigd wordt.

\section{FREQUENTIE}

TABEL 10.13 De frequentie van het contact bij de jongere en oudere patiënten vergeleken met de jongere en oudere referentiepersonen

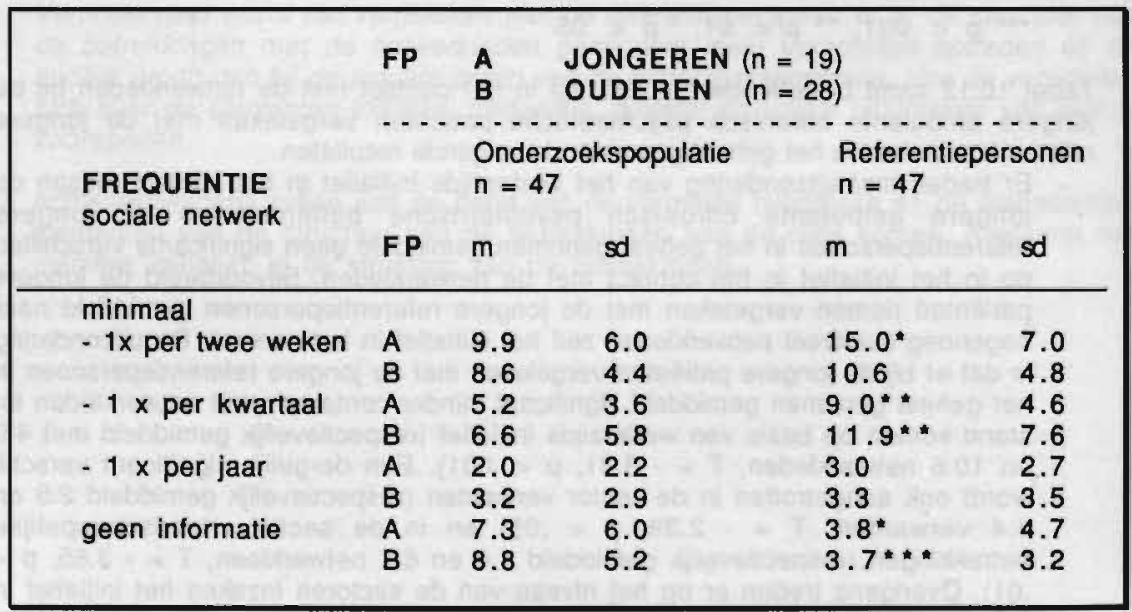

$* * p<.001, * * p, .01, * p<.05$ 
Tabel 10.13 toont dat er in het geheel genomen een aantal significante verschillen optreden fussen enerzijds de jongere en oudere patiènten en anderzijds de jongere en oudere referentiepersonen met betrekking tot de frequentie van hel contact met hun netwerkleden, te weten:

- de jongere patiënten hebben in vergelijking met de jongere referentiepersonen gemiddeld sgnificant minder netwerkleden met wie zij minimaal eenmaal per twee weken contact hebben (respectievelijk gemiddeld 9.9 en 15.0 netwerkleden, $T=$ $-2.40, p<.05$ )

- de jongere patiénten hebben in vergelijking met de jongere referentiepersonen gemiddeld significant minder netwerkleden met wie zij minimaal eenmaal per kwartaal contact hebben (respectievelijk gemiddeld 5.2 en 9.0 netwerkleden, $T=$ $-2.79, p<.01$ )

De jongere patiënten hebben vergeleken met de jongere referentiepersonen gemiddeld significant meer netwerkleden over wie geen adequate informatie inzake de frequentie van het contact gegeven wordt (respectievelijk gemiddeld 7.3 en 3.8 netwerkleden, $\mathrm{T}=2.04, \mathrm{p}<.05$ ).

- de oudere patiënten hebben vergeleken met de oudere referentiepersonen gemiddeld significant minder netwerkleden met wie zij minimaal eenmaal per kwartaal contact hebben, (respectievelijk gemiddeld 6.6 en 11.9 netwerkleden, $T=-2.92, p<.01)$;

- de oudere patienten hebben vergeleken met de oudere referentiepersonen gemiddeld significant meer netwerkleden over wie geen adequate informatie inzake de frequentie van het contact gegeven wordt (respectievelijk gemiddeld 8.8 en 3.7 netwerkleden, $T=4.34, p<.001$ ).

Op het niveau van de sectoren worden overigens nog de volgende verschillen aangetroffen.

- Binnen de sector verwanten blijken de jongere patiënten gemiddeld significant minder netwerkleden te hebben met wie zij minmaal eenmaal per kwartaal contact hebben dan bij de jongere referentiepersonen het geval is(respectievelijk gemiddeld 2.3 en 4.3 netwerkleden, $T=-2.59, p<.05$ ) Hetzelfde geldt voor de oudere patiënten in vergelijking met de oudere referentiepersonen (respectievelijk gemiddeld 3.0 en 6.3 netwerkleden, $T=-2.85, p<.01$ ).

- Binnen de sector vriendschappelijke betrekkingen blijken de jongere patiënten vergeleken met de jongere referentiepersonen gemiddeld significant minder netwerkleden te hebben met wie zij minimaal eenmaal per twee weken contact hebben (respectievelijk gemiddeld 2.7 en 8.0 netwerkleden, $T=-4.17, p<$ $.001)$.

- Binnen de sector vriendschappelijke betrekkingen blijken vervolgens de jongere patiënten in vergelijking met de jongere referentiepersonen gemiddeld significant minder netwerkleden te hebben met wie minstens eenmaal per kwartaal contact bestaat (respectievelijk gemiddeld 1.9 en 4.1 netwerkleden, $T=-2.49$. $p<.05$ ). Een dergelijk significant verschil doet zich hier ook voor bij de oudere patienten vergeleken met de oudere referentiepersonen (respectievelijk gemiddeld 2.1 en 4.6 netwerkleden, $T=-2.71, p<.01$ ).

- Binnen de sector maatschappelijke diensten worden in het geheel genomen geen significante verschillen aangetroffen omtrent de frequentie van het contact.

Al bij al kan gesteld worden dat er inderdaad significante verschillen optreden tussen de beide groepen van de onderzoekspopulatie enerzijds en de beide groepen referentiepersonen anderzijds omtrent de frequentie van hun contacten met netwerkleden. De verschillen die optreden in het gehele sociale netwerk komen overwegend terug op het niveau van de sectoren verwanten en vriendschappelijke betrekkingen. 
Met betrekking tot hypothese 41 tonen de uitkomsten dat de jongere en de oudere ambulante chronisch psychiatrische patiënten met uitzondering van de categorie 'zeer frequent contact' nagenoeg met elkaar overeenkomen inzake de significante verschillen die vergeleken mel de referentiepersonen optreden in de frequentie van het contact met hun netwerkleden. Op dit punt blijkt er vergeleken met de referentiepersonen in tegenstelling tot de oudere patiënten juist een significant verschil op te treden bij de jongere ambulante chronisch psychiatrische patienten. Hypothese 41 kan voor wat betreft de frequentie van het contact niet als bevestigd beschouwd worden.

\section{GEWICHT}

TABEL 10. 14 Het gewicht van het contact bij de jongere en oudere patiënten vergeleken met de jongere en oudere referentiepersonen.

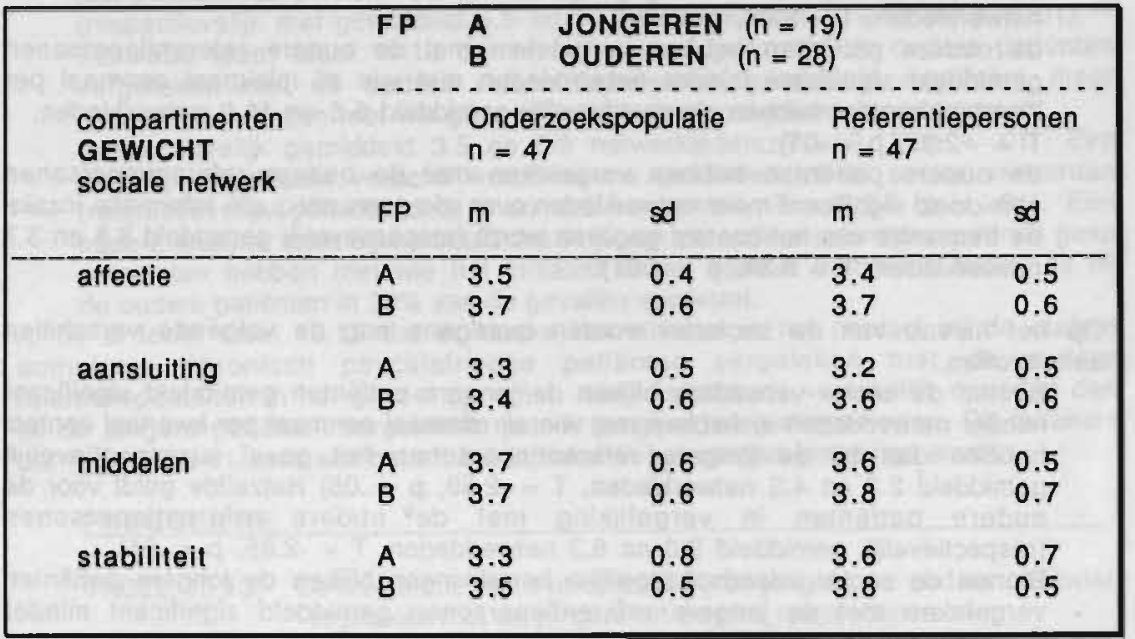

Bovenstaande tabel 10.14 toont dat er in het geheel genomen vergeleken met de referentiepersonen in de structuur van de betrekkingen met de netwerkleden inzake het element gewicht gemiddeld geen verschillen optreden tussen de jongere groep en de oudere groep van de onderzoekspopulatie. Met betrekking tot het element gewicht wordt hypothese 41 niet bevestigd. 


\section{LENGTE}

TABEL 10.15 De lengte van het contact bij de jongere en oudere patienten vergeleken met de jongere en oudere referentiepersonen.

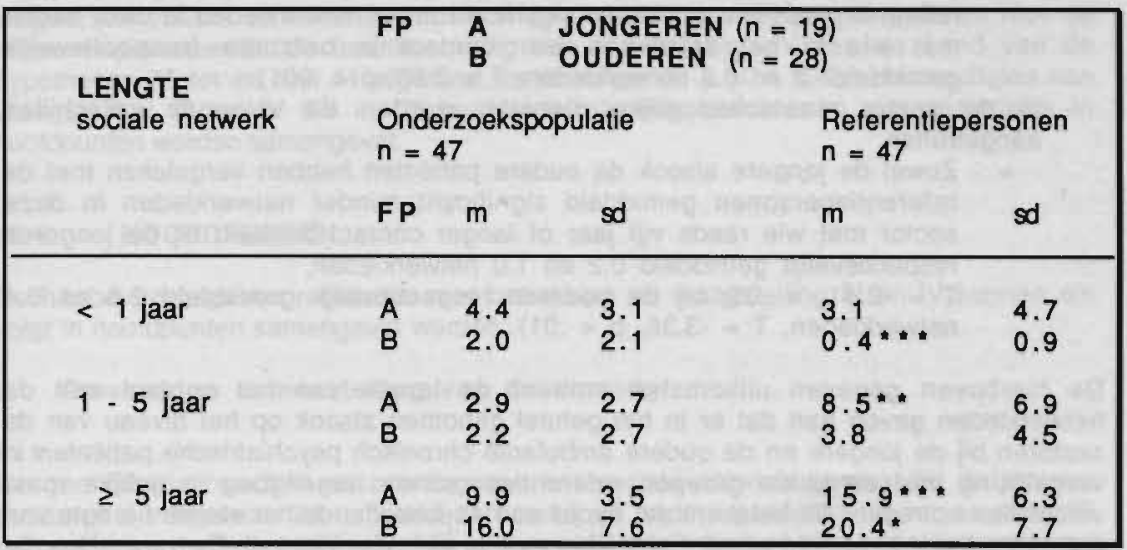

$\star * * p<.001, * * p<.01, * p<.05$

Tabel 10.15 toont in het geheel genomen met betrekking tot hypothese 41 de volgende uitkomsten.

- De jongere patiënten hebben vergeleken met de jongere referentiepersonen gemiddeld significant minder netwerkleden met wie het contact sinds éen jaar dan wel hooguit vier jaar bestaat, (respectievelijk 2.9 en 8.5 netwerkleden, $T=$ $3.30, p<.01$ ).

- De jongere patiënten hebben vergeleken met de jongere referentiepersonen gemideld significant minder netwerkleden met wie vijf jaar of langer contact bestaat, (respectievelijk gemiddeld 9.9 en 15.9 netwerkleden, $T=-3.61, p<$ $.001)$. Een dergelijke uitkomst wordt ook aangetroffen bij de oudere patienten vergeleken met de oudere referentiepersonen (respectievelijk gemiddeld 16.0 en 20.4 netwerkleden, $\mathrm{T}=-2.14, \mathrm{P}<.05)$.

- Tenslotte, de oudere patiënten hebben in het geheel genomen vergeleken met de oudere referentiepersonen gemiddeld significant meer netwerkleden met wie in het afgelopen jaar contact is onistaan (respectievelijk gemiddeld 2.0 en 0.4 netwerkleden, $T=3.70, p<.001)$.

Wanneer op het niveau van de sectoren netwerkleden naar de overeenkomsten dan wel de verschillen in de lengte van het contact wordt gekeken bij beide groepen van de onderzoekspoplatie vergeleken met beide groepen referentiepersonen dan kunnen de volgende uitkomsten gegeven worden.

- In de sector verwanten komt de lengte van hel contact mel de netwerkleden bij de jongere en oudere patiënten nagenoeg nagenoeg overeen mel die bij de jongere en oudere referentiepersonen.

- In de sector vriendschappelijke betrekkingen worden de volgende significante verschillen gevonden.

= De jongere patiènten hebben vergeleken met de jongere referentiepersonen gemiddeld significant minder netwerkleden in deze sector met wie zij minimaal sinds een jaar of hooguil vier jaar contact hebben (respectievelijk gemiddeld 1.2 en 5.9 netwerkleden, $T=3.39, p<.01$ ). 
$=$ De jongere patiënten hebben vervolgens in vergelijking mel de jongere referentiepersonen gemiddeld significant minder netwerkleden in de sector vriendschappelijke betrekkingen met wie zij reeds vijf jaar of langer contact hebben (respeclievelijk gemiddeld 1.7 en 5.8 netwerkleden, $\mathrm{T}=$ $3.64, p<.001)$.

= De oudere patiènten tenslotte hebben vergeleken met de jongere referentiepersonen gemiddeld significant meer netwerkleden in deze sector met wie in het afgelopen jaar contact is ontstaan (respectievelijk gemiddeld1.2 en 0.2 netwerkleden, $T=3.83, p<.001$ )

- In de sector maatschappelijke diensten worden de volgende verschillen aangetroffen.

= Zowel de jongere alsook de oudere patiënten hebben vergeleken met de referentiepersonen gemiddeld significant minder netwerkleden in deze sector met wie reeds vijf jaar of langer contact bestaat; bij de jongeren respectievelijk gemiddeld 0.2 en 1.0 netwerkleden,

$T=-2.41,<.05 ;$ bij de ouderen respectievelijk gemiddeld 2.6 en 6.4 netwerkleden, $T=-3.36, p<.01)$.

De hierboven gegeven uitkomsten omtrent de lengte van het contact met de netwerkleden geven aan dat er in het geheel genomen alsook op het niveau van de sectoren bij de jongere en de oudere ambulante chronisch psychiatrische patiënten in vergelijking met de beide groepen referentiepersonen nagengoeg in gelijke mate verschillen optreden. Dit betekent dat hypothese 41 betreffende hel element lengte van het contact niet bevestigd wordt. Echter hiermee is niet alles gezegd. De verschillen die bij de jongere patiënten vergeleken met de jongere referentiepersonen in het geheel genomen en in het bijzonder in de sector vriendschappelijke betrekkingen optreden betreffen vooral de lang(er) bestaande contacten, terwijl bij de oudere patiënten de verschillen met de oudere referentiepersonen met name de nog kort bestaande contacten betreffen.

Samenvallend kan over de uitkomsten van de analyse van de structuur van de belrekkingen in samenhang met hypothese $\mathbf{4 1}$ gezegd worden dat vergeleken met de referentiepersonen er in het bijzonder betreffende het initiatief in het contact in het geheel genomen meer verschillen optreden bij de oudere dan bij de jongere ambulante chronisch psychiatrische patiènten. Vergeleken met de referentiepersonen nemen de oudere patiënten gemiddeld significant minder zelf het initiatief tot contact en geen initialief tot contact met hun netwerkleden dan de jongere patiënten.

Voor wat betreft de frequentie van het contact kan men stellen dat er vergeleken met de referentiepersonen er in het geheel genomen bij de jongere paliënten meer verschillen optreden dan bij de oudere patiënten. Vergeleken met de referentiepersonen hebben de jongere patiënten gemiddeld significant minder netwerkleden met wie zeer frequent contact bestaat dan de oudere patiënten.

Inzake het gewicht van het contact met de netwerkleden treden er in het geheel genomen geen verschillen op lussen de beide groepen patiënten vergeleken met de beide groepen referentiepersonen.

Betreffende de lengte van het contact met de netwerkleden kan niel gezegd worden dat vergeleken met de referentiepersonen er bij de oudere patiënten meer verschillen optreden dan bij de jongere patiènten. Echter vergeleken met de referentiepersonen blijken de jongere patiënten gemiddeld significant minder netwerkleden te hebben met wie reeds lang(er) contact bestaat terwijl de oudere patiënten gemiddeld significant minder netwerkleden hebben met wie sinds kort contact bestaat.

Al bij al kan gesteld worden dat ook al wordt hypothese 41 grotendeels niet bevestigd er wel degelijk vergeleken met de referentiepersonen in het geheel genomen in de structuur van de betrekkingen significante veschillen optreden tussen de jongere en de oudere ambulante chronisch psychiatrische patiënten. Bovendien blijken de aangetroffen verschillen door te werken op het niveau van de sectoren, in het bijzonder de sector vriendschapelijke betrekkingen. De uitkomsten van de analyse van de 
structuur van de betrekkingen geeft een veel gedifferentieerder beeld dan in hypothese 41 verondersteld werd.

\section{TENSLOTTE}

Met de weergave van de resultaten betreffende de structuur van de betrekkingen bij de jongere en oudere ambulante chronisch psychiatrische patienten vergeleken mel de referentiepersonen is de beantwoording van vraagstelling IV aan de hand van de hypothesen 35 tot en met 41 afgerond. In de volgende $\S 10.4$ zullen de resultaten van vraagstelling III en IV die in dit hoofdstuk uitvoerig beschreven zijn gezamelijk in hoofdpunten worden samengevat.

\subsection{HOOFDPUNTEN}

De hierboven gegeven resultaten met betrekking tot vraagstelling III en IV kunnen als volgt in hoofdpunten samengevat worden.

\section{A Omvang en samenstelling van de omvang}

a.1

De gemiddelde beschikbare omvang van het sociale netwerk bestaat bij de jongere patiënten uit ongeveer 24 netwerkleden en bij de oudere patiënten vit om en nabij 26 netwerkleden. In tegenstelling tot de oudere patiënten treedt er bij de jongere patiènten vergeleken met jongere referentiepersonen een aanzienlijk verschil in de gemiddelde beschikbare omvang van het sociale netwerk op. De gemiddelde omvang van de jongere referentiepersonen bestaat uit ongeveer 30 netwerkleden. Het verschil betreft vooral de sector vriendschappelijke betrekkingen.

a. 2

De gemiddelde omvang van de sector verwantschap van de jongere en oudere ambulante chronisch psychiatrische patiënten komt nagenoeg overeen met die van de jongere en oudere referentiepersonen. Een belangrijk verschil dat evenwel bij de vergeleken groepen jongere patiënten en referentiepersonen wordt aangetroffen betreft het cluster partner / eigen gezin. Ongeveer driekwart van de patiënten in de leeflijd van 18 tot en met 34 jaar is niet in staat een vaste pariner te noemen terwijl dit bij de referentiepersonen in $16 \%$ van de gevallen geldt.

Vervolgens blijken de opmerkelijk geringere gemiddelde omvang van het cluster partner / eigen gezin en vervolgens die van de totale sector verwantschap bij de jongere patiënten vergeleken met die van de oudere patiënten in dezelide mate bij de referentiepersonen voor te komen.

a. 3

De gemiddelde omvang van de sector vriendschappelijke betrekkingen is aanzienlijk groter bij de jongere en oudere referentiepersonen vergeleken mel die van de jongere en oudere patiënten. Het verschil betreft het cluster naaste vrienden. De verschillen blijken bij de jongere patiënten iets groter te zijn dan bij de oudere patiēnten. Overigens lijkt er een tendens op te treden dat de gemiddelde omvang van de sector vriendschappelijke betrekkingen en van de daarbinnen onderscheiden clusters netwerkleden bij de groepen oudere patiënten en referentiepersonen enigszinds daalt vergeleken met die van de groepen jongere patiënten en referentiepersonen.

a. 4

De jongere patiënten hebben gemiddeld aanmerkelijk meer netwerkleden in het cluster werk / scholing dan de oudere patiënten. De jongere patiënten verschillen hier niet van de jongere referentiepersonen tenwijl dit bij de oudere patiěnten vergeleken met de oudere referentiepersonen juist wel het geval is.

a.5

De jongere patiënten hebben gemiddeld een zelfde aantal nelwerkleden in hel cluster hulpverlening als de oudere patiënten. Dat geldt ook voor de jongere en oudere referentiepersonen. Echter zowel de jongere alsook de oudere patiěnten hebben 
aanmerkelijk meer netwerkleden in het cluster hulpverlening als het geval is bij jongere en oudere referentiepersonen.

\section{B. Gevarleerdheld}

b. 1

De jongere patiënten sluiten vergeleken met de jongere referentiepersonen alleen qua werk- en woonsituatie significant minder op hun netwerkleden aan. Het sociale netwerk is bij jongere patiënten hieromtrent significant minder homogeen samengesteld.

\section{b. 2}

De oudere patiënten sluiten vergeleken de oudere referentiepersonen alleen qua leeftijd en werksituatie significant minder op hun netwerkleden aan. Ook hieromtrent geldt dat het sociale netwerk van de oudere patiënten minder homogeen is samengesteld.

b. 3

Een vergelijking van de gevarieerdheid van de netwerkleden tussen de jongere en oudere patiënten toont dat de samenstelling van hun sociale netwerken alleen overeenkomt inzake geslacht en het al dan niet hebben van werk. Inzake leeftijd en opleiding zijn de sociale netwerken van de jongere patiënten significant minder homogeen samengesteld als die van de oudere patienten. De significante verschillen die tussen de jongere en oudere patiënten in de samenstelling van hun sociale netwerken optreden zijn het grootst inzake burgelijke staat en woonsituatie. Het komt er op neer dat de sociale netwerken van de jongere patiënten hieromtrent in tegenstelling tot die van de oudere patiënten overwegend heterogeen samengesteld.

\section{b. 4}

De jongere en oudere ambulante chronisch psychiatrische patiënten hebben evenals de jongere en de oudere referentiepersonen in het algemeen een overwegend homogeen samengesteld sociaal netwerk. Er is een tendens waar te nemen dat bij de oudere patiënten en oudere referentiepersonen het homogene deel informele netwerkleden groter is dan bij de jongere patiënten en jongere referentiepersonen.

\section{Bereikbaarheld}

c. 1

De bereikbaarheid van de informele netwerkleden voor de jongere patiẻnten komt in het geheel genomen overeen met die voor de oudere patiënten. Zowel bij de jongere alsook bij de oudere patiënten wonen gemiddeld de meeste informele netwerkleden in de eigen woonplaats.

c.2

Vergeleken met de referentiepersonen hebben zowel de jongere alsook de oudere patiènten in het geheel genomen gemiddeld significant minder informele netwerkleden die in hun eigen woonplaats wonen. Daarnaast hebben de jongere patiènten gemiddeld significant minder informele netwerkleden die binnen de eigen regio wonen.

\section{Structuur van de betrekkingen}

\section{Initiatief}

d. 1

Tussen de jongere en de oudere ambulante chronisch psychiatrische patiénten treden er in het geheel genomen geen significante verschillen op inzake het initiatief in het contact met hun netwerkleden.

d. 2

Echter vergeleken met de referentiepersonen zijn er voor wat betreft het gehele sociale netwerk wel een aantal significante verschillen. Zowel de jongere als de oudere patienten hebben vergeleken met de referentiepersonen gemiddeld significant minder netwerkleden met wie hel contact gebaseerd is op wederzijds initiatief. 


\section{d. 3}

Vervolgens blijken de oudere patiënten vergeleken mel de relerentiepersonen in het geheel genomen gemiddeld significant minder netwerkleden te hebben naar wie zij zelf het initiatief tot contact nemen en gemiddeld significant meer netwerkleden te hebben met wie geen enkel initiatief tot contact wordt ondernomen.

\section{Frequentie}

d. 4

De jongere ambulante chronisch psychiatrische patiënten verschillen in het geheel genomen niet van de oudere patiënten inzake de frequentie van het contact met hun netwerkleden.

d.5

Vergeleken met de referentiepersonen hebben de jongere patiënten gemiddeld significant minder netwerkleden met wie zij minimaal eenmaal per week en minimaal eenmaal per kwartaal contact hebben. Deze verschillen worden eveneens gevonden op het binnen de sector verwanten en de sector vriendschappelijke betrekkingen.

d. 6

Vergeleken met de referentiepersonen hebben de oudere patiënten alleen gemiddeld significant minder netwerkleden met wie zijn minimaal eenmaal per kwarlaal conlact hebben. Ook dit verschl vindt men terug in de sector verwanten en de sector vriendschappelijke betrekkingen.

\section{d.7}

\section{Gewicht}

Wat betreft het gewicht van de contacten met de netwerkleden treden er voor wat betreft het gehele sociale netwerk geen significante verschillen op tussen de jongere en de oudere patiènten. Vergeleken met de referentiepersonen treden er evenmin bij de jongere en oudere patiënten significante verschillen op in hel gewicht van de contacten met hun netwerkleden.

\section{d. 8}

\section{Lengte}

De jongere ambulante chronisch psychiatrische patiënten hebben in hel sociale netwerk gemiddeld significant meer netwerkleden met wie sinds korte tijd ( $<1$ jaar) contact bestaat dan de oudere patiënten. De oudere patiènten hebben daarentegen in vergelijking met de jongere patiënten gemiddeld significant meer netwerkleden met wie het contact reeds vijf jaar of langer bestaat.

d. 9

Vergeleken met de jongere referentiepersonen beschikken de jongere patiënten over gemiddeld significant minder netwerkleden in het sociale netwerk als geheel met wie zij een (lang)er bestaand contact hebben terwijl de oudere patiënten vergeleken met de referentiepersonen enerzijds over gemiddeld significant meer netwerkleden beschikken met wie in het laatste jaar contact is ontstaan en anderzijds over minder netwerkleden met wie al langdurig contact bestaat. Deze uitkomsten zijn vervolgens grotendeels eveneens te vinden bij de sector vriendschappelijke betrekkingen. 


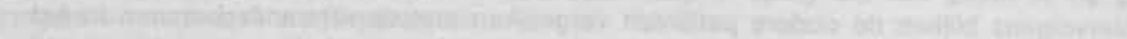

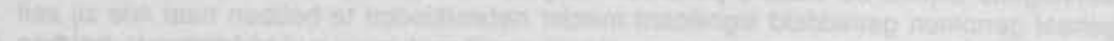

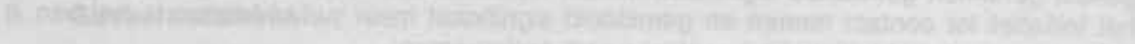

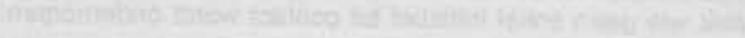

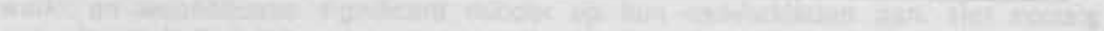

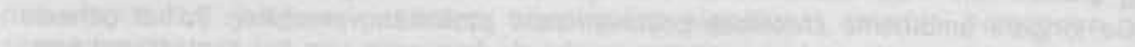

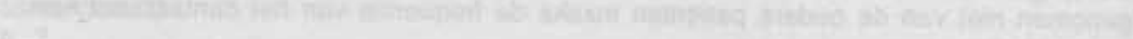
10.

(1) (15)

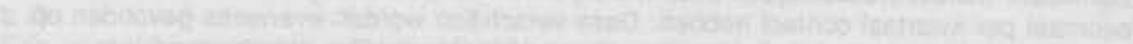

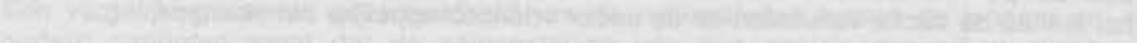

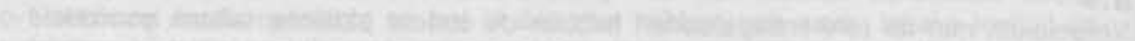

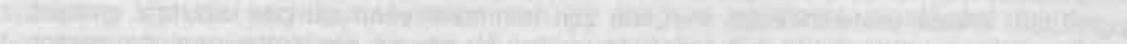

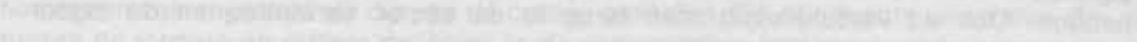

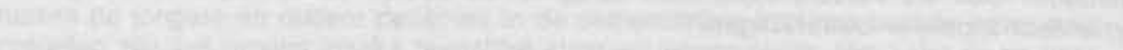




\title{
SOCIALE NETWERKEN VAN \\ JONGERE EN OUDERE PATIENTEN \\ BEKEKEN DOOR DE HULPVERLENING
}

Dit hoofdstuk betreft vraagstelling $V$. Deze luidt:

\begin{abstract}
WELKE VERSCHILEN DAN WEL OVEREENKOMSTEN, C.Q. PATRONEN BESTAAN ER VOLGENS DE MSNA IN DE STRUCTUUR VAN DE SOCIALE NETWERKEN BIJ DE GROEP JONGERE EN DE GROEP OUDERE AMBULANTE CHRONISCH PSYCHIATRISCHE PATIENTEN VERGELEKEN MET DE INFORMATIE DIE DE HULPVERLENERS VAN DE SPD OVER DE STRUCTUUR VAN HUN SOCIALE NETWERKEN VERSTREKKEN?
\end{abstract}

Voor de beantwoording van vraagstelling $V$ wordt gebruik gemaakt van de onderzoekspopulatie ( $n=44$; vergelijk $\S 9.1 .1$ ) bestaande uit 26 jongere en 18 oudere ambulante chronisch psychiatrische patiënten over wiens sociale netwerken de betreffende hulpverleners van de SPD Maastricht geïnterviewd zijn. De resultaten van vraagstelling $V$, en dat geldt voor alle structuurkenmerken, worden beschreven aan de hand van de in $\S 6.2 .5$ gegeven hypothese 42 .

\section{Ad hypothese 42}

Verondersteld wordt dat er verschillen in de structuur van de sociale netwerken zullen optreden wanneer een vergelijking wordt gemaakt tussen enerzijds de informatie die via de MSNA door de jongere en oudere ambulante chronisch psychiatrische patiënten wordt gegeven en anderzijds de gegevens die door de hulpverleners bij beide groepen patiënten verstrekt zijn. De richting van de optredende verschillen wordt vooraf niet nader aangegeven, hetgeen betekent dal de vitkomsten van de vergelijking open liggen.

\subsection{RESULTATEN VRAAGSTELLING $V$}

Achtereenvolgens worden aan de hand van hypothese 42 de resultaten betreffende de omvang van het sociale netwerk, de gevarieerdheid en de bereikbaarheid van de netwerkleden en betreffende de strucluur van de betrekkingen tussen de focale personen en hun netwerkleden gepresenteerd. Dit hoofdstuk wordt afgesloten met een samenvatting van de resultaten in hoofdpunten.

Tabel 11.1 toont de informatie die de jongere patiënten $(\operatorname{ad} A$ ) en de oudere patiënten (ad B) via de MSNA zelf over de omvang van hun sociale netwerken geven en die de hulpverleners erover bij de beide groepen patiënten verstrekken. 
TABEL 11.1 De omvang en de samenstelling van het sociale netwerk bij de jongere en oudere patiënten volgens de MNSA vergeleken met de informatie van de hulpverleners van de SPD

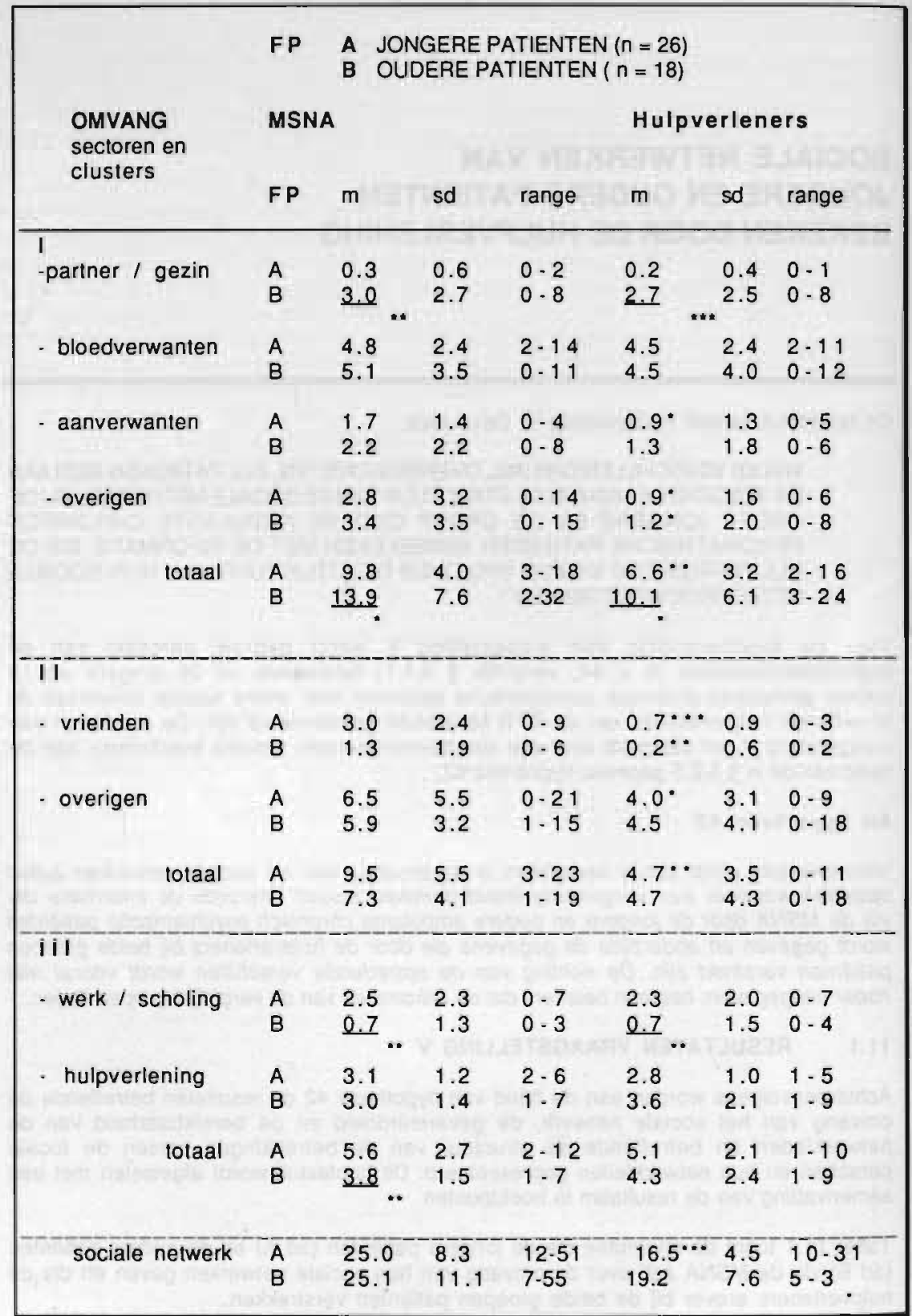

*** $p<.001 ; " * p<.01 ; * p<.05$ 


\subsubsection{Omvang en samenstelling van de omvang}

Tabel 11.1 toont dat er bij de clusters partner / eigen gezin en bloedverwanten geen verschil optreedt tussen de informatie die de jongere en oudere ambulante chronisch psychiatrische patiënten volgens de MSNA geven over de omvang van hun sociale netwerken en die de betrokken hulpverleners erover verstrekken. Een verschil treedt op bij de clusters aanverwanten en overige verwanten. De jongere patiënten geven via de MSNA aan dat zij in deze clusters over een gemiddeld significant grotere omvang netwerkleden beschikken dan door de betrokken hulpverleners vermeld wordt. De jongere patiënten vermelden met behulp van de MSNA gemiddeld 1.7 aanverwanten terwijl de hulpverleners een gemiddelde van 0.9 aanverwanten inventariseren $(T=$ 2.17, $p<.05)$; de jongere patiënten noemen vervolgens via de MSNA nog eens gemiddeld 2.8 overige verwanten behorend tot hun sociale netwerk terwijl de betreffende hulpverleners gemiddeld slechts 0.9 netwerkleden in dit cluster overige verwanten noemen $(T=2.66, p<.05)$.

De oudere patiënten noemen via de MSNA alleen bij het cluster overige verwanten gemiddeld significant meer netwerkleden dan de hulpverleners, (respectievelijk gemiddeld 3.4 en 1.2 netwerkleden, $T=2.32, p<.05$ ). Het komt er op neer dat de informatie van de jongere patiënten over de totale omvang van de sector verwanten via de MSNA significant verschilt met wat de hulpverleners aan informatie verstrekken (respectievelijk gemiddeld 9.8 en 6.6 verwanten, $T=2.04, p<.05$ ), terwijl er ten aanzien van de oudere patiënten nagenoeg geen verschil optreedt.

Deze trend zet zich door in de sector vriendschappelijke betrekkingen. De gemiddelde omvang van het cluster naaste vrienden en van het cluster overige vriendschappelijke betrekkingen (buren, collega's, kennissen) die de jongere patiënten met behulp van de MSNA zelf zichtbaar maken (respectievelijk gemiddeld 3.0 en 6.5 netwerkleden) verschilt significant (respectievelijk: $T=4.42, p<.001$ en $T=2.04, p<.05$ ) van de gemiddelde omvang die uit de informatie van de hulpverleners verschijnt (respectievelijk gemiddeld 0.7 en 4.0 netwerkleden). Bij de oudere patiënten is er alleen een significant verschil in de gemiddelde omvang van het cluster naaste vrienden; de oudere patiënten geven via de MSNA aan gemiddeld 1.3 netwerkleden in het cluster vrienden te hebben terwijl de hulpverleners vermelden dat er bij deze patiënten gemiddeld 0.2 netwerkleden in dit cluster aanwezig zijn ( $T$ = 2.26, $\mathrm{p}<.05$ ).

In de sector maatschappelijke diensten zijn er geen verschillen in de gemiddelde omvang in de informatie van de hulpverleners vergeleken met de gegevens die de jongere en oudere patiënten zelf volgens de MSNA verstrekken.

Tenslotte toont tabel 11.1 dat de totaal gemiddelde omvang netwerkleden in het sociale netwerk bij de jongere patënten op basis van de MSNA significant groter is vergeleken met de informatie die de hulpverleners verstrekken (respectievelijk gemiddeld 25.0 en 16.5 netwerkleden, $T=4.57, p<.001$ ). Het verschil betreft de clusters aanverwanten en overige verwanten en de gehele sector vriendschappelijke betrekkingen. Bij de oudere patiënten treedt er tussen de informatie van de hulpverleners en die volgens de MSNA verkregen is een significant verschil op in het cluster overige verwanten en in het cluster naaste vrienden maar deze verschillen zijn kleiner dan bij de jongere patiënten. De totale gemiddelde omvang van het sociale netwerk die bij de oudere patiënten verkregen wordı via de MSNA verschilt echter niet significant van de totaal gemiddelde omvang die in de informatie van de betreffende hulpverleners te vinden is.

Al bij al tonen de resultaten dat hypothese 42 met betrekking tot de omvang en samenstelling van de omvang bevestigd wordt. De MSNA geeft significant meer informatie dan door de hulpverleners verstrekt wordt. De verschillen tussen de informatie van de MSNA en de gegevens van de hulpverieners treden op in de sector verwanten (de cluster verwanten en overige verwanten) en in de gehele sector vriendschappelijke betrekkingen. 
Echter de meeste optredende verschillen in zowel de sector verwanten als de sector vriendschappelijke betrekkingen betreffen de jongere patiënten en wel in die zin dat er ook met betrekking tot de totale gemiddelde omvang een significant verschil optreedt tussen de informatie van de MSNA en de gegevens van de hulpverleners van de SPD. Bij de oudere patiënten treden minder significante verschillen op en zijn de significante verschillen die optreden in het cluster overige verwanten en het cluster naaste vrienden tevens kleiner. Ze zijn van dien aard dat er in het geheel genomen bij de oudere patiënten geen verschil optreedt tussen de informatie van de MSNA en die van de hulpverleners.

Met het oog op de analyse en beschrijving van de gevarieerdheid ( $\$ 11.1 .2)$ en de bereikbaarheid ( $(11.1 .3)$ van de informele netwerkleden wordt in de volgende tabel 11.2 een overzicht van de gemiddelde omvang informele netwerkleden bij de jongere en oudere ambulante chronisch psychiatrische patiënten gegeven en vergeleken met de gegevens erover in de informatie van de betreffende hulpverleners van de SPD.

TABEL 11.2 De omvang van de informele netwerkleden bij de onderzoekspopulatie ( $n=44$, onderverdeeld in 26 jongere en 18 oudere patiënten) volgens de MSNA vergeleken met de informatie van de hulpverleners van de SPD.

\begin{tabular}{|c|c|c|c|c|}
\hline \multirow[t]{3}{*}{ OMVANG } & \multicolumn{4}{|c|}{ Informele netwerkleden onderzoekspopulatie $(n=44)$} \\
\hline & \multicolumn{2}{|l|}{ MSNA } & \multicolumn{2}{|c|}{ Hulpverleners } \\
\hline & sd & range & sd & range \\
\hline $\begin{array}{l}\text { JONGEREN } \\
\text { OUDEREN }\end{array}$ & $\begin{array}{rr}19.3 & 7.2 \\
21.2 & 10.5\end{array}$ & $\begin{array}{l}10-41 \\
5-51\end{array}$ & $\begin{array}{l}11.3 * * * 4.9 \\
14.8 * 6.9\end{array}$ & $\begin{array}{l}3-25 \\
4-30\end{array}$ \\
\hline
\end{tabular}

$* * *<.001 ; * p<.05$

Tabel 11.2 toont dat er in de gemiddelde omvang informele netwerkleden bij de jongere patiënten een significant verschil optreedt tussen de gegevens volgens de MSNA en de informatie van de betreffende hulpverleners van de SPD (respectievelijk gemiddeld 19.3 en 11.3 informele netwerkleden, $T=4.71, p<.001$ ). Ten aanzien van de oudere patiënten is er eveneens een - weliswaar geringer - significant verschil (respectievelijk gemiddeld 21.2 en 14.8 informele netwerkleden, $T=2.16, p<.05$ ).

\subsubsection{Gevarieerdheid van de netwerkleden}

Zoals zojuist aangegeven heeft de analyse en beschrijving van de gevarieerdheid van de netwerkleden conform hypothese 42 betrekking op de informele netwerkleden. Met betrekking tol de gevarieerdheid van de informele netwerkleden ten opzichte van de focale personen luidt hypothese 42 als volgt:

Verondersteld wordt dat er verschillen in de gevarieerdheid van de informele netwerkleden zullen optreden wanneer een vergelijking wordt gemaakt tussen enerzijds de informatie die via de MSNA door de jongere en oudere ambulante chronisch psychiatrische patiënten wordt gegeven en anderzijds de gegevens die door de hulpverleners bij beide groepen patiēnten worden verstrekt.

In de volgende tabel 11.3 worden de resultaten van de vergelijking conform hypothese 42 gegeven. 
TABEL 11.3 De gevarieerdheid van de informele nelwerkleden bij de onderzoekspopulatie ( $n=44$ onderverdeeld in 26 jongere en 18 oudere patiënten) volgens de MSNA vergeleken met de inventarisatie van de hulpverleners van de SPD.

\begin{tabular}{|c|c|c|c|c|c|}
\hline \multirow[b]{3}{*}{ GEVARIEERDHEID } & \multirow{3}{*}{$\begin{array}{l}\text { FP } \\
F P\end{array}$} & \multicolumn{3}{|c|}{$\begin{array}{l}\text { A JONGERE PATIENTEN }(n=26) \\
\text { B OUDERE PATIENTEN }(n=18)\end{array}$} & \\
\hline & & \multicolumn{2}{|c|}{ MSNA } & \multicolumn{2}{|c|}{ Hulpverleners } \\
\hline & & $m$ & sd & $\mathrm{m}$ & sd \\
\hline - vrouwen & $\begin{array}{l}A \\
B\end{array}$ & $\begin{array}{l}7.4 \\
8.3\end{array}$ & $\begin{array}{l}3.4 \\
4.3\end{array}$ & $\begin{array}{l}3.9 \cdots \\
4.4 \cdots\end{array}$ & $\begin{array}{l}1.9 \\
3.1\end{array}$ \\
\hline - mannen & $\begin{array}{l}A \\
B\end{array}$ & $\begin{array}{l}7.2 \\
8.2\end{array}$ & $\begin{array}{l}3.6 \\
4.2\end{array}$ & $\begin{array}{l}3.2 * * \\
4.0 *\end{array}$ & $\begin{array}{l}1.7 \\
2.4\end{array}$ \\
\hline - jongeren & $\begin{array}{l}A \\
B\end{array}$ & $\begin{array}{l}7.1 \\
3.2\end{array}$ & $\begin{array}{l}4.4 \\
3.3\end{array}$ & $\begin{array}{l}1.9 * \\
1.4\end{array}$ & $\begin{array}{l}1.9 \\
1.9\end{array}$ \\
\hline - ouderen & $\begin{array}{l}A \\
B\end{array}$ & $\begin{array}{l}5.8 \\
8.7\end{array}$ & $\begin{array}{l}2.9 \\
5.8\end{array}$ & $\begin{array}{l}1.9 \cdots \\
2.5 * *\end{array}$ & $\begin{array}{r}1.0 \\
2.2\end{array}$ \\
\hline - met partner & $\begin{array}{l}A \\
B\end{array}$ & $\begin{array}{l}8.0 \\
9.5\end{array}$ & $\begin{array}{l}5.3 \\
7.2\end{array}$ & $\begin{array}{l}3.1 \cdots \\
5.0^{\star}\end{array}$ & $\begin{array}{l}2.4 \\
5.2\end{array}$ \\
\hline - zonder partner & $\begin{array}{l}\mathrm{A} \\
\mathrm{B}\end{array}$ & $\begin{array}{l}5.3 \\
2.6\end{array}$ & $\begin{array}{l}3.0 \\
2.3\end{array}$ & $\begin{array}{l}1.3^{* *} \\
1.4\end{array}$ & $\begin{array}{l}1.0 \\
1.5\end{array}$ \\
\hline - lager opgeleid & $\begin{array}{l}A \\
B\end{array}$ & $\begin{array}{l}2.8 \\
4.9\end{array}$ & $\begin{array}{l}2.8 \\
4.4\end{array}$ & $\begin{array}{l}0.6 * \\
1.1 *\end{array}$ & $\begin{array}{l}0.7 \\
1.4\end{array}$ \\
\hline - hoger opgeleid & $\begin{array}{l}A \\
B\end{array}$ & $\begin{array}{l}6.8 \\
3.9\end{array}$ & $\begin{array}{l}6.5 \\
6.0\end{array}$ & $\begin{array}{l}0.8 * * \\
0.7 *\end{array}$ & $\begin{array}{l}1.0 \\
1.1\end{array}$ \\
\hline - met werk & $\begin{array}{l}\mathrm{A} \\
\mathrm{B}\end{array}$ & $\begin{array}{l}9.6 \\
8.0\end{array}$ & $\begin{array}{l}4.9 \\
6.2\end{array}$ & $\begin{array}{l}2.1 * * \\
2.0 *\end{array}$ & $\begin{array}{l}1.5 \\
1.4\end{array}$ \\
\hline - zonder werk & $\begin{array}{l}A \\
B\end{array}$ & $\begin{array}{l}2.7 \\
2.8\end{array}$ & $\begin{array}{l}2.1 \\
1.7\end{array}$ & $\begin{array}{l}0.6 * * \\
1.1 *\end{array}$ & $\begin{array}{l}0.7 \\
0.9\end{array}$ \\
\hline - alleenwonend & $\begin{array}{l}A \\
B\end{array}$ & $\begin{array}{l}2.7 \\
1.3\end{array}$ & $\begin{array}{l}2.3 \\
1.8\end{array}$ & $\begin{array}{l}0.4^{\star \cdots} \\
0.4^{\star}\end{array}$ & $\begin{array}{l}0.7 \\
0.6\end{array}$ \\
\hline $\begin{array}{l}\text { - met partner/ } \\
\text { eigen gezin }\end{array}$ & $\begin{array}{l}A \\
B\end{array}$ & $\begin{array}{l}8.0 \\
9.0\end{array}$ & $\begin{array}{l}5.1 \\
6.4\end{array}$ & $\begin{array}{l}3.1 \cdots \\
3.1 *\end{array}$ & $\begin{array}{l}2.4 \\
2.0\end{array}$ \\
\hline - inwonend & $\begin{array}{l}\mathrm{A} \\
\mathrm{B} \\
\end{array}$ & $\begin{array}{l}2.3 \\
1.6 \\
\end{array}$ & $\begin{array}{l}2.4 \\
1.8 \\
\end{array}$ & $\begin{array}{l}0.4^{*} \\
1.0\end{array}$ & $\begin{array}{l}0.8 \\
1.2 \\
\end{array}$ \\
\hline
\end{tabular}

*** $p<.001 ; * p<.01 ; * p<.05$ 
De vergelijking in tabel 11.3 van de informatie die de jongere ambulante chronisch psychiatrische patiënten $(n=26)$ met behulp van MSNA over de gevarieerdheid van hun informele netwerkleden geven met de inventarisatie ervan door de betreffende hulpverleners leidt tot de bevinding dat MSNA vergeleken met de inventarisatie van de hulpverleners over gemiddeld significant meer informele netwerkleden informatie geeft inzake hun kenmerken van gevarieerdheid. Ook bij de oudere patiënten geeft de MSNA - zij het in mindere mate - bij gemiddeld significant meer informele netwerkleden informatie over hun gevarieerdheid dan het geval is in de gegevens van de hulpverleners. Vervolgens blijkt dat het gemiddeld aantal informele netwerkleden van zowel de jongere alsook van de oudere ambulante chronisch psychiatrische patiënten over wie de MSNA geen adequate informatie geeft niet verschilt van de inventarisatie van de hulpverleners (zie Bijlage VII,5). Deze algemene bevindingen worden eveneens aangetroffen bij de informele netwerkleden in de te onderscheiden sectoren verwanten en vriendschappelijke betrekkingen in de sociale netwerken van de jongere en oudere patiënten (zie Bijlage VII, 6 en 7).

Meer in bijzonderheden kunnen, zoals weergegeven is in tabel 11.3 en in Bijlage VII, 6 en 7 de volgende resultaten vermeld worden.

\section{Geslacht van de informele netwerkleden}

Volgens de MSNA hebben de jongere patiënten gemiddeld 7.4 vrouwelijke informele netwerkleden terwijl de hulpverleners gemiddeld 3.9 vrouwelijke informele netwerkleden inventariseren. Dit verschil is significant; $T=4.47, p<.001$. Een dergelijk significant verschil treedt eveneens op met betrekking tot de mannelijke informele netwerkleden (respectievelijk gemiddeld 7.2 en 3.2 mannelijke informele netwerkleden; $T=5.15, p<.001)$. Vergelijkbare significante verschillen zijn ook te vinden in de sector verwanten.

- Volgens de informatie van de MSNA beschikken de jongere patiënten gemiddeld over 4.9 vrouwelijke verwanten terwijl de hulpverleners gemiddeld 3.0 vrouwelijke verwanten inventariseren $(T=3.48, p<.01)$.

- Volgens de informatie van de MSNA beschikken de jongere patiënten gemiddeld over 4.7 mannelijke verwanten terwijl de hulpverleners gemiddeld 2.7 mannelijke verwanten inventariseren $(T=3.50, p<.01)$.

In de sector vriendschappelijke betrekkingen treden eveneens dergelijke significante verschillen op. De jongere patiënten hebben volgens de MSNA gemiddeld 2.4 vrouwelijke netwerkleden en volgens de hulpverleners gemiddeld 0.9 vrouwelijke netwerkleden in de sector vriendschappelijke betrekkingen ( $T=2.72, p<.05)$. Voor de mannelijke netwerkleden in de sector vriendschappelijke betrekkingen worden respectievelijk gemiddeld 2.5 en 0.5 netwerkleden vermeld $(T=4.34, p<.001$ ).

Tabel 11.3 toont dat ook bij de oudere patiënten de MSNA gemiddeld significant meer vrouwelijke en mannelijke netwerkleden zichtbaar maaki dan in de inventarisatie van de hulpverlener hel geval is. Dat geldt ook voor de sector verwanten (Bijlage VII,6). Echter in de sector vriendschappelijke betrekkingen treedt er bij de oudere patiènten geen significant verschil op tussen de informatie van de MSNA en de inventarisatie van de hulpverleners betreffende het gemiddeld aantal vrouwelijke en mannelijke informele netwerkleden (zie Bijlage VII,7).

Het zal in de bovenstaande gegevens opgevallen zijn dat in het geheel genomen over een deel van de informele netwerkleden geen adequate informatie over het geslacht beschikbaar is. Dat geldt zowel in de gegevens van de MSNA als die van de hulpverleners bij de jongere patiēnten (respectievelijk gemiddeld 4.7 en 4.2 informele netwerkleden) alsook bij de oudere patiënten (respectievelijk gemiddeld 4.7 en 6.4 informele netwerkleden). De optredende verschillen zijn niet significant (zie Bijlage VII,5). 
In de sector verwanten worden bij de jongere patiënten nauwelijks informele netwerkleden aangetroffen over wie adequate informatie inzake het geslacht ontbreekt. Het gemiddeld aantal informele netwerkleden waarover adequate informatie inzake het geslacht ontbreekt blijkt nagenoeg geheel betrekking te hebben op de sector vriendschappelijke betrekkingen (respectievelijk 4.5 en 3.4 informele netwerkleden; ook dit verschil is niet significant). Een nadere analyse geeft aan dat deze informele netwerkleden overwegend onder het cluster 'overigen' in de sector vriendschappelijke betrekkingen vallen. Bij de oudere patiënten is inzake de sector verwanten en de sector vriendschappelijke betrekkingen een vergelijkbare tendens waar te nemen.

\section{Leeftiid van de informele netwerkleden}

De MSNA maakt bij de jongere patiënten in het geheel genomen gemiddeld 7.1 informele netwerkleden zichtbaar die jonger zijn dan 35 jaar terwijl de hulpverleners hier gemiddeld 1.9 informele netwerkleden inventariseren. Het verschil is significant ( $T=$ $5.48, p<.001)$. Een dergelijk significant verschil doet zich ook voor bij de netwerkleden die 35 jaar of ouder zijn (respectievelijk 5.8 en 1.9 informele netwerkleden; $T=6.34, p<.001$ ). Bij de oudere patiënten treedt tussen de informatie van de MSNA en de inventarisatie van de hulpverleners alleen een significant verschil op inzake de oudere informele netwerkleden (respectievelijk gemiddeld 8.7 en 2.5 informele netwerkleden; $T=4.22, p<.001$ ).

In de sector verwanten treden hieromtrent bij de jongere patiënten eveneens significante verschillen op tussen de informatie van de MSNA en de inventarisatie van de hulpverleners. Hetzelf́de geldt voor de sector vriendschappelijke betrekkingen. Voor de sector verwanten van de jongere patiënten is vervolgens nog opmerkelijk dat in de informatie van de MSNA bij gemiddeld significant minder verwanten adequate informatie over de leeftijd ontbreekt dan het geval is in de inventarisatie van de hulpverleners (respectievelijk gemiddeld 1.2 en 3.2 verwanten; $T=-2.79, p<.01$ ).

In de informatie van de MSNA blijken bij de oudere patiënten vergeleken met de inventarisatie van de hulpverleners gemiddeld significant meer oudere verwanten zichtbaar te worden (respectievelijk gemiddeld 6.4. en 1.9 verwanten, $T=4.28, p<$ $.001)$. Ook in de sector vriendschappelijke betrekkingen treedt ten aanzien van de oudere netwerkleden een significant verschil op tussen de MSNA en de inventarisatie van de hulpverleners (respectievelijk gemiddeld 2.3 en 0.5 oudere informele netwerkleden, $\mathrm{T}=2.48, \mathrm{p}<.05$ ).

\section{Burgerlijke staat van de informele netwerkleden}

Volgens de MSNA hebben de jongere patiënten in het geheel genomen (zie tabel 11.3) gemiddeld 8.0 informele netwerkleden met een partner terwijl de hulpverleners gemiddeld 3.1 informele netwerkleden met een partner inventariseren $(T=4.27, p<$ .001). Een dergelijk significant verschil wordt ook aangetroffen voor de informele nelwerkleden zonder partner (respectievelijk gemiddeld 5.3 en 1.3 informele nelwerkleden; $T=6.38, p<.001)$. Opnieuw zijn dergelijke significante verschillen aan te treffen in de sector verwanten en de sector vriendschappelijke betrekkingen.

Bij de oudere patiënten treden aanzienlijk minder significante verschillen op tussen de informatie van de MSNA en de inventarisatie van de hulpverleners inzake de burgerlijke staat van de informele netwerkleden dan bij de jongere patiènten het geval is. De MSNA maakt bij de oudere patiênten in het geheel genomen gemiddeld significant meer informele netwerkleden met een partner zichtbaar dan het geval is in de inventarisatie van de hulpverleners (respectievelijk gemiddeld 9.5 en 5.0 informele netwerkleden met een partner, $T=2.17, p<.05)$. Een soorlgelijke uitkomst is eveneens te vinden in de sector vriendschappelijk betrekkingen (respectievelijk gemiddeld 1.9 en 0.5 informele netwerkleden met een partner, $T=2.45, p<.05$ ). 
De jongere patiènten geven via de MSNA aan dat zij in hel geheel genomen gemiddeld 2.8 informele netwerkleden hebben die tot de lager opgeleiden gerekend worden, terwijl de hulpverleners hier gemiddeld 0.6 informele netwerkleden inventariseren. Dit verschil is significant ( $T=3.75, p<.01$ ). Volgens de MSNA beschikken de jongere patiënten gemiddeld over 6.8 hoger opgeleide informele netwerkleden terwijl de hulpverleners hier 0.8 informele netwerkleden inventariseren. $\mathrm{Er}$ is eveneens sprake van een significant verschil $(T=4.62, p<.001)$. Dergelijke significante verschillen zijn voor de jongere patiënten eveneens aanwezig in de sector verwanten en in de sector vriendschappelijke betrekkingen.

Ook bij de oudere patiënten worden in het geheel genomen significante verschillen aangetroffen tussen de informatie van de MSNA en de inventarisatie van de hulpverleners inzake de opleiding van de informele netwerkleden. Achtereenvolgens respectievelijk gemiddeld 4.9 en 1.1 lager opgeleide informele netwerkleden ( $T=$ $3.50, p<.01)$ en respectievelijk gemiddeld 3.9 en 0.7 hoger opgeleide informele netwerkleden $(T=2.19, p<.05)$. Soortgelijke uitkomsten zijn bij de oudere patiënten alleen in de sector verwanten aanwezig.

Het gemiddeld aantal informele netwerkleden bij wie de jongere patiënten via de MSNA geen adequate informatie inzake opleiding weten te geven is in het geheel genomen gelijk aan de inventarisatie van de hulpverleners (respectievelijk 9.7 en 9.9 informele netwerkleden). Dat geldt ook voor de oudere patiënten (respectievelijk gemiddeld 12.4 en 13 informele netwerkleden). In de sector verwanten gaat het bij de jongere patiënten respectievelijk om respectievelijk gemiddeld 3.3 en 5.2 verwanten bij wie adequate informatie inzake opleiding ontbreekt. Dit verschil is significant ( $T=$ $-2,28, p<.05$ ) in tegenstelling tot de sector vriendschappelijke betrekkingen waar het gemiddeld aantal informele netwerkleden (respectievelijk gemiddeld 6.4 en 4.7 netwerkleden) waarover geen adequate informatie inzake opleiding gegeven wordt geen significant verschil geeft te zien. Bij de oudere patiënten worden in de sectoren verwanten en vriendschappelijke betrekkingen geen significante verschillen aangetroffen.

\section{Werksituatie van de informele netwerkleden}

Tabel 11.3 toont dat de jongere patiënten volgens de MSNA in het geheel genomen gemiddeld 2.7 informele netwerkleden noemen die geen dagvulling in de zin van werk of studie hebben terwijl dit in de inventarisatie van de hulpverleners gemiddeld 0.6 informele netwerkleden zijn. Dit verschil is significant: $T=4.77, p<.001$. Bij de oudere patiënten gaat het respectievelijk gemiddeld om 2.8 en 1.1 informele netwerkleden, eveneens een significant verschil $(T=3.51, p<.01)$. De jongere patiënten blijken in het geheel genomen volgens de MSNA gemiddeld significant meer informele netwerkleden te hebben die een dagvulling hebben in de zin van werk of studie dan in de inventarisatie van de hulpverleners zichtbaar wordt (respectievelijk gemiddeld 9.6 en 2.1 informele netwerkleden; $T=7.38, p<.001$ ). Bij de oudere patiënten zijn er respectievelijk gemiddeld 8.0 en 2.0 informele netwerkleden met werk of studie $(T=3.97, p<.01)$.

Dergelijke bevindingen zijn bij zowel de jongere alsook bij de oudere ambulante chronisch psychiatrische patiënten eveneens te vinden in de sector verwanten.

- Volgens de MSNA hebben de jongere patiënten gemiddeld significant meer verwanten die geen werk of studie hebben dan in de inventarisatie van de hulpverleners het geval is (respectievelijk gemiddeld 2.2 en 0.6 verwanten; $T=$ 3.86, $\mathrm{p}<.01$ ).

- Volgens de informatie van de MSNA hebben eveneens de oudere patiënten gemiddeld significant meer verwanten die geen werk of studie hebben dan het geval is in de inventarisatie van de hulpverleners (respectievelijk gemiddeld $\mathbf{1 . 9}$ en 0.8 verwanten, $\mathrm{T}=2.60, \mathrm{p}<.05$ ). 
- De jongere patiënten blijken volgens de MSNA eveneens gemiddeld significant meer verwanten met werk of studie te hebben dan in de inventarisatie van de hulpverleners het geval is (respectievelijk gemiddeld 6.1 en 2.0 verwanten; $T=$ $5.81, p<.001$ ).

- De oudere patiënten blijken volgens de MSNA eveneens gemiddeld significant meer verwanten met werk of studie te hebben dan in de inventarisatie van de hulpverleners het geval is (respectievelijk gemiddeld 6.4 en 1.8 verwanten, $T=$ $3.55, \mathrm{p}<.01$ ).

Ook in de sector vriendschappelijke betrekkingen zijn bij de jongere patiènten hieromtrent dergelijke significante verschillen te vinden tussen de informatie van de MSNA en de gegevens van de hulpverleners.

\section{Woonsituatie van de informele netwerkleden}

In het geheel genomen zijn volgens de informatie van de MSNA gemiddeld 2.7 informele netwerkleden van de jongere patiënten alleenwonend, terwijl dit in de inventarisatie bij gemiddeld 0.4 informele netwerkleden het geval is. Dit verschil is significant: $T=$ $4.58, p<.001$. In de sector verwanten gaat het bij de jongere patienten hier respectievelijk om gemiddeld 1.3 en 0.3 verwanten, eveneens een significant verschil: $T=4.33, p<.001$. Ook in de sector vriendschappelijke betrekkingen treedt een dergelijk significant verschil op (respectievelijk gemiddeld 1.4 en 0.2 informele netwerkleden, $T=4.58, p<.001$ ).

In het geheel genomen wonen volgens de informatie van de MNSA gemiddeld 8.0 informele netwerkleden van de jongere patiënten samen met hun partner dan wel met hun eigen gezin. In de inventarisatie van de hulpverleners is dit bij gemiddeld 3.1 informele netwerkleden het geval. Het verschil is significant: $T=4.42, p<.001$. Ook in de sectoren verwanten en vriendschappelijke betrekkingen treden soortgelijke significante verschillen op. Vervolgens blijken in het geheel genomen bij de jongere patiënten volgens de informatie van de MSNA gemiddeld 2.3 informele nefwerkleden in te wonen bij familie of in een woongroep te wonen, terwijl dit in de inventarisatie van de hulpverleners voor gemiddeld 0.4 informele netwerkleden hel geval is. Dit verschil is significant: $T=3.68, p<.01$. Ook hieromtrent treden er in de sector verwanten en de sector vriendschappelijke betrekkingen soorigelijke significanle verschillen op tussen de informatie van de MSNA en de inventarisatie van de hulpverleners bij de jongere patiënten.

Bij de oudere patiënten zijn significante verschillen tussen de informatie van de MSNA en de inventarisatie van de hulpverleners overwegend aanwezig betreffende de informele netwerkleden die samen met hun partner/eigen gezin wonen. In de informatie van de MSNA hebben de oudere ambulante chronisch psychiatrische patiënten zowel in het geheel genomen alsook in de sectoren verwanten en vriendschappelijke betrekkingen gemiddeld significant meer informele netwerkleden die samen met hun partner/eigen gezin wonen:

- in het geheel genomen respectievelijk gemiddeld 9.0 en 3.1 informele netwerkleden ( $T=3.75, p<.01)$,

- in de sector verwanten respectievelijk gemiddeld 7.0 en 2.7 verwanten ( $T=$ $3.31, \mathrm{p}<.01$ ),

- in de sector vriendschappelijke betrekkingen respectievelijk gemiddeld 1.9 en 0.3 informele netwerkleden $(T=2.82, p<.05)$.

\subsubsection{Bereikbaarheid van de netwerkleden}

De bereikbaarheid betreft evenals de gevarieerdheid van de netwerkleden ten opzichte van de focale personen de informele netwerkleden (zie tabel 11.2). Hypothese $42 \mathrm{komt}$ met betrekking tot de bereikbaarheid van de informele netwerkleden op het volgende neer.

Vermoed word dat er verschillen zullen optreden tussen de informatie die de jongere en oudere patiënten over de bereikbaarheid van hun inlormele netwerkleden geven met 
behulp van de MSNA en de gegevens die door de betreffende hulpverleners hierover bij beide groepen patiënten verstrekt worden.

In de volgende tabel 11.4 zijn de resultaten van de vergelijking weergegeven.

TABEL 11.4 De bereikbaarheid van de informele netwerkleden bij de jongere en oudere patiënten volgens de MSNA vergeleken met de informatie van de hulpverleners van de SPD.

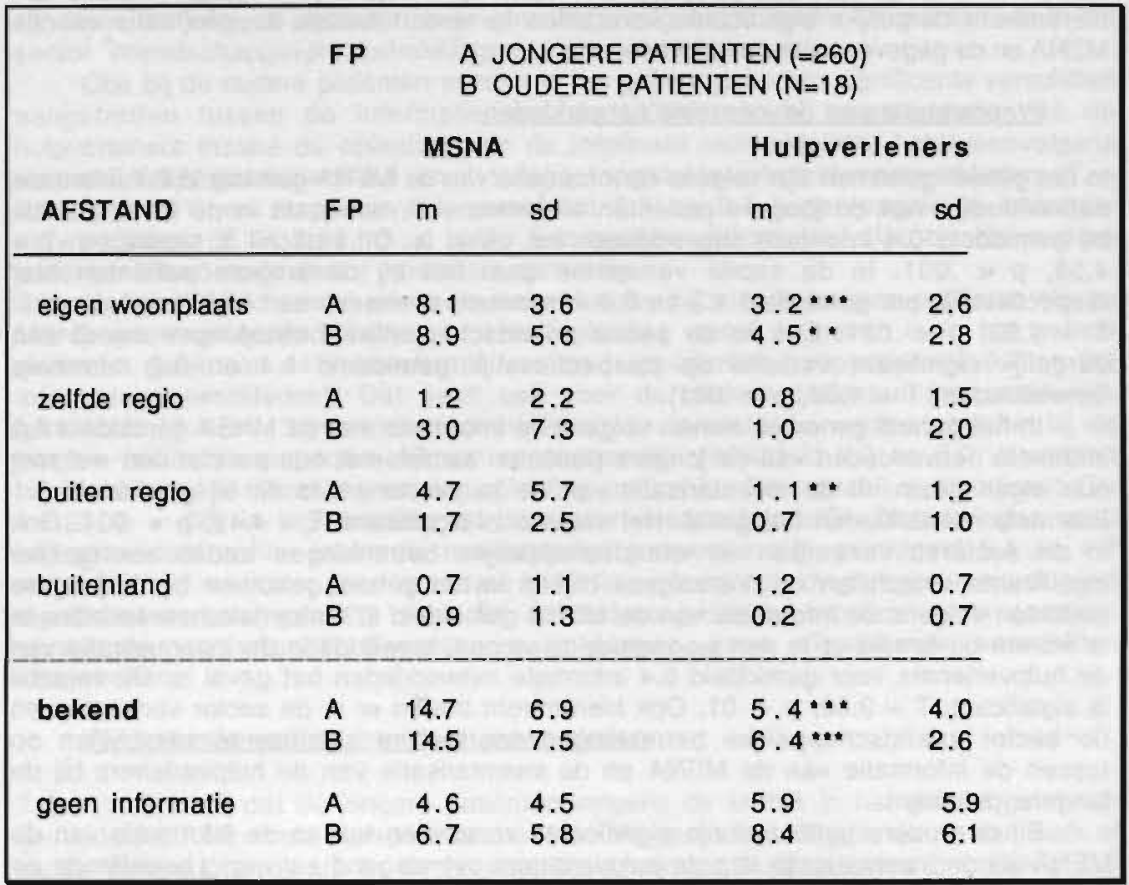

*** $p<.001 ; * * p<.01 ; * p<.05$.

Wellicht ten overvloede: 'bekend' in tabel 11.4 betekent dat er sprake is van adequate informatie; 'geen informatie' houdt in dat adequate informatie ontbreekt.

Een vergelijking van de informatie die de jongere ambulante chronisch psychiatrische patiënten met behulp van de MSNA over de bereikbaarheid van hun informele netwerkleden geven met de inventarisatie ervan door de betreffende hulpverleners van de SPD zoals weergegeven in bovenstaande tabel 11.4 leidt tot de volgende bevindingen.

- Er treedt in het geheel genomen een significant verschil op tussen de gemiddelde omvang informele netwerkleden van de jongere patiënten die bereikbaar zijn volgens de informatie van de MSNA en de gegevens van de hulpverleners (respectievelijk gemiddeld 14.7 en 5.4 informele netwerkleden zijn bereikbaar; $T=5.91, p<.001)$.

- De jongere patiënten hebben volgens de MSNA gemiddeld significant meer informele netwerkleden in hun eigen woonplaats dan de betreffende hulpverleners inventariseren (respectievelijk gemiddeld 8.1 en 3.2 informele netwerkleden, $T=5.47, p<.001)$. 
- De jongere patiënten vermelden via de MSNA gemiddeld 1.2 netwerkleden die in de eigen regio wonen, een gegeven dat nagenoeg overeenkomt met de gemiddelde omvang van 0.8 netwerkleden in de informatie van de betreffende hulpverleners. Via de MSNA geven 17 (65\%) jongere patiënten aan geen netwerkleden in de eigen regio te hebben; de betreffende hulpverleners vermelden bij 19 (73\%) jongere patiënten geen netwerkleden in de eigen regio.

- De jongere patiënten vermelden volgens de MSNA in tegenstelling tot de gegevens van de betreffende hulpverleners in het geheel genomen gemiddeld significant meer informele netwerkleden buiten de eigen regio (respectievelijk gemiddeld 4.7 en 1.1 netwerkleden; $T=3.18, p<.01$ ). Er zijn volgens de MSNA vijf jongere patiënten ( $19 \%$ ) die geen netwerkleden buiten de eigen regio hebben terwijl de hulpverleners aangeven dat 13 jongere patiënten $(50 \%)$ geen netwerkleden buiten de eigen regio hebben.

- Het gemiddeld aantal informele netwerkleden bij wie adequate informatie over de bereikbaarheid ontbreekt is in de informatie van de jongere patiënten op basis van de MSNA vrijwel gelijk aan de gegevens van de hulpverleners (respectievelijk gemiddeld 4.6 en 5.9 netwerkleden).

Het probleem is echter dat dit gemiddeld aantal van 4.6 informele netwerkleden bij de MSNA $24 \%$ van de informele netwerkleden is, terwijl de gemiddelde omvang van 5.9 netwerkleden in de informatie van de hulpverleners neerkomt op $50 \%$ van de informele netwerkleden.

Een vergelijking van de informatie via de MSNA bij de oudere groep patiënten over de bereikbaarheid van hun informele netwerkleden met de gegevens erover bij de betreffende hulpverleners leidt tot de volgende bevindingen.

- De oudere ambulante chronisch psychiatrische patiënten hebben volgens de MSNA in het geheel genomen gemiddeld significant meer bereikbare informele netwerkleden dan uit de gegevens van de betreffende hulpverleners naar voren komt, (respectievelijk gemiddeld 14.5 en 6.4 bereikbare informele netwerkleden, $T=, p<.001$ ).

- De oudere patiënten hebben volgens de MSNA gemiddeld signifcant meer informele netwerkleden in hun eigen woonplaats dan uit de gegevens van de betreffende hulpverleners blijkt, (respectievelijk gemiddeld 8.9 en 4.5 netwerkleden, $\mathrm{T}=$ 2.97, $\mathrm{p}<.01$ ).

- De omvang van gemiddeld 6.7 informele netwerkleden bij de oudere patiënten bij wie via de MSNA geen adequate informatie over de bereikbaarheid gegeven wordt komt nagenoeg overeen met de omvang van gemiddeld 8.4 informele netwerkleden in de informatie waarover de hulpverleners geen informatie verstrekken.

Al bij al komt het er op neer dat de hierboven gegeven bevindingen een bevestiging van hypothese 42 inzake de bereikbaarheid van de informele netwerkleden inhouden.

\subsubsection{Structuur van de betrekkingen}

De analyse en beschrijving van de structuur van de betrekkingen bij vraagstelling $V$ vindt eveneens plaats aan de hand van de hypothese 42 (zie $\S 6.2 .5$ ) en betreft het gehele sociale netwerk, dat wil zeggen de informele en formele netwerkleden tesamen (zie tabel 11.1). Hypothese 42 luidt ten aanzien van de structuur van de betrekkingen als volgt.

Verondersteld wordt dat er verschillen zullen optreden in het initiatief in het contact en in de frequentie, het gewicht en de lengte van het contact bij een vergelijking van enerzijds de gegevens via de MSNA door de jongere en oudere patiênten worden verstrekt en anderzijds de informatie die door de hulpverleners bij beide groepen ambulante chronisch psychiatrische patiënten gegeven wordt. 
TABEL 11.5 Het initiatief in het contact met netwerkleden bij de jongere en oudere groep patiënten volgens de MSNA vergeleken met de informatie van de hulpverleners van de SPD.

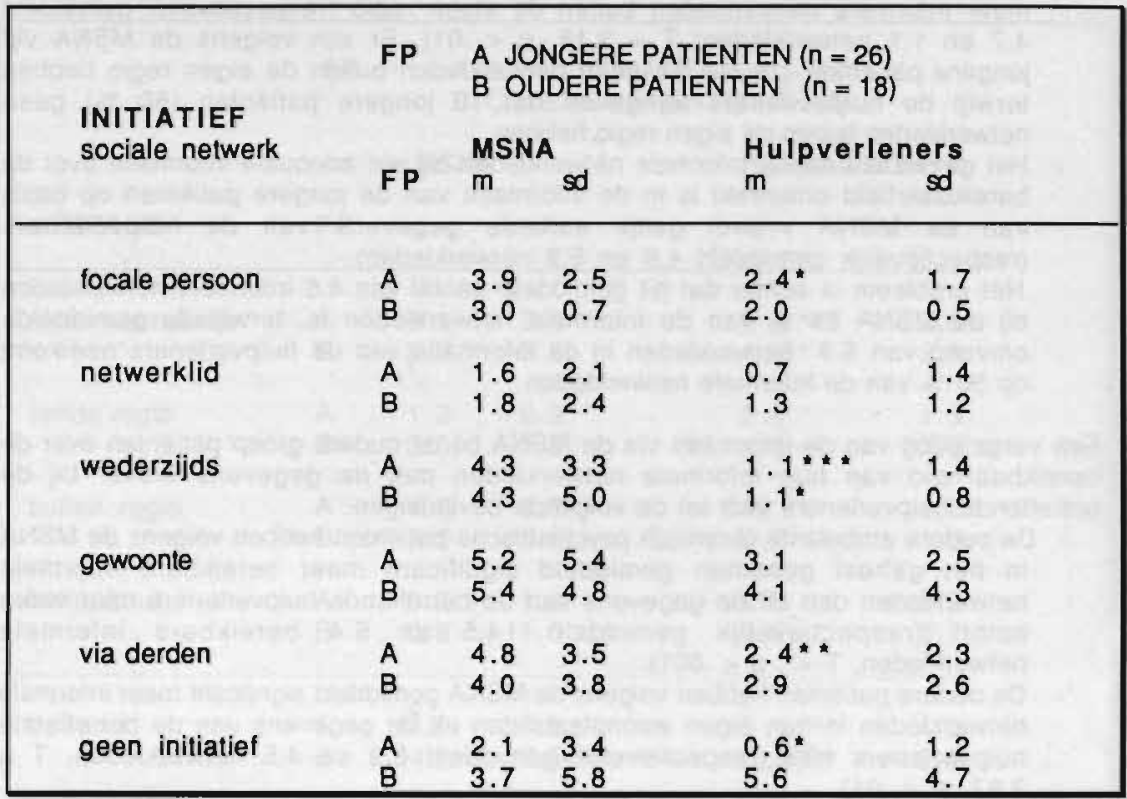

*** $p<.001 ; * * p<.01 ; * p<.05$

Een vergelijking van de informatie volgens de MSNA met die van de hulpverleners van de SPD over het initiatief in hel contact tussen de jongere patiënten en hun netwerkleden laat zien dat in het geheel genomen bij vrijwel alle variabelen van initiatief de informatie via de MSNA verkregen significant verschilt met de informatie van de hulpverleners.

Bij de jongere ambulante chronisch psychiatrische patiënten kunnen betreffende het gehele sociale netwerk en de sectoren netwerkleden de volgende significante verschillen vermeld worden. (Op het niveau van de sectoren zijn verreweg de meeste verschillen te vinden in de sector vriendschappelijke betrekkingen (Bijlage VIII, 2)).

- De jongere patiënten nemen in het geheel genomen volgens de MSNA naar gemiddeld significant meer netwerkleden zelf het initiatief tot contact dan in de informatie van de hulpverleners het geval is (respectievelijk naar gemiddeld 3.9 en 2.5 netwerkleden, $T=2.38, p<.05)$. Alleen binnen de sector vriendschappelijke betrekkingen wordt hieromtrent een soortgelijk significant verschil gevonden (respectievelijk gemiddeld naar 1.2 en 0.3 netwerkleden, $T=$ 2.46, $p<.05$ ).

- In hel geheel genomen treedt er geen verschil op tussen de informatie volgens de MSNA en die van de hulpverleners wat betrelt hel gemiddeld aanlal nelwerkleden die zelf het initiatief tot contact met de jongere patiënten nemen. 
Echter in de sector vriendschappelijke betrekkingen blijken in de informatie via de MSNA gemiddeld 0.5 netwerkleden zelf het initiatief te nemen, terwijl in de informatie van de hulpverleners geen enkel netwerklid in deze sector voorkomt die zelf het initiatief tot contact naar de jongere patiënt neemt. Dit verschil is significant: $T=2.17, p<.05$.

- De jongere patiënten blijken in de informatie via de MSNA vergeleken mel die van de hulpverleners in het geheel genomen gemiddeld significant meer netwerkleden te hebben met wie het contact gebaseerd is op wederzijds initiatief (respectievelijk gemiddeld 4.3 en 1.1 netwerkleden, $T=4.48, p<.001$ ). Een soortgelijk verschil treedt hieromtrent ook op in de sector verwanten (respectievelijk gemiddeld 2.3 en 0.7 verwanten, $T=3.27, p<.01$ ) en wederom in de sector vriendschappelijke betrekkingen (respectievelijk gemiddeld 2.0 en 0.3 netwerkleden, $T=4.15, p<.001$ ).

- Vervolgens geven de jongere patiënten via de MSNA te kennen dat zij in hel geheel genomen significant meer netwerkleden hebben met wie het contact tot stand komt via het initiatief van derden (respectievelijk gemiddeld 4.8 en 2.4 netwerkleden, $T=2.78, p<.01)$. Ook in de sector verwanten treedt hieromtrent een significant verschil op (respectievelijk gemiddeld 2.6 en 1.2 verwanten, $T=2.18, p<.05$ ) en eveneens in de sector vriendschappelijke betrekkingen (respectievelijk 1.1 en 0.3 netwerkleden, $T=2.09, p<.05$ ).

- Tenslolle blijken de jongere patiènten volgens de MSNA in hel geheel genomen gemiddeld significant meer netwerkleden te hebben bij wie geen initiatief tot contact bestaat dan in de informatie van de hulpverleners hel geval is (respectievelijk gemiddeld 2.1 en 0.6 netwerkleden, $T=2.23, p<.05$ ). Dit significante verschil is ook terug te vinden in de sector vriendschappelijke betrekkingen (respectievelijk gemiddeld 1.0 en 0.2 netwerkleden, $T=2.19, p<$ .05 ).

- Omtrent het initiatief in het contact met netwerkleden in de sector maatschappelijke diensten kan vermeld worden dat de informatie volgens de MSNA nagenoeg overeenkomt met die van de hulpverleners.

In tegenstelling tot de informatie volgens de MSNA vergeleken mel die van de hulpverleners omtrent het initiatief in het contact bij de jongere ambulante chronisch psychiatrische patiënten blijkt er zoals tabel 11.5 aangeeft voor wat betreft het gehele sociale netwerk tussen de informatie via de MSNA verkregen en die van de hulpverleners omtrent het initiatief tot contact bij de oudere patiënten nauwelijks een significant verschil op te treden. Het enige verschil dal in het gehele sociale nelwerk wordt aangetroffen is dat de oudere patiënten volgens de MSNA gemiddeld significant meer netwerkleden hebben met wie het contact gebaseerd is op wederzijds initiatief als in de informatie van de hulpverleners het geval is (respectievelijk gemiddeld 4.3 en 1.1 netwerkleden, $T=2.74, p<.05$ ).

Op het niveau van de sectoren treden bij de oudere patiënten nog de volgende significante verschillen op.

- De oudere patiënten blijken via de MSNA vergeleken met de informatie van de hulpverleners in de sector verwanten gemiddeld significant meer netwerkleden te hebben met wie het contact gebaseerd is op wederzijds initiatief (respectievelijk gemiddeld 3.1 en 0.8 verwanten, $T=2.16, p<.05$ ). Tevens blijken de oudere patiënten via de MSNA in vergelijking met de informatie van de hulpverleners aan te geven dat zij gemiddeld significant meer verwanten hebben met wie het contact gebaseerd is op hun eigen initiatief (respectievelijk gemiddeld 1.7 en 0.5 netwerkleden, $T=2.43, p<.05$ ).

- Binnen de sector vriendschappelijke betrekkingen blijken de oudere patiènten via de MSNA vergeleken met de informatie van de hulpverleners eveneens aan te geven dat zij gemiddeld significant meer netwerkleden hebben met wie het contact gebaseerd is op wederzijds initiatief (respectievelijk 1.3 en 0.2 netwerkleden, T $=2.55, p<.05)$. 
- Binnen de sector maatschappelijke diensten blijken zowel in de informatie van de MSNA als die van de hulpverleners gemiddeld nagenoeg geen netwerkleden voor te komen bij de oudere patiënten met wie het contact gebaseerd is op wederzijds initiatief.

Al bij al wordt de veronderstelling conform hypothese 42 bevestigd. Er treden significante verschillen op ten aanzien van het initiatief in het contact met de netwerkleden bij een vergelijking tussen enerzijds de informatie die via de MSNA door de jongere en oudere patiënten wordl gegeven en anderzijds de gegevens die door de hulpverleners bij beide groepen worden verstrekt. Zowel in het geheel genomen als ook op het niveau van de sectoren worden de meeste significante verschillen tussen de informatie van de MSNA en die van de hulpverleners bij de jongere patiënten aangetroffen. Waar significante verschillen optreden komt het er op neer dat de hulpverleners een beperkter beeld geven van de gemiddelde omvang netwerkleden in relatie tot het initiatief in het contact dan de patiënten zelf via de MSNA aan informatie verstrekken.

\section{FREQUENTIE}

TABEL 11.6 De frequentie van hel contact met de netwerkleden bij de jongere en de oudere patiënten volgens de MSNA vergeleken met de informatie van de hulpverleners van de SPD.

\begin{tabular}{|c|c|c|c|c|c|}
\hline \multicolumn{2}{|c|}{$\begin{array}{l}\text { FREQUENTIE } \\
\text { sociale netwerk }\end{array}$} & $\begin{array}{ll}\text { FP } & A \\
& B\end{array}$ & \multicolumn{3}{|c|}{$\begin{array}{l}\text { JONGERE PATIENTEN }(n=26) \\
\text { OUDERE PATIENTEN }(n=18)\end{array}$} \\
\hline & FP & $\begin{array}{l}\text { MSNA } \\
\mathrm{m}\end{array}$ & sd & $\begin{array}{l}\text { Hulpverl } \\
\text { m }\end{array}$ & $\begin{array}{l}\text { eners } \\
\text { sd }\end{array}$ \\
\hline $\begin{array}{l}\text { minimaal } \\
-1 \times \text { per twee } \\
\text { weken }\end{array}$ & $\begin{array}{l}A \\
B\end{array}$ & $\begin{array}{r}10.0 \\
8.7\end{array}$ & $\begin{array}{l}5.6 \\
4.6\end{array}$ & $\begin{array}{l}4.1 * * \\
4.8 * \cdots\end{array}$ & $\begin{array}{l}2.3 \\
2.4\end{array}$ \\
\hline $\begin{array}{c}-1 \times \text { per kwar- } \\
\text { taal }\end{array}$ & $\begin{array}{l}\text { A } \\
B\end{array}$ & $\begin{array}{l}5.3 \\
5.5\end{array}$ & $\begin{array}{l}4.1 \\
6.6\end{array}$ & $\begin{array}{l}1.5^{* * *} \\
2.7\end{array}$ & $\begin{array}{l}1.5 \\
2.3\end{array}$ \\
\hline$-1 \times$ per jaar & $\begin{array}{l}\mathrm{A} \\
\mathrm{B}\end{array}$ & $\begin{array}{l}2.3 \\
3.3\end{array}$ & $\begin{array}{l}3.4 \\
3.4\end{array}$ & $\begin{array}{l}0.5^{*} \\
0.7^{*}\end{array}$ & $\begin{array}{l}1.2 \\
1.2\end{array}$ \\
\hline geen informatie & $\begin{array}{l}\text { A } \\
\text { B }\end{array}$ & $\begin{array}{l}7.4 \\
7.4\end{array}$ & $\begin{array}{l}6.3 \\
5.2\end{array}$ & $\begin{array}{l}10.4^{*} \\
10.7^{*}\end{array}$ & $\begin{array}{l}3.8 \\
7.5\end{array}$ \\
\hline
\end{tabular}

$* * * p<.001, * * p<.01, * p<.05$

Bij de jongere ambulante chronisch psychiatrische patiënten leidt een vergelijking van de informatie over de frequentie van het contact verkregen via de MSNA met de informatie van de betreffende hulpverleners van de SPD, weergegeven in tabel 11.6, tot de volgende resultaten.

- De MSNA toont dat voor wat betreft het gehele sociale netwerk de jongere patiënten gemiddeld significant meer netwerkleden hebben met wie minimaal eenmaal per twee weken contact bestaat dan in de informatie van de hulpverleners naar voren komt (respectievelijk gemiddeld 10.0 en 4.1 netwerkleden, $T=4.89, p<.001$ ).

Dit significante verschil hangt samen met de significante verschillen die hieromtrent optreden in de sector verwanten, de sector vriendschappelijke betrekkingen en de sector maatschappeijke diensten. 
De MSNA toont dat de jongere patiënten met gemiddeld 4.4 verwanten minimaal eenmaal per twee weken contact hebben terwijl dit bij de hulpverleners met gemiddeld 2.2 verwanten het geval is. Dit verschil is significant $(T=3.13, p<.01)$.

= In de sector vriendschappelijke betrekkingen toont de MSNA dat de jongere patiënten gemiddeld met 2.9 netwerkleden minimaal eenmaal per twee weken contact hebben terwijl de hulpverleners aangeven dat dit bij gemiddeld 0.6 netwerkleden het geval is $(T=3.74, p<.01$ ).

In de sector maatschappelijke diensten heben de jongere patiënten volgens de MSNA met gemiddeld 2.5 netwerkleden minimaal eenmaal per twee weken contact terwijl dit in de informatie van de hulpverleners voor gemiddeld 1.2 netwerkleden $n$ deze sector het geval is. Eveneens is er sprake van een significant verschil $(T=2.43, p<.05)$.

- Vervolgens toont tabel 11.6 dat er tussen de gegevens van de MSNA en de informatie van de hulpverleners in het geheel genomen een significant verschil wordt aangetroffen in het gemiddeld aantal nelwerkleden met wie de jongere patiënten minimaal éénmaal per kwartaal contact hebben (respectievelijk gemiddeld 5.3 en 1.5 netwerkleden, $T=4.37, p<.001$ ).

Een dergelijk significant verschil wordt hieromtrent ook aangetroffen in

$=\quad$ de sector verwanten (respectievelijk gemiddeld 2.2 en 0.5 verwanten; $T=3.34, p<.01$ );

$=\quad$ de sector vriendschappelijke betrekkingen (respectievelijk gemiddeld 2.0 en 1.1 netwerkleden, $T=3.43, p<.01$ ) .

- Tabel 11.6 toont tevens dat er tussen de informatie volgens de MSNA en die van de hulpverleners een significant verschil optreedt in het gemiddeld aantal netwerkleden van het gehele sociale netwerk met wie de jongere ambulante chronisch psychiatrische patiënten minimaal éenmaal per jaar contact hebben (gemiddeld respectievelijk 2.3 en 0.5 netwerkleden, $\mathrm{T}=2.54, \mathrm{p}<.05$ )

Op het niveau van de sectoren zet dit significante verschil zich door in de sector vrienschappelijke betrekkingen.

- Tenslotte blijkt dat de MSNA in het geheel genomen gemiddeld significant minder netwerkleden te tonen bij wie geen adequate informatie over de frequentie van de contacten gegeven wordt door de jongere patiënten dan in de informatie van de betreffende hulpverleners het geval is (respectievelijk gemiddeld 7.4 en 10.4 netwerkleden, $T=-2.06, p<.05)$. Dit verschil hangt samen met een vergelijkbaar significant verschil in

= de sector verwanten (respectievelijk gemiddeld 1.4 en 3.4 verwanten, $\mathrm{T}=-2.48, \mathrm{p}<.05)$;

= de sector maatschappelijke diensten (respeclivelijk gemiddeld 1.9 en 3.1 netwerkleden, $\mathrm{T}=-2.28, \mathrm{p}<.05$ )

Bij de oudere ambulante chronisch psychiatrische patiënten patiënten leidt een vergelijking van de informatie verkregen via de MSNA met die van de hulpverleners van de SPD omtrent de frequentie van de contacten met hun netwerkleden in hel geheel genomen (zie tabel 11.6) tot de volgende resultaten.

- De MSNA brengt gemiddeld een significant groter aantal netwerkleden in beeld met wie de oudere patiènten minimaal eenmaal per twee weken contact hebben dan in de informatie van de hulpverleners zichtbaar wordt (respectievelijk gemiddeld 8.7 en 4.8 netwerkleden, $T=3.14, p<.01$ ). Dit verschil venwijst naar een significant verschil hieromtrent in

= de sector vriendschappelijke betrekkingen (respectievelijk gerniddeld 3.1 en 1.3 netwerkleden, $T=2.69, p<.05$ ).

- Met betrekking tot het gemiddeld aantal netwerkleden met wie de oudere patienten minimaal eenmaal per jaar kwartaal hebben is er geen verschil tussen de informatie volgens de MSNA en die van de hulpverleners.

- Wel is er in het geheel genomen een significant verschil tussen de MSNA en de informatie van de hulpverleners van de SPD betreffende hel gemiddeld aantal netwerkleden met wie de oudere ambulante chronisch psychiatrische patiënten 
minimaal eemaal per jaar contact hebben (respectievelijk gemiddeld 3.3 en 0.7 netwerkleden, $T=3.04, p<.01$ ). Op het niveau van de sectoren treden hieromtrent geen significante verschillen op.

Al bij al geven de hierboven gegeven uitkomsten aan dat hypothese 42 met betrekking tot de frequentie van het contact als bevestigd kan worden beschouwd.

\section{GEWICHT}

TABEL 11.7 Het gewicht van het contact met de netwerkleden bij de jongere en de oudere patienten volgens de MSNA vergeleken met de informatie van de hulpverleners van de SPD

\begin{tabular}{|c|c|c|c|c|c|}
\hline \multirow[t]{2}{*}{$\begin{array}{l}\text { compartimenten } \\
\text { GEWICHT } \\
\text { sociale netwerk }\end{array}$} & \multicolumn{4}{|c|}{$\begin{array}{l}\text { A JONGERE PATIENTEN }(n=26) \\
\text { B OUDERE PATIENTEN }(n=18)\end{array}$} & ers \\
\hline & F.P. & $\mathrm{m}$ & sd & $\mathrm{m}$ & sd \\
\hline affectie & $\begin{array}{l}A \\
B\end{array}$ & $\begin{array}{l}3.5 \\
3.8\end{array}$ & $\begin{array}{l}0.4 \\
0.7\end{array}$ & $\begin{array}{l}3.3 \\
3.3^{*}\end{array}$ & $\begin{array}{l}0.6 \\
0.4\end{array}$ \\
\hline aansluiting & $\begin{array}{l}\text { A } \\
B\end{array}$ & $\begin{array}{l}3.3 \\
3.6\end{array}$ & $\begin{array}{l}0.5 \\
0.6\end{array}$ & $\begin{array}{l}2.9^{*} \\
3.2^{*}\end{array}$ & $\begin{array}{l}0.5 \\
0.3\end{array}$ \\
\hline middelen & $\begin{array}{l}\text { A } \\
B\end{array}$ & $\begin{array}{l}3.7 \\
3.8\end{array}$ & $\begin{array}{l}0.6 \\
0.7\end{array}$ & $\begin{array}{l}3.2= \\
3.2^{*}\end{array}$ & $\begin{array}{l}0.5 \\
0.4\end{array}$ \\
\hline stabiliteit & $\begin{array}{l}A \\
B\end{array}$ & $\begin{array}{l}3.3 \\
3.5 \\
\end{array}$ & $\begin{array}{l}0.8 \\
0.6\end{array}$ & $\begin{array}{l}3.0 \\
3.1^{*}\end{array}$ & $\begin{array}{l}0.5 \\
0.5\end{array}$ \\
\hline
\end{tabular}

$* p<.01 ; * p<.05$

Tabel 11.7 toont dat er in het geheel genomen significante verschillen optreden in het gewicht van het contact met de netwerkleden tussen enerzijds de informatie die via de MSNA door de jongere en oudere ambulante chronisch psychiatrische patiënten wordt gegeven en anderzijds de gegevens die door de hulpverleners bij beide groepen patiënten worden verstrekt.

In het geheel genomen geven beide groepen patiènten merendeels gemiddeld een significant hoger gewicht aan het contact met hun netwerkleden dan in de informatie van de hulpverleners het geval is. Op het niveau van de sectoren treden significante verschillen op in de sector verwanten en de sector maatschappelijke diensten (zie Bijlage VIII,4). Voor de verschillende compartimenten behoeften zijn er de volgende resultaten.

\section{Compartiment van de affectieve behoefien}

- In het geheel genomen is er op dit gebied geen verschil tussen het gewicht dat de jongere patienten via de MSNA aan het contact met hun netwerkleden geven en de gegevens van de hulpverlener. Ook binnen de afzonderlijke sectoren treden hier op het gebied van de affectieve behoeften geen significante verschillen op.

- In het geheel genomen geven de oudere patiënten via de MSNA gemiddeld een significant hoger gewicht aan het contact met hun netwerkleden op het gebied van de affectieve behoeften dan de hulpverleners (respectievelijk gemiddeld 3.8 en 3.3, $T=2.36, p<.05$ ). Een significant verschil treedt eveneens op binnen de 
sector maatschappelijke diensten (respectievelijk gemiddeld 3.9 en 3.2, T = $2.38, p<.05)$.

\section{Compartiment van de behoefte aan aansluiting}

- De jongere patiënten blijken via de MSNA vergeleken met de hulpverleners in het geheel genomen gemiddeld een significant hoger gewicht aan het contact met hun netwerkleden op het gebied van de behoefte aan aansluiting te geven (respectievelijk gemiddeld 3.3 en $2.9, T=2.78, p<.01$ ); een significant verschil wordt hieromtrent eveneens aangetroffen binnen de sector verwanten (respectievelijk gemiddeld 3.2 en $2.7, T=2.10, p<.05$ ) en binnen de sector maatschappelijke diensten (respectievelijk gemiddeld 3.9 en $3.4, T=2.30, p<$ $.05)$.

- De oudere patiënten blijken in het geheel genomen via de MSNA eveneens gemiddeld een significant hoger gewicht aan het contact met hun netwerkleden te geven voor de behoefte aan aansluiting dan in de gegevens van de hulpverleners het geval is (respectievelijk gemiddeld 3.6 en 3.2, $T=2.06, p<.05$ ). Een significant verschil wordt hieromtrent tevens aangetroffen binnen de sector maatschappelijke diensten (respectievelijk gemiddeld 3.9 en $3.3, T=2.21, p<$ $.05)$.

\section{Compartiment van de behoefte aan materiële en instrumentele middelen}

- De jongere patiënten geven in het geheel genomen via de MSNA vergeleken met de hulpverleners gemiddeld een significant hoger gewicht aan het contact met hun netwerkleden op het gebied van de behoefte aan materiële en instrumentele middelen (respectievelijk gemiddeld 3.7 en $3.2, T=3.19, p<.05$ ). Een significant verschil wordt hieromtrent ook aangelroffen in de sector verwanten (respectievelijk gemiddeld 3.6 en $3.0, T=2.68, p<.01$ ) .

- De oudere patiënten geven hier in het geheel genomen via de MSNA eveneens gemiddeld een significant hoger gewicht aan het contact met hun netwerkleden dan het geval is in de informatie van de hulpverleners (respectievelijk gemiddeld 3.8 en $3.2, T=2.65, p<.05$ ). Bij de oudere patiënten blijkt vergeleken met de hulpverleners hieromtrent een significant verschil aanwezig te zijn in de sector maatschappelijke diensten (respectievelijk gemiddeld 3.7 en $3.1, T=2.08, p<$ $.05)$.

\section{Compartiment van de behoefte aan stabiliteit}

- De jongere patiēnten geven zowel in hel geheel genomen als ook binnen de sectoren van het sociale netwerk via de MSNA gemiddeld nagenoeg een gelijk gewicht aan het contact met hun netwerkleden inzake de behoefte aan stabiliteit als in de informatie van de hulpverleners wordt aangetroffen.

- Bij de oudere patieznten treedt daarentegen in het geheel genomen wel een significant verschil op in het gewicht dat zij vergeleken met de hulpverleners gemiddeld geven aan het contact met hun netwerkleden op het gebied van de behoefte aan sociale stabiliteit (respectievelijk gemiddeld 3.5 en $3.1, T=2.14$, $p<.05)$. Binnen de sectoren echter wordt een dergelijk verschil niet meer teruggevonden.

De hierboven weergegeven resultaten bevestigen hypothese 42 inzake het element gewicht van het contact met de netwerkleden. De richting van de optredende significante verschillen in het gewicht van het contact kan als volgt samengeval worden.

- De oudere patiěnten geven in het geheel genomen via de MSNA gemiddeld een significant hoger gewicht aan hel contact mel hun nelwerkleden mel betrekking tot alle vier de compartimenten te vervullen behoeften dan in de informatie van de hulpverleners zichibaar wordt.

- Vergeleken met de oudere patiénten treedt bij de jongere patiënten een dergelijk significant verschil alleen op met betrekking tot het compartiment van de behoefte aan aansluiting en het compartiment van de behoefte aan materiële en instrumentele middelen. 
- Bij de jongere patiěnten is het significante verschil in het gewicht van het contact dat met betrekking tot deze beide compartimenten behoeften tussen de informatie van de MSNA en de inventarisatie van de hulpverleners gevonden wordt groter dan bij de oudere patiënten vergeleken met de informatie van de hulpverleners.

- Op het niveau van de sectoren zijn de significante verschillen bij de jongere patiënten te vinden binnen de sectoren verwanten en maatschappelijke diensten terwijl deze bij de oudere patiënten beperkt blijven tot de sector maatschappelijke diensten. Binnen de sector vriendschappelijke betrekkingen worden noch bij de jongere patiënten noch bij de oudere patiënten vergeleken met de informatie van de hulpverleners verschillen met die van de MSNA aangetroffen.

\section{LENGTE}

TABEL 11.8 De lengte van de contacten met de netwerkleden bij de jongere en de oudere patiënten volgens de MSNA vergeleken met de informatie van de hulpverleners van de SPD

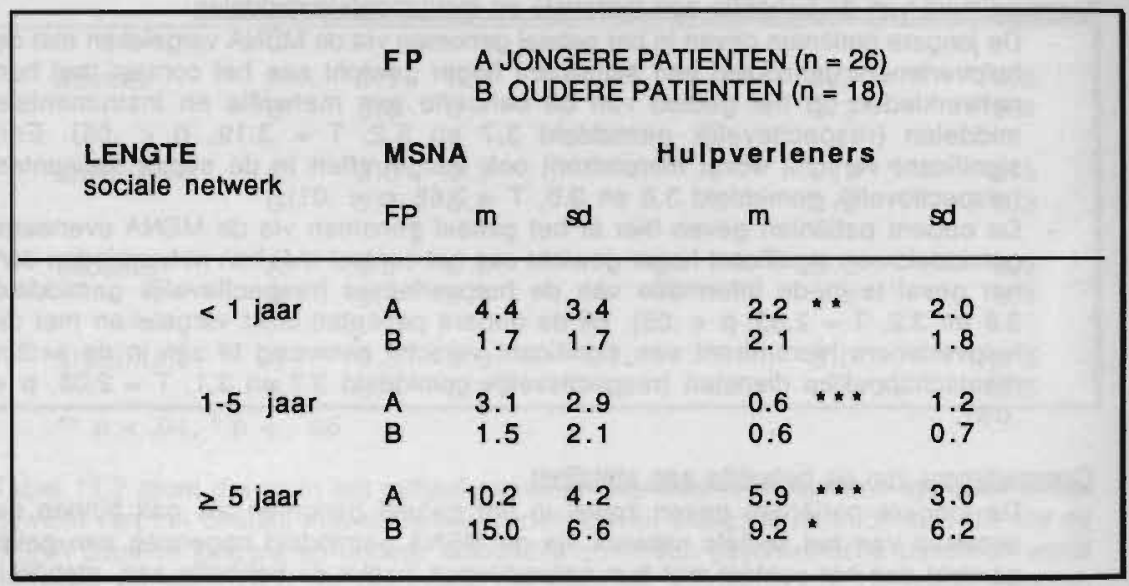

*** $p<.001$, ** $p<.01$, * $p<.05$

Een vergelijking van de informatie van de MSNA met die van de hulpverleners van de SPD over de lengte van het contact van de jongere ambulante chronisch psychiatrische patiênten en hun netwerkleden leidt tot de volgende bevindingen.

- In het geheel genomen hebben de jongere patiënten volgens de MSNA vergeleken met de informatie van de hulpverleners gemiddeld significant meer netwerkleden met wie het contact in het laatste jaar is ontstaan (respectievelijk gemiddeld 4.4 en 2.2 netwerkleden; $T=2.82, p<.01$ ).

Een dergelijk significant verschil treedt hieromtrent ook op in de sector verwanten (respectievelijk gemiddeld 0.4 en 0.1 verwanten; $T=2.12, p<.05$ ) en eveneens in de sector vriendschappelijke betrekkingen (respectievelijk gemiddeld 2.4 en 0.7 netwerkleden; $T=2.68, p<.01$ ).

- In hel geheel genomen hebben de jongere patiënten volgens de MSNA vergeleken mel de informatie van de hulpverleners gemiddeld significant meer netwerkleden met wie er minimaal sinds een jaar of maximaal vier jaar contact bestaat (respectievelijk gemiddeld 3.1 en 2.9 netwerkleden, $T=3.93, p<.001$ ). Een significant verschil treedt hieromtrent ook op in de sector verwanten 
(respectievelijk gemiddeld 0.7 en 0.1 verwanten, $T=2.70, p<.01$ ) en in de sector vriendschappelijke betrekkingen, $T=2.68, p<.01$ ).

- De jongere patiënten hebben in het geheel genomen volgens de MSNA gemiddeld significant meer netwerkleden met wie reeds zij vijf jaar of langer contact hebben dan in de informatie van de hulpverleners het geval is, (respectievelijk gemiddeld 10.2 en 5.9 netwerkleden, $T=4.16, \mathrm{p}<.001$ ).

Een vergelijking van de informatie volgens de MSNA met die van de hulpverleners van de SPD over de lengte van het contact met de netwerkleden bij de oudere ambulante chronisch psychiatrische patiënten leidt tot de volgende bevindingen.

- In het geheel genomen is er tussen de informatie via de MSNA en die van de hulpverleners alleen een significant verschil in het gemiddeld aantal netwerkleden waarmee de oudere patiënten reeds vijf jaar of langer contact hebben (respectievelijk gemiddeld 15.0 en 9.2 netwerkleden, $T=2.33, p<$ $.05)$. Hieromtrent wordt alleen een significant verschil gevonden in de sector vriendschappelijke betrekkingen (respectievelijk gemiddeld 1.5 en 0.2 netwerkleden, $\mathrm{T}=2.23, \mathrm{p}<.01$ ).

Tesamen leiden de resultaten betreffende de lengte van het contact tot een bevestiging van hypothese 42 . De significante verschillen tussen de informatie via de MSNA en die van de hulpverleners treden vooral, dat wil zeggen zowel bij het sociale netwerk als geheel alsook bij de sectoren verwanten en vriendschappelijke betrekkingen, op bij de jongere ambulante chronisch psychiatrische patienten. Bij de oudere patienten is er vergeleken met de jongere patiënten in hoge mate overeenstemming tussen de informatie via de MSNA en die van de hulpverieners van de SPD van de RIAGG Maastricht te vinden.

\section{TENSLOTTE}

Met de weergave van de resultaten van het element duur/ lengte van het contact in de structuur van de betrekkingen aan de hand van hypothese 42 is de beantwoording van vraagstelling $V$ afgerond. In de volgende paragraaf 11.2 worden de resultaten bij vraagstelling $V$ in hoofdpunten samengevat.

\subsection{RESULTATEN IN HOOFDPUNTEN}

De hierboven gegeven resultaten met betrekking tot vraagstelling $V$ kunnen als volgt in hoofdpunten samengevat worden.

\section{A Omvang en samenstelling van de omvang}

\section{a.1}

De hulpverleners van de SPD van de RIAGG Maastricht blijken vergeleken met de informatie van de MSNA bij de jongere patiënten gemiddeld een significant kleiner sociaal netwerk te inventariseren (respectievelijk gemiddeld 16 en 25 netwerkleden), terwijl bij de oudere patiënten de informatie van de hulpverleners vergeleken met die van de MSNA hieromtrent nagenoeg overeenkomt (respectievelijk gemiddeld 19 en 25 netwerkleden).

\section{a. 2}

Wanneer gekeken wordt naar de gemiddelde omvang van de informele netwerkleden dan treden er zowel bij de jongere alsook bij de oudere patiënten significantie verschillen op en wel in die zin dat de hulpverleners vergeleken metde MSNA bij beide groepen patiënten gemiddeld significant minder informele netwerkleden inventariseren. Echter bij de jongere patiënten is de significantie aanzienlijk groter dan bij de oudere patiënten. 
De hulpverleners blijken vergeleken met de informatie van de MSNA zowel bij de jongere alsook bij de oudere patiënten gemiddeld nagenoeg een overeenkomstige omvang netwerkleden te inventariseren in

het cluster partner / eigen gezin

het cluster bloedverwanten

het cluster werk / scholing

a.4

het cluster hulpverlening.

De hulpverleners blijken vergeleken met de informatie van de MSNA bij de jongere patienten gemiddeld significant minder netwerkleden te inventariseren in

het cluster aanverwanten

het cluster 'verre' verwanten

het cluster naaste vrienden

a.5

het cluster overige vriendschappelijke betrekkingen

De hulpverleners blijken vergeleken met de informatie van de MSNA bij de oudere patiënten gemiddeld significant minder netwerkleden te inventariseren in het cluster 'verre' verwanten

het cluster naaste vrienden.

\section{B Gevarieerdheid}

\section{b. 1}

In het geheel genomen blijken de hulpverleners over gemiddeld significant minder informele netwerkleden van zowel de jongere als de ambulante chronisch psychiatrische patiënten gegevens over de gevarieerdheid te verstrekken dan het geval is via de MSNA.

b. 2

In het geheel genomen blijken de hulpverleners vergeleken met de informatie van de MSNA ten aanzien van de informele netwerkleden van de oudere patiënten beter op de hoogte te zijn van hun gevarieerdheid dan bij de informele netwerkleden van de jongere patiënten.

b. 3

Deze bevindingen ad b.1 en b. 2 zijn eveneens te vinden in de sector verwanten en de sector vriendschappelijke betrekkingen.

\section{Bereikbaarheid}

\section{c. 1}

De hulpverleners blijken vergeleken met de informatie van de MSNA bij beide groepen over gemiddeld significant mnder informele netwerkleden adequate informatie te verstrekken over de woon- of verblijfsplaats van hun netwerkleden. Het deel van de informele netwerkleden waarbij de hulpverleners en de MSNA geen adequate informatie verstrekken komt zowel bij zowel de jongere alsook de oudere patiênten nagenoeg gemiddeld met elkaar overeen.

c. 2

De hulpverleners inventariseren vergeleken met de MSNA zowel bij de jongere alsook bij de oudere patiénten gemiddeld significant minder informele netwerkleden die binnen de eigen woonplaats van de patiënten wonen. Bij de jongere patiěnten is de significantie groter.

c. 3

De hulpverleners inventariseren vergeleken met de MSNA in tegenstelling tot de oudere patiënten bij de jongere patiënten gemiddeld significant minder netwerkleden die buiten de regio wonen. 
d.1

Bij de jongere patiënten inventariseren de hulpverleners vergeleken mel de MSNA in het gehele sociale netwerk gemiddeld significant minder netwerkleden

- naar wie de jongere patiënten zelf het initiatief tot contact nemen,

- bij wie het contact uitgaat van wederzijds initiatief,

- bij wie het contact gebaseerd is op het initiatief van de derden met wie geen initiatef wordt.

d. 2

Vergeleken met de informatie van de MSNA inventariseren de hulpverleners in hel geheel genomen bij de jongere en de oudere patiënten gemiddeld significant minder netwerkleden bij wie het contact gebaseerd is op wederzijds initiatief. Echter bij de jongere patienten is het verschil groter.

d. 3

in de sector verwanten inventariseren de hulpverleners vergeleken met de MSNA bij de jongere en oudere patiënten gemiddeld significant minder verwanten bij wie het contact op wederzijds initiatief berust.

d. 4

Vervolgens inventariseren de hulpverleners in de seclor verwanten vergeleken met de MSNA bij de jongere patiënten gemiddeld significant minder verwanten

- bij wie het contact via het initiatief van derden tot stand komt,

- met wie geen initiatief tot contact wordt ondernomen,

en bij de oudere patiënten gemiddeld significant minder verwanten

- naar wie zij zelf het initiatief tot contact nemen.

\section{d. 5}

In de sector vriendschappelijke betrekkingen inventariseren de hulpverleners in vergelijking met de MSNA bij de jongere patienten omtrent nagenoeg alle kenmerken van initiatief gemiddeld significant minder netwerkleden terwijl bij de oudere patiënten alleen een significant verschil optreedt in de gemiddelde omvang netwerkleden bij wie het contact gebaseerd is op wederzijds initiatief.

d. 6

In de sector maatschappelijke diensten komt zowel bij de jongere alsook bij de oudere patiënten de inventarisatie van de hulpverleners betreffende het initiatief tot contact nagenoeg overeen met de informatie van de MSNA

\section{Frequentie}

\section{d. 7}

Zowel in de inventarisatie van de hulpverleners alsook in de informatie van de MSNA hebben de jongere en de oudere patienten met een grote meerderheid van hun netwerkleden minimaal eenmaal per week contact.

d. 8

Echter de hulpverleners inventariseren vergeleken met de informatie van de MSNA zowel bij de jongere alsook bij de oudere patiënten in het geheel genomen gemiddeld significant minder netwerkleden met wie de jongere en de oudere patiěnten minimaal eenmaal per week contact hebben.

d. 9

Bij de jongere en oudere patiënten inventariseren de hulpverleners vergeleken met de MSNA gemiddeld significant minder verwanten met wie zij minimaal eenmaal per week contact hebben terwijl bij de jongere patiënten een dergelijk significanı verschil hieromtrent tevens optreedt in de sector vriendschappelijke betrekkingen. 
d. 10

In het geheel genomen geeft de inventarisatie van de hulpverleners vergeleken met de informatie van de MSNA bij de oudere patiënten betreffende alle compartimenten behoeften gemiddeld een significant lager gewicht aan het contact met hun netwerkleden, terwijl bij de jongere patiënten in de inventarisatie van de hulpverleners een significant lager gewicht aangetrofen wordt inzake de behoefte aan aansluiting en de behoefte aan materiële en instrumentele middelen.

d.11

De significante verschillen tussen de inventarisatie van de hulpverleners en de MSNA in het gewicht van het contact betreffende de behoefte aan aansluiting en de behoefte aan materiële en instrumentele middelen worden vervolgens bij de jongere patiënten teruggevonden in het contact met netwerkleden in de sectoren verwanten en vriendschappelijke betrekkingen en bij de oudere patiënten in de sector maatschappelijke diensten.

\section{Lenate}

\section{d. 12}

In het geheel genomen hebben zowel in de inventarisatie van de hulpverleners alsook in de informatie van de MSNA de jongere en oudere patiënten met een meerderheid van hun netwerkleden reeds vijf jaar of langer contact. Echter zowel bij de jongere alsook bij de oudere patiënten inventariseren de hulpverleners vergeleken met de MSNA gemiddeld significant minder netwerkleden mel wie beide groepen patienten vijf jaar of langer contact hebben. Bij de jongere patiënten is het significante verschil aanzienlijk groter.

d.13

In tegenstelling tot de oudere patiënten inventariseren de hulpverleners in vergelijking met de MSNA bij de jongere patiënten in het geheel genomen gemiddeld significant minder netwerkleden met wie in het afgelopen jaar contact is ontstaan.

\section{d. 14}

De hulpverleners inventariseren vergeleken met de MSNA bij de jongere patiënten in het geheel genomen gemiddeld significant minder netwerkleden met wie hel contact minimaal én jaar en hooguit vier jaar bestaat, terwijl bij de oudere patiënten de informatie van de hulpverleners met die van de MSNA hieromtrent overeenkomt. 
In dit hoofdstuk wordt de balans opgemaakt van het onderzoek naar de structuur van het sociale netwerk van ambulante chronisch psychiatrische patiënten in zorg bij de SPD van de RIAGG Maastricht. Balans opmaken wil zeggen dat achtereenvolgens rekenschap wordt gegeven van de bevindingen en de werkwijze, conclusies worden getrokken en aanbevelingen worden gedaan.

De analyse en beschrijving van de gegevens bij de vraagstellingen I tot en met $\mathrm{V}$ conform de hypothesen 1 tot en met 42 leidt tot tal van uitkomsten. Bij iedere vraagstelling zijn in het overeenkomstige hoofdstuk de uitkomsten in hoofdpunten weergegeven. In bijlage $\mathrm{V}$ is vervolgens een overzicht gegeven van de mate waarin de hypothesen 1 tot en met 42 al dan niet bevestigd zijn. Er zijn resultaten die overeenkomen met de verwachtingen; er zijn ook resultaten die niel overeenkomen met wat eerder verondersteld werd. Ter illustratie een tweetal voorbeelden.

Overeenkomend met de verwachtingen is dat de gemiddelde beschikbare omvang van het sociale netwerk van de ambulante chronisch psychiatrische patienten significant kleiner is vergeleken met die van van de referentiepersonen (respectievelijk gemiddeld 26 en 30 netwerkleden) en significant groter is dan in de informatie van de betreffende hulpverleners van de SPD het geval is. De hulpverleners registreren een gemiddelde omvang van 17 netwerkleden.

Een voorbeeld dat de eerder gestelde verwachting niel bevestigd wordt is de gevarieerdheid van de netwerkleden ten op zichte van de focale personen. Uitgaande van onder meer het Social Breakdown Syndrome (Gruenberg, 1974), een toonaangevend concept in de ambulante psychiatrische hulpverlening (Romme, 1985; Rotteveel, Uffing, De Vries, 1988), werd verondersteld dat de onderzoekspopulatie overwegend een homogeen samengsteld sociaal netwerk zou hebben in tegenstelling tot de referentiepersonen bij wie de sociale netwerken overwegend heterogeen samengesteld zouden zijn. De resultaten tonen echter dat de sociale netwerken van de referentiepersonen in hoge mate homogeen zijn samengesteld en dat de sociale netwerken van de ambulante chronisch psychiatrische patiënten significant minder homogeen zijn samengesteld waar het gaat om de arbeid- en woonsituatie van de netwerkleden ten opzichte van de patienten. Ziehier een niet vermoede en op het eerste gezicht verrassende uitkomst die echter bij nader inzien dermate steekhoudend lijkt dat het eigenlijk vreemd is niet eerder op een dergelijke vanzelfsprekendheid gekomen te zijn. 
Deze en andere verwachte en onverwachte resultaten moeten begrepen worden in samenhang met de probleemstelling bij dit onderzoek. Indertijd formuleerde de Sociaal Psychiatrische Dienst van de RIAGG Maastricht voor haar doelgroep ambulante chronisch psychiatrische patiënten de volgende doelstelling: de bevordering van de sociale integratie dan wel het tegengaan van processen van maatschappelijke uitstoting. Voor de realisering van deze doelstelling is niet alleen een doelgerichte inzet van de ambulante psychiatrische hulpverlening wezenlijk maar ook die van de patiënt zelf én van zijn naaste omgeving onontbeerlijk. Hel komt er op neer dat de ambulante chronisch psychiatrische patiënt voor zijn sociale integratie aangewezen is op een persoonlijk sociaal netwerk van mensen en betrekkingen; het hangt vervolgens in hoge mate van de kwaliteit van de structuur van het sociale netwerk af in welke mate het streven naar sociale integratie kan slagen.

De centrale vraag die in dit onderzoek in de vraagstellingen II, III, IV en V is uitgewerkt luidt dan ook: in welke mate zijn de hulpverleners van de SPD op de hoogte van de feitelijke toestand van de structuur van mensen en betrekkingen waarvan de patient deel uitmaakt. Een verkennende studie die aan de basis van dit onderzoek ligt riep het vermoeden op dat de hulpverleners van de SPD maar ten dele met het sociale netwerk van hun doelgroep bekend zijn (Baars, 1985). Welnu, het onderzoek waarvan hier verslag wordt gedaan bevestigt dit vermoeden. Met behulp van de MSNA wordt duidelijk dat er vergeleken met de informatie die de patiënten over de structuur van hun sociale netwerken geven er in de gegevens van de hulpverleners bij alle structuurkenmerken in meer of mindere mate lacunes optreden.

Deze algemene uitkomst die verderop meer gedetailleerd wordt toegelicht krijgt evenwel vooral reliëf wanneer ze belicht wordt tegen de achtergrond van de structuur van het sociale netwerk die aangetroffen wordt bij adequaat gematchte referentiepersonen bij wie geen sprake is van problemen in de geestelijke gezondheid dan wel psychiatrische problematiek (zie de vraagstellingen I, IV en V). Dan wordt zoals verderop zal worden toegelicht zichtbaar hoe groot in het algemeen de discrepantie is tussen de structurele toestand waarin het sociale netwerk van de ambulante chronisch psychiatrische patiënten in de informatie van de betreffende hulpverleners verkeert en die van normale referentiepersonen.

Tenslotte moet ter inleiding op een nadere beschouwing van de resultaten opgemerkt worden dat vanuit een sociaal psychiatrische oriëntatie een welenschappelijke analyse en beschrijving van de structuur van het sociale netwerk bij doelgroepen van psychiatrische hulpverlening tevens gericht is op het verwerven van informatie die toepasbaar is op patiëntniveau (Romme, Kraan, Rotteveel, 1981; Erickson, 1984). De hierna volgende nadere beschouwing van de belangrijkste bevindingen zal dan ook worden afgesloten met een verkenning naar de praktische betekenis van de gegeven resultaten.

\subsubsection{Soclale netwerken belicht door patiēnt en hulpverlening}

Zoals zojuist globaal is aangegeven bevestigt dit onderzoek dat de ambulante psychiatrische hulpverlening vergeleken met de informatie die de patienten zelf geven via de MSNA maar ten dele gegevens verstrekt over dan wel op de hoogte is van de actuele structuur van mensen en betrekkingen waarbinnen de ambulante chronisch psychiatrische patient in het dagelijks leven bij (her)aanmelding ingebed is. Samenvattend zijn er de volgende belangrijkste bevindingen.

\section{Omvana en samenstellino van de omvano}

- De hulpverieners zijn in het geheel genomen met een significant geringere omvang van het sociale netwerk van de patiēnten bekend dan de patiěnten zelf hierover via de MSNA aangeven (respectievelijk gemiddeld 17 en 26 netwerkleden). Dit verschil hangt samen met de verschillen die optreden bij de secior verwanten (respectievelijk gemiddeld 8 en 11 verwanten) en de sector vriendschappelijke betrekkingen (respectievelijk 5 en 8 netwerkleden). 
- Wanneer een onderscheid wordt gemaakt tussen de sociale netwerken van jongere en die van oudere patienten (Tabel 11.1) dan blijkt de hulpverlening voorai bij de jongere patiěnten met een significant geringere omvang van het sociale netwerk bekend te zijn (respectievelijk gemiddeld 16 en 25 netwerkleden) in het bijzonder voor wat betreft de sector verwanten (respectievelijk gemiddeld 6 en 10 verwanten) en de sector vriendschappelijke betrekkingen (respectievelijk 5 en 9 netwerkleden). Bij de oudere patiënten komen de gegevens van de hulpverleners over de omvang van hun netwerken in het geheel genomen meer overeen met de informatie van deze patiënten via de MSNA. De verschillen die hier optreden betreffen vooral de sector vriendschappelijke betrekkingen (respectievelijk gemiddeld 5 en 7 netwerkleden).

Een nadere beschouwing van de resultaten inzake de omvang laat zien dat de hulpverleners van de SPD vergeleken met de informatie die de patienten via de MSNA geven in het geheel genomen en bij de jongere en oudere patienten vrij nauwkeurig op de hoogte zijn van de omvang van de clusters 'partner/eigen gezin' en 'bloedvenwanten'. Echter met de omvang van de aanverwanten en de zogeheten verre verwanten zijn de hulpverleners in het geheel genomen en bij de jongere patienten veel minder bekend. De hulpverleners blijken tevens zowel in het geheel genomen alsook onderscheiden naar jongere en oudere patiënten vrij nauwkeurig op de hoogte te zijn van de omvang van de clusters 'werk/studie' en 'hulpverlening'.

Grote verschillen tussen de rapportage van de hulpverleners en de informatie van de patiënten via de MSNA treden op inzake de omvang van de sector vriendschappelijke betrekkingen. De hulpverleners zijn zowel in het geheel genomen alsook onderscheiden naar jongere en oudere patienten maar zeer ten dele bekend met de omvang van deze sector, in het bijzonder met de omvang van het cluster 'vrienden'. Echter bij de oudere patiënten is de lacune in informatie bij de hulpverleners geringer dan bij de jongere patiënten.

Al bij al kan ten aanzien van de omvang van het sociale netwerk van de patiënten, in het bijzonder van de jongere patiënten, gesteld worden dat de hulpverleners in het informele deel van het sociale netwerk overwegend informatie bijeenbrengen/hebben over de meest nabije verwanten in de clusters 'partner/eigen gezin' en 'bloedverwanten', het traditionele domein vanwaaruit in de psychiatrie betekenis wordt ontleend omtrent het ontstaan, de continuering en de behandeling van psychiatrische problematiek. In combinatie met de beschikbare informatie omtrent de omvang van de sector maatschappelijke diensten, waarbij het deel hulpverlening overheerst, kan gemakkelijk het beeld ontstaan dat ambulante chronisch psychiatrische patiënten op weinig andere mensen zijn aangewezen dan op naaste verwanten on personen die instellingen van (geestelijke) gezondheidszorg vertegenwoordigen. De informatie van de betreffende patienten verkregen via de MSNA toont echter dat de omvang van het sociale netwerk niet alleen significant groter is maar ook gedifferentieerder is samengesteld dan in de rapportage van de hulpverleners, eveneens in kaart gebracht via de MSNA, het geval is.

\section{Gevarleerdheid van de Informele netwerkleden}

De hypothese (zie $\$$ 6.2.2) dat de hulpverleners gemiddeld minder de status- en positierollen van de informele netwerkleden inventariseren dan dat dit door de MSNA bij monde van de ambulante chronische psychiatrische patiënten gebeurt wordt ten aanzien van alle elementen bevestigd. Dit is ook het geval wanneer een onderscheid wordt gemaakt tussen de informele netwerkleden van jongere en oudere patiěnten, zij het dat de verschillen bij de oudere patiènten kleiner zijn.

Deze uitkomst krijgt meer reliêf wanneer in ogenschouw wordt genomen dat bij alle elementen van de gevarieerdheid er geen verschil is tussen de gegevens van de hulpverleners en de informatie van de patienten via de MSNA betreffende dat deel netwerkleden waarover gemiddeld geen adequale informatie verstrekt wordt. Zowel de hulpverlener als de patiënten blijken over een gemiddeld overeenkomstig deel van de informele netwerkleden niet of niet helemaal op de hoogte van hun status- en 
positierollen te zijn. Het komt er op neer dat de hulpverleners in tegenstelling tot de informatie die de patiënten via de MSNA geven nauwelijks weet hebben van de leeftijd, de burgerlijk staat, de opleiding en de werk- en woonsituatie van de informele netwerkleden van hun doelgroep voor ambulante psychiatrische hulpverlening. Al bij al kan gesteld worden dat de patiënten via de MSNA over de status- en positierollen van hun netwerkleden niet alleen meer informatie geven dan de hulpverleners maar ook een rijker meer gedifferentieerd beeld geven van de gevarieerdheid van hun informele nelwerkleden.

\section{Berelkbaarheid van de informele netwerkleden}

Zowel in de informatie van de hulpverlener alsook in die van de patiënten via de MSNA blijkt een meerderheid van de informele netwerkleden in de eigen woonplaats van de patient te wonen. Dit is ook het geval wanneer een onderscheid wordt gemaakt tussen jongere en oudere patiënten. In legenstelling tot de oudere patiënten hebben de jongere patiënten meer netwerkleden die buiten de eigen regio wonen terwijl de oudere patienten meer netwerkleden in de eigen regio hebben, een gegeven dat in de informatie van de hulpverleners eigenlijk niet opgemerkt wordt.

\section{Structuur van de betrekkingen}

De belangrijkste resultaten kunnen als volgt samengevat worden.

- De ambulante chronisch psychiatrische patiènten geven via de MSNA aan dat zij in het geheel genomen en ook onderscheiden in jongere en oudere patiënten naar gemiddeld meer netwerkleden zelf het initiatief tot contact nemen en dat er bij hen met meer netwerkleden sprake is van wederzijds initiatief tot contact dan de hulpverleners rapporteren. Deze verschillen betreffen de sector verwanten en de sector vriendschappelijke betrekkingen en zijn bij de jongere patiënten groter dan bij de oudere patiënten.

- De patiênten maken via de MSNA duidelijk dat zij zowel met meer netwerkleden contact hebben alsook met gemiddeld meer netwerkleden zeer frequent contact hebben dan uit de gegevens van de hulpverleners blijkt. Deze uitkomst wordt ook aangetroffen wanneer een onderscheid naar jongere en oudere patiënten wordt gemaakt. In de sector vriendschappelijke betrekkingen zijn de verschillen tussen de informatie van de MSNA en die van de hulpverleners bij de jongere patiënten hieromtrent groter dan bij de oudere patiënten.

- De patiënten geven betreffende alle compartimenten "behoeften" gemiddeld een hoger gewicht aan de betrekkingen met hun netwerkleden dan in de informatie van de hulpverleners het geval is. Dit is ook het geval bij de oudere patiënten, terwijl bij de jongere patiēnten een dergelijk verschil alleen oplreedt in de compartimenten behoeften aan aansluiting en behoeften aan materièle en instrumentele middelen.

- Zowel de patiënten als de hulpverleners lalen zien dat er mel de meeste netwerkleden reeds vijt jaar of langer contact bestaat. Echter de patiënten geven via de MSNA aan dat dit deel netwerkleden gemiddeld groter is dan in de informatie van de hulpverleners het geval is. Deze uitkomst is ook aanwezig bij de jongere en de oudere patiënten terwijl hel verschil tussen de informatie van de MSNA en die van de hulpverleners hier bij de jongere patiënten groter is dan bij de oudere patienten. Ten aanzien van de korter bestaande contacten komt de informatie van de MSNA en die van de hulpverleners overeen bij de oudere patiënten terwijl hier bij de jongere patiënten aanzienlijke verschillen optreden. Zo geven de jongere patiěnten onder meer aan dat zij gemiddeld meer netwerkleden hebben met wie zij sinds het afgelopen jaar contact hebben dan uit de informatie van de hulpverleners blijkt. 
Bovenstaande uitkomsten tonen aan dat er inzake de structuur van de betrekkingen over de gehele linie een discrepantie is tussen de informatie die de patienten zelf geven en die van de hulpverleners van de SPD. Bij de jongere patiénten treedt deze discrepantie veelvuldiger op en is ze waar ze optreedt tevens aanzienlijk groter dan bij de oudere patienten. De discrepantie die aanwezig is houdt in dat de hulpverleners minder het eigen en wederzijds initiatief in het contact, een lagere contactfrequentie, een lager gewicht in het contact en minder de kortbestaande contacten zichtbaar maken dan de patienten zelf via de MSNA doen. Anders gezegd: de patiěnten, in het bijzonder de jongere patienten wijzen er via de MSNA op dat zij in legenstelling tot de inventarisatie van de hulpverleners in het contact met hun netwerkleden zelf meer eigen initiatief nemen, er meer sprake is van wederzijds initiatiatief, een hogere contactfrequentie hebben, een hoger gewicht aan het contact met hun netwerkleden toekennen en tenslotte over meer kort bestaande betrekkingen beschikken.

Wat is de betekenis van dit verschil in informatie betreffende de structuur van de betrekkingen? Voor de beantwoording van deze vraag is het nodig de overeenkomsten tussen de inventarisatie van de hulpverleners en de informatie van de patiënten via de MSNA aan de orde te stellen. Een sleutelpositie wordt hierbij ingenomen door het element 'initiatief'. Dan valt op dat er geen verschil in informatie wordt aangetroffen waar het gaat om dat deel van de contacten met de netwerkleden bij wie de patiènt zelf niet in actie komt, namelijk bij dat deel netwerkleden die overwegend zelf het initiatief nemen, bij het deel met wie het contact uit gewoonte bestaat en bij het deel waar uitdrukkelijk sprake is van geen enkel initiatief tot contact. De hulpverleners blijken omtrent het initiatief goed op de hoogte te zijn van die dyadische betrekkingen waarin de richting van de betrekking overwegend 'afhankelijk' is (Cohen, Sokolovsky, 1978) en ze zijn significant minder bekend met die dyadische betrekkingen waarin de richting overwegend en mede bepaald wordt door een actieve inbreng van de patient. Dit gegeven is eveneens terug te vinden op het niveau van de sector verwanten en van de sector vriendschappeljke betrekkingen, zij het dat de optredende verschillen op het niveau van de sector vriendschappelijke betrekkingen groter zijn dan op het niveau van de sector verwanten. Het lijkt er op dat hulpverleners er nauwelijks van uitgaan dat de patiënten ook zelf initiatief nemen en dat er contacten bestaan die uitgaan van wederzijds initiatief.

Het komt erop neer dat de patiënten bij monde van de MSNA een meer vitale structuur van de betrekkingen met hun netwerkleden laten zien dan in de inventarisatie van de hulpverleners het geval is. Dit betreft in het bijzonder de structuur van de betrekkingen bij de jongere ambulante chronisch psychiatrische patiênten.

Het geheel aan resultaten inzake de structuur van de sociale netwerken volgens de informatie van de patiënten op basis van de MSNA vergeleken met de inventarisatie van de hulpverleners van de SPD leidt tot de volgende bevindingen.

- De MSNA geeft aanzienlijk meer informatie en aldus een vollediger beeld van de structuur van het sociale netwerk van mensen en betrekkingen waarop de patiēnt voor zijn sociale integratie is aangewezen dan het geval is in de inventarisatie van de hulpverleners.

- De MSNA geeft bij monde van de patiënten in het bijzonder de jongere patiěnten niet alleen een vollediger beeld maar toont tevens dat de structuur van hel sociale netwerk uitgebreider en vitaler is dan uit de informatie van de hulpverleners blijkt.

De hierboven gegeven samenvattende beschrijving laat verschillen en overeenkomsten zien tussen de informatie van de patiënten op basis van de MSNA en die van de hulpverleners. Het beeld dat de hulpverleners geven toont een sociale werkelijkheid van haar doelgroep voor ambulante psychiatrische hulpverlening dat veel meer op het gebruikelijke profiel van de sociale werkelijkheid van de ambulante chronisch psychiatrische patiênt aansluit ( zie hoofdstuk 2) dan het geval is in hel beeld dat de patienten zelf geven. De MSNA blijkt meer en tevens andere informatie te geven dan dat de patiénten voornamelijk zijn aangewezen op de naaste verwanten en de sector 
maatschappelijke diensten, in het bijzonder het cluster hulpverlening, en dat zij bijvoorbeeld in hun betrekkingen mel andere mensen overwegend een afwachtende houding aannemen. De verschillen en overeenkomsten in informatie wijzen dan ook op een bepaalde context van informatieverzameling bij de hulpverleners wanneer de patient bij hen in zorg komt. Het eerdere vermoeden (Baars, 1985) dat de betreffende hulpverleners een sociale werkelijkheid in beeld brengen die nauw verbonden is met aan de individuele persoon gebonden overwegend psycho-dynamische benadering, door Minuchin (1974) "de tradtionele techniek van geestelijke gezondheidszorg" genoemd wordt hier in dit onderzoek eerder bevestigd dan tegengesproken.

Dit betekent dat de inventarisatie door de hulpverleners van de sociale werkelijkheid van de patiēnt weliswaar in samenhang met deze gebruikelijk context van informatieverzameling in diagnostische zin een voor de hulpverlening waardevol beeld oplevert maar in hoge mate als beperkt moet worden gezien wanneer de hulpverlening hiermee veronderstelt met het oog op haar doelstelling van sociale integratie een zo volledig mogelijk beeld te kunnen verkrijgen. De resultaten van dit onderzoek voorzover tot nu toe samenvattend beschreven maken naar mijn mening in ieder geval duidelijk dat wil de hulpverlening de meer reële capaciteit van de mensen en betrekkingen van de patiënt, in het bijzonder van de jongere patiënt, leren kennen dat dan de toepassing van de MSNA zeer behulpzaam kan zijn. Zo niet en de gebruikelijk weg van inventarisatie van de sociale omstandigheden in de zogeheten 'Probleemanalyse' (zie $\$ 2.3$ ) word voortgezet dan is het bepaald niet denkbeeldig dat er een onderbelichting blijt optreden en er een discrepantie blijt bestaan tussen enerzijds het belang dat algemeen aan het sociale netwerk van de patiënt wordt gehecht en anderzjds de wijze waarop het sociale netwerk feitelijk tegemoed wordt getreden. Deze stellinganme wordt ondersteund door de patiënten zelf die keer op keer bij het afnemen van de MSNA tijdens dit onderzoek lieten weten dat niet eerder zo systematisch en volledig aandacht werd gegeven aan hun dagelijkse sociale omstandigheden en dat zij dit als een verademing ervaarden.

Hier aangekomen ligt er vervolgens de vraag naar de praktische betekenis van deze bevindingen. Een antwoord hierop kan pas gegeven worden wanneer tevens de structuur van de sociale netwerken van referentiepersonen bij wie geen sprake is van problemen in de geestelijke gezondheid dan wel psychiatrische symptomatologie in de beschouwing wordt betrokken.

\subsubsection{Sociale netwerken van patiēnten en referentiepersonen}

De resultaten bij de vraagstellingen I, IV en $V$ bevestigen het vermoeden, dat mede gebaseerd is op eerder uitgevoerd onderzoek (zie hoofdstuk 4) dat de structuur van het sociale netwerk van de ambulante chronisch psychiatrische patiënten in menig opzicht significant verschilt van die van normale referentiepersonen.

\section{Omvang en verdeling van de omvano}

- De gemiddelde omvang van 26 netwerkleden bij de patiënten verschilt significant met die van de referentiepersonen bij wie gemiddeld 30 netwerkleden worden gevonden. Dit verschil is vrijwel terug te voeren op de sector vriendschappelijke betrekkingen, in het bijzonder het cluster naaste vrienden (respectievelijk gemiddeld 3 en 6 netwerkleden).

- Onderscheiden naar jongere en oudere patiénten treedt er betreffende de totale omvang alleen een significant verschil op bij de jongere patiënten, een verschil dat eveneens optreedt in het cluster 'naaste vrienden' waar de jongere referentiepersonen gemiddeld 7 en de jongere patiënten gemiddeld 3 naaste vrienden noemen. Ook bij de oudere patienten is het cluster 'naaste vrienden' kleiner vergeleken met de oudere referentiepersonen (respectievelijk gemiddeld 3 en 5 netwerkleden) doch dit verschil is geringer dan bij de jongere patiënten. 
- Een derde belangrijke vitkomst is dat de patienten vergeleken met de referentiepersonen significant meer netwerkleden noemen die de hulpveriening vertegenwoordigen. Dit geldt ook en wel in gelijke mate voor de jongere en oudere patiënten.

De omvang van het sociale netwerk die gemiddeld bij de referentiepersonen wordt gevonden sluit goed aan op bevindingen in eerder onderzoek bij personen bij wie geen sprake is van problemen in de geestelijke gezondheid (Meuller, 1980). Een probleem is dat niet nagegaan kan worden in welke mate de verdeling over sectoren en clusters met eerder onderzoek in overeenstemming is. Pattison e.a. (1979) vinden dat de zogeheten 'primary social matrix' bij normale referentiepersonen gemiddeld uit 22 á 25 netwerkleden bestaat, een uitkomst die nagenoeg overeenkomt met wat in dit onderzoek het informele deel van een persoonlijk sociaal netwerk wordt genoemd waar een gemiddelde omvang van 26 netwerkleden wordt aangetroffen.

Ondanks de verschillen in vraagstelling en werkwijze in eerder verricht sociale netwerk onderzoek (Knipscheer, Antonnuci, 1990) en de variaties die vanwege afbakening en operationalisatie van de omvang en dergelijke (zie $\$ 4.7 .1$ ) in eerder onderzoek bij psychiatrische populaties optreden zijn er de volgende twee uitkomsten te vinden die constant aanwezig zijn.

- Er wordt steeds een grote discrepantie in de gemiddelde omvang van de sector vriendschappelijke betrekkingen tussen psychiatrische patiënten en normale referentiepersonen gevonden. De normale referentiepersonen hebben gemiddeld significant meer vrienden dan psychiatrische populaties.

- Er is steeds sprake van een significant groter deel hulpverlening in de sociale netwerken van de patiënten vergeleken met referentiepersonen.

Het zijn precies deze algemene bevindingen die ook in de omvang van het sociale netwerk van de ambulante chronisch psychiatrische patiënten in dit onderzoek worden aangetroffen. Het is op zijn minst opmerkelijk dat in de inventarisatie van de hulpverleners het verschil in de omvang van de sector vriendschappelijke betrekkingen bij de patiënten ten opzichte van de referentiepersonen nog groter wordt en er tevens vergeleken met de referentiepersonen een discrepantie in de omvang van de sector verwanten optreedt, terwijl er tussen de onderzoekspopulatie en de referentiepersonen inzake de omvang van de sector verwanten geen verschillen gevonden worden. Het komt mij voor dat deze extra grote verschillen mede voortkomen uit de beperkingen van het gebruikelijke referentiekader dat inhoudelijk onvoldoende afgestemd is op informatieverzameling ten behoeve van sociale integratie.

\section{De aevarieerdheid van de informele netwerkleden}

Zoals vermeld in $\S 4.7 .2$ is er geen eerder onderzoek gevonden waarin de gevarieerdheid van de netwerkleden in termen van status- en positierollen ten opzichte van focale personen onderzocht is.

In tegenstelling tot wat verwacht wordt blijkt het informele deel van de sociale netwerken van zowel de referentiepersonen alsook van de ambulante chronisch psychiatrische patiěnten qua statusrollen (geslacht en leeftijd) en positierollen (burgerlijke staat, opleiding, woon- en werksituatie) overwegend homogeen ten opzichte van de focale personen samengesteld te zijn. Inzake de positierollen betreffende woon- en werksituatie zijn de sociale netwerken van de patiěnten vergeleken met die van de referentiepersonen significant minder homogeen samengesteld. Anders gezegd: in termen van aansluiting bevinden de ambulante chronisch psychiatrische patiënten zich qua woon- en werksituatie ten opzichte van de informele netwerkleden in een sociaal isolement (zie $\$$ 8.3.2). Ook de jongere patiënten bevinden zich ten opzichte van hun netwerkleden vergeleken met de jongere referentiepersonen voor wat betreft werk- en woonsituatie in een sociaal isolement. Bij de oudere patiënten is er qua leeftijd en werksituatie sprake van een sociaal isolement (zie $\S 10.3 .2$ ). 
Deze uitkomsten werden niet vermoed en zijn boeiend. Immers mede op basis van het gangbare concept van het "Social Breakdown Syndrome" (Gruenberg, 1974) werd verondersteld dat de sociale netwerken van de referentiepersonen qua gevarieerdheid overwegend heterogeen samengesteld zouden zijn terwijl die van de ambulante chronisch psychiatrische patiënten overwegend homogeen samengesteld zouden zijn. Het SBS-concept veronderstelt een proces van persoon tot patiěnt en vervolgens tot chronisch patient dat samengaat met een afbrokkeling van de 'gewone' variatie mensen en betrekkingen en dat overgaat in een functioneren vanuit de rol van een patiënt waarbij bestaansprikkels van buitenaf toenemende mate verdwijnen. De structuur van de gevarieerdheid van mensen en betrekkingen zou aldus ten lange leste zeer homogeen ofwel gelijkvormig samengesteld zijn in tegenstelling tot die van focale personen bij wie geen sprake is van een carriere overeenkomstig het SBS. Welnu, de uitkomsten in dit onderzoek zijn niet overeenkomstig deze gebruikelijke gedachtengang. Wat is er aan de hand?

Hoewel er ongetwijfeld meerdere plausibele verklaringen te geven zijn, lijkt het mij dat er eenvoudigweg vooral sprake is van een misverstand die deels samenhangt met het ontbreken van kennis en inzichten die specifiek ambulante chronisch psychiatrische patiēnten betreffen (zie hooldstuk 2 en 4 ) en voor een ander deel voortkomt uit de eerder genoemde beperkingen van de traditionele diagnostische technieken. Het ontbreken van specifieke concepten betreffende ambulante chronisch psychiatrische patienten leidt te gemakkelijk tot een overname van een profiel voor deze doelgroep van zorg inclusief ten aanzien van haar sociale context die vrijwel geheel opgebouwd is vanuit concepten die hun oorsprong vinden aan de hand van intramurale (chronisch) psychiatrische populaties. Ook het SBS, zoals beschreven door Gruenberg (1974) is hieraan ontstaan. Het probleem is dat het SBS het functioneren van de patiënt vanuit en binnen een sociale context beschrijft die wezenlijk verschilt van die van de ambulante chronisch psychiatrische patiënt. Het lijkt mij dat in de overname van het gangbare profiel (zie hoofdstuk 2) niet zozeer vitgegaan is van onderscheiden sociale contexten maar primair aangesloten is op overeenkomsten inzake de koppeling psychopathologie en chroniciteit. Het probleem is zoals Nijhof (1978) stelt of uitgegaan wordt van het onvermogen van de patiënt en hierbij overwegend aangesloten wordt bij een psychologisch apriori (Cohen, 1985) of van de sociale context zelf waarvan de patiënt deel uitmaakt.

De nadruk op de koppeling psychopathologie - chroniciteit die mede bij de overname van een concept als dat van het SBS optreedt is op zich niet geheel onvoorstelbaar. Ze herinnert aan een inzicht dat bijvoorbeeld vertolkt wordt door Goddijn e.a. (1972) die stellen dat mensen in hel algemeen - en ook de ambulante psychiatrische hulpverlening ontkomt daar kennelijk niet aan - vooral oog hebben voor de spectaculaire en indrukkwekkende verschijnselen binnen een samenleving en aan de samenleving zelf als het meest gewone vanzelfsprekend aanwezige gegeven voorbij gaan. Het spectaculaire deel van de totale onderzoekspopulatie $(N=59)$ lijkt in de ambulante psychiatrische hulpverlening gevormd te worden door de groep van twaalf patiënten (zie $\S 8.1$ en Bijlage IV) voor wie geen referentiepersonen gevonden konden worden. Hun sociaal demografisch profiel blijkt van dien aard te zijn dat er geen aansluiting gevonden kon worden voor hen met mensen die geen problemen in de geestelijke gezondheid vertoonden. Wanneer op individueel niveau naar deze twaalf patiënten wordt gekeken dan blijkt de beschikbare structuur van hun sociale netwerk zodanig te zijn dat zij inderdaad vrijwel aangewezen zijn - op een enkel familielid na op mensen die een breed scala van hulpverlening vertegenwoordigen. Een dergelijk verschijnsel is ook gevonden in de verslavingszorg van het CAD waar een relatief kleine groep heroïneverslaafden zowel de visie op verslaving(szorg) alsook de organisatie ervan bepaalden voor een grote groep heroïneversłaafden bij wie 'redelijke' sociale omstandigheden aanwezig bleken te zijn (Baars e.a., 1989).

Welnu de resultaten inzake de gevarieerdheid van de sociale nelwerken van ambulante chronisch psychiatrische patiënten vergeleken met die van de referentiepersonen maken duidelijk dat het nodig is vanuit de eigen sociale context van deze doelgroep de dynamiek van het proces van aansluiting en isolement te bestuderen en te 
conceptualiseren in plaats van een dynamiek van sociale integratie en uitstoting over te nemen die gebonden is aan een wezenlijk andere sociale context of slechts een sociale context betreft die een beperkt deel van de doelgroep ambulante chronisch psychiatrische patiënten betreft.

\section{Bereikbaarheld van de informele netwerkleden}

Vergeleken met de referentiepersonen hebben de ambulante chronisch psychiatrische patiěnten minder informele netwerkleden die in hun eigen woonplaaats wonen. Dit geldt zowel voor de jongere als de oudere patięnten. Deze verschillen blijken voornamelijk samen te hangen met de geringere omvang van de sector vriendschappelijke betrekkingen bij de patiënten vergeleken met de referentiepseronen en het feit dat de patiënten in vergelijking met de referentiepersonen over hun beschikbare netwerkleden in deze sector met name in het cluster overige vriendschappelijke betrekkingen geen adequate informatie weten te geven.

\section{Structuur van de betrekkingen}

De belangrijkste resultaten kunnen als volgt samengevat worden.

- De patiënten nemen vergeleken met de referentiepersonen minder zelf het initiatief tot contact en hebben minder contacten die uitgaan van wederzijds initiatief. Ook onderscheiden naar jongere en oudere patiênten is dit hel geval. Het probleem is vooral het wederzijds initiatief; voor de jongere patiënten betreft dit zowel de sector verwanten als vriendschappelijke betrekkingen, terwijl dit bij de oudere patiènt in het bijzonder in de sector verwanten hel geval is. In de sector maatschappelijke betrekkingen zijn de patiénten opmerkelijk meer afhankelijk van het initiatief van derden dan het geval is bij de referentiepersonen bij wie de contacten meer op basis van gewoonte tot stand komen.

- Vergeleken met de referentiepersonen hebben de patiënten minder verwanten met wie ze van tijd tot tijd contact hebben en minder netwerkleden in de sector vriendschappelijke betrekkingen met wie ze een frequent contact onderhouden. In het algemeen zijn deze verschillen ook te vinden bij zowel de jongere als de oudere patiënten en zowel in de sector verwanten als ook de sector vriendschappelijke betrekkingen. Echter bij de jongere patiënten treden deze verschillen meer op de voorgrond dan bij de oudere patienten. Vervolgens blijken de patiënten vergeleken met de referentiepersonen frequenter en met meer personen in de hulpverlening contact te hebben.

- De ambulante chronisch psychiatrische patienten blijken nagenoeg een zelfde gewicht aan de betrekkingen met hun netwerkleden toe te kennen als de referentiepersonen. Dit geldt ook wanneer een onderscheid wordt gemaakı tussen jongere en oudere patiënten.

- Evenals bij de referentiepersonen bestaat bij de patiënten het contact met een meerderheid van de netwerkleden reeds vijf jaar of langer. Het is met name de sector verwanten die deze uitkomst bepaalt. De patiënten hebben echter minder netwerkleden met wie het contact korter dan vijf jaar bestaat, hetgeen met name de sector vriendschappelijke betrekkingen betreft, maar meer netwerkleden met wie sinds het afgelopen jaar contact bestaat. Bij de jongere patiěnten treden deze verschillen sterker op en ook hier ligt het zwaartepunt in de sector vriendschappelijke betrekkingen.

Een nadere beschouwing leert hel volgende. De uitkomst van dit onderzoek inzake het initiatief nuanceert de algemeen aanwezige bevindingen in eerder verricht onderzoek (§ 4.7.5) dat de (ambulante) chronisch psychiatrische patiënten minder eigen initiatief nemen dan referentiepersonen. Dit is voor wat betreft de totale onderzoekspopulatie juist. Maar wanneer een onderscheid wordt gemaakt tussen jongere en oudere patiēnten - en leeftijd is de doorslaggevende factor voor de structuur van sociale netwerken - dan blijkt dat jongere patiënten met name in de sector 
vriendschappelijke betrekkingen nagenoeg evenveel zelf het initiatief tot contact nemen als de jongere referentiepersonen. Het probleem is dat deze contacten in de sector vriendschappelijke betrekkingen bij jongere patiěnten niet lang stand houden.

Het meest opvallend is het verschil tussen de patiënten en de referentiepersonen inzake werderzijds initiatief in het contact mel de netwerkleden. Wanneer zowel het eigen initiatief en dat van een netwerklid in gelijke mate en wel actief de betrekking bepaalı dan blijken de patiēnten minder dergelijke wederzijdse contacten te hebben dan de referentiepersonen. De patiënten hebben aldus minder contacten waarin zij zelf in termen van initiatief een actieve bijdrage leveren. Dit gegeven komt bij de jongere patiënten zowel in de sector verwanten alsook in hoge mate in de sector vriendschappelijke betrekkingen sterker naar voren dan bij de oudere patiënten.

Vergeleken met de resultaten in eerder onderzoek is het ook hier het geval dat in meerderheid de contacten van de patiënten in termen van initiatief 'afhankelijk' zijn. Echter de patiënten onderscheiden zich hierin nagenoeg niet van de referentiepersonen. De patienten verschillen in het algemeen in initiatief tot contact van de referentiepersonen waar het gaat om een actieve eigen investering in het contact met netwerkleden.

Op hel punt van de frequentie van het contact en de duur / lengte van de contacten is vrijwel geen onderzoek beschikbaar dat een vergelijking toestaat. Dit betekent dat de eerder gegeven resultaten voor zichzelf spreken.

Tenslotte de vitkomsten inzake het gewicht dat de patiënten vergeleken met de referentiepersonen aan het contact met hun netwerkleden toekennen. Er treden gemiddeld geen verschillen op. Al de differentiaties die op individueel niveau zowel bij de patiënten alsook bij de referentiepersonen gevonden worden vallen op populatieniveau zowel in het geheel van de sociale netwerken alsook onderscheiden naar sectoren weg. Dat is bij de patiënten en de referentiepersonen in gelijke mate het geval. Een probleem is, zoals ook eerder beschreven bij het model van sociale netwerkanalyse (zie hoofdstuk 5) dat de informatie betreffende het element gewicht anders dan bij de overige structuurkenmerken gebaseerd is op een persoonlijke inschatting met alle kleuringen vandien. Geconstateerd moet worden dat de bruikbare informatie die op individueel niveau voor de ambulante psychiatrische hulpverlening optreedt op het niveau van de populatie niet meer aan de orde is. Hooguit zou men kunnen zeggen dat ambulante chronisch psychiatrische patiënten in hun strevingen naar de vervulling van affectie, van aansluiting en andere bestaansmiddelen meer met die van referentiepersonen overeenkomen dan vanuit het oogpunt van inzichten en waarnemingen in de ambulante psychiatrische hulpverlening (zie de lagere gewichten die de hulpverleners geven) verwacht dan wel aangenomen wordt.

Met de samenvatting en de nabeschouwing van de belangrijkste resultaten omtrent de structuur van de sociale netwerken van de ambulante chronisch psychialrische patiënten vergeleken met die van referentiepersonen ligt hier de informatie uit het onderzoek om in samenhang met de bevindingen over de structuur van de sociale nelwerken van de patiënten vergeleken mel de gegevens erover bij de hulpverleners nader in te gaan op de praktische consequenties ervan voor de verwerkelijking van een doelstelling van ambulante psychiatrische hulpverlening die primair gericht is op het herslel dan wel de bevordering van de sociale integratie van de patiënt. 


\subsection{3}

\section{Praktlsche consequenties}

Uitgaande van een sociale netwerkaanpak, zoals beschreven in hoofdstuk 3 aan de hand van het werk van Speck en Attneave (1973) en Rueveni (1979) die vanuit een structuurconcept voor sociale netwerkanalyse (Wellmann, Berkowitz, 1988) modelmatig uitgewerkt in onder meer het boek 'Sociale netwerkstrategieên in de sociale psychiatrie' (Baars, Uffing, Dekkers, 1990) vangt het herstel dan wel de bevordering van de sociale integratie van de ambulante chronisch psychiatrische patiènt (de doelstelling van de SPD van de RIAGG Maastricht) aan met de reorganisatie van de structuur van het sociale netwerk.

\section{Reoroanisatie van de emvana}

Vergeleken met de toestand van de omvang in hel sociale netwerk van de referentiepersonen betekent een reorganisatie van de omvang van het sociale netwerk van de ambulante chronisch psychiatrische patiënt:

- herstel en bevordering van een 'gewone' omvang vriendschappelijke betrekkingen, in het bijzonder van het cluster naaste vrienden. Dit is vergeleken met de oudere patiënten in hoge mate voor de jongere patiënten aangewezen;

- herstel en bevordering van een 'gebruikelijk' omvang netwerkleden in het cluster hulpverlening.

Uitgaande van inventarisatie van de omvang door de hulpverlening bestaat een reorganisatie van de omvang van het sociale netwerk van de ambulante chronisch psychiatrische patiënt vooreerst en vooraf uit:

- herstel dan wel bevordering van de informatie over de werkelijk beschikbare omvang van de sector verwanten, in hat bijzonder waar het gaat om aanverwanten en zogeheten 'verre' verwanten. Dit betreft zowel de jongere alsook de oudere patiénten;

- herstel dan wel bevordering van de informatie over de beschikbare omvang netwerkleden in de sector vriendschappelijke betrekkingen. Dit betreft zowel bij de jongere alsook bij de oudere patięnten (zij hel in mindere mate) het cluster naaste vrienden en het cluster overige vriendschappelijke betrekkingen.

\section{Reorganisatie van de gevarieerdheld}

Vergeleken met de toestand van de gevarieerdheid van de netwerkleden ten opzichte van de referentiepersonen betekent een reorganisatie van de gevarieerdheid van het sociale netwerk van de patięnten:

- herstel dan wel bevordering van de aansluiting van de werksituatie van de patiênt ten opzichte van zijn netwerkleden, hetgeen in het bijzonder geldt voor de jongere patiënten.

- herstel dan wel bevordering van de aansluiting van de woonomstandigheden van de patiěnt ten opzichte van zijn netwerkleden; dit geldt zowel voor de jongere als cok voor de oudere patienten.

- herstel dan wel bevordering van de aansluiting met leeftijdgenoten bij met name de oudere ambulante chronisch psychiatrische patienten.

Uitgaande van de inventarisatie van de netwerkleden door de hulpverlening bestaat een reorganisatie van de gevarieerdheid van het sociale netwerk vooreerst en vooraf uit:

- herstel dan wel bevordering van de informatie over de status- en positierollen van alle beschikbare informele netwerkleden. 


\section{Reoraanisatle van de berelkbaarheid}

Vergeleken mel de toestand van de bereikbaarheid van de informele netwerkleden bij de referentiepersonen betekent een reorganisatie van de bereikbaarheid van de informele netwerkleden bij ambulante chronisch psychiatrische patiënten:

- herstel en bevordering van de bereikbaarheid van beschikbare informele netwerkleden in de sector vriendschappelijke betrekkingen door de patiënten te mobiliseren om adequate informatie te verschaffen;

- herstel en bevordering van de omvang van de sector vriendschappelijke betrekkingen met name de opbouw van betrekkingen met informele netwerkleden die woonachtig zijn in de eigen woonplaats en aldus in termen van afstand gemakkelijk bereikbaar zijn;

Vergeleken met de informatie van de hulpverleners betekent een reorganisatie van de bereikbaarheid van de informele netwerkleden voor de patiënten vooreerst:

- herstel en bevordering van informatie over de bereikbaarheid van de informele netwerkleden van de patiënten, met name van die verwanten die familiair verder van de patiënt staan dan de naaste bloed- en aanverwanten vervolgens en van de beschikbare netwerkleden in de sector vriendschappelijke betrekkingen. Meer dan bij de oudere patiënten dient bij de jongere patiënten aandacht gegeven te worden aan beschikbare informele netwerkleden die verder af ofwel buiten de eigen woonplaats wonen.

\section{Reoroanisatle van de structuur van de betrekkingen}

Vergeleken met de toestand van de structuur van de betrekkingen bij de referentiepersonen betekent een reorganisatie van de strucluur van de betrekkingen bij ambulante chronisch psychiatrische patiënten:

- herstel en bevordering van het eigen initiatief van de patiënt in het rechtstreekse en wederzijdse contact met zijn netwerkleden, hetgeen in het bijzonder geldt voor de jongere patiënten in de sectoren verwanten en vriendschappelijke betrekkingen en voor de oudere patiënten in de sector verwanten;

- herstel en bevordering van het contact uit gewoonte in de sector maatschappelijke diensten in plaats van afhankelijk te zijn van het initiatief van derden;

- herstel en bevordering van een lagere frequentie in het contact met verwanten terwijl in de sector vriendschappelijke betrekkingen de frequentie van het contact juist opgevoerd dient te worden;

- herstel en bevordering van een minder frequent contact met personen die instellingen van hulpverlening vertegenwoordigen;

- het mobiliseren van het gewicht dat de patiënten aan het contact met hun netwerkleden toekennen;

- herstel en bevordering van het contact met netwerkleden dat op korte termijn het perspectiel op meer duurzaamheid geeft in plaats van dat de patiënten alleen aangewezen zijn op contacten die kort standhouden en op reeds zeer lang bestaande contacten. Dit geldt met name voor de jongere patiënten in de sector vriendschappelijke betrekkingen.

Vergeleken met de informatie van de hulpverleners betekent een reorganisatie van de structuur van de betrekkingen bij de patiënten vooreerst:

- herstel en bevordering van de informatie over het eigen initiatief van de patiënt en het wederzijds initiatief dat in de sociale netwerken wordt ondernomen met name gedurende het afgelopen jaar. Dit geldt in het bijzonder voor de jongere patiénten zowel voor wat betreft de sector verwanten als de sector vriendschappelijke betrekkingen; 
- herstel en bevordering van de informatie over de frequentie van de contacten met de netwerkleden. Ook hier geldt dat in het bijzonder bij de jongere patiünten de informatie over de contactfrequentie met de netwerkleden in de sector vriendschappelijke betrekkingen hersteld dient te worden in die zin dat de werkelijke toestand zichtbaar wordt met name voor wat betreft de hoge contactfrequentie:

- herstel en bevordering van de informatie over het gewicht dat de patienten zelf aan het contact met hun netwerkleden toekennen zodat niet alleen het accent valt op de teleurstellingen maar ook de strevingen zichtbaar worden.

- herstel en bevordering van de informatie over de duurzaamheid van de betrekkingen bij de patiënten. In het bijzonder gaat het bij jongere patiënten om informatie over de contacten met netwerkleden die in het afgelopen jaar en actueel ontstaan.

\section{Samenvattend}

Al bij al geven de resultaten van dit onderzoek ten aanzien van de doelstelling van sociale integratie aan waar de mogelijkheden en beperkingen liggen in de aanwezige structuur van het sociale netwerk waarop de patiênt voor zijn sociale integratie is aangewezen. In de uitwerking van de praktische consequenties liggen de aangrijpingspunten voor interventies die gericht zijn op deze doelstelling. Natuurlijk, de gevonden resultaten en hun praktische consequenties moeten opgevat worden als algemene bevindingen en aangrijpingspunten die op patiëntniveau zeer serieus te nemen zijn, maar die tegelijk ook steeds in samenhang met de viteenlopende structurele toestand van het sociale netwerk van de patiënt om een eigen op de individuele patiënt en zijn persoonlijke sociale netwerk gerichte vertaling vereisen. Als hierboven gesproken wordt van 'gewoon' of 'gebruikelijk' dan betekent dit dat herstel en bevordering van de structuur van het sociale netwerk van de patiënt op maat van de patiěnt en zijn persoonlijke sociale netwerk dient te geschieden (Baars, Uffing. Dekkers, 1990). Hoe een en ander op patiëntniveau concreet uitpakt, voorwaarde is wel dat de ambulante psychiatrische hulpverlening over zo volledig mogelijke en gedifferentieerde informatie inzake de feitelijke toestand van de structuur van het sociale netwerk van haar doelgroep kan beschikken. De door de hulpverleners gebruikte techniek van informatieverzameling geeft hiervoor bepaald geen garantie. Aldus kan vastgesteld worden dat de MSNA de ambulante psychiatrische hulpverlening in staat stelt vollediger en gedifferentieerder de feitelijke toestand van de structuur van de sociale netwerken van haar doelgroep te achterhalen dan wanneer zij geen gebruik maakt van de MSNA. Wanneer de doelstelling van sociale integratie als de primaire doelstelling van ambulante psychiatrische hulpverlening wordt opgevat dan lijkt de toepassing van de MSNA bij de aanvang van de hulpverlening de aangewezen weg om rechtstreeks in en met het sociale milieu te kunnen werken aan de sociale integratie van de ambulante chronisch psychiatrische patiënt.

\subsection{WERKWIJZE}

Voor zover achterhaald is kunnen worden is het onderzoek dat in dit proefschrift gerapporteerd wordt het eerste dat zich zo specifiek richt op de strucluur van sociale netwerken bij chronisch psychiatrische patiénten in zorg bij de ambulante psychiatrische hulpverlening. Een dergelijke positie heeft het voordeel van een zeker open eind maar tegelijk het nadeel van het ontbreken van ijkpunten. Voor zover er in eerder onderzoek bij min of meer vergelijkbare populaties structuurkenmerken zijn gebruikt - en dat betreft hoofdzakelijk de omvang van een sociaal netwerk en het initiatief in de betrekkingen met nelwerkleden - blijken de uitkomsten van dit onderzoek met die van eerder onderzoek in de pas te lopen. Voor wat betreft de andere structuurkenmerken blijken de resultaten met elkaar in overeenstemming te zijn. In het geheel genomen is er sprake van harmonie en blijken de resultaten constante patronen in de structuur van de sociale netwerken weer te geven. Bijvoorbeeld in de 
resultaten betreffende de informatie die de hulpverleners over de structuur van de sociale netwerken van hun doelgroep geven (vraagstelling II) zijn de uitkomsten van alle structuurkenmerken met elkaar in overeenstemming en wel in die zin dat ze een vast patroon opleveren. Het patroon van gegevens over de sociale omstandigheden van de patiënt dat via de MSNA uit de informatie van de hulpverleners verschijnt sluit niet alleen in alle opzichten aan op de systematiek van informatieverzameling bij de hulpverlening maar ze weerspiegelt ook de gebruikelijke methode en techniek van geestelijke gezondheidszorg waaraan deze systematiek van informatieverzameling voor wat betreft het sociale milieu van de patiënt gebonden is.

Deze constatering voedt de gedachte dat de MSNA inhoudelijk betrouwbaar en valide is, een mening die tot nu toe op theoretische gronden was gestaafd. Overigens kent de MSNA een lange ontwikkelingsgeschiedenis en heeft de toepassing ervan bij dit onderzoek plaats gevonden in een context van lopend onderzoek, het zogeheten 'Sociale Netwerk Project', waarbij eveneens de MSNA gebruikt is (Baars, Uffing, 1993). Vastgesteld kan worden dat ook in het onderzoek naar de structuur van het sociale netwerk van ambulante geriatrische patiënten (Kuypers, 1993) en dat van brandstichters (Boekholt, Hehanussa, 1993) waarbij de MSNA gebruikt is dergelijke vaste patronen in de gegevens worden gevonden. Deze constateringen versterken de zojuist uitgesproken gedachte betreffende de inhoudelijke betrouwbaarheid en validiteit. In het Sociale Netwerk Project is de volgende noodzakelijke stap van empirisch onderzoek naar de predictieve- en constructvaliditeit in voorbereiding.

Bij de beschrijving van de werkwijze is de selectie van de onderzoekspopulatie weergegeven (zie hoofdstuk 7). De complexe procedure kan niet los gezien worden van de fase van academisering waaraan de SPD van de RIAGG Maastricht zich bij de voorbereiding van dit onderzoek en ook tijdens de uitvoering van de opbouw van de onderzoekspopulatie zich bevond. De verkregen gegevens betreffende bijvoorbeeld de psychiatrische diagnostiek en dergelijke weerspiegelen een fase van opbouw van een traditie van op wetenschappelijk onderzoek gerichte protocollaire verslaglegging waaraan de SPD van de RIAGG Maastricht indertijd onderhevig was. Er traden allerlei onvolkomenheden in de registratiegegevens aan het licht die toen voor zover dat mogelijk was bijgewerkt zijn. De beschreven procedure weerspiegelt een situatie inherent aan de toenmalige fase van academisering van de SPD dat onderzoekers en hulpverleners ondanks alle goede wil tot samenwerking nog sterk gescheiden terreinen waren en deels nog zijn. Het gaat hier uiteindelijk om het probleem van onderscheiden bevoegdheden en verantwoordelijkheden tussen onderzoekers en hulpverleners in de samenwerking met patienten bij hulpverlening en bij onderzoek. De integratie hiervan in één persoon die zowel onderzoeker is als deelneemt aan de praktijk van de ambulante psychiatrische hulpverlening was indertijd nog toekomstmuziek. Ook op dit punt is lopende het onderzoek veel verbeterd.

De indertijd met de SPD afgesproken procedure (zie $\S 7.1 .1$ ) sluit in dat de selectie van de onderzoekspopulatie in wezen bepaald is door de hulpverleners. Ondanks deze beperkingen blijkt zoals beschreven in $\S 8.1$ dat de onderzoekspopulatie in hoofdlijnen redelijk aansluit op het totaal aantal nieuw aangemelde patienten en als dwarsdoorsnede van de doelgroep van de SPD Maastricht kan worden opgevat. Uit de verschillen die er zijn zou afgeleid kunnen worden dat de hulpverleners de deelname dan wel de toepassing van de MSNA vanuit een zekere indicatiestelling overwegen. Hoewel er momenteel aanzienlijke verbeteringen zijn opgetreden in protocollaire verslaglegging en de vanzelfsprekendheid van samenwerking tussen praktijk en onderzoek sterk is toegenomen dient bij vervolgonderzoek het niet geheel uit te sluiten gegeven van een vervlechting van selectieprocedure en indicatiestelling een belangrijk aandachtspunt te zijn.

Zoals aan het begin van dit proefschrift aangegeven gaat het hier om op de praktijk van de ambulante psychiatrische hulpverlening gericht onderzoek: de welenschappelijke analyse en beschrijving van de structuur van het sociale netwerk van deze doelgroep van de SPD beoogt informatie op te leveren die als toepasbaar kan worden beschouwd voor de realisering van de doelstelling van sociale integratie van de ambulante chronisch psychiatrische patiënt. Dit betekent tevens dat de uitkomsten toegankelijk dienen te zijn voor de praktijk. Vandaar dat er gekozen is voor een 
beschrijvende wijze van analyse. Geheel conform de vraagstellingen en haar hypothesen is niet gezocht naar verklaringen. Het komt erop neer dat de onderzochte variabelen met betrekking tot de omvang, de bereikbaarheid en de structuur van de betrekkingen uitgedrukt zijn in het gemiddeld aantal netwerkleden waarop een variabele betrekking heeft.

Het zijn de data inzake de netwerkleden die uitgangspunt zijn voor de beantwoording van de vraagstellingen conform haar hypothesen. Een uitzondering op deze benadering is de gevarieerdheid van hel sociale netwerk. Hier is een koppeling aan de orde tussen de kenmerken van gevarieerdheid in de zin van status- en positierollen van de focale personen met die van de netwerkleden. Op dit punt bevindt de analyse van de gegevens zich in wezen op het terrein van de methoden van multi-level analyse (Snijders, 1993). Vanwege de beschrijvende aanpak binnen de doelstellingen van dit proefschrift is de analyse inzake de aansluiting van het sociaal demografisch profiel van de focale personen met hun netwerkleden uitgevoerd in termen van homogeniteit en heterogeniteit. Homogeen wil zeggen dat een bepaald kenmerk, bijvoorbeeld opleidingsniveau, van de focale persoon overeenkomt met dat van zijn netwerklid; heterogeen wil zeggen dat bijvoorbeeld de focale persoon qua opleidingsniveau van zijn netwerklid verschilt. Als grove maat ter bepaling van de mate van aansluiting inzake gevarieerdheidskenmerken is uiteindelijk gekozen voor een vergelijking van de verdeling homogeniteit - heterogeniteit tussen de in dit onderzoek onderscheiden groepen focale personen (bijvoorbeeld tussen de jongere patiënten en de jongere referentiepersonen). In tegenstelling tol de overige variabelen is hier uitgegaan van het totaal aantal netwerkleden zonder een uitspraak te doen over het gemiddeld aantal netwerkleden dat per focale persoon in termen van homogeniteit en heterogeniteit aansluit op een focale persoon. Deze beperking bleek noodzakelijk vanwege de complexiteit van het begrip gevarieerdheid waarbij twee meetniveaus vergeleken moeten worden over zes verschillende kenmerken van gevarieerdheid. Het is achteraf heel voorstelbaar dat in eerder onderzoek het structuurkenmerk gevarieerdheid achterwege is gebleven. In toekomstig onderzoek zal op dit punt nog heel wat werk inzake begripsafbakening en methodeontwikkeling ter bepaling van een maat van homogeniteit / heterogeniteit per netwerk verzet dienen te worden.

De uitkomsten maken duidelijk dat de MSNA op populatieniveau bijzonder waardevolle informatie oplevert (zie de hierboven beschreven praktische concequenties) voor de optimalisering van zorg gericht op sociale integratie van de doelgroep van de SPD in het algemeen alsook vertaald naar hulpverlening op het niveau van de afzonderlijke patiënt. Een moeilijkheid is echter het element gewicht in de structuur van de betrekkingen. Op populatieniveau verdwijnen de in de ambulante psychiatriche hulpverlening als zeer waardevol ervaren gedifferentieerde informatie die via de MSNA op patiëntniveau verschijnt. Ook op dit punt is nader onderzoek geboden.

In de procedure was onder meer een terugkoppeling van de uilkomsten van de MSNA op patiëntniveau ingebouwd. De terugkoppeling ging vergezeld met voorlopig ontwikkelde visualiseringen van de de door de patient verstrekte informatie. Een terugkoppeling met behulp van beeldmateriaal bleek voor de patiënt zeer bruikbaar te zijn. De patiěnt kreeg als het ware zijn sociale werkelijkheid in onderdelen gesystematiseerd in beeld gebracht. De ervaringen die hiermee zijn opgedaan (Baars, Uffing, Dekkers, 1990) verwijzen naar een noodzaak voor de ontwikkeling van een informatiesysteem waarmee de gegeven informatie in beeldmateriaal omgezet kan worden ter bevordering van een adequaal overleg tussen de hulpverlener en de patiènt en zijn netwerkleden als het gaat om gezamelijk inzicht in de situatie waarin de patiênt zich samen met zijn netwerk bevindt en de gezamelijke plannen en akties om de structuur van het sociale netwerk zodanig te reorganiseren dat de sociale integratie hersteld kan worden. Lopende het onderzoek zijn hiertoe reeds initiatieven genomen. 
De belangrijkste conclusies die uit dit ondezoek getrokken kunnen worden luiden:

ambulante chronische psychiatrische paliënten in zorg bij de SPD van de RIAGG Maastricht hebben op bais van de informatie verkregen via de MSNA betreffende alle kenmerken van de structuur van mensen en betrekkingen waarvan zij in het dagelijks leven deel uitmaken een vitaler persoonlijk sociaal netwerk ofwel sluiten meer op de sociale netwerken van normale referentiepersonen aan dan in de gegevens over de sociale omstandigheden bij de betreffende hulpverleners zichtbaar wordt;

- ambulante chronisch psychiatrische patiěnten in zorg bij de SPD Maastricht blijken vervolgens vergeleken met de referentiepersonen betreffende vrijwel alle structuurkenmerken in meer of mindere mate lacunes te vertonen;

- de sector vriendschappelijke betrekkingen is het belangrijkste gebied in het persoonlijke sociale netwerk van ambulante chronisch psychiatrische patiënten waar vergeleken met de referentiepersonen de optredende lacunes in de omvang, de gevarieerdheid en de bereikbaarheid van de netwerkleden én in de structuur van de betrekkingen met de netwerkleden zich concentreren. Echter de sector vriendschappelijke betrekkingen is tevens het gebied dat in de gegevens die de betreffende hulpverleners verstrekken het sterkst onderbelicht is;

- de gevonden lacunes in het sociale netwerk in haar geheel en in de sector vriendschappelijke betrekkingen in het bijzonder zijn het grootst waar het gaat om het sociale netwerk van jongere ambulante chronisch psychiatrische patienten. Dit geldt eveneens voor de onderbelichting van de structuur van het sociale netwerk die in de gegevens van de hulpverleners aangetroffen wordt;

- al bij al bevestigt dit onderzoek het eerdere vermoeden dat de ambulante chronisch psychiatrische patiënt over een structureel veelzijdiger sociaal netwerk beschikt dan algemeen op basis van het gangbare profiel van deze doelgroep van ambulante psychiatrische hulpverlening wordt aangenomen en door de betreffende hulpverleners zichtbaar wordt gemaakt;

- de beschreven verschillen en overeenkomsten die in de structuur van de sociale netwerken van ambulante chronisch psychiatrische patiënten vergeleken met normale referentiepersonen enerzijds en vergeleken met de gegevens van de hulpverleners anderzijds via de Maastrichise Sociale Netwerk Analyse (MSNA) in vaste patronen aan het licht komen leiden tot aangrijpingspunten die de ontwikkeling en toepassing van interventiestrategieën in de ambulante psychiatrische hulpverlening ten goede komen voor het herstel dan wel de bevordering van de sociale integratie van deze patiënten;

- wil de ambulante psychialrische hulpverlening met het oog op haar doelstelling van sociale integratie, anders dan hel geval is in de gangbare werkwijze van informatieverzameling, samen met de patiënt en zijn beschikbare sociale netwerk in staat zijn een zo volledig mogelijk en gedifferentieerd beeld van de structuur van het sociale netwerk van de patiënt verkrijgen, dan stelt de MSNA de hulpverleners en de patiënten hiertoe in staat. 
Wanneer ik het geheel van de resultaten van dit onderzoek en de zojuist gegeven centrale conclusies overzie dan kom ik in de eerste plaats tot de constatering dat dit onderzoek meer dan eerder gebeurd is tal van bouwstenen levert voor een ambulante psychiatrische hulpverlening die passend binnen een beleid van zorg in en met het sociale milieu' (Van Londen, 1982; Ministerie van WVC, 1984) gericht is op de sociale integratie van de patiënt. Pracktisch gezien zijn er vooreerst de volgende twee aanbevelingen.

1. Met het oog op de doelstelling van sociale integratie is het gewenst de MSNA standaard op te nemen in de diagnostische fase bij (her)aanmelding van ambulante chronisch psychiatrische patiënten. Zo dat niet gebeurt wordt, gezien de traditie en gewoonten van informatieverzameling die in de ambulante psychiatrische hulpverlening bestaat, de onderbelichting van mensen en betrekkingen waarop de patiënt van zijn sociale integratie is aangewezen niet opgeheven.

2. Het is in het bijzonder gewenst mede vanuit preventief oogpunt betreffende de langdurige zorg de MSNA in de diagnostische fase van de ambulante psychiatrische hulpverlening standaard te gebruiken als het gaat om jongere ambulante chronisch psychiatrische patienten (precies de leeftijdscategorie psychiatrische patiënten bij wie Speck, Altneave en Rueveni indertijd hun sociale netwerkaanpak ontwikkelden).

Zoals hierboven eerder aangegeven zijn deze beide aanbevelingen er in eerste instantie op gericht de geconstateerde onderbelichting van het sociale netwerk op te heffen. Echter het opheffen van een discrepantie in informatie is één stap. Een tweede stap is dat vervolgens gesteund door de informatie over de patronen die zich in de structuur van sociale netwerken bij ambulante chronisch psychiatrische patiënten aftekenen op patiëntniveau een reorganisatie van de structuur van het persoonlijke sociale netwerk ter hand wordt genomen. Daarvoor is aanmerkelijk meer nodig dan een standaard toepassing van de MSNA. Immers de MSNA impliceert op patiëntniveau een hulpverleningstrategie die in en met het sociale milieu de sociale integratie van de patiënt tracht te realiseren. Deze aanpak vergt een omslag in denken en handelen; immers de aangrijpingspunten liggen niet zozeer bij de patient en zijn vaardigheden maar in de structuur van het sociale netwerk van mensen en betrekkingen zelf. Een logisch volgende stap voor onderzoek betreft onder meer de volgende aanbevling.

3. Het is gewenst dat mede op basis van het databestand dat door standaardgebruik van de MSNA verder kan worden opgebouwd onderzoek wordt verricht waarin vanuit de structuur van sociale netwerken de sociale context van specifieke psychiatrisch diagnostische populaties, zoals bij schizofrene patienten, wordt bestudeerd in plaats vanuit een diagnostische categorie de sociale context te analyseren en te beschrijven.

Behalve wetenschappelijk is er praktisch meer nodig. In de eerste plaats gaat het om het daadwerkelijk besef dat inzake de sociale omstandigheden gangbare concepten zoals die van het SBS bij de ambulante chronisch psychiatrische patiënt op zijn minst onvolledig en beperkt zijn. Dit besef kan toenemen wanneer de ambulante psychiatrische hulpverlening conform de genoemde aanbevelingen een meer uitgebreid en gedifferentieerder beeld waarneemt. Ter ondersteuning van een duurzaam daadwerkelijk besef is er de volgende aanbeveling. 
4. Het is gewenst dal de informatie die de MSNA geeft zodanig geordend met de pationt en zijn nelwerkleden besproken kan worden dat het overleg dienaangaande gericht is en blijft op de doelstelling van sociale integratie. Dit betekent dat er in de vorm van beeldmateriaal een adequate protocollaire verslaggeving van de structuur van het sociale netwerk ontwikkeld wordt.

Vervolgens:

5. Het is gewenst dat deze vorm van protocollaire verslaglegging zodanig in elkaar steekt op patiêntenniveau dat zij ook toepasbaar is op populatieniveau ten behoeve van de analyse en beschrijving van patronen in de structuur van de sociale netwerken.

In de tweede plaats gaat het om het daadwerkelijk besef dat niet alleen gangbare concepten als die van SBS niet (geheel) van loepassing zijn op deze doelgroep maar ook dat het eigen gangbare referentiekader met het oog op sociale integratie inperikend werkt. Zoals aangegeven zijn er in aansluiting op de MSNA voor het herstel van de sociale integratie in en met het sociale netwerk van de patiènt andere en nieuwe aangrijpingspunten, interventiemogelijkheden en verantwoordelijkheden in de verhouding hulpverlening en de patiënt en zijn sociale netwerk dan in de gangbare methoden on technieken van ambulante psychiatrische hulpverlening het geval is (zie hoofdstuk 3; Baars, Uffing, Dekkers, 1990). Er liggen zoals in dit proefschrift aangegeven, bijvoorbeeld inzake het gangbare profiel van de amblante chronisch psychiatrische patiênt, evenwel enkele probleemvelden die bijzonder weerbarstig zijn en niet anders dan binnen en met de praktijk van de ambulante psychiatrische hulpverlening bestudeerd kunnen worden.

6. Het is gewenst in en met de praktijk van ambulante psychiatrische hulpverlening de huidige expertise te richten op de wetenschappelijke analyse en beschrijving van de toepassing en de ontwikkeling van interventiestategieèn die op maat van de patiént op geleide van de MSNA de sociale integratie van de patient beogen. Mede vanuit preventief oogpunt is dit in het bijzonder gewenst bij de jongere ambulante chronisch psychiatrische patiënten.

7. Het lijkt gezien genoemde weerbarstigheden raadzaam dat onderzoekers hierin samenwerken met een speciaal team van hulpverleners uit de ambulante psychiatrische hulpverlening van de SPD van de RIAGG ter plekke en gezamelijk voor dit doel een praktijk gerichte academische onderzoeksgroep vormen.

Met deze laalste aanbeveling gericht op een versterking van de ambulante psychiatrische hulpverlening waar het gaat om de bevordering van de sociale integratie van ambulante chronisch psychiatrische patiënten ben ik aan het eind van de verslaglegging van het onderzoek naar de structuur van het sociale netwerk van de doelgroep van de SPD van de RIAGG Maastricht gekomen. Hiermee is dit proefschrift voltooid.

Ik eindig dit proefschrift zoals ik begonnen ben met het citaat van Gisela Konopka (1963) uit het werk van William Saroyan (1952) : "waar moest ik beginnen ? Hel duurde vele jaren voor ik het geheim ontdekte dat het er helemaal niet toe doet waar men begint en dat het niet nodig is dat wat men schrijft direct groot is, belangrijk is dat een mens zich neerlegt bij de waarheid dat hij slechts een mens is, en werkt.........". Ik zou er aan toe willen voegen: .....'en verder werkt'; want er is nog veel te doen bij wat Konopka "moeilijke krachten" noemt die zowel in de samenleving alsook bij de psychiatrische patiěnt aanwezig zijn als het om sociale integratie gaat. 


\section{LITERATUUR}

A.

Adams, B., 1967, Interaction theory and the social network, in: Sociometry 30, 6478.

Altman, P.J. \& M.J.H. Walterbos (red.),1991, Sociale netwerkstrategieën, Verslag studiemiddag, Het Groot Graffel, Warnsveld.

Anderson, C., 1983, A psychoeducational program for families of patients with schizophrenia, in: W.R. McFarlane (ed), Family therapie in schizophrenia, Guilford, New York.

Angermeyer, M.C. \& D. Klusmann, (Hrsg.), 1989, Soziales Netzwerk, ein neues Konzept für die Psychiatrie, Springer Verlag, Berlin/Heidelberg.

Angermeyer, M.C. \& R. Lammers, 1986, Das soziale Netzwerk schizophrenen Kranker, in: Zeitschrift für Klinische Psychologie, Psychopathologie und Psychotherapie, 34 (2), 100-118.

Arthur, R.J., 1971, Sociale Psychiatrie, Spectrum, Antwerpen/Utrecht.

Asselbergs, L., 1986, Ambulante behandeling van schizofrenie; een literatuurstudie, NCGV-Reeks 91, Utrecht.

Attneave, C.L., 1969, Therapy in tribal settings and urban network intervention, in: Family Process, 8, 192-210.

Attneave, C.L., 1975, Family Network Map, Washington.

Attneave, C.L., 1976, Social networks as a unit of intervention, in: P. Querin (ed.) Family therapy: therapy and practice, Gardner Press, New York.

Attneave, C.L., 1980, Social networks and clinical practice; a logical extension of family therapy, in: D.S. Freeman (ed.), Perspectives on family therapy, Butterworth \& Co., Vancouver.

Auerswald, E.H., 1968, Interdisciplinary versus ecological approach, in: Family Process, 7, 202-215.

Auerswald, E.H., 1972, Families, change, and the ecological perspective, in: Family Process, 18, 263-280.

Auerswald, E.H., 1985, Thinking about thinking in family therapy, in: Family Process, 24, 1-12.

B.

Baan, P.A.H., 1957, Psychiatrie in de maatschappij, Inaugurale Rede, Wolters, Groningen.

Baars, H.M.J., 1984, Sociale netwerkbenadering in de gezondheidszorg, geïllustreerd aan praktijkvoorbeelden, in: Metamedica 63 (1), 68-77.

Baars, H.M.J., 1985, De registratie van het sociale netwerk bij 50 cliënten in de GGZ die langdurig structurerende begeleiding behoeven, in: M.A.J. Romme (red.) De chronisch psychiatrische patiënt, Onderzoeksverslag, Vakgroep Sociale Psychiatrie RL, Maastricht.

Baars, H.M.J., 1992, Die Gruppe, ein Zentrum mit neuen Chancen, Werkstattschriften zur Forensischen Psychiatrie, Nr. 2, Westfallisches Zentrum für Forensische Psychiatrie, Landschaftsverband Westfalen-Lippe, Lippstadt/Münster.

Baars, H.M.J. \& J.T.F. Uffing, 1987, Sociale netwerken, reservoirs van hulp bij problemen in de geestelijke gezondheid, in: Metamedica, 66 (3), 68-77.

Baars, H.M.J. \& J.T.F. Uffing, 1988, Het sociale netwerk, een bouwplaats van geestelijke gezondheid, in: Metamedica, 67, (5), 315-331. 
Baars, H.M.J. \& J.T.F. Uffing, 1991, Het wederopbouwen van sociale netwerken, in: P. van Lieshout \& J.W. van Zuthem (red.), Wonen als werk, zorgverlenen in beschermende woonvormen, Bohn Stafleu Van Loghum, Houten/Antwerpen.

Baars, H.M.J. \& J.T.F. Uffing, 1993, The Social Network Project Maastricht, in: Netletter, 6 (2), 2-3.

Baars, H.M.J., J.T.F. Uffing \& G.F.H.M. Dekkers, 1990, Sociale netwerkstrategieën in de sociale psychiatrie, Bohn Stafleu Van Loghum, Houten/Antwerpen.

Baars, H.M.J., Uffing, J.T.F. \& L.J.J.M. Dreessen, 1991, Het sociale netwerk in de staalkaart van de sociaal psychiatrische praktijk, in: Perspectief, 9 (10) 90-95.

Baars, H.M.J., Uffing, J.T.F. \& J.V. Honée, 1988, Use of social networks in mental health care, in: M.A.J. Romme \& A.D.M.A.C. Escher (eds), Research to practice in community psychiatry, Van Gorcum, Assen/Maastricht.

Baars, H.M.J., Schaeken, M.G., Mevius, G.J., Uffing, J.T.F. \& G.A.M. Driessen, 1989, Het bereik van de ambulante verslavingszorg in een heroïnescene, in: Tijdschrift voor Alcohol, Drugs en andere Psychotrope Stoffen, 15 (3), 97-104.

Bachrach, L.H., 1981, Continuity of care for chronic mental patients, a conceptual analysis, in: American Journal of Psychiatry, 138, 1449-1456.

Barrera, M. \& S.L. Ainlay, 1983, The structure of social support: a conceptual and empirical analysis, in: Journal of Community Psychology, 11, 133-143.

Barrera, M., Sandler, I.N. \& T.B. Ramsay, 1981, Preliminary development of a scale of social support, studies on college students, in: American Journal of Community Psychology, 9, 435-447.

Barnes, J.A., 1954, Class and committees in a Norwegian island parish, in: Human Relations, 7, 39-58.

Barnes, J.A., 1969, Networks and political process, in: J.C. Mitchell (ed.), Social networks in urban situations, Manchester University Press, Manchester.

Baumann, U., Laireiter, A., Pfingstmann, G. \& K. Schwarzenbacher, 1987, Fragebogen zum Sozialen Netzwerk und zur Sozialen Unterstützung (SONET), in: Zeitschrift für Klinische Psychologie, 16, 429-431.

Beels, C.C., 1979, Social networks and schizophrenia, in: Psychiatric Quarterly, 51 (3), 209-215.

Bell, N.W., 1962, Extended family relations of disturbed and well tamilies, in: Family Process, 1, 175-193.

Bell, N.W. \& E.F. Vogel, (eds), 1960, A modern introduction to the family, Free Press, New York.

Bell, N.W. \& J.P. Spiegel, 1966, Social psychiatry, vagaries of a term, in: Archives of General Psychiatry, 14, 337-345.

Bergh, W.M. van den, 1991, Einige Entwicklungen in der niederländischen geistigen Gesundheitssorge in den letzten zehn Jahren, in: J.H. Mauthe \& I. Krukenberg Bateman (Hrsg.), Psychiatrie in Deutschland, Tagungsband zu den 8. PsychiatrieTagen Königsiutter 1990, Vereinsverlag. Königslutter.

Bergh, W.M. van den \& J.A.M. Slager, 1984, Een brug naar de samenleving, in: Balans, 15 (8), 13-16.

Berkowitz, S., 1982, An introduction to structural analysis: the network appraoch to social research, Butterworths, Toronto.

Bernard, H.R., Killworth, P. \& L. Sailer, 1981, Research on informant accuracy in network data, in: Connections, 4 (2).

Bertalanify, L. von, 1966, General system theory and psychiatry, in: S. Arieti (ed.) American Handbook of Psychiatry. III, Basic Books, New York.

Boekholt, F.D. \& N.E. Hehanussa, 1993, De sociale netwerken van brandstichters in Zuid-Limburg, Onderzoeksverslag, Stichting Reclassering Zuid-Limburg MaastrichV Vakgroep Sociale Psychiatrie RL Maastricht.

Bolwijn, P., 1989, Werkt het netwerk? Onderzoek naar het sociale netwerk van psychiatrische patiënten, Doctoraalscriptie Gezondheidswetenschappen, RL Maastricht.

Boissevain, J., 1974, Friends of friends, St. Martins Press, New York. 
Boswell, D.M., 1969, Personal crisis and the mobilization of the social network, in: J.C. Mitchell (ed.) Social networks in urban situations, Manchester University Press, Manchester.

Bott, E., 1957 (2nd ed. 1971), Family and social networks, Tavistock Publications, London.

Bowen, M., 1961, The family as a unit of study and treatment, in: American Journal of Orthopsychiatry, 31, 408.

Bowen, M., 1966, The use of family theory in clinical praclice, in: Comprehensive Psychiatry, 7, 345- .

Braft, J. \& M.M. Lefkowitz, 1979, Community mental health treatment, who works for whom? in: Psychiatric Quarterly, 119-134.

Brim, J.A., 1974, Social network correlates of avowed happiness, in: Journal of Nervous and Mental Disease, 158, 432-439.

Broadhead, W.E., Kaplan, B.H. \& S.A. James, 1983, The epidemiological evidence for a relationship between social support and health, in: Journal of Epidemiology, 117 (5), $521-537$.

Brown, G.W. \& T. Harris, 1978, Social origins of depression, The Free Press, New York.

Brugha, T., Conroy, R., Walsh, N., Delaney, W., O'Hanlon, J., Dondero, E., Daly, L., Hickey, N. \& G. Bourke, 1982, Social networks, attachments and support in minor affective disorders: replication, in: British Journal of Psychiatry, 141, 249255.

Bruhn, J.G. \& B.U. Philips, 1984, Measuring social support, a synthesis of current approaches, in: Journal of Behavioral Medicine, 7 (2) 151-169.

Buchkremer, G., Lewandowsky, L. \& P. Hornung, 1989, Therapeutische Gruppenarbeit mit Angehörigen schizophrener Patienten, in: (G. Guchkremer \& N. Rath (Hrsg.) Therapeutische Arbeit mit Angehörigen schizophrener Patienten; Messinstrumente, Methoden, Konzepte, Verlag Huber, Bern-Stuttgart-Toronto).

C.

Calaço Belmonte, J.A.J., 1979, Lof der sociale psychiatrie, in: Maandblad Geestelijke Volksgezondheid, (12), 854-860.

Caplan, G., 1964, Principles of preventive psychiatry, Basic books, New York.

Caplan, G., 1974, Support systems and community mental health, Behavioral Publications, New York.

Cassel, J.C., 1974, Psychiatric epidemiology, in: American handbook of psychiatry, 2, (ed. G. Caplan), Basic books, New York.

Cassel, J.C., 1976, The contribution of the social environment to host resistance, in: American Journal of Epidemiology, 104 (2), 108-123.

Cartwright, D. \& A. Zander, 1954, Group dynamics, Tavistock, London.

Christ, J. \& U. Hafner, 1989, Die Sozialpsychiatrie als praklische Anwendung der Epidemiologie, in: Schweizer Archiv für Neurologie und Psychiatrie, 140 (6), 495-509.

Christensen, H.T., 1964, Development of the family field of study, in: H.T. Christensen (ed.), Handbook of marriage and the family, Rand McNally \& Company, Chicago.

Ciarlo, J.A. \& J. Reihman, 1978, The Denver community mental health questionnaire: development of a multidimensional program evaluation instrument, in: R.D. Coursey (ed.), Program evaluation for mental health, methods, strategies and participants, Grune and Stratton, New York.

Ciompi, L., 1985, Das Anliegen der Sozialpsychiatrie, in: L. Ciompi (Hrsg.), Sozialpsychiatrische Lernfălle; aus der Praxis - für die Praxis, Psychiatrie Verlag, Bonn.

Clark, D.H., 1981, Social therapy in psychiatry, Livingstone, London/New York.

Cobb, S., 1976, Social support as a moderation of life stress, in: Psychosomatic Medicine, 38, 300-314.

Cohen, P., 1984, is heroïneverslaving een vorm van pathologie: kritiek op een psychologisch apriori, in: Maandblad Geestelijke Volksgezondheid (2), 115-126. 
Cohen, C.I. \& J. Sokolovsky, 1978, Schizophrenia and Social networks, in: Schizofrenia Bulletin, 4, 546-560.

Cohen, C.I. \& J. Sokolovsky, 1979-a, Health-seeking behaviour and social networks of the aged living in single room occupancy hotels, in: Journal of the American Geriatrics Society 27 (6), 270-278.

Cohen, C.I. \& J. Sokolovsky, 1979-b, Clinical use of network analysis for psychiatric and aged populations, in: Community Mental Health Journal, 15 (3), 203-213.

Cohen, C.I. \& J. Sokolovsky, 1981, A reassessment of the sociability of long-term skid row residents: a social network approach, in: Social networks, 3, 91-105.

Collins, A. \& D.C. Pancoast, 1976, Natural helping networks: a strategy for prevention, National Association of Social Workers, Washington.

Craven, P. \& B. Wellman, 1973, The network city, in: Sociological Inquire, 43 $(3 / 4), \quad 57-88$.

Curtis, W., 1974, Team problemsolving in a social network, in: Psychiatric Annals, 4, 11-27.

D.

D'Augelli, A.R., 1981, Social support networks in mental health, in : J.K. Whittaker \& J. Garbarino (eds) Social support networks; informal helping in the human services, Aldine Publishing Company, New York.

D'Augelli, A.R., Vallance, T.R. \& J.S. Danish, 1981, The community helpers project: a description of a preventive strategy for rural communities, in: Journal of Prevention, 1, 209-224.

Diagnostic and Statistical Manual Disorders, 3d. ed. rev., 1987, American Psychiatric Association, Washington.

Doorn, J.J.A. van \& C.J. Lammers, 1969, Moderne sociologie, systematiek en analyse, Spectrum, Utrecht.

Dörner, K.A., Egetmeyer, A. \& K. Könning, 1982, Freispruch der Familie, Psychiatrie Verlag, Rehburg-Loccum.

Dozier, M., Harris, M. \& H. Bergman, 1987, Social network density and rehospitalization among young adult patients, in: Hospital and Community Psychiatry, 38 (1), 61-65.

Driedger, W., 1981, Social networks in family practice, in: D.S. Freeman \& B. Trute (eds) Treating families with special needs, 153-164.

Driedonks, G., Geurts, R \& I. van Tellingen, 1990, Sociaal netwerkbenadering in praktijk I, een verkennende studie, RIAGG Westelijk Utrecht, Utrecht.

Driedonks, G., Licher, Y., \& W. Groen, 1992, Sociale netwerkbenadering in praktijk, II, RIAGG Westelijk Utrecht, Utrecht.

Driedonks, G., 1993, Werken met netwerken: een benadering voor ambulante chronische cliënten, in: Maandblad Geestelijke Volksgezondheid, 48 (5), 467 484.

Dröes, J. van \& P. van Diepen, 1991, Het maken van rehabilitatieplannen, in: P. van Lieshout \& J.W. van Zuthem (red.), Wonen als werk, zorgverlenen in beschermende woonvormen, Bohn Stafleu Van Loghum, Houten/ Antwerpen.

E.

Erickson, G.D., 1975, The concept of personal networks in clinical practice, in: Family Process, 14 (4), 487-496.

Erickson, G.D., 1976, Personal networks and mental illness, Thesis, University of York, York (UK).

Erickson, G.D., 1984, A framework and themes for social network intervention, in: Family Process, 23, 187-204.

Erickson, G.D., 1988, Against the grain, decentering family therapy, in: Journal of Marital and Family Therapy, 14 (3), 225-236.

Erickson, G.D., Rachilis, R. \& M. Tobin, 1974, Combined family and service network intervention, in: The Social Worker (Canadian), 41, 276-282.

Erikson, E.H., 1963, Childhood and Society, Norton, New York. 
Escher, A., Romme, M., Breuls, M. \& G. Driessen, 1987, Maatschappelijk kwetsbaar en langdurig psychiatrisch ziek, in: Tijdschrift voor Psychiatrie, 29 (5), 266281.

Esser, P.H.,1970, Sociale psychiatrie, Kok, Kampen.

F.

Feichtinger, L., Laireiter, A. \& U. Baumann, 1992, Zum Zusammenhang zwischen Persónlichkeit und Sozialem Netzwerk bzw. Netzwerkressourcen Literaturüberblick und Pilotstudie, in: Zeitschrift für Differentielle und Diagnostische Psychologie, 4, 233-247.

Fiedler, P., 1986, Neue Entwicklungen in der sozialtherapeutischen Arbeit mit Angehörigen und Familien schizophrener Menschen, in: Verhaltenstherapie und Psychosoziale Praxis, 2, 146-156.

Fraser, M. \& J.D. Hawkins, 1984, Social network analysis and drug misuse, in: Social Service Review, University of Chicago.

Froland, C., 1978, Improving the social adjustment of mental health clients: the case for social support networks, Dissertation, University of California, Berkeley.

Froland, C., Brodsky, G., Olson, M. \& L. Stewart, 1979, Social support and social adjustment: implications for mental health professionals, in: Community Mental Health Journal, 15 (2), 82-93.

G.

Garrison, J.E., 1974, Network techniques, case studies in screening linking planning conference method, in: Family Process, 13, 337-353.

Garrison, J.E., 1981, Clinical construction of action social networks, in: International Journal Family Therapy, (3), 258-267.

Garrison, J.E. \& S. Werfel, 1977, A network approach in clinical social work, in: Clinical Social Work Journal, 5 (2), 108-116.

Garssen, B., Schreurs, P.J.G., Oei, T.I. \& F.M. Zwart, 1985, Sociale steun en depressieve klachten, in: Tijdschrift voor Psychiatrie, 27 (8), 552-564.

Geelen, K.R.J., 1992, Psycho-educatie: bijscholing voor informele helpers, in: M.J. Steenbergen \& M.H.L. van Tits (red.), Informele zorg en zorgvernieuwing, Interacademiale Werkgroep Ziekenhuiswetenschappen, Utrecht/ Tilburg.

Gersons, B.P.R., 1981, Querido's bijdrage aan de psychiatrie, in: Maandblad Geestelijke Volksgezondheidheid, (9), 780-793.

Gersons, B.P.R., 1983, Het lot van de chronisch psychiatrische patiënt in de Verenigde Staten, in: Maandblad Geestelijke Volksgezondheid, (10), 1023-1036.

Geus, C. de, 1985, Het Registratienet Huisartsenpraktijken: structuur, mogelijkheden en grenzen, functie, Rapport R.N.H., nr. 1, RL, Maastricht.

Giel, R., 1984, Onze moeite met moeilijke mensen, in: Tijdschrift voor Psychiatrie, 26 (4), 244-261.

Goddijn, H.P.M., Thoenes, P., Valk, J.J.M., de \& J.P. Verhoogl, 1972, Geschiedenis van de sociologie, Boom, Meppel.

Goffman, E., 1961, Asylums; essays on the social situation of mental patients and other inmates, Penquin Books, New York.

Goffman, E., 1973, Stigma: gedachten over leven met een geschonden identiteit, Van Loghum Slaterus, Deventer.

Goldstein, M.J., 1981. Family therapy during the aftercare treatment of acute schizophrenia, in: M.R. Lansky (ed.), Family therapy and major psychopathology, Grune \& Stratton, New York.

Gore, S., 1978. The effect of social support in moderating the health consequences of unemployment, in: Journal of Health and Social Behavior, 19, 157-164.

Gottlieb, B.H., 1978. The development and application of a classification scheme of informal helping behavior, in: Canadian Journal of Behavioral Science, 10, 105115.

Gottlieb, B.H., 1981, Preventive interventions involving social networks and social support, in: B.H. Gottlieb (ed.), Social nelworks and social support, Sage Publications, Beverly Hills. 
Gottlieb, B.H., 1985, Social networks and social support: an overview of research, practice and policy implications, in: Health Education Quarterly, 12 (1), 5-22.

Gottlieb, B.H. \& A.E. Coppard, 1987, Using social network therapy to create support systems for the chronically mentally disabled, in: Canadian Journal of Community Mental Health, 6 (2), 117-131.

Gruenberg, E.M.1974, The Social Breakdown Syndrome and its prevention, in: G. Caplan (ed.) American Handbook of Psychiatry, II, Basic Books, New York.

Gruenberg, E.M. \& B. Pepper, 1982, Definition of mental illness, patient, disability and chronic, paper WPA Conference on the chronically mentally ill, an international perspective, Hopkins University, Baltimore.

H.

Haley, J., 1959, The family of the schizophrenic; a model system, in: Journal of Nervous and Mental Disease, 129, 357-374.

Haley, J. (ed.), 1971, Changing families: a family therapy reader, Grune \& Stratton, New York.

Hall, A. \& B. Wellman, 1985, Social networks and social support, in: S. Cohen \& S.L. Syme (eds), Social support and health, Academic Press, New York.

Hamers, H.J.F.R. \& M.A.J. Romme, 1990, Informatie en management in de GGZ, de bijdrage van een casusregister, Van Gorcum, Assen/ Maastricht.

Hamilion, N.G., Ponzoka, C.A., Cutler, D.L. \& R.M. Weigel, 1989, Social networks and negative versus positive symptoms of schizophrenia, in: Schizophrenia Bulletin, 15 (4), 625-633.

Hammer, M., 1961, An analysis of social networks as factors influencing the hospitalization of mental patients, Dissertation, Columbia University.

Hammer, M., 1963-1964, Influence of small social networks as factors on mental hospital admission, in: Human Organization, 22, 243-251.

Hammer, M., 1978, Social networks and schizophrenia, in: Schizophrenia Bulletin, 4 (4), 522-545.

Hammer, M., 1981, Social supports, social networks and schizophrenia, in: Schizophrenia Bulletin, 7 (1), 45-57.

Hansell, N., 1970, Decision counselling method: expanding coping at crisis-intransit, in: Archives of General Psychiatry, 22, 462-467.

Harris, C.C., 1969, The family, Allen \& Unwin, London.

Harris, M. \& H.C. Bergman, 1985, Networking with young adult chronic patients, in: Psychosocial Rehabilitation Journal, 8 (3), 28-35.

Harris, M., Bergman, H.C. \& L.L. Bachrach, 1987, Individualized network planning for chronic psychiatric patients, in: Psychiatric Quarterly, 58 (1), 51-56.

Havely, J., Hemley- Van der Velden, E., Ruhf, L. \& P. Schoenfeld, 1984, Process and strategy in network therapy, in: Family Process, 23, 521-533.

Haveman, M.J. \& M.A. Maaskant, 1990, Psychiatrische gezinsverpleging in Nederland, vakgroep Epidemiologie, Gezondheidszorgonderzoek, RL Maastricht.

Heerma van Voss, A.J., 1980, Vijtig jaar sociale psychiatrie in Nederland, Bijvoegsel Vrij Nederland, nr. 49.

Heerma van Voss, A.J., 1991, Querido, een levensverhaal, in: Maandblad Geestelijke Volksgezondheid, 7-8, 722-811.

Heijendael, P., 1991, Recensie 'Sociale nelwerkstrategieën in de sociale psychiatrie', in: Tijdschrift voor Psychiatrie, 33 (B2).

Henderson, S., 1980, Measuring social relationships: the Interview Schedule for Social Interaction, in: Psychological Medecine, 10, 723-734.

Henderson, S., Duncan-Jones, P., McAuley, H. \& K. Ritchie, 1978, The patients primary group, in: British Journal of Psychiatry, 132, 74-86.

Henderson, S., Duncan-Jones, P., Byrne, D.G. \& R. Scolt, 1980, Measuring social relationships, the Interview Schedule for Social Interaction, in: Psychological Medicine, 10, 723-734.

Hendrickx, J.J.P., 1991, Handboek gezinstherapie, Bohn Stafleu Van Loghum, Houten/Antwerpen. 
Hennecke-Schwab, V., Müller, A. \& V. Vogelsanger, 1985, Selbstthilfe als Leitidee zur Psychiatriereform, in: Gemeindenahe Psychiatrie: Beitrăge zur PsychiatrieReform in Basel, Psychosozialen Arbeitsgemeinschaft, Basel.

Hilberink, T., 1978, Beleidsplan Structurerende Begeleiding en Sociale Strategieèn, Stichting GGZ, Maastricht.

Hill, R. \& B.A. Hansen, 1960, The identification of conceptual frameworks utilized in family study, in: Marriage and Family Living, 22, 299-311.

Hirsch, B.J., 1980, Natural support systems and coping with major life changes, in: American Journal of Community Psychology, 8, 159-172.

Hirschberg, W., Soziale Netzwerke bei schizophrenen Störungen, ein Ubersicht, in: Psychiatrische Praxis, 15, 84-89, 1988.

Honig. A., 1988, Somatic dysfunctioning of the chronic community psychiatric patient: a model for understanding and trealment, in: M.A.J. Romme \& A.D.M.A.C. Escher (eds), Research to practice in community psychiatry, Van Gorcum, Assen/Maastricht.

Honig. A., 1989, mind the body, Dissertation RL, Maastricht.

Honig, A., Radstake, D.W.S., Romme, M.A.J. \& M.G.G.J. Breuls, 1987, Problem analysis: an instrument in the rehabilitation of chronic patients in the community, International Journal of Social Psychiatry.

Hoogduin, C.A.L. \& E. de Haan, 1979, Ambulante behandeling van ernstige psychiatrische patiënten, een manier van werken bij een sociaal psychialrische dienst, in: Maandblad Geestelijke Volksgezondheid, (11), 752-760.

Horn, L., 1986, Een vergeten groep: familieleden van psychiatrische patiènten, in: Maandblad Geestelijke Volksgezondheid, 9, 878-888.

Horn, G.H.M.M. ten \& R. Giel, 1978, De psychiatrische lotgevallen van een opnamecohort uit 1974, in: Tijdschrift voor Psychiatrie, 591-600.

House, J.S. \& R.L. Kahn, 1985, Measures and concepts of social support, in: S. Cohen \& S.L. Syme (eds) Social support and health, Academic Press, Orlando.

House, J.S., Landis, K.R. \& D. Umberson, 1988, Social relationships and health, in: Science, 24, 540-545.

Hulsman, P., 1989, Het sociaal netwerk van chronisch psychiatrische patienten, Doctoraalscriptie, KU Nijmegen.

I.

Intagliata, J., 1982, Improving the quality of community care for chronically mentally disabled: the role of case management, in: Schizophrenia Bulletin, 8 (4), 655-674.

Isele, R. \& J. Angst, 1982, Life-events und prämorbide soziale Beziehungen bei ersterkrankten Schizophrenen, in: G. Huber (ed.), Endogene Psychosen, Diagnostik, Basissymptomen und biologische Parameter, Schattaver, Stultgart.

Israel, B.A., 1982, Social networks and health status: linking theory, research and practice, in: Patient Counseling and Health Education, 4, 65-79.

J.

Jaarverslag 'Sociale Netwerk Project' 1990, Sociale Netwerk Studies, Vakgroep Sociale Psychiatrie RL/RIAGG Maastricht.

Jaarverslag 'Sociale Netwerk Project' 1991, Sociale Netwerk Studies, Vakgroep Sociale Psychiatrie RL/AIAGG Maastricht.

Jackson, D.D. (ed.), 1977, Communication, family and marriage, Science and Behaviour Books, Palo Alto, 1968 (nederlandse uitgave: Communcatie, gezin en huwelijk; over dubbele binding, schizophrenie en gezinsrelaties, Bakker, Amsterdam).

Jacobson, D.,1988, The cultural context of social support and suppont networks, in: Medical Anthropology Quarterly, 42-67.

Janssen, M., 1992, Personal networks of chronic patients, Proefschrift RL Maastricht.

Jay, E.J., 1964, The concepls of field and network in anthropological research, in: Man, 64, 127-139. 
Jimenez, M.A., 1988, Chronicity in mental disorders: evolution of a concept, in: Social Casework: the Journal of Contemporary Social Work, 627-633.

Jong, P. de, 1991, Psychiatrische invaliditeit, in: P. van Lieshout \& J.W. van Zuthem (red.). Wonen als werk, zorgverlenen in beschermende woonvormen, Bohn Slafleu Van Loghum, Houten, Antwerpen.

K.

Kamphuis, M., 1970, Wat is social casework? Samsom, Alphen aan den Rijn.

Kapferer, B., 1969, Norms and the manipulation of relationships in a work context, in: J.C. Mitchell (ed.), Social networks in urban situations, Manchester University Press, Manchester.

Kapferer, B., 1973, Social network and conjugal role in urban Zambia; towards a reformulation of the Bott hypothesis, in: J. Boissevain \& J.D. Mitchell (eds), Network analysis: studies in human interaction, Mouton, The Hague.

Kaplan, B.H., Cassel, J.C. \& J. Gove, 1977, Social support and health, in: Medical Care, 15 (5), supplement: 47-50.

Katschnig, H. \& T. Konieczna, 1984, Psychosoziales Netzwerk und Rehabilitation psychisch Kranker, in: H. van Andel \& W. Pittrich (Hrsg.), Neue Konzepte der Behandlung und Rehabilitation chronisch psychisch kranker Menschen, Westf. Klinik für Psychiatrie Lippstadt, Münster.

Katschnig, H. \& P.P. Sint, 1984, Zwischen Selbsthilfe und Expertenhilfe, die Angehörigenvereinigung "Hilfe für psychisch Erkrankte" in Wien, in: Angermeyer, M.C. \& A. Finzen (Hrsg.), Die Angehörigengruppe, Familien mit psychisch Kranken auf dem Weg zur Selbsthilfe, Enke, Stuttgart.

Killworth, P. \& H.R. Bernard, 1974, Catij, a new sociometric and its application to a prison living unit, in: Human Organization, 33, 335-350.

Kliman, J. \& D. Trimble, 1983, Network theory, in: B. Wolman \& G. Stricker (eds), The handbook of family and marriage, Plenum, New York.

Knipscheer, C.P.M. \& T.C. Antonucci (red.), 1990, Social network research: substantive issues and methodological questions, Swetz \& Zeitlinger, Amsterdam.

Knottnerus, J.A., Hoppener, P. \& J. Metsemakers, 1992, Het Registratie-net Huisartsenpraktijken, in: Gezondheidsproblemen en diagnosen in de huisartspraktijk, RL., Maastricht, 4 (1) 6-15.

Konopka, G., 1963, Social group work, Prentice Hall, New York, (Nederlandse uitgave: Groepswerk, Van Loghum Slaterus, Deventer, 1971).

Kreisman, D. \& V. Joy, 1974, Family responses to the mental illness of a relative, a review of the literature, in: Schizophrenia Bulletin, 10, 34-57.

Kushner, H.S., 1985, Als 't kwaad goede mensen treft, Ten Have, Baarn.

Kuypers, J.G.J., 1993, Sociale netwerken van demente hoogbejaarden. Onderzoeksverslag, Cahier Sociale Netwerkstudies no; 5, Academische Unit SPGD van de RIAGG Maastricht, Vakgroep Sociale Psychiatrie RL, Maastricht.

L.

Laireiter, A., 1989, Soziales Netzwerk und soziale Unterstützung bei Patienten mit psychischen Störungen, in: Dialog, Information Ehe und Familie, 5, 4-9.

Laireiter, A. \& U. Baumann, 1989, Theoretische und methodologische Kriterien der Operationalisierung der Konstrukte "Soziales Netzwerk" und "Soziale Unterstützung", in: D. Rüdiger, W. Nöldner, D. Haug \& E. Kopp (Hrsg), Gesundheidspsychologie - Konzepte und empirische Beiträge, Roderer, Regensburg.

Laireiter, A. \& U. Baumann, 1992, Nefwork structures and support functions, theoretical and empirical analysis, in: H.O.F. Veiel \& U. Baumann (eds.). The meaning and measurement of social support, Hemisphere Publishing Corp., Washington.

Laskin, E., 1968, Breaking down the walls, in: Family Process, 7, 118-125.

Leff, J.P. \& C.E. Vaughn, 1981, Patterns of emotional response in relatives of schizophrenic patients, in: Schizophrenia Bulletin, 7, 43-44.

Lieshout, P. van \& J.W. van Zuthem (red.), 1991, Wonen als werk, over zorgverlenen in beschermende woonvormen, Bohn Stafleu Van Loghum, Houten/Antwerpen. 
Lipton, F.R., Cohen, C.I., Fischer, E. \& S.E. Katz, 1981, Schizophrenia: a network crisis, in: Schizophrenia Bulletin, 7 (1), 144-151.

London, J. van, 1982, Geestelijke gezondheidszorg en overheid, in: F. Schrameijer (red.), Modern ingericht, NCGV-Reeks 52, Utrecht.

M.

Marrelo, A. van, 1979, Beleidsplan S.P.D. Maastricht en omgeving, Stichting GGZ, Maastricht.

McKinlay, J.B., 1973, Social networks, lay consultation and help-seeking behavior, in: Social Forces, 52, 275-292.

Methorst, G., 1985, Mannen en vrouwen van psychiatrische patiénten, Landbouwuniversiteit, Wageningen.

Meuller, D.P., 1980, Social networks, a promising direction for research on the relation of the social environment to psychiatric disorder, in: Social Sciences and Medicine, 14A, 147-161.

Meyer, A., 1906, Fundamental conceplions of dementia praecox, in: British Medical Journal, 757-760.

Mierlo, F. van, 1992, Sociale steun, Landelijk Centrum GVO/LOP-GGZ, Utrecht.

Ministerie van W.V.C., 1984, De Tweede Nota Geestelijke Volksgezondheid, Staatsuitgeverij, Den Haag.

Minuchin, S., 1974, Families and family therapy, Tavistoc, London.

Mitchell, J.C. (ed.), 1969, Social networks in urban situations, Manchester, Manchester University Press.

Mitchell, J.C., 1969, The concept and use of social networks, in: J.C. Mitchell (ed.), Social networks in urban situations, Manchester, Manchester University Press.

Mitchell, J.C., 1973, Networks, norms and institutions, in: J. Boissevain \& J.C. Mitchell (eds.), Network analysis: studies in human interaction, Mouton, Den Haag.

Mitchell, R.E., 1982, Social networks of psychiatric clients; the personal and environmental context, in: American Journal of Community Psychology, 10, 387 402.

Mitchell, R.E. \& E.J. Tricket, 1980, Social networks as mediators of social support; an analysis of the effects and determinants of social networks, in: Community Mental Health Journal, 16, 27-44.

Moreno, J.L., 1953, Who shall survive, Beacon House, New York.

Morin, R.C. \& E. Seidman, 1986, A social network approach and the revolving door patient, in: Schizophrenia Bulletin, 12 (2), 262-273.

N.

Nalone, J., 1988, The social support - social dissupport continuum, in: Journal of Psychosocial Nursing and Mental Health Services, 26 (12), 18-22.

Naparstek, A.J. \& D.E. Biegel, 1982, Community support systems, an alternative approach to mental health service delivery, in: U. Rueveni, R.V. Speck \& J.L. Speck (eds). Therapeutic intervention, healing strategies for human systems, Human Sciences Press, New York.

Nijhof, G., 1978, Individualisering en uitstoting; van maatschappelijke problemen naar psychische stoornis, Link, Nijmegen.

Noble, M., 1973, Social network: its use as a conceptual framework in family analysis, in: J. Boissevain and J.C. Mitchell (eds), Network analysis: studies in human interaction, Mouton, The Hague.

Norbeck, J.S., 1981, Social support, a model for clinical research and application, in: Advances in Nursing Science, 3 (4), 43-59.

P.

Paolino, T.J. \& B.S. McCrady (eds), 1978, Marriage and marital therapy, psychoanalytic, behavioural and systems theory perspectives, Brunner/Mazel, New York. 
Pas, A. van der (ed.), 1973, Gezinsfenomenen, artikelen over theorie van praktijk van de gezinsbehandeling, Samsom, Alphen aan de Rijn.

Pattison, E.M., 1977, A theoretical-empirical base for social system therapy, in: E.F. Foulks, R.M. Wintrob, J. Westermeyer \& A. R. Favazzo (eds), Current perspectives in cultural psychiatry, Spectrum, New York.

Pattison, E.M. \& M.L. Pattison, 1981, Analysis of a schizophrenic psychosocial network, in: Schizophrenia Bulletin, 7, 135-143.

Pattison, E.M., Defrancisco, D., Frazier, H., Wood, P. \& J. Crowder, 1975, A psychosocial kinship model for family therapy, in: American Journal of Psychiatry, 132 (12), 1246-1251.

Pfingstmann, G. \& U. Baumann, 1987, Untersuchungsverfahren zum sozialen Netzwerk und zur sozialen Unterstützung, ein Überblick, in: Zeitschrift für Differentielle und Diagnostische Psychologie, 8 (2), 75-98.

Philipsen, H., 1976, Maatschappij en verslaving, Cahier Biowetenschappen en Maatschappij, 3 (3), 25-31.

Poel, E. van der, Romme, M.A.J., Trimbos, K. \& H. van der Wilk, 1985, Het psychiatrisch ziekenhuis in discussie, Initiatiefgroep Moratorium Bouw Psychiatrische Ziekenhuizen, Amsterdam.

Plog, U., 1986, Wie weit sind Angehörige und Patienten zu trennen? in: Verhaltenstherapie und Psychosoziale Praxis, 2, 163-166.

Polister, P.E. \& E.M. Pattison, 1980, Community groups: an empirical taxanomy for evaluation and intervention, in: R.H. Price \& P.E. Polister (eds), Evaluation and action in social environment, Academic Press, New York.

Pomerantz, H., 1988, Introduction to 'Research to practice in community psychiatry', (red.: Romme, M.A.J. \& A.D.M.A.C. Escher), Van Gorcum, Assen/Maastricht.

Q.

Querido, A., 1946, Groepsbehandeling en groepsselectie, in: Tijdschrift Sociale Geneeskunde, 24 (9), 160-162.

Querido, A., 1952, Geneeskunst in transcendentie, Kroese, Leiden.

Querido, A., 1955, Inleiding tot een integrale geneeskunde, Kroese, Leiden.

Querido, A., 1980, Doorgaand verkeer, autobiografische fragmenten, Tijdstroom, Lochem.

R.

Radstake, D.W.S., 1985, Probleemanalyse als onderdeel van de omgang met chronische patiênten in de ambulante geestelijke gezondheidszorg, in: M.A.J. Romme (red.) De chronische psychiatrische patiënt, Onderzoeksverslag, Vakgroep Sociale Psychiatrie, RL, Maastricht.

Richartz, M.M.W., 1979, Ontwikkelingsplan Team Structurerende Begeleiding en Sociale Strategieën, Noła Stichting GGZ, Maastricht.

Richartz, M.M.W., 1981, Segregatie of integratie, in: Tijdschrift voor Psychiatrie, 23. 347-358.

Richariz, M.M.W. \& J. Crolla (red.), 1980, Evaluatierapport Team Langdurig Structurerende Begeleiding, Interne publicatie, Stichting GGZ, Maastricht.

Richter, H.E., 1970, Patient Familie, Rowohlt, Hamburg.

Romme, M.A.J., 1973, Het aantal patiěnten bij de Sociale Psychiatrische Diensten; een enquête van de Nederlandse Vereniging van SPD's, in: Maandblad Geestelijke Volksgezondheid, (3), 125-131.

Romme, M.A.J. (red.), 1985 , De chronisch psychiatrische patient, Onderzoeksverslag, Vakgroep Sociale psychiatrie, RL, Maastricht.

Romme, M.A.J. \& M.G.G.J. Breuls, 1985, Organisatie van de sociale psychiatrie in de RIAGG in Maastricht, in: M.A.J. Romme (red.), De chronisch psychiatrische patiënt, Onderzoeksverslag, Vakgroep Sociale Psychiatrie, RL, Maastricht.

Romme, M.A.J., Escher A.D.M.A.C. (eds), 1988, Research to practice in community psychialry, Van Gorcum, Assen/ Maastricht.

Romme, M.A.J., Kraan, H. \& R. Rotteveel, 1981, Wat is sociale psychiatrie, Stafleu, Alphen aan den Rijn. 
Romme, M.A.J., Escher A.D.M.A.C., Radstake, D.W.S. \& M.G.G.J. Breuls, 1987, Een indeling van groepen patiënten met een langdurige psychiatrische patiëntencarrière, in: Tijdschrift voor Psychiatrie, 29 (4), 197-211.

Roosenburg, A.M., 1973a, Behandlung gestorter Kriminellen, in: Kriminalitat in moderner psychologischer und medizinischer Sicht, Verslag Deutscher Aertzinnenbund, Magdstadt.

Roosenburg, A.M., 1973b, Interaction between prisoners, victims and their social networks, in: Medical care of prisoners and detainees, CIBA Foundation Symposium, 16 (now series) Elsevier, Amsterdam.

Ross, M., 1963, Holland's Social Psychiatry Service, in: Mental Hospitals, 14 (7), 375-376.

Rotteveel, R.J., 1987, Het Social Breakdown Syndrome bezien vanuit verschillende ambulante settingen, in: R. Rotteveel e.a. (red.), Resocialisatieproject Westelijke Mijnstreek, Eindverslag RIGG Westelijke Mijnstreek, Vakgroep Sociale Psychiatrie, RL, Maastricht.

Rotteveel, R.J., Uffing, J.T.F. \& E.A.A.M. de Vries, (red.),1987, Resocialisatieproject Westelijke Mijnstreek, Eindverslag, RIGG Westelijke Mijnstreek, Vakgroep Sociale Psychiatrie, RL, Maastricht.

Rueveni, U., 1975, Network intervention with a family crisis, in: Family Process, $14,193-204$.

Rueveni, U., 1976, Family networks intervention: healing families in crisis, in: Intellect, 104, 580-582.

Rueveni, U., 1977, Family network intervention, mobilizing support for families in crisis, in: International Journal Family Counseling, 5, 77-83.

Rueveni, U., 1979a, Networking families in crisis, intervention strategies with families and networks, Human Sciences Press, New York.

Rueveni, U, 1979b, The family therapist as a system interventionist, in: International Journal Family Therapy, (1), 63-75.

Rueveni, U., 1982, Healing interventions with families in crisis, in: U. Rueveni, R.V. Speck \& J.L. Speck (eds), Therapeutic intervention, healing strategies for human systems, Human Sciences Press, New York.

Rueveni, U. \& R.V. Speck, 1969, Using encountergroup techniques in the treatment of the social network of the schizophrenic, in: International Journal of Group Psychotherapy, 19, 495-500.

Rueveni, U. \& M. Wiener, 1976, Network intervention of disturbed families; the key role of network activists, in: Psychotherapy, Theory, Research and Practice 13 (2), 173-176.

Ruiter, B de \& L. Henkelman, 1989, Een onderzoek naar chronisch psychiatrische patiënten en hun omgeving, in: Tijdschrift voor Psychiatrie, 31 (1), 29-37.

S.

Sadoun, R., 1989, Social determinants of disorder: the effect of cultural factors on social networks, Paper INSERM Centre Paul Broca, Paris.

Salzinger, S., Kaplan, S. and C. Artemyeff, 1983, Mother's personal social networks and child maltreatment, in: Journal of Abnormal Psychology, 92 (1) 68-76.

Saroyan, W., 1952, The bicycle rider in Beverly Hills, New York.

Satir, V., 1964, Conjoint family therapy, Science and Behavior Books, Palo Alto, (Nederlandse uitgave: Gezinstherapie, Van Loghum Slaterus, Deventer).

Satir, V., 1972, Peoplemaking, Science and Behaviour Books, Palo Alto, (Nederlandse uitgave: Mensen maken mensen, Van Loghum Slaterus, Deventer, 1975).

Scheff, Th. J., 1969, De psychisch gestoorde en zijn milieu, Spectrum, Utrecht.

Schoenfeld, P., 1984, Networktherapy: clinical theory and practice with disturbed adolescents, in: Psychotherapy, 21, 92-100.

Schoenfeld, P., Halevy- Martini, J., Hemley- Van der Velden, E. \& L. Ruhf, 1986, Longterm outcome of network therapy, in: Hospital and Community Psychiatry, 37 (4), 373-376. 
Scholte, J.A.W.M. \& J.T.F. Uffing, 1982, Langdurig verblijf in het Algemeen Psychiatrisch Ziekenhuis, Rapport aan de Ziekenfondsraad. Vakgroep Sociale Psychiatrie, RL, Maastricht.

Schrameijer, F., (red.), 1982, Modern ingericht, NCGV-Reeks 52, Utrecht.

Schrameijer, F., 1990, Sociale steun, analyse van een paradigma, NCGV-Reeks 90 20, Utrecht.

Scott, J., 1988, Trend report social network analysis, in: Sociology, 22 (1), $109-$ 127.

Shepherd, G., 1989, Rehabilitatie van de chronisch psychiatrische patiënt, Bohn Scheliema Holkema, Utrecht.

Snijders, A.B., 1993, Gissen en mikken, Inaugurale rede. Universiteitsdrukkerij, RUG, Groningen.

Sokolove, R.L. \& D. Trimble, 1986, Assessing support and stress in the social networks of chronic patients, in: Hospital and Community Psychiatry, 37 (4), 370-372.

Sokolovsky, J. \& C.I. Cohen, 1978, The cultural meaning of personal networks for the inner city elderly, in: Urban Anthropology, 7 (4), 323-342.

Sokolovsky, J., Cohen, C.I., Berger, D. \& J. Geiger, 1978, Personal networks of exmental patients in a Manhattan SRO-hotel, in Human Organization, 37, 5-15.

Speck, R.V., 1964, Family therapy in the home, in: Journal of Marriage and Family Living, 26, 72-76.

Speck, R.V., 1967a, Psychotherapy of the social network of a schizophrenic family, in: Family Process 6, 208-214.

Speck, R.V., 1967b, Psychotherapy of family social networks, paper presented at the Family Therapy Symposium, Medical College of Virginia, Richmond.

Speck, R.V. \& C.L. Attneave, 1971, Social network intervention, in: J. Haley (ed.), Changing Families, a family therapy reader, Grune \& Stratton, New York.

Speck, R.V. \& C.L. Attneave,1972, Social network intervention, in: C.J. Slager \& H.S. Kaplan (eds), Progress in group and family therapy, Brunner/Mazel, New York.

Speck, R.V. \& C.L. Attneave, 1973, Family Networks, a new approach to family problems, Vintage Books, New York, 1973.

Speck, R.V. \& C.L. Attneave, 1983, Die Familie im Netz soziales Beziehungen, Lambertus, Freiburg.

Speck, R.V. \& E. Morong, 1967, Home-centered treatment of the social network of schizophrenic families: two approaches, paper presented at the annual meeting of the American Psychiatric Association.

Speck, R.V. \& J. Olans, 1967, The social network of the family of a schizophrenic; implications for social and preventive psychiatry, Paper presented at the annual meeting of the American Orthopsychiatry Association.

Speck, R.V. \& U. Rueveni, 1969, Network therapy: a developing concept, in: Family Process, 8, 182-191.

Speck, R.V. \& U. Rueveni, 1977, Treating the family in time of crisis, in: J.M. Masserman (ed.), Current psychiatric therapies, Grune \& Stratton, New York.

Stein, L.I., Test, M.A. \& A.J. Marks, 1975, Alternative to the hospital: a controle study, in: American Journal Psychiatry, 132 (5), 517-521.

Steinglass, P., 1978, The conceptualisation of marriage from a system theory perspective, in: T.J. Paolino \& B.S. McCrady (eds.), Marriage and marital therapy, Brunner/Mazel, New York.

Sullivan, H.S., 1931, Socio-psychiatric research, its implication for the schizophrenia problem and for mental health, in: American Journal of Psychiatry, 10, 977-991.

Sullivan, H.S., 1946, Conceptions of modern psychiatry, the first William Alanson White memorial lectures, New York, (Nederlandse uitgave: Begrippen voor een toekomstige psychiatrie, Ambo, Baarn, 1975).

Sussman, M. \& L. Barchinal, 1962, Kin family network, in: Marriage and family living, 24, 320-332. 
T.

Tessler, R. \& J.H. Mason, 1979, Continuity of care in the delivery of mental health services, in: American Journal Psychiatry, 136 ( ), 1297-1301.

Test, M.A. \& L.I. Stein, 1978, Community treatment of the chronic patient, research overview, in: Schizophrenia Bullelin, 4 (3), 350-363.

Thaxton, L. \& L. L'Abate, 1982, The second wave and the second generation, characteristics of new leaders in family therapy, in: Family Process, 21, 359. 362.

Tolsdorf, C.C., 1975, Social networks and the coping process, University of Massachussets.

Tolsdorf, C.C., 1976, Social networks, support and coping, an exploratory study, in: Family Process, 15, (4), 407-418.

Trimble, D., 1980, A guide to network therapies, in: Connections, 3 (2), 9-21.

Trimble, D. \& J. Kliman, 1981, Community nelwork therapy, strengthening the network of chronic patients, in: International Journal of Family Psychiatry, 2, $116-118$

Trimbos, C.J.B.J., 1982, Waarheen met de psychiatrische inrichtingen, over de-, reen neoinstitutionalisatie, in: F. Schrameijer (red.), Modern ingericht. NCGVReeks 52, Utrecht.

Trimbos, C.J.B.J., 1985, Sociale psychiatrie en universiteit, in: Maandblad Geestelijke Volksgezondheid, (9), 893-905.

Turner, V.W., 1983, Direct, indirect and moderating effects of social support upon psychological stress and associated conditions, in: H.B. Kaplan (ed.). Psychological stress: trends in theory and research, Academic Press, New York.

$U$.

Uffing, J.T.F., Vries, E.A.A.M. de, Rotteveel, R.J. \& A.D.M.A.C. Escher, 1987, Krijgen chronisch psychiatrische patiënten de behandeling die ze nodig hebben, in: Tijdschrift Sociale Gezondheidszorg, 65 (13), 436-440.

Uffing, J.T.F., Baars, H.M.J. \& L.J.J.M. Dreessen, 1992, Interventies in en met het sociale nelwerk, in: Handboek Maatschappelijk Werk, Bohn Stafleu Van Loghum, Houten/Antwerpen.

Uffing, J.T.F., Ceha, M. \& G. Saenger, 1992, The development of deinstitutionalization in Europe, in: Psychiatric Quarterly, 63 (3) 265-279.

V.

Vaughn, C.E. \& J.P. Leff, 1976, The infuence of family and social factors on the course of psychiatric illness, in: Britisch Journal of Social and Clinical Psychology, 129, 125-137.

Vaughn, C.E., Jones, S., Freedman, W.E. \& I.R.H. Falloon, 1984, Family factors in schizphrenia relapse? A Californian replication of expressed emotion, in: Archives of General Psychiatry, 41, 1169-1177.

Vaux, A. \& M. Athanasopolou, 1987, Social support appraisals and network resources, in: Journal of Community Psychology, 15, 537-556.

Veen, C.J.F. \& J.C. van der Meulen, 1970, Gezinsbehandeling, een oriēntatie, Samsom, Alphen aan den Rijn.

Verhagen, H.J.A., 1984, De Sociaal Psychiatrische Dienst, in: M.A.J. Romme (red.), Voorzieningen in de geestelijke gezondheidszorg, een gids voor consument en hulpverlener, Samsom, Alphen aan de Rijn.

W.

Walker, K.N., MacBride, A. \& M.L.S. Vachon, 1977, Social support networks and the crisis of bereavement, in: Social Sciences and Medicine, 11, 35-41.

Watzlawick, P., Beavin, J.H. \& D.D. Jackson, 1967, Pragmalics of human communication, Norton \& Co., New York, (Nederlandse uilgave: De pragmatische aspekten van de menselijke communicatie, Van Loghum Slaterus, Deventer, $1970)$. 
Weiss, R.S., 1974, The provisions of social relationships, in: Z. Rubin (ed.) Doing unto others, Prentice Hall, Englewood Cliffs.

Wellman, B., 1981, Network analysis, from method and melaphor to theory and substance, Working Paper Series 18, Structural Analysis Program, University of Toronto.

Wellman, B., 1988, Thinking structurally, in: (B. Wellman \& S.D. Berkowitz (eds), Social structures, a network approach , Cambridge University Press, Cambridge.

Wellman, B., 1988, Structural analysis, from metaphor to substance, in: B. Wellman \& S.D. Berkowitz (eds), Social structures, a network approach, Cambridge University Press, Cambridge.

Wellman, B., Berkowitz, S.D., 1988, Social structures, a network approach, Cambridge University Press, Cambridge.

Wellman, B., Carrington, P.J. \& A. Hall, 1988, Networks as personal communities, loward a network conception of community, in: B. Wellman \& S.D. Berkowitz (eds), Social structures: a network approach, Cambridge University Press, Cambridge.

Wellman, B. \& B. Leighton, 1979, Networks, neighbourhoods and communities, in: Urban Affairs Quarterly, 14, 363-390.

Wellman, B., Craven, P., Whitaker, M., Stevens, H., Shorter, A., Du Toit, S. \& H. Bakker, 1973, Community ties and support systems, in: L.S. Bourne, R.D. Mackinnon \& J.W. Simmons (eds), The form of cities in Central Canada, University of Toronto Press, Toronto.

Weyer, J.L.R.A. de, 1989, Beeldvorming over schizofrenie in een ambulante setting, Instituut voor Preventieve en Sociale Psychiatrie, EU, Rotterdam.

Wiersma, D., Giel, R., Hoek, H.W., de Jong, A., Nienhuis, F., Rüphan, M. \& A.J. Tholen, 1988, Chronische patiënten in de geestelijke gezondheidszorg, een epidemiologische verkenning van hun behoefte aan zorg, in: Tijdschrift voor Psychiatrie, 30 (6), 388-400, 1988.

Z.

Zuithoff, D., 1963, Een terreinverkenning ten behoeve van de sociale psychiatrie, Van Loghum Slaterus, Arnhem. 


\section{MAASTRICHTSE SOCIALE NETWERK ANALYSE BESCHRINING EN OPERATIONALISATE}

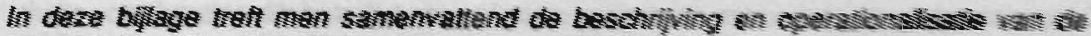

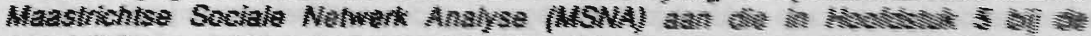

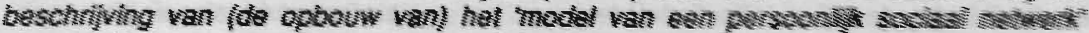

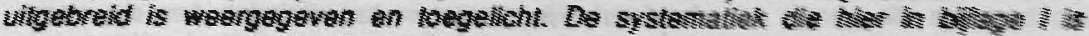

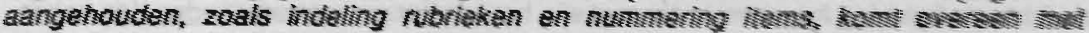

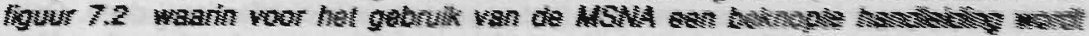
gageven.

\section{A ONVANG}

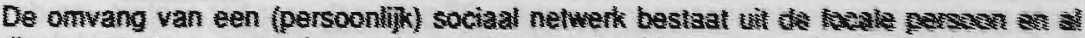

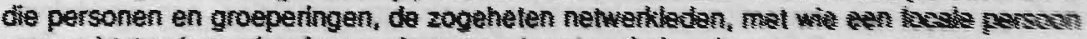
een rechistreekse min of moer duurzame band enderhoudt.

\subsection{Focale Persoon (FP)}

Een individuele persoon of sociale eenheid, bjworbesid een echpesf dis alt onderwerp van sociale netwerk analyse wordt gekozen. Vermelding van naam of anderzinds afgesproken aanduiding.

\subsection{Volgnummer}

In de (psychiatrische) hulpverlening corresponderend met het dossiernummer.

\subsection{Datum interview MSNA}

\subsection{Interviewer}

1.5 Gevarieerdheid (zie tevens ad B.3).

De beschrijving van de sociaal demografische kenmerken van de focale persoon te weten

1.5.1 geslacht

1.5.2 leeftijd

1.5.3 burgelijke staat

1.5.4 opleidingsniveau

1.5.5 laatst uitgeoefend beroep*

1.5.6 actuele situatie

1.5.7 woonsituatie

\footnotetext{
* Het aspect laatst uitgeoefend beroep wordt op patientniveau gebruikt.
} 
Tot de netwerkleden van de focale persoon worden die personen gerekend

- mel wie de focale persoon een min of meer duurzame band onderhoudt,

- mel wie de focale persoon rechtstreeks contact heeft,

- met wie de focale persoon in het afgelopen jaar (in dit onderzoek het jaar voorafgaande aan de aanmelding) contact had,

- bij wie de focale persoon minstens de naam of het beroep weet,

- met wie de focale persoon geen contact meer heeft (maar wel eerder gehad heeft) en die duurzaam in de beleving, positief of negatief gekleurd, van de focale persoon aanwezig zijn.

De genoemde criteria houden in dat de omvang van het sociale netwerk zowel uit personen bestaat met wie actueel (dat wil zeggen: gedurende het laatste jaar) contact wordt onderhouden (het 'effectieve' deel van het sociale netwerk) alsook personen kan bevatten die vanuit een daadwerkelijk contact in het verleden een duurzame plaats in de beleving innemen, maar met wie het contact om wat voor reden dan ook in het afgelopen jaar niet meer aanwezig is (het zogenaamde 'niet-effectieve' deel). Ook bij deze netwerkleden blijt gelden dat zij wel bij naam of beroep gekend worden. Het effectieve en het niet-effectieve deel tesamen vormen de omvang van het zogeheten 'beschikbare' sociale netwerk. Netwerkleden die overleden zijn worden niet binnen de omvang van het netwerk opgenomen.

De omvang van een sociaal netwerk bestaat uit reëel bestaande en door de focale persoon concreet te benoemen personen. Dit geldt ook voor het contact van de focale persoon met groeperingen en instanties, zoals een vereniging, een werkkring, de gezondheidszorg. De focale persoon concretiseert deze contacten in personen. Ter illustratie: het contact met de gezondheidszorg krijgt bijvoorbeeld gestalte in de persoon van de huisarts, het contact met de psychiatrische hulpverlening in de persoon van betreffende hulpverlener(s). leder door de focale persoon genoemd netwerklid wordt ondergebracht in éen van de drie sectoren van het sociale netwerk en vervolgens in één van de clusters binnen de betreffende sector.

\subsection{Seclor verwanten}

bestaande uit de volgende clusters:

- partner; dit betreft degene met wie de focale persoon gehuwd is ofwel met wie de focale persoon ongehuwd samenwoont of een duurzame relatie onderhoudt in de zin van partnerschap. De eventuele ex-partner met wie nog conctact bestaat valt eveneens onder het cluster "partner", ook dan wanneer or geen daadwerkelijk contact meer is, maar deze nog wel een duurzame plaats in de beleving van de focale persoon inneemt;

- kinderen: naast eigen- en stiefkinderen worden hier ook aangenomen dan wel pleegkinderen of bijvoorbeeld kinderen uit een voorechtelijke dan wel buiten een partnerrelatie geregistreerd.

Ook de eventuele partners van deze kinderen worden binnen dit cluster opgenomen;

- @uders; hiertoe worden ook gerekend verzorgers, pleeg- en stiefouders, voor zover door de focale persoon als 'ouders' beschouwd;

- schoonouders; ook als in geval van (echt)scheiding het contact blijt bestaan, dan wel als er sprake is van duurzaamheid in de beleving;

- arootouders: te onderscheiden naar ouders van de vader en van de moeder van de focale persoon;

- breers/zussen; dit betreft de rechtstreekse broers en zusters van de focale persoon.; bij partnerschap (conform de variaties vermeld onder het cluster partner) van broer of zus, wordt deze partner eveneens in de inventarisatie opgenomen; 
- overige aan- en bloedverwanten, die voor de focale persoon belangrijk zijn. In dit cluster gaat het om bijvoorbeeld de broers en zusters van de eigen partner, ooms en tantes, etc.

\subsection{Sector vriendschappelijke betrekkingen}

opgebouwd uit de volgende clusters:

- vrienden: de definiering 'vriend' is persoonsgebonden en wordt door de focale persoon zelf bepaald. In het algemeen betreft het netwerkleden met wie de focale persoon door genegenheid en persoonlijke voorkeur verbonden is. Ook de eventuele partner van de vriend wordt in de inventarisatie meegenomen voorzover dit contact door de focale persoon als rechtstreeks contact wordt beschouwd;

- collega's: dit betreft netwerkleden verbonden met werk- en schoolsituatie, die in persoonlijk opzicht meer betekenis hebben dan collega's, jaar- en klasgenoten in strikt formele zin, met wie buiten het werk en opleiding om geen duurzame banden worden onderhouden;

- buren: dit kunnen naaste buren zijn maar ook mensen in de straat of het flatgebouw die de focale persoon als 'buren' benoemt en met wie meer dan toevallig contact wordt onderhouden;

- kennissen: het betreft netwerkleden met wie duurzame regelmatige contacten bestaan, maar die door de focale persoon niet tot het cluster 'vrienden' gerekend worden;

- overigen: hieronder vallen netwerkleden met wie men duurzaam contact heeft vanwege deelname dan wel lidmaatschap van (vrijetijds)-vereniging of club en cursussen in de zin van ontspanning. Daarnaast kan het netwerkleden betreffen die behalve een zakelijke relatie (boekhouder) ook persoonlijk van belang zijn (aanspreekpunt voor meer persoonlijk zaken). Zo er bijvoorbeeld in geval van de boekhouder geen sprake is van een meer persoonlijk karakter, valt deze persoon binnen een cluster in de sector maatschappelijke diensten.

\subsection{Sector maatschappelijke diensten}

bestaande uit de volgende clusters:

- arbeids- en schoolmilieu; het betreft hier zowel reguliere arbeid als vrijwilligerswerk. Het schoolmilieu heeft betrekking op dag- en avondonderwijs alsook op deelname aan cursussen en deeltijdse praktijkopleidingen;

- hulpverlenina onder te verdelen in:

= eerstelijnszorg, zoals huisarts, maatschappelijk werk, gezinszorg;

$=$ tweedelijnszorg, zoals RIAGG, poliklinische zorg, CAD reclasseringshulpverlening;

$=\quad$ intramurale zorg, waaronder algemeen ziekenhuis, psychiatrische afdeling van algemeen ziekenhuis (PAAZ) en andere algemene dan wel categorale intramurale voorzieningen;

- maatschappeliike instituties; zoals (kerk-)genootschap, arbeidsbureau, woningsbouwvereniging, politieke partij;

- justitie en rechishulp: zoals politie, openbaar ministerie, advocatuur, wetswinkel;

- instanties van sociale wetoeving; zoals GAK, sociale dienst en GMD.

In het algemeen is het duidelijk binnen welk cluster een netwerklid geplaatst dient te worden. Er komen echter ook situaties voor waarin een afweging gemaakı dient te worden. Daarbij worden de volgende regels gehanteerd:

- bij de clusters partner en kinderen wordt het volledige gezin van de focale persoon dan wel huishouden in kaart gebracht; ook alle broers en zusters 
van de focale persoon worden geregistreerd, ongeacht of de focale persoon wel of geen contact met hen heeft;

- het kan voorkomen dat een netwerklid zowel een vriend als een collega is. Dit netwerklid word in hel door de focale persoon aangegeven meest passende cluster geplaatst;

- onder het cluster 'overigen' in de sector vriendschappelijke betrekkingen worden waar sprake is van deelname aan verenigingen, clubs en dergelijke in principe drie personen geregistreerd;

- de deelname aan verenigingen, werk en scholing kan onder meer kennissen, buren, collega's en vrienden impliceren. Een netwerklid die al eerder onder deze laatste clusters vermeld is, vervalt bij de clusters verenigingen, werk en scholing; een netwerklid kan slechts eén keer in de omvang van het netwerk opgenomen ofwel geregistreerd worden.

N.B.

De netwerkleden in de sector verwanten en de sector vriendschappelijke betrekkingen vormen tesamen de 'informele' netwerkleden'. De netwerkleden in de sector maatschappelijke diensten vormen de 'formele' netwerkleden.

\section{B GEVARIEERDHEID}

De gevarieerdheid betreft de focale persoon (ad 1.5) en de informele netwerkleden. Dit structuurkenmerk wordt beschreven aan de hand van sociaal demografische kenmerken. De MSNA betreft de volgende elementen:
3.1 Geslacht
vrouw / - man
3.2 LeeftIld
$<16$ jaar
- $16-24$ jaar
- 25 - 34 jaar
- 35 - 44 jaar
- $45-54$ jaar
- $\quad 55-64$ jaar
- > 75 jaar

3.3 Burgelijke staat - ongehuwd

- gehuwd / partner

- gescheiden

- weduwe / weduwnaar

3.4 Voltooid

opleldingenlveau $\quad$ - $\quad$ bijzonderonderwijs

- LBO/MAVO

- MBO/HAVO

- HBO/WWO

- universitair

L.5 Latst ultgeoefend
beroep

beschrijving van het beroep / vak of van de werkzaamheden op dit moment of eerder.

- Dit aspect wordt op patientniveau gebruikt. 


$\begin{array}{lll}3.6 \text { Actuele situatie } & \text { - } & \text { werkeloos } \\ & - & \text { huishouden } \\ & \text { school / studie } \\ & - & \text { arbeidsproces } \\ & \text { - } & \text { ziek } \\ & \text { arbeidsongeschikt } \\ & - & \text { pensioen }\end{array}$
3.7 Woonsituatle
alleen wonend samen met partner als éénoudergezin als gezin (met pariner en kinderen) bij ouders dan wel familie in woongemeenschap (studentenhuis, bejaardenoord, kloosier) onder toezicht (beschermende woonvorm, psychiatrische of andere zorgselting)

\section{BEREIKBAARHEID}

De bereikbaarheid betreft de geografische alstand tussen de focale persoon en de informele netwerkleden. De plaats waar de focale persoon woont is het uitgangspunt. De volgende zones worden onderscheiden.
4.1 Binnen dezelfde wijk
de naam of code van de wijk wordt geregistreerd
4.2 Binnen dezelfde woonplaats
de naam of code van de woonplaats wordt geregistreerd
4.3 Binnen dezelfde reglo
4.4 Bulten de regio
de plaats en eventueel het land worden geregistreerd

D

\section{STRUCTUUR VAN DE BETREKKINGEN}

De structuur van de betrekkingen betreft alle beschikbare informele en formele netwerkleden. De elementen 5.3 en 5.4 worden op patiëntniveau gebruikt.

\subsection{Initlatief in het contact}

\subsection{Frequentle} van het contact

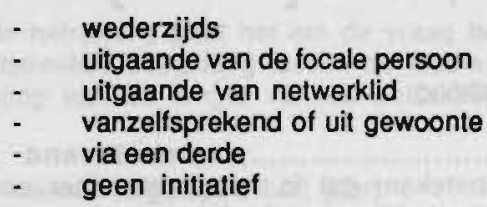
- dagelijks
- enige malen per week
- wekelijks
- tweewekelijks
- maandelijks
- eenmaal per half jaar
- eenmaal per jaar
- geen contact in het laatste jaar




\subsection{Regelmaat* - regelmatig \\ - onregelmatig}

\subsection{Soort contact ${ }^{*} \quad$ - face to face \\ - terloops \\ - telefonisch}

\section{Gewicht van de betrekkingen}

Bij het gewicht van de betrekking tussen de focale persoon en de netwerkleden wordt nagegaan in welke mate de focale persoon vindt dat de netwerkleden tegemoed komen aan de vervulling van de dagelijkse basisbehoeften. Het element 'gewicht' moet, zoals in hoofdstuk 5 is beschreven opgevat worden als de scharnier naar de inhoud ofwel de functies van de betrekkingen. Onderverdeeld in vier compartimenten geeft de focale persoon aan of

6.1 de betrekking vlak dan wel meelevend is;

dit element van gewicht verwijst naar het compartiment van de 'affectieve behoeften';

6.2 de betrekking vluchtig dan wel grondig is;

dit element van gewicht verwijst naar het compartiment van de 'behoefte aan aansluiting';

6.3. de betrekking zakelijk dan wel persoonlijk is;

dit element van gewicht verwijst naar het compartiment van de behoefte aan de zogeheten 'materiële en instrumentele middelen';

6.4. de betrekking uit gewoonte dan wel op voorkeur berust; dit element van gewicht verwijst naar het compartiment van de behoefte aan 'stabiliteit'.

Bij leder compartiment wordt de focale persoon gevraagd het netwerklid een cijfer te geven op een vijfpuntschaal, van 1 oplopend tot maximaal 5:

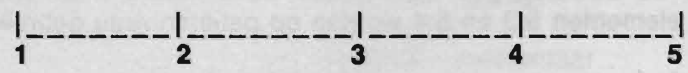

Toelichting:

vlak. meelevend

Vlak betekent dat in het contact met een netwerklid een gevoelsmatige betrokkenheid ontbreekt. Meelevend houdt in dat er over en weer sprake is van delen van gevoelens als verdriet en plezier en persoonlijke ervaringen.

Gewichten: 1 : uitsluitend vlak

2 : merendeels vlak

3 : redelijk meelevend

4 : merendeels meelevend

5 : in zeer hoge mate meelevend

\footnotetext{
" De aspecten 'regelmaat' en 'soort contact' worden op patientniveau gebruikt.
} 
Vluchtig.

grondig.

Bij vluchtig zit er geen diepgang in hel contact; het contact blijft oppervlakkig, bijvoorbeeld bij een praatje over het weer. Grondig betekent dat allerhande belangrijke zaken diepgaand tot in de kern besproken kunnenworden ofwel hel contact over opvaltingen, interessen, emoties en dergelijke is diepgaand en degelijk.

Gewichten: 1 : zeer vluchtig

2 : merendeels vluchtig

3 : zowel grondig alsook vluchtig

$4:$ merendeels grondig

5 : zeer grondig.

Zakelijk persoonlijk

Bij zakelijk contact gaat om een betrekking die materieel gebonden is, bijvoorbeeld een bank-relatie, uitsluitend een contact vanwege het werk, medische hulp en dergelijke. Persoonlijk wil zeggen dat het contact overwegend gebaseerd is op de persoon zelf van het netwerklid los van de vraag of er al dan niet een eventueel zakelijk belang meespeelt.

Gewichten: 1 : uitsluitend zakelijk

2 : voornamelijk zakelijk

3 : zowel zakelijk als persoonlijk

4 : voornamelijk persoonlijk

5 : uitsluitend persoonlijk

Gewoonte. voorkeur

bij gewoonte gaat het om contact vanwege het gegeven dat er nu eenmaal contact is; het contact bijvoorbeeld op het werk met collega's, of met sommige familieleden bestaat gewoon vanwege het feit dat men samenwerkt of familie van elkaar is. Bij voorkeur gaat het om contacten die de focale persoon prefereert;

het betreffende netwerklid is niet inwisselbaar voor een willekeurig andere persoon.

Gewichten: 1 : uitsluitend uit gewoonte

2 : merendeels uit gewoonte

3 : voorkeur en gewoonte gaan gelijk op

4 : de voorkeur overheerst

5 : uitsluitend op voorkeur

Lengte basis* van de betrekkingen

Bij de lengte ofwel de duur van de betrekking gaat het om de vraag hoelang er al sprake is van een duurzame rechtstreekse betrekking tussen de focale persoon en zijn netwerkleden. Voor de bepaling van de lengte van de betrekking wordt de volgende indeling aangehouden:

- recentelijk (binnen afgelopen half jaar)

- sinds het afgelopen jaar

- minder dan twee jaar

- minder dan vijf jaar

- meer dan viji jaar (aantal jaren noemen).

\footnotetext{
* Het element 'basis' van de betrekking wordt op patientniveau gebruikt.
} 
Vervolgens wordt met de focale persoon de oorsprong van de betrekking nagegaan, te weten of deze ontstaan is op basis van

\subsection{Verwantschap \\ en in welk cluster}

7.2 Vriendschappelijke betrekkingen en in welk cluster

7.3 Maatschappelijke diensten en in welke cluster 


\section{INTERVIEW - FORMULIEREN MSNA}

In deze bijlage vindt men de achtereenvolgens het formulier voor de gegevens van de focale persoon (A) en het formulier voor de gegevens van de netwerkleden (B). Op het formulier inzake de netwerkleden (per nelwerklid wordt een formulier gebruiki) vindt men een tweede kolom waarin de gegevens van de eventuele parther van het betreffende netwerklid worden weergegeven.

\section{A. FORMULIER BESCHRIJVING FOCALE PERSOON}

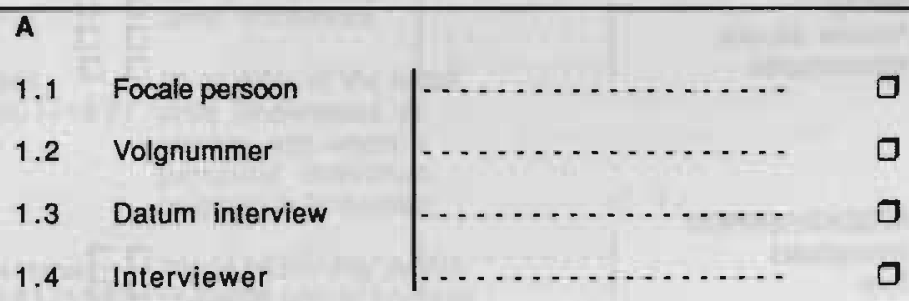

1.5 GEVARIEERDHEID

1.5.1 Geslacht

1.5.2 Leeftijd

1.5.3 Burgerlijke staat

1.5.4 Opleidingsniveau

1.5.5. Beroep

1.5.6 Acluele situatie

1.5.7 Woonsituatie

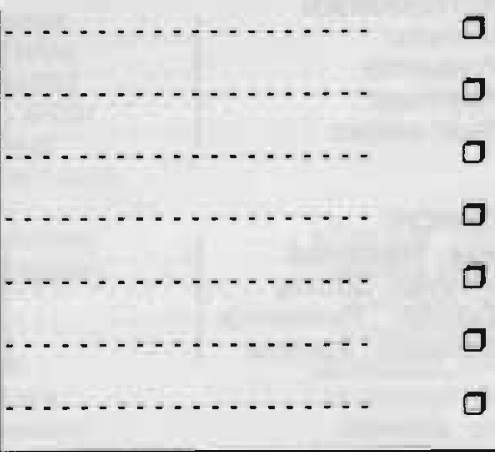




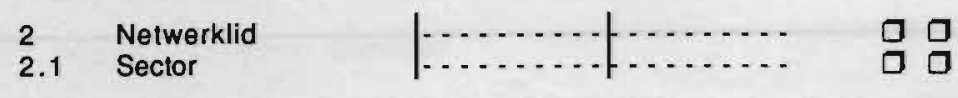

B

3 GEVARIEERDHEID

3.1 Geslacht

3.2 Leeftijd

3.3 Burgerlijke Staat

3.4 Opleidingsniveau

3.5 Beroep

3.6 Actuele situatie

3.7 Woonsituatie

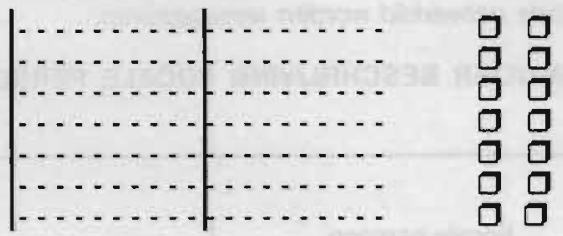

C

4 BEREIKBAARHEID

4.1 Woonplaats

4.2 Zone

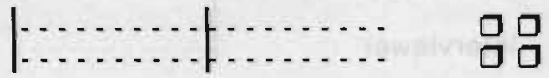

D

BETREKKINGEN

5.1 Initiatief

5.2 Frequentie

5.3 Regelmaat

5.4 Soort contact

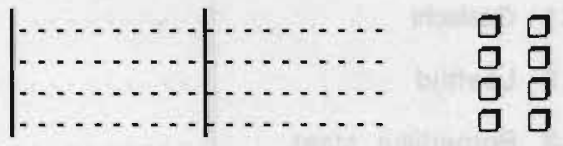

GEWICHT

6.1 Vlak-Meelevend

6.2 Vluchtig-Grondig

6.3 Zakelijk- Persoonilijk

6.4 Gewoonte- Voorkeur

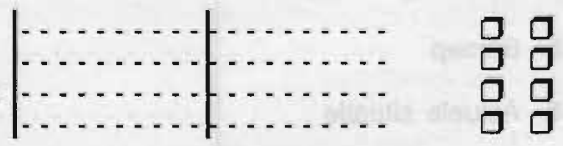

7.1 Lengte

7.2 Basis 


\section{DEFINITIES SOCIAAL NETWERK}

In chronologische volgorde wordt hier een overzicht gegeven van de definities van een sociaal netwerk en hun accenten op de structuur dan wel de functies van een sociaal netwerk zoals die in de literatuur zijn aangetroffen.

\section{STRUCTUUR \\ FUNCTIES}

Barnes The sel of concrete

$1954 / 1969$ interpersonal relationships

linking individuals with

other individuals.

Bott All or some of the social

$1957 / 1971$ units (individuals or groups) with whom a particular individual or group is in contact.

Hammer ties in which any person $1961 / 1963$ or social unit is involved

for maintenance of

existing forms of interaction.

Adams A person's social network 1967 may be defined at the most general level as consisting of those persons with whom he maintains contact and has some form of social bonds.

- relationships = voluntary = obligatory

- persons

$=\mathrm{kin}$

$=$ non-kin * friends

- neighbors

- co-workers

- frequency of interaction
- affection (liking, positive sentiment, attraction, emolional involvement), - concensus_(sharing of common values, interests, attitudes), - social responsibility

\section{Mitchell A specific set of linkages}

(1969) among a difned sel of persons, with the property that the characteritcs of these linkages as a whole may be used. 
Speck, zie Barnes (1954) en Bott (1957)

RuevenI

1969

that group of persons who maintain

Speck, an ongoing significance

Altneave

in each others lives.

by fulfilling

1973

specific human needs.

\section{Brim zie Adams (1969) \\ 1974 \\ - relationships \\ $=$ intensity}

Tolsdort 1976 zie Mitchell (1969)

en Bott (1957, 1971).
- assistance

- value simularity

- concern

- trust

- desired interaction.
- support

- advice

- feedback.

Walker, An individual support

MacBride, network may be defined

Vachon. as that set of personal contacts

1977 through which the individual

maintains his social identity.........................and receives

- size

emotional support, material aid and services, information, new social contacts.

Cohen zie Mitchell (1969).

\section{Sokolovsky}

$1978 / 1979$

Sadoun That group of significant

1987 others which is supposed

to form a natural

supportsystem.

Wellman Sets of nodes (or social

Berkowitz system mebers) and sets

1988

of ties depicting their

interconnections

Erickson Social network analysis offers 1988

information about a network of

persons, relationships and the

structure of relationships

and

how structures, persons and

relationships have changed

over time in particular social

contexts. 
Baars, zie Speck, Attneave (1973); Hammer (1978)

Uffing.

Dekkers

1990

Baars

1992
Al die mensen met wie iemand (de focale persoon) rechtstreekse min of meer duurzame banden onderhoudt

voor de vervulling

van de dagelijkse

levensbehoeften

- omvang (sectoren, clusters)

- affeclieve behoeften

- gevarieerdheid

- behoefte aan

aansluiting

bereikbaarheid

- materiële en instrumentele behoeften:

financiên, advies $\boldsymbol{\theta} . d$.

- behoefte aan sociale stabiliteit 


\section{STRUCTUUR SOCIALE NETWERK RESTGROEP ( $\mathbf{N}=\mathbf{1 2})$}

Ter herinnering: bij twaalf ambulante chronisch psychiatrische patiënten in de onderzoekspopulatie ( $N=59$ ) was het niet mogelijk adequaat gematchte referentiepersonen te vinden. Het gaat om zeven mannen en vijf vrouwen, merendeels in de leeftijd van 25 tot 44 jaar; negen patiënten zijn ongehuwd, de overige drie zijn gescheiden. $\mathrm{Ze}$ wonen in het algemeen alleen en zijn in meerderheid werkeloos dan wel arbeidsongeschikt (zie $\$ 8.2$ ).

Bij deze restgroep van 12 patiënten bestaat de gemiddelde omvang van de sector verwanten uit 6.4 netwerkleden. De sector vriendschappelijke betrekkingen bestaat uit gemiddeld 7.6 netwerkleden, waarvan gemiddeld 1.4 netwerkleden tot het cluster naaste vrienden behoren. In de sector maatschappelijke diensten die gemiddeld uit 5.6 netwerkleden bestaat heeft het cluster hulpverlening een gemiddelde omvang van 3.5 netwerkleden. De totale omvang van het persoonlijke sociale netwerk bestaat bij deze 12 patiënten gemiddeld uit 21.2 netwerkleden. In totaal gaat het bij deze groep ambulante chronisch psychiatrische patiënten om 254 netwerkleden. Het merendeel van de informele netwerkleden (55.1\%) woont binnen de eigen regio en $21.2 \%$ daarbuiten. Bij het resterende deel informele netwerkleden wordt over de bereikbaarheid geen adequate informatie gegeven.

Omtrent de structuur van de betrekkingen kan het volgende gemeld worden. Bij $18.5 \%$ van de beschikbare netwerkleden neemt de patiënt zelf overwegend het initiatief tot contact; in de sector verwanten is dit $24.5 \%$ en in de sector maatschappelijke diensten gaat het hier om $23.5 \%$. Met $8.7 \%$ van de netwerkleden in de sector vriendschappelijke betrekkingen neemt de patiënt zelf overwegend contact op. Bij $6 \%$ van de contacten met de netwerkleden wordt het initiatief door het betreffende netwerklid genomen en bij $9.8 \%$ van de contacten met de netwerkleden is er sprake van wederzijds initiatief.

Met $22.4 \%$ van de netwerkleden ontstaat contact op basis van initiatief via derden (in de sectoren verwanten en maatschappelijke diensten gaat het hieromtrent om ongeveer $25 \%$ en in sector vriendschappelijke betrekkingen is dit voor $16.3 \%$ van de netwerkleden het geval). Met $22.8 \%$ van de netwerkleden is er contact vanuil gewoonte (in de sector verwanten: $8.5 \%$; in de sector vriendschappelijke betrekkingen: $33.7 \%$; in de sector maatschappelijke diensten: $27.9 \%$ ). Met $20 \%$ van de beschikbare netwerkleden is er geen initiatief tot contact.

Deze twaalf ambulante chronisch psychiatrische patiënten hebben met $4 / 5$ van de netwerkleden uit de sector vriendschappelijke betrekkingen frequent contact, dat wil zeggen: dagelijks tot minimaal eenmaal per twee weken. Deze frequentie in het contact komt in de sector verwanten met driekwart van de verwanten voor.

De twaalf patiönten kennen voor de verschillende compartimenten behoeften gemiddeld het volgende gewicht toe aan het contact met hun netwerkleden:

- comparliment van de affectieve behoeften 3.7

- compartiment van de behoefte aan aansluiting.....................................3.5

- compartiment van de materielle en instrumentele behoeften..............3.3

- compartiment van de behoefte aan stabiliteit.......................................8 
In hel geheel genomen hebben deze patienten met $40.2 \%$ van hun netwerkleden reeds langer dan vijf jaar contact. In de sector verwanten geldt dit voor $91.5 \%$ terwijl dit in de sector vriendschappelijke betrekkingen en in de secor maatschappelijk diensten met niet meer dan $11 \%$ van de netwerkleden het geval is.

Wanneer er een vergelijking wordt gemaakt tussen de structuur van het sociale netwerk bij deze twaalf ambulante chronisch psychiatrische patiënten en die blj het deel van de onderzoekspopulatie waarvoor wel referentiepersonen gevonden konden worden ( $n=47)$ dat kunnen de volgende duidelijke verschillen worden waargenomen:

- de gemiddelde omvang netwerkleden is in het geheel genomen kleiner;

- de gemiddelde omvang van de sector verwanten is kleiner;

- de gemiddelde omvang van de sector vriendschappelijke betrekkingen is kleiner;

- bij deze twaall patiènten is meer sprake van initiatief in het contact via derden en minder sprake van wederzijds initiatief;

- de twaalf patiénten hebben meer netwerkleden met wie het contact in het laatste jaar is ontstaan. 


\section{OVERZICHT RESULTATEN HYPOTHESEN}

\section{Vraagstelling I: omvang en samenstelling van de omvang}

1 De omvang van de sector verwanten is gemiddeld bij de onderzoeks populatie en de referentiepersonen gelijk.

Deze hypothese wordt bevestigd.

2 De omvang van de sector vriendschappelijke betrekkingen is gemiddeld bij de onderzoekspopulatie kleiner dan bij de referentiepersonen.

Deze hypothese wordt bevestigd.

3 De omvang van de sector maatschappelijke diensten is wat betreft het aandeel hulpverlening gemiddeld groter bij de onderzoekspopulatie dan bij de referentiepersonen.

Deze hypothese wordt bevestigd.

4 Het totaal effect is dat de omvang van de sociale netwerken van de onderzoekspopulatie gemiddeld kleiner is dan bij de referentiepersonen.

Deze hypothese wordt bevestigd.

Vraagstelling I: gevarieerdheid van de netwerkleden

5 De sociale netwerken van de onderzoekspopulatie zijn overwegend homogeen samengesteld terwijl de sociale netwerken van de referentiepersonen vooral heterogeen zijn samengesteld.

Deze hypothese wordt niet bevestigd. De sociale netwerken van zowel de onderzoekspopulatie als die van de referentiepersonen zijn vooral homogeen samengesteld.

Meer in het bijzonder wordt vermoed:

5.1 De onderzoekspopulatie heeft qua statusrollen een overeenkomstig homogeen samengesteld sociaal nefwerk terwijl de referentiepersonen een meer heterogeen samengesteld sociaal netwerk hebben.

Deze hypothese wordt niet bevestigd; zowel bij de onderzoekspopulatie als ook bij de referentiepersonen wordt qua statusrollen een meer homogeen samengesteld sociaal netwerk aangetroffen.

5.2 De onderzoekspopulatie neemt echter met betrekking tot de positierollen gemiddeld een geïsoleerde plaats in het sociale netwerk in terwijl de referentiepersonen qua positierollen gemiddeld aansluiting hebben met de sociale netwerkleden.

Deze hypothese wordt alleen bevestigd betreffende positierollen inzake werken woonomstandigheden.

\section{Vraagstelling I: bereikbaarheid van de netwerkleden}

6 Er zijn geen verschilien tussen de onderzoekspopulatie en de referentiepersonen inzake de bereikbaarheid van de sociale netwerkleden.

Deze hypothese wordt wordt niet bevestigd. Een belangrijk verschil is dat de referentiepersonen meer netwerkleden in de eigen woonplaats hebben dan de onderzoekspopulatie. 


\section{Inlliatlet}

7 By de onderzoekspopulatie komen de conbcten mel netwerkleden in de sectar verwanten overwegend tol stand vis initialef in de zin van vanzelsprokendheid ferwil er bij de referentiepersonen sprake is van wederzijis haltatiet.

Deze hypothase word deds bevestigd. Bij de retarnhtepersenen wort metr

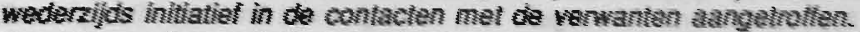

8 De onderzoekspopulatie toont in de contacten met natwerkleden in de sectat viendschappelike betrekkingen nauweliks eigen initiatiet dit in tegenstelling tot de referentiepersonen blj wie er bovendien sprake is van wederzijos initiatief.

Deze hypothese wort deels bevestigd. Bu de rebrentieperzenen word meer wederzijts inilialiet in de contacten met de netwarkiaten in de sectar wiendschappellke betrekkingen asngetrotten.

$9 \quad$ Het contact met netwerkleden in de sector maatschappelike diensien komt bij de onderzoekspopulatie overwegend tot stand vis hilialief van derden, terwijl bij de referentiepersonen hier het eigen initiatiet overheerst.

Deze hypothese kan niet als bevestigd beschouwd worden. De relarentigarsanen hebben vergeleken met de onderzoekspopulatis met de newerkleden in de sacter maatschapelike diensten meer contact op basis van geweonte en minder cantat via initiatiel van derden.

10 Het totaal effect is dat bij de onderzoekspopulatie het tot stand komen van het contact met de netwerkleden minder gebaseerd is op eigen en wederzijds initiatief dan bij de referentiepersonen het geval is.

Deze hypothese word bevestigd.

\section{Frequentie}

11 Tussen de onderzoekspopulatie en de referentiepersonen is er gemiddeld geen verschil in de frequentie van de contacten met verwanten.

Deze hypothese wordt deels bevestigd. Een opmerkeklijk verschil is dat de referentiepersonen met meer verwanten minimaal eenmaal per drie maanden contact hebben.

12 De onderzoekspopulatie onderhoudt gemiddeld aanzienlijk minder frequent contact met mensen in de sector vriendschappelijke betrekkingen dan de referentiepersonen.

Deze hypothese kan als bevestigd beschouwd worden.

13 De onderzoekspopulatie onderhoudt gemiddeld frequent contact met personen in het deel hulpverlening in de sector maatschappelijk diensten; dit is in tegenstelling met de referentiepersonen.

Deze hypothese wordt bevestigd.

\section{Gewicht}

14 Er treden verschillen op in het toekennen van het gewicht aan de netwerkleden tussen de onderzoekspopulatie en de referentiepersonen. De richting van deze verschillen valt niet te voorspellen.

Deze hypothese wordt niet bevestigd.

\section{Lengte}

15 De meerderheid van de onderzoekspopulatie beschikt gemiddeld in tegenstelling tot de referentiepersonen over netwerkleden met wie al lange tijd contact bestaat.

In het geheel genomen wordt deze hypothese niet bevestigd.

\section{Vraagstelling II: omvang en samenstelling van de omvang}

16 De hulpverleners inventariseren gemiddeld een geringere omvang van de sector verwanten dan door de MSNA zichtbaar wordt gemaakt. 
Meer in het bijzonder:

16.1 De hulpverleners inventariseren overwegend de naaste bloedverwanten zoals de ouders en broers en zusters en aanverwanten, met name de partner, terwijl de MSNA daarnaast ook andere bloed- dan wel aanverwanten zichtbaar maakt met wie de onderzoekspopulatie contact heeft.

Deze hypothese word bevestigd.

17 De hulpverleners inventariseren gemiddeld minder netwerkleden in de sector vriendschappelijke betrekkingen dan door de MSNA zichtbaar wordt gemaakt. Deze hypothese wordt bevestigd.

18 De inventarisatie door de hulpverleners van de omvang van de sector maatschappelijke diensten verschilt niet van die met behulp van de MSNA.

Deze hypothese wordt bevestigd.

19 Het lotaal effect is dat de MSNA een gemiddeld omvangrijker netwerk in beeld brengt dan door de hulpverleners zichtbaar wordt gemaakt; het verschil treedt $o p$ in de sector verwanten en in de sector vriendschappelijke betrekkingen.

Deze hypothese wordt bevestigd.

\section{Vraagstelling II: gevarieerdheid van de nelwerkleden}

20 De hulpverleners inventariseren gemiddeld minder de status- en positierollen van de netwerkleden bij de onderzoekspopulatie, dan dat dit door de MSNA gebeurt.

Deze hypothese wordt bevestigd.

\section{Vraagstelling II: bereikbaarheid van de netwerkleden}

21 Het valt niet te voorspellen welke overeenkomsten dan wel verschilien ten aanzien van de bereikbaarheid van de netwerkleden worden aangetroffen tussen de informatie van de hulpverleners en de informatie die door de MSNA hierover wordt gegeven.

Do MSNA geeft significant meer informatie over de bereikbaarheid van de netwerkleden dan in de gegevens van de hulpverleners het geval is.

Vraagstelling II: structuur van de betrekkingen

\section{Initiatief}

22 De hulpverleners laten zien dat de contacten tussen de onderzoekspopulatie en hun netwerkleden overwegend tot stand komen via initiatief in de zin van 'vanzelfsprekendheid' en via initiatief van de netwerkleden, terwijl de M.S.N.A. een meer gedifferentieerd beeld geeft en met name ook het eigen initiatief van de onderzoekspopulatie toont.

Het eerste deel van deze hypothese wordt niet bevestigd, terwijl het tweede deel wel onderschreven wordt.

\section{Frequentle}

23 Er treden verschillen op in de informatie die de hulpverleners geven en die door de MSNA over de frequentie van de contacten tussen de onderzoekspopulatie en hun nelwerkleden verschaft.

De richting van deze verschillen valt niet te voorspellen.

Deze hypothese wordt bevestigd.

\section{Gewicht}

24 De hulpverleners geven gemiddeld een lager gewicht aan de betrekkingen lussen de onderzoekspopulatie en hun netwerkleden dan door de MSNA zichtbaar wordt gemaakt. Dit geldt in het bijzonder voor de onderdelen affectieve behoeften en de behoeften aan aansluiting. 
Deze hypothese wordi voor alle ondendelen bevestigd.

\section{Lengte}

25 De hulpverleners inventariseren in meerderheid de langdurig bestaande contacten van de onderzoekspopulatie terwijl de MSNA tevens de kortero contacten toont en aldus differentiatio aanbrengt.

Deze hypolhese wordt bevesligd.

\section{Vraagstelling III: omvang en samenstelling van de omvang}

26 De omvang van de sector verwanten is gemiddeld voor beide groepen van de onderzoekspopulatie gelijk.

Deze hypothese wordt niet bevestigd. De jongere patienten bliken gemiddeld significant minder verwanten te hobben dan de oudere patiènten.

27 De groep jongere ambulante chronisch psychiatrische patienten heeft gemiddeld meer netwerkleden in de sector vriendschappelijke betrekkingen dan de de groep ouderen.

Deze hypothese wordt niet bevestigd. De jongere patiënten hebben gemiddeld evenveel netwerkleden in de sector vriendischappelijke betrekkingen als de oudere patiënten.

28 Met betrekking tol de omvang van de sector maatschappelijke diensten, in het bijzonder het deel hulpverlening, zullen tussen beide groepen van de onderzoekspopulatie verschillen worden aangetroffen. De richting van de verschillen valt niet te voorspellen.

Deze hypothese wordt omtrent de omvang van do gehele sector maalschappelike diensten bevestigd. Echter bij het deel hulpverlening treden geen varschillen op tussen de jongere en de oudere patiënten.

Vraagstelling III: gevarieerdheid van de netwerkleden

29 De sociale netwerken van de jongere groep van de onderzoekspopulatie zijn gemiddeld qua status- en positierollen homogener samengesteld dan de sociale netwerken van de groep ouderen.

De resultaten zijn tegengesteld aan hypothese 29. De sociale netwerken van de jongere en oudere patiënten zijn homogeen samengesteld. Echter de sociale netwerken van de oudere patiènten zijn homogener samengesteld dan die van de jongere patiënten.

\section{Vraagstelling III: bereikbaarheid van de netwerkleden}

30 Er zijn geen verschillen tussen de jongere en de oudere groep ambulante chronisch psychiatrische patiënten inzake de bereikbaarheid van de sociale netwerkleden.

Deze hypothese wordt bevestigd.

\section{Vraagstelling III: structuur van de betrekkingen}

\section{Initiatief}

31 Bij de jongere groep van de onderzoekspopulatie komen de contacten met de netwerkleden overwegend lot stand via initiatief in de zin van vanzelfsprekendheid, terwijl bij de oudere groep van de onderzoekspopulatie de contacten met de netwerkleden overwegend tot stand komen door initiatiel via derden.

Deze hypothese wordt niet bevestigd. Er treden op geen enkele punt significante verschillen op. 


\section{Frequentie}

32 De jongere groep van de onderzoekspopulatie ouderhoudt gemiddeld frequenter contact met de netwerkleden dan de oudere groep van de onderzoekspopulatie.

Deze hypothese wordt niet bevestigd.

\section{Gewicht}

33 Er zullen verschillen optreden in het toekennen van het gewicht aan de netwerkleden tussen de jongere en de oudere groep van de onderzoeks-populatie.

De richting van deze verschillen is niet te voorspellen.

Deze hypothese wordt niet bevestigd.

\section{Lengte}

34 De jongere groep van de onderzoekspopulatie beschikt gemiddeld over meer netwerkleden met wie het contact sinds korte tijd bestaat dan de oudere groep van de onderzoekspopulatie.

Deze hypothese wordt bevestigd.

\section{Vraagstelling IV: omvang en samenstelling van de omvang}

35 De omvang van de sector verwanten is gemiddeld voor beide groepen van de onderzoekspopulatie gelijk aan die van de referentiepersonen.

Deze hypothese wordt in hoofdlijnen bevestigd.

36 De omvang van de sector vriendschappelijke betrekkingen is gemiddeld bij de jongere groep van de onderzoekspopulatie kleiner dan bij de referentiepersonen, terwijl bij de oudere groep de omvang van deze sector vergeleken met de referentiepersonen gemiddeld nog kleiner is dan bij de jongere groep.

Het eerste deel van hypothese 36 wordt bevestigd. Het tweede deel wordt echter niet bevestigd. Vergeleken met de referentiepersonen wijkt de omvang van de sector vriendschappelijke betrekkingen van de oudere patiënten niet af van die van de jongere patiënten.

37 Bij beide groepen van de onderzoekspopulatie treden in de omvang van de sector maatschappelijk diensten zowel wat betreft het aandeel werkkring als het aandeel hulpverlening verschillen op vergeleken met de referentiepersonen.

De richting van de verschillen valt niet te voorspellen.

Deze hypothese wordt grotendeels bevestigd. Echter fussen de jongere patiënten, vergeleken met de referentiepersonen is geen verschil aangetroffen inzake de omvang van het cluster werk/scholing.

38 Het totaal effect is dat de omvang van de sociale netwerken bij de oudere groep vergeleken met de referentiepersonen gemiddeld kleiner is dan bij de jongere groep van de onderzoekspopulatie vergeleken met de referentiepersonen Het verschil treedt vooral op in de omvang van de sector vriendschappelijke betrekkingen.

Het eerste deel van hypothese 38 wordt niet bevestigd. De omvang van de sociale netwerken bij de jongere patiënten vergeleken met de jongere referentiepersonen is gemiddeld significant kleiner dan die bij de oudere patiènten vergeleken met de oudere referentiepersonen.

\section{Vraagstelling IV: gevarleerdheid van de netwerkleden}

39 In aansluiting op de hypothesen 5 en 29 mag verwacht worden dat vergeleken met de referentiepersonen de sociale netwerken van de jongere groep qua status- en positierollen gemiddeld heterogener zijn samengsteld dan die van de oudere groep van de onderzoeks-populatie.

Deze hypothese kan niet als bevestigd beschouwd worden. De sociale netwerken van de referentiepersonen zijn homogeen samengesteld waarbij die van de oudere referentiepersonen homogener zijn samengesteld dan die van de jongere 
referentiepersonen. Merendeels is deze vilkomst ook aanwezig bij de onderzoekspopulatie. Echter vergeleken met de jongere referentiepersonen zijn de sociale netwerken van de jongere patiënten qua werk- en woonsituatie heterogeen samengesteld, terwijl de sociale netwerken van de oudere patienten inzake leeftijd en werksituatie minder homogeen zijn samengeseld dan die van de oudere referentiopersonen. Deze uitkomsten sluiten aan op die van hypothese 5 en 29.

\section{Vraagstelling IV: bereikbaarheid van de nelwerkleden}

40 In aansluiting op de hypothesen 6 en 30 mag verwacht worden dat vergeleken met de referentiepersonen er geen verschillen optreden in de bereikbaarheid van de netwerkleden voor beide groepen van de onderzoekspopulatie.

Deze hypothese wordt niet bevestigd.

\section{Vraagstelling IV: structuur van de betrekkingen}

41 Gezien eerdere hypothesen inzake de structuur van de betrekkingen mag verwacht worden dat vergeleken met de referentiepersonen er in de structuur van de betrekkingen met de netwerkleden gemiddeld meer verschillen optreden bij de oudere groep dan bij de jongere groep van de onderzoekspopulatie. Hoe de verschillen zich over de elementen initiatief, frequentie, gewicht en lengte zich uitstrekken valt niet te voorspellen.

Deze hypothese wordt alleen inzake het initiatief in het contact met de netwerkleden bevestigd. Ten aanzien van de frequentie van het contact worden vrijwel in gelijke mate verschillen bij de jongere en oudere patiënten vergeleken met de referentiepersonen aangetroffen. Dat is ook het geval voor wat betreft de lengte van de contacten met de netwerkleden. In het gewicht dat aan de netwerkleden wordt toegekend treden in het geheel geen verschillen op.

\section{Vraagstelling $\mathrm{V}$ :}

42 Er zullen verschillen in de structuur van de sociale netwerken ofwel verschillende patronen optreden wanneer een vergelijking wordt gemaakt tussen enerzijds de informatie via de MSNA bij de jongere en de oudere ambulante chronisch psychiatrische patiënten en anderzijds de gegevens die door de hulpverleners bij beide groepen patiënten verstrekt worden. De richting van de optredende verschillen is niet te voorspellen.

Hypothese 42 kan als bevestigd beschouwd worden. Bij alle structuur kenmerken blijkt de MSNA in het geheel genomen gemiddeld significant meer informatie te geven dan door de hulpverleners van de SPD verstrekt wordt. Echter bij de jongere patienten worden de meeste en tevens grootste verschillen gevonden. Deze algemene vitkomst treedt in de sector vriendschappelijke betrekkingen sterker op dan in de sector venwanten. 


\section{TABELLEN OMVANG NETWERKLEDEN IN CLUSTERS EN SECTOREN}

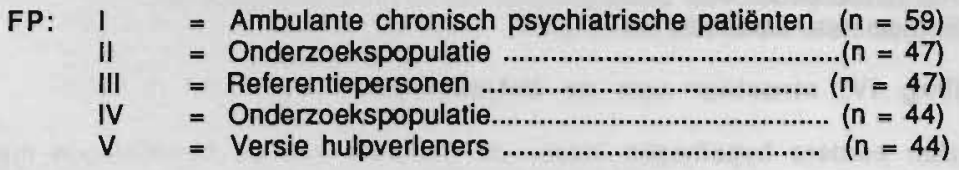

TABEL VI.1 Omvang sector verwanten

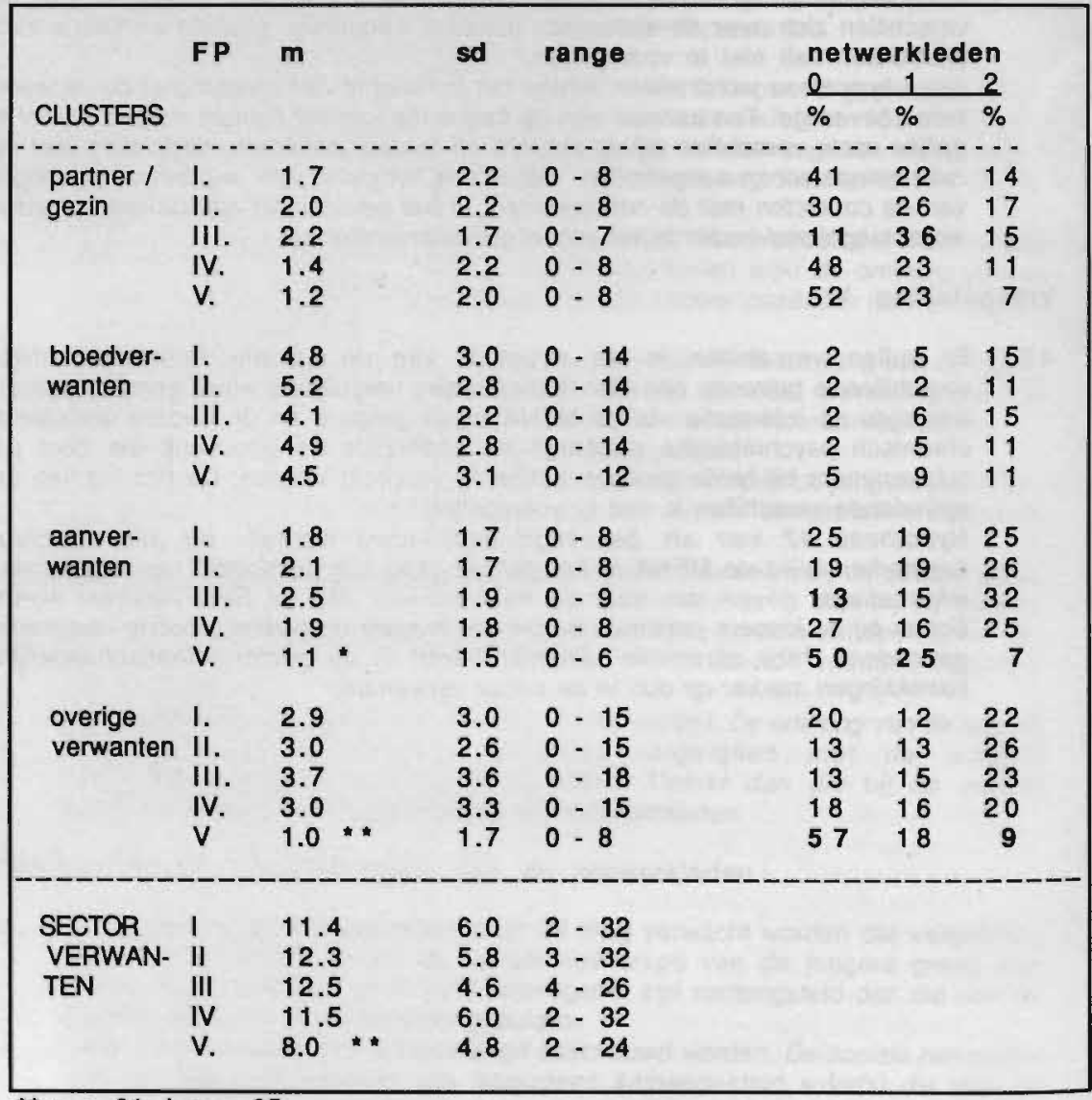

** $p<.01 ; * p<.05$ 
TABEL VI.2 Omvang sector vriendschappelijke betrekkingen

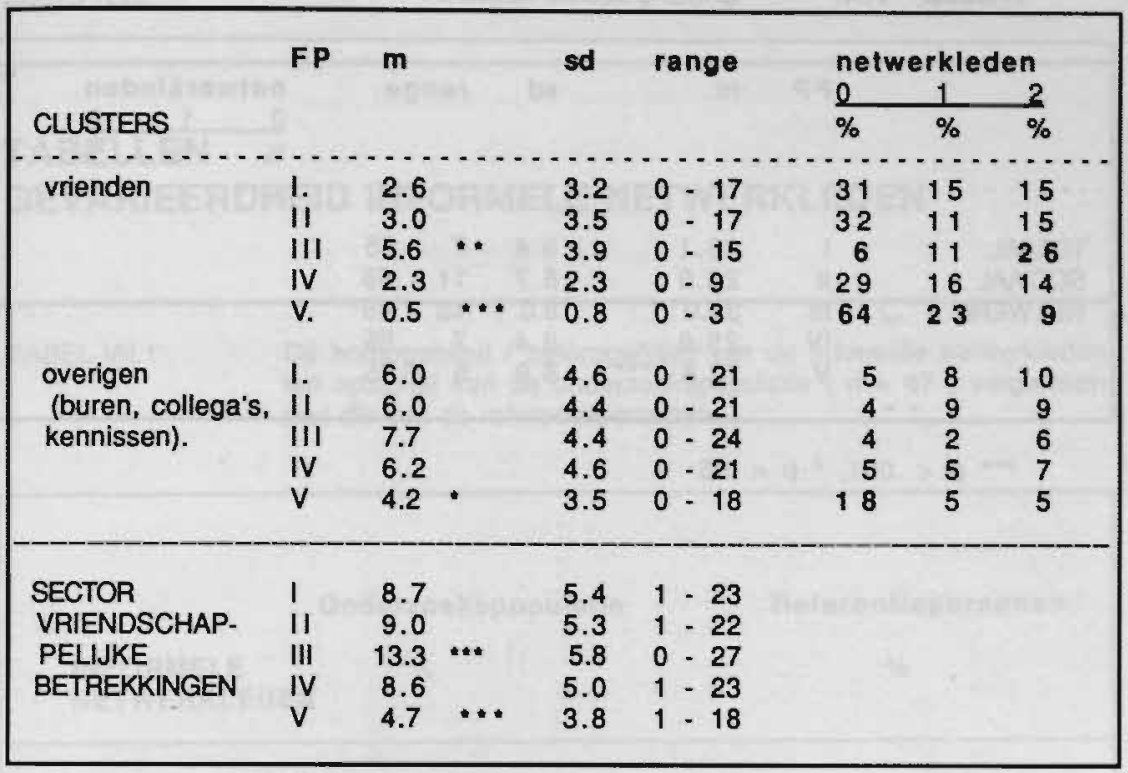

*** $p<.001 ; * * p<.01 ; * p<.05$

TABEL VI.3 Omvang sector maatschappelijke diensten.

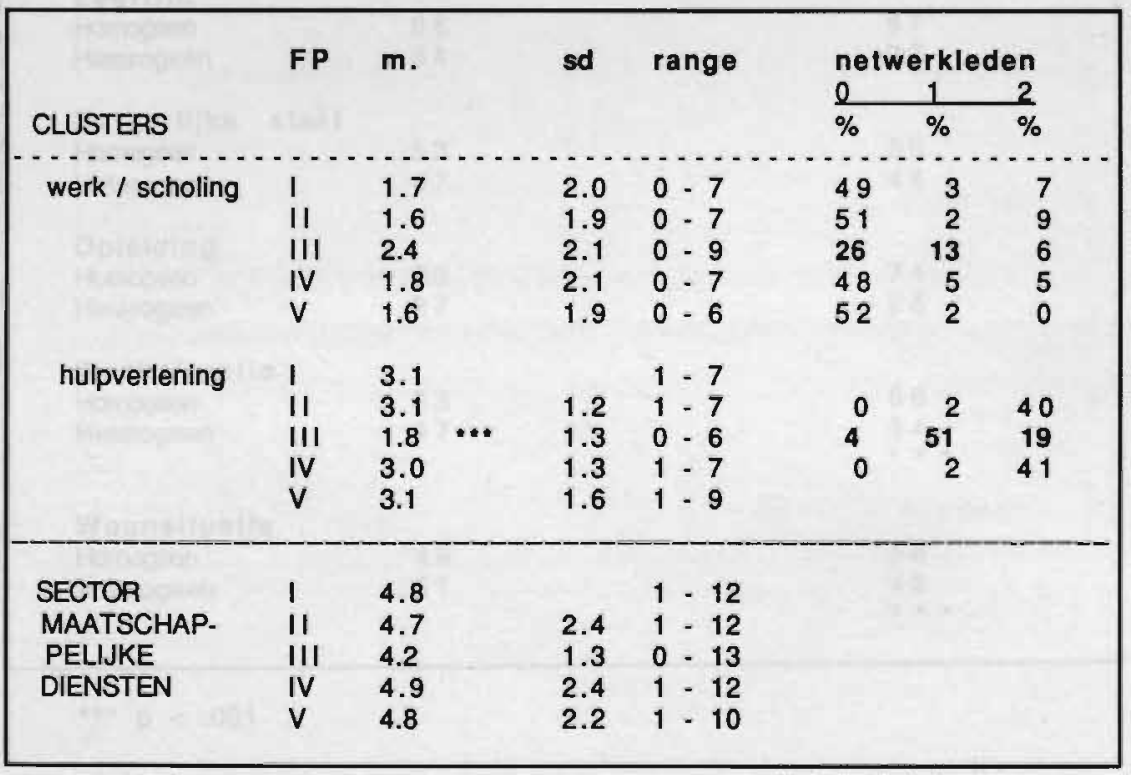

$* * 0<.001$ 
TABEL VI.4. Omvang sociale netwerk

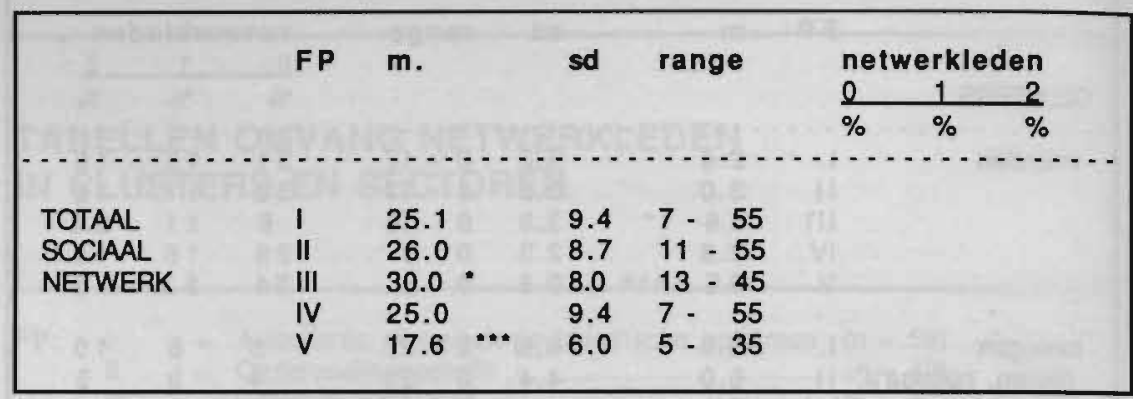

$* * p<.001, * p<.05$ 


\section{TABELLEN}

GEVARIEERDHEID INFORMELE NETWERKLEDEN

TABEL VII.1

De homogeniteit / heterogeniteit van de informele netwerkleden ten opzichte van de onderzoekspopulatie $(n=47)$ vergeleken met die van de referentiepersonen.

Onderzoekspopulatle

INFORMELE NETWERKLEDEN

\section{Geslacht}

Homogeen

Heterogeen

Leeftijd

Homogeen

Heterogeen

Burgerlijke staat

Homogeen

Heterogeen

Oplelding

Homogeen

Heterogeen

Werksituatie

Hornogeen

Heterogeen

Woonsituatle

Homogeen

Heterogeen
54

46

66

34

53

47

73

27

53

47

49

51

\section{Referentiepersonen}

$\%$

57

43

67

33

56

44

74

26

66

34

.

58

42 
De gevarieerdheid van de informele netwerkleden van de onderzoekspopulatie $(n=44)$ in de informatie van de MSNA vergeleken met die van de gegevens bij de hulpverleners van de SPD.

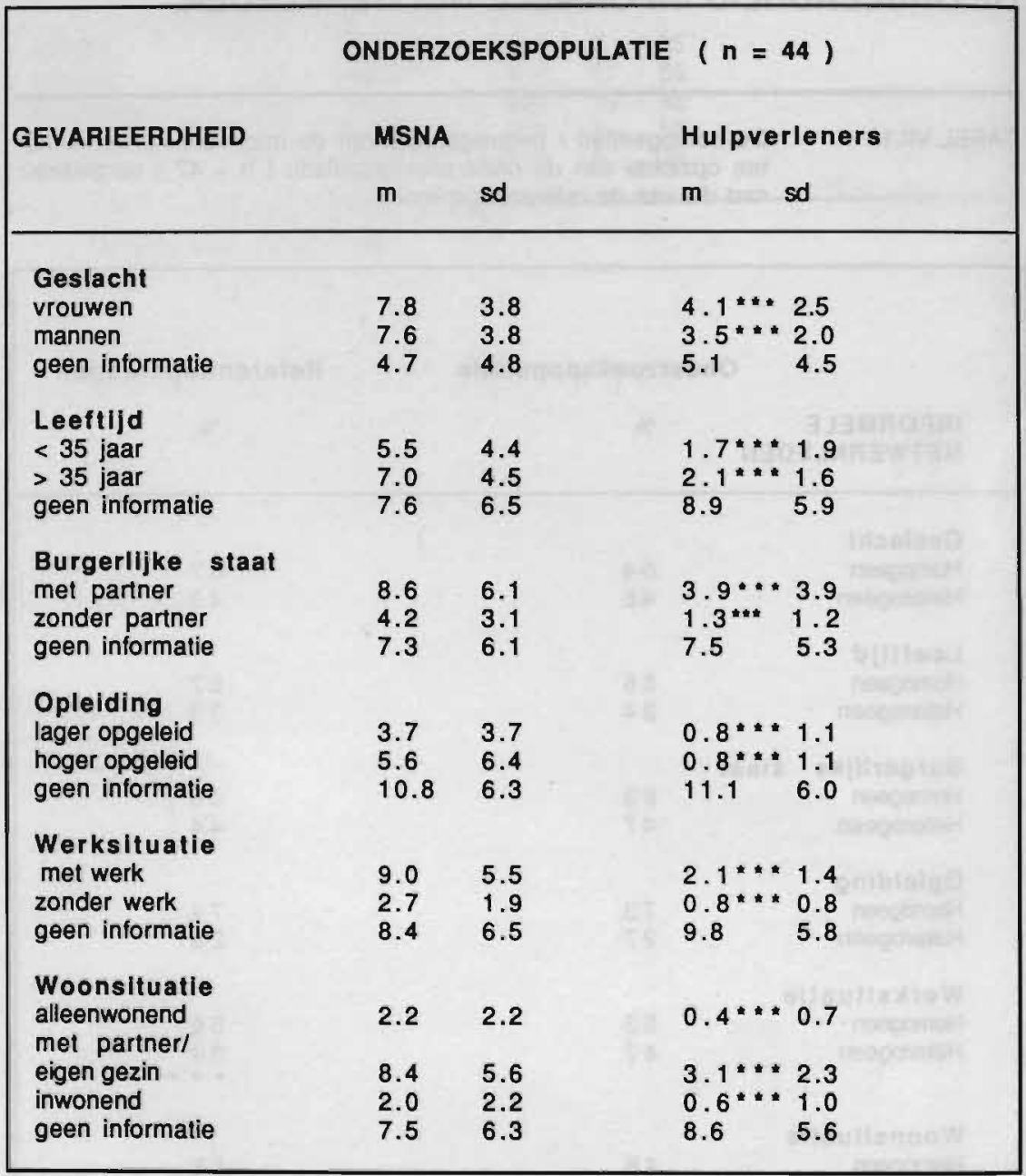

$* p<.001$ 


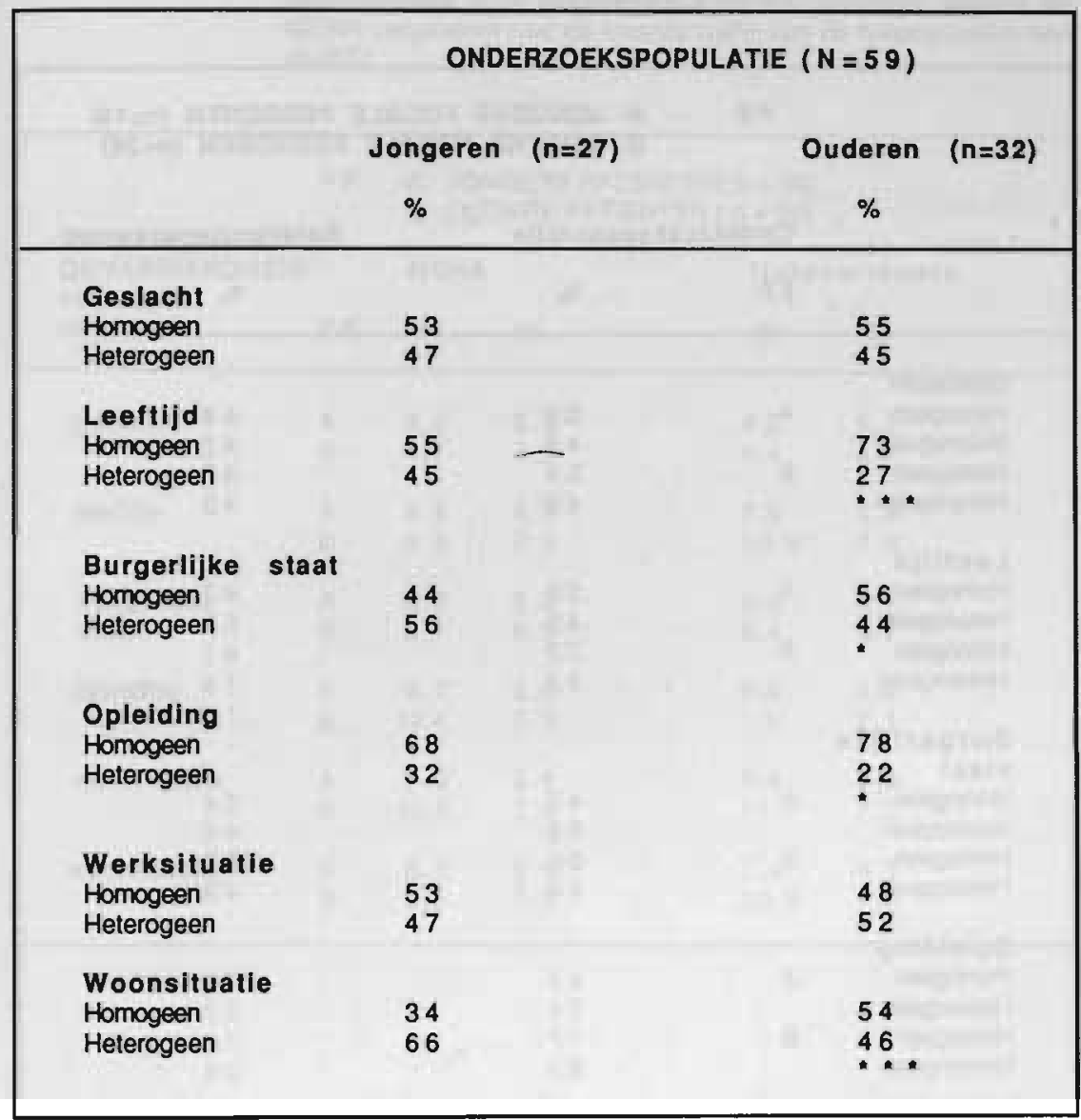

$\star * * p<.001 ; * p<.05$ 

ten opzichte van de jongere patiënten $(n=19$ ) en de oudere ( $n$ $=28$ ) patiènten vergeleken met die van de jongere een oudere referentie personen.

\section{FP \\ A: JONGERE FOCALE PERSONEN ( $n=19$ ) \\ B: OUDERE FOCALE PERSONEN ( $n=28)$}

Onderzoekspopulatle

FP

$\%$

\section{2}

48

54

46

55

45

73

27
Heterogeen

BurgerlIjke

staat

Homogeen

Heterogeen

Homogeen

Heterogeen

Opleiding

Homogeen

Heterogeen

Homogeen

Heterogeen

A

B

Werksituatie

Homogeen

Heterogeen

Homogeen

Heterogeen

Woonsituatie

Homogeen

Heterogeen

Homogeen

Heterogeen
A

B

A

B

A

B

\begin{tabular}{r}
47 \\
53 \\
56 \\
\hline \\
44
\end{tabular}

66

34

77

23

58

42

49

51

A

B

\section{Referentiepersonen}

$\%$
58

42

57

43

47

53

81

19

.

54

46

57

43

73

27

74

26

$\# p<.001 ; * * p<.01$ 
De ontbrekende informatie over de gevarieerdheid van de informele netwerkleden bij de onderzoekspopulatie $(n=44$, onderverdeeld in 26 jongere en 18 oudere patiënten) volgens de MSNA vergeleken met de inventarisatie van de hulpverleners van de SPD

\section{FP A JONGERE PATIENTEN $(n=26)$ \\ B OUDERE PATIENTEN $(n=18)$}

\begin{tabular}{lllllll}
$\begin{array}{l}\text { GEVARIEERDHEID } \\
\text { Informatie } \\
\text { ontbreekt }\end{array}$ & F P & m & sd & m & sd \\
\hline - geslacht & A & 4.7 & 5.0 & & 4.2 & 4.3 \\
& B & 4.7 & 4.5 & 6.4 & 4.7 \\
- leeftijd & A & 6.4 & 5.7 & 7.5 & 4.4 \\
& B & 9.3 & 7.2 & 10.9 & 7.3 \\
- burgerlijke & A & 6.0 & 5.2 & 6.9 & 4.1 \\
staat & B & 9.1 & 6.9 & 8.4 & 6.7 \\
- opleiding & A & 9.7 & 5.6 & 9.9 & 4.8 \\
& B & 12.4 & 7.0 & 13 & 7.1 \\
- werksituatie & A & 7.0 & 5.6 & 8.6 & 5.3 \\
& B & 10.4 & 7.4 & 11.7 & 7.0 \\
- woonsituatie & A & 6.3 & 5.1 & 7.4 & 4.1 \\
& B & 9.3 & 7.1 & 10.3 & 7.0
\end{tabular}


TABEL VII.6

De gevarieerdheid van de sector verwanten bij de onderzoekspopulatie ( $n=44$, onderverdeeld in 26 jongere en 18 oudere patiënten) volgens de MSNA vergeleken met de inventarisatie van de hulpverleners van de SPD.

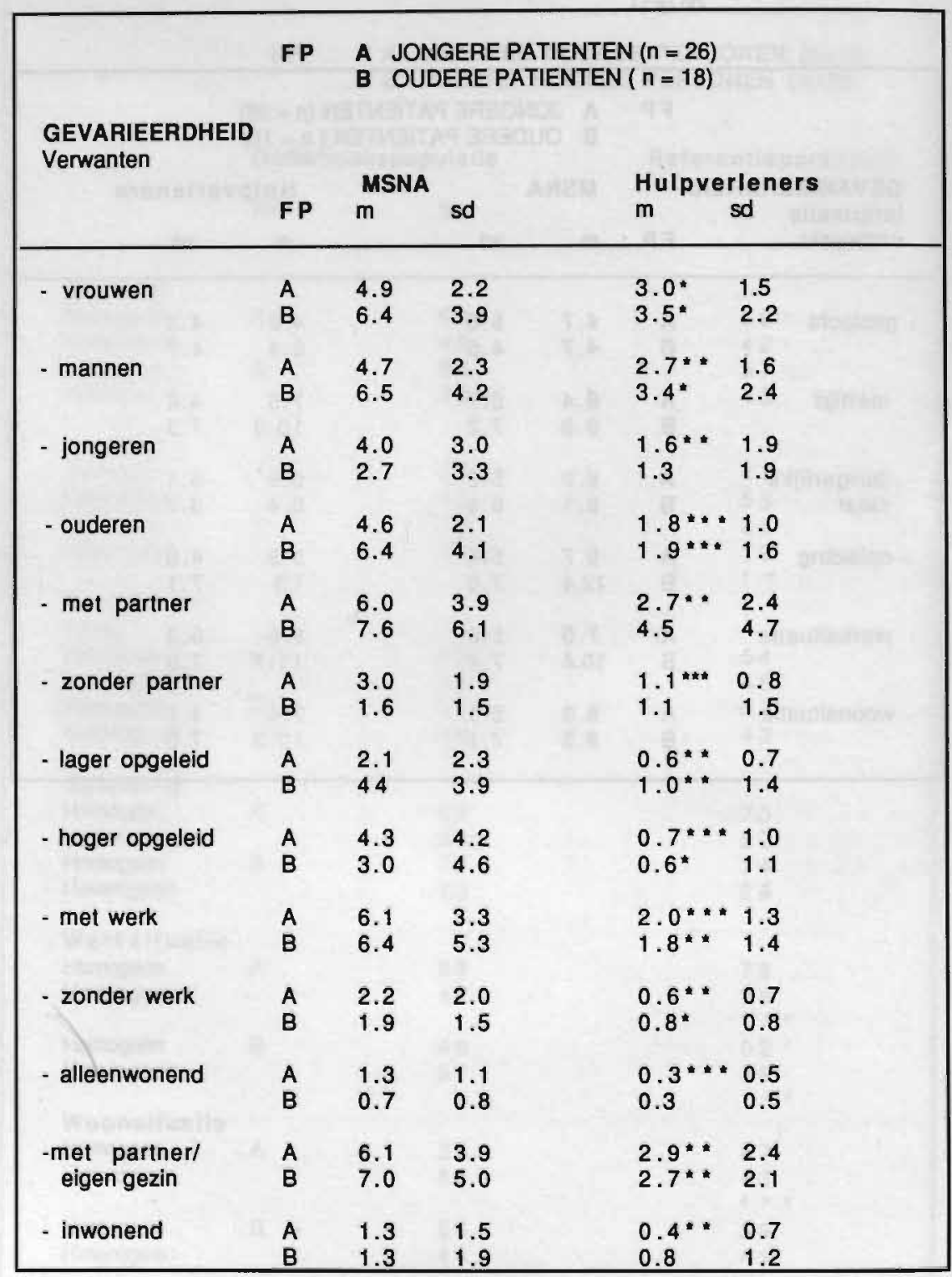

$* * p<.001 ; * * p<.01 ; * p<.05$ 

bij de onderzoekspopulatie ( $n=44$, onderverdeeld in 26 jongere en 18 oudere patiënten) volgens de MSNA vergeleken met de inventarisatie van de hulpverleners van de SPD.

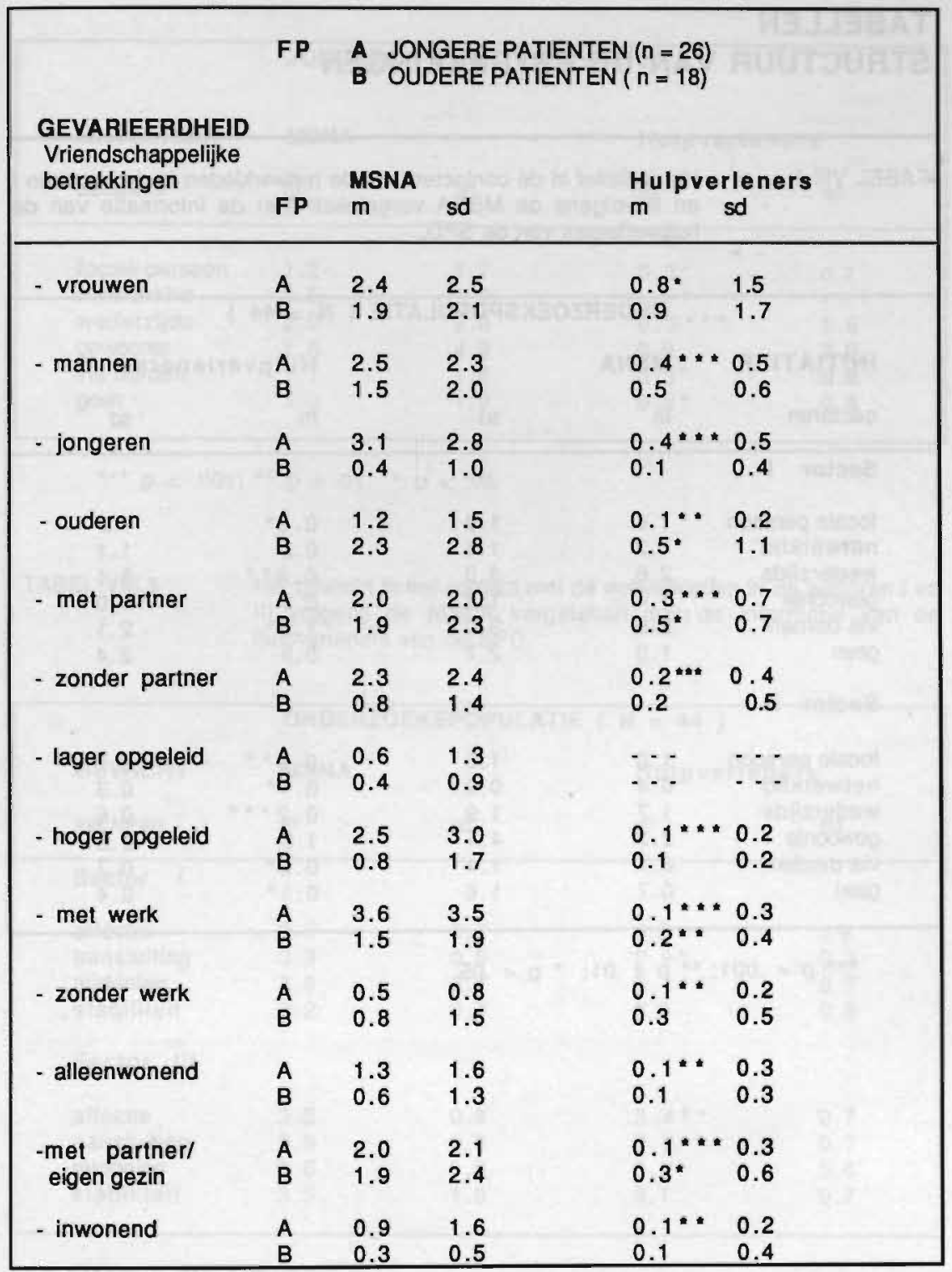

$* * p<.001 ; * p<.01 ; * p<.05$ 


\section{TABELLEN}

\section{STRUCTUUR VAN DE BETREKKINGEN}

TABEL VIII.1

Het initiatief in de contacten met de netwerkleden in de sectoren I en II volgens de MSNA vergeleken met de informatie van de hulpverleners van de SPD.

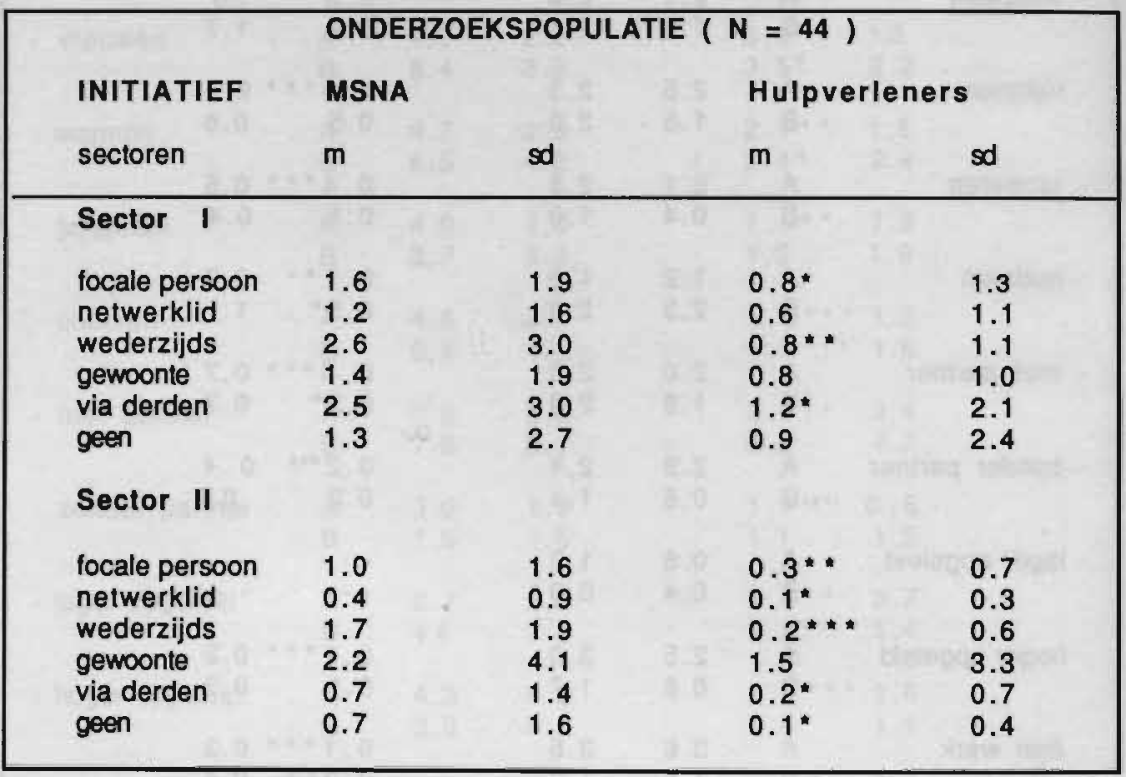

$* * p<.001 ; * p<.01 ; * p<.05$ 
TABEL VIII.2

Het initiatiel in de contacten lussen de jongere patiënten met de netwerkleden in de sector vriendschappelijke betrekkingen volgens de MSNA vergeleken met de informatie van de hulpverleners van de SPD.

\section{JONGERE PATIENTEN $(n=26)$}

\begin{tabular}{|lllll|}
\hline \multicolumn{3}{l}{ JONGERE PATIENTEN $(\mathrm{n}=26)$} \\
INITIATIEF & MSNA & \multicolumn{2}{l|}{ Hulpverleners } \\
sector II & $\mathrm{m}$ & sd & $\mathrm{m}$ & sd \\
\hline & & & & \\
focale persoon & 1.2 & 1.7 & $0.3^{*}$ & 0.7 \\
netwerklid & 0.5 & 1.2 & $\ldots .3^{* *}$ & 0.6 \\
wederzijds & 2.0 & 2.0 & $0.9^{*}$ & 2.0 \\
gewoonte & 1.8 & 4.3 & $0.3^{*}$ & 0.8 \\
via derden & 1.1 & 1.8 & $0.2^{*}$ & 0.4 \\
geen & 1.0 & 1.9 & & \\
\hline
\end{tabular}

${ }^{* * *} p<.001 ; * * p<.01 ; * p<.05$

TABEL VIII.3 Het gewicht in het contact met de netwerkleden in de sectoren I en III volgens de MSNA vergeleken met de informatie van de hulpverleners van de SPD.

\begin{tabular}{|c|c|c|c|c|}
\hline \multirow{3}{*}{$\begin{array}{l}\text { GEWICHT } \\
\text { sectoren }\end{array}$} & \multicolumn{4}{|c|}{ ONDERZOEKSPOPULATIE $(N=44)$} \\
\hline & \multicolumn{2}{|c|}{ MSNA } & \multicolumn{2}{|c|}{ Hulpverleners } \\
\hline & m & sd & $\mathrm{m}$ & sd \\
\hline \multicolumn{5}{|l|}{ Sector I } \\
\hline affectie & 3.6 & 0.7 & 3.3 & 0.8 \\
\hline aansluiting & 3.3 & 0.6 & $2.9^{*}$ & 0.7 \\
\hline middelen & 3.6 & 0.7 & $3.1 *$ & 0.7 \\
\hline stabiliteit & 3.2 & 0.8 & 3.0 & 0.8 \\
\hline \multicolumn{5}{|l|}{ Sector III } \\
\hline affectie & & & $3.4 *$ & \\
\hline aansluiting & 3.9 & 0.8 & $3.3 * *$ & 0.7 \\
\hline middelen & 3.6 & 1.0 & $3.2^{*}$ & 0.6 \\
\hline stabiliteit & 3.5 & 1.0 & 3.1 & 0.7 \\
\hline
\end{tabular}

$* p<.01 ; * p<.05$ 

en oudere patiënten volgens de MSNA vergeleken met de informatie van de hulpverleners van de SPD.

\begin{tabular}{|c|c|c|c|c|c|}
\hline \multirow{3}{*}{$\begin{array}{l}\text { compartimenten } \\
\text { GEWICHT } \\
\text { Sectoren I en III }\end{array}$} & \multirow{3}{*}{$\begin{array}{l}\text { FP } \\
\text { FP }\end{array}$} & \multicolumn{4}{|c|}{$\begin{array}{l}\text { A JONGERE PATIENTEN }(n=26) \\
\text { B OUDERE PATIENTEN }(n=18)\end{array}$} \\
\hline & & \multicolumn{2}{|c|}{ MSNA } & \multicolumn{2}{|c|}{ Hulpverleners } \\
\hline & & m & sd & $\mathrm{m}$ & sd \\
\hline Sector I & & & & 35 & $\operatorname{lath} 2 x+2=0$ \\
\hline affectie & $\begin{array}{l}A \\
B\end{array}$ & $\begin{array}{l}3.5 \\
3.7\end{array}$ & $\begin{array}{l}0.6 \\
0.8\end{array}$ & $\begin{array}{l}3.2 \\
3.4\end{array}$ & $\begin{array}{l}0.9 \\
0.5\end{array}$ \\
\hline aansluiting & $\begin{array}{l}A \\
B\end{array}$ & $\begin{array}{l}3.2 \\
3.4\end{array}$ & $\begin{array}{l}0.6 \\
0.7\end{array}$ & $\begin{array}{l}2.7^{\star} \\
3.2\end{array}$ & $\begin{array}{l}0.8 \\
0.4\end{array}$ \\
\hline middelen & $\begin{array}{l}A \\
B\end{array}$ & $\begin{array}{l}3.6 \\
3.7\end{array}$ & $\begin{array}{l}0.7 \\
0.7\end{array}$ & $\begin{array}{l}3.0^{*} \\
3.3\end{array}$ & $\begin{array}{l}0.8 \\
0.5\end{array}$ \\
\hline stabiliteit & $\begin{array}{l}A \\
B\end{array}$ & $\begin{array}{l}3.1 \\
3.4\end{array}$ & $\begin{array}{l}0.9 \\
0.7\end{array}$ & $\begin{array}{l}2.8 \\
3.1\end{array}$ & $\begin{array}{l}0.8 \\
0.7\end{array}$ \\
\hline \multicolumn{6}{|l|}{ Sector III } \\
\hline affectie & $\begin{array}{l}\mathrm{A} \\
\mathrm{B}\end{array}$ & $\begin{array}{l}3.8 \\
3.9\end{array}$ & $\begin{array}{l}0.8 \\
0.9\end{array}$ & $\begin{array}{l}3.4 \\
3.2^{*}\end{array}$ & $\begin{array}{l}0.7 \\
0.6\end{array}$ \\
\hline aansluiting & $\begin{array}{l}A \\
B\end{array}$ & $\begin{array}{l}3.9 \\
3.9\end{array}$ & $\begin{array}{l}0.8 \\
0.9\end{array}$ & $\begin{array}{l}3.4^{*} \\
3.3^{*}\end{array}$ & $\begin{array}{l}0.7 \\
0.6\end{array}$ \\
\hline middelen & $\begin{array}{l}A \\
B\end{array}$ & $\begin{array}{l}3.5 \\
3.7\end{array}$ & $\begin{array}{l}1.1 \\
0.9\end{array}$ & $\begin{array}{l}3.2 \\
3.1\end{array}$ & $\begin{array}{l}0.6 \\
0.6\end{array}$ \\
\hline stabiliteit & $\begin{array}{l}A \\
B\end{array}$ & $\begin{array}{l}3.5 \\
3.5\end{array}$ & $\begin{array}{l}1.2 \\
0.7\end{array}$ & $\begin{array}{l}3.1 \\
3.2\end{array}$ & $\begin{array}{l}0.7 \\
0.8\end{array}$ \\
\hline
\end{tabular}

$p<.05$ 


\section{LIJST MET GEBRUIKTE AFKORTINGEN}

$\begin{array}{ll}\text { AGGZ } & \text { Ambulante Geestelijke Gezondheidszorg } \\ \text { AMW } & \text { Algemeen Maalschappelijk Werk } \\ \text { APZ } & \text { Algemeen Psychiatrisch Ziekenhuis } \\ \text { AZM } & \text { Academisch Ziekenhuis Maastricht } \\ \text { CAD } & \text { Consultatieburo voor Alcohol en Drugs } \\ \text { EE } & \text { Expressed Emotion } \\ \text { FP } & \text { Focale Persoon } \\ \text { GGZ } & \text { Geestelijke Gezondheidszorg } \\ \text { ISSI } & \text { Interview Schedule for Social Interaction } \\ \text { LSB-team } & \text { Team Langdurig Structurende Begeleiding } \\ \text { Min. van WVC } & \text { Ministerie van Welzijn, Volksgezondheid en Cultuur } \\ \text { MHCR } & \text { Mental Health Case Register } \\ \text { MSNA } & \text { Maastrichtse Sociale Netwerk Analyse } \\ \text { NAP } & \text { Network Analysis Profile } \\ \text { PAAZ } & \text { Psychiatrische Afdeling Algemeen Ziekenhuis } \\ \text { PKI } & \text { Psychosocial Kinship Inventory } \\ \text { RIAGG } & \text { Regionale Instelling voor Ambulante Geestelijke Gezondheidszorg } \\ \text { RL } & \text { Rijksuniversiteit Limburg } \\ \text { PNH } & \text { Registratienet Huisartspraktijken } \\ \text { SBS } & \text { Social Breakdown Syndrome } \\ \text { SNAQ } & \text { Social Network Assessment Questionaire } \\ \text { SNI } & \text { Social Network Inventory } \\ \text { SNT } & \text { Social Network Therapy } \\ \text { SONET } & \text { Social Networks and Social Support } \\ \text { SPD } & \text { Sociaal Psychiatrische Dienst } \\ \text { SPGD } & \text { Sociaal Psychiatrische Geriatrische Dienst } \\ \text { SRO } & \text { Single Room Oocupancy } \\ \text { SRZL } & \text { Stichting Reclassering Zuid-Limburg }\end{array}$




\section{SAMENVATTING}

Dit proefschrift betreft een onderzoek naar de structuur van het sociale netwerk van ambulante chronisch psychiatrische patiénten $(N=59)$ in zorg bij de SPD van de RIAGG Maastricht. Een analyse en beschrijving van de structuur van sociale netwerken brengt de (mate van) sociale integratie in kaart. Bevordering dan wel herstel van de sociale integratie wordt bij de SPD Maastricht gezien als de doelstelling van ambulante psychiatrische hulpverlening.

Gebruik makend van de Maastrichtse Sociale Netwerk Analyse (MSNA) zijn gegevens verzameld over de omvang, de samenstelling van de omvang, de gevarieerdheid en de bereikbaarheid van het sociale netwerk van deze patiënten en over de structuur van de betrekkingen (in termen van initiatief, frequentie, gewicht en lengte)met hun netwerkleden. Om inzicht te krijgen in wat specifiek is voor de structuur van het sociale netwerk van deze doelgroep van ambulante psychiatrische hulpverlening zijn de uitkomsten ervan vergeleken met die bij normale referentiepersonen. Vervolgens zijn de bevindingen omtrent de structuur van de sociale netwerken van de patiënten vergeleken met de informatie die de hulpverleners van de SPD aan het begin van de behandeling over het sociale milieu van deze patiënten inventariseren. De reden voor deze tweede vergelijking is dat ik in een eerdere verkennende studie aanwijzingen vond dat de ambulante chronisch psychiatrische patiënt over een structureel omvangrijker en veelzijdiger sociaal netwerk beschikt dan de betreffende hulpverleners zichtbaar maken en mogelijk in de zorg benutten.

In het geheel genomen maken de uitkomsten van dit onderzoek duidelijk dat het sociale netwerk van de ambulante chronisch psychiatrische patiënten in vergelijking mel de referentiepersonen inzake vrijwel alle structuurkenmerken significante verschillen toont in de zin van beperkingen. Zo blijken de patiënten onder meer gemiddeld 25 netwerkleden te hebben terwijl de referentiepersonen gemiddeld 30 netwerkleden kunnen noemen. In termen van de gevarieerdheid van het sociale netwerk blijken de patienten zich ten opzichte van hun informele netwerkleden inzake woon- en werksituatie in een sociaal isolement te bevinden. De patiënten hebben in vergeljking met de referentiepersonen minder netwerkleden in de eigen woonplaats, zij nemen naar hun beschikbare netwerkleden minder zelf het initiatief tol contact en er is minder sprake van wederzijds initiatief in het contact.

Deze en andere opmerkelijke verschillen concentreren zich vooral in de sector vriendschappelijke betrekkingen, met name in het cluster 'naaste vrienden'; de patiënten noemen bijvoorbeeld in dit cluster gemiddeld drie en de referentiepersonen gemiddeld zes netwerkleden. Wanneer er een onderscheid wordt gemaakt naar jongere en oudere ambulante chronisch psychiatrische patiënten dan blijken de aangetroffen beperkingen in de structuur van het sociale netwerk bij de jongere patiénten groter te zijn dan bij de oudere patiënten.

De ambulante psychiatrische hulpveriener blijkt vergeleken met de informatie die de patiënten zelf via de MSNA geven maar ten dele op de hoogte te zijn van de actuele structuur van het sociale netwerk waarvan de patiênt deel uitmaakt. In het geheel genomen zijn bij de hulpverleners gemiddeld 17 netwerkleden bekend terwijl de patiěnten gemiddeld 25 netwerkleden noemen. De hulpverleners zijn goed bekend met de clusters 'naaste (bloed)verwanten' en de clusters 'scholing/werk' en 'hulpverlening' maar hebben vergeleken met de gegevens die de patiënten via de MSNA verstrakken minder informatie over de clusters 'aanverwanten' en 'verre verwanten' en nauwolijks informatie over de gehele sector vriendschappelijke betrekkingen. 
De hulpverleners blijken vervolgens in het geheel genomen nauwelijks weet te hebben van de status- en positierollen van de informele netwerkleden van hun doelgroep voor ambulante psychiatrische hulpverlening. Inzake de structuur van de betrekkingen valt onder meer op dat de patiěnten via de MSNA aangeven naar gemiddeld meer netwerkleden zelf initiatief te nemen en dat er bij hen met meer netwerkleden sprake is van wederzijds initiatief dan de hulpverteners rapporteren. De patiënten hebben zowel met meer netwerkleden contact alsook met meer netwerkleden zeer frequent contact dan uit de gegevens van de hulpverleners blijkt. Tenslotte blijkt dat de discrepantie tussen de informatie van de MSNA en die van de hulpverleners over de structuur van het sociale netwerk van de patiënten bij de jongere patiénten groter te zijn dan bij de oudere patiënten.

Al bij al tonen de resultaten dat de structuur van het sociale netwerk van ambulante chronisch psychiatrische patiënten in vergelijking met die van normale referentiepersonen significante beperkingen heeft. De grootste verschillen worden aangetroffen in de sector vriendschappelijke betrekkingen en dat geld in het bijzonder voor de jongere patiénten. Met de MSNA blijken de optredende verschillen en hun onderlinge samenhang nauwkeurig en ook gedelailleerd zichtbaar gemaakt te kunnen worden. Vervolgens tonen de resultaten van dit onderzoek dat de MSNA aanzienlijk meer informatie en aldus een vollediger beeld van de structuur van het sociale netwerk van de patiënt geeft dan het geval is in de gebruikelijke inventarisatie van de hulpverleners. Vergeleken met de gegevens van de hulpverleners geeft de MSNA niet alleen een vollediger beeld maar toont de MSNA tevens dat de structuur van het sociale netwerk van deze patiënten uitgebreider en vitaler is dan door de hulpverlening zichtbaar wordt gemaakt.

Ten behoeve van de bevordering dan wel het herstel van de sociale integratie van de ambulante chronisch psychiatrische patiënt, de doelstelling van ambulante psychiatrische hulpverlening, maakt de MSNA zichtbaar waar in de structuur van het sociale netwerk een reorganisatie wenselijk is en waar de aangrijpingspunten liggen voor de opbouw van een vitale structuur van mensen en betrekkingen. Voorwaarde is wel dat de betreffende hulpverleners over zo volledig mogelijke en gedifferentieerde informatie beschikken; de door de hulpverleners gebruikte techniek van verzameling van informatie geeft hiervoor bepaald geen garantie. Met behulp van de MSNA zijn de hulpverteners in staat de geconstateerde onderbelichting van de sociale omstandigheden waarin de patient dagelijks verkeert op te heffen. Wanneer de doelstelling van sociale integratie als primaire doelstelling van ambulante psychiatrische zorg ernstig wordt genomen dan lijkt de toepassing van de MSNA bij de aanvang van de hulpverlening de aangewezen weg om rechtstreeks in en met het sociale netwerk aan de sociale integratie van de ambulante chronisch psychiatrische patiënt te werken. 
This dissertation reports upon a study of the social networks of ambulatory chronic psychiatric patients $(N=59$ ) in care at the Social Psychiatric Services of the Community Mental Health Center in Maastricht. In this research the structural characteristics of these patients' social networks are investigated. In the ambulatory psychiatric care of the Social Psychiatric Services in Maastricht social integration is the objective of treatment. Social integration is a human condition that can be grounded on the analysis and description of the personal social environment in terms of its structural characteristics of persons and ties.

Using the 'Maastricht Social Network Analysis' (MSNA) data are gathered and analyzed on the social network size, the distribution among the three sectors of relatives, friendly relations and social services, the variety and accessibility of the nelwork members and the structural characteristics of network ties in terms of initiative, frequency, weight and length.

The structural characteristics of the patients' social networks are compared with those of a reference group drawn from the normal population. The findings on the patients' social networks are also compared with the information of the mental health care professionals about the patients' social environment. The rationale for this latter comparison is based upon an earlier explorative study suggesting that ambulatory chronic psychiatric patients are embedded in a larger and a more vital social network than is visible in the information of the mental health care professionals.

The results of this research show that the structural characteristics of the patients' social networks differ significantly from the social networks of the normal reference population. For example, the mean size of the patients' social networks consists of 25 network members while the reference group has a larger mean size of 30 network members. On the structural characteristic variety the patients are socially isolated in terms of living and working conditions. Compared with the normal reference population patients are taking less initiative in their contacts with network members and there is less initiative based on reciprocity.

These and other significant differences are concentrated in the sector of friendly relations, especially in the cluster of close friends. The mean size of this cluster in the patients' social networks is three network members while in the reference population a mean size of 6 network members is found. The deficiencies in the structure of the social networks of the younger patients are larger than the deficiencies found in the structure of the older patients' social networks.

Compared with the information of the patients' social networks gathered by using the MSNA the mental health care professionals have limited data about the structural characteristics of the patients' social networks. The mental health care professionals report a mean size of 17 network members while the patients maintain they have an average of $\mathbf{2 5}$ network members. The mental health care professionals are well informed about the clusters close relatives and work and professional care. They know significantly less about the cluster of distant relatives. Furthermore, they hardly know anything about the sector of triendly relations and about the variety (social demographic characteristics) of the patients' informal network members. In contrast with the information of the patients, the mental health care professionals' data show that the patient hardly takes initiative in the contact with his network members. Also the mental health care professionals report less initiative based on reciprocity. 
The patients' data gathered by using the MSNA reveal that the patients not only have contact with more network members but also do so more frequently. Finally, the largest discrepancies between the MSNA data and the mental health care data are found in the group of younger ambulatory chronic psychiatric patients.

in general the results indicate major deficiencies in the structure of the patients' social networks as compared to the normal reference population. The largest differences are found in the sector friendly relations, especially in the case of younger patients. Using the MSNA it is possible to precisely determine these differences and their interconnectedness. Compared with the information of the mental health care professionals, the MSNA results in a more complete and vital description of the patients' social networks.

The use of the MSNA to aid in the social integration of ambulatory chronic psychiatric patients is derived from the fact that the methodology makes visible the structure of the patienis' social network in a manner that suggests a number of intervention points. These points can be used in the reorganization and reconstruction of the patients' vital structure of relations. The therapist is in need of differentiated knowledge of this vital struclure if the aim of social integration is to be accomplished. Without this knowledge through the use of the MSNA, the social integration of the patient cannot be seriously undertaken. 


\section{CURRICULUM VITAE}

Herman M.J. Baars, maatschappelijk werker en universitair docent bij de sectie Sociale Psychiatrie en Psychiatrische Epidemiologie (voorzitter: Prof. Dr. M.W. de Vries) van de vakgroep Psychiatrie en Neuropsychologie (voorzitter: Prof. Dr. H.M. van Praag).

Op 29 maart 1943 ben ik te Nieuwveen geboren. De middelbare school doorliep ik aan het College van het Heilig Kruis te Uden en de Latijnse School te Gemert. In 1965/1966 studeerde ik theologie en filosofie aan het Grootseminarie Breda/ Hoeven en daama tot medio 1968 aan de Stichting Theologische Faculteit te Tilburg. In deze periode volgde ik onder meer nog de Universitaire Leergang in de Problematiek der Ontwikkelingslanden te Tilburg en was ik tevens werkzaam in het Jeugd- en Jongerenwerk te Etten-Leur.

Per 1 december $1968 \mathrm{kwam}$ ik in dienst van de dr. Henri van der Hoevenkliniek te Utrecht. Tot 1975 werkte ik in deze kliniek voor forensische psychiatrie in de groepsleiding en in het coördinatieteam van de behandeling. Tussen 1970 en 1974 studeerde ik tevens aan de Studierichting Maatschappelijk Werk van de Katholieke Sociale Academie Markendaal te Breda; daarnaast specialiseerde ik me in de methodiek van het groepswerk.

Op 1 januari $1975 \mathrm{kwam}$ ik in de functie van medisch-maatschappelijk werker in dienst van de vakgroep Sociale Psychiatrie, Faculteit der Geneeskunde van de Rijksuniversiteit Limburg te Maastricht. Bij besluit van het College van Bestuur RL d.d. 26 mei 1988 werd ik met ingang van 1 maart 1987 benoemd in de functie van universitair docent bij de vakgroep Sociale Psychiatrie.

Vanaf 1980 tot 1986 was ik lid van de Raad van de Faculteit der Geneeskunde RL en in de periode 1987-1992 was ik voorzitter van het Centraal Stembureau van de $\mathrm{RL}$. Ook buiten de universiteit vervulde ik bestuurlijke functies; zo was ik ondermeer in de periode 1980-1987 voorzitter van het bestuur van de ds. Deelemanschool te Grevenbicht.

Inhoudelijk en praktisch heb ik me in de vakgroep Sociale Psychiatrie vooral bezig gehouden met het probleem van de sociale integratie van (ambulante) chronisch psychiatrische patiënten. Voor wat betreft de 'sociale integratie', naar mijn mening de doelstelling van (ambulante) psychiatrische hulpverlening, ga ik overwegend uit van het gedachtengoed en de werkwijze van de sociale netwerk benadering. Met betrekking tot het probleem van de chroniciteit heb ik me steeds gericht op zowel de cliëntèle van de SPD van de RLAGG'n als ook op de cliëntèle van de ambulante categorale hulpverlening op het terrein van de forensische psychiatrie en van de verslavingszorg. 

